\title{
RECINTOS FORTIFICADOS EN ÉPOCA VISIGODA: HISTORIA, ARQUITECTURA Y TÉCNICA CONSTRUCTIVA
}

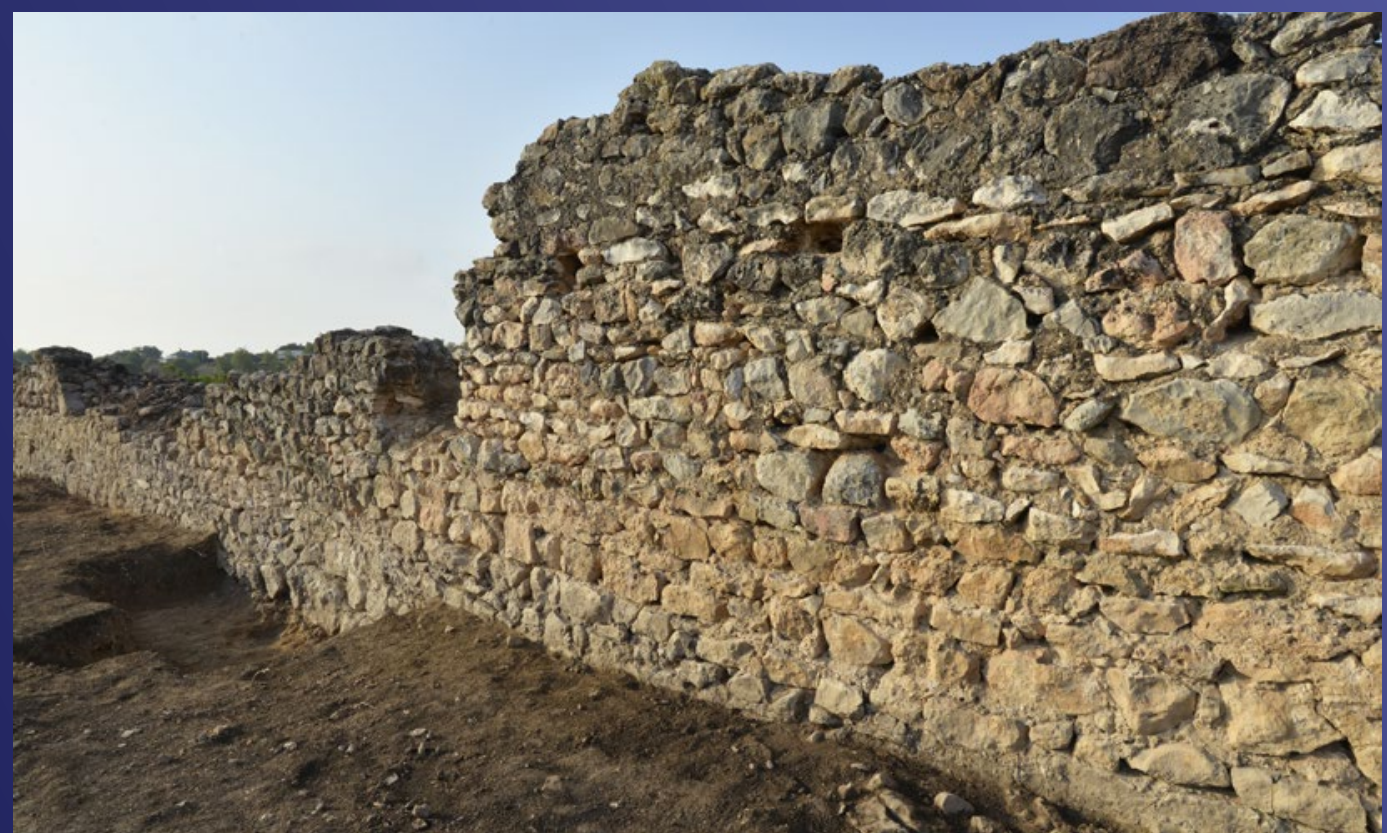

EDITORES CIENTÍFICOS: JOSEP MARIA MACIAS SOLÉ ALBERT RIBERA LACOMBA MIQUEL ROSSELLÓ MESQUIDA

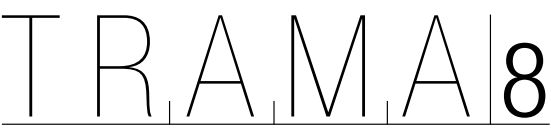

TREBALLS D'ARQUEOLOGIA DE LA MEDITERRÀNIA ANTIGA 

RECINTOS FORTIFICADOS EN ÉPOCA VISIGODA:

HISTORIA, ARQUITECTURA Y TÉCNICA CONSTRUCTIVA 



\section{RECINTOS FORTIFICADOS EN ÉPOCA VISIGODA: HISTORIA, ARQUITECTURA Y TÉCNICA CONSTRUCTIVA}

\section{Editores científicos:}

Josep Maria Macias Solé

Albert Ribera Lacomba

Miquel Rosselló Mesquida

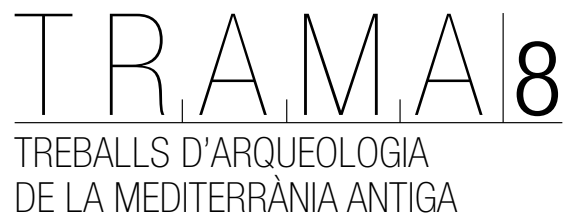

Institut Català d'Arqueologia Clàssica

Tarragona 2020 
Edició de les II Jornades Internacionals d’Arqueologia de Riba-roja de Túria (València), titulades «Recintes fortificats en època visigoda: història, arquitectura i territori», que van tenir lloc a Riba-roja de Túria els dies 8, 9 i 10 de novembre de 2017.

Aquesta obra ha estat possible gràcies al projecte de recerca «Parámetros analítico-evolutivos de las técnicas constructivas del noreste de la Tarraconense en época tardoantigua» (HAR2015-64392-C4-2P-FEDER, 2016-2019) i la col-laboració de l’Ajuntament de Riba-roja de Túria.

Aquesta obra ha passat revisió d'experts. / This is a peer-reviewed publication.

\section{Consell Editorial}

Juan Manuel Abascal (Universitat d'Alacant, Espanya), Susan E. Alcock (Universitat de Michigan, EUA), Achim Arbeiter (Universitat de Göttingen Georg-August, Alemanya), Darío Bernal (Universitat de Cadis, Espanya), Yannis Maniatis (Centre Nacional de Recerca Científica Demokritos, Grècia), Luisa Migliorati (Universitat de Roma La Sapienza, Itàlia), Rosa Plana-Mallart (Universitat Paul-Valéry Montpeller 3, França) i Lucrezia Ungaro (Sovrintendenza Capitolina, Direcció de Museus de Roma, Itàlia)

(C) d'aquesta edició, Institut Català d'Arqueologia Clàssica (ICAC)

Plaça d'en Rovellat, s/n, 43003 Tarragona

Telèfon 977249133

info@icac.cat - www.icac.cat

Durant els nou primers mesos de publicació, qualsevol forma de reproducció, distribució, comunicació pública o transformació d'aquesta obra només es pot fer tenint l'autorització dels seus titulars, amb les excepcions previstes per la llei. Adreceu-vos a CEDRO (Centre Espanyol de Drets Reprogràfics, www.cedro.org) si heu de fotocopiar o escanejar fragments d'aquesta obra.

A partir del desè mes de publicació, aquest llibre està subjecte -llevat que s'indiqui el contrari en el text, en les fotografies o en altres il-lustracions- a una llicència Reconeixement-NoComercial-SenseObraDerivada 3.0 de Creative Commons (el text complet de la qual es pot consultar a http://creativecommons.org/licences/by-nc-nd/3.0/es/deed.ca). Així doncs, s'autoritza el públic en general a reproduir, distribuir i comunicar l'obra sempre que se'n reconegui l'autoria i les entitats que la publiquen i no se'n faci un ús comercial, ni lucratiu, ni cap obra derivada.

(C) del text, els autors

(C) de les fotografies i il-lustracions, els autors, llevat que s'indiqui el contrari

Primera edició: desembre de 2019

Coordinació editorial: Publicacions de l'ICAC

Correcció: Ramon Vidal Muntané, B2B Translation, Paul Turner

Imatge de la coberta: Detall d'un segment de la muralla de València la Vella. Fotografia de Josep Maria Macias (ICAC)

Disseny de la col-lecció i de la coberta: Indústries Gràfiques Gabriel Gibert

Maquetació i impressió: Indústries Gràfiques Gabriel Gibert 
Recintos fortificados en época visigoda: historia, arquitectura y técnica constructiva. Marco general. Josep Maria Macias, Albert Ribera y Miquel Rosselló (editores) ................................

Archeologia della guerra greco-gotica: prolegomeni a una ricerca in corso.

Enrico Zanini, Jacopo Celani

La civitas visigoda de Roda-l'Esquerda: la fortalesa i el territori del riu Ter. Albert Pratdesaba i Sala, Imma Ollich i Castanyer. . . . . . . . . . . . . . . . . 25

Nuevos datos sobre la muralla de Puig Rom (Roses, Alt Empordà, Girona). Eva Subias Pascual, Anna M. Puig Griessenberger, Dolors Codina Reina, Ignacio Fiz Fernández . . . . . . . . . . . . . . . . . . . . . . . 35

El Puig del Cid d'Almenara (Plana Baixa, Castelló). Ferran Arasa . . . . . . . . . 45

Nuevos datos sobre el asentamiento visigodo de València la Vella.

Esperança Huguet Enguita, Josep M. Macias Solé, Albert Ribera Lacomba, Francesc Rodríguez Martorell, Miquel Rosselló Mesquida ................ 59

Fortificaciones tardoantiguas en el entorno del alto valle del Ebro: clausurae, turris y castra como elementos interrelacionados de control territorial. José María Tejado Sebastián . . . . . . . . . . . . . . . . . . . . . . . . . . 7

Fortificaciones tardoantiguas en la frontera entre suevos y visigodos. José Carlos Sastre Blanco . . . . . . . . . . . . . . . . . . . . . . . . . . . . 105

Rediviva moenia. Nuevos datos sobre las murallas de Carthago Spartaria en época bizantina. Jaime Vizcaíno Sánchez, José Miguel Noguera Celdrán, María José Madrid Balanza . . . . . . . . . . . . . . . . . . . . . . . . . . . . . . . . 117

El recinto amurallado de Idanha-a-Velha (Portugal). Jorge Morín de Pablos, Isabel Sánchez Ramos

Una presència difusa: dades i indicis per al reconeixement de les primeres fortificacions altmedievals a l'àrea catalana (segles v-VIII). Jordi Gibert Rebull . . 153

El edificio visigodo de Els Casals del Mas de Sabater, Morella, Els Ports (Castelló). José Manuel de Antonio Otal, Ramiro Pérez Milián . . . . . . . . . . . . . . . 173 



\title{
RECINTOS FORTIFICADOS EN ÉPOCA VISIGODA: HISTORIA, ARQUITECTURA Y TÉCNICA CONSTRUCTIVA. MARCO GENERAL
}

\author{
Josep Maria Macias, Albert Ribera y Miquel Rosselló (editores)
}

Desde el año 2016, el Ayuntamiento de Ribaroja de Túria y el Institut Català d'Arqueologia Clàssica (ICAC) desarrollan en el término municipal de dicha localidad un ambicioso proyecto de estudio de la Antigüedad Tardía y Visigoda, cuya actividad más notoria son los «Cursos anuales de Arqueología Cristiana y Visigoda». Gracias a ellos, y con la ayuda del Área de Cultura de la Diputación de Valencia, se han retomado las excavaciones del centro fortificado de València la Vella.

Entre otras iniciativas, figura la realización bienal de una reunión científica vinculada a un tema del rico patrimonio visigodo de Riba-roja de Túria. En 2015 se celebraron las primeras jornadas sobre el «Pla de Nadal y los palacios y espacios de representación en época visigoda», al mismo tiempo que se homenajeó a la directora de la excavación del Pla de Nadal, Empar Juan. La obra que aquí presentamos es el resultado de las II Jornades Internacionals d'Arqueologia de Riba-roja de Túria ( Recintes fortificats en època visigoda: història, arquitectura i territori»), celebradas en Riba-roja de Túria entre los días 8 y 10 de noviembre de 2017. Y recientemente se han efectuado las terceras jornadas, integradas en la 7th International Conference on Late Roman Coarse Ware (LRCW7), que tuvo tres sedes: Valencia, Alicante y Riba-roja de Túria.

El tema de los recintos fortificados del periodo tardoantiguo fue una obvia elección por su vinculación al yacimiento de València la Vella. Además, el estudio sobre las murallas tardías se ha intensificado recientemente, y se puede afirmar que han pasado de ser ignoradas a acaparar la atención en numerosos foros científicos. El volumen de 2014, Las fortificaciones en la Tardoantigüedad. Élites y articulación del territorio (siglos V-VIII d. C.), inició el camino, aunque en realidad se centró casi exclusivamente en la Meseta Norte y alrededores. Nuestra reunión de 2017 fue complementaria, ya que trató de abrazar las principales áreas hispánicas, más dos referentes internacionales de la península itálica y los Balcanes. Lamentablemente, y por causa ajenas a los editores, este volumen no recoge la totalidad de las ponencias y quedan au- sentes los yacimientos de Iustiniana Prima, Reccopolis y el Tolmo de Minateda.

A finales de 2019, esta temática alcanzó carácter internacional con el congreso «Perchement et réalités fortifiées en Méditerranée et en Europe (vème-xème siècles). Formes, rythmes, fonctions et acteurs. Congrès international d'histoire et d'archéologie», organizado por dos pequeños municipios de Francia e Italia, Roquebrune-surArgens y Riva Ligure, en colaboración con varias universidades e instituciones científicas. En este congreso participaron varios de los ponentes del celebrado en Riba-roja de Túria, y en él València la Vella estuvo representada. Aún más recientemente, en 2020, se acaba de editar City walls in Late Antiquity. An Empire-wide perspective, aunque se centra básicamente en las fortificaciones de los núcleos urbanos romanos.

En el periodo examinado, el medio milenio 400-900, Hispania, antigua provincia del Imperio romano occidental, se convirtió en al-Ándalus. Entre medio, entre la urbs y la medina, entre la villa y la alquería, los asentamientos fueron cambiando. Sin embargo, los datos históricos son escasos y predominan los episodios bélicos y de alta política. Además, hasta hace poco, la arqueología no ha sido muy explícita, por escasa y discontinua, excepto en algunos yacimientos. La evolución de unos pocos centros urbanos romanos se conoce bien, como las colonias de Barcino, Tarraco, Caesaraugusta, Carthagonova, Ilici, Emerita o Valentia, pero la evolución de la mayoría de las ciudades romanas es bastante desconocida, sobre todo para el periodo tardoantiguo. El mundo rural presenta una situación similar, dado que el modelo romano de las villas desapareció, sin que haya suficientes datos para seguir el proceso de cambio con precisión.

En Hispania, la entrada de suevos, vándalos y alanos en 409 supuso el inicio del fin del poder romano. Tras ellos, el primer dominio visigodo fue militar, sin nueva población, y se extendió a casi toda la Península, excepto la Gallaecia sueva. La inevitable alteración de las tramas del poblamiento rural bajoimperial presenta vacíos de in- 
formación debido a la escasez de excavaciones y publicaciones, más acusadas en unas zonas que otras. Una cuestión importante es la evolución y la pervivencia de las villae y sus fundos. La mayor parte debieron de desaparecer. Las que lograron sobrevivir experimentaron un proceso de reconversión en granjas más simples, con áreas de residencia, trabajo (silos, prensas) y enterramiento. En este contexto de cambio, fue inevitable que, un poco por todas partes, surgieran centros fortificados en altura. Para Gallaecia, gracias a Hidacio, se sabe que la población local se enfrentó a los suevos, a veces con éxito, en algunas ciudades y asentamientos fortificados mencionados como castra, sin que se hayan identificado arqueológicamente.

La derrota frente a los francos en 507 supuso el final del reino visigodo de Tolosa y la migración de la población goda a Hispania tras abandonar la Galia, excepto la franja costera mediterránea de los Pirineos al Ródano, la Septimania. En la organización fronteriza del nuevo reino visigodo encajarían los asentamientos defensivos en altura de la frontera franca, los que controlaban los pasos pirenaicos y los del entorno de los vascones y suevos, algunos de los cuales se estudian en este volumen.

A la muerte del rey Teudis (548) se inició un largo periodo de inestabilidad, entre 550 y 570 . Además de una gran epidemia, la peste de Justiniano, el reino visigodo sufrió la triunfante revuelta cordobesa, la guerra civil entre Agila y Atanagildo, la intervención bizantina y la ocupación romana, presumiblemente pactada, del sudeste. Se produjo una sustancial alteración del incipiente reino visigodo, que afectó a sus territorios meridionales y orientales. La instalación de los bizantinos, en plena fase expansiva y ya asentados en Ceuta y Baleares, supuso otra gran amenaza. La creación de la provincia de Spania implicó una nueva organización territorial, tanto por parte goda como romana. Se crearon obispados en la zona visigoda fronteriza para gestionar los territorios de las sedes de Ilici y Carthagonova, sustraídos al poder imperial, Eio (Tolmo de Minateda) y Begastri, que se instalaron en nuevos centros fortificados en altura cercanos a la frontera.

En este periodo se ha constatado una considerable dinámica constructiva en asentamientos defensivos, provocada en su mayoría por la invasión imperial, y la consiguiente reacción visigoda, especialmente durante el reinado de Leovigildo, que propició la consolidación del reino. La principal dificultad es atribuir a unos u otros la autoría de las fortificaciones. Solo Reccopolis y Carthagonova serían los seguros referentes de visigodos y romanos. El primero fue creado por Leovigildo junto al río Tajo, en la vital ruta de Toletum a Cae- saraugusta, como un gran centro militar (murallas, palacio/horreum) y económico (ceca, barrio artesanal), pero no episcopal. El segundo fue el puerto de entrada, base militar y capital de la nueva y efímera provincia de Spania. En la Hispania visigoda la fundación de ciudades fue poco habitual y siempre una prerrogativa exclusivamente real.

La creciente realidad arqueológica y las escasas, pero existentes, noticias históricas avalan la presencia de una zona militarizada, al estilo de lo que sucedía en Italia y África. La defensa de la Italia bizantina, precisamente, se trata en este volumen. Entre el Turia y el Júcar y las montañas del sur de la provincia de Valencia, habría una frontera cambiante que, como indican las fuentes y la arqueología, estaría organizada en fortificaciones menores (castra, castella...) que controlaban las comunicaciones y los lugares estratégicos. Este dispositivo se basaba, en última instancia, en ciudades amuralladas en su retaguardia. $\mathrm{Va}$ lentia se había supuesto, hasta ahora, que sería el principal centro visigodo de la parte norte de esta zona militar. En este contexto se crearía el gran recinto fortificado de València la Vella. Es un nuevo asentamiento fortificado de casi 5 hectáreas sobre un promontorio elevado sobre el río Turia y fundamental para reconstruir la historia del territorio valenciano entre los siglos vi y vIII. Los nuevos datos señalan un urbanismo monumental y planificado, más allá de un simple castrum o castellum con meras funciones defensivas. Podría desarrollar atribuciones administrativas y de jerarquización del territorio. Por sus cerámicas y sus monedas, y ante la ausencia de textos históricos, la fundación de València la Vella coincide con el reinado de Leovigildo.

Dada su entidad, habría que replantearse la localización de algunos hechos atribuidos a Valencia en este periodo: el cautiverio del hijo rebelde de Leovigildo, Hermenegildo, la localización de la ceca de Valentia y la ubicación de la sede del obispo arriano de Valentia, que tal vez podrían haber estado en València la Vella. Se abren nuevos interrogantes en la interpretación y la relación entre este núcleo, la cercana sede episcopal de Valentia y la posterior área palatina del Pla de Nadal.

València la Vella es un caso excepcional, pero no único. Un modelo cercano en el tiempo y en el espacio sería el Tolmo de Minateda, otra nueva ciudad de frontera, con obispo, murallas, basílica y baptisterio. Otras fundaciones de este periodo, conocidas por los textos, carecen de una constatación arqueológica clara, como dos del área vascona: Victoriacum, obra de Leovigildo, y Ologicus, de Suintila. Un caso distinto pero muy interesante sería Els Casals del Mas de Sabater (Morella), en 
la zona montañosa interior al sur del Ebro. Es un singular y sobrio edificio residencial nobiliario, de planta tripartita, con una especie de pequeñas torres en las fachadas laterales, similar al palacio episcopal de Barcino y a la residencia nobiliaria del yacimiento fortificado de Sant Julià de Ramis (Gerona), entre otros. Fue erigida en las últimas décadas del siglo vi y se mantuvo hasta el siglo vIII.

Estos nuevos centros fortificados necesitarían explicaciones razonables para entender su aparición. La cercanía de València la Vella y Valentia, distanciadas 16 kilómetros, no es excepcional, como la dualidad entre Roda de Ter y la episcopal Auso (Vic) (7 km), entre Reccopolis y el obispado de Ercavica $(22 \mathrm{~km})$ o entre Sant Julià de Ramis y Gerunda $(6 \mathrm{~km})$. En estos tres casos, es evidente que estos yacimientos cercanos, alejados de la frontera pero cerca de vías importantes de comunicación, serían complementarios entre sí.

La cuestión principal para explicar la creación de València la Vella es si respondió al modelo de núcleos complementarios dobles -como los mencionados anteriormente- o, por el contrario, se trataba, como se ha visto en zonas fronterizas, de un nuevo centro de poder político y militar visigodo, pero también eclesiástico, enfrentado a otros del área imperial, para hacer frente a la grave amenaza romana oriental y, en menor medida, a la de suevos y vascones. En esta última opción, cabría replantear el papel de Valentia, que tanto podría ser el núcleo urbano a proteger por València la Vella o, por el contrario, el centro a batir o atacar.

El Ravennate, o Anónimo de Ravenna, menciona en el siglo vIII una provincia Aurariola, que aglutinaría tanto a las antiguas posesiones bizantinas como al entramado fronterizo visigodo. $\mathrm{Su}$ último gobernador sería el conocido Teodomiro, reconocido como dux de la región a la llegada de los musulmanes. Aunque tras la derrota de Guadalete y la muerte del rey fue evidente la desintegración de las redes del poder aristocrático visigodo, su repentino colapso no supuso una ruptura social rápida, ya que la islamización fue un proceso continuo pero lento. Son muy escasos los contextos de los siglos VIII y IX para observar la realidad material de las transformaciones de la conquista islámica y distinguir el proceso de desaparición del legado visigodo. Las campañas militares de la conquista islámica resultan imperceptibles. La única excepción es el recinto del Punt del Cid (Almenara), identificado como un campamento, que se trata en esta obra.

El final de València la Vella se debió a un abandono lento, entre finales del siglo vII e inicios del vIII. Esta información alarga su vida casi hasta la llegada de los musulmanes en el 713. Por lo tanto, València la Vella y Pla de Nadal no serían coetáneos, sino que uno sucedería al otro. El complejo palatino de Pla de Nadal no es un edificio aislado, sino que surgiría del traslado a una ladera suave de la población y las funciones de València la Vella. A su alrededor se han localizado varias dependencias más, entre ellas una probable iglesia. La quiebra de la aristocracia en el medio rural también resulta evidente por esas mismas fechas, con los abandonos de castra y residencias campestres. La alteración del poblamiento es difícil de concretar, debido a la indefinición de los principales indicadores cronológicos. Los siglos VIII-IX fueron un periodo de cambios continuos, con conquistas, pactos, abandonos de ciudades y poblados y creación de otros. La inestabilidad fue la norma habitual.

Los capítulos de esta obra recorren los 500 años que van del 400 al 900, cuando surgieron nuevos asentamientos fortificados. Diversas vicisitudes exógenas estuvieron detrás de este cambio de poblamiento, que se concentró en tres momentos, y no siempre está clara la iniciativa o la causa que los originó. Dentro de un contexto general de escasez de información, las primeras reocupaciones de las alturas se dieron en el siglo v. Son las menos conocidas, porque suelen ser pocas y de menor entidad y están cubiertas por otras posteriores más potentes. El conflicto romano-gótico, la frontera franca, la rebeldía vascona y el efímero reino suevo originaron buena parte de las nuevas instalaciones. Hay que suponer que fueron obra de ambas partes contendientes. Perduraron, al menos, hasta la llegada de los musulmanes, como indica la arqueología y documentos como el Pacto de Teodomiro. La mayor parte de las ciudades del Pacto, varias de ellas nuevos centros fortificados tardoantiguos, languidecieron durante el siglo VIII y desaparecieron o se trasladaron en el Ix. Al mismo tiempo, aparecieron nuevos asentamientos, tanto en zonas bajas de la parte sur, la qura de Tudmìr, como en bastante altura, más abundantes en la norte. Los meridionales debieron de ser fundaciones más o menos oficiales, mientras que las septentrionales tendrían otro carácter, probablemente fuera del sistema estatal.

Este volumen pretende aportar nuevos datos al conocimiento histórico y técnico de las fortificaciones de las nuevas «ciudades» en los albores de la Edad Media. Con ello las instituciones promotoras del actual proyecto de investigación manifiestan su interés por la generación y la difusión del conocimiento del patrimonio visigodo de Riba-roja de Túria. 



\title{
ARCHEOLOGIA DELLA GUERRA GRECO-GOTICA: PROLEGOMENI A UNA RICERCA IN CORSO ${ }^{1}$
}

\author{
ENRICO ZANINI, ${ }^{2} \mathrm{JACOPO}^{\mathrm{CELANI}^{3}}$
}

\section{Sommario}

La guerra greco-gotica è tradizionalmente considerata per l'Italia la fondamentale linea di separazione tra età tardoantica e medioevo, spesso a prescindere da un'analisi sufficientemente dettagliata della reale dimensione degli eventi. Obiettivo di questo lavoro è sottoporre a una discussione critica questa immagine, partendo da una rappresentazione grafica su una base GIS degli eventi per sviluppare una riflessione più generale sulla complessità degli effetti che la guerra stessa ebbe nelle diverse regioni dell'Italia del vi e del viI secolo.

\begin{abstract}
The Gothic War is traditionally considered the fundamental dividing line between Late Antiquity and the Middle Ages in Italy, regardless of a sufficiently detailed analysis of the true dimension of the events. This paper focuses on a critical discussion of this perception, based on a graphic representation of war events generated via GIS. This has allowed us to engage in a more general reflection on the complexity of the impact that the war itself had on the different regions of Italy in the 6th and 7th centuries AD.
\end{abstract}




\section{Pars destruens}

La guerra che i Bizantini combatterono in Italia contro gli Ostrogoti per un ventennio, tra il 535 e il 552/554, ${ }^{4}$ e che d'ora in avanti definiremo per brevità con la sigla GGG, costituisce un caso storiografico decisamente interessante, perché per essa disponiamo di un resoconto estremamente dettagliato nelle pagine del De bello Gothico di Procopio di Cesarea.

In buona sostanza, è questo elemento casuale a fare di una cosa come la guerra, -che nel mondo tardoantico era non solo un elemento normale, ma piuttosto una componente strutturale e "strutturante» di tutto un sistema politico, sociale, economico e culturale-, un evento "epocale», in grado di determinare un radicale cambiamento dell'immagine complessiva di un territorio e di una società.

Se la GGG, nella percezione comune e diffusa, non è dunque solo una guerra, ma «la» guerra tardoantica per antonomasia, ${ }^{5}$ lo si deve ad un suo carattere oggettivo -la sua durata- e a due caratteri meno oggettivi: la descrizione che ne fa lo storico di corte di Giustiniano e la ricezione che di questo testo ne ha fatto e continua generalmente a farne la storiografia contemporanea.

La durata è un dato di fatto: la guerra inizia con lo sbarco dell'esercito guidato da Belisario in Sicilia nel 535 e termina solo nel 552/553, anche se ulteriori tentativi di resistenza da parte dei Goti e dei loro nuovi alleati Franchi si ebbero fino al 554 e anche oltre.

Questo dato di fatto andrà però analizzato in maggiore dettaglio, giacché anche a una lettura appena meno che sommaria del testo di Procopio è subito evidente che la guerra che vi è narrata è tutt'altro che una vicenda unitaria che si dipana nel lunghissimo arco di tempo di cui si parla: la GGG è in realtà una sequenza di fasi diverse, che possono essere seguite e analizzate partitamente nel loro svolgersi. ${ }^{6}$ Tra l'avvio e la fine della guerra sono radicalmente diversi i contendenti in campo: una cosa è l'impero bizantino "trionfante» della prima età giustinianea, molto diverso è l'impero della metà del secolo, che ha largamente esaurito la sua spinta espansiva, come dimostrerà l'invasione longobarda di qualche anno dopo; una cosa è il regno ostrogoto di Teodato e Vitige, diretto erede di quello teodericiano e del suo rapporto diretto con l'impero bizantino, e tutt'altra cosa è lo scenario, sia sul fronte interno che su quello delle alleanze, in cui si collocano Totila e Teia.

Ma, soprattutto, la GGG non è «la» guerra combattuta dai Bizantini in quel ventennio, ma solo una parte di una complessa strategia di ampliamento dei confini, di consolidamento delle frontiere e di gestione dei rapporti diplomatici e dei conflitti che vede impegnata l'amministrazione costantinopolitana su molti fronti e con approcci diversi. ${ }^{7} \mathrm{E}$ anche da questo punto di vista gli scenari nel corso di quel ventennio cambiano profondamente, giacché l'impero bizantino si trova a dover gestire situazioni complesse e diversificate in Oriente, nei Balcani e in Africa, con inevitabili riflessi sulla conduzione delle operazioni in Italia.

Il secondo punto critico è rappresentato, come si accennava, dal carattere intrinseco del testo antico che di questa guerra ci racconta. Il De bello Gothico fa parte di una produzione letteraria complessa, con caratteri specifici che non possono non essere presi in considerazione: se la guerra GGG è solo una parte del sistema della bizantina nel secondo quarto del vi secolo, il libro che ce la racconta è solo una parte di un sistema di narrazione messo in piedi da Procopio e che si articola negli altri libri delle guerre (persiana e vandalica), nel trattato/ panegirico sugli edifici e nel libello degli Anecdota. Ognuna di queste parti essendo intesa a costruire una dinamica complessa di narrazione che deve essere analizzata nel suo insieme, per esempio dal punto di vista letterario, per coglierne gli aspetti problematici, gli stilemi propri dell'autore e del genere letterario, le eventuali incongruenze. Su questo punto, occorre dire che la ricerca è appena agli inizi, soprattutto dal punto di vista archeologico: molto, ma forse non ancora abbastanza, si è lavorato sul testo di più immediato interesse archeologico - il de Aedificiis ${ }^{8}$-, assai meno, ripeto, soprat-

4. La data di fine della guerra è argomento dibattuto: al 552/553, con la battaglia dei Monti Lattari e la morte del re goto Teia, risale l'ultimo episodio bellico che contrappone Goti e Bizantini, mentre sacche di resistenza gota rimasero attive ancora per diversi anni; all'ottobre del 554 risale la battaglia del Volturno, in cui Narsete sconfisse l'esercito franco-alemanno che aveva tentato di riaprire le ostilità. Questa data venne assunta come simbolica della fine della guerra dall'amministrazione costantinopolitana, che, con la Pragmatica Sanctio dell'agosto dello stesso anno, estese formalmente al territorio italiano l'applicazione della legislazione imperiale. Le fasi della guerra sono narrate nel dettaglio in Ravegnani $2004 a$.

5. E' interessante a questo proposito notare la ricchezza della voce relativa alla GGG nell'edizione italiana di Wikipedia (https://it.wikipedia.org/wiki/Guerra_gotica), quasi 100.000 caratteri, e un apparato critico e bibliografico di tutto rispetto (oltre 150 note e 10 titoli di bibliografia).

6. Kouroumali 2013.

7. Ravegnani $2004 b$.

8. Roueché, Carrié e Duval 2000; Dell'Osso 2018. 
tutto in una prospettiva archeologica, si è lavorato sui testi storici di Procopio, che pure, ad una analisi appena più ravvicinata, si rivelano potenzialmente portatori di informazioni assai più variate e interessanti di quanto ci si potrebbe aspettare da un semplice resoconto di una spedizione militare. ${ }^{9}$

Eppure, e qui arriviamo al terzo punto critico, un testo in fin dei conti così poco conosciuto e studiato nella sua struttura profonda e nel suo contesto di produzione e destinazione è probabilmente quello più citato nella letteratura archeologica relativa all'Italia di questo periodo. Non c'è infatti praticamente nessuno tra coloro che si sono occupati in vario modo dell'archeologia dell'Italia del vi secolo, ivi beninteso incluso l'estensore di queste note, ${ }^{10}$ che abbia rinunciato alla tentazione di utilizzare la GGG come uno degli elementi fondamentali per spiegare il cambiamento repentino di tutto un mondo (dall'assetto del territorio, al sistema insediativo, alla fine delle città, al cambiamento dell'economia) o per trovare una causa ad un numero impressionante di microepisodi di distruzione e/o abbandono che si registrano archeologicamente nei siti più disparati, sparsi un po' ovunque nella penisola.

La GGG, come e forse anche più dell'invasione/ migrazione longobarda, è divenuta nella percezione collettiva la linea di faglia che marca la fine del mondo antico e l'inizio del mondo medievale in Italia: da un lato assumendo un carattere di una sorta di catastrofe epocale, quasi una guerra termonucleare globale, in grado di fare una sostanziale tabula rasa di un'intera civiltà, nei suoi macrosistemi e nei suoi singoli microsistemi; dall'altro divenendo una sorta di «convenzione storiografica» per trovare un punto di svolta, di fine/inizio tra due mondi diversi. ${ }^{11}$

In questo processo collettivo si sono sommati, a mio parere, due elementi distinti: da un lato quello della cosiddetta "convenienza euristica». Abbiamo a disposizione una fonte ampia e tendenzialmente attendibile (giacché l'autore è stato a lungo testimone diretto e ha comunque sempre potuto attingere a notizie autorevoli e di prima mano), che ci racconta con dovizia di particolari una guerra particolarmente lunga e violenta ed è quindi conveniente concentrare su di essa la nostra attenzione critica, piuttosto che andare a cercare, magari per la ben più complicata e costosa via archeologica, le possibili tracce di una narrazione diversa.
Questo principio di convenienza euristica ha informato di sé, per esempio, tutta una stagione di studi sull'archeologia, l'architettura e l'urbanistica bizantine del vi secolo, che si è concentrata essenzialmente sulla lettura dapprima acritica, poi ipercritica e oggi finalmente più meditatamente critica di un testo complesso qual è il de Aedificiis, che cominciamo solo oggi ad apprezzare e utilizzare per quel che realmente è: un testo complesso, fatto di molte cose, che costituisce un punto di riferimento fondamentale su cui e con cui intessere un dialogo critico. ${ }^{12}$

Da un altro lato, alla convenienza euristica si è associata quella che potrei definire, con una robusta dose di rudimentale semplificazione, una convenienza «accademica». Nel sistema tradizionale della conoscenza archeologica, la necessità di trovare un limite cronologico riconosciuto e condiviso tra le aree disciplinari è evidentemente - e del tutto legittimamente - sentito. Che cosa di meglio, dunque, di avere a disposizione una linea di faglia così netta e collocata esattamente nel "posto giusto»: prima c'è Teoderico, spesso avvertito come l'ultimo dei sovrani romani, poi c'è Giustiniano che è a buon diritto l'erede diretto degli imperatori romani, ma che proprio nei decenni della GGG grecizza abbondantemente il suo stato, aprendo di fatto la connotazione più propriamente bizantina dell'impero romano d'Oriente. Fino alla GGG il mondo mediterraneo, e al centro di esso l'Italia, può essere visto come l'erede della civiltà classica greco-romana, dopo di essa - e soprattutto dopo la migrazione longobarda - il mondo mediterraneo orientale appare più separato e definitivamente "bizantino», mentre quello occidentale più definitivamente medievale.

Per far finire un mondo unitario e farne nascere uno tutt'altro che unitario, una guerra lunga, unitaria e devastante è per l'appunto accademicamente conveniente e forse sta proprio in questo la ragione di quel bizzarro fenomeno storiografico di una guerra continuamente citata, ma di rado realmente studiata.

Da questa considerazione, tutto sommato banale, è nata l'idea di analizzare più da vicino la GGG dal punto di vista archeologico, partendo proprio dalla narrazione che ne fa Procopio di Cesarea: il progetto era quello di leggere il testo procopiano con gli occhi di un archeologo e di «visualizzare» le fasi della guerra utilizzando uno strumento concettuale come il Geographic Informative System, divenuto negli ultimi due decenni 
parte importante del repertorio dell'analisi archeologica a scala territoriale.

«Mappare» nello spazio e nel tempo la guerra narrata da Procopio è il primo passo per sviluppare, nelle fasi successive del progetto, un'analisi più dettagliata del possibile impatto sui singoli territori, da confrontare con i dati archeologici relativi a tracce di crisi (incendi, crolli, devastazioni, abbandoni) potenzialmente riferibili ad episodi bellici rilevanti.

[E. Z.]

\section{Pars construens}

Pur non nascendo come una cronaca oggettiva degli eventi accaduti, dato che gran parte degli eventi narrati sono frutto della selezione critica dell'autore, ${ }^{13}$ i quattro libri del de Bello Gothico dedicati alla campagna di riconquista dell'Italia forniscono moltissime informazioni riguardo luoghi di battaglie o assedi, forze coinvolte, vittorie e sconfitte, utili alla ricostruzione dello svolgimento del conflitto nell'arco dei diciotto anni della sua durata.

Nella prima parte del trattato, che narra gli eventi tra il 535 e il 540, queste informazioni risultano essere più precise e circoscritte, perché tratte direttamente sia dai rapporti degli ufficiali che dalla testimonianza personale dell'autore, presente in Italia come segretario di Belisario fino alla presa di Ravenna.

Nella seconda parte, invece, redatta da Procopio dopo il suo ritorno a Costantinopoli, le informazioni risultano meno puntuali, basate principalmente su una serie di fonti secondarie che possiamo supporre essere documenti amministrativi, rapporti, citazioni di atti di valore o ambascerie alla corte imperiale. ${ }^{14}$

Nel testo visto nel suo insieme, quindi, accanto ad elementi letterari come gli excursus etnografici, le descrizioni stereotipate delle battaglie o i discorsi dei vari generali, sono presenti una serie di dati geografici precisi (città, strade ecc.): l'individuazione e la catalogazione di queste indicazioni hanno permesso di riportare in una piattaforma GIS, suddividendoli anche in senso cronologico anno per anno, gli spostamenti, gli eventi salienti e le divisioni territoriali tra i due eserciti durante il conflitto.

Nella trasposizione cartografica di un GIS, che notoriamente si basa sulla tripartizione degli sha- pefiles in tre distinte categorie (punti, linee e superfici), i centri assediati e i luoghi delle battaglie campali sono ovviamente visualizzati sotto forma di punti, ad indicare i luoghi in cui la guerra si concretizzò nei suoi aspetti drammatici direttamente sul territorio e quindi, potenzialmente, i luoghi in cui dovrebbe essere teoricamente più probabile rinvenire tracce archeologiche di questi eventi. ${ }^{15}$ Gli spostamenti delle armate sono invece rappresentati come linee, identificando le direttrici lungo le quali la guerra si mosse all'interno della penisola. Le regioni e le aree progressivamente controllate dai due schieramenti coincidono con le superfici e consentono di osservare i vari fronti durante il conflitto. La combinazione di questi tre elementi, insieme alla ripartizione cronologica degli eventi anno per anno, ha permesso di ottenere una prima immagine dinamica della guerra, evidenziandone sia l'effettiva estensione geografica che il suo svolgimento diacronico lungo tutti i diciotto anni, consentendo di osservare concretamente i modi e i tempi con cui la guerra coinvolse il territorio italiano.

Un primo elemento da sottolineare, ancorché ormai piuttosto consolidato nella percezione comune degli studiosi, è che il lungo periodo che va dal 535 al 552/553 non costituisce un unico, ininterrotto momento di crisi, ma è articolato almeno in due grandi fasi.

La prima, dal 535 al 540, corrisponde alla rapida avanzata bizantina che dalla Sicilia risalì fino a Ravenna (fig. 1). Tra il 535 e il 538 le truppe guidate da Belisario occuparono gran parte delle regioni meridionali, Napoli, Roma e i centri a ridosso del tratto umbro della via Flaminia. Nel periodo tra il 539 e il 540 gli imperiali, preso definitivamente il controllo della pianura padana a sud del Po, espugnarono i fortilizi e le città ancora in possesso degli Ostrogoti in Toscana, nelle Marche e in Emilia, avanzando fino a Ravenna, occupata nel maggio del 540, ponendo fine alla guerra, o almeno a questa sua prima fase.

La seconda fase, invece, ha inizio con l'incoronazione di Totila nel 541, per concludersi solo nel 552-553 con la vittoria di Narsete su Teia ai monti Lattari. A differenza del primo periodo, in cui il passaggio del fronte di contrapposizione tra Bizantini e Ostrogoti sul territorio delle regioni di volta in volta interessate fu molto rapido, e quindi difficilmente in grado di avere un impatto distruttivo rilevante, questo è contrassegnato da un aumento delle regioni e dei centri coinvolti nella 


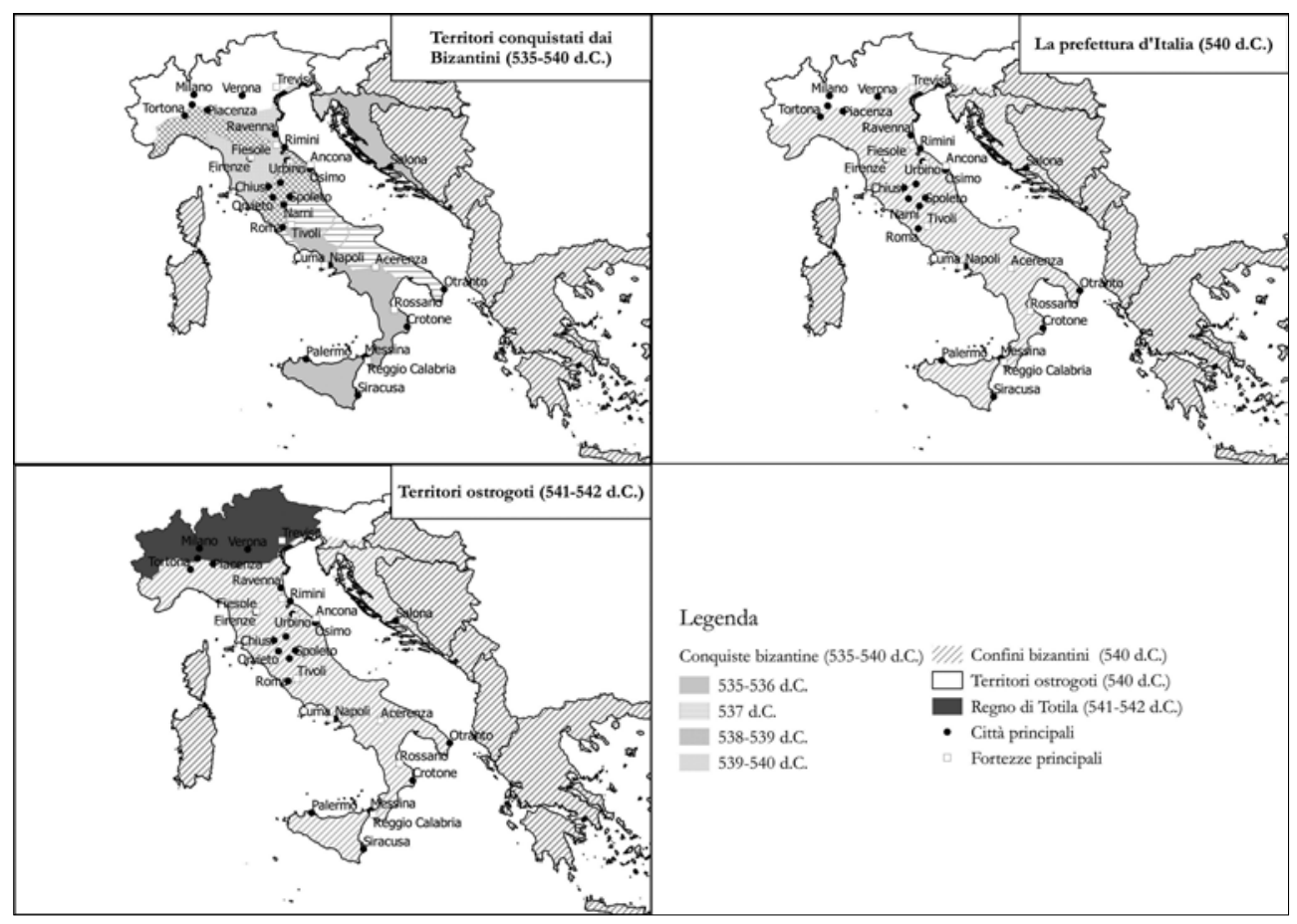

FIgURA 1. L'avanzata bizantina durante la prima fase della guerra (535-540 d.C.) e i confini tra la prefettura bizantina d'Italia e il regno ostrogoto (540-542). guerra. Gli scontri continuarono ad insistere sulle regioni del centro Italia e intorno a Roma, mentre a partire dal 542-543 numerosi episodi di assedio o di battaglie coinvolsero progressivamente anche il Meridione, soprattutto nelle aree costiere, interessando marginalmente invece le aree della pianura padana centro-occidentale (Fig. 2-5).

La divisione della guerra in due fasi trova un riscontro di potenziale interesse archeologico proprio in relazione all'ampliamento dell'estensione del conflitto sul territorio italiano: nel periodo 535-540 la guerra fu soprattutto combattuta lungo l'asse Roma-Ravenna, mentre nel periodo tra il 541 e il 552-553, se da un lato gran parte dei combattimenti continuarono a pesare sulle regioni centrali, dall'altro furono aperti nuovi fronti anche nelle regioni meridionali, limitando invece i danni in quelle a Nord del Po.

Se nella prima fase il Meridione, fatti salvi gli assedi di Palermo e Napoli, passò sotto il controllo imperiale senza subire alcun combattimento, fu proprio qui che, nel periodo 540-553-553, gli Ostrogoti concentrarono i combattimenti, assediando progressivamente le diverse città portuali e i numerosi castra che erano divenuti le basi del controllo amministrativo e militare bizantino all'indomani della conclusione della prima fase della guerra.

La rapida avanzata bizantina nel primo periodo del conflitto è connessa a due elementi. Innan- zitutto, nella prima metà del VI secolo, l'intera Italia meridionale era caratterizzata da una profonda ruralizzazione del paesaggio, dominato dai latifondi in possesso delle grandi famiglie aristocratiche di tradizione romana e della nuova aristocrazia tardoantica rappresentata dalla Chiesa, con una conseguente crisi delle istituzioni urbane già da tempo avviata. ${ }^{16} \mathrm{Il}$ carico fiscale gravante sui possessores locali, legato alle necessità annonarie di Roma, e la crisi economica generale del periodo avevano indotto gli aristocratici ad abbandonare le città, rendendoli sempre più insofferenti al governo ostrogoto e alla sua pressione fiscale favorendo, quindi, la transizione rapida e pacifica di queste regioni sotto il controllo imperiale. ${ }^{17}$ In secondo luogo, l'avanzata bizantina nel Meridione non fu ostacolata dalla presenza di un sistema difensivo organizzato e articolato come quello presente nel Centro-Nord. Il Sud era stato risparmiato dallo stanziamento ostrogoto soprattutto per motivi legati alla politica di equilibrio tra Goti e italici voluta da Teoderico. ${ }^{18}$ Di conseguenza, l'intero Meridione era caratterizzato dalla presenza di poche guarnigioni, principalmente poste a guardia dei grandi porti e dei grandi centri urbani di Palermo, Siracusa e Napoli: proprio intorno a queste città si consumarono i pochi assedi della guerra nei primi cinque anni. Nella seconda fase, invece, a partire dall'assedio ostrogoto di Napoli nel 543, i combattimenti si estesero anche alle 


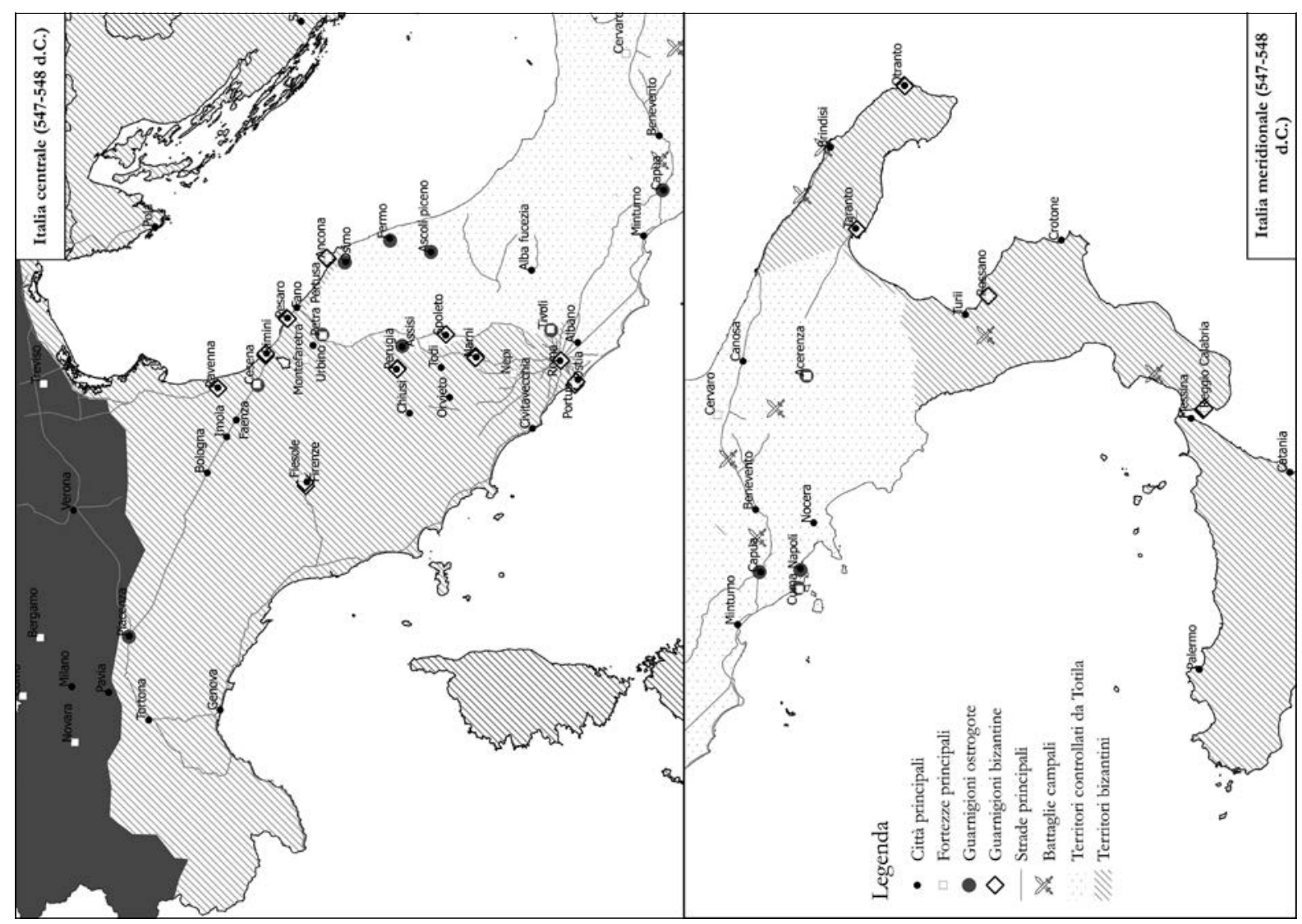

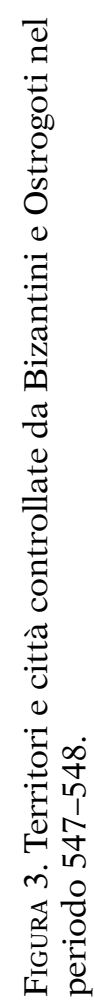

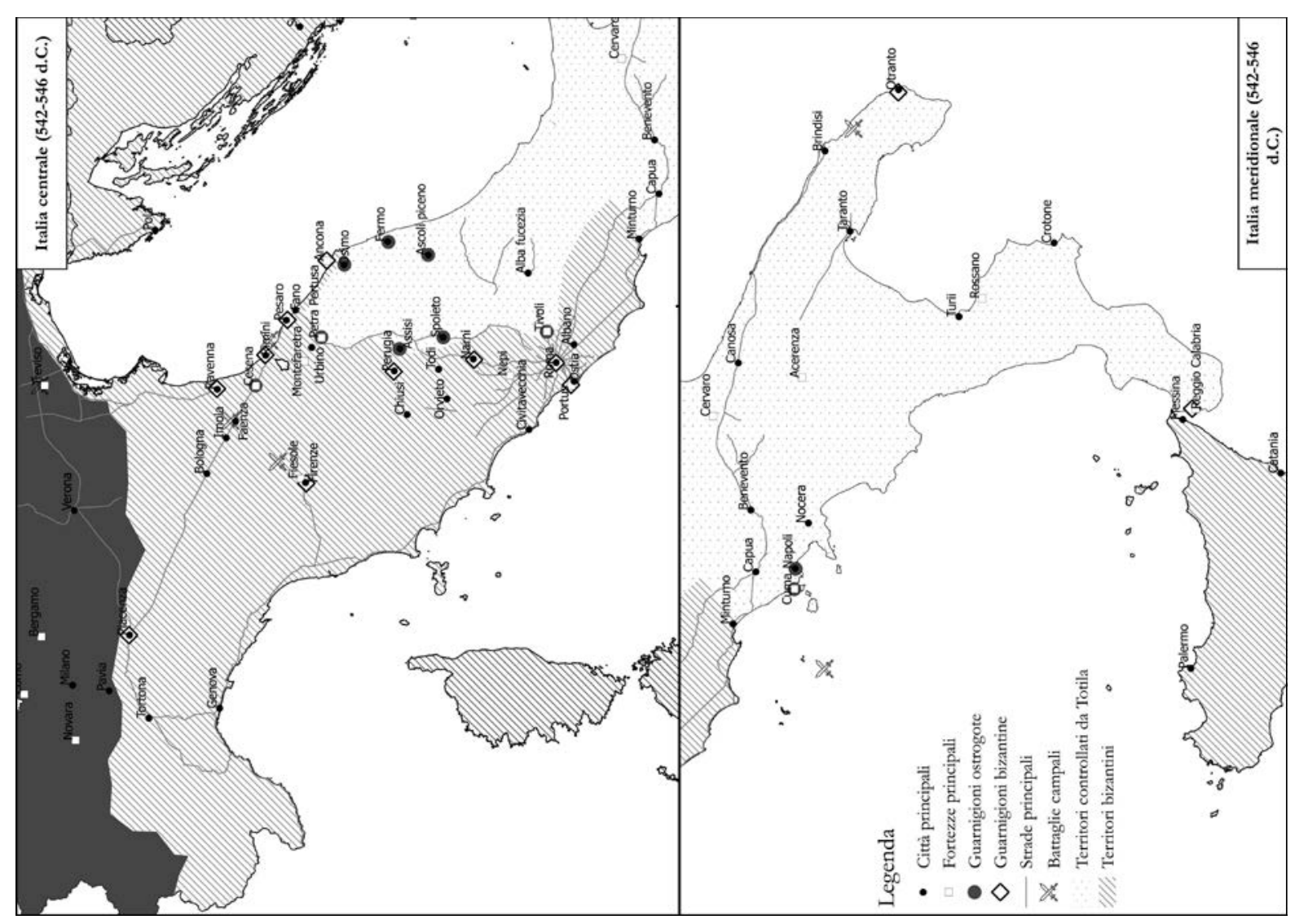

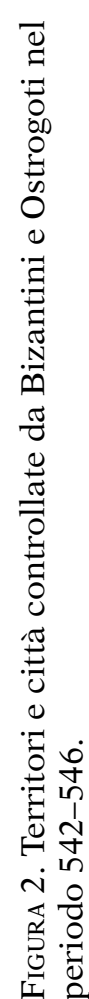




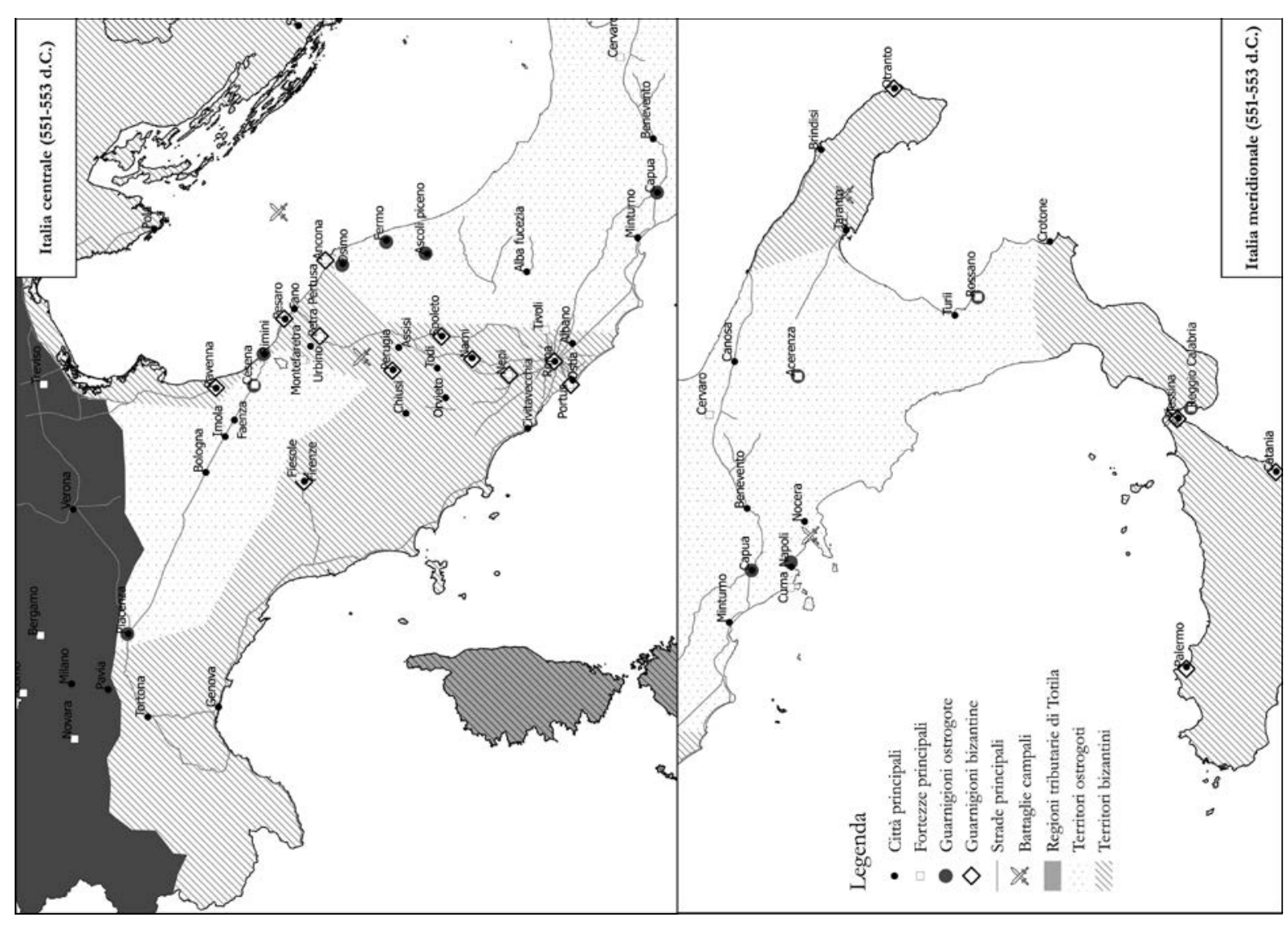

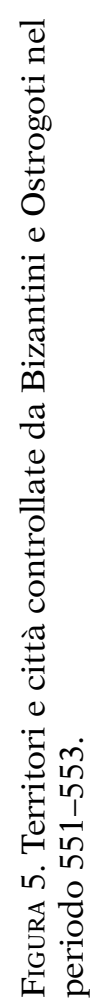

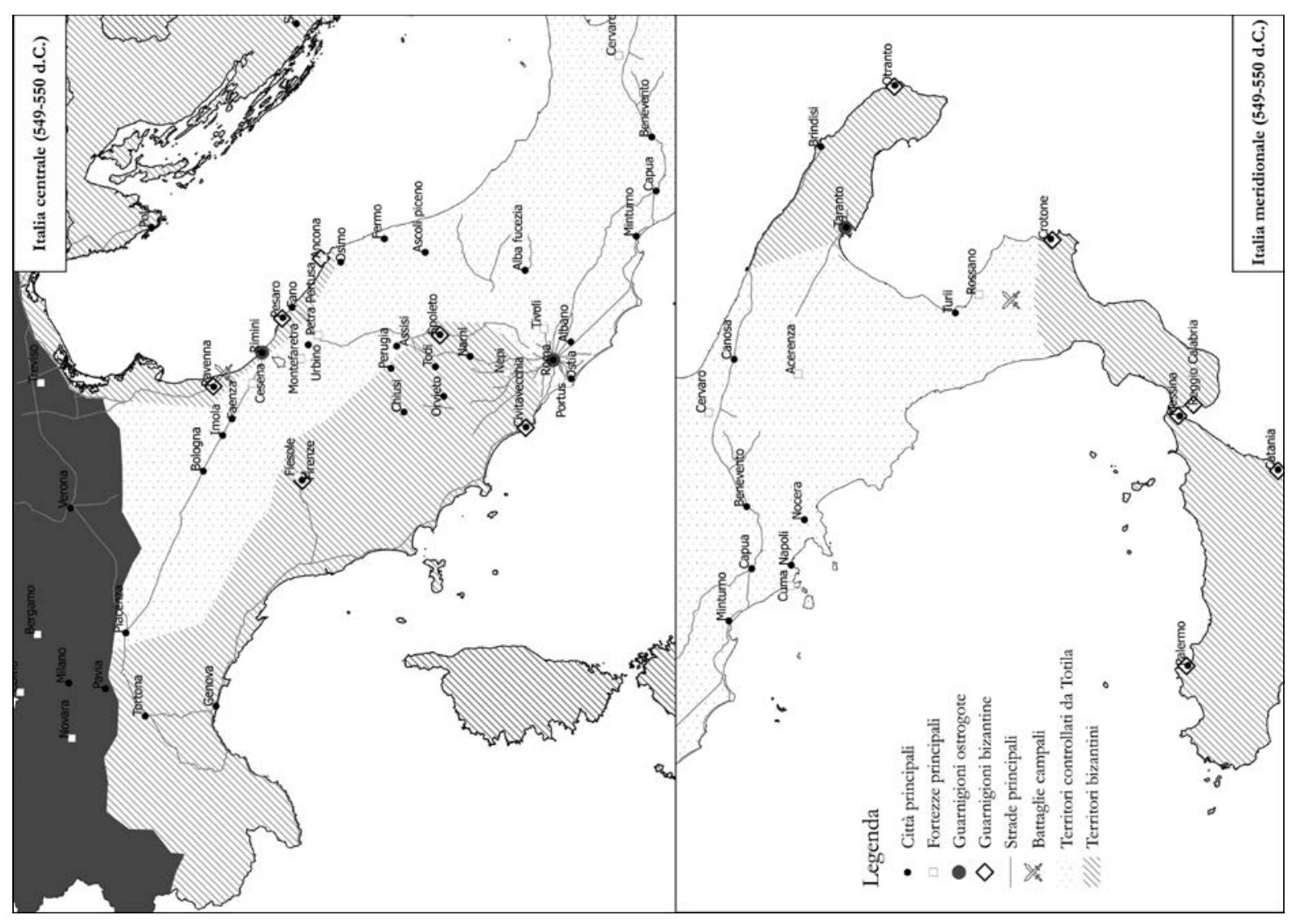

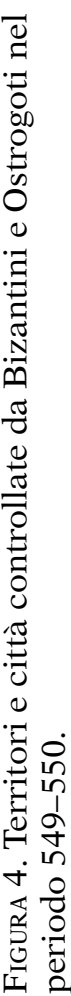


aree costiere meridionali, dove i Bizantini avevano organizzato un primo sistema difensivo per soddisfare le loro necessità amministrative e logistiche, fortificando alcuni porti strategici come quello di Otranto, Taranto, Reggio Calabria o Turi, difeso dalla fortezza di Rossano, che garantivano i collegamenti marittimi con le province orientali e con la Sicilia. ${ }^{19}$

Le aree comprese tra le moderne Umbria, Marche, Toscana orientale e Lazio, invece, furono contese sin dal 537-538 fino alla fine della guerra, subendo per più tempo il peso del conflitto. Qui i combattimenti e gli assedi si susseguirono per un quindicennio, interessando sia alcuni grandi centri urbani come Roma, assediata tre volte per lunghi periodi, sia tutta una serie di città e castra disposti a controllo della rete viaria di collegamento tra Roma a Ravenna. Sebbene la guerra insistette in quest'area per quasi tutti i diciotto anni, la sua estensione geografica fu limitata per tutto il conflitto soprattutto a ridosso del complesso sistema viario gravitante intorno alla Flaminia. Questo costituiva la cerniera di collegamento fondamentale attraverso la dorsale appenninica tra Roma, l'area adriatica e Ravenna. Data la grande importanza strategica di questo sistema viario composto dalla Cassia, dai due percorsi della Flaminia e dalla via l'Amerina, sia le aree dell'antica Tuscia centro-orientale che del Picenum erano state interessate sin dalle prime fasi dello stanziamento ostrogoto in Italia di un notevole insediamento di guarnigioni, acquartierate in diversi centri d'altura a guardia della viabilità di valle. ${ }^{20}$ Sia nella prima che nella seconda fase, l'Italia centrale fu quindi ampiamente coinvolta nel conflitto; la presenza di diverse grandi città come Roma, Firenze, Rimini e Ravenna, unite al gran numero di castra che difendevano la viabilità, obbligò necessariamente entrambi gli schieramenti a una lunga serie di assedi ed espugnazioni, necessari, da un lato, a tagliare le comunicazioni tra Roma e Ravenna e dall'altro a stabilire il controllo sui percorsi che collegavano l'area tirrenica a quella adriatica.

A Nord, invece, la guerra ebbe un impatto generalmente più limitato. Nella prima fase i Bizantini riuscirono a occupare nel 538 Milano e i castra della zona, ottenendo in questo modo il controllo di gran parte della pianura padana centro-occidentale. Tuttavia, nello stesso anno, l'assedio congiunto posto alla città dalle forze ostrogote e burgunde costrinse le guarnigioni imperiali a ripiegare a Sud del Po, attestandosi per tutta la guerra lungo una linea difensiva che, partendo dai castra delle Alpes Cottiae, passava per l'area tortonese e seguiva il corso del Po fino alla sua foce. ${ }^{21}$

Anche nel Nord-Est i Bizantini non riuscirono a stabilire un controllo durevole sul territorio: nel 540 Belisario inviò truppe oltre il Po con lo scopo di prendere il controllo delle due sponde del fiume e rendere difficoltosi i rifornimenti ostrogoti diretti a Ravenna. All'indomani della presa della capitale, nel 540, diverse città, come Treviso, trattarono la resa con gli imperiali, ma l'elezione di Ildibado e poi quella di Totila riuscirono, tra il 541 e il 542, a ricompattare gli Ostrogoti. Il fallito tentativo di occupare Verona, impedì ai Bizantini di consolidare la presenza nel Nord-Est fino alla conclusione della guerra, limitando il controllo imperiale alla sola fascia costiera del Veneto che collegava Ravenna all'Istria e alla Dalmazia attraverso la via Popilia. Proprio da qui, nel 552, l'armata comandata da Narsete fu costretta a passare per evitare le forze franco-gote che controllavano la via Postumia. Nella seconda fase, dunque, la pianura padana rimase poco coinvolta nelle vicende belliche, perché gli Ostrogoti, riorganizzata la capitale a Pavia, mantennero il controllo di tutta la rete di fortificazione alpina e della viabilità principale che la collegava fin oltre la fine del conflitto, anche se gran parte dell'area fu progressivamente ceduta da Totila ai Franchi in cambio del loro aiuto militare.

Dalla ricostruzione delle vicende riportate da Procopio e dalla loro trasposizione in mappe diacroniche si evince piuttosto chiaramente come la guerra greco-gotica sia stata un conflitto sicuramente lungo, ma che interessò in maniera discontinua il territorio italiano solo a un livello sub-regionale, concentrando la maggioranza degli episodi bellici nei territori intorno alle città, ai kastra e ai phrouria che mantenevano uno stretto rapporto con le principali vie di comunicazione fluviali, marittime e terrestri (fig. 6-8).

In questo, la guerra greco-gotica non differisce in alcun modo da ogni altro conflitto antico: l'organizzazione di ogni campagna militare, affinché avesse successo, doveva necessariamente garantire a chi la intraprendeva un guadagno in termini economici a fronte delle spese previste, mantenendo economicamente ed ecologicamente sostenibile il peso che l'invio di un corpo militare a grande distanza costituiva per uno Stato. In termini di guadagno, una guerra vittoriosa poteva fornire diversi profitti: il primo, contingente, era 

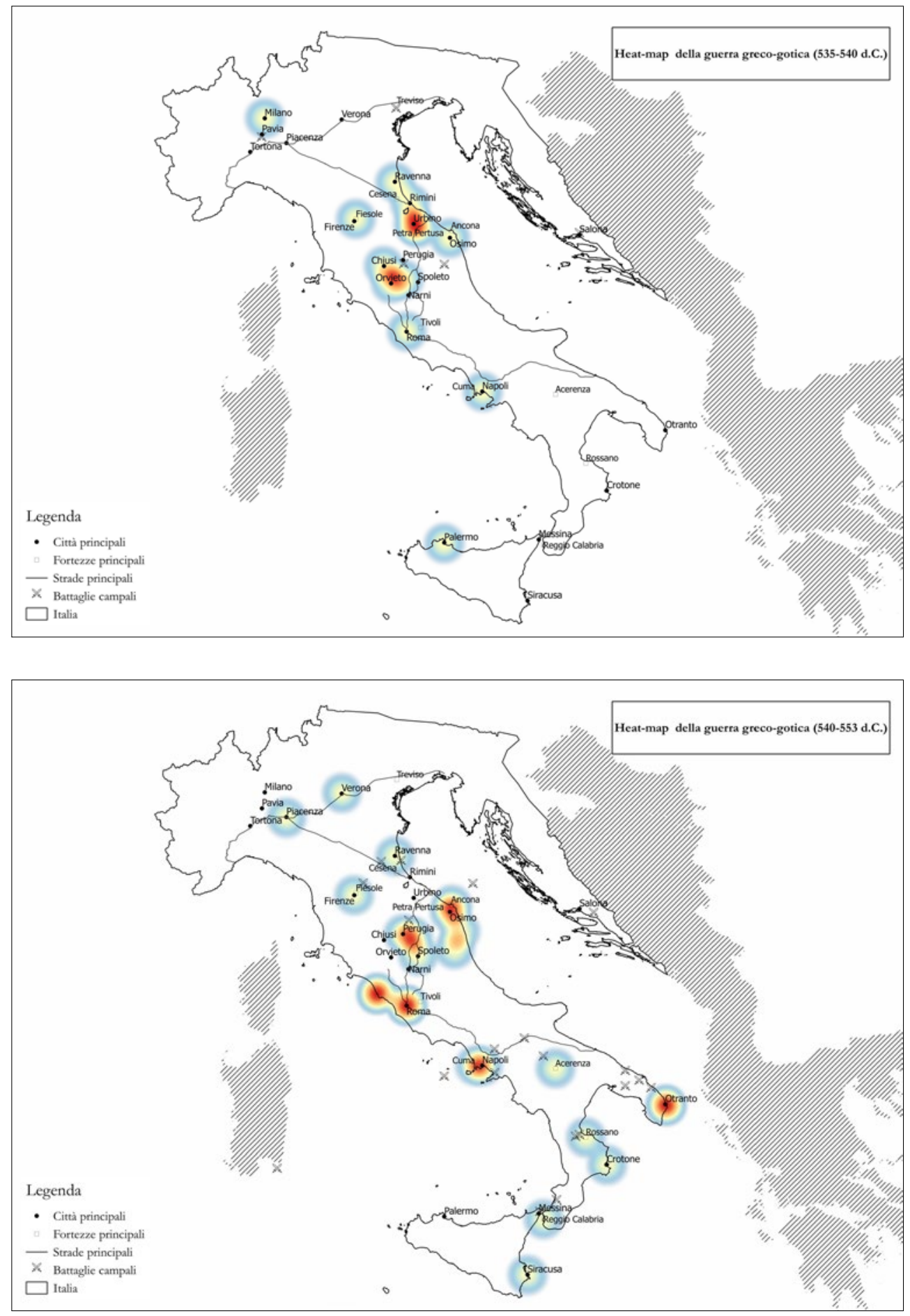

Figura 6. Mappa di densità del conflitto nel periodo 535-540.

FIgURA 7. Mappa di densità del conflitto nel periodo $540-552-$ 553. quello costituito dai bottini frutto del saccheggio; il secondo invece, più a lungo termine, era dato dallo sfruttamento fiscale dei territori occupati. ${ }^{22}$ Per quanto riguarda la sostenibilità economica della spedizione, il principale problema era legato all'approvvigionamento dell'esercito: questo imponeva che una volta uscito dal proprio territorio, dove poteva avvalersi di un sistema di approvvi- gionamento collaudato e organizzato, l'esercito fosse costretto a sfruttare il territorio in cui si trovava. $^{23}$

Ne consegue, dunque, che anche in Italia il modo migliore per i Bizantini di soddisfare questi obbiettivi fosse quello di concentrare gli sforzi militari nella conquista di quelle zone della penisola caratterizzate dalla presenza di grandi centri ur- 




Figura 8. Mappa

di densità generale della guerra grecogotica $(535-552-$ $553)$. bani e di vie di comunicazione marine e terrestri. Le città infatti costituivano ancora le basi dell'organizzazione fiscale, nelle quali si concentravano ingenti risorse economiche sia in termini di bottino che di entrate fiscali. In secondo luogo, possedevano un territorio organizzato e dipendente da esse che poteva fornire il necessario sostentamento alle armate. ${ }^{24}$ Le risorse accumulate, dunque, potevano poi essere spostate da un fronte all'altro attraverso le strade o i porti, facilitando e velocizzando sia i rifornimenti che le comunicazioni. ${ }^{25}$ Non sorprende dunque che gran parte degli episodi della guerra greco-gotica coinvolgano grandi città, come Napoli e Roma, diversi centri portuali e tre principali arterie viarie come l'Appia, la Flaminia e l'Emilia. La conquista e la difesa di questi tre elementi costituivano le basi necessarie sia a stabilire un controllo territoriale efficiente sia, in termini più pratici, a garantire il successo di una campagna militare.

Se la conquista e il controllo di queste aree era di vitale importanza per il successo della campagna militare risulta chiaro come, sia nella prima che nella seconda fase, gran parte degli episodi bellici insistettero sui grandi centri urbani e su quelli posti a difesa della rete viaria della penisola, allargandosi solo dopo il 540 anche verso alcuni centri portuali meridionali che assunsero con i Bizantini il ruolo di snodi marittimi di collegamento tra la neonata prefettura e il resto dell'impero.
Tuttavia, sebbene i fenomeni di distruzione imputabili alla guerra risultino archeologicamente più evidenti rispetto a quelli di conservazione, ${ }^{26}$ anche nelle aree coinvolte più a lungo la guerra non costituì un ininterrotto periodo di crisi, soprattutto a causa della stagionalità delle campagne militari e dell'intermittenza con cui i centri e i loro territori vennero coinvolti. Alle fasi di assedi e scontri, che indubbiamente causarono danni alle infrastrutture urbane stressando economicamente le strutture produttive e la loro organizzazione a livello locale, si alternarono altri periodi di stasi del conflitto in cui fu possibile alle forze occupanti ricostruire e riorganizzare quanto danneggiato durante la guerra.

\section{Pars quaerens}

Dall'analisi GIS emergono dunque con chiarezza alcuni elementi su cui, nel prosieguo del nostro progetto, varrà la pena di sviluppare la riflessione.

Il primo punto è la natura della guerra. Le dinamiche narrate da Procopio rendono evidente che la guerra greco-gotica segna, al suo interno, un punto di mutamento in qualche misura «epocale»: nella prima fase siamo di fronte a una guerra tutto sommato tradizionale, che vede due eser- 
citi contrapposti, non così diversi l'uno dall'altro, che si muovono su un terreno unitario - la penisola italiana - seguendo una linea di fronte determinata dalla avanzata degli uni e dalla ritirata degli altri. Questo scenario sembra cambiare radicalmente nel secondo periodo della guerra, quello che va dal 540 in poi, quando la strategia dello scontro ripetuto fra eserciti contrapposti lascia lo spazio a una prima frammentazione dei fronti, con una progressiva localizzazione degli scontri.

Si tratta di una guerra di tipo sostanzialmente nuovo, almeno per la tradizione militare bizantina, che preannuncia già la tipologia di conflitto che caratterizzerà di lì a qualche decennio la guerra di contrasto alla migrazione longobarda e che si estenderà progressivamente anche ad altri fronti. Si tratta, in altri termini della prima comparsa di una nuova strategia operativa che andrà in seguito consolidandosi come prassi e che finirà per divenire nel giro di alcuni decenni una norma nella trattatistica militare bizantina. ${ }^{27}$

Il secondo punto, strettamente connesso al primo, è la possibilità di valutare l'impatto potenziale di queste due tipologie di operazioni militari sul territorio interessato. Nella prima fase della guerra, il fronte si muove rapidamente e i momenti di confronto, con annesse distruzioni, sono una questione fondamentalmente militare: battaglie in campo aperto o assedi di singole città o impianti fortificati. In questo contesto, a maggior ragione se a prevalere negli assedi sono le truppe imperiali che non hanno ovviamente alcun interesse a esercitare forme di saccheggio nei confronti delle città conquistate, sembrerebbe ragionevole immaginare un impatto distruttivo relativamente basso e concentrato comunque in pochi punti.

In operazioni militari di questo tipo, che seguono dunque le regole tradizionali della gestione di un esercito in campagna, il maggior impatto sui territori attraversati dal passaggio del fronte dovrebbe essere quello relativo al sostentamento delle truppe in movimento, in particolare di quelle bizantine che non potevano contare sulla rete di punti di rifornimento di cui certamente disponeva l'esercito goto $^{28}$ e che potevano appoggiarsi solo in misura limitata su un sistema di vettovagliamento su lunga distanza. ${ }^{29}$

Il passaggio, per quanto rapido, di un fronte di guerra e di un esercito in campagna aveva certamente un impatto rilevante sulla microeconomia di un territorio, sia in termini di difficoltà poste allo svolgimento delle normali attività agricole, sia in termini di risorse che venivano drenate in misura rilevante, presumibilmente con forme di tassazione diretta straordinaria, dal territorio stesso. La somma di questi due elementi, in un'epoca in cui comunque la produzione agricola arrivava a coprire a malapena i fabbisogni della popolazione e non era in grado di generare surplus da utilizzare per sopperire a eventuali difficoltà, si traduceva certamente in un peso senz'altro significativo per le popolazioni locali. ${ }^{30}$ Ma si tratta di una difficoltà economica contingente di cui appare estremamente improbabile pensare di riuscire a cogliere delle tracce archeologiche, in assenza di indicatori di attività economica in grado di registrare variazioni così rapide nel tempo. ${ }^{31}$

Del tutto diversa appare la situazione nella seconda parte della guerra, dove la localizzazione del conflitto e il prolungarsi, o il ripetersi, di operazioni su territori relativamente limitati creò certamente le condizioni per il verificarsi di eventi distruttivi ai danni del patrimonio monumentale o comunque dei nuclei insediativi di singoli territori, determinando una visibilità archeologica della guerra teoricamente assai più concreta.

In questa prospettiva diviene quindi vitale arrivare a determinare con la maggior precisione possibile quali siano stati di volta in volta i territori effettivamente coinvolti nelle operazioni e su questo punto sarà dunque decisivo il confronto tra le mappature costruite sulla base del testo di Procopio e quelle dei siti in cui le tracce di eventi distruttivi sono state ipoteticamente collegate alle vicende della guerra. Su questo aspetto, come si è già detto, il progetto non è che agli inizi e il lavoro fin qui svolto costituisce solo il prerequisito indispensabile per poter approfondire l'analisi.

Il terzo punto di riflessione riguarda un aspetto particolare del rapporto costi-benefici che ogni

27. Dennis 1985; Haldon 2014.

28. Zanini 2014, 439.

29. Haldon $2010 a$.

30. In un interessantissimo lavoro recente John Haldon (2011) ha cercato di valutare l'impatto economico della spedizione bizantina nella campagna che condusse alla disastrosa battaglia di Mantzikert, rappresentandone graficamente gli areali su una base geografica.

31. Paradossalmente, l'indicatore di attività economica più sensibile, le monete, potrebbe teoricamente registrare un dato inverso, giacché è ampiamente probabile che il passaggio o la permanenza di un esercito su un territorio abbia prodotto un aumento di circolazione monetaria (legata all'arrivo delle paghe dei soldati e alle diverse forme di loro microridistribuzione sul territorio) anziché una diminuzione. Ma si tratta ovviamente di una pura speculazione teorica, dato che è estremamente improbabile imbattersi in un contesto archeologico in grado di restituire una informazione così raffinata riguardo la circolazione monetaria. 
guerra porta necessariamente con sé. Che ogni guerra determini un mutamento degli assetti economici di un territorio e che ciò non comporti necessariamente solo elementi negativi è un dato consolidato. E questo aspetto appare, almeno nella mia percezione, particolarmente rilevante proprio nel caso della GGG, che determinò certamente grandi difficoltà nei territori che furono di volta in volta teatro del conflitto, ma che in linea generale e nel medio periodo determinò anche un indubbio beneficio economico per molte regioni della penisola italiana, la cui inclusione nel sistema macroeconomico bizantino è alla base di una loro maggiore resilienza al rapido deperimento delle condizioni di benessere che caratterizza l'Occidente mediterraneo tra VI e VII secolo.

Alla fine di una guerra lunga e per molti versi disastrosa, l'Italia divenne una provincia, sì di frontiera, ma tutt'altro che "periferica» nel sistema mediterraneo bizantino dell'età di Giustinia$n^{32}$ e questo le assicurò - o almeno assicurò ad alcune regioni della penisola ritenute più importanti dall'amministrazione centrale di Costantinopoli - un afflusso tutt'altro che irrilevante di risorse legate alla complessa struttura economica e amministrativa dell'impero e alla presenza sul territorio delle élites che la gestivano. ${ }^{33}$

Gli indicatori archeologici che parlano di una differenza strutturale dell'economia delle regioni dell'Italia bizantina rispetto a quelle che non entrarono di fatto mai sotto il controllo effettivo di Costantinopoli $-\mathrm{o}$ che vi rimasero solo per qualche decennio fino all'invasione longobarda-, non sono altro in buona sostanza che il prodotto ultimo, nel medio periodo, proprio della GGG, che fu il momento in cui si disegnò una nuova geografia amministrativa dell'Italia. ${ }^{34}$ Una geografia fatta di regioni che vennero conquistate rapidamente e mai più rimesse in discussione (la Sicilia e buona parte dell'Italia meridionale, la costa adriatica fino a Ravenna) e che rappresentarono il cardine economico del ruolo della provincia italica nel contesto mediterraneo bizantino. Una geografia fatta anche di territori che fin dai tempi della guerra sembrano essere destinati ad essere sacrificati, come l'Italia a Nord del Po, che appare prima quasi concessa agli Ostrogoti, poi usata come area cuscinetto e possibile merce di scambio nei confronti dei Franchi e infine lasciata quasi senza colpo ferire ai Longobardi. E una geografia fatta anche di un terzo tipo di territori, su cui torneremo però fra un momento.
Per concludere, almeno provvisoriamente, la questione del rapporto costi-benefici è infatti opportuno sottolineare come le due distinte fasi della GGG costituiscano un modello profondamente diverso anche da questo punto di vista. Caratteristica della guerra nel mondo antico è quella di avere un rapporto costi-benefici sempre territorialmente sbilanciato, nel senso che a pagare $\mathrm{i}$ costi, in termini microeconomici, sono, nella fase del conflitto, territori specifici più o meno limitati in tempi più o meno circoscritti, mentre a godere degli eventuali benefici in termini macroeconomici sono invece territori assai più estesi e per tempi assai più lunghi.

Così è chiaramente anche per la GGG, giacché i benefici macroeconomici riguardarono gran parte della penisola o almeno alcune grandi regioni per un periodo di tempo relativamente lungo, mentre i costi microeconomici vennero sopportati da centri o territori circoscritti. A fare la differenza, anche in questo caso, fu proprio la localizzazione del conflitto nella lunga seconda fase, in cui per alcuni territori la guerra ebbe un costo assai più pesante che non in altri, e in cui quindi un teorico rapporto costi-benefici appare nettamente più sbilanciato a favore dei primi rispetto ai secondi.

Su questa considerazione si aggancia anche il quarto e ultimo punto di riflessione, che è relativo a un'ipotesi di lavoro ancora tutta da verificare, ma che vale la pena di accennare almeno in conclusione. Una volta ottenuta la mappa di densità della seconda fase della GGG è facile verificare che essa coincida in larga misura con le mappe - assai più rudimentali, perché prodotte in un'epoca antecedente alla diffusione delle applicazioni GIS in archeologia - del conflitto bizantino-longobardo tra la seconda metà del VI e la fine del VII secolo. ${ }^{35}$

Come si accennava appena sopra, accanto alle due Italie - bizantina e longobarda - ormai consolidate nella storia degli studi, e forse all'interno delle tante Italie bizantine disegnate in un mio lavoro di ormai venti anni fa, sembra di poter cogliere l'esistenza di un'ulteriore Italia: un'Italia delle regioni «lungamente contese», essenzialmente quelle a ridosso del corridoio della Flaminia, che costituiva il cordone ombelicale che congiungeva i due centri del potere nell'Italia bizantina, Roma e Ravenna.

Forse si tratta solo di una distorsione determinata dalle fonti che abbiamo a disposizione, giacché non possiamo ignorare che in entrambi i casi - Procopio per la GGG e Gregorio Magno per 
la guerra bizantino-longobarda - si tratta di fonti che possono aver privilegiato notizie ritenute più rilevanti rispetto ad altre nella prospettiva di una geografia del potere; e per questo sarà dunque essenziale la comparazione con i dati archeologici per provare a valutarne l'attendibilità anche su base statistica.

Ma se questa, che al momento è solo un'impressione generata dalla sovrapposizione visiva di carte, trovasse una sua validazione ci troveremmo di fronte a un altro interessante elemento di riflessione a proposito della complicata geografia dell'Italia altomedievale, una geografia fatta non solo di aspetti fisici e di aree soggette a diverse amministrazioni, ma anche di aree che nel medio periodo assunsero una connotazione specifica come luoghi di frontiera interna a un territorio, che noi continuiamo spesso a percepire come unitario, ma che lo fu probabilmente assai meno di quanto ci appaia.

[E. Z.]

\section{Bibliografia}

Aprosio, M. 2005: «Paesaggi tardoantichi di Brindisi», in: Paesaggi e insediamenti rurali in Italia meridionale fra tardoantico e altomedioevo, Bari, 443-454.

ARCURI, R. 2008: «La Calabria nella guerra gotica di Procopio di Cesarea», Koinonia 32, 41-87.

Arthur, P. 2004: «From Vicus to Village: italian landscapes, AD 400-1000», in: CHristie, N. (ed.), Landscapes of Change: Rural Evolutions in Late Antiquity and the Early Middle Ages, Aldershot-Burlington, 103-133.

BoccI, S. 1996: L'Umbria nel Bellum Gothicum di Procopio, Roma.

Brogiolo, G. P. 2000: «Towns, forts and the countryside: archaeological models for northern Italy in the early Lombard period (AD 568650)», in: Brogiolo, G. P.; Gauthier, N.; ChrisTIE, N. (eds.), Towns and their Territories between Late Antiquity and the Early Middle Ages, Leiden-Boston-Köln, 299-323.

CACciaguerra, G. 2009: «Dinamiche insediative in Sicilia tra v e $\mathrm{x}$ secolo: tre contesti a confronto nell'area megarese», in: Atti del V Congresso Nazionale di Archeologia Medievale, Firenze, 296-301.

Cameron, A. 1985: Procopius and the sixth century, London.

Colvin, I. 2013: «Reporting battles and understanding campaigns in Procopius and Agathias: classicising historians' use of archived documents and sources», in: Sarantis, A.; Christie, N. (eds.), War and Warfare in Late Antiquity
(Late Antique Archaeology 8.2), Leiden-Boston, 571-596.

CRACCO RUGGINI, L. 1995: Economia e società nell'Italia annonaria: rapporti tra agricoltura e commercio dal IV al vi secolo d.C., Bari.

Dell'Osso, C. 2018: Procopio di Cesarea. Gli edifici, Città del Vaticano.

DenNIs, G. T. 1985: Three Byzantine military treatises, Washington (DC).

Haldon, J. 2010: "The Army and Military Logistics», in Stephenson, P. (ed.), The Byzantine World, London - New York, 47-60.

Haldon, J. 2011: «Marching across Anatolia: Medieval Logistics and Modeling the Mantzikert Campaign», Dumbarton Oaks Papers 65/66, 209-235.

HaLdon, J. F. 2014: A critical commentary on the Taktika of Leo VI, Washington (DC).

Kouroumali, M. 2013: «The Justinianic Reconquest of Italy: Imperial Campaigns and Local Responses», in: Sarantis, A.; Christie, N. (eds.), War and Warfare in Late Antiquity (Late Antique Archaeology 8.1), Leiden-Boston, 969-1000.

Lee, A. D. 2007: War in Late Antiquity: A Social History (Ancient World at War), Malden-Oxford-Victoria.

Lillington-Martin, C. 2013: "Procopius on the Struggle of Dara in 530 and Rome in 537-38: Reconciling Texts and Landscapes», in: SARANTIS, A.; Christie, N. (eds), War and Warfare in Late Antiquity (Late Antique Archeology 8.2), Leiden-Boston, 599-630.

Lillington-Martin, C.; Turouois, E. (eds.) 2018: Procopius of Caesarea: Literary and Historical Interpretations, Abingdon - New York.

Noyé, G. 2006: «Le città calabresi dal IV al vII secolo», in: Le città italiane tra la tarda antichità e l'alto medioevo, Firenze, 477-517.

Petersen, L. I. R. 2013: Siege Warfare and Military Organization in the Successors States (400-800 $A D)$ : Byzantium, the West and Islam (History of Warfare), Leiden-Boston.

Porena, P. 2012: L'insediamento degli Ostrogoti in Italia, Roma.

RaVEGNANI, G. 2004a: I Bizantini in Italia, Bologna. RAVEGNANI, G. 2004b: I Bizantini e la guerra, Roma. Roma, G. 2005: «Paesaggi della Calabria tardoantica e medievale: fonti scritte e documentazione archeologica», in: Paesaggi e insediamenti rurali in Italia meridionale fra tardoantico e altomedioevo, Bari, 585-608.

Roueché, C.; Carrié, J. -M.; Duval, N. (eds.). 2000: De aedificiis: le texte de Procope et les réalités (Actes du colloque de Londres, 25-26 septembre 1998), Turnhout-Parigi.

SAVINO, E. 2005: Campania tardoantica, Bari. 
Tione, R. 2005: «Tarda antichità e alto medioevo nel tortonese: primi risultati di una ricerca in corso", in: Dopo la fine delle ville: le campagne dal vi al IX secolo, Mantova, 105-129.

VolPe, G. 2005: «Paesaggi e insediamenti rurali dell'Apulia tardoantica e altomedievale», in: Paesaggi e insediamenti rurali in Italia meridionale fra tardoantico e altomedioevo, Bari, 299314.

ZaninI, E. 1998: Le Italie bizantine. Territorio, insediamenti ed economia nella provincia bizantina d'Italia (VI-VIII secolo), Bari.

ZANINI, E. 2003: «La ceramica bizantina in Italia tra VI e VIII secolo. Un sistema informativo territoriale per lo studio della distribuzione e del consumo», in: Actes du VIIe Congrès International sur la céramique médiévale en Méditerranée, Salonicco, 381-394.

ZANINI, E. 2010: «L'arte di costruire presso i Bizantini. L'apporto delle fonti scritte alla conoscenza dei processi costruttivi», in: Camporeale, S.; Dessales, H.; Pizzo, A. (eds.), Arqueología de la construcción II. Los procesos constructivos en el mundo romano: Italia y provincias orientales. Madrid-Mérida, 265-280.

ZANINI, E. 2014: «Economia dell'Italia bizantina e indicatori archeologici: qualche ulteriore riflessione», Cahiers de Recherches Médiévales et Humanistes 28(2), 431-458. 


\title{
LA CIVITAS VISIGODA DE RODA-L'ESQUERDA: LA FORTALESA I EL TERRITORI DEL RIU TER
}

\author{
Albert Pratdesaba i Sala, ${ }^{1}$ Imma Ollich i Castanyer ${ }^{2}$
}

\section{Resum}

Les campanyes d'excavació arqueològica realitzades des del 2012 al jaciment de l'Esquerda han posat al descobert tot el traçat de tancament emmurallat del període medieval. Els materials arqueològics recuperats, l'estudi de l'estratigrafia, la datació per radiocarboni i l'anàlisi de paraments han pogut determinar que la muralla va ser construïda durant el període visigòtic. La posició militarment estratègica, el control de les vies de comunicació i la seva relació amb la seu episcopal d'Auso (Vic) van fer de l'indret un lloc perfecte per construir i fortificar la Roda Ciutat del període visigòtic. Tot i que va tenir una continuïtat d'ocupació durant el període carolingi i feudal fins al segle XIV dC, la funcionalitat inicial ens queda encara difusa entre la possibilitat d'un emplaçament fortificat durant la revolta del Dux Paulus al segle vir dC i la creació d'un centre de poder aristocràtic paral.lel al religiós, a l'espera que futures intervencions puguin aportar nous coneixements.

\begin{abstract}
The archaeological fieldwork carried out since 2012 at l'Esquerda has revealed the full length of the medieval town wall. From the archaeological remains, the stratigraphic study, the radiocarbon dating and an analysis of the wall it has been possible to determine that the town wall was built during the Visigoth period. The strategic location, control of the roads and link to the Holy See of Auso (Vic) makes it a perfect position to build and fortify the Roda Civitas of the Visigoth period. The fortified settlement was reused during the Carolingian and the feudal periods until the $14^{\text {th }}$ century. This investigation considers two options: the first, that the fortified settlement was built during the Dux Paulus riot in the $7^{\text {th }}$ century, and the second, that it was the establishment of an aristocratic central place in parallel to the religious power.
\end{abstract}




\section{Introducció}

L'actual jaciment arqueològic de l'Esquerda es troba ubicat en un dels meandres del riu Ter al seu pas per la comarca d'Osona.

L'indret on se situa l'Esquerda va ser triat indubtablement, des de l'inici de l'ocupació humana de la Plana de Vic, per la seva situació estratègica a l'interior d'un meandre encaixat del riu Ter, just quan el riu deixa la Plana per travessar la Serralada Transversal Catalana pel massís de les Guilleries. Aquesta situació, rodejada per l'est, el sud i l'oest de penya-segats i pendents molt pronunciats, va facilitar de manera clara la tasca defensiva de l'emplaçament, que va esdevenir un nucli fortificat des d'època ibèrica fins al període feudal.

Des d'aquest mateix lloc es té un control visual sobre la major part de la Plana de Vic, i especialment dels dos eixos de comunicació: la Strata Francisca i el camí ral Vic-Olot.

\section{Fases històriques}

Fins a deu etapes d'ocupació, s'han pogut reconèixer al jaciment de l'Esquerda. En els seus orígens (fase 1) es tracta d'un assentament format per cabanes circulars amb parets de terra i fusta, que es pot datar cap al segle VIII-VII aC, a la fi de l'edat del bronze. L'assentament evoluciona amb l'arribada dels productes, les tècniques i les idees que porten els pobles colonitzadors a partir del segle vi aC, com la metal-lúrgia del ferro o el torn de terrissaire (fase 2). Entre els segles v i III aC, l'assentament es transforma en un gran oppidum fortificat, amb un urbanisme planificat i una organització econòmica i social evident (fase 3). És en aquest període que trobem ja un territori ausetà organitzat en el qual l'Esquerda participa plenament.

Vers la fi del segle III aC, l'Esquerda, com totes les altres fortaleses ausetanes, reforça les seves defenses, com a preludi de la seva participació en la Segona Guerra Púnica com a aliada dels cartaginesos, i posteriorment en els successius aixecaments del poble ausetà contra els nous invasors a inicis del segle II aC (fase 4). Aquest episodi convuls acabarà amb l'enderrocament de totes les estructures defensives de la fortalesa. Malgrat aquesta destrucció, l'assentament va seguir ocupat fins al segle $\mathrm{I} \mathrm{aC}$, durant el període iberoromà (fase 5).

És molt significatiu l'abandonament de l'oppidum ausetà a inicis de l'època imperial romana, coincidint amb el moment de reorganització del territori impulsada per l'emperador August, i que va portar a la fundació de la ciutat d'Auso, a Vic (fase 6). A partir de la crisi baiximperial, però, l'Esquerda torna a ser ocupada en les èpoques visigòtica (fase 7) i carolíngia (fase 8), fins a esdevenir un poblat feudal (fases 9 i 10) que perviurà fins a la seva destrucció l'any 1314 (Rocafiguera et al. en premsa).

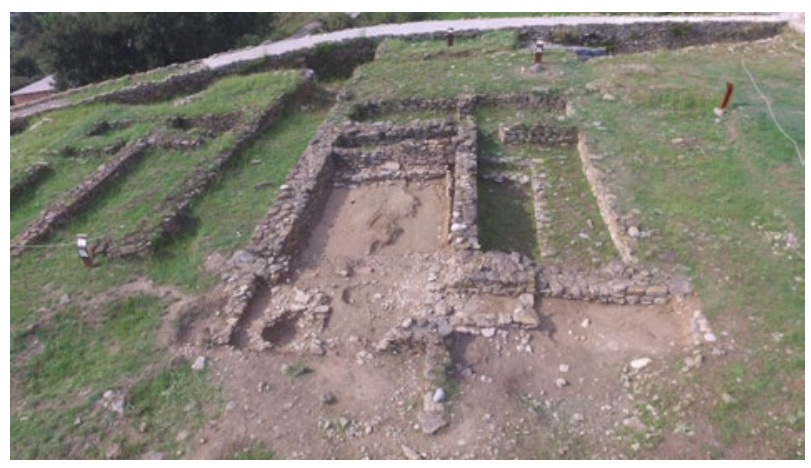

Figura 1. Vista aèria de les estances ibèriques (foto: Museu Arqueològic de l'Esquerda).

\section{Els antecedents de la fortificació medie- val}

Si bé fins avui dia no podem definir amb precisió l'existència d'una fortificació del període del Bronze Final o del Primer Ferro, les excavacions realitzades han pogut determinar que s'hauria construitt una primera fortificació durant el període ibèric entorn dels segles VI-V aC (Mestres 2017). Aquesta construcció estaria formada, com a mínim, per tres torres massisses de pedra, de 5 per 11 metres de costat $\mathrm{i}$ alçats de tàpia, amb petites estances posteriors o armora, que servirien com a cossos de guàrdia i accessos a la part superior de les torres. Aquesta primera fortificació hauria estat destruïda durant el segle III aC en el context de les Guerres Púniques, ja que els ausetans haurien format part del contingent aliat de les forces cartagineses. A partir d'aquest moment, es documenta una fase de reconstrucció de la fortalesa entorn del segle II aC. La reforma consistiria en la unió entre torres de murs atalussats de pedra local lligada amb fang, similar a les construccions ibèriques del Tolmo de Minateda (Gutiérrez i Abad 2002). Aquesta, però, no durarà més enllà del segle II aC, amb la romanització del territori. Les diverses intervencions realitzades a la muralla entre 2011 i 2018 han permès documentar que la muralla ibèrica estaria formada per un basament de pedra i un alçat murari de tàpia o tovot, amb reforços puntuals a les cantonades de les torres.

Aquesta muralla, ubicada a la zona nord del jaciment, tancaria el poblat ibèric en el seu interior, i quedaria protegit per la resta de costats pel mateix riu i pels cingles de més de 50 metres. 


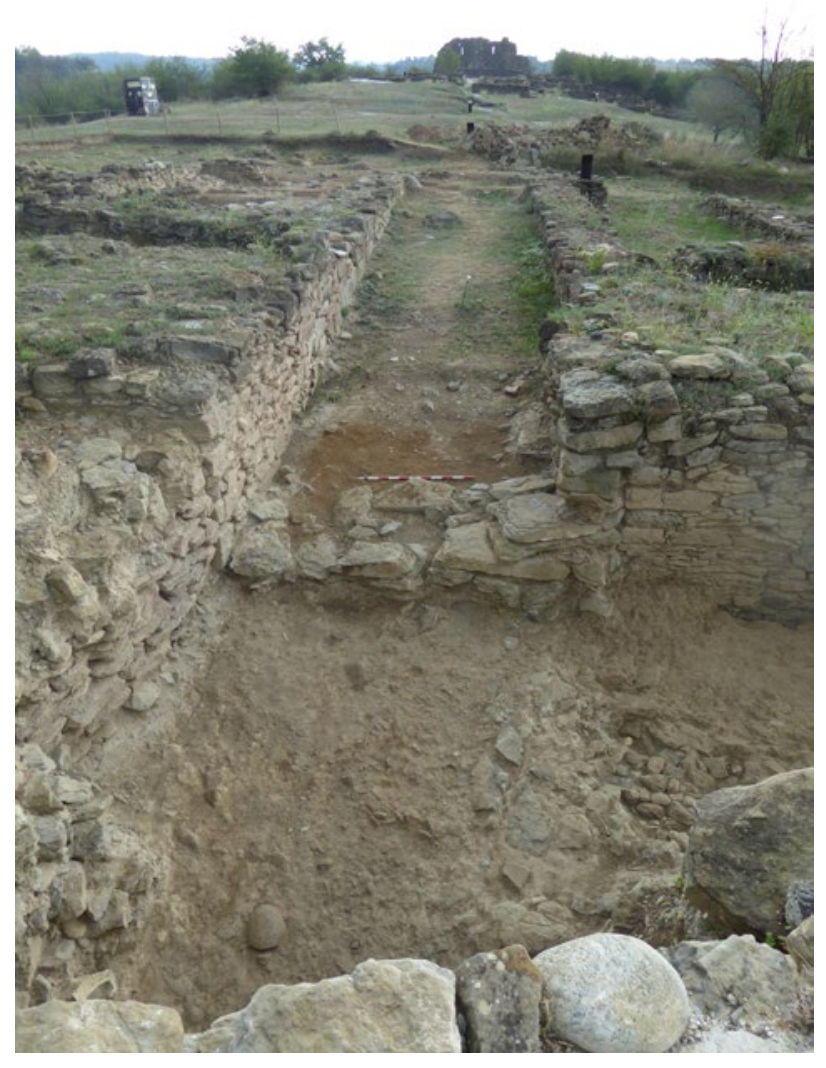

Figura 2. Vista de l'entrada a l'oppidum ibèric, amb una porta flanquejada per dues torres (foto: Museu Arqueològic de l'Esquerda).

Les intervencions de 2013 i 2014 van documentar dues estructures muràries avançades, a l'exterior del perímetre emmurallat i just davant de la porta d'accés. Aquests dos murs limitarien i canalitzarien l'accés a la porta en direcció nord-est - sudoest. Trobem exemples similars d'aquests murs al Castellet de Banyoles (Tivissa, Ribera d'Ebre) (Sanmartí et al. 2012) i a Ullastret (Alt Empordà) (De Prado 2010).

\section{Els elements del període visigòtic}

Després d'un hiatus d'ocupació corresponent al període romà, l'emplaçament actualment conegut com a l'Esquerda es torna a ocupar durant el període visigòtic. En aquest cas, els treballs arqueològics del 1992 ja van documentar un camp de sitges que alterava completament els nivells del període ibèric. Aquest camp és format per 66 fons de sitges que van ser amortitzades entre els segles VII i vIII dC.

Els materials ceràmics recuperats del seu interior són fragments de ceràmica nord-africana de cuina, sigil.lades, àmfores diverses, morters i ceràmiques reductores de producció local amb cuites irregulars, fons pla i vores en alguns casos en perfil en S. Una datació més precisa ha estat apor- tada per la troballa, a l'interior de la sitja número 16, d'un garrí en connexió anatòmica (Rocafiguera 2012). L'anàlisi radiocarbònica ha donat com a resultat una datació entre mitjans del segle vII dC i finals del segle vIII dC (cal AD 643-781 94,4\%) (Mestres 2004).



FIgura 3. Vista aèria del conjunt de la muralla i el camp de sitges sobre el sector ibèric (foto: Museu Arqueològic de l'Esquerda).

L'anàlisi dels 1.546 fragments ha permès observar com el $59 \%$ del total de fragments estudiats correspon a material d'època romana i de la tardoantiguitat, mentre que el $41 \%$ restant serien materials del període altmedieval corresponents a ceràmiques reductores o de cuita mixta (Rocafiguera 2012).

Les intervencions de 2015, 2016 i 2017, per altra banda, han aportat nombrosos fragments de fons i vores de dolia, localitzades a la zona oest, a l'interior del recinte fortificat, i que es relacionarien amb el mateix moment del camp de sitges (Ollich, Rocafiguera et al. 2018).

Per altra banda, l'excavació entre 2012 i 2013 va permetre descobrir una necròpolis extramurs, de la qual només se n'ha excavat una part (Ollich, Pratdesaba i Pujol 2014). S'han documentat 13 tombes orientades E-W, de dues tipologies: de fossa i de caixa de lloses. No s'ha recuperat cap mena d'aixovar del seu interior. Aquest conjunt presenta una barreja d'edats i sexes. La descoberta d'aquesta necròpolis va plantejar diversos dubtes, sobretot perquè anteriorment s'havia excavat una necròpolis a l'entorn de l'església amb una cronologia datada en diverses fases d'ús que aniria des del segle Ix dC fins al segle xIV dC.

La relació estratigràfica vincularia els enterraments amb el mateix moment de construcció i ús de la muralla. En aquest cas, les tombes estan tallades i construïdes directament sobre els ni- 




FIgURA 4. Vista de la tomba 268 , corresponent a una tomba de lloses d'un individu infantil de la necròpolis extramurs (foto: Museu Arqueològic de l'Esquerda). vells argilosos que corresponen a nivells de tàpia enderrocada del període ibèric, i queden cobertes pels nivells d'enderroc de pedra de la muralla del període medieval.

Les datacions radiocarbòniques de la necròpolis extramurs (Mestres 2014), però, han proporcionat una datació anterior en relació amb la que es troba a redós de l'església, datada concretament entre finals del segle vII $\mathrm{dC}$ i el segle IX dC (Ollich, Rocafiguera i Amblàs 2015).

Aquest conjunt presenta grans similituds amb una necròpolis excavada al jaciment de La Muntanyeta, situat en un turó a menys de 800 metres en línia recta del jaciment de l'Esquerda. A la necròpolis de La Muntanyeta s'hi van localitzar cinc sepultures de lloses, amb una orientació E-W (Ollich i Raurell 1989). A l'interior d'una s'hi va localitzar una sivella de ferro anular (Tomba 4), i en una altra, una sivella de bronze (Tomba 2), a la



qual li mancaria la plaqueta i que seria en forma de creu, una tipologia catalogada com a nivell $\mathrm{v}$ $(600 / 40)(710 / 20)$ i que es podria datar entorn del segle VII (Ripoll 1998, 61).

La necròpolis trobada a l'exterior de la muralla seguiria els patrons d'enterrament del període clàssic: separació del món dels vius i el dels morts, ubicació sempre a l'exterior i a tocar de les vies d'accés a les ciutats/pobles.

\section{La muralla del període visigòtic}

Les restes de la muralla es coneixien d'antic, ja que era un dels pocs elements, juntament amb la paret de l'església, que restaven a la vista de l'antic poblat de Roda Ciutat -terme amb el qual apareix aquest indret a la documentació altmedieval-, que posteriorment va esdevenir Sant Pere de Roda. Aquest fet va provocar que entorn dels anys seixanta del segle xx arqueòlegs amateurs de la Unió Excursionista de Roda excavessin la torre ubicada a llevant. Entre els anys 1981 i 1991, ja dintre de les excavacions programades per la Universitat de Barcelona des del 1977, es van fer un seguit de cales a la zona interior de la muralla que li van donar una datació inicial d'època ibèrica, ja que tots els nivells d'argiles que tocaven a la muralla contenien materials ibèrics. L'any 2011, però, la realització d'una cala de dimensions més grans va permetre observar com els nivells d'argiles es trobaven en pendent i que la muralla seguia el desnivell de l'enderroc ibèric, i que la cara interna fonamentava a més alçada que l'externa. També es va poder observar que tant l'interior de la

FIguRA 5. Detall de la sivella de bronze MART 362/0.1 (foto: Museu Arqueològic de l’Esquerda). 




Figura 6. Vista aèria del jaciment envoltat pel riu Ter i tancat per la muralla, en primer terme (foto: Museu Arqueològic de l'Esquerda).

muralla com les mateixes pedres estaven lligades amb morter de calç pobre, que a més havia sobresortit de les juntes de la cara interna fins a tocar de les argiles, creant d'aquesta manera un encofrat perdut. A partir d'aquest moment, i gràcies a la subvenció rebuda del Conveni de Caixes, l'any 2012 s'inicia l'excavació en exterior de tota la muralla. Els treballs de delimitació superficial no van ser fàcils, ja que, a 20 metres del sector de llevant, l'antiga muralla medieval es trobava camuflada entre el bosc i les feixes de cultiu. La delimitació total va acabar el 2015, i va donar com a resultat un tancament murari de més de 150 metres lineals que delimitava el poblat per la cara nord de la península, l'única part desprotegida.

Tot i que encara no s'han esgotat els nivells arqueològics ni a l'interior ni a l'exterior de la muralla, els treballs que s'han portat a terme fins avui dia han permès saber que la muralla hauria estat construïda entorn del segle vII dC, tal com hem vist anteriorment, per diversos equips treballant alhora, i això hauria donat com a resultat trams de paret amb treballs de pedra desigual (ús de diversos materials petris), juntes entre els trams molt irregulars i gruixos irregulars i escalonats segons el tram. Aquest mateix fet fa que l'amplada també oscil.li, segons el tram, entre els 2,7 i els 2,9 metres. Aquest mur es va reforçar amb una torre al sector de llevant (torre 6) que es va construir imbricada amb el mateix mur. Per contra, a la zona central de la muralla s'hi han detectat dues torres, de les quals només se'n conserva una de forma visible, i de l'altra només en restaven unes poques pedres dels fonaments d'una de les parets i es va tapar durant el procés de consolidació de la muralla.

Aquestes torres van ser construïdes seguint un sistema diferent al del sector de llevant. No es troben imbricades amb la paret defensiva, sinó que s'hi adossen. Són, per tant, posteriors a la construcció de la muralla. El que és impossible de saber ara com ara és si van passar pocs dies o bé anys. Els materials arqueològics recuperats no han permès una datació més precisa del període altmedieval. El sistema constructiu d'aquestes torres centrals és diferent al del sector est. Aquestes torres tenen una projecció exterior, però també interior, de tal manera que la muralla queda incorporada al seu interior o grapada, donant com a resultat una planta quadrangular d'uns 8 x $7 \mathrm{~m}$ de costat i uns $64 \mathrm{~m}^{2}$. La distància entre les torres és equitativa, entorn dels 15 metres. El mateix sistema constructiu es troba tant a la fortificació del Puig Rom (Roses) (Subias et al. 2018, 357-368) com a Recópolis (Guadalajara) (Gómez 2008). L'excavació dels nivells exteriors ha permès determinar que la muralla estaria formada per un sòcol de pedra local, on la part inferior presenta grans blocs barrejats amb còdols granítics de riu, tot lligat i esquerdejat amb morter de calç. Per sobre, les parets superiors serien de tàpia (Pratdesaba 2015). 


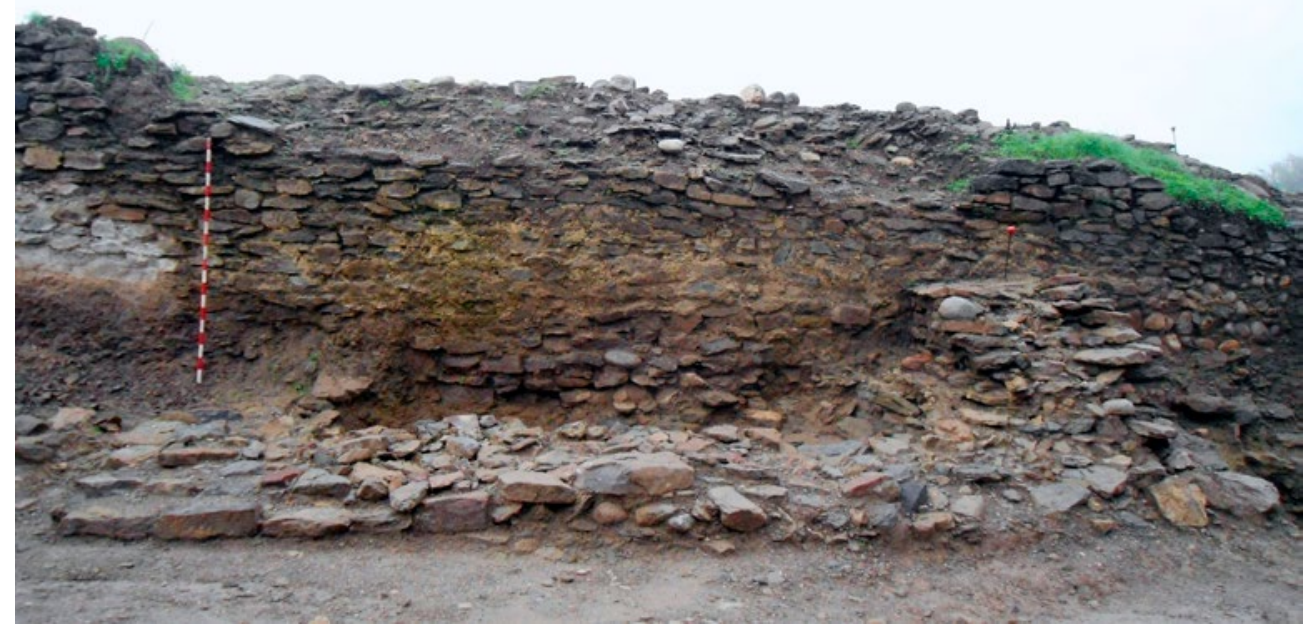

Figura 7. Vista de la projecció exterior de les restes de la torre 3 en relació amb la muralla (foto: Museu Arqueològic de l'Esquerda).
Si bé encara no s'ha trobat l'entrada principal-que creiem que estaria ubicada al sector de llevant-, es va localitzar una entrada secundària o poterna al sector de ponent. La campanya del 2018 ha permès definir que aquesta entrada hauria estat construïda en el mateix moment que es feia tota la muralla. Es tracta d'una entrada d'1,5 metres d'amplada i que es troba construïda 2 metres per sobre del nivell de circulació. L'accés a aquesta poterna es duia a terme mitjançant un camí fortificat que passava per davant de la torre 5, i el mur del camí acabava a uns 2 metres abans de la porta i en angle recte. Aquest fet fa suposar que entre el mur del camí i la porta hi hauria una estructura perible tipus pont de fusta, que en cas de setge podia ser desmuntat per dificultar-hi l'accés (Ollich, Rocafiguera et al. 2018). Caldria acabar de comparar aquesta poterna amb les recents excavacions al Puig Rom (Subias et al. 2018, 357-368) per tal de poder veure l'existència de possibles paral.lelismes.

\section{La relació de Roda Ciutat amb el seu ter- ritori durant el període visigòtic}

Com hem pogut veure, Roda Ciutat és un emplaçament fortificat d'unes 12 hectàrees ubicat en una zona estratègica a cavall entre la Plana de Vic i les Guilleries. No es tracta, però, d'un emplaçament aillat, sinó que es troba directament relacionat amb la ciutat de Vic (Ollich et al. 2019), així com amb altres indrets de la Plana on darrerament han aparegut restes del període visigòtic, fins avui dia força desconeguts.

Segons l'inventari arqueològic, figuren fins a vuit jaciments arqueològics amb una cronologia similar. La major part estan concentrats a l'entorn de Vic i fan referència a estructures d'hàbitat i em- magatzematge, com el Graell, la plaça del Pes de Vic o el Bosc del Quer. Per altra banda, ens trobem amb un elevat nombre d'enterraments aillats, sense lloc de culte associat, com els enterraments a Can Branques, el turó de La Muntanyeta, el Serrat dels Morts o el turó del Mas Atalaia del Xiprer. Aquestes evidències exemplifiquen que aquest territori estava evidentment poblat $i$ que les dinàmiques de continuïtat pobladora han desdibuixat $o$ esborrat les petjades del període visigòtic i les del període baixmedieval són més visibles.

Un altre element que cal considerar és l'advocació de l'església de l'Esquerda, dedicada a sant Pere, amb el conjunt de les seves dues esglésies sufragànies, Santa Maria del Pont i Sant Miquel de la Guàrdia, que ens remeten a la típica trilogia de les seus visigòtiques (Ollich et al. 2019).

Cal recordar que durant el període visigòtic la ciutat d'Auso -el Vicus Ausonensis medieval, actual Vic- ja era seu episcopal, tal com mostra la presència del bisbe Cinidi al Concili de Tarragona del 516. És important remarcar que durant els segles VI-VIII dC hi hauria hagut una dualitat pel que fa als centres de poder (polític i eclesiàstic), repartits entre Auso i Roda Ciutat; i cal recordar que el topònim civitas era freqüent durant el període visigòtic. Al territori català hi trobem diversos casos d'aquesta dualitat, com per exemple Urgell i Castellciutat (Sancho 2018) o Sant Julià de Ramis i Girona (Burch et al. 2005).

L'anàlisi simplista de l'estructura del jaciment de l'Esquerda, amb una muralla que tanca un poblat al seu interior, ens podria portar a pensar que es tractaria d'un castrum, però caldria recordar que es tracta d'un punt estratègic tant pel que fa a fortificació com al control de vies terrestres i fluvial, amb una extensió de més de 12 hectàrees i una relació directa amb la ciutat episcopal, a tan sols 7 quilòmetres de distància. Aquests elements 




Figura 8. Mapa amb els jaciments documentats amb cronologia d'època visigòtica a Osona (mapa: Albert Pratdesaba i Sala). són els que justificarien el topònim de Roda Ciutat que apareix a la documentació.

\section{Evidències del període carolingi i la seva relació amb els antecedents visigòtics}

Després de l'ocupació del període visigòtic, no documentem cap fase de destrucció ni d'ús fins al voltant del segle Ix dC. Les fonts escrites parlen d'aquest lloc com a Roda Ciutat (Ollich 2000), fet que ens fa pensar que, ja en el període visigòtic, aquest emplaçament es tractava d'un lloc fortificat important: una seu administrativa militar que contrastava amb una altra ciutat, en aquest cas episcopal: Vic. El nom de Roda Ciutat es mantindrà a la documentació fins que, a partir del segle XII dC, es passarà a anomenar amb el nom parroquial de Sant Pere de Roda.

Durant aquest període documentem arqueològicament la presència de l'exèrcit franc a través d'una moneda que sol aparèixer en contextos de frontera: un diner de plata del rei Lluís el Piadós (Clua, Ollich i Rocafiguera 2018) i de ceràmica espatulada (Travé 2017). Aquesta moneda no es feia servir per pagar, sinó que era una moneda de representació, gens circulada. És en aquest moment que l'emplaçament es torna a reocupar i a utilitzar, refent i modificant algunes de les parts de la muralla. Exemple d'aquest fet seria la remodelació de la torre 5, ubicada a ponent i tocant a la poterna. Durant aquesta remodelació, la torre es lliga amb la muralla i es massissa per l'interior amb blocs de pedra local. A la projecció interna de la torre es documenta un paviment de morter de calç, a diferència de la resta. És també tant a l'interior com als nivells d'enderroc exteriors associats a aquest edifici que es documenten diversos fragments de ceràmica espatulada carolíngia (Ollich, Rocafiguera i Ocaña 2016).

Al tram excavat al sector de llevant es va poder documentar el fons d'un fossat, que tallava algunes de les tombes de la necròpolis extramurs citada anteriorment. De moment no s'ha pogut delimitar tot el traçat del fossat, ja que la part central encara resta per excavar. Possiblement hauria servit de defensa avançada per impedir un accés directe als peus de la muralla. La construcció d'aquest fossat ens ajuda a delimitar una cronologia en relació amb les tombes abans descrites.

També la documentació escrita del període carolingi ens remet a la importància que hauria tingut Roda durant el període visigòtic. Els pergamins carolingis conservats citen la Roda Civitas destruïda durant la revolta d'Aissó el 826 (Annales Regni Francorum i Vita Ludovici). La continuïtat de l'ús del topònim serà una constant durant tot el segle $\mathrm{x}$ dC en tota la documentació escrita conservada a l'Arxiu i Biblioteca Episcopal de Vic.

És sabut que les civitates formen part del sistema organitzatiu visigot. Segons Balari i Jovany, a la Marca Hispànica la civitas -i concretament la civitas fracta- era la ciutat dividida en dues parts, la ciutat pròpiament dita i un suburbi o raval, que també es coneixia com a burg, vilanova o vicus (Balari 1899). Era aquest el model al qual responia la Roda Ciutat que esmenten els documents altmedievals? 
Josep Maria Font i Rius va analitzar des d'un punt de vista jurídic el concepte de civitas, entenent-la com un recinte emmurallat, amb un terme que s'estenia a fora de les seves muralles, en un espai circumdant, sense l'extensió que havia tingut el territorium de la civitas romanovisigòtica. Segons aquest autor, el terme vicus tenia el sentit de població compacta dins l'àmbit i la dependència d'una civitas, i aquest sentit continua vigent en els casos en què encara apareix al segle $\mathrm{Ix} \mathrm{dC}$, com ara Vic, Urgell i Badalona, el primer donant nom a la localitat que ha arribat fins a l'actualitat, esborrant l'antic d'Ausa o Ausona. Continuen relacionats a una civitas de la qual no estan gaire allunyats i que en alguns casos els va cedir el seu lloc i la seva importància. Esmenta els casos de Castellciutat, que té com a vicus la Seu d'Urgell, i Mataró, que tindria el seu paral.lel a Badalona (tot i que la recerca arqueològica actual indica el castell de Burriac) (Garcia i Cerdà 1990). Respecte a Vic, ens diu que «ignorem on era la seva civitas fracta (és a dir, l'antiga Ausona), que potser seria la Rota civitas (avui vila de Roda de Ter, no gaire allunyada) tan citada en els documents de l'època» (Font 1985). Altres exemples que ha aportat la recerca arqueològica actual són els conjunts de Sant Julià de Ramis amb Girona i de Roses amb Sant Martí d’Empúries (Ollich et al. 2019).

\section{Reflexions}

L'excavació de la muralla de l'Esquerda - Roda Ciutat, així com de diversos punts a través d'intervencions preventives i d'urgència, fan evident una ocupació del territori osonenc durant el període visigòtic, en un territori que fins a l'actualitat es desconeixia i tan sols se'n tenia una nota a través de la presència del bisbe Cinidi al Concili de Tarragona del 516.

La construcció d'una potent muralla en un emplaçament estratègic, tant de control territorial com militar, no és estranya en un moment d'inestabilitat i lluites constants, com és característic de la societat visigòtica.

Són molts avui dia els interrogants que no ens permeten definir de manera precisa per què es construeix una defensa entorn dels segles VII-VIII dC. El context d'inestabilitat provocada per la revolta del Dux Paulus a la zona de la Septimània va tenir la seva repercussió en una àmplia zona de la Tarraconesa entre el 671 i el 673. Possiblement, aquest fet provocà la fortificació de Roda Ciutat, intentant frenar l'avanç d'una de les branques de l'exèrcit del rei Wamba que es dirigia des de Barcino a esclafar la rebel.lió (Pratdesaba 2015). Però també caldria reflexionar sobre el fet que la pos- sible construcció del poblat fortificat respongués a una altra dinàmica, comuna també a la societat visigòtica, en aquest cas d'un poder militar aristocràtic que hauria fet de Roda Ciutat un centre de recaptació d'impostos paral.lel a l'episcopal de la seu d'Auso.

La presència dels carolingis a l'Esquerda, aprofitant i refent la muralla visigòtica, es pot associar amb una primera línia de frontera establerta al llarg del Ter pels francs a finals del segle vIII dC (Ollich 2004). Abans de la conquesta de Barcelona i de la zona del Llobregat l'any 801, l'Esquerda Roda Ciutat hauria servit com a centre de control d'una xarxa militar al llarg del Ter per defensar Girona i controlar els camins per la Plana de Vic cap als Pirineus (Ollich, Rocafiguera i Ocaña 2016).

El control es feia a través de torres de guaita de fusta encaixades a la roca i situades sobre turons i llocs alts sobre el Ter. L'anàlisi del territori ens mostra la presència d'encaixos i forats de pal en llocs clau d'alta visibilitat (Ollich, Pratdesaba et al. 2018).

El fet que l'enclavament de Roda Ciutat fos estratègic va provocar una ocupació continuada durant tot el període medieval. Les modificacions de l'ocupació del període carolingi, i posteriorment les feudals, han provocat la desfiguració de la muralla original, així com una alteració en els nivells arqueològics, aquesta última agreujada pels treballs agrícoles que s'hi van dur a terme fins a finals del segle Xx.

Actualment resta per excavar tota la franja central a l'exterior de la muralla, així com una superfície de més d'11 hectàrees a l'interior del poblat que podrien aportar noves dades sobre el poblament del període visigòtic al jaciment de l'Esquerda.

\section{Bibliografia}

BalaRi, J. 1899: Orígenes históricos de Cataluña, Barcelona, Establecimiento Tipográfico de Hijos de Jaime Jepús.

Burch, J.; Nolla, J. M.; Farahí, J.; Sagrera, J.; SuREDA, M.; Vivó, D. 2005: «El castellum de Sant Julià de Ramis (Gironès): Darreres novetats», Tribuna d'Arqueologia, 2005, vol. 2001-2002, Generalitat de Catalunya, Departament de Cultura, Barcelona, 189-205.

Clua, M.; Ollich, I.; Rocafiguera, M. 2018: «La localisation de l'atelier de Rodda à la lumière des dernières découvertes archéologiques à Roda de Ter (Catalogne)», Revue Numismatique, 175, París.

FonT, J. M. 1985: Estudis sobre els drets i institucions locals en la Catalunya Medieval. Col- 
lectànea de treballs del professor J. M. Font $i$ Rius amb motiu de la seva jubilació acadèmica, Universitat de Barcelona, Barcelona.

GARCIA, J.; CERDÀ, J. A. 1990: «Darreres actuacions arqueològiques al castell de Burriac (Cabrera de Mar. El Maresme)», Sessió d'Estudis Mataronins [en línia], 7, 61-72.

García, G.; Vivó, D. 2003: «Sant Julià de Ramis y Puig Rom: dos ejemplos de yacimientos con armamento y equipamiento militar visigodo en el noreste peninsular», Gladius, XXIII, 161190.

Gómez, A. 2008: «La muralla de Recópolis», Zona Arqueológica (Recópolis y la ciudad en época visigoda), 9, 77-86.

GutiérRez, S.; ABAD, L. 2002: «Fortificaciones urbanas altomedievales del Tolmo de Minateda (Hellín, Albacete, España): el baluarte occidental», a: Ferreira, I. C. (coord.), Mil Anos de Fortificações na Península Ibérica e no Magreb (500-1500), Edições Colibri / Câmara Municipal de Palmela, Lisboa, 133-143.

Mestres, J. S. 2004: «Datació per radiocarboni de material osteològic i carbonós procedent de l'Esquerda (Les Masies de Roda de Ter, Osona)», a: LABORATORI DE RADIOCARBONI DE LA UNIVERSITAT DE BARCELONA, L'Esquerda 2004-2005. Memòria de les intervencions arqueològiques Sector Medieval, Arxiu DGPC, Barcelona.

- 2014: «Datació per radiocarboni dels esquelets de la necròpolis extramurs», a: LABORATORI DE Radiocarboni de la Universitat de Barcelona, L'Esquerda 2014-2015. Memòria de les intervencions arqueològiques Sector Medieval, Arxiu DGPC, Barcelona.

- 2017: «Informe de datació per radiocarboni núm. 03420/2016», a: LABORATORI DE RADIOCARBONI DE LA UNIVERSITAT DE BARCELONA, L'Esquerda 2016-2017. Memòria de les intervencions arqueològiques Sector Medieval, Arxiu DGPC, Barcelona.

Ollich, I. 2000: «Roda: L'Esquerda. La ciutat carolíngia», a: Catalunya a l'època carolíngia. Art $i$ cultura als segles IX $i$ x. Catàleg de l'exposició al MNAC, Barcelona, 84-88.

- 2004: «Roda Ciutat (l'Esquerda) i la defensa de la línia del Ter al comtat d'Osona (s. VIII-X)», a: Actes del congrés «Els castells medievals a la Mediterrània nord-occidental», Ed. Museu Etnològic del Montseny, Arbúcies, 179-194.

Ollich, I.; Ocaña, M.; Pratdesaba, A.; Travé, E.; RoCAFIGUERA, M. [en premsa]: «La ceràmica medieval de l'Esquerda. Aproximació tipològica i arqueomètrica», a: Actes d'Homenatge al Dr. Alberto López Múllor, Barcelona.

Ollich, I.; Pratdesaba, A.; Pujol, M. A. 2014: Intervenció arqueològica a les Muralles de l'Esquer- da. Campanyes 2012-2013, Arxiu DGPC, Barcelona.

- 2018: Memòria de la intervenció arqueològica a l'espai entre la muralla ibèrica i la medieval, Arxiu DGPC, Barcelona.

Ollich, I.; Pratdesaba, A.; Rocafiguera, M.; Ocaña, M.; Amblàs, O.; Pujol, M. A.; Serrat, D. 2018: «The Experimental Building of a Wooden Watchtower in the Carolingian Southern Frontier», EXARC Journal Online. Issue 2018/1, $<$ https://exarc.net/issue-2018-1/ea/experimental-building-wooden-watchtower-carolingiansouthern-frontier>.

Ollich, I.; Raurell, S. 1989: "Tombes de llosa als turons de la Plana de Vic: una població altmedieval per cristianitzar?», a: Acta Historica et Archaeologica Mediaevalia, 10, Universitat de Barcelona, Barcelona, 223-250.

Ollich, I.; Rocafiguera, M.; Amblàs, O. 2015: L'Esquerda sector medieval. Memòria de les excavacions arqueològiques. Campanyes programades juny-agost 2012-2013, Arxiu DGPC, Barcelona.

Ollich, I.; Rocafiguera, M.; Amblàs, O.; PratdeSABA, A.; OCAÑA, M. 2018: "L'Esquerda sector medieval. Memòria de les excavacions arqueològiques. Campanyes programades juny-agost 2015-2016», inèdit, Arxiu Departament de Cultura de la Generalitat de Catalunya.

Ollich, I.; Rocafiguera, M.; Ocaña, M. 2016: «The Southern Carolingian Frontier in Marca Hispanica along the River Ter: Roda Civitas and the Archaeological Site of l'Esquerda (Catalonia)», a: Christie, N.; Herold, H. Fortified Settlements in Early Medieval Europe. Defended Communities of the 8th-10th Centuries, Oxbow, Oxford.

Ollich, I.; Rocafiguera, M.; Ocaña, M.; PratdesaBA, A.; Serrat, D. 2019: «De Roda Ciutat a la parròquia de Sant Pere de Roda. Evidències arqueològiques a l'Esquerda en el període inicial del Bisbat d'Osona», a: Actes del Congrés Episcopus, Vic.

Ollich, I.; Rocafiguera, M.; Pratdesaba, A. 2018: "Informe de les excavacions juny-agost 2018», inèdit, Servei d'Arqueologia, Arxiu Direcció General d'Arxius, Biblioteques, Museus i Patrimoni Cultural, Barcelona.

Prado, G. de 2010: «La fortificación ibérica del Puig de Sant Andreu (Ullastret, Cataluña): aspectos técnicos, formales y funcionales», a: Tréziny, H. (ed.). Grecs et Indigènes de la $\mathrm{Ca}$ talogne à la mer Noire. Actes des rencontres du programme européen Ramses (2006-2008), Publications du Centre Camille-Jullian, Aix-enProvence.

Pratdesaba, A. 2015: «El procés de fortificació i reocupació del territori a Catalunya entre els rius Ter i Llobregat en època altmedieval i ca- 
rolíngia: el cas de l'Esquerda, segles VIII-X», tesi doctoral de la Universitat de Barcelona, Barcelona.

Ripoll, G. 1998: Toréutica de la Bética (siglos vi y VII $d C$ ), Reial Acadèmia de Bones Lletres, Barcelona.

ROCAFIGUERA, M. 2012: «Les sitges visigòtiques del jaciment de l'Esquerda (Les Masies de Roda Osona). Memòria del treball», inèdit.

Rocafiguera, M.; Ollich, I.; Amblàs, O.; Pratdesaba, A.; Pujol, M. A.; Serrat, D. [en premsa]: «Noves fases cronològiques al jaciment de l'Esquerda», a: Actes de les IV Jornades d'Arqueologia de la Catalunya Central, Solsona, 2016.

SANCHO, M. 2018: «Apunts per a una arqueologia dels castells i fortificacions prefeudals a l'Alt Pirineu (Urgell, Pallars i Ribagorça), segles VIX», Treballs d'Arqueologia, 22, 5-28.
Sanmartí, J.; Asensio, D.; Miró, M. T.; Jornet, R. 2012: «El Castellet de Banyoles (Tivissa): Una ciudad ibérica en el curso inferior del río Ebro», Archivo Español de Arqueología, 85, CSIC, Madrid, 43-63.

Subias, E.; Puig, A. M.; Codina, D.; Fiz, J. I. 2018 : «Les campanyes del bienni 2016-2017 al nucli fortificat del Puig Rom (Roses, Alt Empordà)», a: Actes de les XIV Jornades d'Arqueologia de les Comarques de Girona. Caldes de Malavella, 1-2 juny 2018, Generalitat de Catalunya - Departament de Cultura, Girona, 357-368.

TRAvÉ, E. 2017: «Anàlisi petrogràfica de la Ceràmica Espatulada procedent del jaciment de l'Esquerda», inèdit. 


\title{
NUEVOS DATOS SOBRE LA MURALLA DE PUIG ROM (ROSES, ALT EMPORDÀ, GIRONA)
}

\author{
Eva Subias Pascual, ${ }^{1}$ Anna M. Puig Griessenberger, ${ }^{2}$ Dolors Codina Reina, ${ }^{2}$ Ignacio Fiz \\ FERNÁNDEZ ${ }^{1}$
}

\section{Resumen}

La muralla de Puig Rom supone una pieza arquitectónica clave para el período visigótico en el Alt Empordà. Nuestra investigación ha permitido alargar la vida útil del núcleo desde mediados del siglo viI hasta bien entrado el período franco y añadir a la función de control territorial y de manifestación de prestigio del castrum una perduración como núcleo agropastoral. El análisis en curso de las técnicas constructivas pone de manifiesto la destreza en la explotación de los recursos geológicos del lugar y la solidez de una construcción que apenas utiliza ligantes para la cohesión de sus elementos.

\begin{abstract}
The wall of Puig Rom is a significant architectural piece for the Visigothic period in the Alt Empordà. Our research has extended the useful life of the nucleus from the middle of the seventh century until the Frankish period and allows adding a perduration as agropastoral nucleus to the function of territorial control of the castrum. The ongoing analysis of construction techniques reveals the dexterity in the exploitation of the geological resources of the site and the strength of a construction that hardly uses mortar for the cohesion of its elements.
\end{abstract}




\section{Antecedentes}

El yacimiento de Puig Rom ha encarnado durante varias décadas la imagen del período visigodo en el nordeste peninsular. Las primeras excavaciones en el yacimiento de Puig Rom fueron llevadas a cabo en 1917 i 1918 por Joaquim Folch i Torres, a instancias de la Junta de Museus de la Mancomunitat de Catalunya. Sin embargo, fue Pere de Palol el responsable de reconocer la singularidad del yacimiento y su importancia capital para analizar el paso del mundo antiguo a la Alta Edad Media fechándolo en el siglo vII. Sus intervenciones arqueológicas, también puntuales, dieron lugar a una monografía final publicada en el 2004 que recopilaba e interpretaba todos los datos conocidos hasta entonces sobre el castrum. Entre el 2014 y el 2017 hemos retomado la excavación del yacimiento, que sigue siendo un referente en la bibliografía, con el objeto de ampliar las perspectivas de análisis y de preparar una posible musealización. ${ }^{3}$

Para referirnos al asentamiento utilizaremos el término castrum, que fue el elegido por Pere de Palol, a sabiendas de que esta denominación ya no es en la actualidad del agrado de toda la comunidad científica para designar un asentamiento en altura fortificado de la Antigüedad Tardía. ${ }^{4}$ Pero esta discusión deberá quedar en suspenso hasta tener más datos del yacimiento y del contexto arqueológico en el que aparece, puesto que en las últimas décadas la carta arqueológica se ha ampliado considerablemente. ${ }^{5}$ El objeto de nuestra comunicación es poner de relieve el valor arqueológico del elemento arquitectónico más destacable del yacimiento: su muralla. La muralla es todavía, a día de hoy, un testimonio capital para debatir la función del asentamiento, el estatus de sus promotores y su relevancia en el contexto de la transición hacia las demarcaciones político-administrativas del período tardovisigótico.

Hemos titulado nuestra comunicación «Nuevos datos sobre la muralla de Puig Rom» porque, como nuestros predecesores, nosotros también hemos querido poner énfasis en esta construcción, confiando en que un estudio más completo de sus características y relaciones estratigráficas permitiría ir más allá de las descripciones e interpretaciones formuladas previamente. Agruparemos las cuestiones principales bajo los siguientes conceptos: técnicas de puesta en obra y detalles constructivos, homogeneidad de la construcción y contexto histórico-artístico.

\section{Técnicas de puesta en obra y detalles constructivos}

Ya en 1917 Folch i Torres describió someramente la técnica de puesta en obra de la muralla y realizó un croquis de la sección del muro que muestra su concepción tripartita, con paramentos exteriores de mampostería y un relleno informe de piedras de tamaño pequeño. La campaña de Pere de Palol de 1987 permitió documentar mejor el núcleo de los muros en ocasión de la limpieza de las torres, poniendo de relieve una obra bien trabada no solo con pedregal sino también, en determinados puntos, con grandes bloques que ligaban el relleno y las paredes exteriores (Palol 2004, 17). Veremos más adelante, respecto a la puesta en obra, que existen tramos de muro con variaciones substanciales en el tipo de material y en su colocación, y deberemos discutir si se pueden interpretar como fases constructivas o no. En cualquier caso, cabe destacar la ausencia de mortero para cohesionar la obra, aunque sí que se documenta un uso abundante de mortero para proteger las juntas de la mampostería.

También, desde el punto de vista técnico, cabe notar que en algunos tramos la mampostería cuenta con segmentos de piedras inclinadas, técnica de puesta en obra conocida a veces desacertadamente como opus spicatum. De hecho, la colocación oblicua afecta tan solo a pequeños grupos de lajas y no caracteriza a todo el lienzo. Se trata de una estrategia puntual que sirve para aprovechar un material no apto para el trabajo de cantería pero que se puede combinar con otros bloques para buscar la regularidad de las hiladas de construcción. Es este un recurso frecuente en el territorio catalán de la Alta y Baja Edad Media, indicador de unos procesos tecnológicos adaptados a una economía de recursos muy locales. En

3. Este estudio se enmarca en el proyecto cuadrienal «El nucli fortificat de Puig Rom i el seu entorn immediat. Estudi sobre el poblament d'època visigoda a la serra de Rodes. Segles vII-X dC» (2014-017), subvencionado por la Generalitat de Catalunya. Hemos contado con la colaboración de Miquel Fort como geólogo y de Pere Manel Martín Serrano para los trabajos de fotogrametría y fotografía aérea con dron.

4. Se ha debatido largamente sobre la pertinencia de este término, ante otras opciones como por ejemplo la noción de castellum. Sin embargo, el estudio detallado de la terminología demuestra que estos términos no logran dar cuenta de una tipología estricta y que los debemos usar como un indicio de la estructuración administrativa del poblamiento (Carrié 2012).

5. Para un estudio sintético de los yacimientos fortificados del período, véase Nolla 2014. 
época visigoda aparece también puntualmente, pero sin la consistencia que alcanzará en Cataluña a partir del período carolingio. ${ }^{6}$

Lo interesante es la pericia con la que los albañiles usan materiales de diferente consistencia. En el caso de Puig Rom, hemos solicitado un estudio geológico del terreno que ha permitido hacer un mapa de los afloramientos de material en todo el ámbito del yacimiento. Se ha podido constatar y cartografiar la presencia de materiales granulosos que se pueden extraer en bloques más o menos regulares (granodiorita) frente a placas de material de gran dureza (cuarcitas) de corte más irregular, y finalmente de material que solo se puede extraer en lajas (filitas). También se encuentran zonas puntuales de granodiorita alterada que da lugar a una textura de arenisca no apta para la construcción pero sí para la excavación de silos. Cada uno de estos estratos geológicos da lugar a materiales de construcción muy diferentes. Todos ellos aparecen integrados en la muralla, pero en cada tramo se utiliza el material más cercano a los distintos afloramientos. Esto da lugar a una técnica de puesta en obra que se va adaptando harmónicamente a los materiales presentes en el relieve.

El yacimiento se asienta sobre una estribación de los montes del Cap de Creus, dominando la zona rocosa de la bahía de Roses. En concreto, en el extremo norte del promontorio, sobre una elevación de forma aproximadamente triangular que se encuentra divida de NE a SO por una cresta de material granítico. Hacia poniente de estos afloramientos el yacimiento se presenta con una vertiente muy pronunciada y fuertemente erosionada. Hacia el sur, donde se localiza la puerta principal, la pendiente es algo más suave, pero el terreno presenta también afloramientos muy duros (leucogranito) que valía la pena aprovechar para asentar los muros. La torre número 5, en un ángulo meridional de la muralla, se asienta sobre uno de dichos afloramientos sin apenas molestarse en recortar el terreno por la cara occidental. La otra cara de la torre se sitúa a una cota mucho más alta, aprovechando que el terreno permitía, con un sencillo trabajo de regularización, asentar horizontalmente las hiladas de bloques. Es importante destacar que esta forma de cimentar dio lugar a un escalonamiento delante del muro que iba en contra de toda lógica poliorcética, pues facilitaría el acercamiento de las tropas enemigas. En otros puntos del circuito se puede apreciar la audacia de cimentaciones tan desiguales como la descrita, que además ponen en riesgo la estabilidad de todo el muro. La estructura tripartita, cohesionada solo con un relleno de piedras, da paso en estos casos a un muro desigual, con un lienzo colocado simplemente contra la roca.



Figura 1. Detalle del modelado 3D a partir de vuelos con dron sobre la torre número 5. Se aprecia la forma irregular de cimentar la estructura.

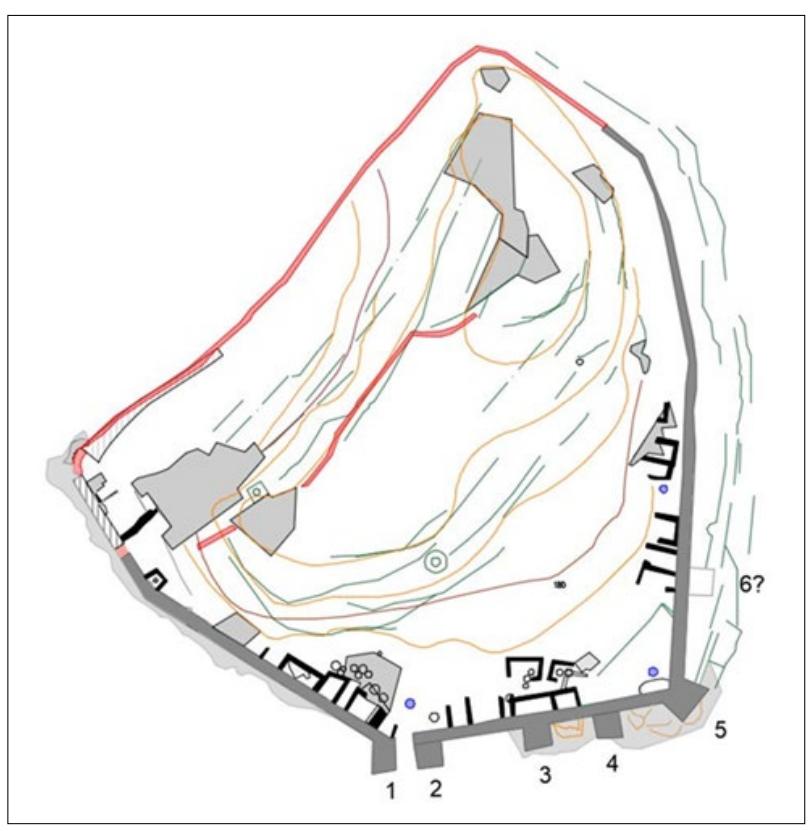

FIGURA 2. Planimetría del castrum con indicación de las torres y de los taludes modernos, así como de los principales afloramientos graníticos.

Hasta la fecha se han localizado cinco torres en la muralla meridional, muy próximas entre ellas y separadas por distancias irregulares. Se intuye, por las fotografías aéreas, que podría haber más torres en el tramo de levante. Más difícil es, por ahora, saber si las otras caras, mejor defendidas por el relieve, también contaban con torres de

6. Pere de Palol $(2004,53)$ aludía al caso de la iglesia de Sant Bartomeu de Peralada, muy cercana al yacimiento, como posible paralelo para la muralla de Puig Rom. Los lienzos no son actualmente visibles (Llinàs et al. 1998). Las lajas oblicuas aparecen en casi todos los monumentos medievales de la sierra de Rodes, muchos de los cuales no han sido objeto de excavación y se desconoce su origen exacto. 
refuerzo. No podemos definir la altura de los lienzos, pero sabemos que se elevarían por lo menos unos 2,5 metros respecto al nivel de circulación interior, tal como hemos podido constatar en las zonas mejor conservadas. Por encima de dicha cota no sabemos si el muro podía proseguir con mampuesto o con otros materiales.

En cuanto a las torres, se trata de estructuras macizas, si bien no todas se presentan de la misma manera, como ya observara Pere de Palol (2004, 28 y fig. 83). La torre número 1 es diferente de su equivalente (torre número 2 ) al otro lado de la puerta de acceso. En la primera los lienzos que contienen el relleno de la torre están construidos con bloques medianos dispuestos de forma regular que se entregan a la cara exterior de la muralla, mientras que la torre opuesta fue construida con muros de dos caras independientes del relleno. Esta diferente configuración ha dado lugar a dudas sobre la fecha de su construcción y se ha pensado que podría ser un añadido. Sobre todo porque da la impresión de que los muros de la torre no están trabados con la muralla. Sin embargo, si se observa con detenimiento la entrega de los muros de la cara oriental se podrá observar que existe una ligera trabazón puntual, poco visible porque en este sector la muralla se encuentra muy erosionada y retocada. El lienzo occidental de la torre, en cambio, no está trabado en ningún punto, pero hay que decir que está alineado con la jamba de la puerta principal, que presenta un acabado distintivo con bloques más grandes que la media para definir bien y reforzar el elemento estructural. De modo que es posible interpretar que la trabazón no se produjo para poder trabajar independientemente el acabado de la puerta. Este encuentro entre la jamba y la torre resulta torpe, pero es posible que los constructores entendieran como más prudente desligar el muro perimetral respecto de la torre para evitar un colapso gene- ralizado si fallaba esta última. En las otras torres documentadas, siempre que es posible observarla, la entrega entre las estructuras está presente. También es cierto que la estructura de la torre 2 es especial, con muros perimetrales de dos hojas bien diferenciados del relleno. Esta estructura permitiría un uso del espacio interior a partir de cierta cota. El estado de conservación de la muralla no permite ni descartar ni dar por buena esta solución, que, por otra parte, tendría cierta lógica si pensamos en un control más eficaz del acceso al castrum.

En la zona de la puerta, el marchapié tampoco estaba ligado con el perímetro de la muralla. Se trata de un muro bajo que es ligeramente más ancho que la muralla, según describe Palol (Palol 2004, 50). Dicho marchapié se eleva sobre la cota de circulación exterior por lo menos medio metro e incluye un pequeño canal de drenaje. El investigador encontró restos de un posible muro y un enlosado de pizarra. Todos estos datos, hoy irrecuperables, podrían sugerir una estructura a modo de vestíbulo cubierto para la entrada al castrum. Las torres debían de estar unidas por un forjado de madera, pues descartamos una construcción en piedra con arcuación. Por otra parte, el acceso peatonal o con animales de carga requeriría una rampa o escalón también de madera para salvar el desnivel.

A propósito de la hidráulica del yacimiento, hay que señalar que a lo largo de todo el recinto se encuentran desagües que atraviesan la muralla, y que aparecen situados alrededor de medio metro por encima de los niveles de circulación actual. Son pequeñas aberturas con dintel por la parte superior, definidas con precisión a pesar del material heterogéneo de la construcción. Nuestros predecesores hablaron de ventanas (Palol 2004, fig. 9) porque en algún caso daba la sensación de que el conducto se encontraba muy alto, pero se

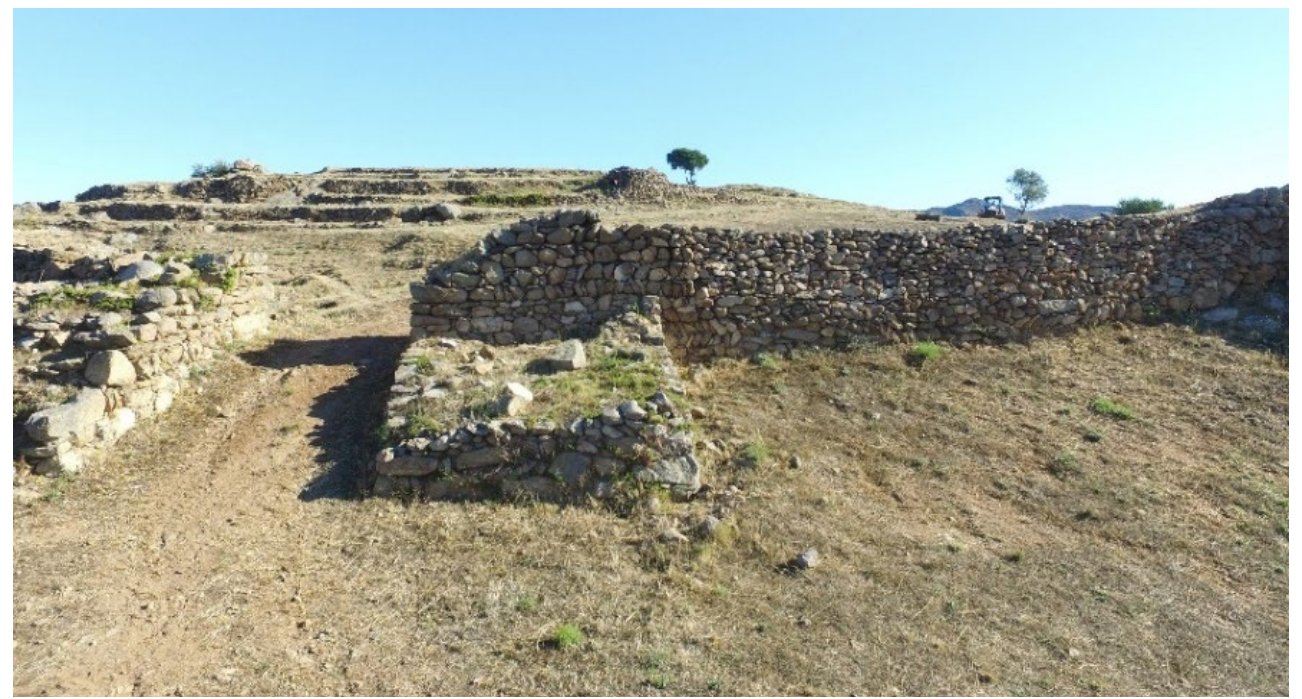

Figura 3. La torre número 2, que flanquea la entrada al yacimiento, se entrega a la muralla solo puntualmente. 
trata de un error de apreciación causado por las extrañas formas que la circulación interior del poblado tuvo que asumir en el sector sudoccidental, donde la roca aflora a una cota muy elevada y la muralla cabalga sobre ella. En la actualidad estos conductos aparecen algo por encima de los niveles de circulación, pero ello es debido a la erosión.

Además de los desagües señalaremos que se tomaron otras medidas para combatir los efectos de los aguaceros. En los puntos en los que hubo que cavar un poco para cimentar la muralla, ex-

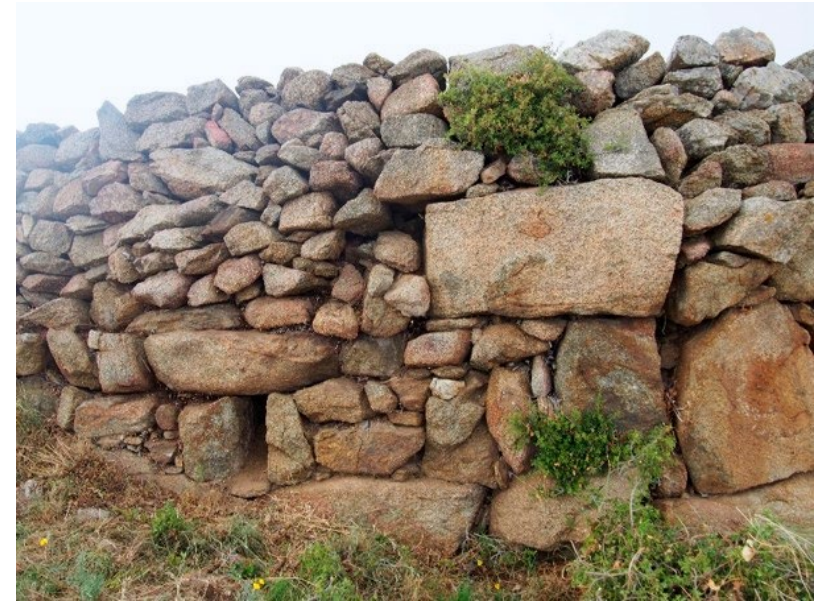

Figura 4. Conducto de desagüe en el tramo occidental de la muralla y junta sin trabar en el ángulo.

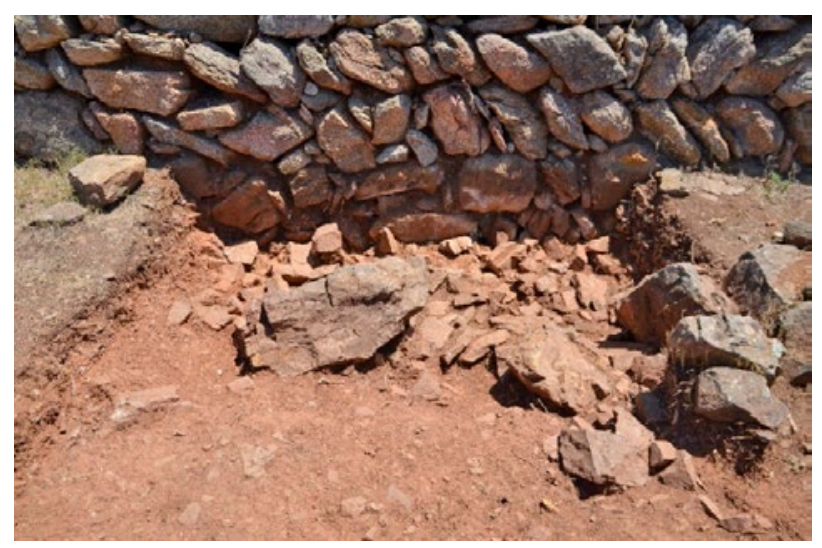

FIgURA 5. Drenaje contra la muralla en el sector sudoriental.

cavando incluso en ocasiones una trinchera de cimentación, encontramos un sistema de drenaje y protección del muro: se dispusieron paquetes de piedras y lajas que, colocados de forma irregular, dejaban numerosos resquicios por donde el agua podía circular sin empapar la tierra y así se evitaba la concentración de humedad contra la pared.

\section{Fases de la construcción y contexto histórico-artístico}

Pere de Palol, analizando y comparando la estructura, comprobó la dificultad de afiliar la fortificación de Puig Rom a algún ejemplo similar de arquitectura militar. El investigador retenía que el tipo de fortificación en altura, con planta irregular ceñida estrictamente a la orografía de la cima y el aprovechamiento de las laderas más abruptas como elemento defensivo, no se correspondía con el panorama habitual de la arquitectura militar de los tiempos romanos y bizantinos, ni en ciudades ni en castra de frontera. Evocaba ciertos paralelismos con la muralla de Recópolis, salvando las distancias que imponen el tamaño y la función de la estructura, pero también tenía en cuenta la diferente concepción de las torres que revelaba la distancia entre ambas murallas. Finalmente, Palol apuntó como mejor paralelo conocido el recinto fortificado de Riba-roja de Túria, destacando las dimensiones del castrum y su posición geográfica en relación con posibles funciones de defensa estratégica de paso de los ejércitos. En este sentido, cabe matizar que las murallas de Riba-roja, aunque presenta ciertas similitudes, están cohesionadas con mortero, a diferencia de las de Puig Rom, y también cabe hacer notar que las dimensiones de ambos yacimientos son muy diferentes. El rol de Puig Rom como fortaleza de carácter específicamente militar es bastante dudoso, pues no se encuentra cerca de pasos realmente estratégicos. Su posición parece corresponder mejor a la estrategia de dominio sobre un territorio. Desde los estudios de Palol otros yacimientos visigodos han sido identificados, en particular el yacimiento de Roda de Ter, con una amplia muralla que también podría ser objeto de comparación, aunque cabe decir que también en este caso el mampuesto está cohesionado con mortero, aunque pobre en calcio (Ollich et al. 2015).

Por lo que respecta a la datación de la muralla, hemos conseguido unas aproximaciones de C14 para estratos relacionados con el muro que proporcionan una horquilla entre mediados del VII y mediados del VIII, confirmando a grandes rasgos las interpretaciones de Palol pero con un margen demasiado amplio. ${ }^{7}$ De modo que, treinta años

7. Los análisis han sido realizados por la empresa Beta Analytic. Para esta muestra proporcionan un resultado de $662-$ $774 \mathrm{cal} \mathrm{AD}(95,4 \%)$. Aunque la horquilla es grande, creemos que la datación válida corresponde a la segunda mitad del siglo VII, sobre la base de los hallazgos recopilados y estudiados por Pere de Palol. 
después, la cronología y la función del castrum siguen siendo objeto de estudio, aunque se pueden introducir nuevos matices a la discusión gracias al análisis de su técnica constructiva. En efecto, la gran cuestión que se planteaban nuestros predecesores, en torno a si se trataba de un proyecto unitario o si se podían diferenciar diversas fases, es capital para establecer un posible cambio de uso del yacimiento entre el período de la Antigüedad Tardía y el de la Alta Edad Media.

Para analizar dicha cuestión, hemos procedido a analizar en detalle todo el muro que se encuentra a la vista. En diversos puntos se pueden apreciar intentos de consolidación relacionados con la utilización del recinto como parcela agrícola en época contemporánea. De hecho el interior del poblado fue distribuido mediante un muro largo divisorio, en dos zonas de cultivo de la vid con una barraca de aperos cada una. Sin embargo, otros tramos de consolidación son todavía más recientes, pues Palol describe como en 1987, ante el derrumbe del tramo meridional de la muralla, su equipo procedió a la reconstrucción para proteger el resto de la estructura (Palol 2004, 29). En cualquier caso, las reconstrucciones no suponen un problema para distinguir los tramos antiguos porque no se hicieron con un criterio de imitación de la puesta en obra original.

Palol añade en su monografía que en el año 1987 desmontaron algunas hiladas que habían sido reconstruidas anteriormente en el tramo occidental de muralla, lo que le permite efectuar observaciones sobre las técnicas constructivas que lo desconciertan hasta el punto de pensar que seguramente el poblado había sido reconstruido en algún momento (Palol 2004, 45). No obstante, como hemos apuntado anteriormente, nosotros pensamos que los cambios que se observan en cuanto a técnicas de puesta en obra no constituyen un indicio de diferenciación cronológica. Aunque en las soluciones constructivas más extremas podamos distinguir entre un mampuesto regular y de tamaño medio, con lajas para ajustar las hiladas, versus bloques de mayor tamaño con hiladas más o menos regulares, la realidad apunta a muchos más matices que no se pueden resumir en tipologías cerradas. Los cambios de paramento se presentan de forma paulatina sin soluciones de continuidad. En cuanto al tamaño y la forma del material, depende básicamente de la veta de donde se obtenga, y el rigor en la horizontalidad puede ser cuestión de la cuadrilla que trabaja y de la orografía del terreno sobre el que se construye.

El paramento meridional, alrededor de la puerta de entrada, es el que presenta las formas más cuidadas y características de la puesta en obra de la muralla. La más llamativa es la que da lugar a una disposición con lajas inclinadas siguiendo un ángulo constante de unos $45^{\circ}$. La regularidad de la inclinación no procede como en el opus spicatum del apilamiento continuo, puesto que las lajas aparecen aisladas y separadas por bloques horizontales. En realidad la colocación de todas las piezas parece trabajada con cierto rigor formal con el objetivo de mantener una inclinación general del mampuesto. Como se puede observar en la figura 6, en un momento dado la orientación de las lajas cambia y se genera entre los dos tramos una cuña. El uso de lajas inclinadas en un mampuesto se justifica como un mecanismo de cohesión y de resistencia a la compresión cuando se apilan por paquetes o hiladas. Cuando las lajas aparecen aisladas entre bloques horizontales, como en este caso, se trata hasta cierto punto de una elección economicista (usar el material local) sin renunciar a un aparejo pulido y resistente. El resultado es, en cualquier caso, que la construcción del muro seguramente fue avanzando en horizontal y generó un talud que evitó jornadas acabadas en vertical que pudiesen resistir mal la espera. El cambio de inclinación de las lajas sería una ventaja para la estática general del lienzo.

Por el contrario, el tramo más occidental de la muralla aparece con una técnica de puesta en obra algo diferente. En esta zona los bloques de granodiorita pueden alcanzar tamaños considerables, como grandes losas que contribuyen a la horizontalidad de las hiladas, como veremos más adelante. En líneas generales, sin embargo, la diferencia con la técnica anterior reside en la forma y el tamaño resultante de la extracción de los bloques. Aquí se trata de material de corte más geométrico y no aparecen lajas delgadas de filitas sino cortes y ripios del mismo material. Como los bloques no pueden aproximarse siempre a un paralelepípedo y no se puede obtener un paramento regular, se incluyen también bloques de sección triangular. Aunque no sea sistemático, el uso de estos bloques de aspecto piramidal debía de responder a la misma intencionalidad de las cuñas antes descritas. Los bloques, ya sea con el vértice hacia arriba o hacia abajo, contribuyen a distribuir las cargas en las dos direcciones horizontales del crecimiento del muro. $\mathrm{Y}$ este uso es especialmente necesario porque, en este tramo de la muralla, la orografía del terreno es especialmente caprichosa y, para no andar recortando la roca y nivelando la cota de cimentación, los constructores optaron por acomodarse a los recovecos de los afloramientos graníticos. En la figura 7 podemos observar como se colocó un gran bloque en la hondonada de la roca natural y se calzó con pequeñas piedras para evitar el movimiento. A lo 

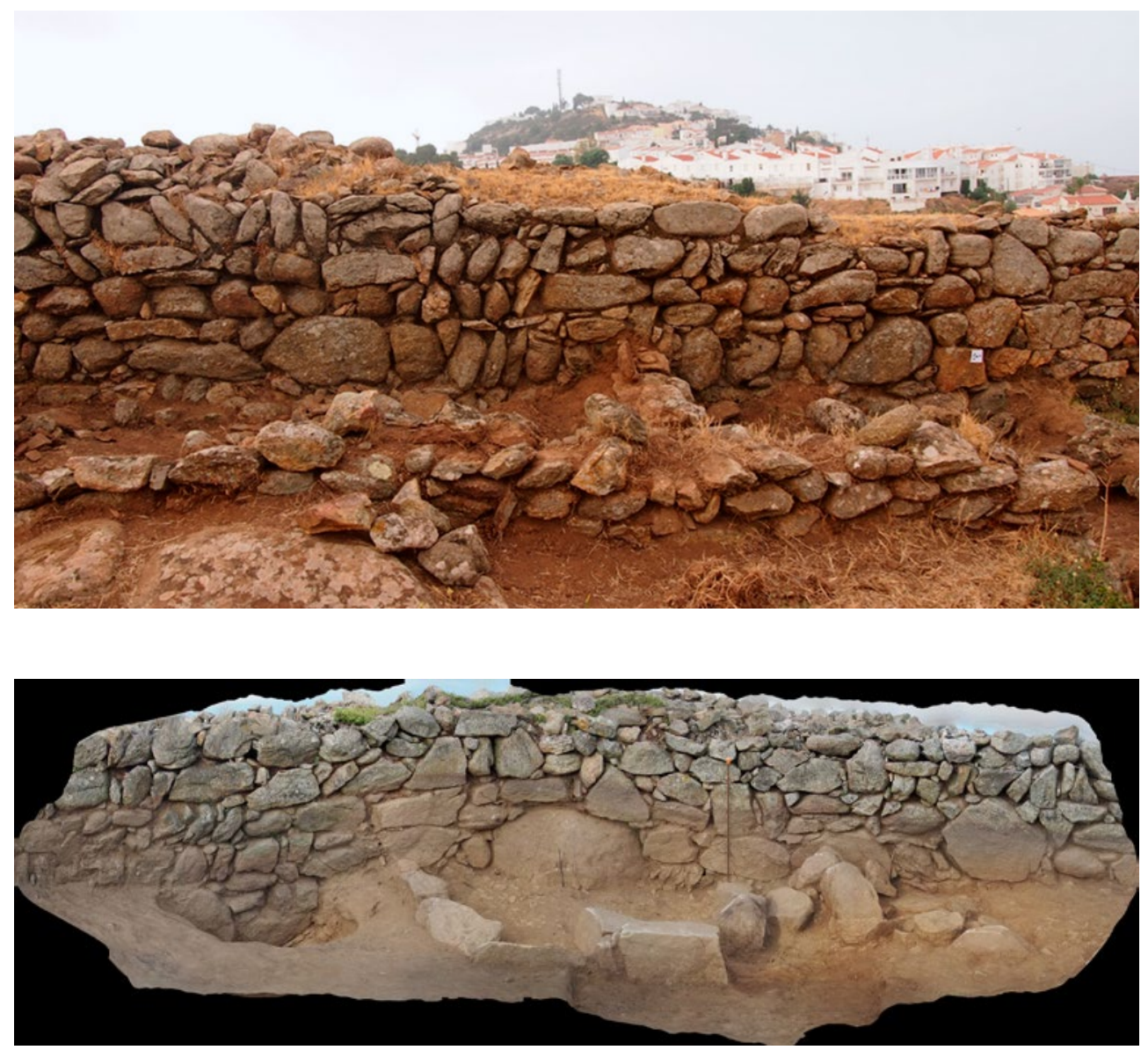

FIgURa 6. Disposición alternando la dirección del mampuesto con cuñas de contrarresto.

Figura 7.

Contrarresto

horizontal del muro a partir de los bloques de forma triangular. Obsérvese también como la muralla cabalga sobre los bolos graníticos. largo de todo el tramo el terreno presentará este tipo de situaciones y la muralla se adaptará, dándose inevitablemente cierta ondulación de las hiladas.

Ninguna de las diferencias de puesta en obra que hemos señalado se puede relacionar directamente con un cambio de cronología. Para demostrar que se trata de dos fases sería preciso encontrar el punto de ruptura entre las dos fábricas. El mismo tramo de muralla de la figura 7, que presenta una evidente continuidad, corresponde a un punto en el que se produce un quiebro en la dirección del circuito amurallado. Por el exterior, el encuentro entre los dos intervalos se produce por yuxtaposición de grandes bloques sin trabar que dan lugar a una fisura vertical. La estrategia de este encuentro es sorprendente, pues probablemente era obvio que los empujes de la estructura, y de los sedimentos que pudiera ir reteniendo, conducirían a una abertura de la junta. Sin embargo, es la misma estrategia que podemos encontrar en el ángulo sudeste de la muralla, donde nada indica, tampoco, que forme parte de un proyecto diverso. La diferencia estriba, en este caso, en que la junta en ángulo de los dos tramos queda consolidada por una torre exterior que hace de contrafuerte. En el tramo que examinamos no hemos podido explorar todavía los cimientos por el exterior para buscar restos de un contrafuerte o torre, pero lo cierto es que en algún momento, tal vez en época contemporánea, la muralla cedió y tuvo que ser en gran parte "reconstruida», o quizás sería mejor decir «enderezada» porque se hizo por simple apilamiento de piedra informe.

Volviendo al extremo occidental de la muralla, que presenta grandes bloques horizontales en su vertiente meridional, debemos señalar que coincide con una puerta de 2 metros de ancho, actualmente tapiada, que hemos podido documentar en la campaña de 2017 y que se abrió en la antigüedad rompiendo la muralla. En efecto, la puerta presenta dos jambas realizadas con técnicas algo diversas: a la izquierda, grandes bloques descansan sobre una banqueta de cimentación; a la derecha, bloques medianos en hiladas horizontales rematan la jamba que descansa directamente sobre la roca, por debajo de la cota de cimientos de la otra jamba. Se trata del único dato fehaciente de una reforma -puntual- del recinto. Es difícil determinar la cronología de la operación por las dificultades estratigráficas del yacimiento, donde los materiales cerámicos son prácticamente inexistentes. Procedentes de un nivel de circulación que se ha podido documentar por el interior, se han analizado fragmentos óseos con una datación de C14 entre mediados del siglo vIII y media- 
dos del siglo Ix, ${ }^{8}$ de la cual retenemos la fecha más antigua por coherencia con todo el desarrollo del yacimiento. Esta fecha, de todos modos, no tiene por qué coincidir necesariamente con la abertura de la puerta, pues las relaciones estratigráficas no aportan dicha certeza. Sin embargo, lo cierto es que parece corresponder a un momento pacificado, ya que es muy amplia y no parece estar protegida por torres, aunque convendrá explorar los cimientos por el exterior.

Cabe decir que en este sector del poblado predominan estructuras diferentes a las de la parte meridional. Hemos documentado un gran muro perpendicular a la muralla que presenta también una puesta en obra heterogénea: la hilada que se apoya sobre la roca es de apariencia antigua, con bloques de tamaño mediano aparejando un muro de dos caras con relleno intermedio, mientras que el tramo más próximo a la puerta combina por un lado grandes ortostatos y por el otro, a una cota superior, un cimiento de piedra menuda granítica de composición similar al material de la jamba de la derecha de la nueva puerta. Esta observación invita a relacionar la abertura de la puerta con una reconstrucción de este muro que en realidad sirve para compartimentar un gran espacio diáfano que se había generado entre la muralla y las faldas del gran macizo granítico que domina en este punto el yacimiento.

En dicha mole se pueden observar abundantes recortes, algunos de los cuales pudieron ser el resultado de la extracción de grandes bloques para la construcción de la muralla. Pero al mismo tiempo que se obtiene material de construcción, se consigue trabajar el terreno dejando espacios con un tamaño adecuado para alojar unas estancias. Creemos que es posible reconocer en estos grandes recortes la traza negativa de una estructura que se levantaría sobre la prominencia granítica, tal vez para dar lugar a una sala o una torre.

En estas circunstancias, una nueva puerta en la muralla podría tener justificación como forma directa de circulación hacia la zona logística a los pies de la torre. Por otra parte, cabe decir que antes de la gran urbanización de la colina, en los años 60-70, existía un camino directo desde el mar hasta el castrum que daba exactamente a este lugar; es por lo que seguramente Folch i Torres quiso ver una puerta en este sector, aunque en realidad lo que veía era una oquedad moderna. De todos modos, es un acceso difícil de entender, porque añade un punto de debilidad a la estructura defensiva. Por esta misma razón, su abertura parece sugerir que no se presentía ningún peligro inminente.

Por último, como novedad de esta campaña, podemos anunciar que hemos empezado a ubicar con exactitud el tramo de muralla noroccidental. Mediante un sondeo justo en el ángulo del circuito, hemos podido recuperar, a un metro de profundidad, un segmento de la muralla cuyo trazado discrepa del muro de cierre actual. Todo el sector ha sido remodelado en diversas ocasiones, fundamentalmente para definir el recorrido de la

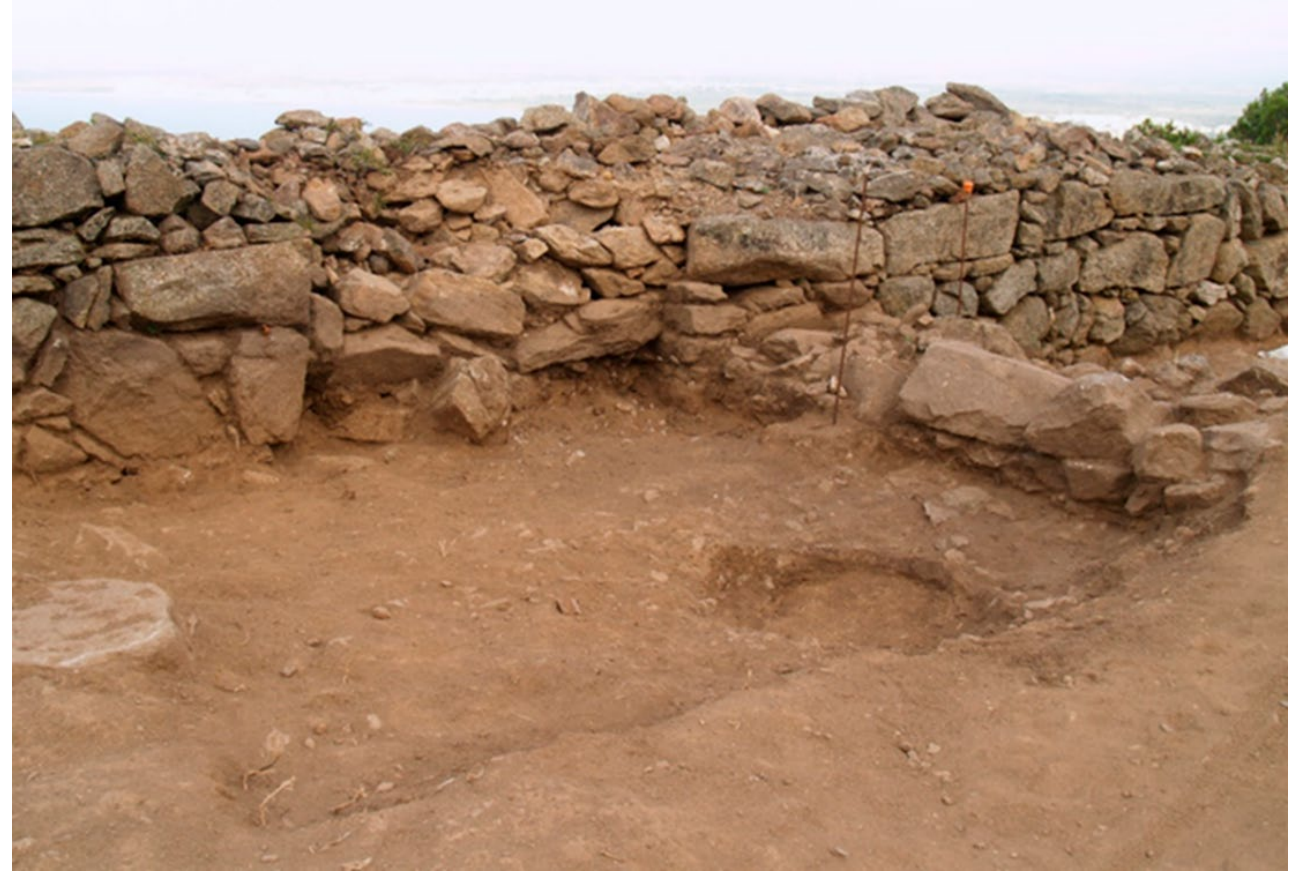

Figura 8. Tramo sudoccidental de la muralla, con una puerta de acceso abierta en la segunda fase. 


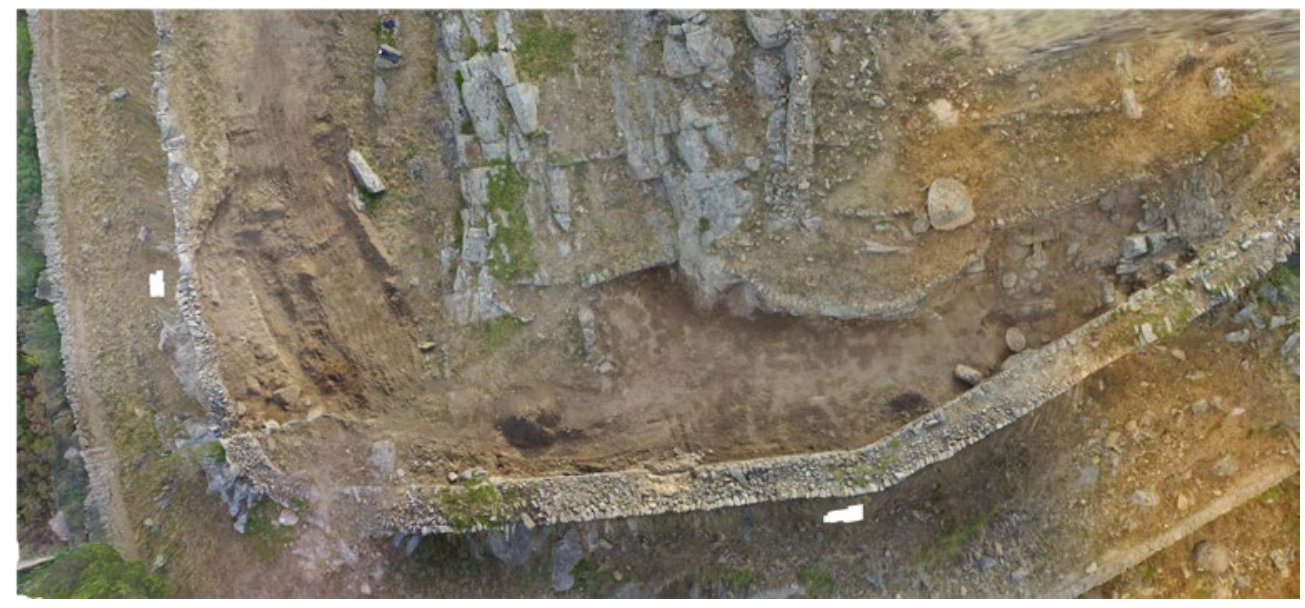

FIgURA 9. Vista cenital sobre el macizo granítico, con recortes en la roca e indicios de construcciones.

visita turística, que constituye al mismo tiempo un muro de contención para frenar la erosión del yacimiento. Por ello, es difícil documentar la forma de la muralla en este ángulo. Sin embargo, la disposición de algunos grandes bloques nos permite aventurar que estamos delante de los cimientos de una torre de ángulo hoy día desaparecida.

Seguidamente, un sondeo más alejado hacia levante permitió comprobar que el circuito de la muralla quedaba dentro del perímetro consolidado por el talud, pero que se ondulaba para adaptarse a las eminencias rocosas del terreno. Cabe decir que aquí la técnica de puesta en obra presenta sus propias características, pues los bloques son medianos y pequeños, rejuntados con mortero por el exterior y aparejados sin una atención rigurosa por la formación de hiladas. Es en este tramo donde hemos podido documentar una estratigrafía para la cual la datación por C14 nos proporciona la horquilla de mediados del VII y mediados del vIII, que coincide con la cronología tradicional del yacimiento.

Frente a la visión tradicional del asentamiento, se han producido ligeros cambios que amplían la vida del yacimiento y por lo tanto su significación histórica, aunque es obvio que quedan muchos aspectos por resolver. En primer lugar, ciertamente, la cronología inicial de la muralla, para la cual todavía falta precisión. A lo largo de las excavaciones de Palol aparecieron algunas cerámicas de importación que se pueden adscribir a finales del $\mathrm{vI} ;{ }^{9}$ sin embargo, la falta de contextos claros puede indicar una presencia residual que no sea significativa. A este dato fundamental, cabe añadir la constatación de una reforma del poblado que se visualiza a partir de la sucesión entre silos y habitaciones y que podría haber sido coetánea de la

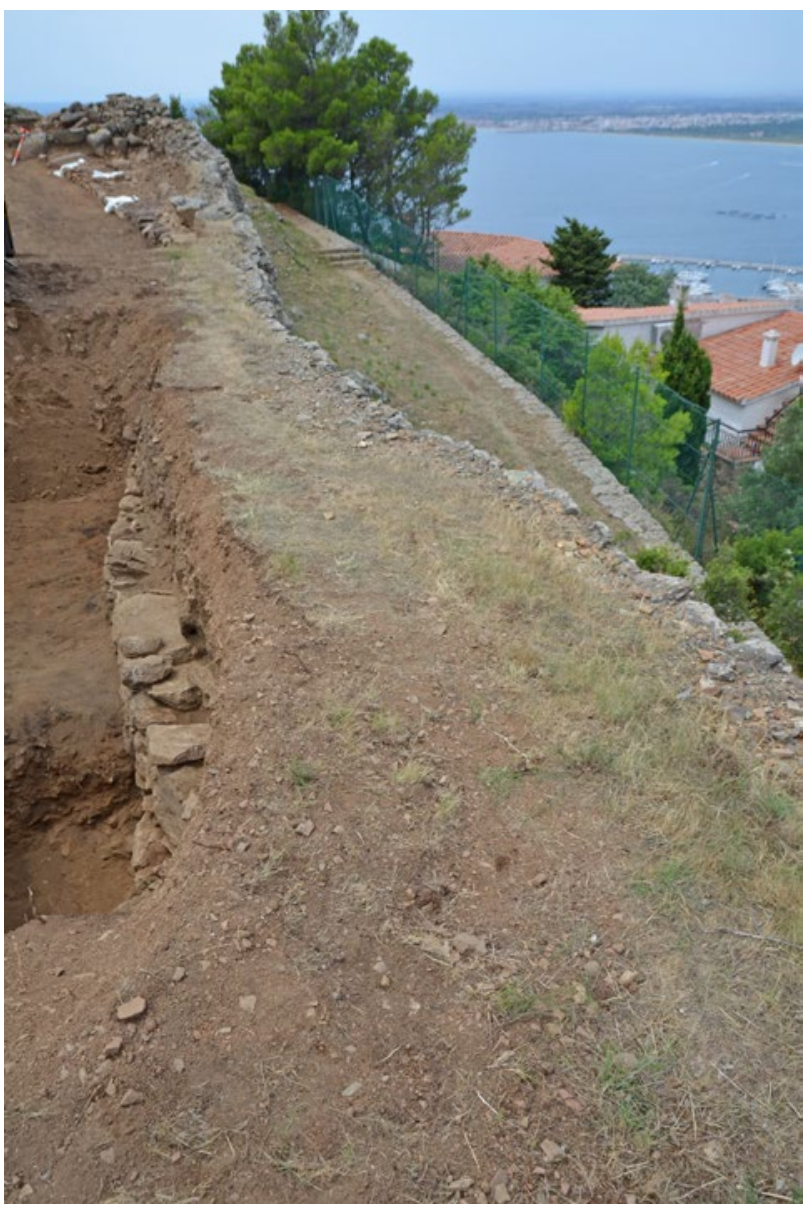

Figura 10. Tramo noroccidental del recinto, con la muralla original enmascarada por los sedimentos y el talud.

abertura de la puerta occidental. La amortización de los silos contiene elementos tardovisigóticos con los que se fecha tradicionalmente el origen del poblado. Por último, falta conocer hasta qué punto las fechas de C14 más avanzadas, ya dentro

9. Los materiales antiguos han sido revisados por Marc Soler López en el contexto del proyecto cuadrienal «Les excavacions arqueològiques a Puig Rom: Estudi dels materials dels anys 1946 i 1947», TFM del Màster en Recerca en Humanitats Girona 2015, consultable en <https://dugi-doc.udg.edu/handle/10256/11389>. 
del período franco, son indicativas de una perduración del castrum como asentamiento de prestigio y centro de control territorial o como núcleo agropastoral. Ante la amplitud de las dos horquillas de datación obtenidas, hemos optado por la datación baja de cada una de ellas, ya que no es posible armonizar las dataciones arqueométricas con las ceramológicas. Sin embargo, las reformas de la segunda mitad del siglo vIII dan a entender que el yacimiento no solo no se abandona como consecuencia de la presencia árabe en el territorio sino que es objeto de un proyecto de remodelación.

\section{Bibliografía}

CARrié, J.-M. 2012: "Nommer les structures rurales entre la fin de l'Antiquité et Haut Moyen Âge: le répertoire lexical gréco-latin et ses avatars modernes", AnTard, 20, 25-46.

Casas, J.; Nolla, J. M. 1997: «Material ceràmic del Puig de les Muralles (Puig Rom, Roses)», a: Contextos ceràmics d'època romana tardana $i$ de l'alta edat mitjana (segles $I V-X$ ) (taula rodona, Badalona, 6-8 de novembre de 1996), Arqueo Mediterrània, 2/1997, Barcelona, 7-19.

Llinàs, J.; Merino, J.; Miró, M.; Montalbán, C.; PALahí, L.; SAgrera, J. 1998: La Peralada ibèrica $i$ medieval segons l'arqueologia. Les excavacions de 1989-1995, Institut d'Estudis Empordanesos, Figueres.

Martín Serrano, P. M.; Fiz Fernández, J. I. [en prensa]: «El jaciment de Puig Rom (Roses): del camp a l'ordinador. La documentació tridimensional del jaciment», póster presentado en las XI Jornadas de Jóvenes Investigadores en Arqueología (Tarragona 09/05/2018-12/05/2018).

Nolla, J. M. 1998: «Els objectes de vidre del Puig de les Muralles (Puig Rom, Roses)», Empúries, 51, Barcelona, 237-249.

- 2014: «Ciudades, torres y castella. La defensa de la Vía Augusta», a: Catalán Ramos, R.; Fuentes
Melgar, P.; Sastre Blanco, J. C. (coord.): Las fortificaciones en la tardoantigüedad. Élites y articulación del territorio (siglos V-VIII d.C.), Madrid, 43-56.

Ollich i Castanyer, I.; Rocafiguera i Espona, M. de; Pratdesaba i Sala, A.; Pujol i Camps, M. A. 2016: «La muralla de Roda Ciutat. Visigots i carolingis al jaciment de l'Esquerda (les Masies de Roda, Osona)», Tribuna d'Arqueologia 2012-2013, Barcelona.

Palol, P. de 2004: El castrum del Puig de les Muralles de Puig Rom (Roses, Alt Empordà), MAC Sèrie Monogràfica, 22, Girona.

Subias Pascual, E.; Puig Griessenberger, A. M.; Codina Reina, D.; Fiz Fernández J. I. 2016: «El castrum visigòtic de Puig Rom revisitat», Annals de l'Institut d'Estudis Empordanesos, 47, 75-96.

- 2018: «Memòria d'excavacions en el marc del projecte quadriennal (2014-017) "El nucli fortificat de Puig Rom i el seu entorn immediat. Estudi sobre el poblament d'època visigoda a la serra de Rodes. Segles VII-X dC" ", documento en poder del Servei d'Arqueologia del Departament de Cultura de la Generalitat de Catalunya.

- [en preparación]: «Les campanyes del bienni 2014-2015 al nucli fortificat del Puig Rom (Roses, Alt Empordà)», en: XIII Jornades d'Arqueologia de les comarques de Girona, Museu Darder de Banyoles (divendres 10 i dissabte 11 de juny de 2016), Barcelona.

- [en preparación]: «El nucli fortificat de Puig Rom i el seu entorn immediat. 2014-2017», Tribuna d'Arqueologia 2016-2017 (octubre del 2017), Barcelona.

- [en preparación]: «Les campanyes del bienni 2016-18 al nucli fortificat del Puig Rom (Roses, Alt Empordà)», en: XIV Jornades d'Arqueologia de les comarques de Girona (Cal Ferrer de la Plaça, Caldes de Malavella, divendres 1 i dissabte 2 de juny de 2018), Girona. 


\title{
EL PUIG DEL CID D’ALMENARA (PLANA BAIXA, CASTELLÓ)
}

\author{
FERRAN ARASA $^{1}$
}

\section{Resum}

El Puig del Cid (Almenara, Castelló) és una extensa fortificació, situada al nord de Sagunt, a curta distància, que fou donada a conèixer per L. Cebrián Mezquita cap al final del segle XIx. Posteriorment, A. Schulten la va identificar amb un campament romà, però les primeres intervencions que s'hi van realitzar van mostrar el seu caràcter medieval. L'any 1980 es va fer una primera campanya d'excavacions en un edifici situat a prop de l'angle SE, amb els resultats de la qual es va fer una primera aproximació cronològica. Ara, la revisió dels materials ha permès precisar una datació entre els segles VIII i IX, però encara queden per resoldre qüestions de gran importància, com la seua funció i el context històric en el qual es va construir.

\begin{abstract}
Puig del Cid (Almenara, Castellón) is a large fortification located north Sagunto, a short distance away, which was disseminated by L. Mezquita in the late 19th century. Later, it was identified like Roman camp by A. Schulten, but the first interventions that were carried out showed medieval signs. In 1980 a first excavation campaign was carried out in a building located near its southern corner, with their results was made a first chronological approximation. Now, the review of its pottery has made it possible to specify a dating between 8th and 9th centuries, but there are still issues of great importance such as its function and the historical context in which it was built.
\end{abstract}




\section{Introducció}

Entre els anys 1874 i 1882, el poeta, periodista, historiador i polític L. Cebrián Mezquita -membre destacat de la Renaixença valenciana- va exercir de metge a la població valenciana d'Almenara (Plana Baixa), on va desenvolupar la seua afecció a l'arqueologia explorant alguns jaciments i fenthi almenys una excavació. Les seues notícies arqueològiques, com quasi tota la seua obra històrica, romanen inèdites i només darrerament ha començat a estudiar-se (Arasa 2014-2015). El que podem considerar el seu principal descobriment és un gran recinte fortificat que va denominar el Punt del Cid. ${ }^{2}$ En el seu manuscrit sobre Almenara (FLCM, 80, 1, 25-31 i 168-169) el descriu de manera detallada en dues ocasions, en la segona de les quals inclou un croquis del jaciment, i l'identifica amb un campament romà, que posteriorment hauria ocupat el Cid en el seu setge al castell d'Almenara entre els anys 1097 i 1098.

La notícia sobre el seu descobriment la van publicar dos autors als quals va deixar consultar el seu manuscrit: el poeta, periodista i polític $\mathrm{T}$. Llorente $(1887,261-262)$ i el metge i historiador de Sagunt A. Chabret (1888, 25-28). A través del llibre d'aquest sobre Sagunt la notícia va arribar a A. Schulten, que es va posar en contacte amb L. Cebrián per tal de visitar el jaciment. La visita tingué lloc els dies 18-19 d'octubre de 1928 i, donada l'avançada edat de l'aleshores cronista de València, el seu fill L. Cebrián va acompanyar l'arqueòleg alemany. El mateix L. Cebrián va anotar la notícia de la visita en el segon i més breu dels textos sobre el jaciment, on explica que l'investigador alemany opinava que la fortificació era semblant als campaments coneguts d'Escipió, però que la part est li pareixia més moderna per haver-se emprat argamassa de calç en la construcció dels murs. Com que el lloc es troba prop de la Muntanyeta dels Estanys, on des de principis del segle XIX es coneixen unes ruïnes romanes que s'identifiquen amb el temple d'Afrodita que cita Polibi en el curs de la Segona Guerra Púnica, no lluny del qual van acampar els Escipions, A. Schulten va concloure que es tractava del seu campament en la hipotètica primera aproximació de l'exèrcit romà a Sagunt l'any $217 \mathrm{aE}$, i va considerar que era el més antic dels existents a la península Ibèrica, va alçar un plànol topogràfic del recinte i el va donar a conèixer en diverses publicacions, tant a Alemanya com a Espanya (Schulten 1928a-b).
Aquesta identificació amb un campament romà encara va perdurar algunes dècades (García y Bellido 1976, 64; Morillo 1991, 148).

Una proposta pareguda fou la de M. González Simancas (1928), que quan estava excavant a Sagunt, en 1926, el va explorar, va fer un sondeig al cim oriental i va concloure que es tractava del campament d'Anníbal en el setge a aquella ciutat, tot $\mathrm{i}$ que posteriorment va assenyalar el seu caràcter medieval. Aquest origen el va determinar inicialment N. P. Gómez Serrano en 1929, que va donar compte en 1933 de la donació a la Secció d'Antropologia i Prehistòria del Centre de Cultura Valenciana d'un lot de materials medievals d'aquest jaciment (Gómez Serrano 1929, 200; 1933, 32), potser els recuperats en l'excavació de M. González Simancas. Anys després, J. Alcina (1950, 121 i 128), en estudiar les ruïnes del suposat temple de Venus situat a la Muntanyeta dels Estanys, expressava els seus dubtes sobre l'origen romà del jaciment i recordava que les anteriors excavacions havien proporcionat materials medievals. La confirmació del seu origen medieval vingué de la mà dels investigadors francesos A. Bazzana i P. Guichard (1976, 27-28; Bazzana 1978, 186 i 195), que el van explorar i van obrir un sondeig a la vora del tram nord de la muralla. Aquests autors destacaven les seues grans proporcions, l'escàs nombre d'habitacions visibles al seu interior i l'absència de cisternes; també trobaven un cert paregut amb els jaciments castellonencs del Tossal de Mollet (Sant Joan de Moró) i la Mola (la Pobla Tornesa), tot i que en aquests els murs són de pedra seca. Finalment, l'any 1980 el Servei d'Arqueologia de la Diputació de Castelló va fer una excavació en un edifici pròxim a l'angle SE del recinte, de la qual es va publicar una notícia preliminar en què es proposava una datació altmedieval (Arasa 1980), que en una publicació posterior es concretava entre els segles VII i IX (Arasa 2000, 117-118).

Posteriorment, diversos autors s'han referit a aquest jaciment. En un article sobre el recinte fortificat de València la Vella (Riba-roja de Túria, Camp de Túria), M. Rosselló (1996, 440-442) establia un cert paral-lelisme entre els dos jaciments i plantejava la seua identificació amb un castrum d'època visigòtica, que tindria una funció defensiva i de control del territori i podria posar-se en relació amb les campanyes militars dels monarques Gundemar (610-612) i Sisebut (612-621). Aquesta fortificació formaria part d'un hipotètic doble limes construït per la monarquia visigòtica per tal

2. En l'actualitat estem estudiant de nou el jaciment i els materials recuperats en la campanya d'excavacions del 1980 amb el doctor J. Negre (Museu Arqueològic de Gandia). També vull expressar el meu agraïment als col-legues que han atès les meues consultes: P. Guichard, S. Gutiérrez Lloret, J. M. Macias i M. Rosselló. 
de fer front a l'ocupació bizantina. Posteriorment, M. Martí (2001, 28-29) plantejava la hipòtesi que fos un establiment bizantí de la segona meitat del segle vi amb funcions de protecció de la Via Augusta. Finalment, V. Ll. Pérez García (2012, 180, 182-183) el considerava un castellum de la frontera entre les províncies Tarraconensis i Carthaginensis, destacava la seua situació prop de la mar i la funció de control de l'important eix estratègic que segueix la Via Augusta, i recordava que aquest tipus de recintes estan situats prop de ciutats que encunyen moneda en els segles V-VII.

Alguns documents del segle XIV citen aquesta fortificació amb diferents topònims, entre els quals figura el que hem recuperat per a denominar-lo, ja que el considerem més adequat per tractar-se d'un orònim i fins ara no hem trobat suport documental del terme punt emprat per L. Cebrián. Així, segons notícia facilitada pel professor J. Torró (UV), a qui volem agrair la informació, el lloc apareix citat en un document de 1317 com a Bastitam del Cit: la Bastida del Cid, amb un primer element genèric que s'aplica a recintes emmurallats, que més endavant desapareixerà en favor d'un orònim. Anys més tard, en el marc de l'anomenada Guerra dels dos Peres, Pere IV el Cerimoniós d'Aragó i Pere I el Cruel de Castella (1356-1369), les tropes castellanes van atacar Morvedre (Sagunt) l'any 1364, raó per la qual Pere IV va establir la frontera militar a Almenara. En la descripció de l'itinerari que havia de seguir l'avituallament del castell d'Almenara, s'explica que havia d'arribar per mar des de Borriana fins a l'«estanyol tro al Puig del Cit qui es endret del dit castell»: havien de desembarcar a la platja d'Almenara i per la marjal arribar fins al Puig del Cid i al castell d'Almenara (Bosó 2011, 33-34).

\section{Descripció}

El Puig del Cid forma part de la serralada d'Almenara, que amb la Muntanya Blanca, el castell d'Almenara i altres altures menors configuren una barrera orogràfica que tanca el pla litoral a 9,5 km al nord de Sagunt (figura 1). Aquesta disposició li confereix un especial valor estratègic, ja que controla el camí que segueix la costa i l'accés a aquesta ciutat des del nord. D'altra banda, es troba a 2,5 km de la mar, cosa que facilita l'aprovisionament, tot i que entre tots dos s'interposa una extensa marjal. La seua altitud absoluta és de 106 $\mathrm{m}$ a l'angle NO, i la relativa, de $92 \mathrm{~m}$; aquesta darrera és la que hi ha entre el cim i el lloc on es trobava la porta principal del recinte, situada en el costat sud. La muntanya presenta una forma de U oberta cap al sud, amb dos braços que davallen en aquesta direcció, dels quals el de l'est és més llarg. La cresta topogràfica és estreta i els vessants interiors tenen un fort pendent, per la qual cosa no presenta molt bones condicions per a l'edificació ni per a l'existència d'un recinte menor en la part més elevada. La muralla s'adapta a la topografia de la muntanya i segueix per les cotes més altes del costat nord i dels laterals amb un traçat una mica irregular, i davallava fins a la depressió que els separa, per on discorria en un tram quasi recte.

El recinte té una forma rectangular irregular, amb un perímetre de $1.250 \mathrm{~m}$ i una superfície de 9,7 ha. La grossària de la muralla varia entre 1,2 i $1,6 \mathrm{~m}$, presenta un parament carejat de pedres irregulars travades amb morter, de manera quasi exclusiva de gres de la mateixa muntanya, i en algun punt encara conserva quasi $2 \mathrm{~m}$ d'alçària (figura 2). El morter conté arena i grava de la platja, amb restes de malacofauna, i s'esmicola fàcilment. Avui



Figura 1. Fotografia de Google Earth (2019) amb la localització del Puig del Cid. 




FIgURA 2. Fotografies del tram est de la muralla.

el recinte es troba molt deteriorat $\mathrm{i}$ ha quedat en bona part ocult pel pinar que hi ha crescut en les darreres dècades, de manera que en llargs trams a penes es pot reconèixer per la franja que forma l'acumulació de pedres en la cresta de la muntanya. La fotografia aèria del vol americà del 1945 ofereix una imatge més clara del seu traçat com-

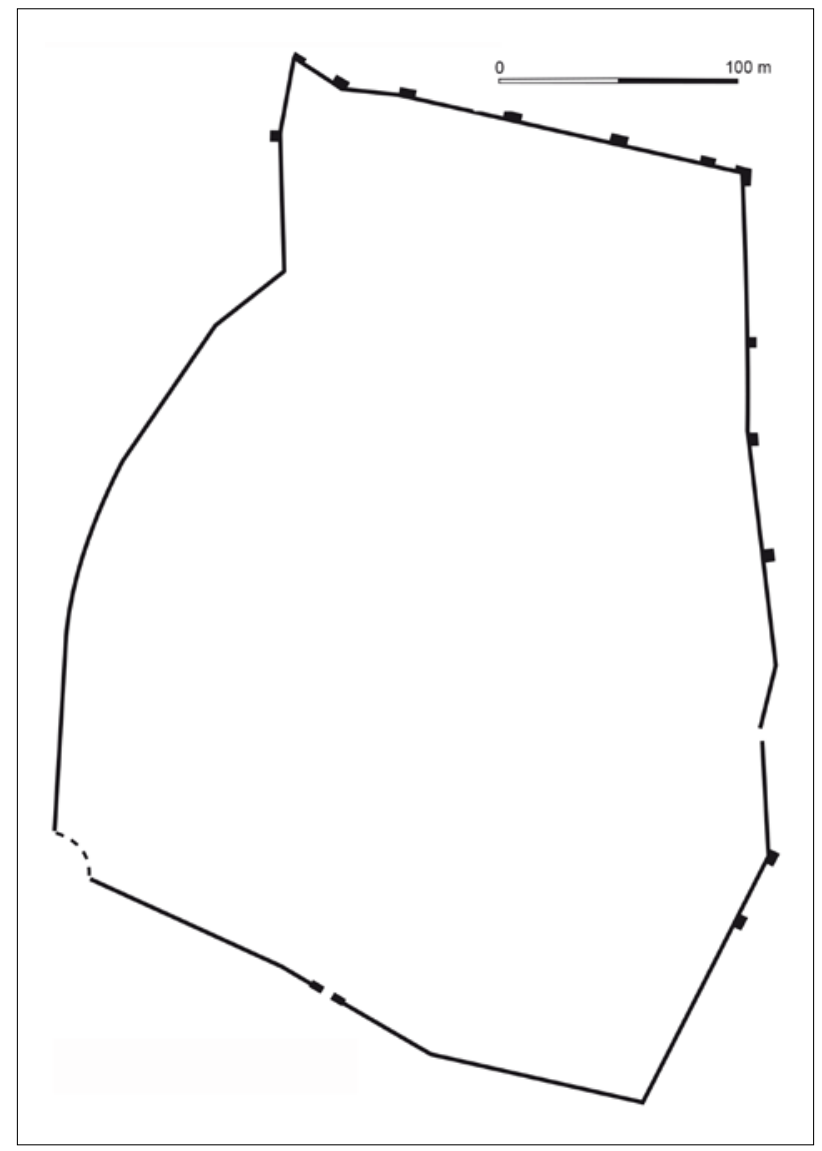

FIgURA 3a. Calc del plànol topogràfic d'A. Lammerer i A. Schulten. plet, que, amb el plànol d'A. Schulten, permet ferhi algunes precisions: als angles NO i NE s'identifiquen dues construccions majors que les torres, $\mathrm{i}$ a l'extrem SO es veu com recula formant un angle recte, per a seguir de nou cap a l'est (figura 3).

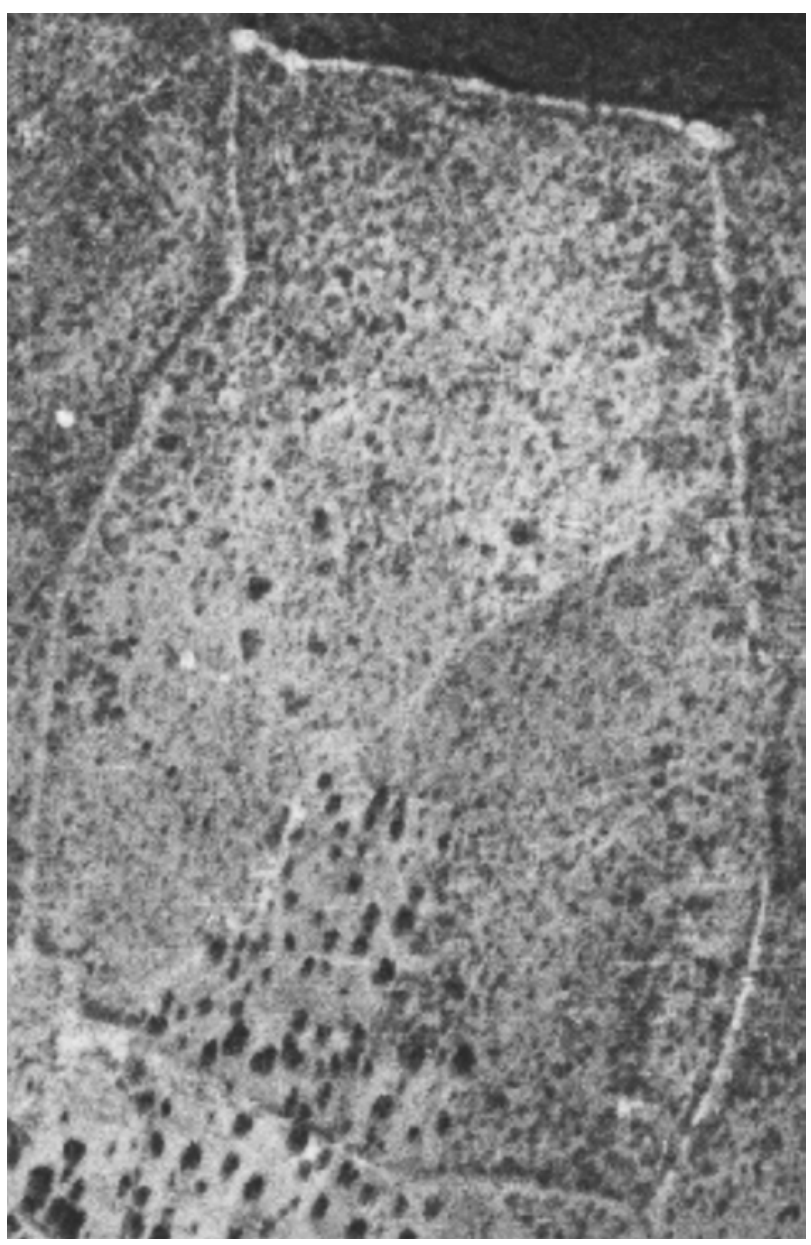

FiguRA 3b. Fotografia aèria del 1945 amb el recinte visible (vol americà, ICV). 
El llenç est, com ja va assenyalar L. Cebrián, es troba més ben conservat, tant pel que fa a la muralla com a les construccions interiors. Tot el pany meridional, per on resultava més fàcil l'accés, ha desaparegut a causa de les transformacions agrícoles. Ací es trobava la que A. Schulten denomina porta praetoria, de $3 \mathrm{~m}$ de llum, que sens dubte era la principal del recinte i estava flanquejada per dues torres. L. Cebrián cita en aquest pany dues escales afrontades que ocupaven la meitat del gruix de la muralla, i una altra de semblant en el del costat oest. També indica l'existència d'una porta al costat est, en el qual -en els trams que conservaven més altura- es veien pedres que sortien a manera de mènsules que podien servir per a sostenir una estructura de fusta, potser el camí de ronda. Tot i que aquest autor parla de setze torres, segons l'investigador alemany n'hi havia quinze: set al costat nord, cinc a l'est, una a l'oest i dues al sud; d'aquestes, avui només se'n reconeixen quatre. Segon assenyala L. Cebrián, la de l'angle NE era més gran, com un petit recinte. Les dimensions de les torres eren, segons aquest autor, de 2,30 m d'amplària i 2,20 m de profunditat; i segons A. Schulten, de 4-6 m d'amplària i 3-4 m de profunditat; les del costat sud tenien $2 \mathrm{~m}$ de profunditat i $5 \mathrm{~m}$ d'amplària. Avui el seu estat de conservació impedeix comprovar-ne les dimensions sense realitzar treballs de neteja i excavació; les torres visibles són massisses, i en una s'hi distingeix el principi de l'escala d'accés en la part central. Crida l'atenció que el pany més ben fortificat amb torres siga el nord, on la muntanya presenta més altitud, i que el costat sud -que en la part central segueix per terreny pla-només estiga reforçat per les dues torres que flanquejaven la porta.

A l'interior del recinte són visibles algunes edificacions, en els costats nord i est, com ja assenyalava L. Cebrián: «no muy grandes estancias, unas veces aisladas, otras veces agrupadas en línea recta». Tant M. González Simancas com A. Bazzana i P. Guichard van fer els sondeigs al costat nord, el primer cap a l'angle NE. Les construccions del costat est són les més ben conservades i es distribueixen de manera paral.lela a la muralla, separades d'aquesta per un espai sense construir a manera d'intervallum. La tècnica constructiva emprada en aquestes és la mateixa que en la muralla, un parament carejat de pedres irregulars travades amb morter, entre les quals es troben alguns carreus romans de calcària grisa, fins i tot motlurats. En el costat nord són difícils de reconèixer, però en el braç est es pot veure que són construccions discontínues disposades de manera escalonada en els trams amb menys pendent fins a prop de l'angle SE, amb unes dimensions semblants. Com ja van destacar P. Guichard i A. Bazzana, a l'in- terior del recinte no s'hi ha pogut identificar cap cisterna. L. Cebrián cita la troballa de monedes i ceràmica romanes, així com grans carreus en la zona plana del costat sud. Per la seua banda, N. Mesado (1966, 191, n. 15) va assenyalar la troballa de ceràmica ibèrica a l'interior del recinte, en la zona del tàlveg. També en les excavacions del 1980 es van trobar alguns fragments de ceràmica de l'edat del bronze, ibèrica i romana, alguns amb restes de morter adherit.

\section{L'edifici excavat}

L'any 1980 el Servei d'Investigacions Arqueològiques i Prehistòriques de la Diputació de Castelló hi va realitzar una campanya d'excavacions, que fou dirigida pel seu cap, F. Gusi Jener. La intervenció tingué lloc a l'extrem sud del braç est de la muntanya, prop de l'angle SE del recinte, que presenta una superfície horitzontal on es troba la darrera de les edificacions, que ja apareix representada en el plànol d'A. Schulten (figura 4a). Ací, aproximadament a l'altura del mur sud d'aquesta construcció, el llenç est de la muralla gira lleugerament cap al SSO fins a formar un angle obtús amb el pany sud. En superfície es veien alguns murs, i en l'angle NO hi havia un sondeig de planta aproximadament quadrada i 1,60 m de costat. L'excavació va treure a la llum una construcció de planta rectangular amb unes dimensions de 19,6 x 7,5 m i una superfície construïda de $147 \mathrm{~m}^{2}$, que està orientada NNE-SSO, amb una disposició quasi paral.lela a la muralla en el llenç est i exacta en el sud (figura 4b). El seu mur nord afronta amb una altra edificació semblant i es prolonga cap a l'est, com també ho fa el mur oest cap al nord. La distància des del mur meridional fins al pany de la muralla és de 19,5 m, pràcticament la mateixa que la seua longitud. Els murs tenen $60-70 \mathrm{~cm}$ de grossària, presenten un parament semblant al de la muralla i en la seua construcció es van aprofitar carreus romans, alguns d'ells motlurats (figura 5). Les parets s'assenten sobre el nivell natural i en la seua base tenen un petit sòcol de reforç.

El mur est de l'estança excavada té 12,6 m de llargària i està travat en l'extrem sud amb un altre que segueix cap a l'est formant un angle recte que es prolonga més enllà del límit de l'excavació; possiblement deu ser la paret mitgera que separa aquesta d'una altra part de l'edifici que deu trobar-se en aquest costat. A l'altura d'aquest angle, des del mur oest arranca una paret adossada de $70 \mathrm{~cm}$ de grossària que deixa una obertura d'1,80 $\mathrm{m}$ en el costat est, que compta amb un llindar format per dos grans carreus de calcària. Aquesta paret tanca l'espai de 4,70 m que resta fins a 


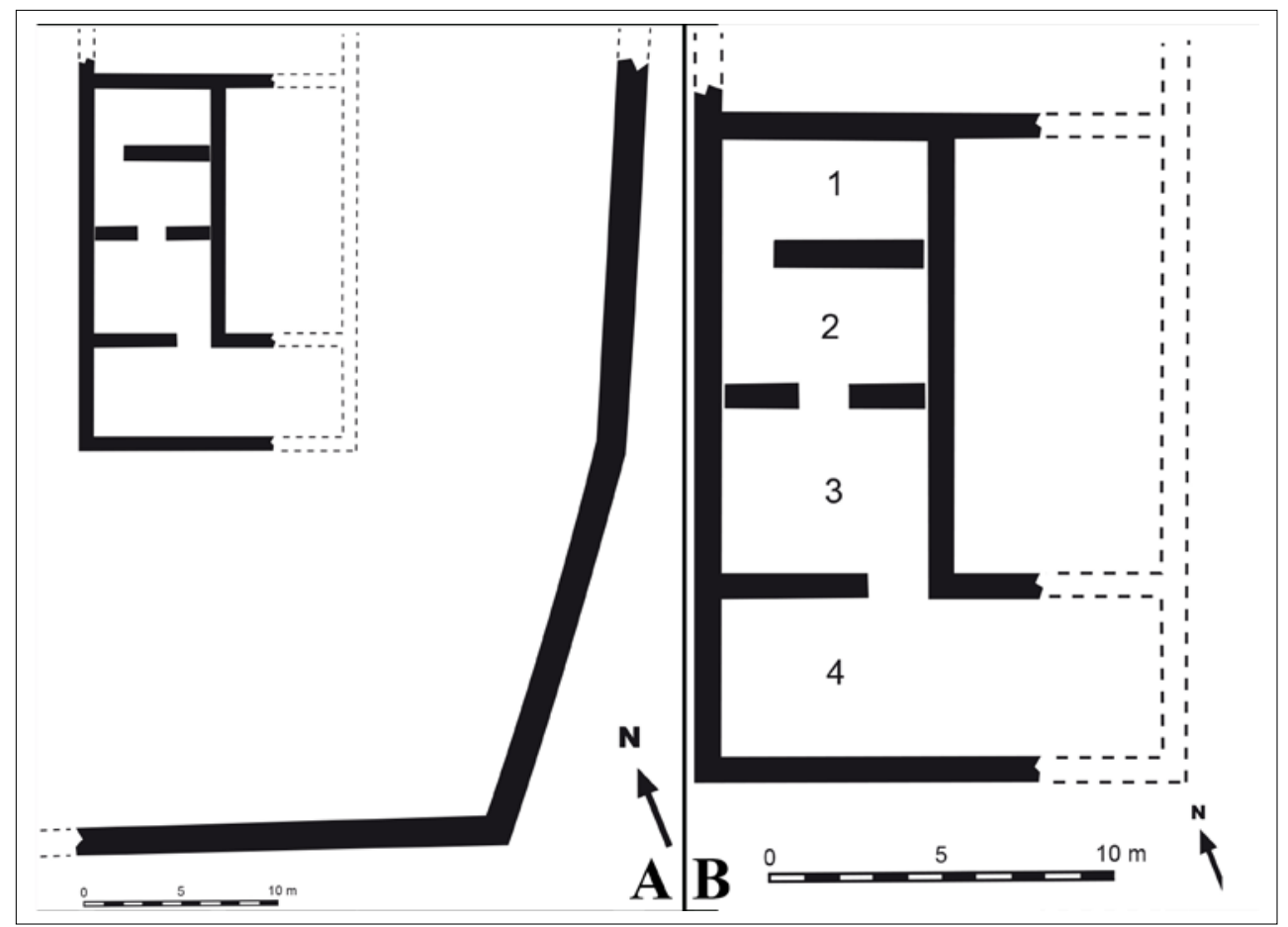

Figura 4. (A) Planta del sector SE de la fortificació, amb l'edifici parcialment excavat l'any 1980; (B) Planta de la part excavada d'aquest edifici i la seua restitució hipotètica.

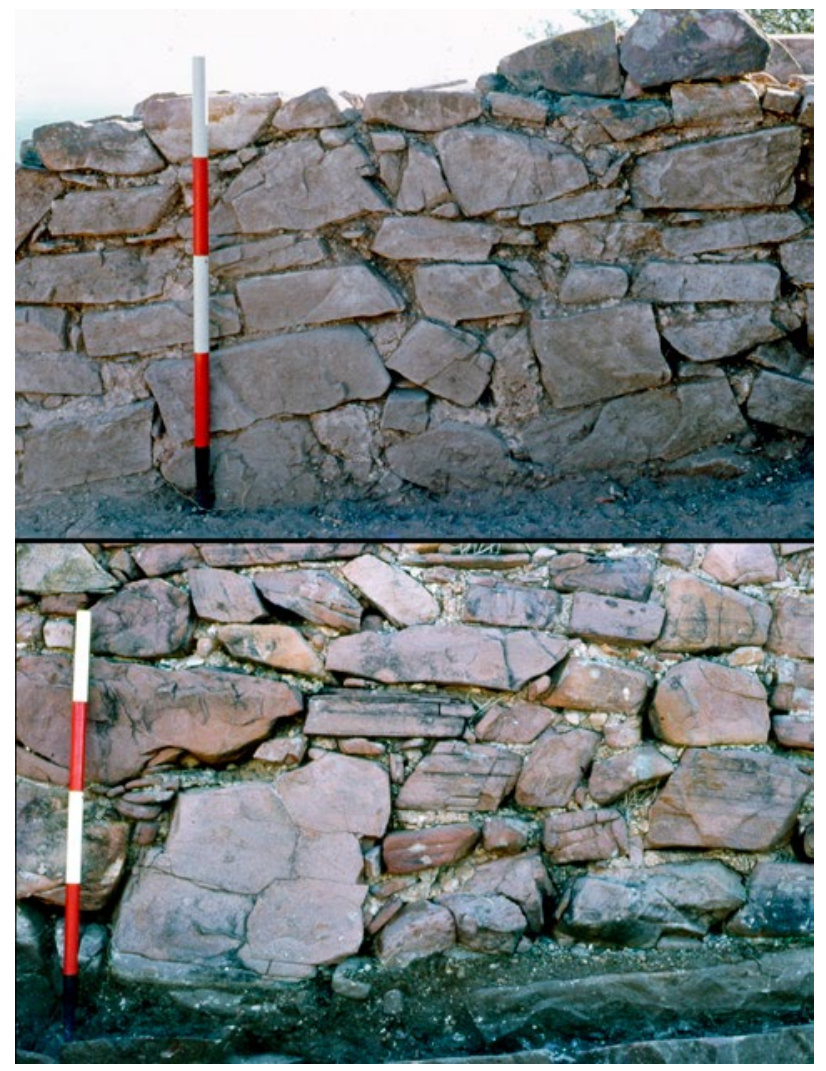

Figura 5. Detalls del parament de l'edifici.

l'extrem sud i que es prolonga cap a l'est, per on devia trobar-se l'accés a les dues parts. L'espai que resta al nord, que correspon aproximadament a dos terços de la longitud total, està dividit en tres habitacions per altres dues parets de factura molt grollera adossades als murs laterals, que pertanyen a una reforma interna posterior a la construcció. La primera es troba a $3 \mathrm{~m}$ del mur nord, conserva una sola filada de pedres travades amb fang i disposades de manera prou irregular, amb una amplària màxima de $80 \mathrm{~cm}$, i deixa una obertura d'1,50 m en el costat oest. La segona habitació té 4,40 m de longitud i està delimitada al sud per una paret de característiques semblants i $70 \mathrm{~cm}$ d'amplària, amb una obertura al centre d'1,50 m (figura 6b). La tercera habitació té 4,90 $m$ de longitud i està delimitada al sud per la paret on s'obre la porta principal que hem descrit anteriorment.

Segons la distribució que acabem de veure, i sobre el supòsit d'un disseny simètric, la seua amplària total podria ser de $14,35 \mathrm{~m}$; la superfície construïda seria d'uns $280 \mathrm{~m}^{2}$ i tindria la següent distribució: al costat sud, una mena de distribuiidor de planta rectangular, potser un pati descobert, orientat E-O, on es trobaria la porta; des d'aquest s'accediria a la resta de l'edifici, que s'estendria cap al nord i estaria dividit per una paret mitgera en dues sales similars de planta rectangular; la sala situada a la banda oest estava dividida en tres habitacions per dues parets de factura grollera construïdes en una segona fase, $i$ tenia la porta en el costat est; possiblement també devia ser així en l'altra sala, ja que es conserva el principi de la paret que la tanca pel sud i forma angle amb la mitgera. D'aquesta manera, la distància des de la paret que tancaria aquest edifici pel costat est fins a la muralla seria d'uns $13 \mathrm{~m}$. La porta podria trobar-se tant en el costat est del mur meridional com en l'extrem sud del mur oriental. 




Figura 6. (A) Mur oest de l'edifici; (B) Paret divisòria entre les habitacions $2 \mathrm{i}$ 3 amb l'entrada al centre.
Sobre aquest supòsit, la seua coberta seria en vessant a dues aigües i -donat que no s'han trobat teules- estaria feta de branques i fang.

L'excavació va posar al descobert una estratigrafia molt senzilla i prou homogènia en les quatre habitacions. Per sota d'un nivell de terra orgànica d'uns $10 \mathrm{~cm}$ de grossària, n'aparegué un altre d'enderrocs amb pedres i fragments de morter de gruix molt irregular. A continuació se'n trobà un altre de terra grisa negrosa, amb una potència un poc irregular de $5-15 \mathrm{~cm}$, que contenia tots els materials recuperats. Aquest descansava sobre una altra capa de terra rogenca amb pedres que anivellava l'interior de l'edificació. Per la inclinació del terreny cap a l'oest, aquesta capa presenta una major potència en aquest costat. En algun punt, com al racó NO del vestíbul, s'emprà arena com a material de rebliment. Lúnica filada de pedres de les dues parets divisòries de la segona fase descansava sobre la terra grisa negrosa del nivell d'ocupació, de manera que aquestes es van alçar quan l'edifici ja estava ocupat; aquest nivell s'estenia pels costats de les parets, per la qual cosa sembla que l'ocupació hi va continuar. Tot i que els carbons i la cendra eren relativament abundants en el nivell d'ocupació, no s'hi va poder identificar cap llar o estructura de combustió. La interpretació que en fem -que hauran de confirmar futures excavacions- és que només hi ha un període d'ocupació no molt prolongat, en el qual es va realitzar una reforma interna consistent en la subdivisió de l'estança principal en tres habitacions.

\section{El material moble}

Els materials de caràcter moble van aparèixer distribuïts de manera desigual per les quatre estances. A més de restes de fauna i ictiofauna, es tracta en la seua majoria de ceràmica i algunes peces de metall i vidre. En la primera habitació eren escassos i es trobaven pròxims a les parets; hi destaquen alguns fragments de dues olles, dos fragments d'escòria i una perla gallonada de pasta vítria de color blau. En la segona eren també poc nombrosos i es trobaven majoritàriament per la zona central. En la tercera eren més nombrosos $i$, encara que es concentraven majoritàriament per la part oest, es trobaven distribuïts per tot el terra; a més d'abundant ceràmica, s'hi van trobar nombroses restes de fauna, cinc fragments de vidre, una sivella i un clau de ferro, un altre de bronze i un fragment de statera d'aquest material. Finalment, en la quarta els materials eren escassos i aparegueren majoritàriament en el rebliment d'arena de l'angle NO, potser una mena d'abocador; aquest reduït nombre sembla encaixar amb la seua hipotètica funció de distribuïdor. S'hi van trobar un altre fragment de la mateixa statera, que aparegué a l'angle SE, una pedra foradada i trencada, alguns fragments ceràmics, un fragment de vidre i, de ferro, dos punxons, un clau, un possible anell, una placa de cinturó amb l'anella i altres fragments informes.

De ceràmica se'n van trobar un total de 1.101 fragments, la majoria de reduïdes dimensions, dels quals 42 són de ceràmica ibèrica, 2 de roma- 
na i 5 poden ser de l'edat del bronze, que deuen correspondre a ocupacions anteriors o fins i tot haver-se portat amb la terra i el material constructiu utilitzat. En conjunt, la seua distribució per habitacions és, tret del material residual, la següent: 185 en la primera, 152 en la segona, 736 en la tercera i 28 en la quarta. Està fabricada en la seua totalitat a torn, i la gran majoria és de cocció reductora i de factura molt homogènia, amb pastes granuloses que contenen desgreixants de grandària petita o mitjana, entre altres calcaris i de mica, i superfícies rugoses de tonalitats grises i negroses que sovint presenten senyals d'haver estat exposades al foc. Alguns fragments palesen una cocció poc homogènia en les pastes, amb un nucli grisenc i superfícies ocre-ataronjades. La de cocció oxidant és escassa en general, presenta unes pastes majoritàriament depurades i superfícies llises de coloracions beix, ataronjada o rogenca.

El grup de cocció reductora està constituït de manera quasi exclusiva per recipients de cuina, majoritàriament olles de vora exvasada, boca ampla, coll sovint decorat amb acanalats -i en un cas amb una línia ondulada incisa superficialment sobre elles-, cos globular o ovoide, anses de secció rectangular i base plana (figures 7 i 8, 1-2). Les vores són variades: majoritàriament tenen el llavi engrossit $\mathrm{i}$ arrodonit, però en algunes és triangular, i té un petit graó a l'exterior o a l'interior per a la tapadora. El coll acaba en una carena que, quan hi ha decoració, està formada per la darrera estria. En els casos en què es conserva l'ansa, aquesta és de secció ovalada, arranca de la mateixa vora i arriba fins a la part superior del cos, per davall de la carena; en aquesta franja és per on s'estén la decoració. Els diàmetres de les vores varien entre 17 i $19 \mathrm{~cm}$. Un exemplar de morfologia diferent que presenta un bon acabat té la vora recta amb el llavi bisellat, no té coll, presenta una carena alta poc marcada i té un diàmetre de $17 \mathrm{~cm}$ (figura 8 , 3). Alguns fragments de bec indiquen la presència de gerretes que tenen una morfologia semblant $\mathrm{i}$ de vegades han estat exposades al foc; possiblement es tracta dels recipients amb uns diàmetres menors, al voltant de $12-14 \mathrm{~cm}$.

Entre la ceràmica de cocció oxidant, clarament minoritària, s'ha pogut classificar una gerra, dos cànters i una olla de pasta rogenca i superfície ennegrida per exposició al foc. Dels tres exemplars més complets, una gerra de grandària mitjana té la vora recta amb el llavi lleugerament engrossit i arrodonit i $9 \mathrm{~cm}$ de diàmetre, coll sense diferenciar, anses de secció rectangular i quatre estries incises a l'altura d'aquestes (figura 9, 1); un cànter té la vora recta amb el llavi engrossit i diferenciat $i$ un diàmetre de $12 \mathrm{~cm}$, coll cilíndric i anses de sec-

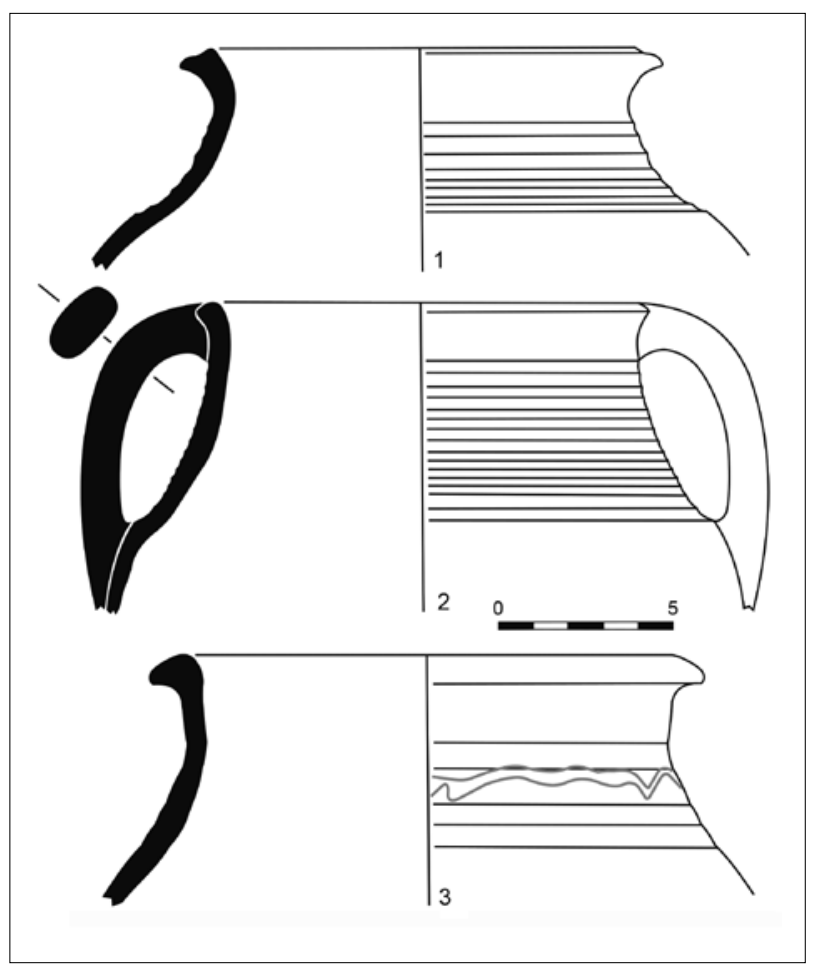

FIgURA 7. Ceràmica de cocció reductora: olles.



Figura 8. Ceràmica de cocció reductora: olles.

ció ovalada (figura 9, 2); i l'altre, que no conserva la vora, té un coll cilíndric de $10 \mathrm{~cm}$ de diàmetre amb un petit engrossiment a l'altura del principi de l'ansa, la qual presenta una secció ovalada amb dues estries amples en la part superior del cos i una base també plana i de $10 \mathrm{~cm}$ de diàmetre (figura 9, 3). 


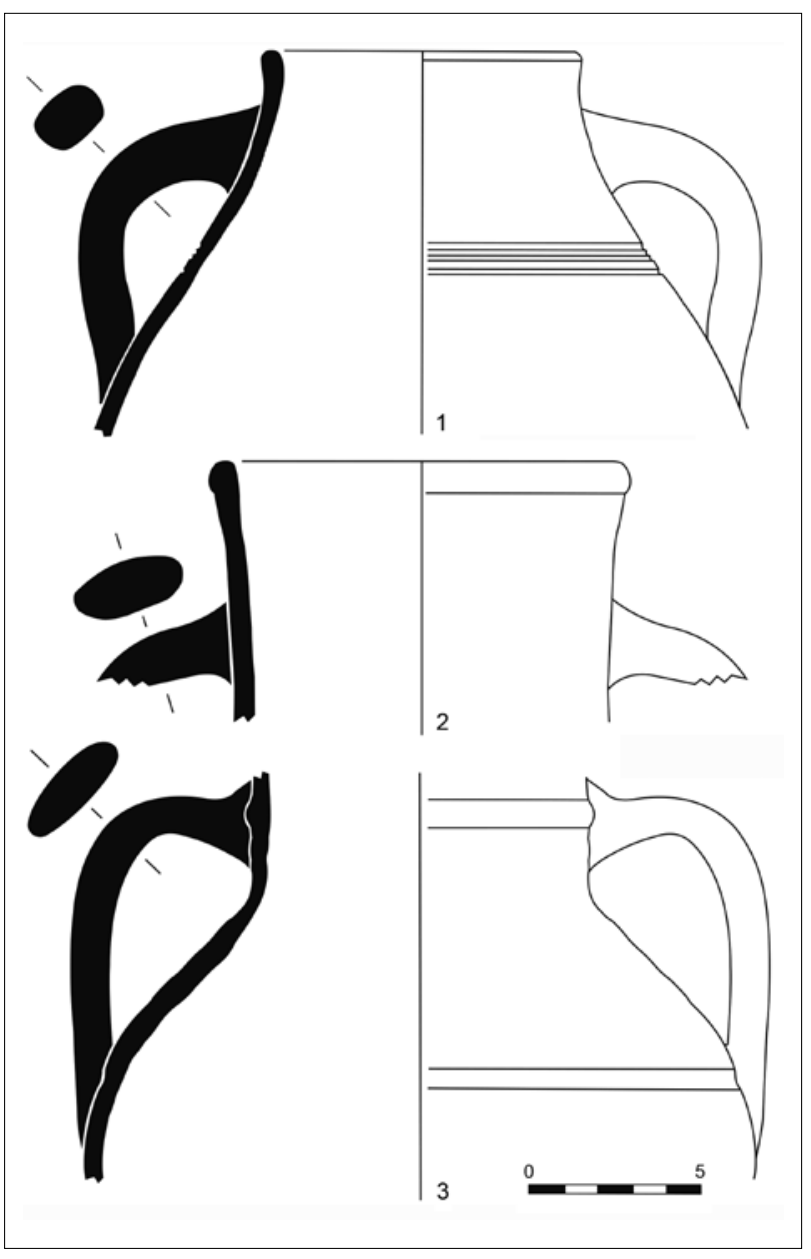

Figura 9. Ceràmica de cocció oxidant: gerra i cànters.

De manera general, el context ceràmic del Puig del Cid difereix d'altres conjunts datats en els segles VI-VII, encara que se'n puguen trobar similituds puntuals en algunes formes, com els de València la Vella (Riba-roja de Túria, València) (vid. en aquest mateix volum) i de la ciutat de València (Pascual, Ribera i Rosselló 2003, 69-108, fig. 1-31; Rosselló i Ribera 2004); del segle vII a Tarraco (Remolà i Macias 2000; Rodríguez Martorell i Macías 2016) i del VIII al port d'aquesta mateixa ciutat (Rodríguez Martorell i Macías 2018); i d'aquest període en general al Tolmo de Minateda (Albacete) (Amorós 2011; 2018). Pel que fa a la forma més representada, les olles, cal remetre a l'estudi inicial de Bazzana (1986), que proposava una cronologia àmplia entre els segles VIII $i \mathrm{x}$, tot $\mathrm{i}$ que exemplars semblants amb decoració acanalada al coll es troben ja en alguns dels contextos anteriorment citats del segle viI. Entre altres jaciments, al Tossal de Mollet (Sant Joan de Moró, Castelló), l'abandonament del qual es data amb anterioritat al segle $\mathrm{x}$, hi trobem una gran uniformitat en la ceràmica $i$ la presència quasi exclusiva d'aquest tipus (Bazzana i Guichard 1978, 488-489, 498, fig. 3). Al testar del Mas de Pere (Onda, Castelló), aquesta forma -que presenta una notable variabilitat en els llavis- data dels segles IX-X (Montmessin 1980, 268, 286, làm. 1). Al Mas de Rambla, situat al peu del castell de la Magdalena (Castelló de la Plana), la cronologia d'un conjunt ceràmic en el qual hi ha olles amb decoració acanalada s'ha fixat amb una datació radiocarbònica entre el final del segle Ix i la segona meitat del x (García Borja et al. 2018). A València hi ha olles de característiques semblants amb aquesta datació, que es troben amb gerretes que poden tenir una ansa i bec de pessic, i gerres i gerretes de pasta clara i vora recta (Pascual et al. 1997, 187, fig. 10, 1; Pascual, Ribera i Rosselló 2003, 108-110, fig. 33; 113, fig. 33). I a Tortosa (Tarragona), J. Negre (2014, 50-51) ha estudiat olles amb vores i decoració semblants i aquesta mateixa cronologia.

Al Tolmo de Minateda (Albacete) les olles del tipus 1.4.5, amb cos de tendència ovoide i vora exvasada amb llavi triangular, apareixen a mitjan segle VIII, en la fase 4.2, amb variants que tenen un petit graó a l'interior per a la tapadora o a l'exterior, i es generalitzen en la fase 5 al segle ix; les denominades olles valencianes, del tipus 1.5 , amb estries amples al coll, apareixen en aquest mateix segle (Amorós 2018, 101-102, 125-129 i 131, fig. 98). Quant a l'olla de vora bisellada, un paral.lel podria ser el tipus 1.1.1a, amb una cronologia semblant (Amorós 2018, 117, fig. 87f-h). Al voltant de València, aquest tipus -que sovint porta una decoració incisa de meandres al coll- es troba al palau del Pla de Nadal (Riba-roja de Túria, València) i a la vil.la de l'Horta Vella (Bétera), i es data entre la segona meitat del segle VII i principis del VIII (Juan i Pastor 1989, 141, fig. 3; Rosselló i Ribera 2004,158 , fig. 4, 14-15). Pel que fa a la ceràmica de cocció oxidant, entre els recipients d'emmagatzemament, els cànters, recipients de dimensions mitjanes o grans, cos de tendència ovoide, amb coll estret, anses de secció ovalada i base plana o lleugerament convexa, de pastes clares, apareixen cap a mitjan segle VIII al Tolmo de Minateda (fases 4.2-4.3) i es generalitzen en el Ix (fase 5), quan comencen a portar decoració pintada; els del tipus 5.8.8 presenten diversos tipus de vores, i en alguns casos mostren un engrossiment al coll a l'altura de l'ansa (Amorós 2018, 173-174, fig. 140a-g). Finalment, un paral.lel aproximat de la gerra pot ser el tipus 5.7, un contenidor de grans dimensions, cos ovoide, vora engrossida, coll troncocònic, sense muscle i anses robustes, que apareix en el segle IX (fases 5.2-5.3) (Amorós 2018, 169-170, fig. 135, $a-b)$.

Els dos fragments de statera -que es van trobar separats- encaixen, però no la completen (figura 10). La peça es va trencar pel braç i es va reparar amb l'afegit de dues plaques allargades que se 


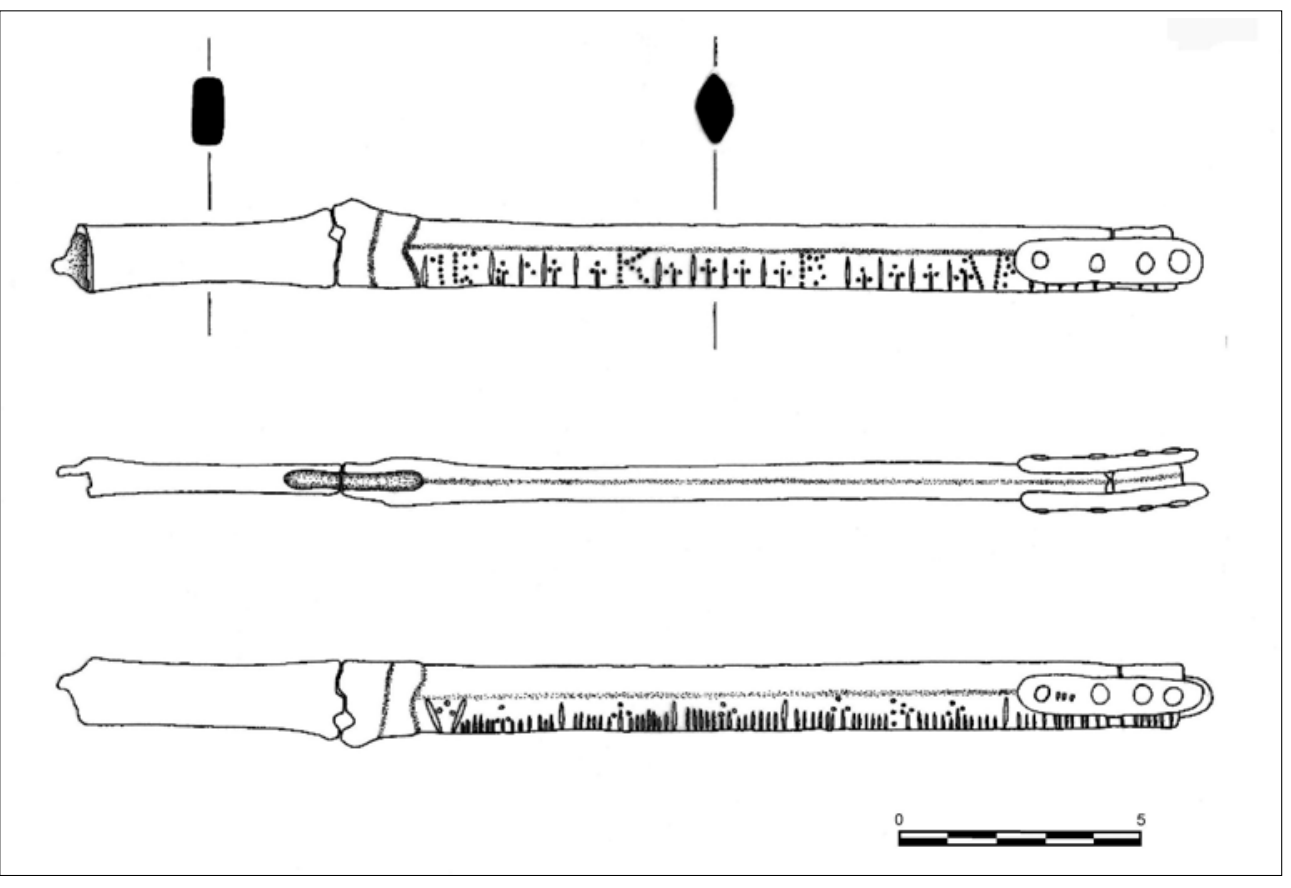

Figura 10. Els dos fragments de la statera bizantina. subjecten amb quatre reblons; posteriorment es va trencar definitivament en dues parts a l'altura de l'apèndix on es troba el forat de suspensió. Avui conserva $23 \mathrm{~cm}$ de longitud i li falten els dos extrems. Presenta una secció romboidal en la part corresponent a la numeració i rectangular en la part més curta on es troba l'apèndix. El braç de les escales conserva $15,5 \mathrm{~cm}$ de longitud, i aquestes figuren en les dues cares, senyalades amb fines línies incises de diferent llargària, grups de punts i lletres gregues fetes també amb punts, que representen les lliures i les unces. Es pot classificar en el tipus Constantinopla dels establerts per Franken (1993, 89-94, 113-116, fig. 11), propi de l'època bizantina, que reuneix 54 exemplars distribuïts majoritàriament pel Mediterrani oriental, on es troben en ciutats com Corint, Efes, Pèrgam, etc. (Visy 1994). Entre els diferents paral-lels que podem citar es troba l'exemplar recuperat al derelicte bizantí de Yassi Ada, de 27,8 cm de longitud, que data del segle VII (Bass i Van Doorninck 1982, 218-230, fig. 10-19 i 10-20). A la península Ibèrica només es coneixien fins ara dues balances d'aquest tipus al dipòsit de bronzes del Collet de Sant Antoni de Calonge (Girona), que fou publicat per P. de Palol (1953), l'ocultació del qual data del principi del segle viII. Posteriorment s'han donat a conèixer alguns accessoris, com ara ponderals i una cadena amb ganxo del barri bizantí del teatre romà de Cartagena (Vizcaíno 2009, 805-806, làm. 109). Per comunicació del professor L. Olmo, sabem que a Recópolis es va trobar un altre exemplar de balança d'aquest tipus.

De vidre hi ha cinc fragments, dels quals un és de color blavenc i pertany a una vora recta de
$9 \mathrm{~cm}$ de diàmetre amb el llavi engrossit i estries a l'exterior, possiblement d'una copa, i l'altre és part d'una tija massissa de color verdós amb torsió helicoidal i $9 \mathrm{~mm}$ de diàmetre, possiblement d'una copa de la forma Foy 27 (Foy 1995, 211). Aquest tipus de copes de tija alta poden datar-se en els segles VII-VIII; sembla que corresponen a importacions d'Àfrica o Orient i són molt típiques de l'etapa bizantina. Se n'han trobat, entre altres, en alguns jaciments catalans com Can Gambús (Sabadell) i Puig Rom (Coll 2011, 208, làm. 2, 15, i làm. 4, 32-24), i al Tolmo de Minateda i en nivells bizantins de Carthago Spartaria (Sánchez de Prado 2018, 353-354, fig. 223, 14-17). L'altra peça destacada és una perla de vidre de color blau i cos decorat amb gallons que devia tenir una ànima d'un altre material que ha desaparegut. Es tracta d'un tipus que apareix en època romana i és particularment freqüent en els segles VI-VII formant part de collars, braçalets i penjolls (Mastykova 2010). Es troba majoritàriament en contextos funeraris d'època visigoda, com per exemple a les necròpolis de Carpio del Tajo de Toledo (Ripoll 1985, 32, fig. p. 217, 1) i el Camino de los Afligidos d'Alcalá de Henares (Maczynska 1991), i també bizantina, com a la necròpolis oriental de Carthago Spartaria, amb una datació de la segona meitat del segle VI (Madrid i Vizcaíno 2007, 190-191). Al País Valencià les trobem a la necròpolis del Tossal de les Basses (Alacant) en tombes del segle VII (Rosser 2013, 361, 533, 535). 


\section{Consideracions finals}

La problemàtica que planteja aquest jaciment se centra en dues qüestions fonamentals, com són la funció i la datació. Si, en el cas de la segona, el millor coneixement de les produccions ceràmiques avui en permet una millor aproximació, per a la primera seguim sense poder donar respostes convincents; el fet que no se'n conega cap referència en les fonts no ajuda a clarificar-la. Sobre les dues qüestions hi pesa la limitació que suposa comptar només amb la informació obtinguda en una sola campanya d'excavacions. Pel que fa al context ceràmic, cal considerar que la mostra no és molt nombrosa i futurs treballs poden canviar la limitada perspectiva actual amb l'aparició de nous tipus i produccions, tècniques i motius decoratius, etc. Del que tenim avui poden destacar-se alguns trets com són el predomini de la ceràmica de cocció reductora, amb l'olla com a forma majoritària i les gerretes en nombre reduït; el caràcter minoritari de la ceràmica de cocció oxidant, amb contenidors de líquids com les gerres i els cànters; i la presència exclusiva entre les tècniques i els motius decoratius de les estries, els acanalats i les línies ondulades incises. El reduït repertori tipològic i l'absència de tècniques decoratives com la pintura amb òxid de ferro o el vidrat poden tenir una justificació de caràcter cronològic.

L'ocupació del Puig del Cid creiem que ha de fixar-se de manera general entre la fi de les importacions de ceràmica de tradició romana -fonamentalment africana i oriental--, en el segle vII, i l'extensió de les tècniques decoratives andalusines com el vidrat monocrom, en el segle x. Encara que alguns dels tipus ceràmics identificats tenen paral.lels en contextos datats des del segle VII, la majoria tenen una cronologia més avançada que pot situar-se entre la segona meitat del segle vIII i el segle Ix. Aquesta datació, però, sembla presentar algunes discordances amb la d'altres peces de metall i vidre. Es tracta de la statera, que data dels segles VI-VII, i la copa de vidre, dels segles VII-VIII; es pot admetre que la primera haja perdurat llarg temps pel seu material i caràcter utilitari, hipòtesi que pot trobar suport en la reparació de què fou objecte; però en el cas del vidre aquesta possibilitat sembla més estranya per la seua fragilitat, tot i que no puga descartar-se.

També en el cas de la fortificació la utilització del morter de calç com a material constructiu, així com les característiques de les torres, poden plantejar problemes cronològics. Els paral-lels més pròxims són alguns recintes d'època visigoda que poden datar-se en els segles VI-VII. L'únic conegut al País Valencià és el de València la Vella, amb una superfície de 4,5 ha i una muralla d'1,8-2 m de grossària, reforçada amb torres massisses de planta aproximadament quadrada i reduïdes dimensions (Rosselló 1996, 439; vid. en aquest mateix volum). Altres paral.lels més allunyats poden ser el castrum de Puig Rom (Girona), on la muralla té uns 2,30 m de grossària i està reforçada amb algunes torres massisses que no pareixen seguir una disposició regular (Subías et al. 2016, 94-95; vid. en aquest mateix volum). Finalment, podem esmentar la muralla de Recópolis (Toledo), que presenta una grossària d'1,80-2 m; està reforçada amb torres massisses majoritàriament quadrangulars situades a distàncies irregulars que tenen d'amplària fins a $6,5 \mathrm{~m}$ i es projecten tant cap a l'interior com cap a l'exterior entre 2 i 3 m (Gómez de la Torre-Verdejo 2008). Els recintes de cronologia posterior estan construïts en la seua majoria de pedra seca o amb morter de fang. El més pròxim és el Tossal de Mollet, que presenta una estructura tripartida, amb un castrum al cim, un recinte denominat «acròpolis» i una extensa vila, l'abandonament del qual es data amb anterioritat al segle $\mathrm{x}$, però on totes les construccions són de pedra seca (Bazzana i Guichard 1978). Més allunyat és el cas del Castellar d'Elx, amb una superfície d'11,4 ha, l'ocupació del qual es data entre la segona meitat del segle $\mathrm{x}$ i la primera de l'XI, on la muralla té una longitud aproximada de $1.050 \mathrm{~m}$, és de pedra seca i només alguns trams tenen morter de fang; tan sols el recinte superior, l'Edifici III o Castellet, està construït amb morter de calç (Gutiérrez Lloret, Menéndez Fueyo i Guichard 2008, 180-182; Gutiérrez Lloret et al. 2010, 20-21 i 29-34).

Si les proporcions i característiques de la fortificació no pareixen pròpies d'un campament temporal, la falta d'infraestructures hidràuliques sembla que no permet atribuir-li un caràcter urbà; en aquest cas, a més, resultaria estrany que es trobés a tan curta distància de Sagunt. També el nombre d'edificis existent a l'interior del recinte emmurallat sembla escàs per a la seua gran superfície. D'altra banda, l'escassa potència de l'únic nivell d'ocupació prova que aquesta no degué ser molt prolongada, i el fet que no s'hagen trobat evidències de destrucció o incendi es correspon a un abandonament sense violència. Quant als edificis existents al seu interior, la planta de l'excavat parcialment no s'assembla a la de les cases excavades als jaciments citats del Tossal de Mollet (Bazzana i Guichard 1978, 494, fig. 7) o el Castellar d'Elx (Gutiérrez Lloret et al. 2010, 35-38, fig. 01-08), que es caracteritzen per comptar amb un pati al voltant del qual es distribueixen les diferents estances.

En resum, podem dir que l'estudi de la fortificació i dels materials recuperats en l'excavació 
del 1980 ha permès avançar un poc en la seua datació, que cal portar a l'època emiral, però no en altres qüestions fonamentals com la seua funció i el context històric en el qual es va construir. Es tracta, doncs, d'unes conclusions que s'han de prendre amb les reserves naturals perquè s'ha comptat només amb els resultats d'una sola campanya d'excavacions, i que resten a l'espera de noves dades que sens dubte aportaran futurs i desitjables treballs.

\section{Bibliografia}

Alcina Franch, J. 1950: «Las ruinas romanas de Almenara (Castellón)», Boletín de la Sociedad Castellonense de Cultura, xxvI, Castelló, 92-128.

Amorós Ruiz, V. 2011: Contextos cerámicos del siglo VIII en el Tolmo de Minateda, Albacete.

- 2018: El Tolmo de Minateda en la Alta Edad Media. Cerámica y contexto, Alacant.

Arasa I GIL, F. 1980: «El Punt del Cid d'Almenara (la Plana Baixa, Castelló). Notes sobre la primera campanya d'excavacions", Cuadernos de Prehistoria y Arqueología Castellonense, 7, Castelló de la Plana, 219-242.

- 2000: «El conjunto monumental de Almenara (la Plana Baixa, Castelló)», en: Los orígenes del cristianismo en Valencia y su entorno, València, 113-118.

- 2014-2015: «Lluís Cebrian Mezquita: l'arqueologia en l'obra d'un destacat representant de la Renaixença», Saitabi, 64-65, València, 183-202.

Bass, G. F.; Doorninck, JR., F. H. van 1982: Yassi Ada. A Seventh-Century Byzantine Shipwreck, I, Texas.

Bazzana, A. 1978: «Les villages désertés de l’Espagne orientale: état présent et perspectives d'une recherche archéologique», Archéologie Médiévale, vIII, Caen, 165-223.

- 1986: «Essai de typologie des ollas valenciennes», en: II Congreso Internacional de Cerámica Medieval del Mediterráneo Occidental, Toledo, 93-99.

Bazzana, A.; Guichard, P. 1976: «Recherche sur les habitats musulmans du Levant espagnol», en: Atti del Colloquio Internazionale di Archeologia Medievale, Palerm, 60-69.

- 1978: «Un important site-refuge du haut MoyenÂge dans la région valencienne. Le despoblado du Monte Mollet (Villafamés, Castellón)», en: Mélanges de la Casa de Velázquez, xIv, París, 485-501.

Bosó Doménech, E. 2011: «Referències al port de l'Estany d'Almenara», Boletín de la Sociedad Castellonense de Cultura, LxxxvII, Castelló de la Plana, 27-50.
Chabret Fraga, A. 1888: Sagunto. Su historia y monumentos, Barcelona.

Coll RiERA, J. M. 2011: «Els vidres d'època visigoda a Catalunya: primeres dades», en: De la fi de la Tarraconense a la consolidació dels comtats. Actes del IV Congrés d'Arqueologia Medieval i Moderna de Catalunya, I, Tarragona, 201-209.

FLCM = Relación de Fondos Personales. Luis Cebrián Mezquita. Universidad de Navarra (UN). Archivo General, Pamplona.

Foy, D. 1995: «Le verre de la fin du Ive au viIIe siècle en France méditerranéenne. Premier essai de typo-chronologie», en: Le verre de l'Antiquité Tardive et du Haut Moyen Âge. Typologie-Chronologie-Diffusion, Guiry-en-Vexin, 187-242.

FRANKEN, N. 1993: «Zur Typologie antiker Schnellwaagen», Bonner Jahrbücher, 193, 69-120.

García y Bellido, A. 1976: «El ejército romano en Hispania», Archivo Español de Arqueología, 49, Madrid, 59-101.

García Borja, P.; Palmer, J.; Selma, S.; Carrión, Y.; Pérez Jordà, G.; Real, C. 2018: «Les primeres evidències andalusines al tossal de la Magdalena», Quaderns de Prehistòria i Arqueologia de Castelló, 36, Castelló de la Plana, 217-229.

Gómez de la ToRre-VerdeJo, A. 2008: «La muralla de Recópolis», Zona Arqueológica (Recópolis y la ciudad en la época visigoda), 9, Alcalá de Henares, 77-86.

Gómez Serrano, N. P. 1929: «Secció d'Antropologia i Prehistòria. Resum dels seus treballs», Anuario del Centro de Cultura Valenciana, vI, València, 200-201.

- 1933: «Secció d'Antropologia i Prehistòria. Resum dels seus treballs durant l'any $1931 \mathrm{i}$ del curs 1931-32», Anales del Centro de Cultura Valenciana, vI, València, 28-35.

GonZÁLEZ SimANCAS, M. 1928: «Excavaciones arqueológicas en Almenara. El campamento de Aníbal», Las Provincias, 18 de setembre, València.

Gutiérrez Lloret, S.; MenÉndez Fueyo, J. L.; GuiCHARD, P. 2008: «El Castellar de la Morera de Elche: ¿Madīna o Hiṣn?», Lucentum, xxvII, Alacant, 175-190.

Gutiérrez Lloret, S.; Menéndez Fueyo, J. L.; Guichard, P.; Martí Oltra, J.; Pascual Pacheco, J.; López Padilla, J. A.; Ferrer Carrión, R.; Pina Mira, J.; Checa Martínez, N.; Candela TorreGrosa, L. 2010: El Castellar d'Elx. L'origen de la ciutat medieval, Alacant.

Juan, A.; Pastor, I. 1989: «Los Visigodos en Valencia. Pla de Nadal: ¿Una villa áulica?», Boletín de Arqueología Medieval, 3, Ciudad Real, 137179.

Llorente Olivares, T. 1887: Valencia. Sus monumentos y arte; su naturaleza e historia, I, Barcelona. 
Maczynska, M. 1991: «Westgotische Perlen. Funde vom Gräberfeld Carpio del Tajo und aus den Sammlungen in Barcelona und Nürnberg», Madrider Mitteilungen, 33, 145-183.

Madrid BalanzÁ, M. ${ }^{a}$ J.; Vizcaíno Sánchez, J. 2007: «Collares de época bizantina procedentes de la necrópolis oriental de Carthago Spartaria», Verdolay, 10, Múrcia, 173-196.

Martí Matías, M. R. 2001: Visigodos, Hispanoromanos y bizantinos en la zona valenciana en el siglo VI (España), BAR International Series, 943, Oxford.

Mastykova, A. 2010: «Les perles en Espagne et en Gaule méridionale à l'époque wisigothique ( $\mathrm{v}^{\mathrm{e}}$ $\mathrm{VII}^{\mathrm{e}}$ s.)», Zona Arqueológica. El tiempo de los «bárbaros». Pervivencia y transformación en Galia e Hispania (ss. V-VI d. C.), 11, Alcalá de Henares, 461-474.

Méndez Madariaga, A.; Rascón Marqués, S. 1989: Los Visigodos en Alcalá de Henares, Alcalá de Henares.

Mesado Oliver, N. 1966: «Breves notas sobre las ruinas romanas de "Els Estanys" (Almenara)», Archivo de Prehistoria Levantina, XI, València, 177-196.

Montmessin, I. 1980: «Description analytique de la céramique commune du testar de Onda / Mas de Pere (Castellón)», Cuadernos de Prehistoria y Arqueología Castellonenses, 7, Castelló de la Plana, 243-288.

Morillo Cerdán, A. 1991: «Fortificaciones campamentales de época romana en España», Archivo Español de Arqueología, 64, Madrid, 135190.

Negre Pérez, J. 2014: «La cerámica altomedieval de Tortosa (siglos VII-X). Una primera clasificación y análisis interpretativo», Arqueología y Territorio Medieval, 21, Jaén, 39-67.

Palol DE Salellas, P. 1953: "Cronología de los bronces del "Collet de Sant Antoni de Calonge" (Gerona)», PSANA, 2, Saragossa, 39-68.

Pascual, J.; Ribera, A. V.; Rosselló, M. 2003: «Cerámicas de la ciudad de Valencia entre la época visigoda y omeya (siglos VI-X)», en: CABallero, L.; Mateos, P.; Retuerce, M. (ed.). Cerámicas tardorromanas y altomedievales en la Península Ibérica. Ruptura y continuidad, Anejos de AEspA, XXVIII, Madrid, 67-117.

Pascual, J.; Ribera, A. V.; Rosselló, M.; Marot, T. 1997: "València i el seu territori: Contexts ceràmics de la fi de la romanitat a la fi del califat (270-1031)», en: Contextos ceràmics d'època romana tardana $i$ de l'alta edat mitjana (segles $(V-X)$, Arqueo Mediterrània, 2, Barcelona, 179202.

Pérez García, V. Ll. 2012: «Late Roman and Visigothic Military Fortifications in Conventus
Tarraconensis (Hispania): The Organization of Border Defence», Aqvila Legionis, 15, 165-202.

Remolà Vallverdú, J. A.; Macias i Solé, J. M. 2000: «Tarraco visigoda. Caracterización del material cerámico del siglo vII dC», en: V Reunió d'Arqueologia Cristiana Hispànica, Barcelona, 485-498.

RIPOLL LóPEZ, G. 1985: La necrópolis visigoda de El Carpio del Tajo (Toledo), EAE, 142, Madrid.

Rodríguez Martorell, F; Macias Solé, J. M. 2016: «Un nuevo contexto cerámico de la segunda mitad del siglo vII d. C. en Tarracona (Tarraconensis, Regnum Visigothorum)», en: JÁRREGA, R.; BERNI, P. (ed.). Amphorae ex Hispania: paisajes de producción y consumo, Tarragona, 936-952.

- 2018: «Buscando el siglo viII en el puerto de Tarracona: entre la residualidad y el desconocimiento», en: MARTín VISo, I. [et al.] (coord.). Cerámicas Altomedievales en Hispania y su entorno (siglos V-VIII d. C.), Valladolid, 573-589.

Rosselló Mesouida, M. 1996: «El yacimiento de València la Vella (Riba-roja de Túria, Valencia). Algunas consideraciones para su atribución cronológica y cultural», Quaderns de Prehistòria i Arqueologia de Castelló, 17, Castelló de la Plana, 435-454.

Rosselló Mesouida, M.; Ribera i Lacomba, A. V. 2004: "Las cerámicas del siglo VII d.C. en Valentia (Hispania) y su entorno», Rei Cretariae Romanae Fautorum Acta, 39, 155-164.

Rosser Limiñana, P. 2013: Arqueología del poblamiento de un territorio del Mediterráneo occidental (Alicante, España) desde época tardía a la primera ocupación islámica. Un espacio activo sin ciudad: de villas a aldeas, tesi doctoral, Universitat d'Alacant, Alacant.

SÁnchez de Prado, M. ${ }^{a}$ D. 2018: La vajilla de vidrio en el ámbito suroriental de la Hispania romana. Comercio y producción entre los siglos I-VII $d$. C., Alacant.

Schulten, A. 1928a: «Campamentos romanos en España», Investigación y Progreso, 5, Madrid, 34-36.

- 1928b: «Römischen Lager in Spanien», Forschungen und Fortschritte, 4, Berlín, 41-43.

Subías, E.; Puig, A. M.; Codina, D.; FIZ, J. I. 2016: «El castrum visigòtic de Puig Rom revisitat», Annals de l'Institut d'Estudis Empordanesos, 47, 75-96.

VISY, Z. 1994: «Römische und byzantinische Schnellwaagen aus der Türkei», en: Akten der 10. Internationalen Tagung über antike Bronzen, Stuttgart, 435-444.

Vizcaíno SÁnchez, J. 2009: La presencia bizantina en Hispania (siglos VI-VII). La documentación arqueológica, Múrcia. 



\title{
NUEVOS DATOS SOBRE EL ASENTAMIENTO VISIGODO DE VALĖNCIA LA VELLA
}

\author{
Esperança Huguet Enguita, ${ }^{1}$ Josep M. Macias Solé, ${ }^{1}$ Albert Ribera Lacomba, ${ }^{1}$ Francesc \\ Rodríguez Martorell, ${ }^{1}$ Miquel Rosselló Mesquida ${ }^{2}$
}

\section{Resumen}

Presentamos los primeros resultados obtenidos en el proyecto de excavaciones arqueológicas en València la Vella y ejecutados entre los años 2016 y 2018. En estas primeras campañas hemos optado por la documentación topográfica del asentamiento y la ejecución de sondeos de verificación estratigráfica. Además se ha incidido en la documentación de los tramos de muralla más afectados por destrucciones realizadas en el siglo xx.

Estas actividades han permitido corroborar la cronología visigoda de un núcleo amurallado de casi 5 ha y constatar la importancia del urbanismo intramuros, así como de las actividades económicas que se pudieron realizar en su interior. De este modo, València la Vella se ofrece a la comunidad científica como uno de los yacimientos arqueológicos visigodos más relevantes para el conocimiento del urbanismo y la sociedad de los siglos VI y viI.

\begin{abstract}
We present the first results obtained in the archaeological research project carried out in València la Vella between 2016 and 2018. In these first campaigns we documented the settlement topographically and dug stratigraphic verification trenches. We have also started to document the section of the wall most damaged by actions in the twentieth century.

These activities have allowed us to corroborate the Visigothic chronology of a walled nucleus of almost 5 hectares and to confirm the importance of the intramural urban planning and the economic activities undertaken in it. In this way we are able to offer València la Vella to the scientific community as one of the most important Visigothic archaeological sites for contributing to our knowledge of urban planning and society in the sixth and seventh centuries.
\end{abstract}




\section{Presentación y antecedentes}

El yacimiento arqueológico de València la Vella ha representado una de las incógnitas más relevantes de la arqueología e historiografía del País Valenciano. Al misterio implícito que siempre conlleva un pasado desconocido, debe añadirse la presencia y visibilidad de un conjunto amurallado que llamaría la atención desde siglos atrás y que ya aparece mencionado en la Baja Edad Media. No en vano, se trata de una extensa área fortificada que cubría casi 5 ha de superficie sobre un promontorio ubicado entre el río Turia y el barranco de la Cabrassa, y hoy en día todavía conserva murallas de más de $3 \mathrm{~m}$ de altura. El recinto amurallado sobresalía entre los 24 y $41 \mathrm{~m}$ sobre el curso del río Turia, y su perímetro defensivo (hipotéticamente, unos $980 \mathrm{~m}$ de longitud) se adaptó a las características topográficas del enclave, dominando parte del valle fluvial y perfectamente visible des de los montículos vecinos de Els Cara-sols, La Muntanyeta dels Frares, el Tossal de Montiel, La Vallbona, La Vallesa de Mandor y La Lloma de Betxí.

Posiblemente, a través de caminos fluviales, el enclave constituiría un punto de control óptimo de la comunicación entre la antigua ciudad romana de Valentia y su hinterland. Además, prueba de su interés estratégico fue, durante la guerra civil española, la instalación de estructuras de hormigón y trincheras pertenecientes a la línea defensiva de La Immediata. Esta elevación, desde el punto de vista geológico, presenta una parte basal de materiales sedimentarios del Mioceno marino, parcialmente cubiertos por afloramientos de conglomerados. Ha sido, preferentemente, en el estrato miocénico donde se han excavado diversos túneles de la Guerra Civil o se han realizado extensos rebajes de acondicionamiento de la base de la muralla visigoda.

Este topónimo ya aparece mencionado en el año 1374, con ocasión de un proyecto, también recurrente, de trasvase de aguas entre los ríos Júcar y Turia (Sanchis Sivera 1922, 268; Martínez Ortiz 1980, 535). Y su condición de sitio conocido de ruinas y de hallazgos antiguos queda reflejada en la concesión de una licencia del año 1458 para la búsqueda de tesoros (Terol 1997, 150 y 152). El poeta Jaume Roig en el siglo xv dedica unos versos, en su obra L'Espill, a los restos de València la Vella y en clara contraposición a la actual ciudad de Valencia. Cabe recordar que el yacimiento pertenece al término municipal de Riba-roja de Túria, de la cual dista unos $3 \mathrm{~km}$, y se halla a unos $16 \mathrm{~km}$ al noroeste de Valencia. También hay que destacar que el recinto amurallado solo dista unos $4 \mathrm{~km}$ del conocido palacio tardovisigodo de Pla de Nadal (Ribera et al. 2015; Juan et al. 2018) (fig. 1).

Ya en época moderna estas ruinas impresionaron a los principales cronistas del reino, que trataron de identificarlas con alguna de las ciudades mencionadas en las fuentes clásicas, especialmente con la ciudad romana de Pallantia, según una teoría de un religioso dominico de finales del siglo Xv (un análisis más detallado en Juan [s. a.] y Rosselló 1996). En la etapa contemporánea,



FIgURA 1. Localización del yacimiento y de Riba-roja de Túria (2) en el contexto hispano y (1) del área metropolitana de València. A partir del Institut Cartogràfic Valencià. 
algunos historiadores y estudiosos asumieron la interpretación clásica de los antiguos cronistas o bien plantearon otras propuestas basándose en las ciudades mencionadas en las fuentes: Etobesa o la Etovissa cartaginense. Valls David (1902) defendió que Etobesa o Etovissa y Pallantia eran una misma ciudad; la Pallantia de los romanos sería así la Etovissa de los cartagineses. Su obra destaca porque incorpora el primer plano del recinto más una descripción detallada del mismo (fig. 2).

Toda esta tradición historiográfica refleja, básicamente por el nombre de València la Vella (la vieja), la suposición que estos restos correspondían a una primigenia fundación de Valencia que luego fue abandonada y trasladada al emplazamiento actual. Esta teoría ha sido rechazada por todos los investigadores actuales y definitivamente rebatida por la arqueología.

En el siglo xx, el Centro de Cultura Valenciana (1927) y Domingo Fletcher (1952) prospectaron el yacimiento, pero sin resolver los interrogantes que hemos apuntado. El primer punto de inflexión sobre su consideración patrimonial se produjo en el año 1977, a raíz de la extracción, mediante una máquina retroexcavadora, de varias toneladas de tierra y piedras del promontorio, que ocasionó el arrasamiento descontrolado de parte de la muralla, más el rebaje irrecuperable de una porción del sector oeste del recinto. Estos hechos lamentables se produjeron por las obras de construcción de un paso elevado sobre el trazado de la vía del ferrocarril Valencia-Liria (Pastor 1981; Juan [s. a.]). Obviamente, no fue la primera destrucción sufrida por el yacimiento, pero sí la primera con un impacto mediático y, además, en plena efervescencia de una sociedad en vías de democratización y de búsqueda de sus raíces históricas. Al respecto, solo hay que apuntar la noticia recogida por $\mathrm{R}$. David Valls referente a la construcción del puente ferroviario sobre el barranco de la Cabrassa a partir de sillares extraídos del mismo enclave.

Pero los hechos de la década de los setenta propiciaron que el Servicio de Investigación Prehistórica (SIP) de la Diputación de Valencia, en colaboración con el Laboratorio de Arqueología de la Universidad de Valencia, decidiera intervenir. Se realizaron tres cortas campañas en los años 1978, 1979 y 1980, dirigidas las dos primeras por Gerardo Pereira y la última por Carmen Aranegui. Los resultados fueron dados a conocer en las respectivas series de La labor del SIP y su Museo (SIP 1979; 1980; 1981). Las excavaciones se focalizaron en un gran edificio de la zona sureste del recinto, junto a la teórica puerta principal de la muralla y a una posible gran plaza anexa de recepción o redistribución interior. La documentación efectuada constató la existencia de una actividad constructiva notable, alzada mediante segmentos de mampostería de cal junto con grandes bloques de piedra de cohesión o bien en posición esquinera. Una técnica que recuerda las obras de pseudo opus africanum características del período visigodo (Beltrán de Heredia y Macias 2016). El otro gran logro fue la definición de una cronología tardoantigua (siglo IV o posterior) para estas construcciones. Este hecho desmontó las teorías precedentes sobre la cronología antigua del enclave y abrió nuevos interrogantes en torno a la interpretación y relación entre este núcleo y las cercanas sede episcopal de Valentia y área residencial palacial de Pla de Nadal. A la vez, desgraciadamente, el nuevo marco cronológico no enca-

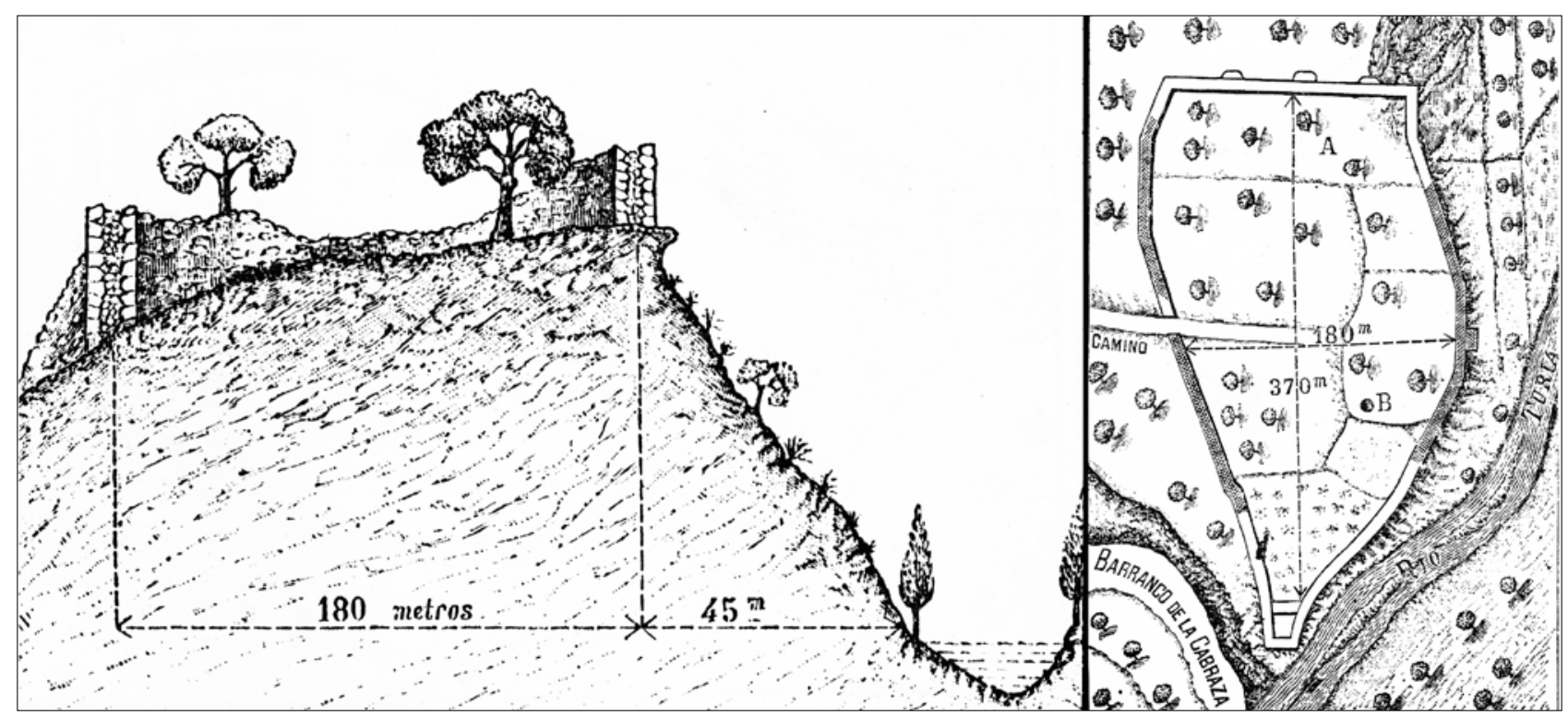

FIgURA 2. Documentación gráfica de València la Vella efectuada por R. Valls (1902). 
jaba en las líneas de investigación institucionales de la Diputación y la Universidad de Valencia. De modo que el yacimiento quedó al margen de todo proyecto de investigación, no así de las problemáticas intrínsecas a la protección del patrimonio arquitectónico rural.

En 1998 la Consejería de Cultura costeó el levantamiento topográfico del yacimiento y autorizó una prospección arqueológica, realizada bajo la dirección de Miquel Rosselló, quien comprobó, a pesar de las agresiones que se habían efectuado, su gran potencialidad y, mediante el análisis de las estructuras y las técnicas constructivas y el estudio de los materiales arqueológicos de superficie, pudo fijar la cronología del yacimiento y su contexto histórico en plena etapa visigoda (Rosselló 1996; 1998; 2000). A pesar de estos esfuerzos, entre los años 2001-2002 se arrasó, nuevamente, otra parte de la muralla. En esta ocasión, un segmento de $25 \mathrm{~m}$ de longitud situado al NW del yacimiento, y para instalar una canalización de agua potable.

Finalmente, en el año 2016, y a instancias del Ayuntamiento de Riba-roja de Túria, se firmó un convenio de colaboración entre este consistorio y el Institut Català d'Arqueologia Clàssica para la documentación y el estudio de València la Vella. Además, en el contexto de esta iniciativa local, se viene realizando en los últimos años la compra o permuta de las fincas rurales por donde se extiende el asentamiento, a fin de generar un espacio público de interés histórico y natural. El yacimiento se halla dentro del parque natural del Turia, de modo que no podemos considerarlo únicamente un espacio de interés patrimonial, sino también paisajístico y biológico. A diferencia de otros extensos núcleos rurales hispanos, este enclave se halla perfectamente conectado dentro de la comarca del Camp de Túria, una de las mayores áreas metropolitanas del Estado español. Por todo ello, las posibilidades de socialización del yacimiento permiten considerar a València la Vella, y dentro de su período histórico, uno de los recintos con mayor potencialidad del occidente europeo. A esta potencialidad, cabe añadirle el conjunto palaciego de Pla de Nadal y la reciente creación del Museo Visigodo de Pla de Nadal (MUPLA), ambos gestionados por el área de Turismo y Patrimonio del municipio.

En esta primera fase, las excavaciones arqueológicas se han realizado, después de 36 años de la última intervención, de forma anual desde el año 2016 a partir de los Cursos de Arqueología Cristiana y Visigoda, organizados por el Ayuntamiento y el ICAC, y con la colaboración de la Diputación, el Ayuntamiento de Valencia, el Museo de Prehistoria de la Diputación de Valencia y el proyecto mi- nisterial HAR2015-64392-C4-2P MINECO-Feder. Se trata de una iniciativa que no se ha planteado exclusivamente como un proyecto científico, sino como una apuesta docente a largo plazo de potenciación del interés por el estudio de la Antigüedad Tardía y visigoda en tierras valencianas.

Las actuaciones arqueológicas desarrolladas se han centrado en la identificación de las principales áreas del yacimiento y en el estudio de sus murallas. Este último elemento se ha considerado fundamental para la precisión cronológica de la fundación, a la vez que constituye el elemento patrimonial más necesitado de una intervención arqueológica de restauración. En una parte, porque se halla afectado por la vegetación existente; en otra, porque un segmento de $200 \mathrm{~m}$ fue cortado transversalmente por los rebajes mecánicos de los años setenta del siglo pasado. Este hecho conllevó el rebaje de varias torres y que un tramo defensivo solo haya conservado el paramento interno y parte de su relleno. En estos puntos la vegetación afecta considerablemente la estabilidad e integridad de la muralla.

Para este fin, se han realizado diversos sondeos arqueológicos, con especial incidencia en un sector interno y anexo al perímetro defensivo, área suroeste del asentamiento. Los sondeos efectuados y las primeras pruebas de prospección geofísica realizadas por el departamento de Geodesia de la Universitat Politécnica de València muestran una considerable densidad urbanística que, hipotéticamente, se halla zonificada según la orografía del yacimiento. Hoy por hoy planteamos una especie de «acrópolis» situada junto al escarpe fluvial del promontorio y donde hemos documentado, en superficie, diversas estancias de entidad arquitectónica y de «construcción clásica». Son ámbitos pavimentados con mortero de cal de gran entidad y consistencia donde se han recuperado numerosas tegulae. También ha sido localizada, en el centro de la parte baja, junto a una probable entrada, una gran explanada interior que podría identificarse como la principal área de recepción o redistribución del recinto amurallado. En este punto, las prospecciones geofísicas no detectaron ocupación arquitectónica, mientras que a su alrededor se localizan las relevantes estructuras halladas en los años setenta del siglo pasado, más un acceso importante en la muralla. En este punto asoman los restos de dos torres muy próximas entre ellas, pero ocultas por la vegetación, más evidencias de una vía periférica de acceso, cuyo itinerario fue en parte recortado en el substrato geológico (figs. 3 y 4).

Las excavaciones del sector suroeste $\left(122 \mathrm{~m}^{2}\right)$ junto a la muralla han identificado una posible zona productiva con evidencias de un taller de vidrio y silos de almacenamiento en el subsuelo. 
Este hecho, evidenciado a partir de fragmentos de bloques de vidrio y crisoles de fundición, apunta a la existencia de una producción local de vidrio, un hecho significativo y común respecto a otros centros visigodos, como Reccopolis (Gómez 2011), y que pone de manifiesto la relevancia urbana del enclave. Destaca también la circunstancia de que los ámbitos descubiertos no se adosan a la mura- lla, sino que se intuye un pasillo de circulación a modo de intervallum (fig. 6). Otra actuación, realizada en el exterior de la ciudad y a unos escasos $20 \mathrm{~m}$ de la muralla, ha constatado prácticas de estercoladura de los campos que hemos relacionado con la elaboración premeditada de abono para el uso intensivo de las terrazas agrícolas ubicadas en el barranco de la Cabrassa. De ser así, este indi-

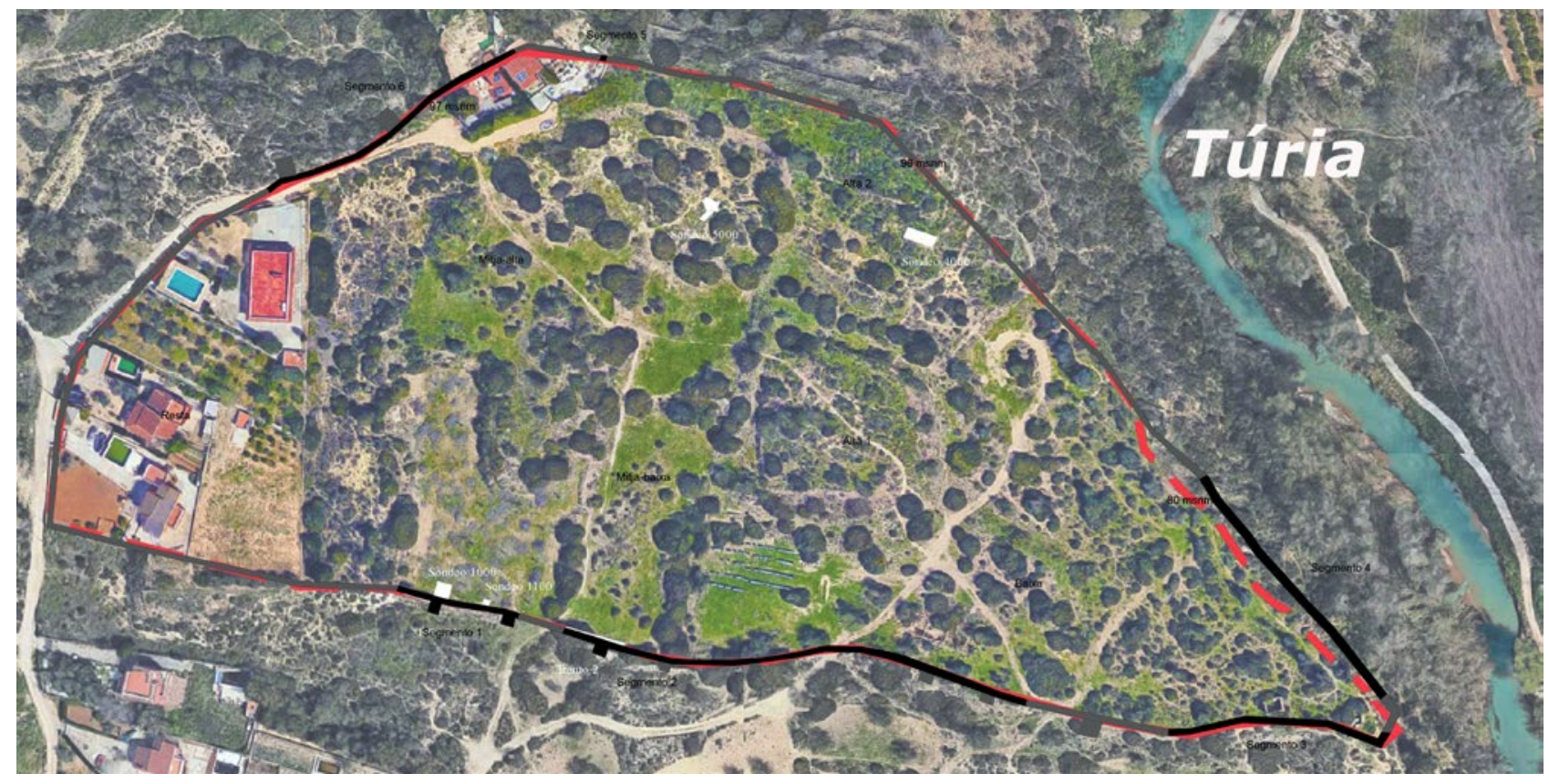

FIGURA 3. Imagen aérea del entorno natural del yacimiento (Google Earth) con la planimetría incorporada (autor: I. Fernández).

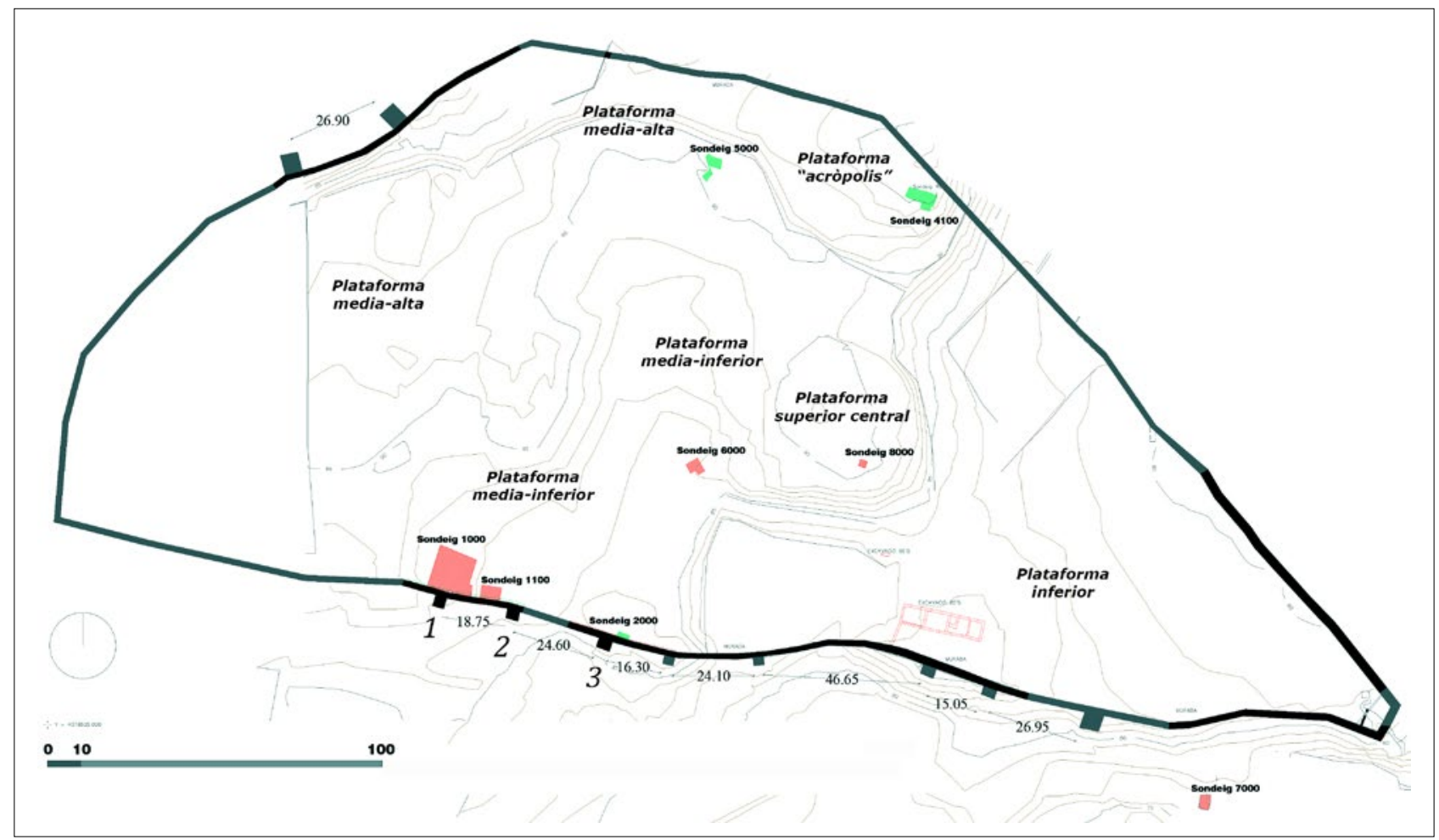

FIGURA 4. Planimetría general del yacimiento, zonificación y emplazamiento de los sondeos efectuados (autor: I. Fernández). 
cio nos indica una organización selectiva de los procesos de eliminación de residuos urbanos y del proceso productivo de autoabastecimiento.

Finalmente, otro de los principales objetivos de esta fase inicial ha sido la actualización de la documentación topográfica del yacimiento. Una tarea que se ha acompañado de actuaciones de prospección y delimitación del teórico perímetro defensivo, así como de la documentación fotogramétrica de los sondeos estratigráficos y de los segmentos de muralla analizados o descubiertos tras puntuales trabajos de desbrozo (fig. 4). Toda esta actividad, necesaria para posteriores trabajos de análisis y de restauración arquitectónica, es visible en una colección de modelos tridimensionales ubicada en el portal Sketchfab (<https://skfb. ly/6qzRu>). Todos estos nuevos datos convergen en señalar que se trata de un centro fortificado con un urbanismo monumental para su época y planificado, más allá de un simple castrum con meras funciones defensivas. Este asentamiento podría agrupar a la población de su entorno y desarrollar atribuciones administrativas y de jerarquización del territorio. En resumen, el balance de estas tres campañas ha sido muy positivo, tanto por la respuesta a la convocatoria de un curso veraniego con vocación formativa como por los resultados científicos de las excavaciones arqueológicas y las primeras actuaciones de difusión social.

\section{Las excavaciones junto a la muralla}

\subsection{Estratigrafía y rebaje constructivo}

Las actuaciones desarrolladas al pie de la muralla constatan que, tras una simple regularización del suelo geológico, sin voluntad de escalonamiento, se dispusieron grandes bloques de piedra que actuaron de base del resto del paramento, aunque no existe una regularidad estricta al respecto. En el costado interior, los restos de la estratigrafía natural, y en ocasiones la propia roca, fueron la superficie de trabajo durante este proceso constructivo inicial. A los pies de esta cimentación se ha documentado una compacta franja paralela de asentamiento e integrada por restos del nivel geológico extraído más piedras pequeñas y cal, que servía de refuerzo y de unión entre los bloques inferiores de la muralla y la roca. Por encima de ella hemos identificado, al pie del muro, una fina capa de cal con una ligera pendiente que hemos atribuido a un elemento de protección o drenaje de la base, a fin de evitar posibles escorrentías del ripio interno de la muralla. En este punto también se han apreciado goterones de la cal caída durante la fase de revoco del paramento de la muralla.
A continuación se dispuso una potente nivelación del terreno que uniformizaba y regularizaba la superficie geológica de un área interior adosada a la muralla, aunque con una pendiente paralela al perfil orográfico. Estos estratos estaban compuestos por tierra suelta grisácea y de granulometría fina con abundantes cantos y gravas, presentes también en una estancia anexa parcialmente excavada. Este hecho permite plantear la simultaneidad del proyecto urbanístico de la muralla y las construcciones internas contiguas en este sector del yacimiento. Tenían una potencia de entre 25 y $30 \mathrm{~cm}$, y en ellos se recuperó abundantísimo material cerámico, fauna, malacofauna, restos de elementos metálicos y fragmentos de vidrio. La parte superior de estos estratos constituyó el horizonte de circulación que sellaba este proceso constructivo.

\subsection{Materiales cerámicos y propuesta crono- lógica}

Estos rellenos constructivos de nivelación contenían un reducido conjunto cerámico que permite establecer una propuesta inicial de datación de la obra defensiva a partir de mediados del siglo vi (Huguet et al. en prensa). También se han recuperado restos de tegulae, imbrices, una loseta de pavimentación, fragmentos de dolia y otros residuales de sigillata itálica y de cerámica ibérica lisa. En lo que nos atañe, no aparecieron fragmentos de vajilla del servicio de mesa, pero sí ánforas, tanto de importación como de producción local o regional. Había algunos fragmentos de ánforas orientales, como la LRA 2; un pivote norteafricano Keay 62 datado en el siglo vi (Bonifay 2004, 137-140), con paralelos en las costas mediterráneas (Pascual, Ribera y Rosselló 2003, 73, fig. 3.112; Remolà 2000; Palol 2004, 98, fig. 129.8); y dos individuos de producción local o regional de ánforas de pequeñas dimensiones del tipo Keay 72, muy característico en Valencia en la segunda mitad del siglo vi (Rosselló y Cotino 2005, 150; Ribera y Rosselló 2012, 394).

Entre las cerámicas comunes no destinadas al fuego, las pastas eran mayoritariamente de cocción oxidante, y en menor cantidad también reductoras y siempre modeladas a torno. Se deben identificar como producciones locales o regionales producidas en un área relativamente cercana. Las formas más abundantes eran los morteros con visera de borde triangular y decoraciones incisas, los cuencos carenados, los boles de borde redondeado, las tapaderas, las jarras de borde trilobulado y una orza con tubo vertedor. Las decoraciones eran abundantes, y se repetían los motivos incisos de líneas paralelas y meandros. Los escasos frag- 
mentos decorados presentaban una pasta beis y más depurada que podría ser de origen baleárico, e incluso ibicenco (cfr. Buxeda et al. 2005; Ramón 2008, 582).

Las pastas de la cerámica de cocina eran duras y compactas, poco depuradas, de tonalidades rojizas, ocres, marrones, grises y negras, con desgrasantes medianos blancos calcáreos y cuarzo, probablemente de origen local o regional. La batería de cocina se reducía a un tipo de cazuela, una olla y una tapadera, aunque con diversas variantes. Las cazuelas de borde engrosado y reentrante eran una forma común en el Mediterráneo occidental durante la Antigüedad Tardía (Reynolds 1993, 143 y 148; Fulford y Peacock 1984; Macias 1999; Pascual, Ribera y Rosselló 2003), que en el área valenciana tienen unas características asas o elementos de prensión semilunares (Rosselló y Ribera 2004; Martínez-Porral et al. 2018; 2019). Muy numerosas también eran las ollas de borde exvasado con y sin asas, también abundantes en otros contextos y que, junto con la cazuela anterior, forman los recipientes más numerosos del yacimiento. Mención especial merece una olla de borde exvasado que se utilizó como crisol. Presenta la parte interior con una capa vítrea adherida y algunos goterones en el borde. Se han documentado también otros fragmentos informes de crisol en los alrededores y en posición superficial, algunos de ellos con una densa capa vítrea en la base. En cuanto a las tapaderas, aparecen de mediano y gran tamaño, con diferentes variantes de borde: plano, triangular y de perfil en $\mathrm{T}$.

El contexto cerámico aparecido en las unidades constructivas indica una cronología de siglo VI, posiblemente de mediados del siglo vi en adelante. Esta referencia debe tomarse como una primera aproximación temporal, a la espera de más datos materiales. Aun así, se trata del primer conjunto cerámico fundacional recuperado, y su incidencia en el contexto interpretativo del yacimiento es relevante. Este pequeño contexto presenta paralelos claros con los hallados en el área valenciana, en concreto con contextos de Valencia (Pascual, Ribera y Rosselló 2003), Cullera (Rosselló y Cotino 2005) y Alcácer (Alapont y Ballester 2007; Martínez-Porral et al. 2018; 2019). Todos ellos con numerosas cazuelas de borde reentrante, ollas de borde vuelto, hervidores con pico y un asa, cuencos carenados y morteros con ala.

Los datos aquí presentados, así como los obtenidos en otros sondeos estratigráficos, son temporalmente coincidentes con los materiales recuperados en el siglo pasado. Destacamos lo anecdótico del porcentaje de materiales de cronologías más antiguas e, incluso, de los siglos IV y v (cfr. Rosselló 1996, 443-445). Nuestra propuesta cronológica se irá perfilando en futuros trabajos arqueológicos; así como la sensación, todavía por ratificar, de que esta obra fue la primera gran edificación en el promontorio. No obstante, todas estas evidencias son suficientes para atestiguar la continuidad de los flujos comerciales mediterráneos hasta, como mínimo, mediados del siglo VII.

La campaña de excavaciones de 2018 ha proporcionado un interesante lote numismático que permitirá avanzar en el conocimiento del numerario corriente de los siglos VI y VII en el territorio valenciano. El uso metódico de un detector de metales como herramienta auxiliar ha proporcionado un conjunto de unas 120 monedas que abraza un período comprendido entre el siglo II a. C. y el VII d. C., entre las cuales destaca el numerario reutilizado del siglo IV. Y entre las emisiones de los siglos VI-VII, las de procedencia bizantina superan a las visigodas (Caldés en prensa). El hallazgo de numerosas monedas de bronce revela la plena circulación y aprovisionamiento de numerario, así como la capacidad adquisitiva de sus habitantes y la pervivencia de una economía monetaria. Un indicio más que ratifica la conectividad cosmopolita de este enclave fortificado.

\section{Las murallas de València la Vella}

\subsection{Dimensiones y componentes}

El reconocimiento topográfico efectuado actualiza el levantamiento realizado en el año 1998, si bien, en lo substancial, no se ha obtenido una visión divergente de la existente. La nueva planimetría reconstruye teóricamente el cierre occidental del asentamiento, alterado por las afectaciones mencionadas, y la planta obtenida dibuja, esquemáticamente, un recinto trapezoidal extremadamente apuntado en el cierre oriental por la proximidad con la unión del Túria y el barranco de la Cabrassa. Sus dimensiones teóricas aproximadas serían de unos $420 \mathrm{~m}$ de base por unos $170 \mathrm{~m}$ de altura, aunque el reconocimiento del perímetro no ha visualizado, junto al escarpe de $40 \mathrm{~m}$ que limita con el Túria, la continuidad de los muros. Cabría suponer que, ante esta ventaja, no fuera necesaria la prolongación de la muralla, pero la documentación efectuada por Valls David sí que dibuja su continuidad. Por otro lado, el cierre occidental es una propuesta teórica a partir de la orografía y de los caminos hoy existentes.

Las mediciones y prospecciones efectuadas concluyen un asentamiento con una extensión hipotética de 4,8 ha y con un perímetro teórico de $981 \mathrm{~m}$, de los cuales hemos visualizado unos 416. La muralla discurre entre las cotas 80 y $97 \mathrm{~m}$ 




FiguRA 5. Ortofotografía parcial de lienzos internos. Superior: sector 1000, cara opuesta torre 1. Inferior: sector 2000.

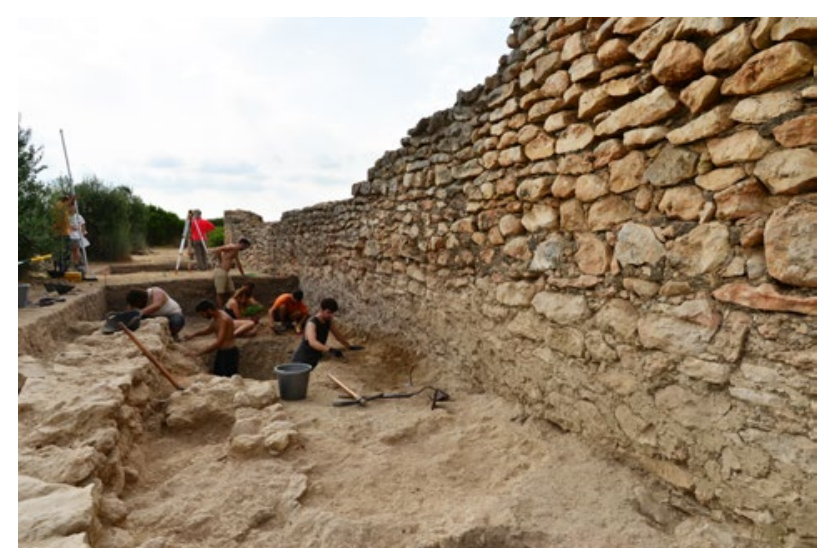

FIgURA 6. Sondeo 1000. Corredor lateral interior de la muralla. Nótese el sellado de las juntas de la mampostería de la muralla en el segmento protegido por la estratigrafía.

s. n. m., mientras que el curso del río se halla en torno a los $56 \mathrm{~m}$; y su grosor oscila entre un máximo de 2,10 m y un mínimo de 1,90 m. La altura máxima conservada es de 3,11 m. Hemos documentado arqueológicamente, pero de forma parcial, tres torres consecutivas, y creemos haber hallado siete más dispersas y ocultas por una espesa vegetación. La distancia entre las torres estudiadas es de 18,75 m y 24,60 m, mientras que otros pares de torres están distanciadas por $26,90 \mathrm{~m}$, $26,95 \mathrm{~m}, 24,10 \mathrm{~m}, 16,30 \mathrm{~m}$ y 15,05 m. Con estas referencias podemos prever un número aproximado de entre 25 y 28 torres, aunque insistimos en el
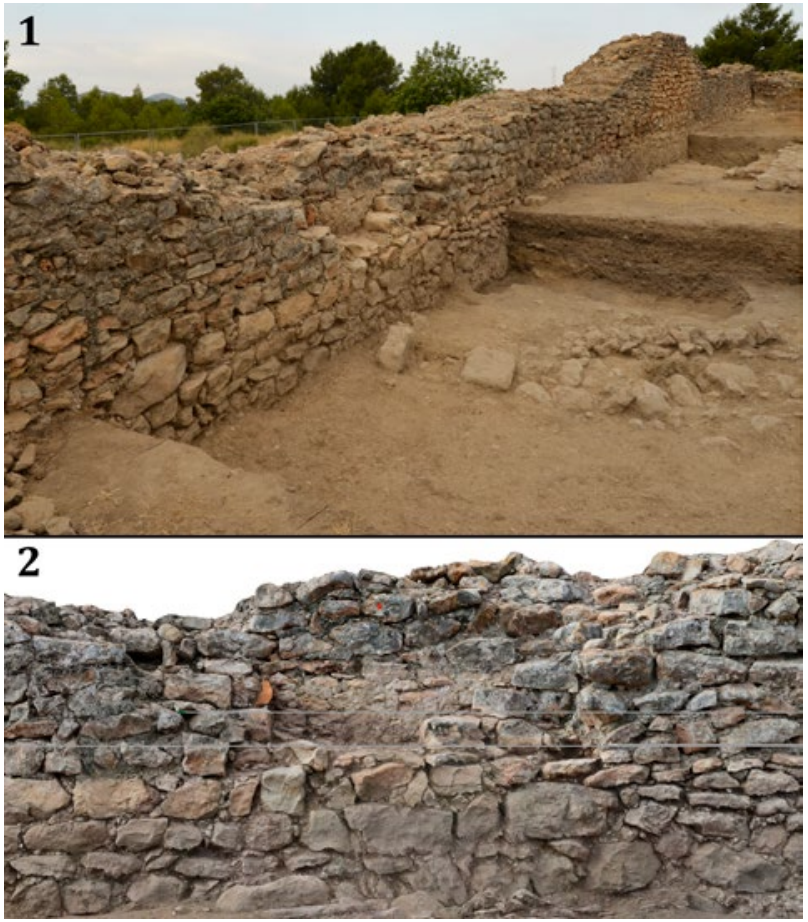

Figura 7. Detalle oblicuo de la muralla: (1) en el centro, la escalera doble integrada en el lienzo interior; (2) Ortofoto de la escalera.

hecho diferencial que pudieron tener los tramos contiguos al escarpe fluvial.

Asimismo, los trabajos de topografía y el análisis de la documentación aérea apuntan a la existencia de unas terrazas urbanísticas u orográficas un tanto imprecisas, dado que las actividades de 
parcelación agrícola modernas y/o contemporáneas, más sus consecuentes rellenos de nivelación, han alterado la fisonomía original del promontorio. En la zona superior hallamos una primera plataforma elevada de unas 0,3 ha de superficie y desarrollada sobre los $90 \mathrm{~m}$. Se halla delimitada con potentes muros de margen de época incierta, y su posición céntrica le permitió dominar visualmente todo el asentamiento. En los años 1979 y 2018 se realizaron sondeos estratigráficos y se constató la ausencia de vestigios. La segunda plataforma elevada de 0,22 ha se halla en una posición excéntrica, junto al escarpado fluvial y entre los 90 y $97 \mathrm{~m}$. En este punto ya se efectuó un sondeo en el año 1979, y las excavaciones del año 2016 (sondeo 4100) documentaron estancias pavimentadas con mortero de cal. La plataforma inferior de 1,27 ha se desarrolla en el extremo oriental del asentamiento y preferentemente entre los 80-84 m de altura. En este sector se exhumaron los restos arquitectónicos de la década de los setenta. También se ha identificado una zona media-alta de 1,44 ha y a una cota entre $88-91 \mathrm{~m}$. Aquí, sector 5000 , se han documentado vestigios arqueológicos de cimientos de mampostería, basamento y una fosa que amortiza el conjunto, con algunos fragmentos cerámicos que ya podrían pertenecer a época emiral. Finalmente, la zona media-inferior de 0,77 ha se desarrolla entre los $85-88 \mathrm{~m}$ de altitud. Es la zona inferior más céntrica del asentamiento, sectores de excavación 1000, 2000 y 6000, con una intensa actividad urbanística y posiblemente artesanal, como la producción de vidrio.

\subsection{Técnicas y procesos constructivos}

Procedemos a un análisis técnico preliminar de la muralla, dado que este objetivo queda condicionado al hecho de que la mayor parte de su trazado se halla todavía oculto por la maleza o bien enmascarado por la estratigrafía. Los tramos mejor conocidos se hallan en la mitad meridional, mientras que el nivel de conservación de los septentrionales es incierto, así como su grado de afectación ante posibles derrumbes por la cercanía del escarpado fluvial. Es una muralla de doble lienzo, tipo emplecton, como otras documentadas en este período (figs. 8 y 9). Consta de dos lienzos paralelos de una anchura irregular comprendida entre los $65-80 \mathrm{~cm}$ cada uno y levantados en mampostería de cal. Finalmente, las consideraciones siguientes deben tomarse como indicios detectados puntualmente, ya que todavía es pronto para calibrar la generalidad de algunos de los aspectos que aquí apuntamos.

El aparejo de los muros es de mampuestos irregulares ligeramente escuadrados y distribuidos

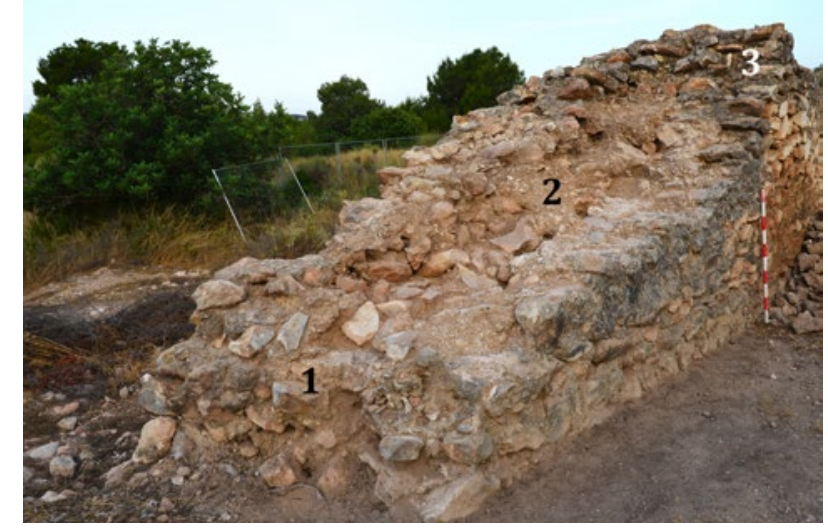

FiguRa 8. Detalle de segmento seccionado de la muralla: (1) zócalo inferior de la muralla; (2) relleno entre paramentos; (3) muro de tirante procedente de la torre 2 .



FIGURA 9. Vista lateral de la muralla con sus dos lienzos y el relleno interno.

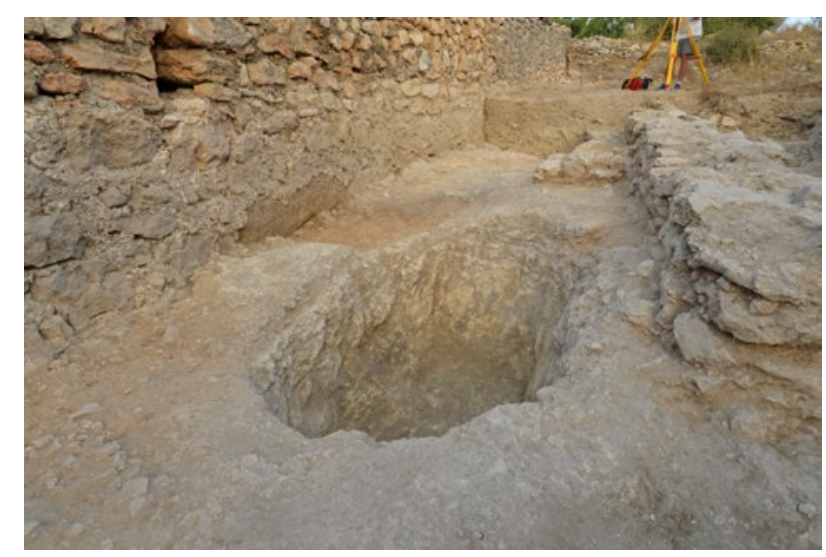

Figura 10. Detalle de la unión de dos tramos de trabajo del paramento interior. Obsérvese la lechada de asentamiento de la primera hilera. 
en hileras rectangulares. Mientras que las caras externas se hallaban regularizadas, el interior no tenía ningún tipo de acabado, mezclándose con el ripio dispuesto con posterioridad a las paredes, que, de este modo, ejercían una función de «encofrado». No podemos hablar de una disposición y un labrado rígido de las piedras. Hay diferente calidad o desigualdad en los tramos estudiados e, incluso, la volumetría del mampuesto no siempre siguió un orden decreciente estricto a medida que se alzaba el muro. Las hileras inferiores, en general con bloques de mayores dimensiones, presentaban una horizontalidad condicionada a la existencia o no de desnivel orográfico.

En algunos segmentos de los paramentos detectamos una cierta regularidad en la altura de los tramos constructivos de la muralla. En torno a los $90 \mathrm{~cm}$ se observan restos puntuales de lechadas de mortero de sellado que, presumiblemente, facilitaban el agarre del tramo superior (fig. 10). Uno de estos horizontes constructivos coincide, además, con el inicio de la continuación de uno de los muros de la torre cuando se adentraban en la muralla. También, aunque con una discontinuidad evidente, observamos como la primera hilada de piedras de algún tramo superpuesto se caracteriza por el uso de grandes losas rectangulares, mientras que los bloques superiores tienden a formas cuadradas.

La técnica de alzado de los muros de la muralla también está presente en las estructuras documentadas por Pereira y Aranegui, aunque sin el relleno interno. Esto puede indicar una cierta homogeneidad técnica y temporal, pero también apreciamos que, en todo el recorrido de la muralla estudiado, aparentemente no se reutilizaron materiales constructivos precedentes. Como, por el contrario, sí fueron utilizados profusamente en los edificios de la plataforma inferior: básicamente sillares y elementos arquitectónicos de caliza dolomítica gris azulada de la cercana Sierra Calderona (Cebrián 2000, 68-69), también visibles en el palacio de Pla de Nadal (Juan et al. 2018) y que seguramente serían expoliados de la cercana y abandonada ciudad romana de Edeta.

En relación con el emplecton, un corte contemporáneo de la muralla muestra como la base interior del relleno, aproximadamente un metro, presentaba una serie de hileras regulares de piedras medianas no labradas y con una ligazón de mortero pobre. Esta base se entrelazaba con los lienzos exteriores ya trabados con un mortero de calidad superior (fig. 11). Mientras que el ripio superior estaba constituido básicamente por piedras pequeñas o medianas mezcladas con gravas y guijarros, probablemente procedentes de los cursos fluviales cercanos. Todo ello junto con ar-

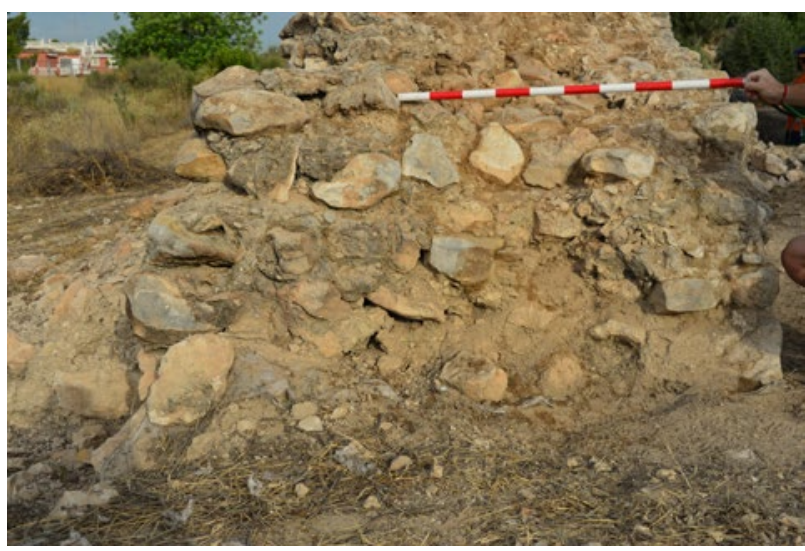

Figura 11. Detalle de la base de asentamiento de la muralla.

cillas rojizas-ocres procedentes de las actuaciones previas de rebaje. Esporádicamente, se identifican restos o núcleos de mortero de cal de escaso valor aglomerante, desechados del alzado de los muros.

Otra característica ha sido el enfoscado de las junturas de los mampuestos mediante un mortero de cal consistente y de calidad (fig. 13). Este acabado es característico de todo conjunto y fue intenso en su aplicación, tal como han demostrado los segmentos internos exhumados en los sondeos estratigráficos colindantes. También ha sido constatado en las torres.

Un elemento singular ha sido la identificación de una escalinata abierta en el paramento interno de la muralla, sector 1000. Era una escalera doble de acceso al paso de ronda superior de la muralla y prevista durante el proceso constructivo, dado que sus peldaños formaban parte del mismo lienzo. No obstante, el escalón estaba a $70-80 \mathrm{~cm}$ por encima del nivel de circulación. El escalón inferior central tenía una anchura aproximada de unos $57 \mathrm{~cm}$ y una huella de $50 \mathrm{~cm}$. Se han conservado cuatro peldaños laterales con una anchura mínima de $25 \mathrm{~cm}$, una huella de entre $15-20 \mathrm{~cm}$ y una contrahuella de 10-15 cm (fig. 7).

En el año 2016 se procedió a la limpieza parcial de las torres que habían sido intensamente destruidas. La torre núm. 1 sobresalía unos 3,5 m respecto a la muralla y tenía una anchura de 3,6 m (fig. 12). La torre 2 tenía una anchura de $4 \mathrm{~m}$ y una profundidad teórica de $4 \mathrm{~m}$. En la torre 3, limítrofe con rebajes agrícolas modernos, solo se ha podido determinar una anchura de 4,2 $\mathrm{m}$. Los muros laterales de la torre 1 medían $75 \mathrm{~cm}$, mientras que los de las torres 2 y 3 eran de unos $90 \mathrm{~cm}$ de anchura. En todos los casos los muros perpendiculares eran solidarios y coetáneos con el lienzo defensivo externo.

La torre mejor estudiada es la 1, donde apreciamos como sus paramentos presentaban mam- 
puestos más pequeños que los de la muralla, e incluso podemos ver como el muro de fondo, alineado con el exterior de la muralla, tiene una disposición en hileras diferente y más irregular en comparación con la fachada defensiva. Incluso en algún punto de este lienzo las piedras se hallan ligeramente inclinadas para mantener la altura de su hilera correspondiente. Es una ligera tendencia al opus spicatum que también se constata en otras obras coetáneas (Beltrán y Macias 2016). Esto nos indica que el perímetro externo de las torres pudo ser alzado juntamente con el paramento exterior de la muralla, y posteriormente se cuadró la torre con un lienzo interno de factura o preocupación estética menor. De modo que el ripio de la muralla y el de la torre no se hallaban en contacto en la base de la torre. No obstante, el nivel de arrasamiento de la torre 2 ha permitido ver como, a unos 2 metros del arranque constructivo, los muros perpendiculares a la muralla de la torre penetran en el interior de la muralla y enlazan con sus lienzos. De este modo, la parte superior de la torre cosía como un tirante los muros de la torre mejorando su cohesión y la contención del empuje oblicuo de los ripios interiores (fig. 8).

Otro elemento que llama la atención reside en una imagen fotográfica que apareció en el artícu- lo periodístico de 1978 (Mestre). En ella puede apreciarse una especie de arco de descarga en el interior de una de las torres que, en la actualidad, no es visible (fig. 12). No parece factible un arco de este tipo, dado que esta defensa se hallaría rellena de ripio. Más bien creemos que el firme superior de la construcción tenía una base de piedra y mortero que, cuando se destruyó lateralmente, produjo esta sensación visual. También hemos apreciado en las torres 1 y 2 como las esquinas externas tendrían una gran losa de asentamiento de sus ángulos respectivos.

\section{Conclusiones}

Tras tres campañas anuales de excavaciones, de tres semanas cada una dentro del «Curso de arqueología cristiana y visigoda en el yacimiento de València la Vella (Riba-roja de Túria)», los nuevos estudios topográficos y los interesantes hallazgos constructivos y estratigráficos, asociados a una aceptable cantidad de cerámicas y monedas, han aportado suficiente información para presentar e introducir el yacimiento en el debate científico actual sobre los procesos urbanísticos y geopolíticos de la Hispania visigoda, si bien reconocemos que

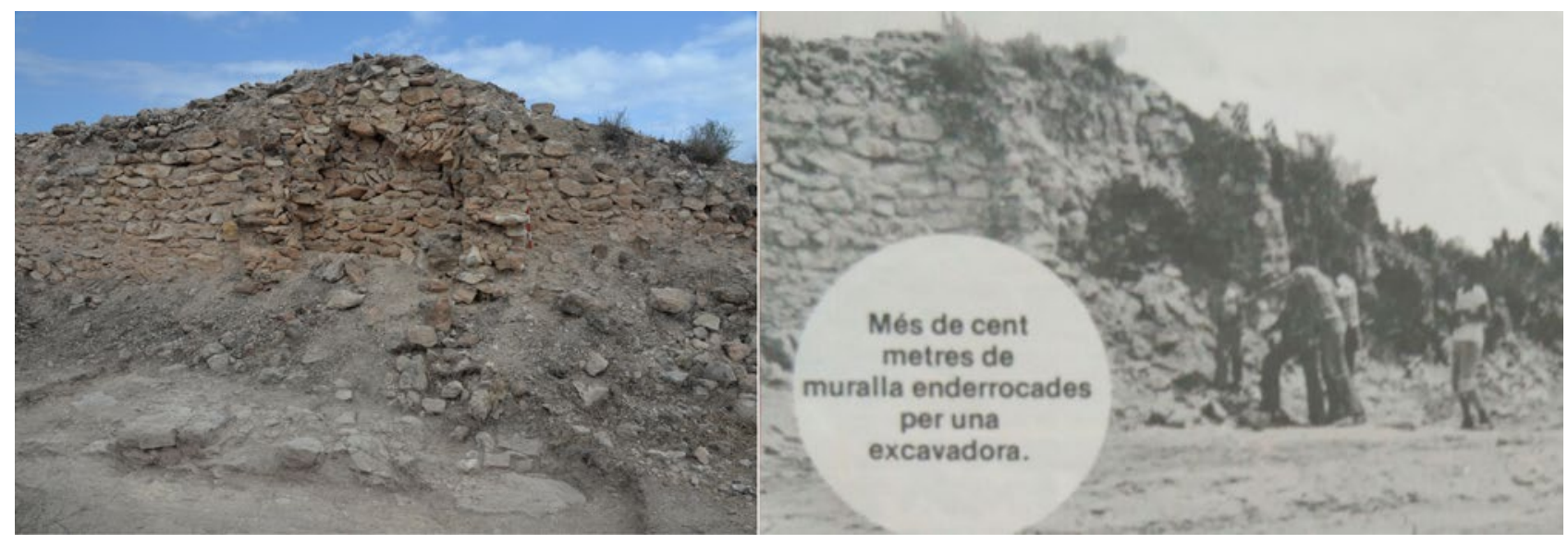

Figura 12. Vista actual de la torre núm. 1 (izq.). Imagen del estado de destrucción en 1978 (Mestre 1978).

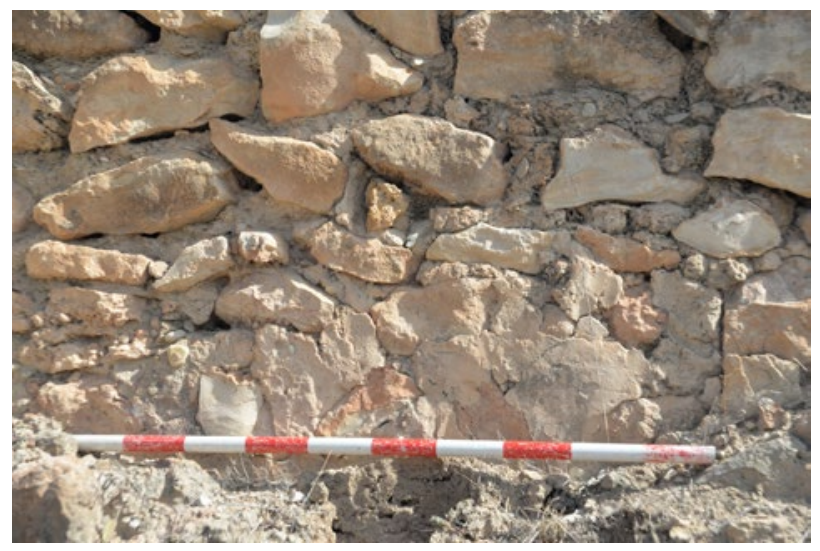

FIGURA 13. Detalle del mortero de enlucido del paramento exterior, junto a la esquina de la torre 1. 
nos hallamos en una fase incipiente de la investigación, donde las preguntas todavía superan de mucho a las respuestas.

Aunque no hay duda de la cronología visigoda de esta nueva fundación, los trabajos arqueológicos han recuperado algunos escasos materiales cerámicos y numismáticos desde el período tardorrepublicano. Hoy por hoy no disponemos de evidencias arquitectónicas precedentes, pero, dada la gran extensión del yacimiento y su excelente ubicación topográfica, siempre será una posibilidad a tener en cuenta en trabajos futuros.

De todas maneras, y a pesar del estado preliminar del proyecto, se empieza a disponer de datos sobre cuestiones fundamentales como la fecha de fundación, establecida a partir del año 550, como dan a entender las cerámicas recuperadas, especialmente en la campaña del 2017. En esta misma línea, parecerían determinantes los hallazgos numismáticos del 2018; los más claros son los dos tremises de Leovigildo, que, de momento, serían la principal fecha post quem.

Con relación al abandono del asentamiento, cabe apuntar la inexistencia de evidencias estratigráficas de destrucción. Nuestras excavaciones no pueden aportar información al respecto, dado que los sondeos estratigráficos fueron efectuados en emplazamientos muy afectados por remociones agrícolas posteriores. Además, los muros exhumados, básicamente zócalos de alzados de tapia, siempre se documentaron de forma sesgada, y la estratigrafía de relleno, bajo la cota de remoción agrícola, presentaba una elevada matriz arcillosa. $\mathrm{Al}$ respecto, es interesante reflejar las observaciones recogidas a partir de los informes del Dr. Gerardo Pereira sobre el edificio principal, documentado en los años 1978-1980:

- «Todo el edificio se vino abajo en época desconocida y algunos de los sillares de las paredes se derrumbaron, unos sobre otros, como fichas de dominó puestas en hilera [...]»(SIP 1979, 76).

- «[...] s'hi troben abundants testimonis de l'enderrocament de l'edifici, amb freqüentíssims fragments de morter, alguns de proporcions considerables [...]» (SIP 1980, 108).

Las excavaciones permiten plantear que el final de València la Vella se debió a un abandono lento y no a una destrucción, y que pudo tener lugar entre finales del siglo vII e inicios del vIII, más de medio siglo después de lo que se suponía. Parece cada vez más evidente, pues, que los dos grandes yacimientos visigodos de Riba-roja de Túria, el gran recinto fortificado de València la Vella y el magnífico palacio de Pla de Nadal (Ribera et al. 2015; Juan et al. 2018), no fueron coetáneos sino que uno sucedió al otro. Si esa fecha inicial coincide con lo que se venía suponiendo desde hace tiempo (Rosselló 1998), la reciente información posibilita alargar la vida del yacimiento hasta casi la llegada de los musulmanes en el 713 y plantea nuevas perspectivas sobre la relación de València la Vella con Valentia y con el Pla de Nadal.

Las cerámicas, que se extienden desde la segunda mitad del vi al vII, muestran, en su conjunto, un panorama general más propio del siglo VII que del vi. Las importaciones continúan llegando, pero en proporciones cada vez menores. La más significativa es la ARSW/D, siendo la forma Hayes 107 la más representativa, junto con las 91D, 99, 104 o 105. También se han identificado ánforas de diversas áreas y contenidos: aceite del Egeo y África, vino de Siria y Palestina, además de otras de Ibiza, de contenido por determinar, y alguna de posible procedencia local (Cau et al. 2019).

Las más de 120 monedas, la inmensa mayoría pequeños bronces, abarcan un período comprendido entre el siglo II a. C. y el vir d. C., entre las que abunda el numerario del siglo iv d. C., fenómeno habitual en el período tardoantiguo hispano. Entre las pequeñas piezas de los siglos VI-VII, las de procedencia bizantina superan a las visigodas (Caldés 2020). Estas numerosas y minúsculas monedas de bronce, entre las que aún se usaban divisores ibéricos, revelan la pervivencia de una economía monetaria plena. Un indicio más del carácter cosmopolita y mediterráneo de este enclave fortificado.

Aunque las fortificaciones son su elemento más evidente, los diferentes sondeos y las prospecciones con georradar, realizados todos en su mitad occidental, hablan de un urbanismo relevante y organizado, con calles y, al menos, una plaza, pero también adaptado a un terreno en pendiente en esta parte oeste; mientras que la mitad oriental, aún por investigar, es prácticamente plana. En la parte superior septentrional, la denominada acrópolis, se ha localizado un gran edificio, que conserva sólidos pavimentos de mortero de cal, desde donde se domina todo el yacimiento, un largo tramo del río y su entorno circundante.

Sobre la naturaleza y función de este asentamiento fortificado, son muchas las posibilidades que se barajan y no pocas las dudas al respecto. Su ubicación topográfica y sus murallas marcan un acusado carácter militar, por lo que en un principio se interpretó como un castellum o centro fortificado (Rosselló 1996; 2000). Pero tras la revisión y actualización de la topografía, se ha constatado una superficie en torno a las 4,8 ha, lo que, sin descartar su evidente faceta defensiva y militar, no excluye la posibilidad de que nos hallemos ante un centro urbano. Aunque, hoy por hoy, solo podemos plantear un asentamiento estable de nueva planta para controlar directamente un 
territorio periférico de reciente adquisición por el reino visigodo, como sería este caso, y dentro de un contexto concreto, tan coyuntural y conflictivo como evidente: la discontinua y latente guerra romano-gótica del 555 al 624.

La fundación de ciudades en este período fue un hecho poco habitual pero en absoluto extraño, $\mathrm{y}$, en todo caso, fue una prerrogativa exclusivamente real. En este contexto, València la Vella es un caso excepcional pero no único (Arce 2000; Rizos 2017). En Hispania, un modelo cercano en el tiempo y en el espacio sería la fundación de Reccopolis (Zorita de los Canes, Guadalajara), una nueva ciudad sin obispo, que estaba en Ercavica, pero con ceca y murallas, iglesia, un gran y alargado palacio (o un gran horreum para algunos), barrio artesanal... (Olmo 2008). El Tolmo de Minateda (Hellín, Albacete) sería otro caso semejante aún más cercano, con sus murallas, basílica, baptisterio, etc. (Gutiérrez y Cánovas 2009). Otras nuevas fundaciones conocidas de este período aún carecen de constatación arqueológica, como dos del área vascona: Victoriacvm, obra de Leovigildo, y Ologicus, del reinado de Suintila (Martínez 2017, 235).

El contexto histórico y territorial de la fundación de València la Vella coincide plenamente con la gran crisis del reino visigodo entre 555-570, que vio la guerra civil entre los reyes Agila y Atanagildo, la ocupación bizantina del sudeste de la Península, que ya dominaban Ceuta y las Baleares (Vizcaíno 2009), y la reacción del rey Leovigildo, que permitió superar la crisis y puso las bases de un reino fuerte (Rosselló 1998).

En esta coyuntura, el entorno de Valencia se convirtió en un área fronteriza militarizada donde contendieron visigodos y bizantinos hasta la expulsión de estos últimos en el 624; aunque su permanencia en las cercanas Baleares no dejó de ser una amenaza. Pero València la Vella, a $16 \mathrm{~km}$ de València, no es un caso aislado para este período, ya que entre el Turia y el Júcar hay una serie de hallazgos arqueológicos propios de zonas militarizadas, como las numerosas monedas de oro de Alcácer, a $15 \mathrm{~km}$ al sur de Valencia (Alapont y Tormo 2005), en un contexto funerario peculiar de la segunda mitad del siglo vi en adelante (Alapont y Ballester 2007). El inicio de las cecas de $\mathrm{Va}$ lentia y de Saguntum también enlazaría con esta coyuntura político-territorial (Ribera 2005), en la que Valencia sería el centro principal de esta zona militar, o tal vez lo fuera València la Vella.

En relación con este documento, cuanto mejor conozcamos València la Vella mejor podremos calibrar, sin menoscabo alguno, la función territorial de Valentia. Por un lado, la cercanía de dos núcleos como València la Vella y Valen- tia, distanciados a unos $16 \mathrm{~km}$, no es un hecho excepcional. Así se constata en la dualidad entre la ciudad episcopal de Auso (Vic) y Roda Ciudad (7 km), entre Reccopolis y Ercavica $(22 \mathrm{~km})$ o entre el núcleo fortificado de Sant Julià de Ramis y Gerunda $(6 \mathrm{~km})$. Por otro, la realidad arqueológica actual nos plantea dudas sobre la denominación del asentamiento de València la Vella. En la redacción de este documento hemos minimizado el uso de vocablos como ciudad o ciudadela, aunque reconocemos que esta prevención puede estar condicionada por nuestra visión clásica del término ciuitas. Estas dudas reflejan los problemas de definición de la organización territorial y política del reino visigodo (cfr. Isla 2001; Martínez Melón 2006); y confiamos en que futuras excavaciones puedan caracterizar este gran recinto amurallado. Es cierto que las murallas confieren una clara función militar, pero también constituyeron un elemento de prestigio urbano, tal como nos refleja la percepción de Isidoro de Sevilla (Cervera 1994).

En nuestro caso queda por configurar la existencia de edificios relacionados con la arquitectura del poder, fueran religiosos o civiles, más espacios productivos y residenciales. De algunos de los cuales se supone su ubicación y están esperando a ser descubiertos y puestos en valor. Por todo lo expuesto, es un yacimiento excepcional y básico para reconstruir la historia del territorio valenciano entre los siglos VI y vIII. En esta situación, habría que empezar a pensar en replantearse la localización de algunos hechos históricos remarcables que tuvieron lugar alrededor de Valencia en este período: como el cautiverio del hijo rebelde de Leovigildo, Hermenegildo, la localización de la ceca monetaria y la ubicación de la sede del obispo arriano de Valencia, presente en el III Concilio de Toledo; que tal vez también podrían haber estado en València la Vella.

\section{Bibliografía}

Alapont, Ll.; BaLLESTER, C. 2007: «Ánforas y cerámica común de un conjunto funerario de Alcàsser (València)», en: BonifaY, M.; Tréglia, J. Ch. (eds.). LRCW 2. Late Roman Coarse Wares. Cooking Wares and Amphorae in the Mediterranean. Archaeology and Archaeometry (Aixen-Provence 2005), BAR International Series, 1662, I, Oxford, 199-210.

Alapont, L.; Tormo, F. 2005: «El tesoro de monedas de oro visigodas de la Senda de l'Horteta (Alcàsser, València)», en: Ribera, A.; RIPOLlès, P. P. (eds.). Tesoros monetarios de Valencia y su entorno, Grandes Temas Arqueológicos, 4, Valencia, 169-176. 
ARCE, J. 2000: «La fundación de nuevas ciudades en el Imperio romano tardío: de Diocleciano a Justiniano (s. IV-VI)», en: Sedes regiae (ann. 400800), Reial Acadèmia de Bones Lletres, Barcelona, 31-63.

Beltrán de Heredia, J.; Macias, J. M. 2016: «Técnicas constructivas en la Tarraconensis durante la Antigüedad Tardía. Planteamientos y estrategias de investigación para una propuesta de síntesis», Quarhis, 12, Barcelona, 16-38.

BonIfay, M. 2004: Études sur la céramique romaine tardive d'Afrique, BAR International Series, 1301, Oxford-Archaeopress.

Buxeda, J.; Cau, M. A.; Gurt, J. M.; Tsantini, E.; Rauret, A. M. 2005: "Late Roman Coarse and Cooking Wares from the Balearic Islands in Late Antiquity», en: Gurt, J. M.; BuxedA, J.; CAU, M. A. (eds). LRCW 1. Late Roman Coarse Wares, Cooking Wares and Amphorae in the Mediterranean. Archaeology and Archaeometry (Barcelona 2002), Oxford, 223-254.

CALDÉs, O. 2020: «Las monedas del yacimiento visigodo de València la Vella (Riba-roja de Túria)», en Huguet, E., RiBERA, A. (eds), El temps dels visigots al territori de València, València.

Cau, M. A.; Fantuzzi, J.; Tsantini, E.; Ribera, A.; Rosselló, M. 2019: "Archaeometric characterization of common and cooking wares from the Late Antique city of Valentia (Valencia, Spain)», Archaeological and Anthropological Sciences, 11, <https://doi.org/10.1007/s12520019-00802-x>.

CEBrí́n, R. 2000: Titulum fecit. La producción epigráfica romana en tierras valencianas, Bibliotheca Archaeologica Hispana, 7, Real Academia de la Historia, Madrid.

Cervera, L. 1994: "Algunas definiciones urbanísticas y arquitectónicas de San Isidoro de Sevilla», Anales de la Historia del Arte, 4 (Homenaje al profesor Dr. D. José María de Azcárate y Ristori), Madrid, 71-82.

Fulford, M. G.; Peacock, D. P. S. 1984: The Avenue du Président Habib Bourguiba, Salammbo: the pottery and other ceramic objects from the site. Excavations at Carthage: the British Mission, I, 2, Sheffield.

Gómez, A. 2011: «La producción de vidrio en época visigoda: el taller de Recópolis», Zona Arqueológica (711. Arqueología e historia entre dos mundos), 15, Alcalá de Henares, 257-280.

Gutiérrez, S.; CÁnovas, P. 2009: «Construyendo el siglo VII: arquitecturas y sistemas constructivos en El Tolmo de Minateda», en: El siglo viI frente al siglo VII: arquitectura, Anejos de AEspA, LI, Madrid, 91-132.

Huguet, E.; Rodríguez, F.; Macias, J. M.; Ramón, M. A.; Ribera, A.; Rosselló, M. [en prensa]: «Pro- ducciones locales e importaciones (s. VI-VII) en el recinto fortificado visigodo de València la Vella (Riba-roja de Túria)», en: $L R C W$ 6. $6^{\text {th }}$ International Conference on Late Roman Coarse Wares, Cooking Wares and Amphorae in the Mediterranean: Archaeology and Archaeometry. Land and Sea: Pottery Routes (Agrigento 2017).

IsLA, A. 2001: «Villa, villula, castellum. Problemas de terminología rural en época visigoda», Arqueología y Territorio Medieval, 8, Jaén, 9-19.

JuAn, E. [s. a.]: València la Vella, Hojas Didácticas y de Información, 1, Museo Municipal de Ribaroja de Túria.

Juan, E.; Escrivà, I.; Morín, J.; Ribera, A.; RosseLLÓ, M.; SÁnchez, I. 2018: "Pla de Nadal: la residencia de Teodomiro. Entre visigodos y omeyas», en: SÁnchez, I; Mateos, P. (eds.). Territorio, topografía y arquitectura de poder durante la Antigüedad Tardía, Mytra, 1, Mérida, 261-282.

MAcIAS, J. M. 1999: La ceràmica comuna tardoantiga a Tàrraco. Anàlisi tipològica $i$ històrica (segles V-VII), Monografies Tarraconenses, 1, Tarragona.

Martínez JimÉnEZ, J. 2017: «Water supply in the Visigothic urban foundations of Eio (El Tolmo de Minateda) and Reccopolis», en: Rizos, E. (ed.). New Cities in Late Antiquity, Documents and Archaeology, Bibliothèque de l'Antiquité Tardive (BAT 35), Tourhout, 233-246.

Martínez Melón, J. I. 2006: «El vocabulario de los asentamientos rurales (siglos I-IX d.C.): evolución de la terminología», en: Chavarría, A.; Arce, J.; Brogiolo, J. P. (eds.). Villas Tardoantiguas en el Mediterráneo Occidental, Anejos de AEspA, XxxIX, 113-131.

Martínez Ortiz, J. 1980: «Precedente histórico del trasvase Júcar-Turia (Un proyecto de construcción del canal y aprovechamiento de las aguas del siglo XIV)», en: I Congreso de Historia del País Valenciano, II, Valencia, 527-538.

Martínez-Porral, R.; Molina, M.; NúñEz, G.; RosSElló, M.; García-Prósper, E.; Polo, M.; GarcíaVillanueva, I. 2018: "Senda de l'Horteta. Nuevas aportaciones al estudio de un asentamiento visigodo», en: Jornades d'Arqueologia de la Comunitat Valenciana 2013-2015, Generalitat Valenciana, Valencia, 191-203.

Martínez-Porral, R.; Molina, M.; NúñEz, G.; RosSelló, M.; Hurtado, T.; García-Prósper, E.; Polo, M.; García-VIllanUeVA, I. 2019: «El poblamiento visigodo de Alcàsser. Senda de l'Horteta. Un asentamiento rural en l'Horta Sud (València)», en: Primer Congrés d'Història Local d'Alcàsser, Ajuntament d'Alcàsser, Valencia, 277-309.

Martínez-Porral, R.; Molina, M.; Rosselló, M.; García-Prósper, E.; Polo, M. [en prensa]: «Senda de l'Horteta. Nuevas aportaciones al estudio 
de un yacimiento visigodo", en: XVII Assemblea d'Història de la Ribera, La Pobla Llarga.

Mestre, A. 1978: "Una altra víctima de la despersonalització. Valencia la Vella, una ciutat romana a descobrir», Valencia Semanal, 37 (1017 septiembre), València, 36-37.

Olmo, L. 2008: "Recópolis: una ciudad en una época de transformaciones», en: Olmo, L. (ed.). Recópolis y la ciudad en época visigoda, Zona Arqueológica, 9, Madrid, 41-62.

Palol, P. DE 2004: El Castrum del Puig de les Muralles de Puig Rom (Roses, Alt Empordà). Girona, Museu d'Arqueologia de Catalunya, Barcelona.

Pascual, J.; Ribera, A.; Rosselló, M. 2003: “Cerámicas de la ciudad de Valentia entre la época visigoda y omeya (siglos VI-X)», en: CABALLERo, L.; Mateos, P.; Retuerce, M. (eds.). Cerámicas tardorromanas y altomedievales en la Península Ibérica, Anejos de AEspA, xxvIII, Madrid, 67117.

PAstor, I. 1981: «València la vella: La ¿inevitable? degradación de nuestro patrimonio histórico», Generalitat, 24, Valencia, 23.

RAMón, J. 2008: «La cerámica ebusitana en la Antigüedad Tardía», en: Bernal, D.; RiBERA, A. (eds.). Cerámicas hispanorromanas. Un estado de la cuestión, Universidad de Cádiz, Cádiz, 563-583.

Remolà, J. A. 2000: Las ánforas tardo-antiguas en Tárraco (Hispania Tarraconensis), Universitat de Barcelona, Barcelona.

Reynolds, P. 1993: Settlement and pottery in the Vinalopó Valley (Alicante, Spain). A.D. 400-700, Oxford.

RiBERA, A. 2005: «El contexto histórico y arqueológico de las emisiones monetarias visigodas en el País Valenciano», Gaceta Numismática, CLVII, Barcelona, 45-61.

Ribera, A.; Barroso, R.; Escrivà, I.; JuA, E.; MAcias, J. M.; Morín, J.; Puche, J. M.; Rosselló, M.; SÁnchez, I. 2015: Pla de Nadal (Riba-roja del Túria). El Palacio de Teudinir, Ajuntament de Riba-roja del Túria, Valencia.

Ribera, A.; Rosselló, M. 2012: “Las ánforas tardoantiguas de Valentia», Rei Cretarice Romance Favtorum Acta 42, 385-396.

Rizos, E. 2017: New Cities in Late Antiquity. Documents and Archaeology, Bibliothèque de l'Antiquité Tardive (BAT 35), Tourhout.
Rosselló, M. 1996: «El yacimiento de València la Vella (Riba-roja de Túria, València). Algunas consideraciones para su atribución cronológica y cultural», Quaderns de Prehistòria i Arqueologia de Castelló, 17, 435-454.

- 1998: «La politique d'unification de Léovigild et son impact à Valence (Espagne): évidences littéraires et archéologiques», en: XIII Congreso Internacional de Arqueología Cristiana, Ciudad del Vaticano - Split, 735-744.

- 2000: "El recinto fortificado de "València la Vella" en Riba-roja de Túria», en: RiBERA, A. (ed.). Los orígenes del Cristianismo en Valencia y su entorno, Grandes Temas Arqueológicos, 2, Valencia, 127-133.

Rosselló, M.; Cotino, F. 2005: «Panorama cerámico de los siglos v-VII dC en Cullera (Ribera Baixa, València)», Saguntum (P.L.A.V.), 37, 139-152.

Rosselló, M.; RiBera, A. 2004: «Las cerámicas del siglo VII dC en Valentia (Hispania) y su entorno», Rei Cretarice Romance Favtorum Acta 39, 155-164.

SANChis Sivera, J. 1922: Nomenclátor geográficoeclesiástico de los pueblos de la diócesis de Valencia, Valencia.

SIP 1979: La labor del Servicio de Investigación Prehistórica y su museo en el pasado año 1978, Diputación Provincial de Valencia, Valencia.

SIP 1980: La tasca del Servei d'Investigació Prehistòrica $i$ del seu museu el passat any 1979, Diputació de València, Valencia.

SIP 1981: La labor del Servicio de Investigación Prehistórica y su Museo en el año 1980, Diputación Provincial de Valencia, Valencia.

TERol, V. 1997: "A la recerca de tresors: excavacions medievals al País Valencià (14041471)», Intervenció i Patrimoni, 1, Comissió d'Arqueologia del CDL de València i Castelló, Valencia, 149-162.

Valls David, R. 1902: Pallantia, vulgo Valencia la vieja, Vinaroz.

Vizcaíno, J. 2009: La presencia bizantina en Hispania (siglos VI-VII). La documentación arqueológica, Antigüedad y Cristianismo, xxIV, Murcia. 



\title{
FORTIFICACIONES TARDOANTIGUAS EN EL ENTORNO DEL ALTO VALLE DEL EBRO: CLAUSURAE, TURRIS Y CASTRA COMO ELEMENTOS INTERRELACIONADOS DE CONTROL TERRITORIAL
}

\author{
José María Tejado Sebastián ${ }^{1}$
}

\begin{abstract}
Resumen
En este texto vamos a analizar el registro arqueológico de algunas fortificaciones que se encuentran en el entorno riojano del valle del Ebro. Concretamente, nos centraremos en tres: castillo de los Monjes, castillo de Viguera y Castro Bilibio. Todas ellas están enclavadas en pasos obligados (clausurae) de los ríos Iregua -en los dos primeros casos- y Ebro -en el último-. "Casualmente», las vías de comunicación discurren forzosamente por esos mismos puntos.

Tal y como apuntamos en el subtítulo del trabajo, estas fortificaciones no solo se componen de núcleos «principales» tipo castra de origen militar. Únicamente podrían ser operativas funcionalmente mediante el empleo y desarrollo de un sistema de turris interconectado para que el sistema de control territorial fuera efectivo. Estas torres serían los nodos de la red que servirían como medio de vigilancia que se estableció, sobre las vías de comunicación adyacentes. A su vez, valdrían también de canal de transmisión y réplica de la información en caso necesario. Los sistemas de emisión de mensajes son tanto visuales, de día y de noche, como sonoros, especialmente útiles estos últimos los días de niebla.
\end{abstract}

\begin{abstract}
In this text we will analyse the archaeological record of some of the fortifications in the Upper Ebro Valley (La Rioja area). We will focus specifically on three: Castillo de Los Monjes, Castillo de Viguera and Castro Bilibio. They are all located in narrow passes (clausura) carved out by rivers, in the first two cases the Iregua and in the last the Ebro. These are the only routes available for travel through the area.

As indicated in the subtitle of this study, these fortifications networks did not only consist of the "main" nuclei (castra) of military origin. They could only be functionally operative through the development and use of an interconnected turris system forming an effective territorial control system. These towers would have been the nodes of the network and would have served as surveillance points. They would also have been used as a means of transmitting and replicating information if necessary. The message transmission systems were visual during the daytime and night and with sound, the latter also being useful on foggy days.
\end{abstract}

\footnotetext{
1. josemaria.tejado@ehu.eus. Departamento de Didáctica de las Ciencias Sociales de la Universidad del País Vasco (UPV/ EHU). La financiación de los trabajos que aquí mostraremos, tanto arqueológicos como de documentación geométrica, ha sido asumida mayoritariamente por el Servicio de Arqueología y Conservación del Patrimonio de la Dirección General de Cultura del Gobierno de La Rioja. Sin su apoyo, constante y dilatado en el tiempo, no podrían haberse dado. Así mismo, este trabajo ha sido realizado en el marco del proyecto «Agencia campesina y complejidad sociopolítica en el noroeste de la Península Ibérica en época medieval» (Ministerio de Economía, Industria y Competitividad, AEI/FEDER UE HUM201676094-C4-2-R), del Grupo de Investigación en Patrimonio y Paisajes Culturales (Gobierno Vasco, IT936-16) y del Grupo de Estudios Rurales (Unidad Asociada UPV/EHU-CSIC), ambos dirigidos por Juan Antonio Quirós Castillo.
} 


\section{Introducción}

En este trabajo vamos a analizar el registro arqueológico de algunas fortificaciones que se encuentran en el entorno riojano del valle del Ebro. Una vez visto, se intentará ofrecer un marco interpretativo que, a modo de síntesis, nos sirva para comprobar (ratificar, modificar o desmentir) esas ideas en los yacimientos en los que continuamos trabajando y que presenten unas funciones militares de control territorial. Esta especificidad que marcamos se debe a cuestiones funcionales, como veremos más adelante, no a aspectos regionales.

$\mathrm{Al}$ abordar el aspecto de las fortificaciones, vemos que hay una gran heterogeneidad de casos y funciones de las mismas (Christie y Herold 2016; Baker, Brookes y Reynolds 2013; Quirós y Tejado 2012; Martí 2008; Brogiolo y Gelichi 1996). No es, por tanto, una definición sencilla ni simple. Existen fortificaciones muy variadas: castros, torres y atalayas "naturales», faros para la emisión de señales visuales y lugares de emisión de señales acústicas, castillos habitacionales-señoriales, motas, prisiones, fortificaciones de concentración de rentas y excedentes, o de población («incastellamento»), ciudades amuralladas, etc. Son realidades tan variadas como las funciones para las que fueron diseñadas.

Como comentamos hace unos años (Tejado 2012, 310), la versatilidad de la herramienta fortificación ha hecho posible esa gran capacidad de adaptación a diferentes entornos, paisajes y medios socioeconómicos. Su consecuencia ha sido que la fortificación ha resultado ser un instrumento muy eficiente para la gestión del territorio en el que estaba inserta. Presenta una gran mutabilidad para adaptarse rápidamente a cada función y necesidad. De ahí su éxito.

Esa característica operativa fue sin duda una variable muy ventajosa en el momento de su utilización, pero que añade dificultad a la hora de su análisis arqueológico actual. La sistematización arqueológica pretende seriar, aglutinar, sintetizar y poner orden en el registro arqueológico con el que opera. El objeto fortificación difícilmente se puede encuadrar dentro de esos parámetros por su variabilidad intrínseca. Por tanto, podríamos decir que falta sincronía epistemológica entre la disciplina arqueológica y el objeto de estudio de las fortificaciones en este caso.

Así pues, si bien el título del trabajo pretende ser genérico con el empleo del sustantivo fortificaciones, el subtítulo será el que verdaderamente marcará la línea de trabajo de esta aportación. Es solo a una parte de ese gran abanico que son las fortificaciones antes mencionadas a la que nos va- mos a dedicar: las fortificaciones encargadas del control territorial.

Esas fortificaciones militares se encuentran enclavadas en puntos geográficamente relevantes. Su preeminencia en la localización viene dada por la obligatoriedad de las personas que circulan por el territorio de transitar por unos puntos determinados: los pasos obligados o clausuras. Habitualmente son pasos estrechos que han abierto los ríos o arroyos a su paso por zonas generalmente rocosas. Sustratos duros que encauzan los cursos fluviales por puntos concretos. Esas hendiduras que realizan los ríos son aprovechadas por los humanos para transitar de unos territorios a otros. La supervisión directa de esos espacios mediante el empleo de fortificaciones era crucial para intentar llevar a cabo ese control territorial amplio.

Un control territorial como paso primero e imprescindible de un ansiado y anhelado control social y económico en último término. Veremos que esas herramientas cumplieron esa tarea por la que fueron creadas de control territorial y social. ¿O solo lo intentaron?

No se puede aventurar si tales inversiones constructivas y logísticas fueron suficientes o no para cada caso particular de tal o cual red de fortificaciones. En términos generales, todo parece indicar que las fortificaciones sí que fueron elementos de control social muy exitosos. Tanto por su dilatado empleo y proyección temporal (longue durée) y espacial (Europa), como por las acciones particulares derivadas de su plan de derribo en el territorio peninsular. Los profundos movimientos de oposición a su desmantelamiento son indicadores, precisamente, de la pujanza y de su utilidad hasta los inicios de la Edad Moderna.

De otro modo, los Reyes Católicos no se hubieran tomado las «molestias» de derribar multitud de castillos y fortalezas y desmochar infinidad de torres por todo el solar peninsular. Un esfuerzo muy notable con el fin de conseguir una ansiada «paz social» evitando rebeliones de algunas secciones de la nobleza que les habían sido contrarios en sus disputas y conflictos previos. Así, a modo de ejemplo, tras la orden del cardenal Cisneros de 1516, un territorio como Navarra, que contaba con gran cantidad de fortificaciones, se quedó con apenas un puñado de ellas, que se mantuvieron por prevención ante posibles ataques de sus vecinos franceses. Se conservó una defensa contra un «enemigo» externo a la concepción política del momento, pero cuyo proceso de derribo respondió a directrices internas; que ciertas secciones de la nobleza no pudieran volver a utilizar esas fortificaciones para poner sobre las cuerdas al poder político hegemónico mediante movimientos «internos» de sublevación. 
Los intentos de reconstrucción de esas fortificaciones y torres, como hemos certificado en el caso de Castro Bilibio (Haro) en 1499 y 1500, por el duque de Nájera (que también era conde de Treviño en ese momento), indica a las claras que, en unas fechas tan «tardías» como esas, todavía se concebían este tipo de fortificaciones como útiles y potentes herramientas de control y gestión territorial. Máxime si tenemos en cuenta que el noble se estaba oponiendo a una directriz regia y que podía ser tomado (lo era de facto) como un desafío a su autoridad en cuanto a la gestión del territorio norteño del área riojano-alavesa (Quirós 2016) sobre la que se asentaban esas fortificaciones.

No fue un caso único. Al contrario. Lo traemos aquí a colación a modo de ejemplo de un proceso de oposición al poder regio por medio del enfrentamiento que se produjo (o que se intentó) a los procesos de derribo por medio de la reconstrucción de diversos tipos de fortificaciones (castillos, castros y torres) relacionados con la gestión territorial. Después del episodio navarro comentado arriba, es significativa la carta que envía el militar Cristóbal Villalba al cardenal Cisneros en referencia a la orden dada por este último de los derribos: "Navarra está tan baxa de fantasía después de que vuestra señoría reverendísima mandó derrocar los muros, que no ay ombre que alçe la cabeza [...]» (Usunáriz 2006, 143).

No obstante, descendamos del análisis más conceptual o teórico expuesto en este marco introductorio, y pasemos al plano más analítico de los datos que ofrecen las fortificaciones en las que hemos trabajado.

\section{Datos}

La información que vamos a presentar aquí responde a una doble naturaleza: de una parte están los datos que ya hemos presentado desde hace años en varios trabajos, más conocidos, particularmente desde la lectura de la tesis doctoral en 2010. Básicamente, nos referimos a los trabajos del castillo de los Monjes (Lumbreras) y a la serie de castros y torres detectadas en lo alto del río Iregua.

Por otro lado, desde 2014, hemos realizado campañas de excavación en Castro Bilibio (Haro) y el castillo de Viguera-Valdemetria (Viguera). Sus datos son menos conocidos. Las publicaciones al respecto o bien acaban de ser publicadas (Tejado $2018 b$ ), o bien están en prensa. Incluso hay datos inéditos que mostraremos en este artículo por primera vez, especialmente los referentes al Castillo de Viguera.
La localización espacial de las tres fortificaciones que vamos a analizar responde a dos realidades territoriales bien distintas desde el punto de vista macroespacial. Así, de un lado está el potente corredor de comunicación que es el valle del Ebro desde época prehistórica. Es llano, fértil y notablemente habitado. En él se encuentra el complejo fortificado de Castro Bilibio. Por otro lado, nos encontramos con unos sistemas de fortificación en el valle del río Iregua, una zona montañosa que conecta de norte a sur el valle del Ebro con el interior peninsular por la submeseta norte. En términos comparativos con el valle del Ebro, no es fértil, ni llano, y muchísimo menos habitado.

En esa zona alta del río Iregua comenzamos hace más de quince años nuestras investigaciones (castillo de los Monjes y su red asociada), y ahora mismo estamos inmersos en el estudio de su clausura baja en la zona de contacto con el valle del Ebro (castillo de Viguera y su red asociada) (véase figura 1).

Sin más dilación, pasemos a analizar en detalle cada uno de los yacimientos.

\subsection{Castillo de los Monjes (Lumbreras, La Rioja)}

Este yacimiento fue el pionero de nuestros trabajos en esta rama de investigación de las fortificaciones tardoantiguas y altomedievales. Fue el trabajo base y la prueba de fuego para nuestra tesis doctoral sobre la red de fortificaciones tardoantiguas en el alto valle del Iregua. Existen abundantes y extensas publicaciones al respecto (Tejado 2010; 2011; 2012; 2014; 2018b; en prensa). La mayoría de ellas se pueden consultar de manera gratuita en Internet.

Se realizaron tres campañas en el yacimiento $(2003,2004$ y 2005) antes de la defensa de la tesis doctoral (2010), así como una cuarta limitada pero interesante intervención en 2012 para resolver una cuestión puntual surgida tras la investigación a fondo del yacimiento. A partir de los resultados de todas ellas, y en particular de la última, continuamos con la investigación en este yacimiento, sobre un aspecto relevante desde el punto de vista arqueometalúrgico.

Respecto a la breve descripción del yacimiento, hay que decir que se trata de un pequeño castro de casi $8.000 \mathrm{~m}^{2}$ de superficie entre los cuatro recintos amurallados que presenta. Tras la intervención en todos ellos, podemos asegurar que los cuatro son coetáneos en su edificación. La cronología propuesta de construcción de esos muros y de la primera ocupación del yacimiento es de la segunda mitad del siglo VII / principios del VIII. 


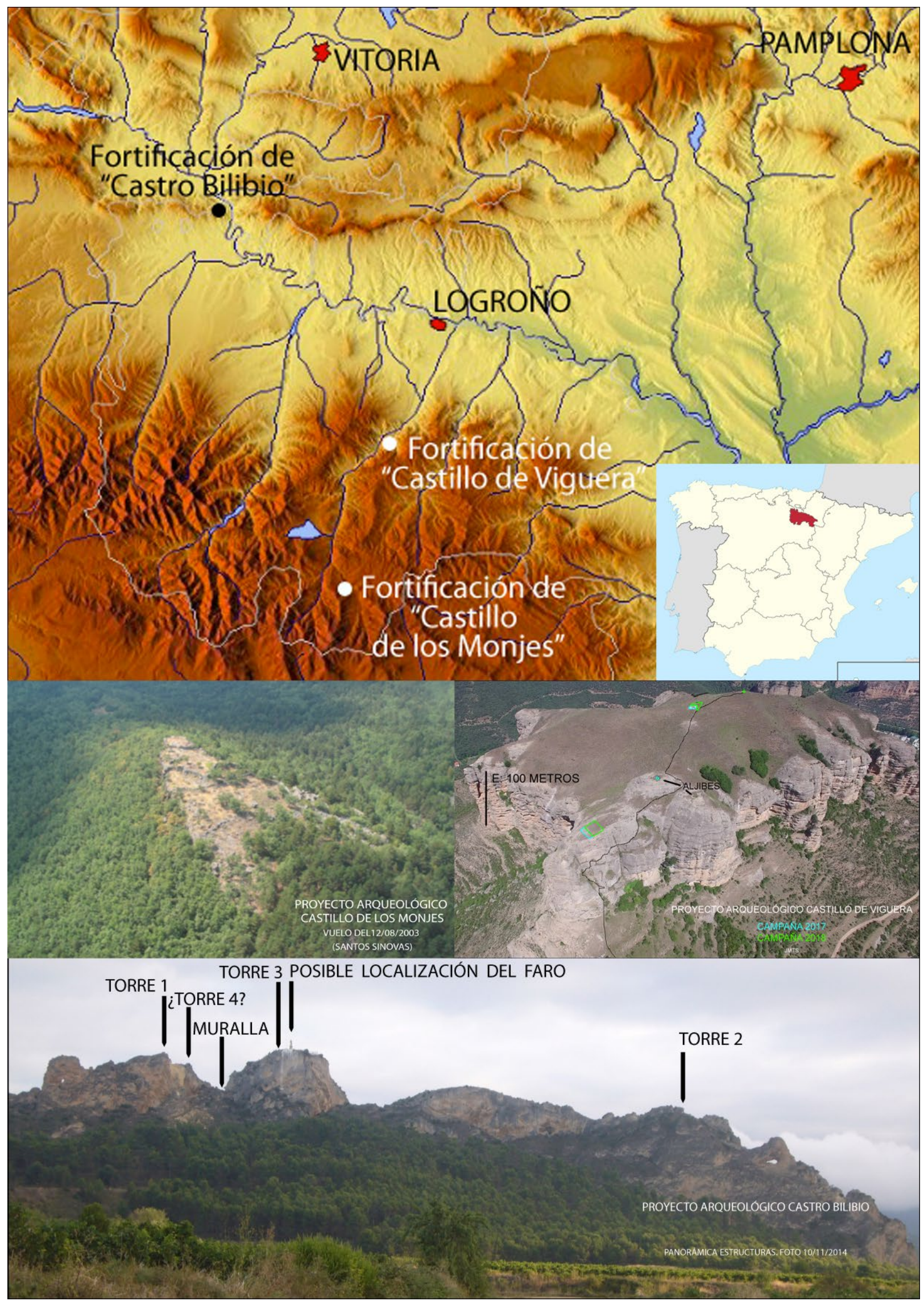

Figura 1. (1) Localización de los tres yacimientos citados y de las actuales capitales de provincia del País Vasco, Navarra y La Rioja. Imagen base tomada de $<$ https://maps-for.free.com>. (2) Vista aérea de la fortificación del castillo de los Monjes (autor: S. Sinovas). (3) Vista aérea de la fortificación del castillo de Viguera (autor: LDGP - Laboratorio de Documentación Geométrica del Patrimonio de la UPV/EHU). (4) Panorámica de la localización de las diferentes estructuras de la fortificación de Castro Bilibio. 




Figura 2. (1) y (2). Comparación entre las áreas de extracción de piedra para la construcción de las murallas e itinerario planificado para la circulación interna. (3) Planta del yacimiento con los sectores intervenidos en 2003, 2004 y 2012. En sombreado, el área habitada del castro. Elaboraciones propias sobre planos base del yacimiento realizados por LDGP. 


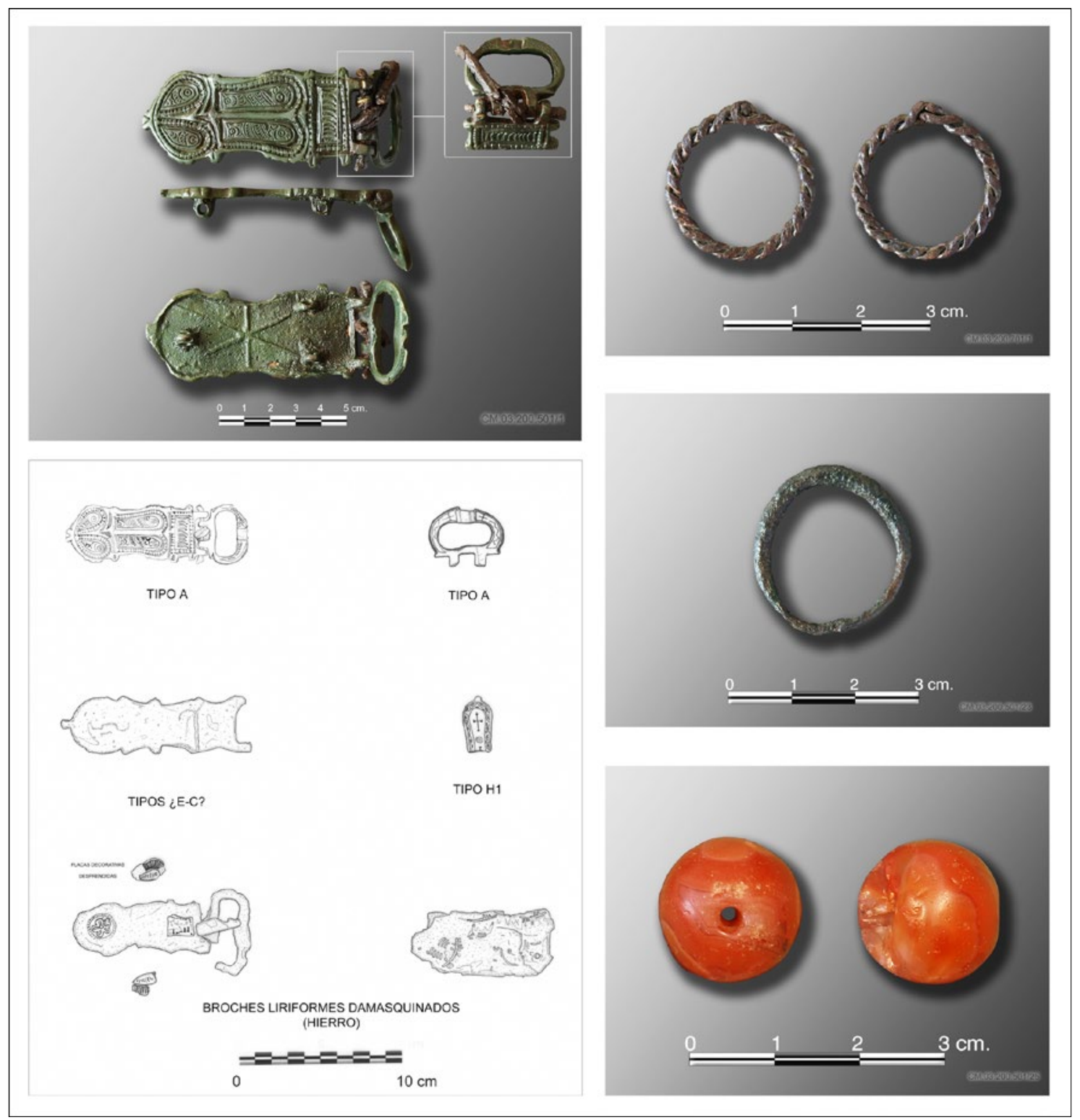

FigURA 3. Selección de algunos materiales arqueológicos recuperados en contextos de habitación en el castillo de los Monjes. Conjunto de broches de cinturón y detalle de uno de ellos completo de bronce, anillo trenzado de cobre, anillo de latón y cuenta de collar de ágata carneola.

Ese marco temporal se definió, principalmente, por criterios tipológicos de un grupo de hebillas liriformes del Nivel V de Ripoll, encontradas todas ellas en contexto arqueológico habitacional, no funerario. ${ }^{2}$ Dos de ellas con restos de damasquinado en plata y presencia de latón. ${ }^{3}$ Los materiales cerámicos responden a las típicas producciones de ollas de cocina de fondo plano, perfil en

2. En la campaña de 2012 se llevó a cabo una datación radiocarbónica en los escasos restos de carbón de una hoguera (UE 212501) que contenía en su interior una hebilla tipo H1 del Nivel V, correspondiente a la pequeña placa de cinturón recuperada a menos de $6 \mathrm{~m}$ de distancia en la campaña arqueológica de 2003, con el lamentable resultado de que la datación correspondía a una hoguera del siglo xx, probablemente fruto de las abundantes y esporádicas actividades cinegéticas detectadas en el yacimiento desde la primera campaña. El yacimiento fue usado como puesto de caza durante el siglo pasado debido a su buena y preeminente disposición visual en el entorno circundante. No obstante, sí que podemos apuntar que, de los dos sectores intervenidos en esa misma campaña de 2012 en el cercano castro de Peña Yerre (a más de 1.700 m s. n. m.), sí que hemos podido datar por radiocarbono (sobre carbón) una interesante ocupación, centrada en el siglo Ix. Muestra n. ${ }^{\circ}$ Beta-448087, $1170 \pm 30$ BP. La interceptación con la curva de calibración da la fecha de cal AD 885 . A dos sigmas (95\% de probabilidad), da cal AD entre 770 y 905 y cal AD entre 920 y 965 . A una sigma (68\% de probabilidad), cal AD entre 775 y 790 y entre 800 y 895 . Una datación muy interesante, sobre todo si tenemos en cuenta que es casi idéntica a una que hemos obtenido en el castillo de Viguera en 2017 sobre hueso.

3. Más una posible tercera de la que seguimos a la espera de su confirmación y estudio tras su limpieza y restauración. 
S, etc. (vid. Tejado 2016). Se realizó un exhaustivo estudio de todos los materiales encontrados en la citada tesis doctoral, que se encuentra accesible en Dialnet.

No obstante, si hay algún elemento que destaca por encima de otros son sus potentes murallas. Como hemos dicho, presenta cuatro recintos amurallados con un elaboradísimo y detallado plan de diseño, desarrollo y ejecución.

Los dos primeros recintos amurallados presentan características comunes en cuanto a problemas de cimentación sobre sustrato plástico arcilloso sin llegar a buscar la roca madre (con los problemas de conservación que ello supuso), menores dimensiones de sus muros en altura y anchura, morfología rectilínea y acceso con una simple discontinuidad del muro.

Sin embargo, las dos murallas últimas (M2 y M1) presentan también otras características comunes entre ambas y detalles constructivos mucho más cuidados: utilización de enormes bloques ciclópeos trabados a seco y de varias toneladas alguno de ellos, ${ }^{4}$ cimentación sobre roca madre (y mejor conservación de sus lienzos), dimensiones superiores en anchura y altura de muros, accesos con medidas supletorias de defensa (puerta en codo y en corredor, lo que lleva a realizar modificaciones del trazado hacia plantas y disposiciones más sinuosas de las murallas), con cuerpo de guardia circular en el interior del área habitada al lado del acceso para controlarlo, calzos en cimentación para ayudar en el drenaje de agua y deshielo, etc. Un «detalle» mínimo este último, si se quiere, pero no insignificante sino todo lo contrario, muy relevante para su estabilidad, como ha demostrado su excelente estado de conservación hasta nuestros días (vid. figura 4, especialmente alzados).

Esas variables diferenciadoras, unidas a los resultados de los sondeos y las áreas de excavación realizados dentro de los espacios de los cuatro recintos amurallados (sin materiales en unos casos y abundantes en los dos últimos recintos, con más de un $90 \%$ del total), así como los resultados de una prospección electromagnética completa de todo el yacimiento en 2012, certifican, sin ningún género de dudas, que solo los dos últimos recintos estaban ocupados de manera permanente. Así, mientras que los dos primeros espacios dentro de sus muros eran espacios vacíos cuyo fin ponemos en relación con la presencia de espacios de seguridad para poder evitar un ataque por sorpresa, los dos últimos sí que eran los pequeños espacios donde habitaban los escasos efectivos de la guarnición allí instalada.

Una muestra de la cuidada planificación llevada a cabo en la concepción y ejecución de esta fortificación (la que presenta un mayor y mejor detalle de los ocho enclaves pertenecientes a esta red de fortificaciones del alto Iregua) es el hecho de que las obras de extracción de piedra del cerro se detuvieron en los puntos exactos en los que se había planificado dejar en el lateral derecho los cuatro accesos para, de ese modo, condicionar el flujo y tránsito de individuos que quisieran acceder al interior del mismo (cfr. figura 2). De esta manera se dificultaba un ocultamiento de un posible asaltante, al condicionar su tránsito por zonas concretas y perfectamente controladas, tanto visualmente como físicamente en los tres últimos recintos. Además, con ese modo de proceder, de parar las obras de extracción de bloques en esas zonas concretas, se consiguió un zócalo o banco de piedra «natural» (pero de corte artificial) sobre el que recrecer las defensas con las piedras extraídas del lugar, ganando en altura, firmeza y estabilidad de los muros.

Esa medida, la de dejar el flanco derecho descubierto, responde a una táctica militar básica: el flanco derecho es el más vulnerable al llevar en ese lado, los diestros (que son la mayoría de los componentes de los ejércitos), el arma de ataque y la defensiva (escudo) en el izquierdo. Un aspecto que aparece en los libros de táctica militar de la época, cuyos máximos exponentes en ese momento eran los tratados bizantinos (cfr., entre otros, Dagron y Mihăescu 2011; Dennis 1984; 1985; 2010; Pringle 1981; Garlan 1974).

No nos parece anecdótica esa preocupación de hacer los accesos con esa máxima de dejar el flanco derecho del asaltante al descubierto, puesto que da una enorme ventaja táctica a los defensores del castro. Ello, unido a otros parámetros poliorcéticos muy específicos, así como los condicionamientos del propio espacio interno o la limitación en la disponibilidad de agua, nos hacen decantar por un uso exclusivamente militar del enclave, antes que un imposible uso poblacional de aglutinar en su interior población campesina circundante. Eso no podría darse ni en el quehacer cotidiano, ni en períodos concretos de excepcionalidad como un episodio bélico. No hay ni espacio, ni sobre todo disponibilidad de agua, para mantener a un grupo de población numeroso durante un tiempo prolongado.

4. Colocados y concentrados en la parte baja, lógicamente, así como en el exterior de la muralla, con el fin de aguantar su propio empuje, que ejerce sobre su parte más exterior al estar asentada sobre un plano inclinado. 


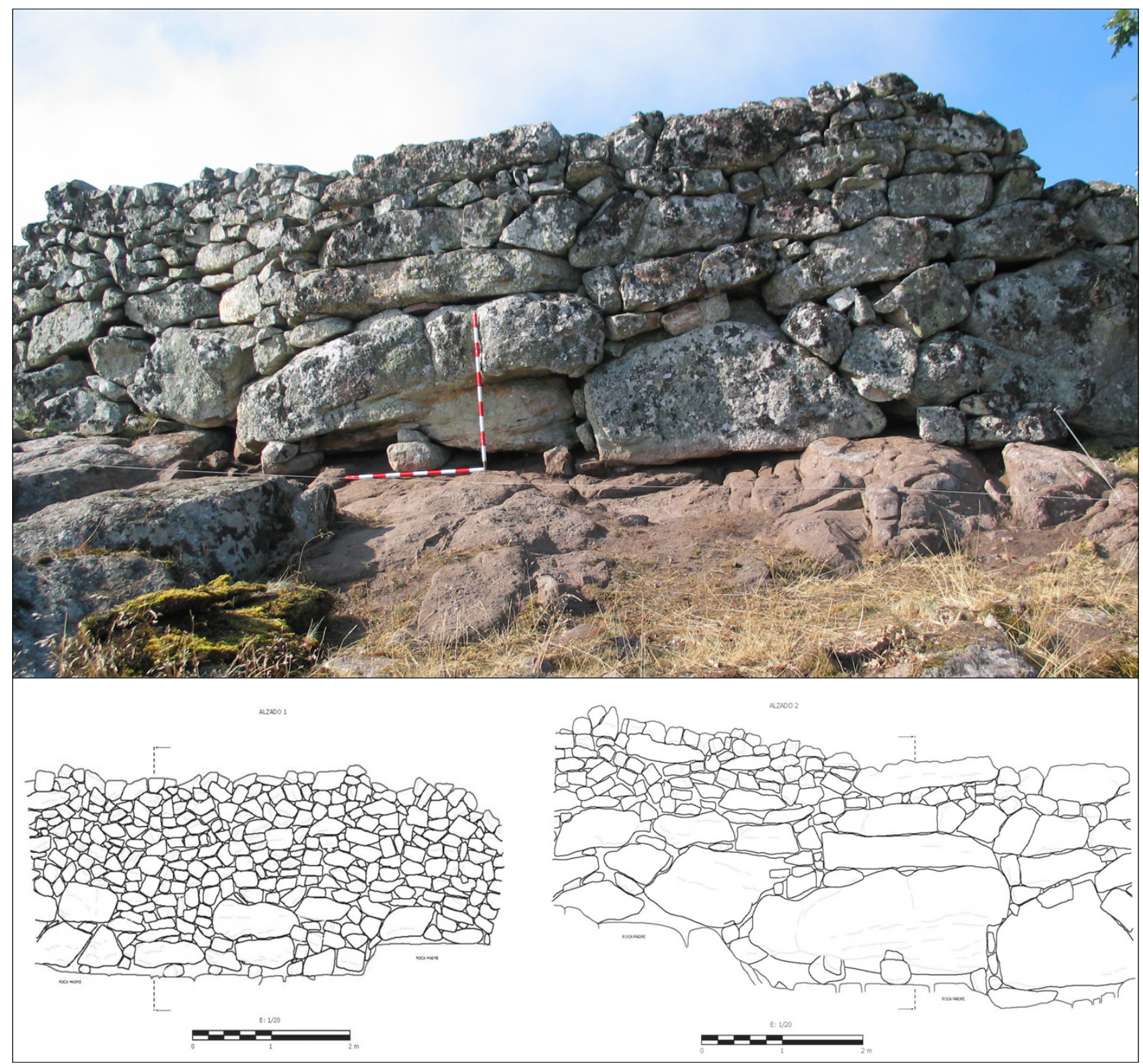

FIgURA 4. Vista parcial de la muralla M1 al exterior con aparejo ciclópeo. Dibujos del alzado interior (izq.) y exterior (der.), realizados por Iberotec, S. L.

Este aspecto del agua es crucial para el desarrollo cotidiano del enclave. Sin duda. Luego abordaremos con mayor profusión este punto. Por ahora, podemos avanzar que en lo prospectado y excavado en el yacimiento no hemos detectado el o los aljibes, si es que los tenían. La naturaleza de la roca del lugar nos hace dudar de que pudieran haberse realizado.

En la tesis doctoral avanzamos diferentes sistemas de conservación del agua, como por ejemplo el empleo de vinagre, que prevenía y retardaba la aparición de bacterias en el agua recogida, o su aireación mediante su trasvase periódico. Su almacenamiento pudo haberse dado en materiales perecederos (tipo pellejos o, en menor medida, ¿toneles?; sin detectar los flejes de hierro anulares exteriores). Se han encontrado asas torsas espiriliformes de hierro para cubos de madera, como las aparecidas en numerosos yacimientos de la época.

Lo que sí se pudo observar es que, en períodos no bélicos, es decir, en la mayoría o la totalidad del tiempo de uso del castro, el abastecimiento de agua se tuvo que realizar de un arroyo cercano por medio de un camino localizado. Este discurría de manera muy protegida, escondido a la vista de los posibles atacantes entre extensos canchales de grandes piedras. Salía desde la zona ocupada del castro, por detrás, su zona sur, hasta un pequeño arroyo de montaña (ahora denominado arroyo de 
los Monjes); un curso que no se seca en verano y de agua excelente, que incluso abastece actualmente al núcleo de Lumbreras.

\subsection{Castro Bilibio (Haro, La Rioja)}

En este yacimiento se intervino debido a las labores de prospección arqueológica que nos encargó la Dirección General de Cultura del Gobierno de La Rioja en 2014 con motivo de la revisión y actualización del inventario arqueológico del término municipal de Haro.

Gracias a ello pudimos detectar una serie de enclaves inéditos, entre los cuales destacamos aquí los muy interesantes del entorno de la ermita de San Felices, que se encuentra encaramada en lo alto de un crestón rocoso. Esta construcción religiosa reocupa y recontextualiza hacia parámetros eclesiásticos un espacio civil fortificado anterior.

Esos peñascos se siguen denominando a día de hoy Riscos de Bilibio. Es por ello que, además de que la tradición local ha asociado el término de Castro Bilibio a ese punto concreto (incluso con la colocación en el siglo xxi de una placa nominal sobre la muralla), nosotros hemos denominado a todo ese complejo sistema fortificado (recinto amurallado + torres + faro) como «fortificación de Castro Bilibio».

A los pies de la actual ermita y diseminadas por los diferentes crestones, se encuentran tanto el recinto fortificado como los retalles de otras cuatro torres de vigilancia (tres seguras y una solo probable), de madera. Como se puede ver en las figuras 1.4 y 5.1, es un espacio preeminente de dominancia del entorno visual más inmediato. Tiene una gran visibilidad y se ve desde varios kilómetros alrededor.

Pues bien, con motivo de la voladura controlada en 2014 de un crestón rocoso anexo a la ermita de San Felices, subimos a uno de ellos y allí, en lo más alto, pudimos localizar restos cerámicos de un objeto extraño. Algo que posteriormente, al localizar dos fragmentos de la boquilla, se reveló como los restos de una grande e interesante trompa cerámica de aviso. Con estos datos, elevamos una petición de intervención de urgencia al órgano competente, ante la inminente llegada del invierno y la más que posible pérdida de todo este depósito arqueológico por los nuevos desprendimientos en las rocas resquebrajadas; era necesario saber el contexto arqueológico de ese puesto de guardia-relevo para las tareas de vigilancia de la anexa torre superior (vid. torre 1 en figura 5.2).

Los resultados de la intervención en este pequeño sondeo fueron muy satisfactorios. Hubo una gran concentración de materiales arqueológicos que respondía, sin ningún género de dudas, a que no existía espacio material más allá de lo excavado $\left(2 \mathrm{~m}^{2}\right)$. El resto era cortado vertical de unos $10 \mathrm{~m}$ por un lado y de unos $60 \mathrm{~m}$ por el otro. Hay que trepar $2 \mathrm{~m}$ para poder subir. Para tal fin, se realizaron una serie de presas-huecos alternantes en la roca para que los vigilantes pudieran acceder allí a diario metiendo los pies y las manos en esas oquedades.

Es por ello que, como también se intuye en la figura 5.3, tuvimos que realizar labores de excavación y cribado de los depósitos con medidas de sujeción supletorias de un arnés fijado con cuerda al buzón de montañeros. Este se encuentra ahora al lado, justo encima del parapeto a modo de adarve o paseo de ronda inferior. Este fue retallado en la roca para facilitar el tránsito por esa zona tan escarpada y a su vez servir de cortavientos al cercano y ligeramente más bajo puesto de relevo. Esa plataforma minúscula era el único espacio llano y más habitable del que dispondrían los soldados encargados de realizar los cambios y relevos de guardia de la persona que se encontraba vigilando en la torre superior (vid. figura 5.2). Es lo que hemos denominado como "puesto de relevo» (vid. figura 5.3).

En ese lugar encontramos un pequeño hogar conformado por bloques de piedra arenisca enrojecidos por la acción del fuego, de mediano tamaño y traídos ex profeso desde abajo (zona del recinto fortificado). Consideramos que este detalle de las piedras exógenas era crucial y responde a que, como bien tuvieron que saber los soldados allí apostados, ante un fuego potente, la caliza estalla fuertemente si entra en contacto directo y constante con el fuego, pudiendo provocar serios daños a los que se encuentren alrededor de la hoguera. ${ }^{5}$

En cuanto al registro material, encontramos abundantes fragmentos cerámicos: ollas de perfil en $\mathrm{S}$, fondo plano y una tapa de piedra (losa de canto de río con restos de acción de fuego por su circular marca roja exterior) para evitar la entrada segura de ceniza en un espacio tan expuesto a los vientos; así como varias vasijas más, una de ellas de almacenaje de grandes dimensiones pero de pared no gruesa. Junto a ello, apareció una probable punta de lanza de hierro y dos objetos

5. Areniscas traídas casi con toda seguridad de una cantera que se encuentra a $5 \mathrm{~km}$ de distancia para la construcción, principalmente, de los dos hilos exteriores de la muralla del recinto fortificado. 

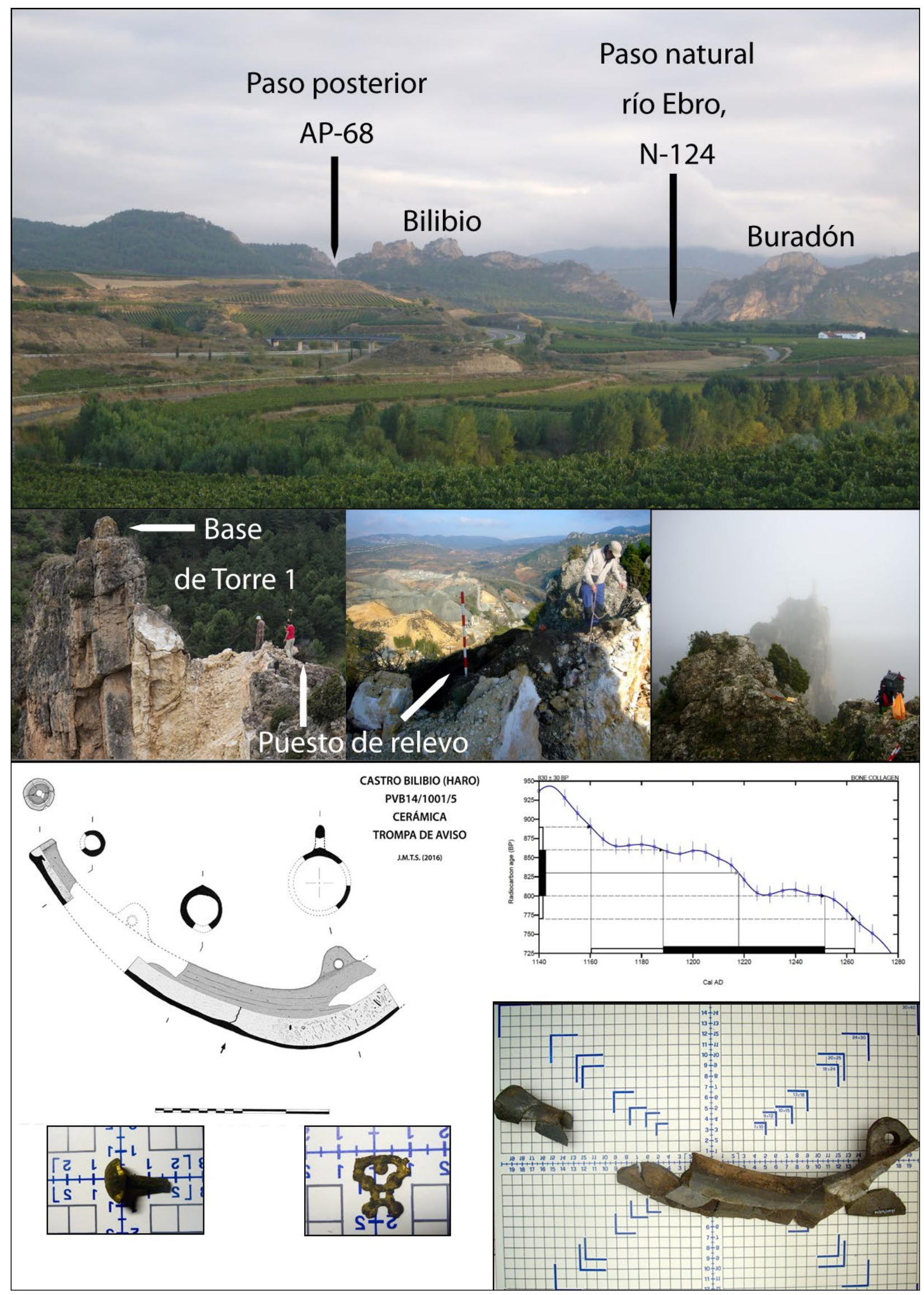

Figura 5. (1) Panorámica del entorno de las Conchas de Haro. (2) y (3) Base de la torre 1 y su puesto de relevo en el momento de su intervención. (4) Vista desde el puesto de relevo un día de niebla. (5) Fotografía y dibujo arqueológico de la trompa, con parte del contexto arqueológico aparecido: apliques de cobre con recubrimiento de oro de una micra de grosor, así como gráfico de la datación radiocarbónica sobre hueso del contexto. 
de cobre $(99 \%)$, bañados en oro con una micra de espesor. ${ }^{6}$

De la trompa cerámica se continuaron recuperando fragmentos, hasta completar un total de 39. Con ellos pudimos hacer el dibujo arqueológico de cómo pudo ser el objeto original, de un tamaño muy considerable (conservados unos $40 \mathrm{~cm}$ pero sería de unos 50-60 cm, aproximadamente). A partir de ese dibujo, aventuramos una hipótesis de su pabellón (completamente desaparecido) conforme a los abundantes paralelos europeos documentados. Se realizó una reproducción en cerámica (vid. figura 6.4), con el fin de poder mostrar en el Museo de La Rioja un objeto que fuera comprensible para el público en general. ${ }^{7}$

En España, hasta ese momento, el único estudio arqueológico de trompas cerámicas del que nosotros tenemos constancia es el realizado por $\mathrm{J}$. I. Padilla y K. Rueda en 2010. Nosotros, por nuestra parte, estamos inmersos en un estudio de este tipo de instrumentos, buscando paralelos tanto en el entorno hispano más cercano como en los abundantes ejemplos y bibliografía que hay en el ámbito europeo.

De ese contexto arqueológico se realizaron dos dataciones radiocarbónicas, una en carbón y otra en hueso. Esta última nos interesa especialmente, pues pertenecía a la segunda fase de ocupación de este espacio y evitábamos el posible peligro de «efecto de madera vieja» en la lectura del carbón. Se trataba de un hueso largo de fauna, con signos de aprovechamiento para alimentación por fractura, pero no pudimos identificar la especie. Se dató por AMS. El resultado, como se puede intuir en la figura 5.5, fue muy interesante y proporcionó una fecha, grosso modo, de primera mitad del siglo XIII (a una sigma). ${ }^{8}$

El marco contextual e interpretativo más amplio de este tipo de piezas nos parece relevante para comprender su función. Así, en el entorno más cercano hemos encontrado las interesantes pinturas realizadas en almagre en las iglesias de Alaiza y de Añua, ambas en Álava y con el mismo motivo iconográfico: el asalto a una torre de madera - ¿castillo?- por parte de soldados armados. Lo más relevante, desde el punto de vista pictóri- co, es la defensa de sus ocupantes con armas (ballestas, lo que sería coherente con esa cronología propuesta), y especialmente tocando «cuernos» en la parte más alta de la torre. Incluso se pueden apreciar detalles, en los tres ejemplos de Alaiza y los dos de Añua, de las cuerdas que se habrían utilizado para ser colgados. ${ }^{9}$

Estos objetos se emplearían especialmente los días de niebla, algo habitual en esta zona del Ebro en invierno (cfr. figura 5.4). Como hemos visto en abundantes escenas militares romanas (sarcófagos, Columna Trajana, relieves, arcos triunfales) e instrumentos, ${ }^{10}$ este tipo de artefactos sonoros eran muy habituales en los entornos militares ya desde época clásica. Es por esos precedentes, y sobre todo por la propia disposición, localización y dispersión de los yacimientos (en especial en referencia a las turris), que hay que tener en consideración su uso en época tardoantigua. Si estaban realizados con materiales orgánicos en ese período (cuernos de bueyes), entonces es lógico pensar que su certificación arqueológica será muy difícil (al menos en el entorno castrense hispánico). No sucede lo mismo en el caso cerámico para períodos medievales posteriores, que, como vemos, están presentes en el registro arqueológico.

Fruto de esa línea de investigación es la presentación de un trabajo en el XII Congreso Ibérico de Arqueometría. ${ }^{11}$ En él se analizan 24 fragmentos cerámicos de la fortificación de Castro Bilibio, de sus dos ocupaciones de finales del siglo $\mathrm{x} /$ principios del XI y del siglo XIII, así como un fragmento de tégula de época tardorromana -¿romana?- aparecida en una unidad estratigráfica de época contemporánea. Todos ellos se han analizado por tres métodos: análisis químicos (ICPMS), microscopio electrónico de barrido (SEM) y difracción de rayos X (DRX). Sin entrar en las particularidades de cada pieza, lo que aquí nos interesa especialmente es la trompa. Esta pieza presenta una muy cuidada cocción reductora que tuvo que rondar los $950-1.000{ }^{\circ} \mathrm{C}$, por la presencia de Espinela y Kfs. ${ }^{12}$

Ello nos da una idea de la importancia conferida a estas piezas, o al menos a su proceso de cocción. Es muy probable que su elevada cocción

6. Análisis arqueometalúrgicos realizados por cortesía de D. Joan Puyol (Fischer Instruments S. A.), al que nuevamente agradecemos desde aquí su amabilidad y disposición.

7. Caracterización de la reproducción realizada por Nuria Esteso, responsable de Giornata Taller de Arte y Restauración. Alfarero: Antonio Naharro, Navarrete (La Rioja).

8. Muestra . $^{\circ}$ Beta-405900, $830 \pm 30 \mathrm{BP}$. La interceptación con la curva de calibración da la fecha de cal AD 1220 . A dos sigmas (95,4\% de probabilidad), da cal AD entre 1160 y 1265 . A una sigma (68\% de probabilidad), cal AD entre 1190 y 1250 .

9. El ábside de Alaiza se considera que se realizó o bien a finales del siglo XII, o bien a principios del XIII (Venegas 1994).

Por tanto, las pinturas tienen que ser de esa época o posterior.

10. Bishop y Coulston 2006, 115, 146 y esp. 189.

11. García y Tejado 2017.

12. Investigación realizada gracias a una ayuda concedida por el IER, convocatoria de 2016. 




Figura 6. (1) Ábside de Alaiza con escena bélica de asalto a una torre. (2) Detalle del mismo ábside con dos soldados tocando la trompa (o cuerno) en la parte superior de la torre. (3) Iglesia de Añua con motivo similar. (4) Fragmentos originales y reconstrucción cerámica hipotética de la trompa de Castro Bilibio. (5) Grabados de escena bélica en torno a un castillo en el interior de la iglesia de Moings (Haute-Saintonge), datados entre 1130 y 1140 . Nótese como en lo alto de la torre de madera hay un soldado tocando un cuerno o trompa (detalle). Foto: APEMUTAM, tomada de L. Dieu 1999, 49. (6) Trompa de Craponoz. Único ejemplar completo original. $44 \mathrm{~cm}$ de longitud. Vidriada, cronología propuesta hacia finales del siglo XIII - principios del XIV. Foto de Yves Bobin, Patrimoine de l'Isère. (7) Trompa grande de Faudon. $63 \mathrm{~cm}$ de longitud. Restaurada. Sin vidriar. Cronología propuesta de hacia finales del siglo XIII (Dieu 1999, 2).

le ayudase a reducir la absorción del sonido por parte del material y de esa manera sonara más y «mejor» (en este caso, más lejos).

Estamos a la espera de realizar pruebas sonoras reales comparativas entre la réplica realizada en cerámica y un gran cuerno de buey para comprobar si la proyección sonora sufre variaciones entre un material y otro. Las pruebas experimentales en el sur de Francia han demostrado que estas trompas podrían llegar a enviar el sonido hasta $7 \mathrm{~km}$ de distancia en línea recta entre lo alto de sus cerros (Dieu 1999, 4).

Afortunadamente, en otras excavaciones cercanas también están comenzando a detectarse 
más ejemplares de trompas cerámicas. Estaremos atentos a cualquier novedad, así como a las publicaciones que se realicen a este respecto. ${ }^{13}$

Antes de entrar a analizar el recinto fortificado, es necesario seguir deteniéndonos en lo alto de algunos de esos crestones rocosos de los Riscos de Bilibio. Como hemos dicho, hemos localizado más indicios de torres repartidas por ellos. Un ejemplo que queremos analizar es la torre 2 (vid. figura 7).

En la parte inferior de uno de los últimos crestones colgados sobre el río Ebro se encuentra un gran bloque tallado de piedra caliza local, igual que ocurría en la torre 1 . De un volumen considerable, en torno a $1 \mathrm{~m}^{3}$, nuevamente, sirvió de base para la cimentación de una torre de madera que se sustentó sobre él. Prueba de ello es la aparición a $2 \mathrm{~m}$ de altura de los dos mechinales cuadrangulares de $20 \times 25 \mathrm{~cm}$ que se encuentran en la pared de roca vertical (cfr. figura 7.2). A $4 \mathrm{~m}$ de altura se encuentran otros mechinales aún más potentes (cfr. figura 7.1). Pensamos que todos ellos servirían para anclar la torre a ese farallón rocoso mediante vigas y travesaños que fijaron y dieron firmeza a toda la estructura ante los fuertes y constantes vientos dominantes en una zona tan expuesta como es esa. A partir de esos $4 \mathrm{~m}$ es donde pensamos que se desarrollaría la propia garita donde harían los soldados sus labores de vigilancia.

La importancia de esta torre es múltiple. Principalmente, aunque no solo, porque nos permite saber las dimensiones tanto de la propia estructura como de algunos elementos que la componían: anchura, altura o dimensiones de los maderos de las vigas y los tirantes.

El otro elemento en el que es necesario detenerse es el faro terrestre. Este faro adolece de una notable falta de conservación de su registro arqueológico por la profunda remodelación de este espacio tan «singular». El motivo más reciente es el de ser un espacio de referencia religiosa: se encuentra en el espacio que actualmente ocupa una enorme estatua de San Felices, para que sea vista desde infinidad de puntos del territorio circundante. Requerido desde diferentes aspectos de la vida jarrera (militar, religiosa, festiva, turística...), este espacio se configura como el elemento dominante del entorno más inmediato. Ello se debe a que su dominio visual es abrumador. No tanto por su altitud absoluta (642 m), sino por su altitud re- lativa respecto al área circunvecina, en particular en su orientación sur. Es allí, en el punto más alto, en donde pensamos que, aun con los escasos indicios de retalles conservados en la roca, debiera encontrarse el faro de Bilibio. Hasta al menos en tres ocasiones se menciona la presencia del faro de Bilibio, a falta de hacer una revisión aún más exhaustiva de la documentación conservada en el Archivo Histórico Municipal de Haro.

La primera es en la famosa carta de arras fechada en 1040 de "donación» del rey Don García, el de Nájera, a su esposa, D. ${ }^{a}$ Estefanía de «Bilibium cum faro et cum sua pertinentia», literalmente, de «Bilibio con faro y con sus pertenencias», no «Bilibio y Haro (ciudad)» como interpreta la historiografía erudita local, desde A. C. Govantes (nacido en Foncea, perteneciente al partido judicial de Haro), en su diccionario geográfico de 1846, hasta los estudiosos más recientes (García de Cándamo 1996 o Cegarra 2013, entre otros), con el fin de dotar de una mayor antigüedad a la fundación de la ciudad de Haro.

La segunda mención es de un documento de 1292 (desaparecido a día de hoy pero del cual se conserva una transcripción del 17 de septiembre de 1751), en el que Sancho IV hace donación de los terrenos y jurisdicción del faro de Bilibio a la nueva villa de Haro, con todos los derechos de terrenos y poblaciones. Un interesante ejemplo por tres motivos: el primero es que aquí ya no hay confusión posible en la entidad del faro, como algunos interpretan erróneamente para el caso anterior, pues se menciona tanto el faro como la villa de Haro. El segundo, por la importancia y entidad que se confería al elemento faro, que sirve para designar a toda la fortificación y sus territorios dependientes, su jurisdicción. Nada menos. Y en tercer lugar, por ser nuevamente una orden regia, lo que nos indica quién tenía la autoridad sobre este elemento del faro (para donarlo, etc.).

Finalmente, el último testimonio es el expedido por el notario Nicolás Urquiola en el que se certifican diferentes cláusulas del privilegio de fundación de Haro y en donde se menciona el antiguo faro de Bilibio (signatura 3024/29 del AHMH).

Un par de documentos modernos consultados recientemente apuntan a otros parámetros igualmente interesantes en lo referente a sus refacciones y últimos estadios de utilización de esta

13. La empresa Arqueorioja está excavando en el castillo de Nalda (La Rioja) y está registrando también fragmentos como los que aquí mostramos. Todos ellos, unidos a los más de doscientos fragmentos de varios ejemplares que llevamos ya detectados en el castillo de Viguera, nos confirman nuestra idea inicial de que este tipo de trompas cerámicas tuvieron que ser muy habituales en las fortificaciones de estos períodos. Su «singularidad» arqueológica reside únicamente, a nuestro parecer, en la falta de conocimiento arqueológico de este registro (reconozcámoslo humildemente y hagamos autocrítica), no por el hecho de que fueran unos objetos excepcionales, que no lo creemos. Tuvieron que ser objetos usuales, a la par que importantes por la función que desempeñaban al ser el medio sonoro de conectar la red de fortificaciones. 

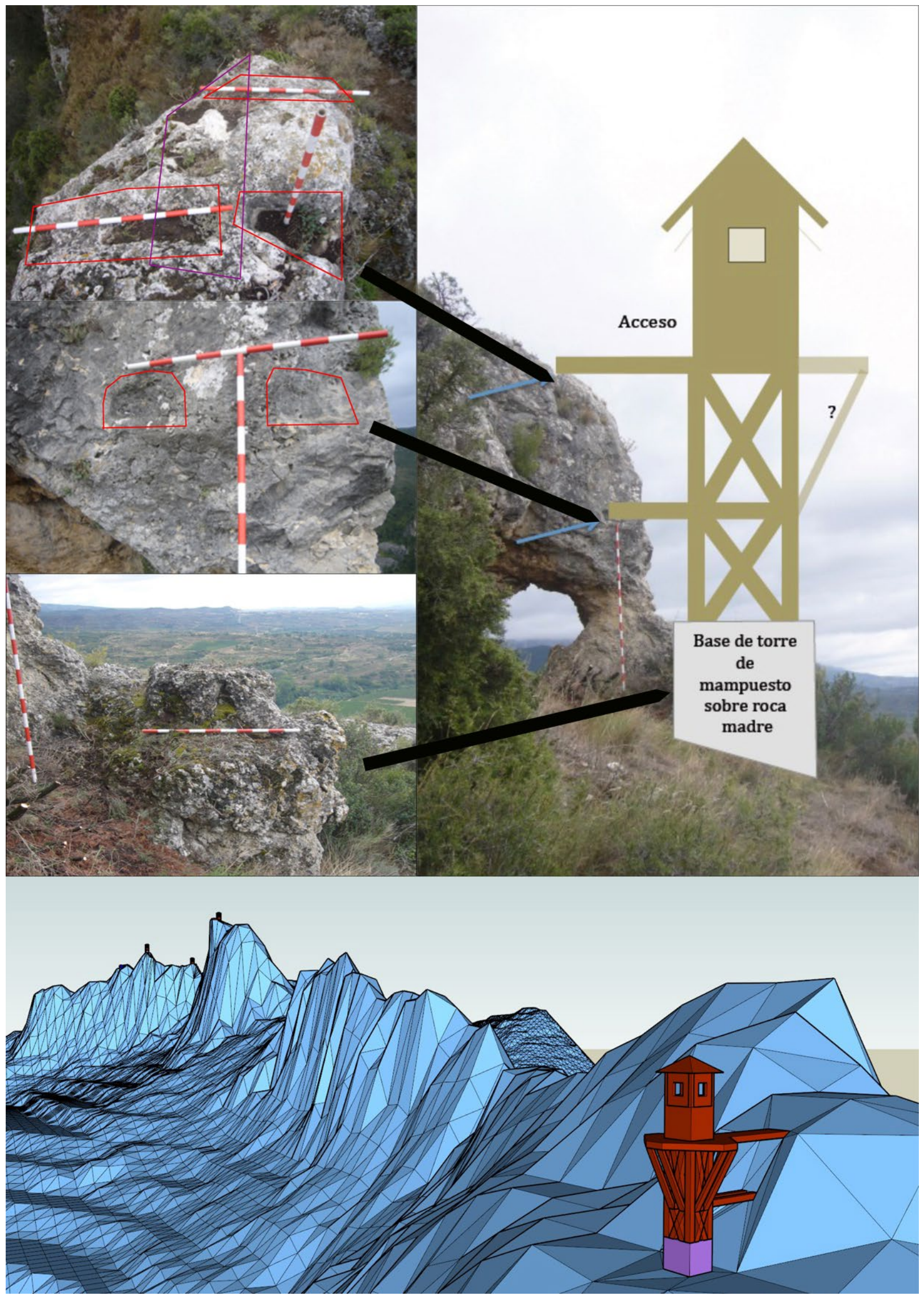

Figura 7. (1) Retalles superiores en la roca para anclar los maderos de sujeción de la torre 2 en su parte alta (a $4 \mathrm{~m}$ ). (2) Retalles en la pared de la roca para encastrar los tirantes intermedios. (3) Base cuadrangular de la torre realizada mediante retalle. (4) Reconstrucción hipotética de cómo pudo haber sido la torre de vigilancia $\mathrm{n}^{\circ} 2$ sobre la vía oriental (margen derecha del río Ebro). (5) Reconstrucción hipotética de la torre 2 sobre MDT de los Riscos de Bilibio (autor: LDGP). 
fortificación, como hemos mencionado en la introducción. $^{14}$

Resulta obvio decir que este faro sería un faro terrestre, de emisión de señales luminosas durante la noche y de humo durante el día, visibles a largas distancias (vid. Sheldon 2005, 199-249; Woolliscroft 2001). Los avisos sonoros, caso de ser necesarios, se podrían realizar desde las diferentes torres de madera dispersas. En ellas, por ser de madera, no se podrían hacer grandes fuegos para la transmisión de señales en caso necesario. Sí en las torres macizas de piedra y mortero, como la detectada en Viguera (Peña Candil), encima de Peña Castillo. Faros terrestres que servían para que, una vez enviada la señal de aviso a los núcleos pertinentes (ciudades en último término) con el fin de abortar el ataque por sorpresa, estos tuvieran el tiempo suficiente para pertrecharse, proteger y recoger personas, alimentos y animales en el interior de sus murallas.

La imagen que tenemos de la plataforma donde podría ir el faro de Bilibio es muy simple, a la par que parcial. Simple por el mero hecho de que su estructura sería muy sencilla. Se trataría de un retalle realizado en la piedra que en la actualidad presenta unas dimensiones (no regulares) de 1,20 $\mathrm{m}$ de ancho por $2 \mathrm{~m}$ de largo y $70 \mathrm{~cm}$ de alto. Pero como hemos dicho, estas dimensiones han podido sufrir importantes mermas (principalmente en planta) como resultado de procesos de derrumbe natural, o bien por motivos de refacciones posteriores muy severas.

La regularización que ahora se ve en la parte superior de ese gran retalle es una solera de hormigón que se aplicó a lo largo de las reparaciones del siglo xx, probablemente a mediados de siglo, momento en el que se colocó allí la estatua y se «adecuó» el entorno más próximo. Esta solera de hormigón es de un grosor bastante regular y aparentemente reducido (entre 3 y $5 \mathrm{~cm}$ ). Las dimensiones aproximadas de esta sencilla plataforma descrita son similares, grosso modo, a las de la estructura presente en Buradón (al otro lado de la clausura sobre el río Ebro), y que según nuestra interpretación se trataría de otro faro. Máxime si tenemos en cuenta que se encuentra en su punto más alto (justo encima del aljibe).

Finalmente, el último punto de análisis de la fortificación de Castro Bilibio se centra en su recinto amurallado. Los datos se obtuvieron en la campaña de un mes realizada en 2015. Se llevaron a cabo tres dataciones radiocarbónicas, dos sobre hueso (AMS) y una en carbón, que apuntaron dos horizontes conocidos: una última ocupación de la primera mitad del siglo XIII, ${ }^{15}$ perfectamente sincrónica (cuasi idéntica) a la detectada en el puesto de guardia de la torre 1 un año antes. Y otra fase fundacional de finales del siglo $\mathrm{x}$ / principios del XI con dos dataciones. ${ }^{16}$

De ese momento inicial entre finales del siglo $\mathrm{x}$ y principios del siglo XI son la mayoría de las fábricas detectadas en arenisca con aparejo isódomo, una vez que se ha hecho un detallado estudio arquitectónico de las unidades presentes en sus alzados (vid. figura 8.2). Es reseñable una reconstrucción importante del lienzo exterior al lado del acceso (UEM 50010). Probablemente esa refacción (diferencias en labra, aparejos y morteros, presencia de calzos, irregularidad de hiladas, etc.) fue fruto de una ocupación militar que tuvo el yacimiento durante la Tercera Guerra Carlista, entre 1873 y 1876. Esa restauración apresurada

14. Hemos podido consultar dos documentos de 1499 y 1500 gracias a la información facilitada por nuestro colega y amigo Diego Téllez Alarcia, historiador especialista en la Edad Moderna, al que desde aquí agradecemos tanto su noticia como su transcripción. Versan acerca de los pleitos que tiene el duque de Nájera por realizar obras para rehabilitar Castro Bilibio, con el claro interés de controlar esa ruta crucial para sus intereses territoriales y económicos. El contenido dice: «respondieron [los canteros] que eran allí venidos por mandado del duque de Nájara». Y las autoridades locales, siguiendo las directrices de los Reyes Católicos, le ordenan al bachiller Francisco Riquel que «si algo fallardes fecho o labrado o hedificado en la dicha fortaleza, de nuevo lo fagáys derrocar fasta sacar los çimientos» (datado en 1499, Archivo General de Simancas. Ref. RGS, LEG, 149909, 126). Un año más tarde dice: «Por virtud de la qual, él [Francisco Riquel] fue a la dicha fortaleza e derrocó çiertos edifiçios que falló fechos» (datado en 1500, Archivo General de Simancas. Ref. RGS, LEG, 150002, 345). No sabemos si hacia el 1500 este comisionado Francisco derribó las torres, o el edificio de madera que existió para albergar la guarnición, aunque pudiera ser. Pero al menos el intento de llevar a cabo esas obras por parte del duque, en unas fechas «tan tardías» como esas, es un dato muy útil en cuanto a las inferencias relativas a las lecturas de gestión territorial y control social que de ahí se pueden derivar.

15. Muestra n. ${ }^{\circ}$ Beta-420102: 100.002H (AMS sobre hueso, extracción de colágeno), $820 \pm 30$ BP. La interceptación con la curva de calibración da la fecha de cal AD 1220. A dos sigmas (95,4\% de probabilidad), da cal AD entre 1165 y 1265 . A una sigma (68\% de probabilidad), cal AD entre 1210 y 1255.

16. Muestra n. ${ }^{\circ}$ Beta-420101: 100.005M (carbón), $1050 \pm 30 \mathrm{BP}$. La interceptación con la curva de calibración da la fecha de cal AD 995. A dos sigmas (95,4\% de probabilidad), da cal AD entre 905 y 920, y especialmente cal AD entre 965 y 1025. A una sigma (68\% de probabilidad), cal AD entre 980 y 1020. Muestra n..$^{\circ}$ Beta-420100: $100.005 \mathrm{H}$ (AMS sobre hueso, extracción de colágeno), $1080 \pm 30$ BP. La interceptación con la curva de calibración da la fecha de Cal AD 980 . A dos sigmas (95,4\% de probabilidad), da cal AD entre 895 y 1020. A una sigma (68\% de probabilidad), cal AD entre 905 y 920 y, especialmente, cal AD entre 965 y 995. 
y de factura descuidada se hizo con aparejos recuperados del propio derrumbe que se dio en esa zona meridional. El lienzo en esa parte baja se encuentra mejor conservado al haber estado tapado por ese propio derrumbe hasta, previsiblemente, finales del siglo XIX.

La cimentación inicial de la muralla se realizó de manera cuidada, muy profesional y con gran

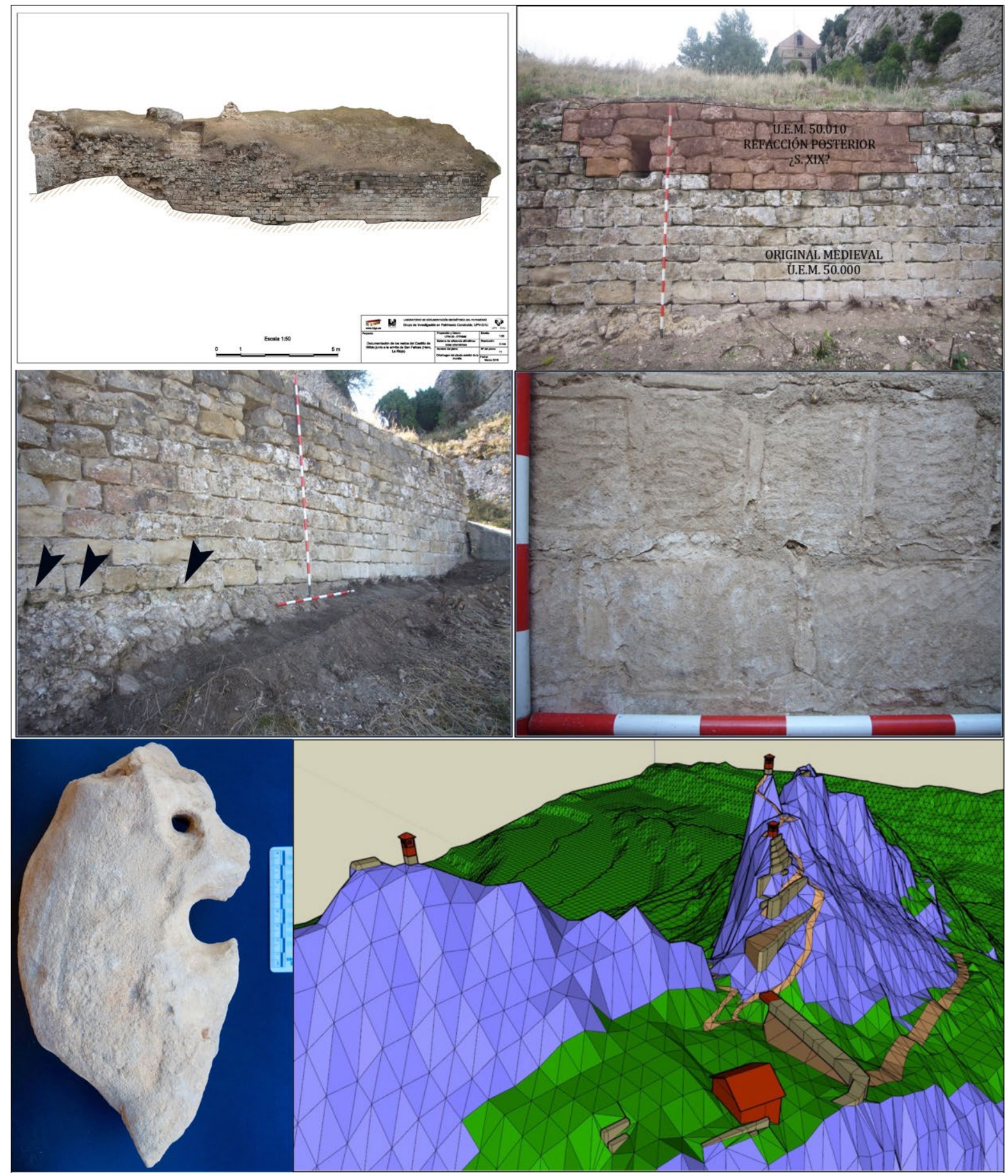

Figura 8. (1) Ortoimagen del alzado exterior de la muralla. E: 5 m (autor: LDGP). (2) Lectura de paramentos de su lado meridional. (3) Vista lateral de la muralla para observar el tallado de la roca natural para cimentar a $90^{\circ}$. Marcados los restos de argamasa. (4) Paramento interior de la muralla, perfectamente conservado. Nótese el rejuntado de sillares con cal, y la interesante técnica de labra de «filo curvo». (5) Fragmento de arenisca empleada como plomada en dos ocasiones. (6) Modelo 3D de la hipótesis del aspecto de la fortificación de Castro Bilibio, conforme a los datos arqueológicos recogidos, en el período (siglos X-XIII). Nótese la pequeña plataforma en la esquina superior izquierda, que hemos denominado «faro» (autor: LDGP). 
esmero técnico. Se talló la roca natural hasta su horizontal. Por los indicios observados, hay que pensar que es probable que en la unión entre ambos elementos, primera hilada de cimentación y roca madre, pudiera existir una pequeña adición de argamasa de cal que a modo de media caña protegiera la unión entre ambas de la lluvia, principal enemigo de esta arenisca, y evitara también que se introdujera al interior de la muralla. Desaparecida ahora esta unión de argamasa, solo nos quedan leves indicios en esa zona (cfr. figura 8.3).

Es destacable también la presencia, para estas fechas, de la técnica del filo curvo para la labra de estos sillares de arenisca (cfr. fig. 8.4). Se ha conservado perfectamente en la parte interior del lienzo, tapada por los rellenos constructivos y no expuesta a los agentes atmosféricos (lluvia, nieve y viento), que hubieran imposibilitado su detección por la erosión de su superficie. Es un punto importante, porque, como bien nos comentó el autor de la tesis de referencia sobre este particular (Sánchez 2007), es algo infrecuente detectar en fechas tan tempranas esta técnica, máxime en un entorno civil como el militar, cuando el objeto de estudio prioritario han sido los edificios religiosos (iglesias y ermitas). ${ }^{17}$

Desde el punto de vista instrumental, la presencia de una gruesa plomada habla de la profesionalidad de los maestros canteros, necesaria para llevar a cabo la obra de la muralla. Esta plomada está hecha con piedra arenisca con dos perforaciones para realizar su función de suspensión; central en un primer momento $\mathrm{y}$, una vez rota, reaprovechada con otra perforación lateral-excéntrica (cfr. figura 8.5). Se encontró en la parte más baja del cajeado de cimentación interior, en contacto con la roca madre y la muralla. Parece ser que lo primero que hicieron los maestros canteros tras acabar la construcción de la muralla fue deshacerse y «enterrar» una plomada que ya no les servía para nada más que no fuera colmatar y rellenar la banqueta de cimentación. Cuestiones de reaprovechamiento de materiales como zahorras constructivas de relleno una vez acabada la obra.

Llaman la atención las descomunales obras de desmonte que afectan a todo el cerro objeto de fortificación, no solo al espacio que se va a cercar o amurallar, que es relativamente pequeño. Se realizan, además, mediante el retalle de diferentes escalones sobre los que apoyar la obra de la muralla regularizada. También del propio camino de acceso, picado en la roca en ocasiones más de 1,5 $\mathrm{m}$, así como los abundantes caminos de distribución interna y los potentes retalles para cajear muros de aterrazamiento que se dan por todo el cerro, en particular entre la torre $1 \mathrm{y}$ la posible torre 4 (cfr. figura 8.6).

Esta gran antropización y la realización de potentes procesos constructivos del cerro han hecho que, si hubo una ocupación tardoantigua allí, como los indicios textuales (Vita Sancti Aemiliani) y arqueológicos ${ }^{18}$ apuntan, sufrieron una enorme alteración. Sería necesario acometer, por lo menos, otra campaña que intentase despejar varias de estas incógnitas.

Hemos detectado también el espacio de habitación de la pequeña guarnición militar allí asentada. Desbrozada y delimitada la extensión en superficie del espacio de hábitat, se observan importantes obras de desmonte para realizar una estancia de pequeñas dimensiones (planta de 40 $\mathrm{m}^{2}$ ), que fue también en madera, vistos los abundantes y contundentes mechinales para apoyar las vigas, o incluso escaleras repicadas en la roca para descender y entrar en su interior. Pensamos que su planta baja serviría de despensa y almacén. Fue picada en la roca, por lo que sería más fresca e idónea para la conservación de ciertos alimentos (frescos, principalmente). La planta y los espacios superiores, menos húmedos, pensamos que servirían para contener otro tipo de enseres e incluso otros alimentos secos, así como las estancias para habitar y dormir.

Sin embargo, a pesar de nuestros intentos por continuar las labores allí comenzadas, no han resultado fructuosas nuestras peticiones a la corporación local, por lo que de momento no sabemos si se podrá profundizar en el estudio de todos esos aspectos aquí simplemente enunciados, ni cómo, ni cuándo. Desgraciadamente, por el momento parece improbable, al menos a corto plazo, a pesar del enorme interés de lo que todavía queda por investigar allí.

17. Queremos agradecer a Leandro Sánchez Zufiaurre el intercambio de pareceres e información ante el hecho de la detección de la técnica de «filo curvo» en los aparejos de la fortificación de Castro Bilibio. Esperamos que, más adelante, podamos realizar por fin conjuntamente un estudio específico sobre este particular.

18. De momento muy débiles por la presencia de un seguro fragmento de tégula en posición secundaria en un contexto arqueológico contemporáneo (¿siglo XIx?), lo que obviamente no es prueba de nada. Sin embargo, su mera presencia allí, en esa zona tan elevada, no es fruto obviamente de acciones de arrastre, o raramente pueden responder a cuestiones azarosas, por lo que debe ser tenida, al menos, en consideración. 


\subsection{Castillo de Viguera-Valdemetria (Viguera, La Rioja)}

Se encuentra situado en el valle del Iregua, pero esta vez no en su cabecera, como en el caso del castillo de los Monjes, sino en su zona de contacto con el valle del Ebro, conformando una clausura natural debido a sus potentes mallos.

Son ya tres campañas arqueológicas las que llevamos interviniendo allí (una en la vía de comunicación, 2016, y dos en el castillo, 2017 y 2018). Al estar en curso las investigaciones, los resultados presentados aquí serán provisionales.

Antes de comenzar los trabajos de intervención arqueológica en esta fortificación, se llevó a cabo un estudio de la documentación de las fuentes árabes y latinas relativas a Viguera y su entorno entre los siglos IX y XIII. A inicios de 2017 se encargó al investigador especialista en textos árabes Jesús Lorenzo Jiménez el vaciado exhaustivo (y traducción-edición en el caso de los textos árabes, ya que las latinas estaban editadas desde hacía años por múltiples investigadores) de las menciones a Viguera y su entorno, con especial atención a su castillo y su territorio-dominio (castrum Vecaria / Hiṣn Baqīra / tenencia de Meltria). Su resultado ha sido un volumen de 290 páginas que todavía estamos analizando desde el punto de vista de la investigación (Lorenzo 2017). Podemos avanzar que sus resultados son interesantes, sobre todo por su confrontación con el registro arqueológico aparecido y datado.

Durante los meses de junio y julio de 2017 y de 2018 se realizaron los trabajos de intervención arqueológica y de su documentación geométrica respectiva en la fortificación del castillo de Viguera, también denominado como Valdemetria. ${ }^{19}$

Hacemos esta puntualización para distinguirla de las abundantes y numerosas fortificaciones aglutinadas en este punto concreto de Viguera.
Pensamos que esta masiva concentración de diferentes tipos de fortificaciones (castillo de VigueraValdemetria, castillo de Castañares de las Cuevas, fortificación de San Esteban, Peña Castillo y torre de vigilancia de Peña Candil, puestos de control del paso del Barranco de los Infiernos, puesto de Las Guardias, etc.) responde al deseo prolongado en el tiempo de intentar controlar la clausura baja del río Iregua. Aunque estamos reconociendo e interviniendo de una manera u otra en todos ellos (fotografiando, visitando, midiendo, realizando dataciones radiocarbónicas), lo cierto es que la intervención arqueológica más potente es la que estamos conduciendo actualmente en el castillo de Viguera-Valdemetria. ${ }^{20}$

Se trata de una gran superficie de unas 18 ha que se encuentra rodeada en todo su perímetro por cortados naturales que rondan los 100-120 m de caída (figura 1.3). Solo se puede acceder por su zona sur, algo más baja, donde se retalló su acceso en la roca para poder subir. Por tanto, esa fue la primera acción arquitectónica, sustractiva en este caso.

La segunda acción fue la realización de los dos potentes aljibes circulares (de $6 \mathrm{~m}$ de $\varnothing$ ) mediante el vaciado de la roca. Ello lo sabemos porque para la construcción de la primera fase detectada hasta el momento, romana del siglo Iv, se tuvieron que utilizar miles de litros de agua para los morteros con los que se edificó el potente edificio allí localizado. Fue realizado con opus caementicium y pavimentado con opus signinum.

Por los indicios que tenemos, solo unas pocas zonas de toda esa extensión de la fortificación fueron ocupadas de manera «estable», con los condicionantes que las ocupaciones militares suponen. Actualmente estamos calibrando dicha ocupación, pero pensamos que, en el mejor de los casos, no llegaría al $5 \%$ de ese total. No obstante, todavía es muy prematuro para avanzar un dato preciso a este respecto.

19. Reitero mi agradecimiento a todos los integrantes del equipo por su esfuerzo y dedicación, sin los cuales no hubieran podido realizarse las dos campañas aquí expuestas: Simona Berardino, Summer Courts, Chiara d'Anna, Mikel Gómez, Juan Lozano, Ana Medrano, Alberto Quintana, Inês Ribeiro, Carlos Rodríguez, Gontzal Tomás y Amaya Valle. La sección del LDGP (Laboratorio de Documentación Geométrica del Patrimonio de la UPV/EHU) estuvo compuesta por José Manuel Valle (dir.), Garbiñe Elorriaga, Beñat García y Álvaro Miranda. Hay que hacerlo extensivo también a todo el pueblo de Viguera (instituciones, asociaciones y particulares), así como al CEIP (Centro Europeo de Información y Promoción del Medio Rural) para el desarrollo de la campaña de 2018. Un acercamiento divulgativo de las actividades realizadas se puede ver en $<$ https://www.facebook.com/CastillodeViguera/>.

20. Respecto a «la posible ubicación del castillos [sic] de Viguera en la Meseta de Valdemetria no existen restos de suficiente entidad que así lo atestiguen [sic]» (Pascual 1994, 345), el trabajo que aquí presentamos demuestra lo incorrecto de tales presupuestos. Existen restos de entidad. Precisamente, la relevancia de los restos que comienzan a detectarse inciden en esa asociación. Contextualización: sobre los procesos de transformación en época tardoantigua desde un marco de trabajo global y con la inclusión del registro arqueológico, véase Christopher Wickham 2008. Respecto al sistema de tenencias en La Rioja y la organización de su territorio por parte de la monarquía navarra, en particular de la tenencia de Meltria, se puede consultar un reciente acercamiento historiográfico (Olcoz 2009; 2010), y mucho antes desde las fuentes (Rodríguez de Lama 1975). Finalmente para comprender el contexto específico de lo que suponía la gestión territorial de este espacio fronterizo del Ebro en la plena Edad Media, es imprescindible la consulta del libro de Ignacio Álvarez Borge de 2008. 
El resto de la superficie pensamos que fue aprovechada especialmente por los sucesivos pequeños rebaños de cabras (y en menor medida ovejas), mejor adaptadas que otros animales a este entorno y con escaso consumo de agua. Esos grupos de animales pudieron pastar allí para el abastecimiento de las diferentes guarniciones que se instalasen: leche para quesos por la presencia de fragmentos de varios individuos de cerámica perforada (poscocción) localizada en estratigrafía (¿quesera?), carne, piel para cuero, tendones, huesos, lana (presencia de fusayolas), cuernos.

En algunos puntos muy concretos aparecían en superficie abundantes y heterogéneos fragmentos de tégulas, algunos fragmentos de TSHT (decoradas únicamente en el segundo estilo de los cercanos talleres del Najerilla), sillares de piedra de toba (exógena y sin duda alguna traída del entorno cercano, pero desde abajo). Con todo ello planteamos la intervención en tres sectores con el fin de intentar resolver algunos problemas, a saber: el principal de ellos era averiguar la secuencia estratigráfica y la cronología de las ocupaciones que allí se intuían. La segunda era conocer la entidad, la potencia y la evolución de sus estructuras. La tercera, saber más acerca de la cuestión del almacenamiento del agua. No podemos desarrollar todos los detalles de ambas campañas, explicados en los preceptivos Informe Final 2017 (79 pp.) e Informe Final 2018 (67 pp.) depositados en la correspondiente consejería, junto con las memorias de documentación geométrica con los planos de secciones, alzados, modelos digitales en 3D, etc. Sin embargo, sí que mencionaremos algunos puntos relevantes.

En el punto más elevado del cerro se planteó en 2017 un sector de $6 \times 6$ m con el fin de averiguar a qué se debía la presencia masiva de esos materiales constructivos en superficie y ver qué resultados deparaba su secuencia estratigráfica. Como se puede comprobar en la figura 9, la relación estratigráfica de estructuras y depósitos fue rica a la par que compleja. Ello se tradujo en la detección de siete fases de ocupación (más una acción puntual), ${ }^{21}$ basadas tanto en las dataciones radiocarbónicas realizadas (veintidós en las dos campañas) como en la estratigrafía relativa y en el estudio preliminar de materiales. Ello hizo que en 2018 ampliáramos el área de excavación en ese sector.

La última fase de ocupación corresponde a un estadio del siglo XIX-XX. El registro cerámico vidriado es patente. Han aparecido tres monedas de Felipe IV, maravedíes de a 8 , reselladas posteriormente a VI y a IIII (entre 1641 y 1659). ${ }^{22}$ Apuntamos la naturaleza de su ocupación pastoril por los testimonios orales de la población a la que hemos entrevistado.

La fase anterior es del siglo xIV. Su naturaleza es de raigambre militar, vistos los hallazgos recuperados por el momento: puntas de flecha cuadrangulares de ballesta, numerosas placas de cobre dorado, nuevamente, más de doscientos fragmentos de trompas cerámicas de varios individuos... Las dataciones responden a tres criterios: una datación radiocarbónica (abandono del aljibe), otra de termoluminiscencia sobre un fragmento de trompa cerámica y los hallazgos numismáticos en contexto: dos monedas novenes de Alfonso XI de la ceca de Burgos. ${ }^{23}$

La fase anterior pertenece a los estadios de finales del siglo XI / mediados del XII. Cuenta con abundantes dataciones radiocarbónicas. Para esta fase se han podido asociar dos inhumaciones (vid. figura 10.1). En la campaña de 2018 se han excavado otros cuatro individuos, y se ha realizado el estudio osteoarqueológico de todos ellos: podemos avanzar que se trata de tres individuos masculinos adultos, una mujer de avanzada edad con abundantes pérdidas dentales en vida y un infante de 3-4 años. Sin ajuar en origen y todos ellos en decúbito supino. ${ }^{24}$

Algunas tumbas presentan unas ligeras variaciones de orientación, similares a las del edificio, en torno a $100^{\circ}$ de orientación sureste, mientras que otras tienen una orientación al este más «canónica» de $90^{\circ}$ respecto al norte (cfr. figura 9.1). Sin embargo, ello no tiene que ver con su cronología de uso, pues, a pesar de tener orientaciones relativamente análogas, una presenta una indudable cronología visigoda (606-680 AD a dos sigmas 95,4\%), otra islámica (764-891 cal AD a dos sigmas $84 \%$ ) y otra de finales del siglo x y principios del XI (940-1021 cal AD a dos sigmas 74,6\% y a una sigma 968-1016 cal AD 58,8\%).

21. Repoblación de pino laricio en 1961 por parte del Ministerio de Agricultura del momento, vista la Memoria Informativa del Consorcio. Lógicamente, esta acción afectó de manera notable al registro arqueológico. Queremos agradecer a la Consejería de Medio Ambiente su colaboración, especialmente a David Bengoa.

22. El estudio numismático ha sido realizado por Fernando López Sánchez. Los interesantes resultados del más de centenar de monedas estudiadas se publicarán más adelante en un artículo específico.

23. Casualmente, en la campaña de 2003 en el castillo de los Monjes aparecieron tres novenes de Alfonso XI, de la ceca burgalesa también, acuñados presumiblemente entre 1328 y 1334 (cfr. Tejado 2010, 222 e inventario).

24. El estudio osteoarqueológico de estos individuos ha sido realizado por Maite Iris García. 
Esta fase es amortizada por el derrumbe del edificio de culto anterior. Sus morteros están hechos íntegramente en yeso (en el núcleo y en ambos revocados de los muros). Un yeso de elevadísima calidad debido a las excelentes propiedades de la materia prima (todavía en explotación industrial a día de hoy) y al preciso conocimiento de su proceso de cocción, vistos los resultados obtenidos. ${ }^{25}$

El edificio tuvo que ser derribado-demolido en la fase de ocupación del siglo xIv, probablemente para la obtención de materiales y evitar el peligro de derrumbe. De hecho, ya estaba parcialmente en desuso en el siglo XI, como lo demuestra la presencia de un hogar en el interior de la esquina noreste del espacio anexo lateral a sus pies.

Anterior a esta fase, además de la inhumación citada, hemos detectado un pequeño depósito cerrado, con materiales cerámicos y huesos, a los que hemos sometido a datación radiocarbónica, que ha dado un interesante siglo Ix. Una datación casi idéntica a la ya vista en el yacimiento del castro de Peña Yerre (sobre carbón), en el alto valle del Iregua. Por el momento, no podemos avanzar más de esta interesante fase, tan presente en las fuentes documentales.

La fase de construcción de ese edificio de excelente factura con aparejo en opus pseudospicatum (vid. figura 9.2) de mampuesto local de calizas y piedras de río obtenidas de los conglomerados del propio cerro, con abundante mortero de yeso local traído de un afloramiento que se encuentra a los pies del cerro a $1 \mathrm{~km}$, presentó una datación radiocarbónica a una sigma de siglos VII/VIII, y a dos sigmas de finales del siglo VII / principios del siglo vIII. ${ }^{26}$ En la campaña de 2018 hemos tomado otra muestra del ábside, que nos ha dado una refacción de finales del siglo x / principios del XI (idéntica a una inhumación).

En la parte del ábside se ha podido observar la máxima concentración de piedras de toba. Además, al excavar el derrumbe, se han identificado cuatro dovelas de una pequeña ventana que estaría situada en la orientación norte del ábside (figura 9.5). El edificio cayó (o fue derribado) todo él sobre la orientación sur, que es la zona inferior de la pendiente.

Es por ello que, al ser la orientación norte la menos apropiada para un vano (por el viento y el frío) y constatar la presencia de una abertura en el norte, pensamos que el ábside tendría tres pequeñas ventanas para permitir la entrada de luz (este, norte y sur). No sabemos si podría llegar a estar cerrada con algún tipo de lapis specularis, o alabastro... No tenemos datos, ni el más mínimo indicio o fragmento, para pensar en esa opción (aunque creemos que podría ser plausible).

Los restos de sillares de toba con forma cóncava en su cara interna nos indican que el hueco del ábside $(1,30 \mathrm{~m}$ de $\varnothing$ al interior) estaría cubierto con una pequeña cúpula de toba sobre pechinas. El resto de espacios (nave central y espacio anexo a los pies), creemos que podrían estar cubiertos por vigas de madera y cubierta a dos aguas con las abundantes tégulas reutilizadas (Utrero y Sastre 2012) e ímbrices.

El tránsito entre el ábside y la nave central se hacía mediante un arco triunfal realizado en piedra de toba (figura 9.7). Se conservan in situ los arranques de los pilares y se ha recuperado una dovela del mismo de idéntica anchura $(55-60 \mathrm{~cm})$. El trasdós de la dovela presenta una perforación central que hemos interpretado para su posible sujeción.

El alero del edificio era amplio para proteger de la lluvia el lienzo exterior de yeso, como lo demuestra el largo canecillo trilobulado de arenisca recuperado (figura 9.4).

Con todos estos datos, desde el LDGP se ha llevado a cabo un boceto o primera aproximación de cómo podrían haber sido la geometría y el aspecto exterior del edificio. Su autora ha sido Garbiñe Elorriaga (vid. figura 9.6).

Visto esto, hemos comparado los datos aquí presentes con los paralelos de otras edificaciones del momento (v. Caballero 2015 para el contexto general de iglesias con cúpula sobre pechinas). Para el entorno más próximo, véase el ejemplo de la cercana iglesia de Las Tapias (Albelda de Iregua) (Espinosa 2011). Recientemente, pudimos observar otro ejemplo en la iglesia de Finaga con pequeño ábside cuadrangular y arco triunfal (Unzueta 2015).

Queremos detenernos en la presencia de un elemento destacado en este discurso: hemos vuelto a detectar más de doscientos fragmentos de trompas cerámicas de aviso. Se han individualiza-

25. Queremos agradecer especialmente a Carmelo Martínez Garrido, responsable de calidad de la fábrica de yesos de Viguera de Saint-Gobain Placo Ibérica, y a los responsables del Laboratorio de I+D+i en Madrid de dicha empresa, la colaboración y buena disposición mostrada desde un primer momento para la realización de las analíticas: análisis térmico diferencial (ADT), dureza Shore C, fluorescencia de rayos X (XFR) y termogravimetría (TGA), tanto a morteros de yeso como a los minerales de yeso nativo, a la cal del opus signinum y al opus caementicium para averiguar su composición.

26. Muestra n. ${ }^{\circ}$ Beta-474572: CV17/100.006/1 (AMS sobre carbón), $1280 \pm 30$ BP. A dos sigmas (95,4\% de probabilidad) da cal AD entre 662 y 774. A una sigma (68,2\% de probabilidad), cal AD entre 681 y 721 , con un 40,8 \%, y entre 740 y 766 , con un $27,4 \%$. 


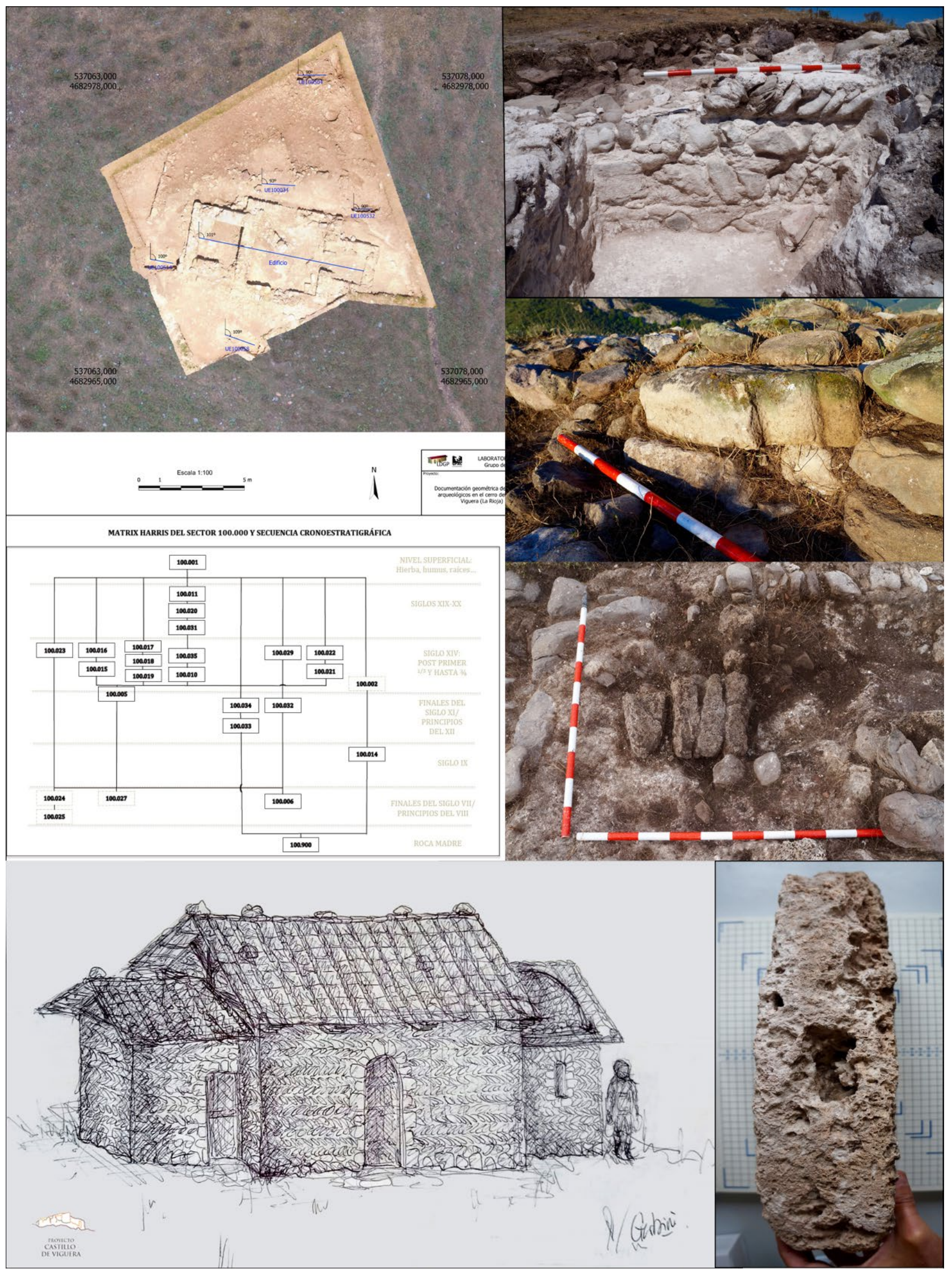

FIGURA 9. (1) Vista cenital del sector 100.000; campaña 2018 con eje de simetría, orientación y relación con las tumbas excavadas. E: 5 m (autor: LDGP). (2) Aparejo en opus pseudospicatum del edificio de culto, realizado íntegramente con mortero de yeso. (3) Matrix Harris del mismo sector; campaña 2017. (4) Canecillo del edificio reutilizado en estructura circular superior (siglo XIV). (5) Derrumbe del interior del ábside con cuatro dovelas detectadas. (6) Boceto preliminar del posible aspecto exterior del edificio de culto (realización: Garbiñe Elorriaga (LDGP)). (7) Vista cenital del trasdós de dovela perteneciente al arco triunfal. 
do, hasta la fecha, varios fragmentos de boquilla, así como numerosos fragmentos de la parte final de los pabellones. Mientras realizamos un estudio detallado, parece que pertenecen al menos a cinco trompas cerámicas diferentes. En un fragmento cerámico se realizó una datación por termoluminiscencia que apuntó a una cronología de producción del siglo xIv. Ello coincide con la datación radiocarbónica de esa fase en los otros sectores del yacimiento, así como con el contexto numismático recuperado en la misma unidad estratigráfica (novén alfonsino). Recientemente hemos podido datar piezas (por C14) de contextos estratigráficos en la fase de finales del siglo XI/principios del XII.

Por intentar resumir algo este vuelo sucinto y comprimido a la materialidad de la fortificación del castillo de Viguera, lo primero que podemos apuntar es que, tras estas dos campañas de aproximación a su contexto, secuencia y caracterización arqueológica, se puede confirmar la gran potencialidad arqueológica de este yacimiento. Un yacimiento militar que, como hemos remarcado al inicio, no tiene murallas. No son necesarias. Algo evidente cuando se accede al yacimiento. Las murallas son naturales, son sus cortados, que se escalan al subir a él. Es indudable que solo se podría acceder a su interior si sus residentes lo permitían, pues era inexpugnable desde el punto de vista defensivo (no así si había una reducción por hambre por medio de asedios, como nos cuentan las fuentes que sufrió en alguna ocasión, particularmente en el año 919).

Ello ha sido el principal motivo, en nuestra opinión, para que, si bien la presencia de ciertos materiales en su superficie es algo conocido desde hace años, no se haya contemplado en algunas publicaciones recientes la potencialidad del yacimiento o se haya negado explícitamente la posibilidad de que se tratase de la fortificación del castillo de Viguera al que tanto se referían las fuentes (Pascual 1994). Por tanto, queda demostrado, según los argumentos apuntados, que, independientemente del desarrollo arqueológico que pueda mostrar este yacimiento, la entidad y relevancia de esta fortificación queda fuera de toda duda.

El siguiente punto a destacar es que, si bien nos encontramos en los albores de la investigación arqueológica en esta fortificación, que no ha hecho nada más que comenzar, parece que, afortunadamente, las fuentes escritas pueden ser de gran ayuda para comprender el contexto arqueológico que se nos presenta en primer término (caso del Informe de 1961 para entender los grandes hoyos debidos a las acciones de repoblación forestal). Y el contexto histórico general en un segundo momento.

Así, no es de extrañar que el registro arqueológico perfectamente definido por numerosas dataciones radiocarbónicas de finales del siglo XI y principios del siglo XII, con una actividad de necrópolis y una presencia allí, en lo alto de esa fortificación, que podría despistarnos, pueda ser encuadrado en los términos de la tenencia de Meltria que tanto mencionan las fuentes, precisamente en ese período (cfr. fig. 10.3). Y algo similar habría que pensar con los otros tres individuos datados y sus respectivas fases: a finales del siglo $\mathrm{x}$, durante el viII y el Ix y en el siglo vII. Tarde o temprano tendremos que dotarlos de contenido histórico: ¿fase del denominado «reino de Viguera»?, ¿su ocupación Banu Qasi y la ocupación inmediatamente anterior de época visigoda? Veremos, pero todo parece indicar que sea plausible.

Por tanto, la sincronía entre fuentes escritas y registro arqueológico la entendemos como algo beneficioso, no como algo que haya que evitar para la «asepsia del método arqueológico». ${ }^{27}$ Podría ser (esperamos) que ambas, arqueología y fuentes documentales, saliesen beneficiadas de esa relación simbiótica.

El uso de la metodología comparativa en diferentes aspectos, no solo entre fuentes y registro arqueológico sino incluso «tan poco arqueológicos» como los artísticos en este caso, puede sernos de gran ayuda para perfilar la contextualización de fases completas de un yacimiento (cfr. fig. 10.4 y 10.5). Algo así nos ha ocurrido con la «sorpresa» de la potencia del registro del siglo XIV de esta fortificación.

Hay que decir que, ya en 2003, detectamos en el castillo de los Monjes una fase de ese siglo XIV (post primer tercio), en los mismos marcos temporales de los aquí vistos y datada por criterios numismáticos exclusivamente. Casualmente, tienen el mismo tipo de moneda en ambos: novenes de Alfonso XI.

Poníamos de manifiesto la relevancia de ese período en todo el valle del Iregua al analizar otros elementos de fortificaciones en esta área (castillo de Castañares de las Cuevas y Torre Fuerte de Lumbreras, principalmente; cfr. Tejado 2011, 311312). Es por ello que no nos parece tan fortuita, la reocupación de espacios en ambas fortificaciones, incluso con materiales numismáticos idénticos. Sin embargo, la pregunta que nos hacíamos ya en la tesis de si «¿Pudieron volver a darse comporta-

27. Algo que por otra parte es tan pretendido como falso, pues dentro del método arqueológico ya operan prejuicios conceptuales que limitan o condicionan, en origen, el análisis de la realidad arqueológica. 


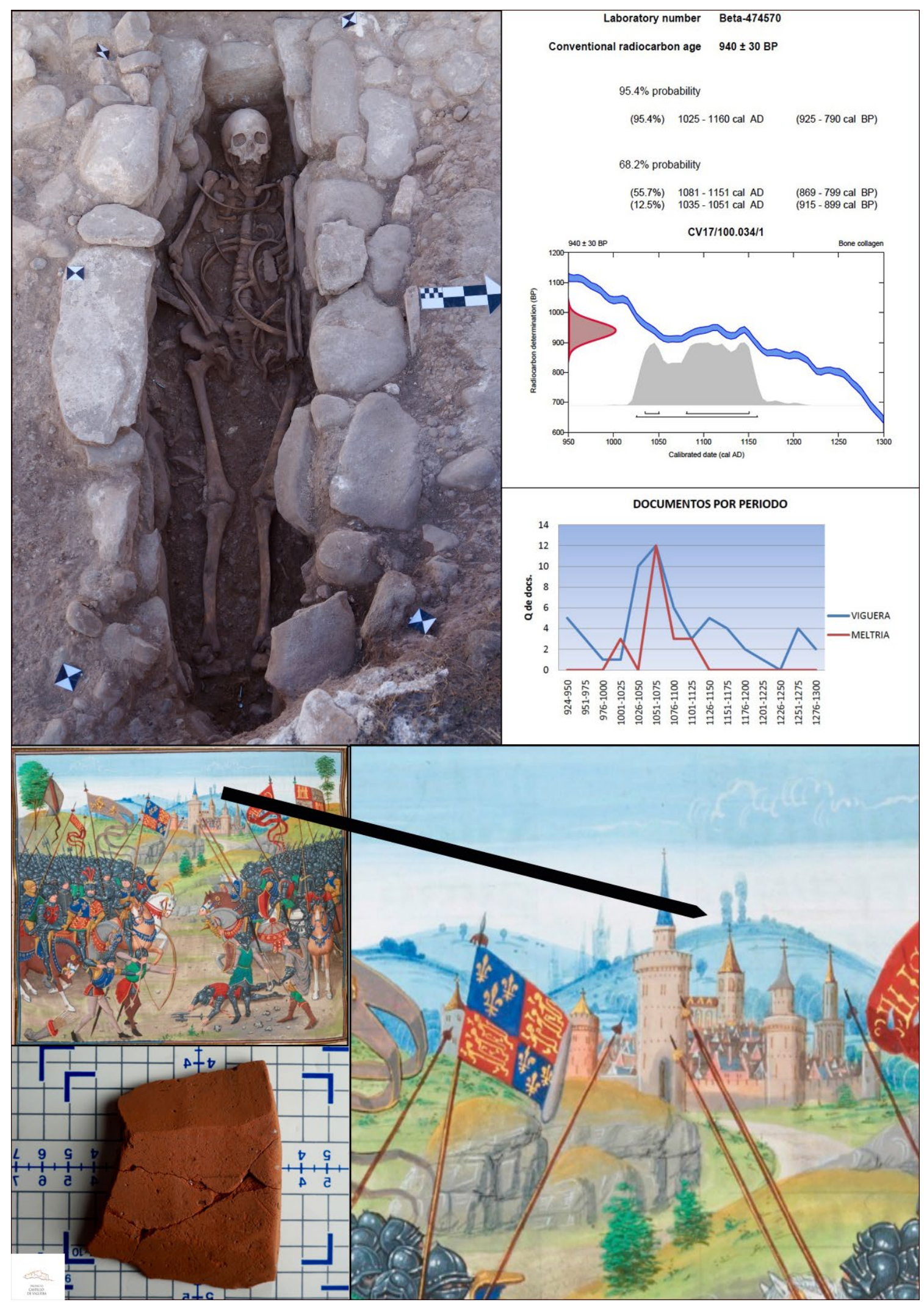

Figura 10. (1) Imagen del individuo 100034 antes de su extracción. (2) Imagen del resultado de la datación radiocarbónica del individuo, con especial probabilidad $(55,7 \%)$ de entre finales del siglo xi y mediados del XII (a una sigma). (3) Número de documentos que mencionan Viguera y Meltria por segmentos temporales de 25 años (autor: Jesús Lorenzo Jiménez $(2017,211)$ ). (4) Cuadro de la Batalla de Nájera o Navarrete (1367). Manuscrito de las Crónicas de Jean Froissart, siglo xv (Biblioteca Nacional de Francia, FR 2643, fol. 312v). (5) Detalle del fondo del mismo, donde se observan en un cerro cercano, en un ambiente bélico y de día, dos grandes columnas de humo que interpretamos como el resultado de haber puesto en funcionamiento el sistema de aviso que aquí estamos analizando para el control territorial. (6) Fragmento de pabellón de trompa cerámica, biselada al exterior. 
mientos de vigilancia de los estrechos desfiladeros de este valle, nuevamente [repitiendo el comportamiento del VII/VIII], en el siglo XIV?...» (Tejado 2011, 312), creemos que es plenamente pertinente. Y la respuesta a esa pregunta está cada vez más cerca de poder responderse afirmativamente.

\section{Conclusiones}

Como hemos dicho en el apartado introductorio, las fortificaciones tienen un carácter muy heterogéneo, tanto desde el punto de vista funcional como en cuanto a dispersión espacial y temporal. Fueron herramientas de gestión territorial muy útiles y de gran éxito, empleadas en infinidad de espacios y a lo largo de dilatados períodos de tiempo. Creemos que eso se debió a su gran versatilidad. Su magnífica capacidad de adaptación a entornos y funciones muy diversos hicieron de ellas unos instrumentos muy utilizados y extendidos con el fin de gestionar de manera adecuada, en primer término, el territorio sobre el que se asienta una sociedad dada. Sin embargo, será precisamente el propio control de esa sociedad el fin último por el cual el uso de las fortificaciones fue tan recurrente y exitoso. El control territorial sería así un medio para lograr ese ansiado control social.

Partiendo de que toda generalización en este campo de las fortificaciones es cuando menos arriesgada, como hemos argumentado antes, sí que nos aventuramos a destacar una selección de características principales (sin ser las únicas) en lo tocante al tipo específico de las fortificaciones militares en el período tardoantiguo. Como decimos, este solo es uno de los varios tipos de fortificaciones que existen.

Nos centraremos en las vistas y analizadas en el entorno del valle del Ebro. La cuestión de la circunscripción espacial se debe a que podemos hablar sobre aquellas que aquí hemos examinado en detalle, pero ello no significa que los parámetros que vamos a destacar sean exclusivos de ese espacio. Al contrario, observamos que varias de estas características que aquí vamos a poner de relieve son comunes en muchos ámbitos espaciales y temporales para las fortificaciones específicas del control militar de las vías de comunicación.

Algunas características destacables de estos enclaves son, desde nuestro punto de vista, las siguientes:

- Existencia de aljibes o, en menor medida, de sistemas alternativos de almacenamiento de agua.

Consideramos que esta es una de las características principales. Hemos visto que hay algunos yacimientos que no conservan esos aljibes por su pérdida (por procesos postdeposicionales, caso de Castro Bilibio), o que incluso es probable que algunos (los menos) no los presentasen por las características propias de la roca natural sobre la que se asentaban (caso del castillo de los Monjes, con un abastecimiento de un arroyo relativamente cercano por un acceso solo visible para sus residentes internos).

En cualquier caso, sea el que fuere el método empleado para tener abastecimiento-almacenamiento de agua para su uso de boca en condiciones -pellejos de cuero, toneles de madera, aireación del agua y empleo de vinagre para evitar que se corrompiera (Tejado 2010, 559)-, tendría que ser un sistema efectivo que permitiera abastecer de agua el enclave.

¿Por qué este punto de la cuestión de la disponibilidad del agua es crucial, desde nuestra perspectiva? Porque la localización de este tipo de fortificaciones se encuentra en zonas de amplio control visual, aunque, como veremos, no siempre en el máximo grado. Los lugares seleccionados para su emplazamiento son cerros, crestones, desfiladeros, sobre afloramientos rocosos casi siempre (al menos en los tres casos aquí vistos). Ello limita que haya cursos de agua (arroyos) o surgencias (fuentes) disponibles en el interior de esos puntos.

Y siendo el agua un aspecto vital para el desarrollo humano del tipo que sea, ese aspecto es sacrificado por otro parámetro que los constructores de las fortificaciones y sus ordenantes consideraron aún más prioritario: el control visual del entorno en el que se encuentra esa vía o vías de comunicación que pretenden controlar. Y eso se consigue desde los cerros, no en los valles, que es donde está la disponibilidad de agua. Una relación inversamente proporcional: disponibilidad de agua y visibilidad del territorio en la que, para este sistema operativo, siempre predomina la visibilidad. Por tanto, la disponibilidad de agua se limita a otros sistemas «alternativos», donde los aljibes suelen jugar un rol principal.

Así lo hemos visto en el caso de Viguera: Almacenamiento de agua de origen pluvial. Mediante pequeñas hendiduras en el terreno, se conducía el agua hacia estos. Con un estado de limpieza absoluto, es probable que tuvieran algún tipo de cubierta de vigas de madera con tablas y pieles. Ello evitaría que se ensuciase el agua de polvo y hierbas, que se calentara, que se evaporara y que otros animales bebieran, gastaran el agua y la ensuciaran. Con alguna pequeña portezuela se podría acceder al interior del aljibe. Es una hipótesis que planteamos para este yacimiento. No tenemos datos (entalles), ciertamente. Solo operamos con la lógica de la posibilidad. 
- La superficie ocupada-construida es pequeña.

Ello es distinto a decir que la superficie de la fortificación es pequeña. Existen fortificaciones, caso de Peña Amaya, o el caso del castillo de Viguera, de más de 18 ha, que no cumplen esa variable porque responden a otros parámetros de fortificación de tipo natural. Es impensable plantear la hipótesis de una fortificación con murallas que circunden un espacio tan amplio para el asentamiento de una pequeña guarnición militar. Pensamos que un contingente limitado operaba en las tres fortificaciones aquí vistas. Cuanto más pequeño era el grupo para asegurarla, más eficiente era la fortificación. Menos es mejor.

Así, aunque el castro del castillo de los Monjes presentaba cuatro recintos amurallados coetáneos, solo en los dos últimos se establecería el uso cotidiano del castro. Los dos primeros recintos, los más amplios, se dejarían como espacios vacíos (a lo sumo, puntualmente con pocas cabezas de ganado para el autoconsumo). Su función originaria era la conducción de las personas por ciertos espacios y puntos concretos para evitar pillar por sorpresa a la guarnición del interior.

El espacio disponible en Castro Bilibio aún era más pequeño. Ínfimo. Cabrían, físicamente, unas pocas personas en su interior. Literalmente, no hay sitio para más. Y ello a pesar de las importantes y cuidadas obras de fortificación de todo el cerro, como hemos visto.

La superficie disponible en el castillo de Viguera-Valdemetria sería muy grande. Sin embargo, por lo que estamos viendo hasta la fecha, creemos igualmente que el contingente militar sería pequeño: por la limitada capacidad de los aljibes (30.000-32.000 1), por la concentración de materiales en superficie en unos pocos puntos, así como por los datos de prospecciones electromagnéticas de los que disponemos.

En esta última campaña se nos ha unido un argumento más para esta idea: el edificio de culto, construido ex novo, creemos que se adapta escrupulosamente a las necesidades y funciones para las que fue construido. Así, el ábside es tan pequeño (1,30 $\mathrm{m}$ de $\varnothing$ en el interior) que se adapta perfectamente para que el oficiante realice sus ritos, pero no hay espacio para nadie más. Se optimizan así los recursos de construcción de un espacio importante pero costoso logísticamente si se hubiera decidido sobredimensionar de manera innecesaria para una autorrepresentación hacia otras elites sociales. Algo que allí no hubiera tenido mucho sentido. No podemos perder de vista el enclave del edificio y lo difícil de acarrear allí los materiales constructivos. Y esa misma adaptación dimensional pensamos que se dio con la nave principal. De pie solo caben unas $15-20$ personas en su interior. Ello nos apunta un indicio de cuál podría ser la población máxima de esa guarnición militar en el momento de construcción de ese edificio. Lo funcional prima.

Eso no implica que el resto de hectáreas de la superficie del cerro no se utilizaran: pensamos que, como ya hemos apuntado arriba, sería un espacio aprovechado por el ganado (ovino y caprino). Con ese gran espacio disponible, un pequeño rebaño podría pastar de manera libre y permanente para abastecer a esa guarnición. De hecho, estaría «cercado» y sin necesidad de pastor que lo cuidase.

En otro tipo de fortificaciones, de carácter más poblacional, o donde la autorrepresentación social sea más relevante y donde la logística no imponga fuertemente sus reglas como en este tipo de fortificaciones enriscadas, puede darse una cierta sobredimensión de los edificios del interior de la fortificación. En estos otros que estamos viendo aquí, por estos limitantes expuestos, es mucho más compleja, por no decir directamente inviable.

- Desde el punto de vista estratigráfico, predominio de estratigrafías "simples».

Esta característica no es nueva. Publicaciones tan antiguas pero todavía muy válidas como Brogiolo y Gelichi 1996 ya lo ponían de manifiesto.

La naturaleza de la formación de este tipo de secuencias estratigráficas sencillas, o, mejor dicho, breves, responde al tipo del segmento social preeminente que lo configuró: el estamento militar. La movilización de este tipo de grupos militares conlleva la inversión, movilización y amortización de una serie de recursos importantes: no solo para la costosa construcción de sus materialidades, sino, en términos humanos, para su mantenimiento.

Mantener un destacamento, por pequeño que sea, aunque simplemente se trate de guarniciones limitadas a 40 o 50 individuos dispersos en diferentes puntos de un territorio (torres, pasos angostos, puentes y clausuras, castros y castillos, etc.), requiere un importante aprovisionamiento de útiles y utensilios de los que hay que dotar a esas guarniciones. Pero, sobre todo, representa un esfuerzo potente desde el punto de vista logístico: hay que alimentar a una población que no produce.

Se tienen que detraer, en términos productivos, los excedentes generados por el estamento productor campesino. Además, hay que pagar un «sueldo» a los soldados. La liquidez monetaria será un punto clave a la hora de sostener a esos destacamentos dispersos por el territorio. Como podemos constatar en el magnífico libro de Simon Esmonde Cleary (2013), fue un elemento clave en 
la desestructuración de un sistema de gestión y control territorial articulado ya en época romana (durante los siglos III y IV d. C.) en su parte occidental. El pago a la tropa con monedas fue un punto clave para comprender que esos sistemas de gestión territorial eran gravosos en términos económicos, en todas sus acepciones: monetarias, de excedentes alimentarios y de inversiones constructivas y logísticas.

Son los yacimientos de tipo poblacional (principalmente aldeas o ciudades) los que generan estratigrafías más complejas y densas por lo prolongado de las ocupaciones que se fosilizan en esos depósitos. Un carácter del yacimiento más estable, surgido de una ocupación del espacio más continuada y sobre todo sincronizada en la explotación del entorno, genera ese tipo de estratigrafía más prolongada y por ende más compleja. Son yacimientos endógenos a la estructura socioeconómica del territorio en el que surgen. Lo contrario a estas fortificaciones que vemos aquí.

Yacimientos de carácter más coyuntural como son los militares, exógenos desde el punto de vista de la imbricación en el territorio en el que se insertan, suelen generar, habitualmente, una potencia estratigráfica más limitada. Ello es consecuencia de sus breves ocupaciones, en comparación con esos otros yacimientos poblacionales. Sin embargo, no significa que no puedan presentar una numerosa superposición estratigráfica, fruto de esas puntuales «reocupaciones» de las fortificaciones, de sus idas y venidas político-militares. El caso del castillo de Viguera-Valdemetria es un buen ejemplo por la importancia geoestratégica del enclave. La continuidad entre esas fases diferentes es lo que aquí se pone en entredicho. Mantener un sistema defensivo como el que hemos planteado es costoso desde el punto de vista social y económico. Si se acota en un período concreto y puntual, es un sistema oneroso pero viable, como lo demuestra la presencia de abundantes fortificaciones. Si pretende mantenerse sin solución de continuidad, es decir, de manera indefinida, ello resultaría inviable e ilógico, por innecesario, en períodos de mayor estabilidad social y económica.

- Se observa un emplazamiento en lugares elevados y dominantes, «cerca» de vías de comunicación.

Estamos viendo que esta variable se aplica al caso de castros y centros fortificados donde residía la autoridad responsable de la red de información. Ahora bien, esos enclaves no siempre tenían por qué ser los puntos más elevados. Ello implica y hace entrar en juego uno de los elementos más relevantes de nuestro discurso. Las pequeñas y simples torres (desde el punto de vista material), pero tan importantes y cruciales desde el punto de vista operativo-funcional-estructural. Sin ellas ese sistema de control territorial se vendría abajo.

$\mathrm{Si}$, como vemos, esos castros no se instalan sistemáticamente en las máximas cotas de visibilidad, sino que se marca para su emplazamiento una distancia adecuada para el control visual de vías de comunicación cercanas, ello nos indica que el factor relevante o determinante no es la máxima visibilidad, que, obviamente, se da en los puntos más altos del territorio. En no pocas ocasiones ello se sacrifica mediante la colocación de una pequeña torre de vigilancia de otros nodos (castros o torres) que, en caso necesario, repliquen y transmitan la información emitida por esos otros nodos de la red. Por vía visual mediante el empleo de fuego de noche, y por el día a través de «ahumadas» (columnas de humo), como aparecen en las fuentes más tardías de los siglos XIII y xIV (Olivé 1990). Y algo interesante que hemos podido comprobar en campo: por vía acústica, los días de niebla, por medio de trompas cerámicas (seguro) y cuernos (probable). dio.

- Adaptación al entorno y antropización del me-

Realizar una fortificación supone una gran inversión inicial, pero sobre todo, visto en perspectiva, un gran coste de mantenimiento. Ello implica que las fortificaciones deban hacerse con el máximo cuidado y esmero. Las fundaciones se hacen con cimientos adecuados; si hay tiempo y recursos y no hay premura por fortificar tal punto ante un hecho concreto. Las técnicas empleadas también serán bien seleccionadas. Aunque algunas fortificaciones vayan a ser ocupadas por un breve espacio temporal, sus defensas tienen que poder aguantar los embates de un posible asedio $o$ ataque.

Ahora bien, en la longue durée, las murallas y torres se caen o desmontan (que es otra manera de caer): indefectiblemente. Y los fosos se rellenan, más temprano que tarde. Siempre. Desde el punto de vista constructivo y de su mantenimiento, una fortificación es una inversión no rentable. Sin embargo, desde el punto de vista social, por su control social y por extensión económico, una fortificación es una inversión muy rentable si cumple su función y está bien realizada, ya que renta pingües beneficios. Y así parece que fue en muchos casos.

La máxima primera y prioritaria de los tratadistas poliorcéticos bizantinos arriba citados es la perfecta adaptación al medio. Las defensas naturales son las mejores. Solo en el caso de que resulten insuficientes, habrá que construir otras nuevas, o supletorias, de origen antrópico. Ello no implica que el medio natural no tenga que adecuarse a las funciones, a los efectivos humanos 
disponibles, a los recursos de materias primas utilizables, etc., para la fortificación que se vaya a construir. Los trabajos de repicados y desmontes de roca en ese proceso de fortificación son, eventualmente, espectaculares para la época. Máxime si tenemos en cuenta los medios de los que disponían y los emplazamientos en los que se encontraban. Las labores de repicado para conseguir la verticalidad en algunos de los cortados de piedra y conseguir así ser inexpugnables por esa zona son en ocasiones titánicas.

Pero ello no nos puede hacer perder de vista que una fortificación puede constituirse como tal solo con sistemas de «defensas naturales». Cortados naturales y desplomes de más de 50-100 metros son más efectivos que cualquier muralla. Que no haya muchas fortificaciones de esas características, sin murallas de ningún tipo, se debe a lo inusual de estos cerros testigo de roca con cortados impresionantes. Pero no por ello hay que pensar que no son fortificaciones. Lo son, pero con murallas naturales, algo extraño si lo planteamos con las ideas y concepciones previas que tenemos al pensar en fortificaciones. Cuando nos dicen que pensemos en el concepto castillo, nos viene a la mente una imagen de una construcción con altas murallas. Y hemos visto que no siempre es así. A veces existen murallas que circundan todo el perímetro. Pero en otras ocasiones, solo una parte, un flanco: el accesible. Y en algunas pocas ocasiones, las más inexpugnables no presentan ninguna muralla. Sencillamente no les hace falta. Son las óptimas desde el punto de vista de construcción y mantenimiento.

Por tanto, podríamos decir sin temor a equivocarnos que existe una potente antropización del medio para la construcción de cualquier fortificación. Lo que ocurre es que no siempre ello tiene que pasar por la realización de potentes murallas (por más que sea la norma habitual). Desde esta perspectiva, la mejor muralla era la que no se construía.

\section{- Sistema constructivo cuidado.}

Pudiera parecer un punto contradictorio con el anterior, pero no lo es. Como hemos dicho, no siempre se tiene que asociar fortificación con murallas. Así, lugares emblemáticos de gran potencia defensiva desde el punto de vista natural (Peña Amaya o castillo de Viguera) no tienen grandes murallas como sería de esperar, vista la importancia que les conceden las fuentes del período tardoantiguo.

Ello no implica que no se haya llevado a cabo un cuidadoso estudio y ejecución de obras en su interior. En muchas de esas construcciones se realizan potentes acciones de extracción de volúme- nes de piedras. No es tanto la adición de volúmenes (presentes en las potentes murallas) como la extracción y realización de tallados y repicados en la roca que potencien los sistemas defensivos naturales: por ejemplo, acentuando la verticalidad en algunos puntos delicados, tallando el acceso en puntos concretos, paseos de ronda, etc.

En el caso de Viguera, por ejemplo, hemos visto que no hay un sistema cuidado de construcción en las murallas, porque no las hay; o, mejor dicho, no las hay de origen antrópico, porque sí las hay naturales (farallones de entre $100 \mathrm{y}$ hasta 120 metros en algunos puntos). Sin embargo, en el interior de la fortificación, en los pocos edificios en los que hemos intervenido todavía, se observan elaboradas técnicas constructivas: opus pseudospicatum, mortero de yeso de calidad óptima para todo el edificio de culto, cúpula de piedra de toba sobre pechinas para el pequeño ábside, cubierta de tégulas e ímbrices con digitaciones en $\mathrm{S}$, o incluso suelo de opus signinum para el pavimento de otro edificio anexo. Materiales todos ellos que fueron acarreados y subidos allí ex profeso, o elaborados in situ, lo que nos indica el interés mostrado por el poder ordenante de ejecutar esas obras.

El segundo punto sobre el que queremos llamar la atención es el de que ese interés mostrado por llevar a cabo un sistema constructivo esmerado pensamos que se da siempre y cuando la elaboración de esa fortificación o sistema de fortificaciones sea concebida como un plan integral de gestión territorial. Planificado y con recursos, se pretende que ese sistema de fortificación tenga una cierta implantación sobre el territorio. Es por ello que se seleccionan con detalle los emplazamientos, los lugares de abastecimiento y acarreo de materias primas, las técnicas de construcción empleadas, la cuidada localización de los accesos, el abastecimiento del agua...

Pero si el proceso de fortificación de un enclave responde a cuestiones coyunturales y precipitadas, como por ejemplo un hecho bélico, se construye ad hoc, con los materiales de los que se dispone, sin técnicas elaboradas, sin tanto esmero en cuestiones básicas como cimentaciones, o durabilidad de los lienzos de los muros (si los hay), etc. A veces simplemente no hay tiempo. Si solo se dispone de unas pocas semanas o días para pertrechar o reacondicionar una fortificación, entonces el resultado no puede ser otro que el que estamos constatando en algunas excavaciones: materialidades muy descuidadas. Las prisas no son buenas consejeras para la ejecución de un plan constructivo esmerado.

Así pues, la constatación de parámetros que indican indefectiblemente una construcción apre- 
surada en los parámetros poliorcéticos de la fortificación sí que denotaría, precisamente, la realización de esas actividades constructivas durante un episodio bélico inminente, tanto en coordenadas espaciales como temporales. Un marcador que, desde nuestro punto de vista, nos parece relevante para poder encuadrar o contextualizar arqueológicamente tal o cual fase, período o actividad de una fortificación concreta.

Por intentar cerrar este apartado conclusivo, a modo de colofón, pensamos que el intento de control social arriba mencionado fue el origen de todo este entramado conceptual y material de la fortificación. Una fortificación que fue selectiva en algunos espacios y lugares concretos de los territorios intervenidos: clausuras, principalmente, con la necesaria colaboración de las torres de vigilancia. Sin ellas, a pesar de su relativa «escasa materialidad» (por ser muy limitada, así como por sus materiales perecederos y menos detectables en ocasiones, con lo que pasan más desapercibidos arqueológicamente), la red para mantener ese sistema de vigilancia y transmisión de información no hubiera podido estar operativa. Gracias a estos pequeños nodos el sistema fue viable.

Este intento de control social fue, en nuestra opinión, la causa última de todos los desvelos de las clases sociales que podían permitirse esa potente inversión y que eran las únicas beneficiarias de ese modelo de gestión territorial: las clases más elevadas, tanto la propia corte regia en algunos casos como las aristocracias potentes que pudieron desarrollarlas y mantenerlas. Los costes económicos y logísticos eran elevados. Ellas sí se lo podían permitir (medios) y querían hacerlo (voluntad). Querer hacer algo y poder hacerlo se juntaron en un único actor: las aristocracias.

El beneficio de la construcción de una fortificación no radica en un aumento del rendimiento productivo agrícola ni implica que se vaya a producir tal incremento. Con la construcción de esos complejos de fortificación no se aumentaba la producción de las cosechas. Si se vigila no se produce, y si se produce no se vigila. El punto de visión es distinto. O se mira al surco o al horizonte, pero no se pueden hacer ambas cosas a la vez.

El tema del control de pastos como origen de estas fortificaciones, como en ocasiones se ha sugerido, tampoco lo concebimos. Hay que realizar inversiones logísticas de primer orden a causa del tremendo coste de mantenimiento de personal en esas zonas de vigilancia. Hay que pertrechar y alimentar a esas personas. Para vigilar el ganado ya estaban los pastores, sin necesidad de realizar esas fuertes inversiones logísticas y económicas.

Sobre el cliché de concebir esas fortificaciones como lugares de defensa y refugio para la pobla- ción, es un tema ya tratado sobre el que nos hemos detenido en otros lugares con mayor detalle (Tejado 2018b, 106 y ss.; en prensa). Tampoco lo contemplamos como exponemos en esos otros trabajos, por varios motivos: agua insuficiente para un grupo notable de personas, espacio muy limitado en la mayoría de ellos para que puedan caber ni siquiera físicamente, o por lo tremendamente agreste y escarpado del terreno, no apto para un desarrollo vital adecuado para ese supuesto grupo grande de personas.

Durante períodos de sitio o asedio de una fortificación poblacional con gran número de personas en el interior de las murallas (generalmente una ciudad), se constata por las fuentes que, en ocasiones, no hubo ningún rubor en expulsar fuera de la ciudad a un gran número de ellas para evitar que consumieran los recursos y alimentos que había en su interior (Petersen 2013, 196-197). Se dejaba así a las personas a su suerte. No parece que sea un comportamiento de defensa, altruista y humanitario, como en muchas ocasiones, todavía a día de hoy, se pretende mostrar para la función de este tipo de fortificaciones militares como refugio poblacional ante episodios bélicos.

Por todo ello, reiteramos que seguimos considerando y argumentando que muchos de estos enclaves no pudieron ser erigidos por grupos organizados de campesinos productores, como parece que se continúa apuntando en algunas recientes aportaciones. En derecho existe una máxima que reza así: Cui prodest scelus, is fecit. Parece que fue el hispano Séneca quien la dijo o reprodujo, y que vendría a decir algo así como que A quien aprovecha el crimen, ese es su autor. Si, desde el punto de vista de la gestión territorial, a quien beneficia su control y el de sus recursos y excedentes es a quien los gestiona (no a quien los produce, que es algo muy distinto), entonces tenemos que indicar que las fuertes inversiones en la construcción de redes de fortificación (castros, torres, puentes $\mathrm{y}$ potentes retalles de roca para pasos obligados, etc.) y su mantenimiento temporal solo podían tener un único beneficiario: las poderosas aristocracias, incluida aquí la corte regia. Esas aristocracias estarían interesadas en su realización por los beneficios socioeconómicos que su construcción comportaría y que materialmente solo ellas podrían llevar a cabo, vistas las potentes inversiones que suponían.

\section{Bibliografía}

ÁlVAREZ, I. 2008: Cambios y alianzas. La política regia en la frontera del Ebro en el reinado de Alfonso VIII de Castilla, 1158-1214, CSIC, Madrid. 
BAKer, J.; Brookes, S.; ReYNolds, A. 2013: Landscapes of Defence in Early Medieval Europe, Brepols, Turnhout.

Bishop, M. C.; Coulston, J. C. N. 2006: Roman military equipment. From the Punic Wars to the Fall of Rome, Oxbow, Oxford.

Brogiolo, G. P.; Gelichi, S. 1996: Nuove ricerche sui castelli altomedievali in Italia settentrionale, All'Insegna del Giglio, Florencia.

Caballero, L. 2015: «Un conjunto constructivo altomedieval. Quintanilla de Las Viñas y las iglesias con cúpulas sobre pechinas de piedra toba de las provincias de Álava, La Rioja y Burgos», Arqueología de la Arquitectura, 12, Madrid-Vitoria, <http://dx.doi.org/10.3989/arq. arqt.2015.011>.

Cegarra, J. 2013: Haro en el contexto de la Historia de España. Los documentos del Archivo Histórico (1099-1700), Gobierno de La Rioja, Haro.

Christie, N.; Herold, H. (eds.) 2016: Fortified settlements in Early Medieval Europe: Defended Communities of the 8th-10th Centuries, Oxbow, Oxford.

Dagron, G.; Mihăescu, H. 2011: Le Traité sur la guérilla de l'empereur Nicéphore Phocas, CNRS Éditions, París.

Dennis, G. T. 1984: Maurice's Strategikon. Handbook of Byzantine Military Strategy, traducido por George T. Dennis, University of Pennsylvania Press, Filadelfia.

- 1985: Three Byzantine Military Treatises, Dumbarton Oaks, Washington.

- 2010: The Taktika of Leo VI, Dumbarton Oaks, Washington.

Dieu, L. 1999: "Cors et trompes en terre cuite», Archéologie, 354, 48-55.

- 2009: "Les trompes gothiques», APEMUTAM, disponible en <http://www.apemutam.org/ apemutamfree/trompes.pdf $>$ [Consulta: 22 diciembre 2014].

Esmonde, S. 2013: The Roman West, AD 200-500. An Archaeological Study, Cambridge University Press, Cambridge.

EsPinosa, U. 2011: La iglesia de Las Tapias y los monasterios tardoantiguos de Albelda de Iregua y Nalda (La Rioja), Servicio de Publicaciones de la Universidad de La Rioja, Logroño.

GARCíA, J.; TEJADO, J. M. ${ }^{\text {a }}$ 2017: «Trompa cerámica militar (s. XIII) de Castro Bilibio (Haro, La Rioja): Análisis arqueométricos y contexto arqueológico», en: XII Congreso Ibérico de Arqueometría, Burgos.

García de CÁndamo, L. 1996: Viña Tondonia. Biografía del Rioja supremo, Madrid.

GARLAN, Y. 1974: «Recherches de poliorcétique grecque», Bibliothèques de l’École française
d'Athènes et de Rome, Série Athènes, 223, De Boccard, París.

LoREnZo, J. 2017: "Informe sobre Viguera y su entorno en la documentación escrita. Recopilación de los registros escritos con mención a Viguera (ss. VIII-XIII)», Dirección General de Cultura del Gobierno de La Rioja, inédito.

Martí, R. (ed.) 2008: Fars de l'Islam. Antigues alimares d'al-Andalus, Ediciones EDAR, Barcelona.

Olcoz, S. 2009: "Pampaneto, el monasterio de San Fructuoso y su influencia en la organización del valle riojano del río Leza, bajo la monarquía pamplonesa (siglos x y xI)», Espacio, Tiempo y Forma. Serie III, Historia Medieval, 22, 229-254.

- 2010: «Fortún Ochoaz, las tenencias pamplonesas de Viguera, Cantabria, Meltria y el mítico origen del señorío de Cameros», Berceo, 158, Logroño, 97-158.

Olivé, S. 1990: Historia de la telegrafía óptica en España, Madrid.

Padilla, J. I.; RuedA, K. A. 2010: «El sonido de la guerra: Las trompas de la fortaleza medieval de Ausa (Zaldibia, Gipuzkoa)», Acta Historica et Archaeologica Mediaevalia, 30, 453-485.

Pascual, M. ${ }^{\text {a }}$ P. 1994: «Puente Caneco y Castillo de Viguera (La Rioja)», en: IV Semana de Estudios Medievales de Nájera, 341-350.

Petersen, L. I. R. 2013: Siege Warfare and Military Organization in the Successor States (400800 AD): Byzantium, the West and Islam, Brill, Leiden-Boston.

Pringle, D. 1981: The Defence of Byzantine Africa from Justinian to the Arab Conquest. An account of the military history and archaeology of the African provinces in the sixth and seventh centuries, BAR International Series, 99, Oxford.

Quirós, J. A. 2016: «Early and High Medieval 'Incastellamento' in Northern Iberia: Fortified Settlements in the Basque Country and Upper Ebro Valley (9th-12th Centuries)», en: CHRIsTIE, N.; Herold, H. Fortified settlements in Early Medieval Europe: Defended Communities of the 8th-10th Centuries, Oxbow, Oxford, 192-204.

Quirós, J. A.; TEJADO, J. M. ${ }^{\text {a } 2012: ~ L o s ~ c a s t i l l o s ~ a l t o-~}$ medievales en el noroeste de la Península Ibérica, Servicio de Publicaciones de la UPV/EHU, Bilbao.

RodRíguez DE LAMA, I. 1975: «La tenencia de Meltria en el siglo XI», Berceo, 88, Logroño, 105108.

SÁNchez, L. 2007: Técnicas constructivas medievales. Nuevos documentos arqueológicos para el estudio de la Alta Edad Media en Álava, Servicio de Publicaciones del Gobierno Vasco, Vitoria. 
SHELdon, R. M. 2005: Intelligence Activities in Ancient Rome. Trust in the Gods, but verify, Routledge, Londres - Nueva York.

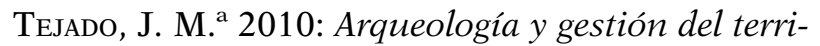
torio en el alto valle del Iregua: el castro de «El Castillo de los Monjes» (Lumbreras, La Rioja), Servicio de Publicaciones de la Universidad de La Rioja, <https:/dialnet.unirioja.es/servlet/ tesis?codigo=21890 $>$ [Consulta: 5 junio 2017].

- 2011: "Castros militares altomedievales en el alto Valle del Iregua (La Rioja, España): Una realidad 'poco común'», Archeologia Medievale, XXXVIII, Florencia, 137-181.

- 2012: «¿A modo de conclusiones... o mejor, agenda de trabajo?», en: Quirós J. A.; TEJADo, J. M. ${ }^{a}$ (eds.). Los castillos altomedievales en el noroeste de la Península Ibérica, Servicio de Publicaciones de la UPV/EHU, Bilbao, 309-320.

- 2014: "Comparación entre los espacios del valle del Ebro y la Meseta: La Rioja y Burgos en la Antigüedad Tardía», en: Catalán, R.; Fuentes, P.; Sastre, J. C. (eds.). Las fortificaciones en la tardoantigüedad: Élites y articulación del territorio (siglos V-VIII d.C.), La Ergástula, Madrid, 95-120.

- 2016: «Cerámica altomedieval en La Rioja: un estado de la cuestión», en: VigiL, A.; Quirós, J. A. (coords.). La cerámica de la Alta Edad Media en el cuadrante noroeste de la Península Ibérica (siglos $V$-X). Sistema de producción, mecanismos de distribución y patrones de consumo, Servicio de Publicaciones de la UPV/EHU, Bilbao, 315338.
- (coord.) 2018a: Vislumbrando la Tardoantigüedad. Una mirada desde la Arqueología, Instituto de Estudios Riojanos, Logroño.

- 2018b: «Fortificaciones militares en el alto valle del Ebro: tres ejemplos de herramientas de control territorial y social», en: TEJADO, J. M. ${ }^{\mathrm{a}}$. Vislumbrando la Tardoantigüedad: Una mirada desde la Arqueología, Instituto de Estudios Riojanos, Logroño, 73-113.

- [en prensa]: «Fortificaciones en La Rioja con discontinuidad (variabilidad) en técnicas constructivas y continuidad en formas de control territorial: Hacia una lectura integrada de ambos registros", Agira, Ix (Arqueología Medieval. La fortaleza: territorio y arquitectura en el valle del Ebro).

Unzueta, M. 2015: «Necrópolis de San Martín de Finaga», Arkeiokuska, 14, Vitoria, 168-172.

UsunÁRIZ, J. M. 2006: Historia breve de Navarra, Sílex, Madrid.

Utrero, M. ${ }^{\text {a }}$ A.; SAstre, I. 2012: «Reutilizando materiales en las construcciones de los siglos VIIx. ¿Una posibilidad o una necesidad?», Anales de Historia del Arte, 22, núm. especial (II), 309323.

Venegas, C. 1994: Pintura mural en los templos medievales de la Llanada Occidental Alavesa, Servicio de Publicaciones de la Universidad del País Vasco, Bilbao.

Wicкham, C. 2008: Una nueva historia de la Alta Edad Media, Crítica, Barcelona.

Woolliscroft, D. 2001: Roman military signalling, Tempus Publishing Ltd., Stroud. 


\title{
FORTIFICACIONES TARDOANTIGUAS EN LA FRONTERA ENTRE SUEVOS Y VISIGODOS
}

José Carlos Sastre Blanco ${ }^{1}$

\section{Resumen}

Las investigaciones arqueológicas han puesto de manifiesto una importante red de poblados fortificados situados en torno al valle del río Esla. Estos asentamientos van a permitir a sus pobladores disponer de un control del territorio y de los recursos circundantes, ofreciendo unas zonas de protección ante las posibles agresiones o amenazas. Muchos de estos asentamientos se localizan junto a vados en el río, que permiten establecer rutas de comunicación y rutas comerciales, tal y como evidencian los restos arqueológicos.

\begin{abstract}
Archaeological research has revealed an important network of fortified villages located around the River Esla valley. These settlements would have allowed the inhabitants to control the territory and surrounding resources, as well as offering protection zones against possible threats or aggressions. Many of these settlements are situated near fords in the river, which allowed communications and trade routes to be established, as evidenced by the archaeological remains.
\end{abstract}




\section{Introducción}

En la denominada, desde un punto de vista histórico, como la frontera entre los pueblos suevo y visigodo, especialmente entre el valle del río Esla y el río Sabor, nos encontramos con una serie de fortificaciones que comparten determinadas características, desde su origen a finales del siglo v o principios del vi d. C.: los sistemas defensivos, los espacios habitacionales, los materiales arqueológicos documentados hasta la fecha, e incluso las motivaciones que llevaron a sus pobladores a la creación de estos nuevos centros de poder.

Las últimas investigaciones arqueológicas que se han llevado a cabo en algunos yacimientos como El Castillón (Santa Eulalia de Tábara, Zamora) o la Quinta de Crestelos (Mogadouro, Portugal), unidas a la información existente, permiten tener una visión más amplia sobre este periodo tardoantiguo en esta zona y conocer cómo los hechos históricos y políticos afectaron a estos poblados, así como la configuración de los mismos en relación con los dos grandes reinos que ocupaban en aquel momento la península ibérica, y muy especialmente en lo que se refiere a la economía y el comercio en esta zona.

\section{El Castillón: un poblado fortificado en la frontera entre suevos $y$ visigodos}

Uno de los principales yacimientos, situados en la frontera suevo-visigoda, en los cuales se han llevado a cabo excavaciones arqueológicas es el de El Castillón (Santa Eulalia de Tábara, Zamora), al encontrarse emplazado en un importante cerro localizado en el estrechamiento que el río Esla sufre a su paso por la zona conocida como El Piélago, aguas abajo del Puente Quintos. Esta ubicación estratégica, unida a lo escarpado de sus pendientes en los sectores norte y sur, así como el imponente farallón rocoso que se localiza al este, le dota de un gran carácter defensivo. La zona más accesible se encontraría en el lado oeste, donde se encuentran situados los elementos defensivos más importantes.

Consta de una muralla perimetral que cierra la totalidad del poblado a excepción del sector este, donde se encuentra el mencionado farallón rocoso. Está constituida por bloques de cuarcitas trabajadas, de formas irregulares y generalmente de gran tamaño. Estos sillares se encuentran trabados entre sí por una arcilla rojiza muy compacta. Esta muralla presenta una mayor anchura en su zona oeste, de entre 4 y $5 \mathrm{~m}$, donde el acceso al castro es más fácil, y donde, lógicamente, se encuentra mejor protegido. La altura máxima conservada es de unos $8 \mathrm{~m}$ de altura en la esquina que la muralla posee en el sector suroeste.

La construcción de la muralla se produciría a finales del siglo v d. C., y perduraría hasta el vi d. C., con alguna reparación puntual, al menos localizada en el sector norte, sin que se pueda determinar su perduración más allá de este último momento, que iría en concordancia con los niveles identificados en la zona habitacional de este poblado.

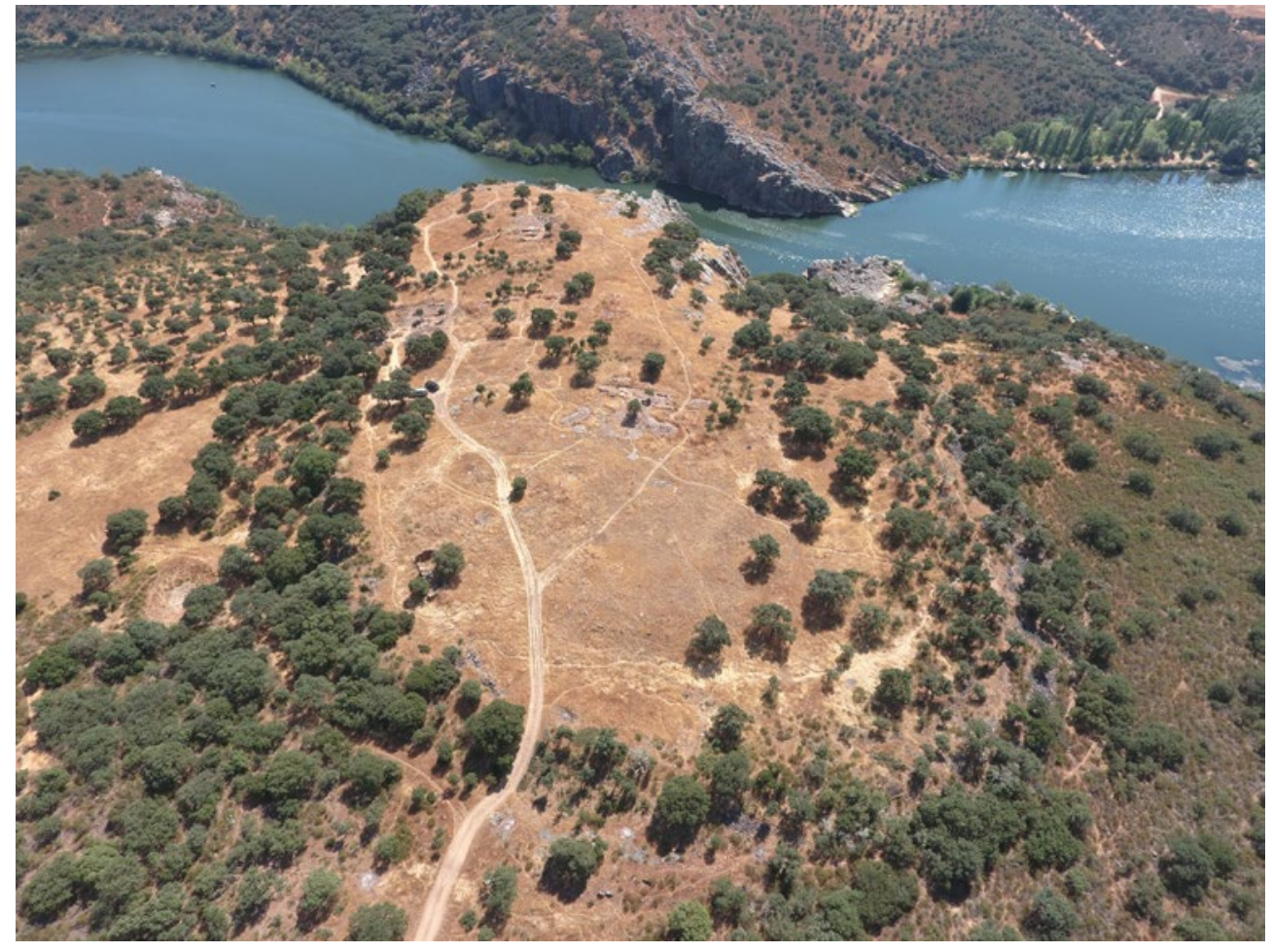

FiguRA 1. Vista aérea del yacimiento de El Castillón (Santa Eulalia de Tábara, Zamora). 
Existe una segunda línea de muralla, que se extiende paralela a la primera, desde el acceso norte, en dirección hacia donde la muralla principal se une al farallón rocoso en el sur.

Por lo que se ha podido documentar en las prospecciones realizadas, no parecen apreciarse torres en ningún punto de la muralla, al contrario de lo que ocurre en otros poblados con características semejantes, como es el caso del Cerro del Castillo de Bernardos (Segovia), en el cual se conservan varias torres circulares correspondientes al siglo v d. C. (Barrio et al. 1999, 329-340).

En la zona oeste se identifican, en la zona interna, una serie de estructuras habitacionales que se adosan a la muralla principal, de las cuales se ha intervenido en una de ellas, definida como una posible casamata destinada a albergar cualquier tipo de productos, como cereales o incluso ganado. Dada la ausencia de armamento en esta zona, debemos desechar, por el momento, su posible funcionalidad estrictamente de casamata dedicada a albergar tropas militares.

Las excavaciones efectuadas hasta la fecha han puesto de manifiesto la presencia de dos sectores fundamentales, que nos proporcionan una información de gran valor sobre la ocupación tardoantigua de este poblado, y las gentes que lo ocuparon.



FIgURA 2. Muralla norte del poblado de El Castillón.

\subsection{Sector metalúrgico}

En la denominada zona metalúrgica se ha intervenido sobre tres grandes estructuras ovaladas, próximas a la muralla, que se han podido identificar como hornos metalúrgicos destinados a la reducción de mineral de hierro. Presentan paredes convergentes de grandes bloques de cuarcitas y adobes en su parte más alta. Contarían además con una pequeña entrada, jalonada por dos grandes bloques verticales de cuarcita.
Denotan una prolongada utilización de estas estructuras, y fueron recuperados más de $90 \mathrm{~kg}$ de escorias de hierro, así como varios restos de mineral de hierro que no habían sido reducidos, y sobre los cuales pudimos realizar algunos análisis metalúrgicos.

Los análisis que se han llevado a cabo muestran como el mineral de hierro recogido en la zona metalúrgica de El Castillón y el mineral de hierro procedente de la mencionada Sierra de la Culebra poseen unas mismas características, lo que demostraría que este mineral procedería de esta zona montañosa de Zamora (Sastre, Criado y Fuentes 2011, 486-487).

Estos datos permiten confirmar la existencia de un abastecimiento de este mineral durante los siglos v-vi d. C., cuando estarían en funcionamiento los hornos metalúrgicos, desde esta región montañosa, especialmente rica en hierro, hacia el poblado de El Castillón.

En lo referente a la actividad metalúrgica del hierro que puede documentarse en otros enclaves con contextos y cronologías similares a los que encontramos en El Castillón, uno de los más cercanos se ubica en el yacimiento de La Legoriza (San Martín del Castañar), donde se localiza un poblado emplazado en la zona montañosa del sur de Salamanca (Gómez 2006, 217-236). En en Sabugal Velho (Sabugal, Guarda), se localizó una estructura metalúrgica semejante a las que identificamos en el poblado de El Castillón (Ósorio da Silva 2002, 791-794). En el caso del yacimiento de Tintinolho (Guarda), se identifica en su parte superior una amplia concentración de escorias de hierro, que parecen indicar la presencia de un espacio destinado a una determinada actividad metalúrgica (Tente y Martín 2012, 59-62). En la zona gallega nos encontramos con el caso del yacimiento de Penadominga (Quiroga, Lugo), identificado como un castro minero, donde se han registrado diversos restos cerámicos, correspondientes a TSHT, que lo situarían en un mismo momento cronocultural al que encontramos en El Castillón (López 2002, 84; Novo 2000; Sánchez 2012, 34).

\section{2. Área habitacional}

En lo referente al área habitacional, se han documentado dos grandes estructuras: por una parte, la denominada vivienda central, que estaría formada por un total de ocho habitaciones, con diferentes funciones y características, pero que guardan particularidades comunes, lo que otorga a todo el conjunto una gran homogeneidad.

La fase más antigua es la que se correspondería con la edificación original de todo el complejo habitacional, de la segunda mitad del siglo v d. C. 
Esta fase concluye con la destrucción de todo el complejo habitacional por el incendio que se identifica en toda la vivienda, lo que provoca su total destrucción.

La función principal de este complejo habitacional, en este periodo, se vincularía con el almacenamiento de productos alimentarios, especialmente aquellos faunísticos, de los cuales se han podido recuperar una gran cantidad correspondientes a ovicaprinos y aves, y en menor medida a suidos, cérvidos, roedores, vacunos, e incluso malacofauna e ictiofauna, lo que pone de manifiesto la importancia del almacenamiento de estos productos para la alimentación de los habitantes del poblado.

Se documentan numerosos restos de cerámicas de almacenamiento, situadas en estas habitaciones, y que estarían destinadas a albergar diversos productos; incluso, algunas de ellas, se podrían haber destinado al almacenamiento de restos faunísticos u otro tipo de productos.

Después del incendio y la destrucción que se produce en el complejo habitacional central, se pone fin a la ocupación correspondiente a la segunda mitad del siglo v d. C. Y, poco tiempo después, se iniciaría una nueva fase de ocupación en este sector, ya dentro de la primera mitad del siglo vI d. C., que provoca un cambio radical en esta zona.

Es en este momento de reestructuración de los espacios anteriores cuando se produce el enterramiento del ovicáprido en la esquina suroeste de la estancia 02, cubierta por el nuevo nivel de pavimento de lajas de pizarra. Sin duda, este enterramiento responde a algún tipo de ritual cuyo objetivo desconocemos, pero sí que es muy significativo cuándo se produce, justo después de que acontezca el mencionado incendio, y justo en el momento de crear el nuevo espacio funcional.

Comprobamos como en esta nueva fase de utilización de este sector se ha perdido totalmente el



FIgURA 3. Vista general de la habitación de almacenamiento de fauna de la estructura habitacional localizada en el centro del poblado. carácter de lugar de almacenamiento, para pasar a convertirse en una zona vinculada a la producción de estos hornos.

Por otra parte, en la vivienda sur se encuentra una estructura con características muy semejantes a la mencionada anteriormente, para este momento de edificación, durante la primera ocupación del poblado, correspondiente a finales del siglo v, comienzos del vi d. C.

En esta fase se ha localizado una cerámica de almacenamiento situada in situ en una fosa excavada en el nivel geológico, así como la presencia de una punta de flecha y de diversos fragmentos de TSHT y cerámicas estampilladas. Es en este momento cuando se produce una reformulación de todo este espacio, con la creación de un enlosado que cubriría la totalidad de esta habitación, y su zona este se adapta con un nuevo muro lateral, al cual se adosa un banco corrido en la esquina noreste, sobre la que se situaba una gran cantidad de cerámicas in situ, alguna de las cuales contenía abundantes semillas de trigo común (Triticum aestivum-durum).

\subsection{Paralelos de las producciones cerámicas tardoantiguas}

Entre los principales materiales que tenemos para poder caracterizar estos yacimientos, nos encontramos con las producciones de TSHT y cerámicas grises estampilladas, las cuales son especialmente numerosas en el yacimiento de El Castillón (224 ejemplares).

Los trabajos de investigación han permitido diferenciar entre las producciones cerámicas de los siglos v y vi d. C. Por una parte, para el primer momento de ocupación sobresale la presencia de las TSHT y de las cerámicas grises estampilladas, que son muy numerosas respecto a lo que ocurre en otros poblados de características similares, donde las producciones de este tipo aparecen en menor cantidad.

De entre esta vajilla de mesa destaca el porcentaje de la cerámica gris estampillada, de la que se han recuperado un total de 110 ejemplares hasta la fecha, lo que supone un número muy elevado, elementos a los que hay que otorgar una destacada importancia. Presentan una gran variedad de motivos estampillados: círculos, cenefas, palmetas, cruciformes, etc., que en ocasiones se representan en decoraciones muy barrocas.

En lo que se refiere a la cerámica de cocina, entre las formas documentadas abundan las ollas y los cuencos, que presentan un amplio repertorio y variedad tipológica. En cuanto a los motivos decorativos, abundan las incisiones de ondulaciones y bandas horizontales de formas sencillas. Predo- 
minan las pastas no decantadas, con desgrasantes de cuarcita y mica plateada de gran tamaño, con producciones elaboradas a torno y cocción reductora, de características semejantes a las de la siguiente fase.

Las cerámicas de almacenamiento son muy numerosas, pero en proporciones menores que las de los dos grupos anteriores. Por lo general, se trata de dolia de gran tamaño, de formas abiertas, que presentan acabados groseros con desgrasantes de cuarcita y mica plateada de gran tamaño.

Por otra parte, en lo referente a las producciones cerámicas del siglo vi d. C., predominan las cerámicas de almacenamiento y cocina. Todo este repertorio presenta grandes diferencias con respecto a las cerámicas adscritas al siglo v d. C., sobre todo en lo que respecta a la ausencia y sustitución de las producciones depuradas destinadas al servicio de mesa, que representan un alto porcentaje durante el anterior periodo.

Es notorio como un conjunto de piezas que era especialmente numeroso y representativo de la fase anterior desapareció por completo durante el siglo vi, tanto las sigillatas (en sus dos formatos, anaranjado y gris) como la cerámica estampillada depurada de mesa, que contaba con un amplio repertorio formal.

Por lo que respecta a las producciones de cocina y almacenamiento, el panorama general es de cierta continuidad con los rasgos básicos que caracterizaban a las de la fase del siglo $\mathrm{v}$, si bien se ven ciertas diferencias en cuanto a la morfología presente. Continúan empleándose de forma mayoritaria piezas levantadas a torno rápido, con cocciones reductoras y pastas con desgrasantes de mica plateada, de tamaño variable, pero se constata un incremento importante de las producciones a torno lento y mano.

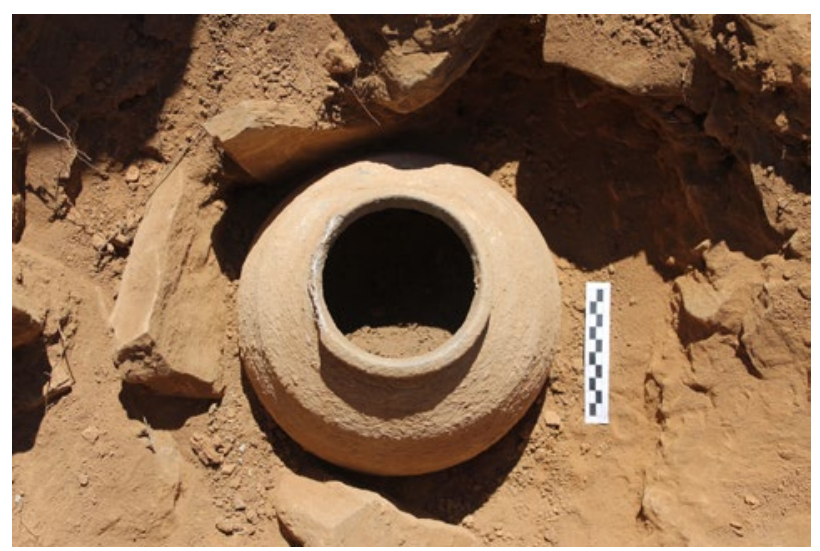

Figura 4. Cerámica de almacenamiento localizada in situ en el poblado de El Castillón, correspondiente a la fase de fundación del poblado tardoantiguo.
Por último, un aspecto destacado en esta fase es la desaparición de la cerámica estampillada, pero esto no supone una ausencia de la decoración mediante motivos estampillados, ya que continuará presente, de forma recurrente, en otro tipo de cerámicas, como ollas, y sobre todo en la cerámica de almacenamiento, tanto en el cuerpo de las piezas como sobre el labio de las mismas.

Quizás estos cambios puedan deberse a dos factores: por una parte, la desaparición de un determinado grupo social demandante de este tipo de producciones, lo cual explicaría la total ausencia de estos elementos durante el siglo vi; mientras que, por otra parte, puede explicarse desde un punto de vista económico, debido a un cambio en las rutas comerciales que pudiera ocasionar esta modificación en los productos que llegarían hasta este enclave, o incluso propiciando un mayor autoabastecimiento de los mismos, en detrimento de las importaciones.

En relación con estos conjuntos cerámicos, contamos con paralelos cercanos en yacimientos zamoranos como los de El Cementerio - Camino Pedrosa y Las Escorralizas - Camino de Quiñones (Morales de Toro), Valorio (Villafáfila), El Tesoro - La Corralina (Castroverde de Campos) (Bragado 1994, 11-95) o la necrópolis del Prado de la Rinconada (Vadillo de la Guareña), la propia capital zamorana (Juan 2012, 365-372), y muy especialmente las producciones procedentes del cercano poblado del Cristo de San Esteban (Muelas del Pan, Zamora) (Domínguez y Nuño 2002, 105-120; Larrén et al. 2003, 279-281).

Existe una conexión, en cuanto a las producciones cerámicas, con otros yacimientos, como es el caso de El Pelambre (Villaornate, León), en lo que a los materiales cerámicos se refiere, ya que nos encontramos con elementos cerámicos semejantes en uno y otro lugar en cuanto a formas, tipos, decoraciones, tratamientos, acabados, etc. Especialmente, identificamos formas totalmente similares en lo que se refiere a los grandes contenedores, ollas, cuencos, copas, entre las que destaca la presencia de cerámicas facetadas similares a las que localizamos en nuestro yacimiento, a las cuales se ha hecho referencia con anterioridad (Pérez y González 2010, 328, fig. 16).

En otras zonas del interior de Portugal, más cercanas a El Castillón, encontramos yacimientos muy significativos, como es el de Tintinolho (Guarda), que depararon un importante lote de cerámica estampillada y cerámica común bruñida (Tente y Martín 2012, 64-66). Un grupo de cerámicas estampilladas muy sobresaliente es el que actualmente está siendo excavado en la zona de Crestelos (Meirinhos, Mogadouro), de donde procede un fragmento cerámico muy semejante 
a nuestras cerámicas, con motivos a base de círculos concéntricos y semicírculos puntillados que engloban un motivo cruciforme (Pereira, Sastre et al. 2014, 277-289; 2015, 161-180; Sastre, Fuentes et al. 2015, 161-180; Delgado et al. 2014, 413-438).

\section{Poblados fortificados}

\subsection{Poblados fortificados tardoantiguos durante los siglos v-VII d. C.}

Las fuentes escritas mencionan la gran importancia de la presencia de estos castra y castella durante los siglos V-VII d. C. (Zeumer 1902, IX, 2, 6; Isla 2001, 9-19). Contamos con la referencia que Hidacio realiza de los castella tutiora, en los que se refugiaron los habitantes del mundo rural ante los ataques suevos a inicios del siglo v d. C. Sin embargo, en opinión de Sánchez Pardo (2012), un buen número de los casos atribuidos a la inestabilidad o búsqueda de refugio corresponderían a la continuidad o expansión de una estructura de poblamiento y explotación del entorno. Estos castros no tendrían un papel de refugio, sino que se trataría de un nuevo uso del contexto socioeconómico del mundo rural, de estos antiguos recintos, como áreas de trabajo (metalurgia, talleres cerámicos, minería, etc.) (Sánchez 2012, 18-58), como parece que sucede con el caso de El Castillón, aunque con ciertos matices.

En las zonas del valle del Duero y la Meseta, parece que este fenómeno afectaría en mayor medida a aquellas zonas donde se produjo una mayor concentración del mundo urbano y una desintegración de sus territorios, lo que reflejaría una profunda reorganización con cuadros de élites militarizadas (Sánchez 2012, 18-58).

Estos asentamientos fortificados se vienen interpretando como centros de articulación de carácter local que se afianzan sobre un territorio tras la desarticulación del poder estatal (Martín 2012, 31-63) y que pueden ser coetáneos dentro de la organización de las grandes villae, que responderían a una estructuración económica muy distinta. Pero mientras que estas villae desaparecen a inicios del vi d. C., los asentamientos fortificados en altura se mantienen como los principales elementos de ordenación del territorio, afianzando su control y convirtiéndose en los protagonistas de las nuevas estrategias económicas (Fernández 2009, 149-165).

\subsection{Poblados fortificados en altura en la frontera suevo-visigoda}

Todos los asentamientos que se sitúan en la hipotética frontera suevo-visigoda presentan rasgos que indican una cierta función militar en el momento en que el espacio es escenario de disputa entre los reinos suevo y visigodo. El carácter defensivo de los asentamientos se infiere de la presencia de recintos defensivos en todos los casos referidos. En casos como los de Castro Ventosa y el Cerro del Castillo, así como en El Castillón, es además llamativa la homogeneidad que presenta la técnica constructiva utilizada en las murallas. El Cristo de San Esteban presenta una muralla construida con una técnica menos cuidada; uno de sus rasgos característicos es la reutilización de piezas arquitectónicas, epígrafes y esculturas de época romana, en una forma que indica un cierto apresuramiento constructivo. El Castro de Tintinolho presenta una estructura de muralla formada por varios recintos jerarquizados, pero en cambio no incluyen doble paramento relleno con tierra ni cubos de defensa (Ariño y Díaz 2014, 186187; Sastre y Catalán 2012, 193-212).

Martín (2008) se centra en el papel que juegan los poblados de altura en la ordenación del territorio rural de la cuenca del Duero, con especial énfasis en la situación de estos lugares en relación con la caracterización del paisaje de buena parte de esta región desde el siglo iv d. C. Se trataría de un proceso muy complejo y heterogéneo en el que se mezclarían iniciativas y formas diversas. Para ello se centra en dos aspectos fundamentales: por una parte, la información que proporcionan las fuentes escritas, con la referencia de Hidacio sobre la resistencia de los habitantes de Gallaecia, que permanecerían protegidos en los castella tutiora, frente a los suevos; y por otra parte, la información que proporciona el propio registro arqueológico (Martín 2008, 230-231; Vigil-Escalera 2009, 107-136).

De esta forma, en la provincia de Zamora el número de castros, con características semejan-



Figura 5. Yacimiento de El Castillón - Castilcabrero (Riego del Camino, Zamora), localizado en la orilla del río Esla. 
tes a las de El Castillón, en cuanto a su modelo de poblamiento y ubicación, es muy abundante, especialmente en las zonas más montañosas del noroeste, donde encontramos numerosos casos en los que estos lugares reocupan durante este periodo antiguos poblados protohistóricos, como son el Castro de los Frenos (Nuez de Aliste), el Cerro del Castillo (Almaraz de Duero), la Dehesa de Morales - Brigecio (Fuentes de Ropel), El Castro (San Pedro de la Viña), la Virgen de la Encina (Abraveses de Tera), El Castillón (Riego del Camino), El Castrico (Abejera) o Castrotorafe (San Cebrián de Castro), entre otros. Estos castros se identifican, sobre todo, por la presencia de TSHT estampada cuya cronología abarcaría los siglos v y vi d. C. (Martín 2008, 230-231; Sastre y Catalán 2012, 193-212).

Uno de los principales yacimientos en los cuales se han llevado a cabo excavaciones arqueológicas es el Cristo de San Esteban (Muelas del Pan, Zamora), cercano a El Castillón. Se trata de un castellum situado sobre un espigón que se levanta por encima del nivel de las aguas del río Esla, junto a un antiguo vado, bien defendido por los desniveles naturales excepto en el sur y el sureste, por donde es fácilmente accesible (Nuño 2006; Domínguez y Nuño 2002).

Se ha podido documentar un poblado tardoantiguo, datado entre finales del siglo Iv o inicios del v y fines del siglo vi o principios del vII. Para Nuño (2006), esa primera ocupación «un tanto precaria» datada a fines del siglo IV o comienzos del v d. C. quedaba testimoniada "por una especie de fuegos de campamento", en torno a la cual se levanta la monumental pero irregular muralla que caracteriza a este poblado. Según sus investigadores, este lugar habría operado como un castellum de control en la frontera suevo-visigoda (Nuño 2006, 173; Domínguez y Nuño 2002, 105-120).

En este enclave se ha localizado un conjunto armamentístico, el cual se reduce a tres puntas de flecha de tipología alana, una moharra u hoja de lanza y dos dudosos dardos, además de cinco cuchillos que difícilmente pueden ser asignados como armas. Uno de estos elementos se correspondería con un cuchillo tipo Simancas, que no podría considerarse como un arma, pero sí como un elemento perteneciente al ajuar militar (Domínguez y Nuño 2002, 109-112).

En el caso de El Castillón, el número de elementos bélicos puede considerarse escaso, a excepción de tres puntas de flecha que podrían haber tenido un carácter bélico de forma puntual y una pequeña punta de jabalina arponada de hierro. Si bien las características morfológicas y funcionales de estos objetos los asociarían con las actividades cinegéticas, perfectamente identifica- das en el poblado de El Castillón, no se puede desdeñar su utilización, puntual, como un elemento bélico (Sastre y Catalán 2012, 193-212).

Similares características, aunque con peculiaridades, se pueden atribuir a Castro Ventosa, situado en la actual Cacabelos y en las inmediaciones de la civitas de Bergidum Flavium, que posee una importante ocupación en los siglos iv y v (Balboa, Díaz y Fernández 2003).

En la zona portuguesa de Guarda encontramos el yacimiento de Tintinolho, el cual se localiza en un pequeño cabezo que domina el valle del Mondego y todo el paisaje envolvente. Posee una extensión inferior a una hectárea, y cuenta con hasta tres líneas de muralla. El inicio de la ocupación tardoantigua de este poblado se ha fechado en torno a finales del siglo Iv o principios del siglo $\mathrm{v}$ d. C. Las excavaciones arqueológicas depararon un importante conjunto de cerámicas estampilladas y cerámica común bruñida, similar a las que se puede identificar en el caso de El Castillón. Las investigaciones efectuadas en este lugar documentaron la presencia de varias estructuras de plantas circulares y rectangulares (Tente y Martín 2012, 57-76).

\subsection{Presencia de élites y aristocracias en los poblados fortificados}

A partir de los poblados del siglo v d. C. comienzan a surgir este tipo de poblados fortificados, llevados a cabo por iniciativas vinculadas a determinadas élites, que se convierten en sedes de la aristocracia, que disponía de un excedente a través de la annona y el tributo. Algunos autores opinan que en realidad serían antiguos centros planificados para el Estado y ahora en manos de una aristocracia que, a partir del siglo vII d. C., basaría su riqueza en sus bienes fundiarios, abandonando los sitios en altura (Brogiolo 2006, 261-263; Martín 2014, 248).

En primer lugar, destaca como en muchos de estos lugares la construcción de las murallas originales suele producirse durante el siglo $\mathrm{v} d$. C., especialmente en su primera mitad, lo que podría responder a una necesidad de defensa frente a algún tipo de amenaza para las poblaciones que ocuparon estos lugares. También observamos como en la mayor parte de los poblados fortificados en altura se producen remodelaciones y reconstrucciones a lo largo del siglo vi d. C., y en momentos posteriores. Estos dos factores se han podido constatar en el caso de El Castillón, donde la construcción de la muralla se produciría durante la segunda mitad del siglo v d. C., con posteriores reparaciones que se situarían dentro de un momento avanzado del siglo vi d. C. 
Estas aristocracias son visibles dentro del ámbito rural posromano, las cuales se pueden reconocer en el paisaje, a través de la presencia de estos castra o castella, caracterizados por su marcado carácter defensivo, así como por la existencia de materiales asociados con estas élites, como pueden ser elementos epigráficos, monetarios, edificios religiosos, etc. (Martín 2014, 248), aunque, como vemos en el caso de El Castillón, encontramos otros elementos que refieren la presencia de una destacada aristocracia local, dada la gran cantidad de cerámicas grises estampilladas y TSHT, así como otro tipo de elementos de adorno personal.

La construcción de elementos defensivos, como es el caso de la muralla documentada en el yacimiento de El Castillón, responde a una necesidad de defensa o protección de esta sociedad contra un determinado factor que percibirían como una amenaza para sus intereses, protegiendo la posición que una determinada élite local tendría sobre este territorio.

El yacimiento de El Castillón podríamos incluirlo dentro del grupo de los denominados castella, que, como indican algunos autores, responderían a iniciativas específicamente privadas de las oligarquías locales (Vigil-Escalera 2007, 239-284). En este caso, es esencial la presencia de una élite local que, ante alguna necesidad económica, bélica o de algún otro tipo, se viese en la obligación de abandonar sus antiguas villae o zonas agrícolas con la finalidad de proteger o defender sus modos de vida, o simplemente por las ventajas que les podría ofrecer este nuevo asentamiento, frente a los espacios que anteriormente ocupaban.

Se puede comprobar que este tipo de enclaves fortificados se encuentran ante la necesidad de proteger y defender sus posesiones a lo largo del siglo $v \mathrm{~d}$. C. A finales del siglo v d. C. existe la necesidad, por parte de un grupo de población, de defender sus intereses y su posición ante una posible amenaza externa o un cambio significativo en la situación política que podría haber provocado un vuelco significativo en los modos de vida de estas gentes. Por este motivo, podrían trasladarse de zonas más fértiles desde el punto de vista agropecuario, y con un mayor acceso a determinados recursos, hacia lugares en altura, más fáciles de defender pero donde continuarían teniendo un control muy importante de los recursos, como se ha podido comprobar en el registro arqueológico gracias a la presencia de grandes cantidades de escorias de hierro, restos de fauna y otro tipo de productos.



FIgURA 6. Estructura habitacional correspondiente al siglo vi d. C., yacimiento de El Castillón.

\section{El Castillón: un poblado entre suevos y visigodos}

La zona del valle del Esla ha sido identificada, desde el punto de vista de las fuentes clásicas, como la tradicional frontera entre los reinos suevo y visigodo. Este factor podría explicar de una forma simple la implantación de El Castillón en esta zona. Sin embargo, consideramos que el emplazamiento de este poblado fortificado, como referíamos, respondería más a una necesidad de una élite ante una determinada problemática local que a una infraestructura promovida por un poder central, muy alejado de esta zona, y con un fin de control fronterizo.

Esta zona se podría concebir, más que como una frontera, en el sentido estrictamente geopolítico que se puede entender hoy en día, como una zona de comunicación y conexión con la Meseta, a través del vado que presenta el río Esla en esta región, y que la dotaría de una singular importancia, al ejercer como un área de comunicación entre dos sectores diferenciados, y a la vez actuando de modo fiscalizador, al poder controlar el comercio.

Esta mencionada frontera entre suevos y visigodos quedaría definida como un espacio de disputa entre ambos reinos, en la que actuarían otros factores con capacidad para resistir o negociar según las circunstancias, por lo que, más que de una frontera, habría que hablar de un espacio en el que los poderes mayores ejercerían su hegemonía y en la que se alternarían los episodios bélicos con otros periodos de paz (Ariño y Díaz 2014, 185-186).

Se debe entender esta frontera no como un auténtico limes entre ambos reinos, sino como la plasmación material y física de una amplia red de ciudades, castra y castella, destinada a disuadir al enemigo y desde la que organizar una respuesta 
en caso de agresión. Los castra y castella actuarían como centros secundarios en el reparto del poder (Ariño y Díaz 2014, 185-186).

En el caso de yacimientos como el de El Castillón, la defensa de este poblado estaría asociada a una zona de inestabilidad, carente del control o influencia que los reinos suevo o visigodo pudieran ejercer en áreas tan alejadas de los principales centros de poder, siendo necesaria su defensa frente al bandidaje que pudiera existir, así como frente a otras poblaciones. Con los datos que manejamos hoy en día, no se sostiene la posibilidad de una hipótesis defensiva de una zona claramente fronteriza, sujeta a los diferentes acontecimientos bélicos, entre ambos reinos.

Todos los acontecimientos turbulentos que jalonan este periodo histórico no parecen verse reflejados en el contexto histórico que muestra El Castillón, que presenta una ocupación muy estable desde finales del siglo v d. C. hasta su definitivo abandono a finales del siglo vi. Las reestructuraciones que se aprecian en la zona norte de la muralla parecen corresponderse con reparaciones propias del paso del tiempo y la pérdida de estabilidad de las propias estructuras, nunca asociadas a un acontecimiento de carácter bélico.

\section{Conclusiones}

Se constata la presencia de una importante red de poblados localizados en la zona de la histórica frontera suevo-visigoda, controlando lugares de vado y comunicación. Estos asentamientos surgen de una necesidad de control por parte de un poder local para organizar y estructurar este poblado. Lo más probable es que se vinculasen con unas élites locales, supeditadas en cierto modo al control suevo, pero muy alejadas de los centros de poder principales, lo cual les otorgaría una cierta independencia.

Si bien algunos poblados se han vinculado específicamente con un carácter militar, como sucede con el Cristo de San Esteban (Muelas del Pan) (Domínguez y Nuño 2002), para El Castillón se considera que el factor principal que justificaría su ubicación en este lugar es un control estratégico de los recursos a los que tiene acceso, como son la minería, la ganadería, la agricultura y los recursos fluviales, además de poseer un control sobre una zona de vado del río Esla, lo que le otorga una dominancia fundamental en el territorio, para su implantación, evolución y desarrollo.

Algunos poblados, como el de El Castillón, tienen una estrecha vinculación con el medio que los rodea, del cual aprovechan todos los recursos disponibles. El Castillón puede considerarse un enclave principal dentro de la red de asentamientos de este tipo que observamos en el valle del Esla. Mantiene diferentes relaciones comerciales con otros poblados dentro de una gran área de influencia, con los que establecieron lazos y comunicaciones dentro de una red existente para el tráfico y comercio de diversos productos, entre los cuales se encuentran ciertas cerámicas que podríamos considerar que eran destinadas al uso de una élite local.

Algunos investigadores han interpretado la ubicación de estos lugares en altura asociándolos a un posible incremento de las actividades ganaderas (Ariño et al. 2004), como se ha podido identificar en el caso de El Castillón, a través del aprovechamiento agropecuario de la zona, especialmente vinculado con la ganadería ovicaprina, la explotación de las aves y de los recursos faunísticos que ofrece el río Esla. La agricultura también ocuparía un lugar destacado en este poblado, documentada a través de los restos de semillas de diferentes cereales, y la presencia de numerosas cerámicas de almacenamiento.

Uno de los factores principales en la edificación de estos poblados es el tipo de control existente que llevaría a cabo una obra de semejantes características. Todos los datos que tenemos, y especialmente con la información de la que disponemos de algunos de los yacimientos en los cuales se ha podido excavar hasta la fecha, nos encontraríamos ante la presencia de unas determinadas élites locales que buscarían tanto proteger una zona sobre la cual ejercen el control de determinados territorios y productos como mantener un estatus y una seguridad personal, frente a la inestabilidad política que se vive en este momento. Lo cual va a condicionar las características arquitectónicas y funcionales de cada poblado.

\section{Bibliografía}

Alonso Ávila, A. 1988: «Suevos y visigodos en el territorio actual de la provincia de Zamora», Studia Zamorensia, vI, 51-60.

Ariño Gil, E.; Dahí Elena, S. 2008: «Contextos cerámicos de la antigüedad tardía y la alta Edad Media en la provincia de Salamanca (España)», en: SFECAG, Actes du Congrès de L'Escala-Empúries, 265-276.

ARiño Gil, E.; Díaz Martínez, P. C. 2014: «La frontera suevo-visigoda: ensayo de lectura de un territorio en disputa», en: Catalán, R.; Fuentes, P.; SASTRE, J. C. (coords). Fortificaciones en la tardoantigüedad: élites y articulación del territorio (siglos v-VIII d.C.), La Ergástula, Madrid, 179-190. 
Ariño Gil, E.; Gurt Esparraguera, J. M.; Palet i Martínez, J. M. 2004: El pasado presente: arqueología de los paisajes en la Hispania romana, Edicions de la Universitat de Barcelona, Barcelona.

Balboa de Paz, J. A.; Díaz Álvarez, I.; Fernández VÁzquez, V. 2003: Actas de las Jornadas sobre Castro Ventosa, Ayuntamiento de Cacabelos.

Barrio, J.; Fuentes, A.; Gómez, J. A.; Urbina, A. 1999: "Técnicas de construcción, estado de deterioro y sistemas de conservación preventiva en el hábitat del Cerro del Castillo de Bernardos (Segovia)», en: Actas del V Congreso de Arqueología Medieval Española, 329-340.

Bragado Toranzo, J. M. 1994: «Poblamiento romano y prerromano de la provincia de Zamora», Studia Zamorensia, 1, 11-95.

Brogiolo, G. P. 2006: «La fine delle ville: dieci anni dopo», en: Chavarria, A.; Arce, J.; Brogiolo, G. P. (coords.). Villas Tardoantiguas en el Mediterráneo Occidental, Anejos de AEspA, xxxIx, 253-273.

Caballero Zoreda, L. 1995: "Zamora en el tránsito de la Edad Antigua a la Edad Media. Siglos V-X», en: Historia de Zamora, I. De los orígenes al final del Medievo, 339-430.

Delgado Fraga, A.; Garibo Bodí, J.; Paniagua Vara, E.; Pereira, S. 2014: "El Baixo Sabor y el Valle de Vilariça entre los siglos v y XIII. Territorio y espacios funerarios», en: III Jornadas de Jóvenes Investigadores del valle del Duero: del Paleolítico a la Edad Media, 413-438.

DíAz MARTínez, P. C. 1987: «La monarquía sueva en el s. v. Aspectos políticos y prosoprográficos», Studia historica. Historia antigua, 4-5 (Homenaje al Profesor Marcelo Vigil (I)), 205-226.

- 2011: El reino suevo (411-585), Akal, Madrid.

Domínguez Bolaños, A.; Nuño GonzÁlez, J. 2002: «Aspectos militares del castro del Cristo de San Esteban, en Muelas del Plan (Zamora). Un asentamiento en la frontera suevo-visigoda», en: Mil Anos de Fortificações na Península Ibérica e no Magreb (500-1500). Actas do Simpósio Internacional sobre Castelos. Lisboa, Edições Colibri, Câmara Municipal de Palmela, 105120.

- 2014: «Dos viviendas del siglo vi sin noticias de élites locales en el Cristo de San Esteban (Muelas del Pan, Zamora)», en: CATALÁN, R.; FuEnTES, P.; SASTRE, J. C. (coords.). Las fortificaciones en la tardoantigüedad: élites y articulación del territorio (siglos V-VIII d.C.), La Ergástula, Madrid, 275-296.

Esparza Arroyo, A. 1986: Los castros de la edad del hierro del noroeste de Zamora, Instituto de Estudios Zamoranos Florián de Ocampo (Diputación de Zamora), Zamora.
FERnández Mier, M. 2009: «La génesis de la aldea en las provincias de Asturias y León», en: QuIRós CAstillo, J. A. (ed.). The archeology of early medieval villages in Europe, Documentos de Arqueología e Historia, 1, Universidad del País Vasco, 149-165.

Gómez Gandullo, J. A. 2006: "Avance sobre las excavaciones arqueológicas en el yacimiento de época visigoda de La Legoriza, San Martín del Castañar (Salamanca)», Zona Arqueológica (La investigación arqueológica de la época visigoda en la Comunidad de Madrid), 8 (1), 217-236.

Isla, A. 2001: "Villa, villula, castellum. Problemas de terminología rural en época visigoda», $A r$ queología y Territorio Medieval, 8, Jaén, 9-19.

JuAN Tovar, L. C. 2012: "Las cerámicas imitación de sigillata (CIS) en la Meseta Norte durante el siglo v. Nuevos testimonios y precisiones cronológicas», en: In Durii Regione Romanitas - Estudios sobre la presencia romana en el valle del Duero en homenaje a Javier Cortes Álvarez de Miranda, 365-372.

Larrén Izquierdo, H.; Martín Carbajo, M. A.; MiSiego Tejada, M. Á.; Salvador Velasco, M.; Viñé Escartín, A. I.; Sanz García, F. J.; Marcos Contreras, G. J.; Pérez Rodríguez, F. J. 2001: $P a-$ trimonio Arqueológico y Monumental en el embalse del Esla (Zamora), Instituto de Estudios Zamoranos Florián de Ocampo, Zamora.

Larrén IzQuierdo, H.; Villanueva Zubizarreta, O.; Caballero, J.; Domínguez Bolaños, A.; Misiego Tejeda, J. C.; Marcos, G. J.; Blanco García, J. F.; Sanz Huesma, F. J.; Martín, M. A.; Nuño GonzÁLEZ, J. 2003: "Ensayo de sistematización de la cerámica tardoantigua en la Cuenca del Duero», en: Caballero, L.; Mateos, P.; Retuerce, M. (eds.). Cerámicas tardorromanas y altomedievales en la Península Ibérica. Ruptura y continuidad, Anejos de AEspA, xvIII, 273-306.

López Quiroga, J. 2002: «Fluctuaciones del poblamiento y hábitat fortificado de altura en el noroeste de la Península Ibérica (siglos V-IX), en: Mil Anos de Fortificações na Península Ibérica e no Magreb (500-1500). Actas do Simpósio Internacional sobre Castelos. Lisboa, Edições Colibri, Câmara Municipal de Palmela, 83-91.

López Quiroga, J. (coord.). 2018: In Tempore Sueborum. El tiempo de los Suevos en la Gallaecia (411-585). El primer reino medieval de Occidente (volumen de estudios), Orense.

López Quiroga, J.; Martínez Tejera, A. M. (coords.) 2017: In Tempore Sueborum. El tiempo de los Suevos en la Gallaecia (411-585). El primer reino medieval de Occidente (catálogo de exposición), Orense.

Martín Viso, I. 2008: «La ordenación del territorio rural y la tributación en el suroeste de la mese- 
ta del Duero (siglos VI-VII)», en: CASTEllanos, S.; Martín Viso, I. (eds.). De Roma a los bárbaros. Poder central y horizontes locales en la cuenca del Duero, 227-261.

- 2012: «Un mundo en transformación: los espacios rurales en la Hispania post-romana (siglos V-VII)», en: Visigodos y omeyas. El territorio, Anejos de AEspA, LXI, 31-63.

- 2014: "Castella y elites en el suroeste de la meseta del Duero postromana», en: Catalán, R.; Fuentes, P.; SAstre, J. C. (coords.). Las fortificaciones en la tardoantigüedad: élites y articulación del territorio (siglos V-VIII d.C.), La Ergástula, Madrid, 247-274.

Novo Guisán, J. M. 2000: De Hidacio a Sampiro. Los castros durante la época visigoda y la primera conquista, Lugo.

Nuño GonZÁLEZ, J. 2006: «Poblamientos de encrucijada: las tierras zamoranas entre el mundo visigodo y la Edad Media», en: II Congreso de Historia de Zamora, 159-198.

Ósorio DA Silva, M. D. 2002: «Metalurgia no povoado fortificado alto-medieval do Sabugal Velho (Sabugal, Guarda)», en: Mil Anos de Fortificações na Península Ibérica e no Magreb (500-1500). Actas do Simpósio Internacional sobre Castelos. Lisboa, Edições Colibri, Câmara Municipal de Palmela, 791-794.

Pereira, S.; Sastre, J. C.; Amorim, A.; Roiz, A.; Espí, I.; Liberato, M.; Cosme, S.; Rodrigues, Z.; PaniaGUA, E. 2015: «Espaços funerários no sítio da Quinta de Crestelos: do Baixo-Império à Idade Media (Mogadouro, Portugal)», en: Quirós Castillo, J. A.; Castellanos, S. (dirs.). Identidad y etnicidad en Hispania. Propuestas teóricas y cultura material en los siglos V-VIII, Documentos de Arqueología Medieval, 8, Universidad del País Vasco, 161-180.

Pereira, S.; Sastre, J. C.; Espí, I.; Pereira, J. A.; Mateos, R.; Larrazabal, J. 2014: «O Povoado da Quinta de Crestelos (Meirinhos, Portugal): Fortificação e o controlo de um território», en: Fortificaciones en la Edad del Hierro: Control de los recursos y el territorio, 277-289.

Pereira, S.; Silva, B.; Espí, I.; Larrazabal, J.; GariBo, J.; Nisa, J.; Pereira, J. A.; Mateos, R.; CoseME, S. 2014: «A Romanização do Vale do Sabor: de Meirinhos a Remondes (Mogadouro)», en: I Encontro de Arqueologia de Mogadouro, 95143.

Pérez Rodríguez-Aragón, F.; González FernánDEZ, M. ${ }^{a}$ L. 2010: "La cerámica de época hispanovisigoda de "El Pelambre" (Villaornate, León)», en: Crespo Díez, M.; Martínez PeÑín, R. (coords). Metodología de Análisis Aplicada a los Estudios de Cerámica Tardoantigua y Medieval de la Península Ibérica, Lobo Sapiens, León.
SÁnchez PARdo, J. C. 2012: "Castros, castillos y otras fortificaciones en el paisaje sociopolítico de Galicia (siglos IV-XI)», en: QuiRós CAstillo, J. A.; Tejado Sebastián, J. M. (eds.). Los castillos altomedievales en el noroeste de la Península Ibérica, Documentos de Arqueología Medieval, 4, Universidad del País Vasco, 18-58.

Sastre Blanco, J. C.; Catalán Ramos, R. 2012: «Un asentamiento fortificado en la tardoantigüedad: el castro de El Castillón (Santa Eulalia de Tábara, Zamora)», en: Quirós CAstillo, J. A.; Tejado Sebastián, J. M. (eds.). Los castillos altomedievales en el noroeste de la Península Ibérica, Documentos de Arqueología Medieval, 4, Universidad del País Vasco, 193-212.

Sastre Blanco, J. C.; Catalán Ramos, R.; Fuentes Melgar, P. 2014: «El conjunto cerámico de El Castillón (Zamora) y las cerámicas de imitación de Sigillata en el contexto del siglo V», en: Morais, R.; Fernández, A.; Sousa, M. J. (eds.). As produções cerâmicas de imitação na Hispania. Monografias Ex Officina Hispana, II (I), 471-481.

Sastre Blanco, J. C.; Criado Portal, A. J.; Fuentes Melgar, P. 2011: «Metalurgia del hierro en el yacimiento tardoantiguo de El Castillón (Santa Eulalia de Tábara, Zamora)», en: Povoamento e Exploração dos Recursos Mineiros na Europa Atlântica Ocidental, 483-500.

Sastre Blanco, J. C.; Fuentes Melgar, P.; Catalán Ramos, R.; Rodríguez Monterrubio, O. 2014: «El poblado fortificado de El Castillón en el contexto del siglo v d.C.», en: CataláN, R.; FuENTES, P.; SASTRE, J. C. (coords.). Las fortificaciones en la tardoantigüedad: élites y articulación del territorio (siglos V-VIII d.C.), La Ergástula, Madrid, 353-368.

Sastre Blanco, J. C.; Fuentes Melgar, P.; Honrado CAStro, J. 2015: «Urbanismo en el Poblado tardoantiguo de El Castillón (Santa Eulalia de Tábara, Zamora): adaptación y control del territorio», en: Martínez PeÑín, R.; Cavero DoMíNGUEZ, G. (eds.). Evolución de los espacios urbanos y sus territorios en el Noroeste de la Península Ibérica, Instituto de Estudios Medievales de la Universidad de León y Unidade de Arqueologia de la Universidade do Minho, Ediciones El Forastero, 441-457.

Sastre Blanco, J. C.; Pereira, S.; Amorim, A.; Roiz, A.; Espí, I.; Liberato, M.; Cosme, S.; Rodrigues, Z.; Paniagua, E. 2015: «Espaços funerários no sítio da Quinta de Crestelos: do Baixo-Império à Idade Media (Mogadouro, Portugal)», en: Quirós Castillo, J. A.; Castellanos, S. (dirs.). Identidad y etnicidad en Hispania. Propuestas teóricas y cultura material en los siglos V-VIII, 
Documentos de Arqueología Medieval, 8, Universidad del País Vasco, 161-180.

Tente, C.; Martín Viso, I. 2012: «O Castro do Tintinolho (Guarda, Portugal). Interpretação dos dados arqueológicos como fortificação do período pós-romano», en: QuiRós CASTILlo, J. A.; Tejado Sebastián, J. M. (eds.). Los castillos altomedievales en el noroeste de la Península Ibérica, Documentos de Arqueología Medieval, 4, Universidad del País Vasco, 57-76.

Vigil-Escalera Guirado, A. 2007: «Granjas y aldeas altomedievales al norte de Toledo (450800 d.C.)", Archivo Español de Arqueología, 80, 239-284.

- 2009: «Apuntes sobre la genealogía política de aldeas y granjas altomedievales», en: MARTín
Viso, I. (coord.). ¿Tiempos oscuros?: Territorio y sociedad en el centro de la Península Ibérica (siglos $V I I-X), 31-44$.

- 2013: «Las últimas producciones de TSHT en el interior peninsular», Mesa Redonda «La Terra Sigillata Hispánica Tardía y sus contextos: estado de la cuestión». Monografías Ex Officina Hispana. Cuadernos de la SECAH, I, La Ergástula, 11-24.

Zeumer, K. 1902: "Leges Visigothorum», en: Monumenta Germaniae Historica, Legum sectio I. Legum nationum Germanicarum, I, HannoverLeipzig. 


\title{
REDIVIVA MOENIA. NUEVOS DATOS SOBRE LAS MURALLAS DE CARTHAGO SPARTARIA EN ÉPOCA BIZANTINA
}

\author{
Jaime Vizcaíno Sánchez, ${ }^{1}$ José Miguel Noguera Celdrán, ${ }^{1}$ María José Madrid Balanza ${ }^{1}$
}

\section{Resumen}

Las excavaciones arqueológicas realizadas en la cima del cerro del Molinete (arx Hasdrubalis) de Cartagena (Carthago Nova; Hispania citerior, conventus Carthaginiensis) entre 2010 y 2011 han descubierto parcialmente varias murallas sucesivas (púnica, romanorrepublicana, bizantina y moderna) construidas para defender la ciudad y el flanco septentrional de la acrópolis entre el siglo iII a. C. y el siglo xVI. Este trabajo se centra en la cinta protobizantina, que puede datarse a mediados del siglo vI, después de la conquista justinianea del sureste hispano. Desde un punto de vista arquitectónico, esta nueva fortificación se caracteriza por la reutilización de las murallas precedentes (púnica y romanorrepublicana), que están parcialmente recrecidas con materiales heterogéneos, en su mayoría también reutilizados. Hemos hallado dos muros longitudinales que están relacionados con distintas estancias. Se trata de una de las pocas evidencias sobre las fortificaciones protobizantinas en Spania. También estudiamos el depósito cerámico asociado, que incluye contenedores y otros recipientes orientales, baleáricos y, sobre todo, tunecinos, que muestran el acontecer diario de la ciudad durante la ocupación bizantina.

\section{Summary}

The archaeological excavations carried out on the summit of Cerro del Molinete (arx Hasdrubalis) in Cartagena (Carthago Nova; Hispania citerior, conventus Carthaginiensis) in 2010 and 2011 have partially revealed the successive walls (Punic, Roman Republican, Byzantine and modern) built to defend the city and its northern acropolis between the $3^{\text {rd }}$ century $\mathrm{BC}$ and $16^{\text {th }}$ century. The subject of this paper is the early Byzantine rampart, which can be dated to the second half of the $6^{\text {th }}$ century, following the Justinian conquest of southern Spain. From an architectural point of view, this new rampart is characterized by the reuse of the earlier fortifications (Punic and Roman Republican) that were partially enlarged with heterogeneous materials, also mostly reused. We have found two longitudinal walls that are linked to several rooms. They are one of the few pieces of evidence of the early Byzantine fortifications in Spania. We also studied the associated pottery assemblage, which includes Oriental, Balearic or most frequently Tunisian receptacles and vessels that reveal something of everyday life in the city during the Byzantine occupation. 


\section{Introducción}

Aunque los procesos de fortificación y cristianización de los recintos urbanos son dos de los fenómenos más característicos de las transformaciones de las ciudades en época tardoantigua (Diarte y Gurt 2015), por el momento la documentación arqueológica de Cartagena apenas permite comprender su lógica en la ciudad, ni reconocer siquiera una parte sustancial de los elementos que habitualmente los integran. ${ }^{2}$ No deja de ser paradójico por cuanto en el caso de la antigua Carthago Nova, la Carthago Spartaria de época tardía, el componente militar es intrínseco a su propio devenir histórico.

El potencial geoestratégico de esta ciudad del sureste hispano ha motivado que desde sus orígenes haya tenido una fuerte impronta castrense. La fortificación de su recinto fue una de las preocupaciones esenciales desde época púnica -momento en que fue capital de los dominios bárquidas en Hispania - hasta las primeras décadas del siglo $\mathrm{xx}$, cuando se mantuvo como uno de los últimos baluartes de la España republicana en el contexto de la Guerra Civil. En el Bajo Imperio, su promoción administrativa en el último cuarto del siglo III como capital de la nueva provincia Cartaginense, su esplendor durante los siglos iv y v -momento este último en que los textos refieren su destrucción por parte de los vándalos (Hyd., Chron. 86)y los esfuerzos que para acabar con estos desplegó en su entorno Mayoriano (Hyd., Chron., 200), son una muestra inequívoca de la vigencia de esa relevancia geoestratégica. Su ulterior conversión en uno de los principales centros direccionales de la provincia bizantina de Spania «vivificó» este rol militar y se convirtió en acicate para su fortificación por los milites romani. También ese protagonismo le reportará en última instancia la conquista y destrucción por las tropas enviadas por el rey visigodo Suintila, quedando la ciudad in desolationem, como señala Isidoro de Sevilla (Etym. Xv, I, 67-68).

En este contexto en que el componente militar pasa a primer plano, causa sorpresa la escasez de datos arqueológicos acerca de las defensas de la ciudad entre los siglos IV y VII (Ramallo y Vizcaíno 2007, 494-516). La carencia se antoja aún mayor dado que, durante las últimas cuatro décadas, múltiples intervenciones arqueológicas en el solar urbano han proporcionado un ingente volumen de información, capaz de redibujar el co- nocimiento histórico de la ciudad en casi todos sus periodos históricos (Ruiz 2017). Con todo, por desconcertante que pueda resultar la ausencia de registro arqueológico sobre los equipamientos defensivos tardíos, tal sorpresa se atenúa si sopesamos que el desconocimiento es aún mayor para el otro gran vector de transformación urbana en este periodo: la cristianización de la topografía urbana. Y es que, aunque la ciudad fue uno de los centros que experimentó una más temprana evangelización, con una comunidad organizada cuyo representante ya participó en el concilio de Elvira, el refrendo arqueológico de tal proceso es exiguo (Vizcaíno 2008a, 345-353), limitándose apenas al mundo funerario (Vizcaíno 2011) y, en especial, a la iconografía cristiana presente en una ingente documentación cerámica (Vizcaíno, Noguera y Madrid 2019). La importancia que adquirirá la sede episcopal, sobre todo en época bizantina, momento en que su titular se transformó en una suerte de archiepiscopus de la provincia de Spania (Vallejo 2012, 299-304), con obispos como el emblemático Liciniano (Isid. Hisp., De Virs. Ills. XXIX-XXXII), contrasta, a día de hoy, con un registro arqueológico prácticamente nulo.

Creemos importante remarcar este escaso nivel de conocimiento sobre ambos fenómenos de fortificación y cristianización, y su actual evanescencia, para recalcar lo azaroso del registro arqueológico y la necesidad de manejar prudentemente algunas de las hipótesis que, en función de indicios sólidos, ya directos o indirectos, podamos ir acuñando.

En el caso de las defensas tardías de Carthago Spartaria, hasta hace apenas dos décadas solo disponíamos del epígrafe del magister militum Comitiolus (Abascal y Ramallo 1997, n. ${ }^{\circ} 208$; Prego 2000) que menciona una intervención sobre la puerta úrbica en época del emperador bizantino Mauricio. Afortunadamente, las excavaciones desarrolladas en el Barrio Universitario y, con posterioridad, en el cerro del Molinete aportan novedades para comenzar a perfilar una realidad que, no obstante, sigue siendo difusa. En el caso del primero, la documentación de una necrópolis que presumimos extra moenia (Madrid y Vizcaíno 2009) permite inferir toda una serie de datos para el sector suroriental de la fortificación. Con posterioridad, los trabajos arqueológicos acometidos entre 2010 y 2011 en la cima del cerro del Molinete, la antigua arx Hasdrubalis de Polibio (x, 10, 9), han permitido localizar un paño de estas mismas

2. Este trabajo se enmarca en el proyecto de I+D+i titulado «Exemplum et spolia. El legado monumental de las capitales provinciales romanas de Hispania. Perduración, reutilización y transformación en Carthago Nova, Valentia y Lucentum» (HAR2015-64386-C4-2-P), financiado por el Ministerio de Ciencia, Innovación y Universidades del Gobierno de España. 


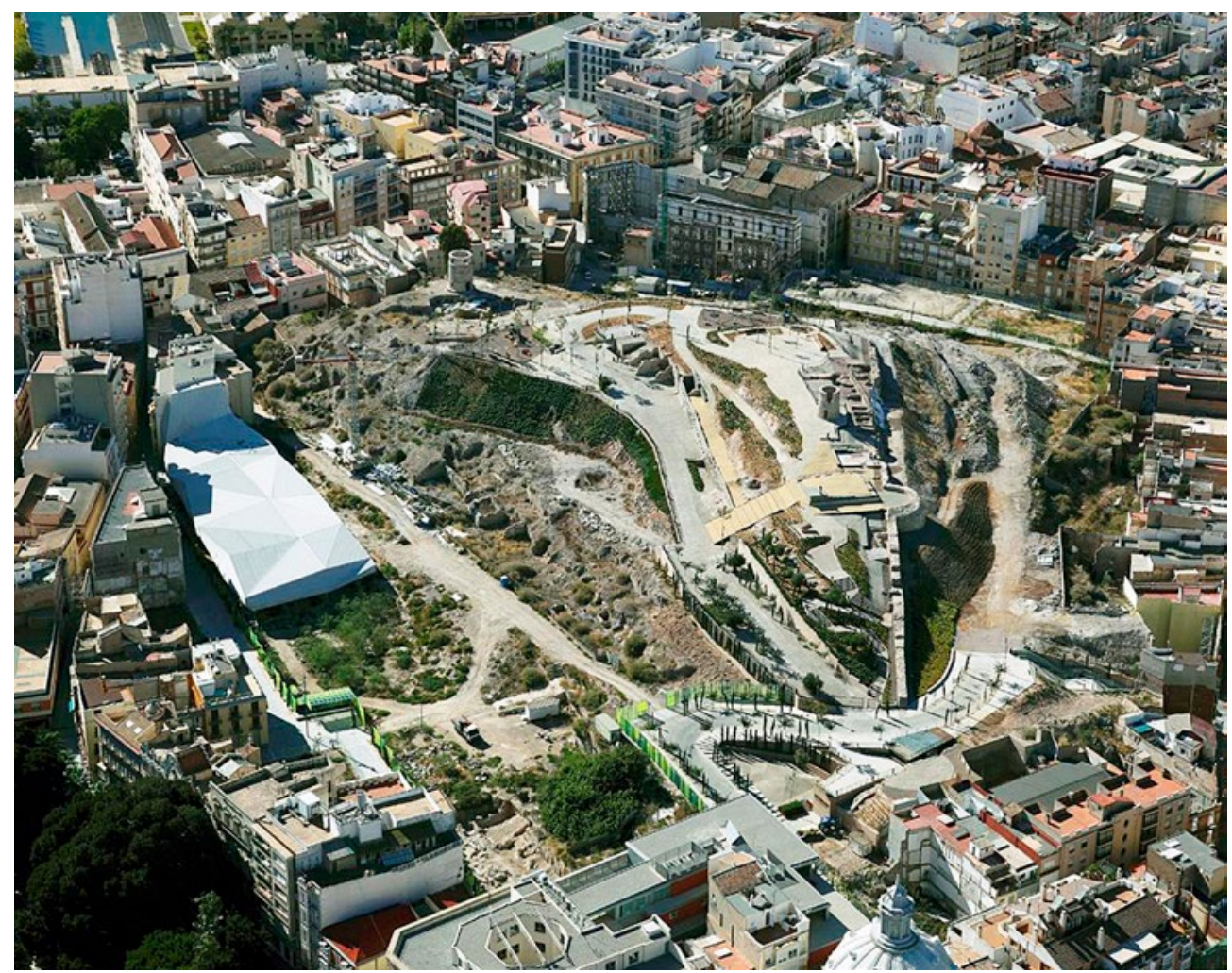

FIgURA 1. Vista aérea del Parque Arqueológico del cerro del Molinete. En la cima de la colina, cerrando su lado septentrional, se aprecian las sucesivas murallas superpuestas. Archivo gráfico del Proyecto Arx Hasdrubalis. defensas que, como veremos, conviven con las de otros periodos (fig. 1). De este modo, en la actualidad es posible abordar un planteamiento diacrónico de las dinámicas de fortificación de la ciudad desde época púnica (Noguera et al. 2017) hasta el siglo XVI (Martínez et al. 2014). Conviene insistir en esa amplia horquilla temporal, pues en ella radica gran parte de la singularidad de tales equipamientos. A este respecto, la peculiar orografía cartagenera ha motivado que los sucesivos recintos defensivos se reutilicen, superpongan, fosilicen o anulen, en una compleja cadena cuyos eslabones no siempre se prestan a ser individualizados con claridad. Con ello, el valor de los nuevos hallazgos reside tanto en la exhumación de un primer paño de la muralla tardoantigua como en la constatación de que la resiliencia que preside la dinámica urbana de Cartagena a lo largo de su historia puede reconocerse también en sus equipamientos defensivos.

Como veremos, el nuevo cerco no hace sino seguir las pautas de sus defensas predecesoras y posteriores, es decir, adaptarse a los peculiares condicionantes orográficos de la ciudad. Tengamos en cuenta que su situación en una antigua península delimitada por cinco colinas obligó siempre a una lógica adaptación al medio, intentando paliar sus eventuales «inconvenientes» $\mathrm{y}$, en la medida de lo posible, «rentabilizarlos». Por ello no extraña que en la cima del cerro de la Concepción la muralla romanorrepublicana se superponga a un tramo de la fortificación bárquida (Ramallo, Murcia y
Vizcaíno 2010, 214, fig. 3; Murcia, Ruiz y Ramallo 2013); o que, en la vaguada entre los cerros de Despeñaperros y San José, el lienzo de la muralla púnica acasamatada se fosilizara en el siglo XVIII en la Puerta de San José, incluida dentro de las nuevas defensas borbónicas que flanqueaba el acceso principal a la ciudad.

\section{Urbs ipsa moenia sunt (Isid. Hisp., Etym. XV, II, 1). Murallas para una ciudad tardía}

Las excavaciones arqueológicas muestran cómo, a partir del siglo III, el sector oriental de la península sobre la que se asentaba Carthago Nova fue abandonándose. Su perímetro habitado quedó reducido al área occidental, en torno al puerto (Ramallo, Murcia y Vizcaíno 2010, 233-247) (fig. 2). Todo induce a pensar en la implícita desatención de las antiguas murallas romanas, que comprendían un perímetro fortificado de unas 40 ha, enlazando sus cinco colinas. Un nuevo cerco englobaría la zona que siguió habitada, es decir, el espacio de poco más de 20 ha delimitado entre solo dos de esos cerros (Concepción y Molinete) (Ramallo y Vizcaíno 2007, 494-505). A este respecto, aunque en la Hispania bajoimperial no suele detectarse una reducción generalizada de la superficie in urbe (Ruiz 2018, 28), conocemos casos similares de contracción y consiguiente repliegue defensivo, como los de Egitania, Conimbriga o Italica (Gurt e Hidalgo 2005, 73-75). También lo cons- 




FIgURA 2. Carthago Spartaria entre los siglos iv y vII, con indicación de su necrópolis oriental, zona habitada y posible trazado de su perímetro amurallado (Ramallo, Murcia y Vizcaíno 2010). En la cima de la $\operatorname{arx}$ Hasdrubalis se señaliza el paño excavado.

tatamos en el norte de África, en ciudades como Trípoli, Sabratha y, especialmente, Leptis Magna, cuyas defensas tardías solo comprenderán 28 ha de las 130 originarias (Zanini 1998, 196). No hay que perder de vista que la misma administración imperial ( $C I$ I, 27, 2 y 14) recomendaba la reducción del perímetro fortificado para poder asegurar la defensa con el menor número posible de soldados (Ravegnani 1983, 24).

En Carthago Spartaria, aunque los contextos de abandono localizados en su zona oriental permitían intuir este repliegue, la localización de una extensa necrópolis en este sector es una prueba concluyente. El hecho de que este cementerio, levantado sobre un antiguo barrio residencial altoimperial (Madrid 2004; Madrid, Celdrán y Vidal 2005), supere los $c a .1 .600 \mathrm{~m}^{2}$, con más de doscientos enterramientos, implica necesariamente una ubicación extra moenia. La ocupación intensiva del espacio, su densidad y, en conjunto, su carácter masivo diferencia la ciudad de aquellos otros núcleos cementeriales más reducidos que proliferan intramuros, casi siempre ad sanctos, a partir del siglo VI (Godoy 2005, 66). El límite occidental de esta necrópolis tardía ayuda a perfilar el hipotético trazado del cinturón defensivo acoplado a la mutada realidad urbana de Carthago Spartaria (Ramallo, Murcia y Vizcaíno 2010, 233-247). Dicho límite se ubica en la ladera oriental del cerro de la Concepción, lugar por donde han discurrido las sucesivas murallas de época moderna, hasta enlazar con el cercano cerro del Molinete (Gómez y Munuera 2002) (fig. 3).

Lamentablemente, el potencial geoestratégico de estos cerros y su aprovechamiento secular ha derivado en una "fagocitación» consecutiva. Cada uno de los cercos que se han trazado entre ambas colinas, en una línea de alguna forma preservada en el viario contemporáneo -el eje determinado desde la calle Faquineto hasta la elocuente calle Adarve-, han ido reutilizando lienzos y/o materiales de las murallas precedentes, a veces incluso desmantelándolas, todo lo cual ha derivado en una cierta invisibilidad arqueológica. En la Spania bizantina encontramos casos similares de enmascaramiento, como el de Septem, donde el acuartelamiento referido por Procopio (Aedif. VI, $7,16)$ se engloba en las murallas califales (Bernal 2018, 113-114). Algo similar parece ocurrir en la acrópolis de la fortissima civitas de Asido (Iohh. 


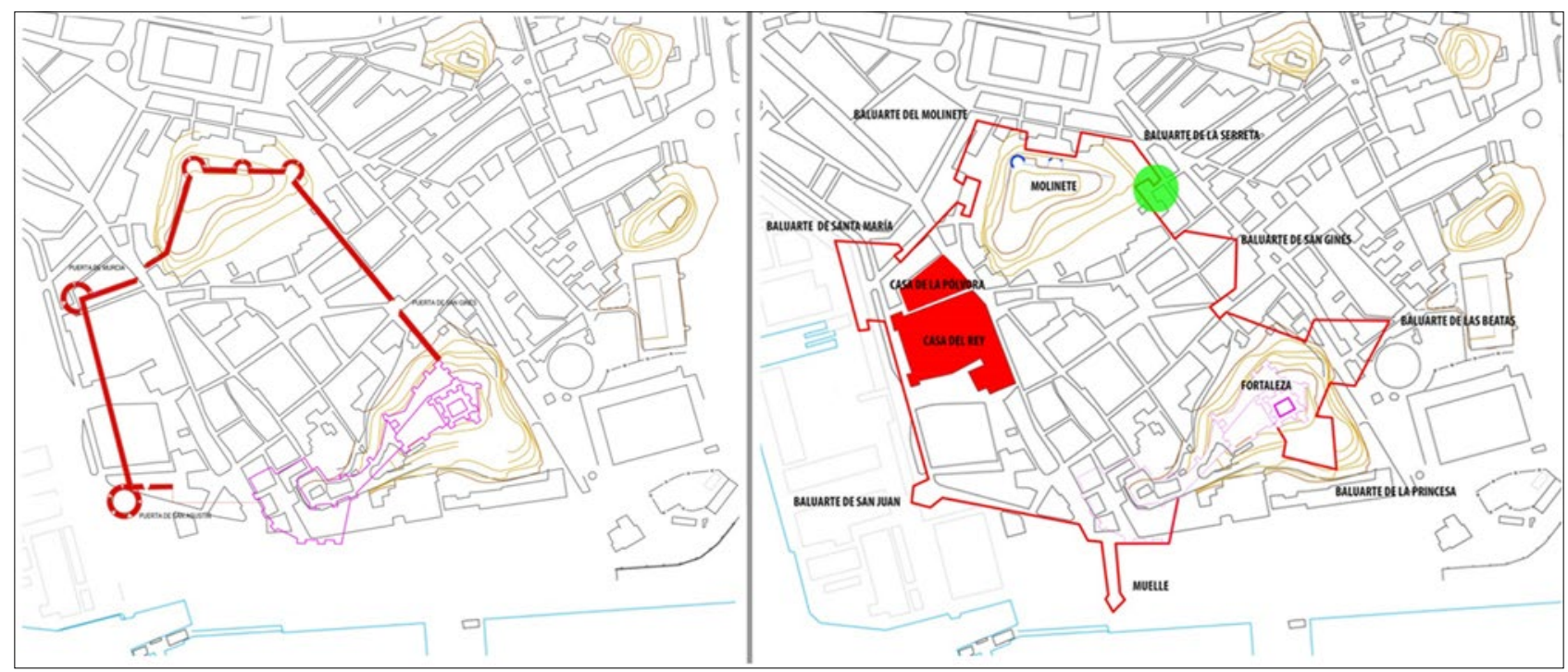

FIgURA 3. Propuestas de trazado de las fortificaciones de Carlos I y Felipe II sobre la topografía urbana actual (Martínez et al. 2014).

Bicl, Chron. ad a. 571.3), amortizada bajo el castillo medieval y moderno de Medina Sidonia (Montañés y Montañés, 2009).

Por otro lado, en Carthago Spartaria también pesarían otros factores a la hora de elegir este trazado. Hemos de tener en cuenta que es precisamente a partir del límite occidental de la necrópolis, y en la línea que permite la unión de los cerros de la Concepción y Molinete, donde se concentran buena parte de los equipamientos monumentales de la civitas altoimperial. Sin duda, la posibilidad de que estos edificios, o al menos sus materiales, nutrieran la construcción de los nuevos muros, dándoles una mayor entidad y economizando la obra, debió de ser un importante aliciente. Ocurre así en otras muchas ciudades, en las que foros (Dougga), termas (Calama, Mactar, Thubursicu Numidarum), arcos (Theveste, Thubursicu Bure, Mactar o Ammaedara) y, en menor medida, casas (Sbeitla) acaban engrosando murallas, fuertes y fortines (Ghedini 1993, 325). En Hispania resulta ilustrativo el caso de Pollentia, cuyo antiguo epicentro urbano, integrado por la plaza forense, fue también reutilizado para la erección de la muralla tardía (Orfila et al. 2000, 229-236).

En Carthago Spartaria pudo darse esta misma situación, con edificios como el Augusteum de la calle Caballero, el templo que remata la terraza superior forense y la curia de la calle Adarve o los porticados y las estructuras colindantes al foro, en cuyos procesos de excavación se han hallado pa- ños de las murallas de época moderna. En nuestra opinión, el mimetismo con el que estas defensas posteriores fosilizaron los cercos más antiguos, con trincheras de expolio y fosos, implicaron su reaprovechamiento y desaparición. ${ }^{3}$ En el Augusteum, junto a la referida muralla moderna, se documentó además un vertedero fechado entre los siglos v y vII. Tales contextos de vertido de residuos, aunque proliferan por todo el solar urbano (Vizcaíno 1999), suelen ubicarse sobre todo extramuros y, frecuentemente, en la vecindad de las murallas, como ocurre asimismo en el baluarte tardío del Tolmo de Minateda (Gutiérrez y Abad 2001).

En este mismo orden de cosas, el periodo de uso de la necrópolis tardía cartagenera y, de forma concreta, su gestación pueden tomarse como un eficaz terminus ante quem para la datación del nuevo cinturón defensivo. En este sentido, a pesar de que algunos enterramientos aislados podrían tener una cronología previa, el sector más temprano, ubicado junto al borde occidental, se data a partir del siglo v. Partiendo de esta línea en dirección al este, es decir, distanciándose progresivamente del hipotético cerco en función de la saturación espacial, los enterramientos son más tardíos, y conforman un nuevo sector que seguirá activo durante todo el periodo bizantino.

Dado que a día de hoy solo disponemos de este tipo de documentación indirecta, no es posible precisar más sin adentrarse en el terreno de

3. Ocurre así, por ejemplo, con la muralla proyectada en el último cuarto del siglo xvı por Juan Bautista Antonelli, que en su tramo septentrional llega a cimentarse directamente sobre la escalinata oriental de la terraza del templo forense (Martín 2006, 63-66). En el mismo sentido, refiriendo el impacto de la fortificación moderna junto al edificio que limita el edificio del ordo augustalis por su lado occidental, vid. Miquel y Roldán $(1999,468)$. Sobre los equipamientos monumentales referidos, vid. Noguera 2016 y Noguera, Martín y Soler 2013. 
la mera especulación. No sabemos, por ejemplo, si este cerco pudo ser erigido de forma previa al uso de la necrópolis, quizá no mucho después de la promoción de la ciudad en época dioclecianea, dentro del impulso defensivo general que se aprecia en muchas urbes hispanas desde finales del siglo III y comienzos del siglo Iv, como Lucus Augusti, Bracara Augusta, Asturica, Legio, Gijón, Barcino o Gerunda (Rodríguez y Rodà 2007). Parece difícil pensar que el renovado interés estratégico de Carthago Spartaria, que la convirtió en blanco de las apetencias vándalas en el 425, como refiere Hidacio (Chron. 86), o más tarde en punto de referencia en la concentración naval de Mayoriano para hacer frente al reino norteafricano (Hyd., Chron., 200), no conllevase el refuerzo de esta infraestructura vital. El valor definidor del hecho urbano que Ausonio, Libanio, Casiodoro y, en un momento postrero, Isidoro de Sevilla dan a las murallas, identificando la civitas por sus moenia, testimonian como este equipamiento era imprescindible para una ciudad que se tuviera como tal (Cracco Ruggini 1982, 79; Cantino Wataghin 2007).

La particular dinámica evolutiva de Carthago Spartaria -que a partir de finales del siglo Iv vive una verdadera efervescencia constructiva, a diferencia de la atonía de los siglos precedentes- lleva a sugerir que en ese momento se debió reforzar la ciudad, (Vizcaíno 2018). Entraría así en sintonía con los renovados esfuerzos de fortificación en ciudades como Gerunda o, más tarde, ya en el 483, en Emerita (Nolla 2007, 641; Alba 2018). Cosa distinta es poder determinar si tal muralla es la que se siguió utilizando en época bizantina, o si la actuación que prueba el epígrafe conmemorativo de Comitiolus supuso la erección de un nuevo cinturón defensivo. Tal inscripción, inserta en la retórica habitual de la época, utiliza las fórmulas estereotipadas de la ekphrasis, lo que impide conocer la envergadura de la intervención promovida por el gobernador enviado por Mauricio o, siquiera, características concretas de la fortificación (Fontaine 2000; Vizcaíno 2009, 736-741).

En resumen, en el frente oriental de la ciudad aún no se ha documentado el cerco tardío, pero sí hay indicios que ayudan a establecer su trazado, como es el suburbium generado a sus pies por una necrópolis, como ocurre habitualmente en otros vici christianorum (Gurt y Sánchez 2010, 334340 ). No hay por el momento indicio alguno para señalar su posible carácter martirial, ya que conforma -como se ha defendido para otros lugaresuna suerte de cinturón de protección espiritual, una corona que reemplaza al antiguo pomoerium (Godoy 2005).

\section{Fosilización, expolio y reempleo: dinámi- cas de readaptación defensiva constata- das en la arx Hasdrubalis}

El proyecto de excavación e investigación del cerro del Molinete ha contribuido a ampliar nuestro conocimiento sobre la Carthago Nova tardía. ${ }^{4}$ Respecto a lo que aquí interesa, ha permitido localizar la muralla que ciñó la ciudad por este flanco, el noroccidental, así como el adyacente barrio intra moenia al que custodiaría (fig. 4). Dicho barrio, diseminado por toda la ladera meridional de la colina y dispuesto sobre las antiguas insulae romanas cercanas al foro (Vizcaíno 2016, 146-151; Vizcaíno 2019, 123-129), tuvo una fuerte impronta artesanal; entre otras instalaciones, cabe destacar una herrería y un almacén de ánforas (Vizcaíno, Noguera y Madrid e. p.). La documentación del nivel de abandono de este último, cuyo depósito cerámico se puede datar en el primer cuarto del siglo VII, enlaza con las trazas de destrucción registradas sobre el barrio de época bizantina levantado sobre el antiguo teatro augusteo (Ramallo, Ruiz y Berrocal 1997). En ambos casos es sugerente vincular dichos niveles de destrucción con la toma visigoda de la urbe por las tropas de Suintila ca. 625.

El tramo de muralla tardía fue excavado en el marco de las campañas arqueológicas acometidas entre 2010 y 2011 en la cima del cerro del Molinete. ${ }^{5}$ Constituye un eslabón más dentro del complejo proceso que la colina jugó en las obras de fortificación de la ciudad a lo largo de la historia (Noguera et al. 2017). Así, en el vértice norocciden-

4. Actualmente, siguen en marcha los trabajos arqueológicos, de conservación-restauración y adecuación del Parque Arqueológico del Molinete, promovidos por el Consorcio Cartagena Puerto de Culturas, financiados por la Fundación Repsol, y dotados del soporte de la Universidad de Murcia y varios proyectos de I+D+i del Ministerio de Ciencia, Innovación y Universidades. La bibliografía asociada al mismo ya es ingente, de modo que remitimos a tres estudios de conjunto para seguir algunos de sus hitos más notables: Noguera y Madrid 2009, Noguera et al. 2016 y Noguera et al. 2019.

5. Los trabajos arqueológicos, promovidos por el Ayuntamiento de Cartagena y financiados con cargo al Plan E, fueron dirigidos por dos de nosotros (José Miguel Noguera Celdrán y María José Madrid Balanza) y contaron con la intervención como técnicos arqueólogos de Víctor Velasco, Victoria García, María Fuentes y José Antonio Martínez. Asimismo, el proyecto contó con un equipo de seis conservadores-restauradores dirigidos por Izaskun Martínez, y otro de inventario y catalogación. La dirección de la obra civil correspondió a Manuel Giménez. Sobre esta actuación: Giménez et al. 2011. 


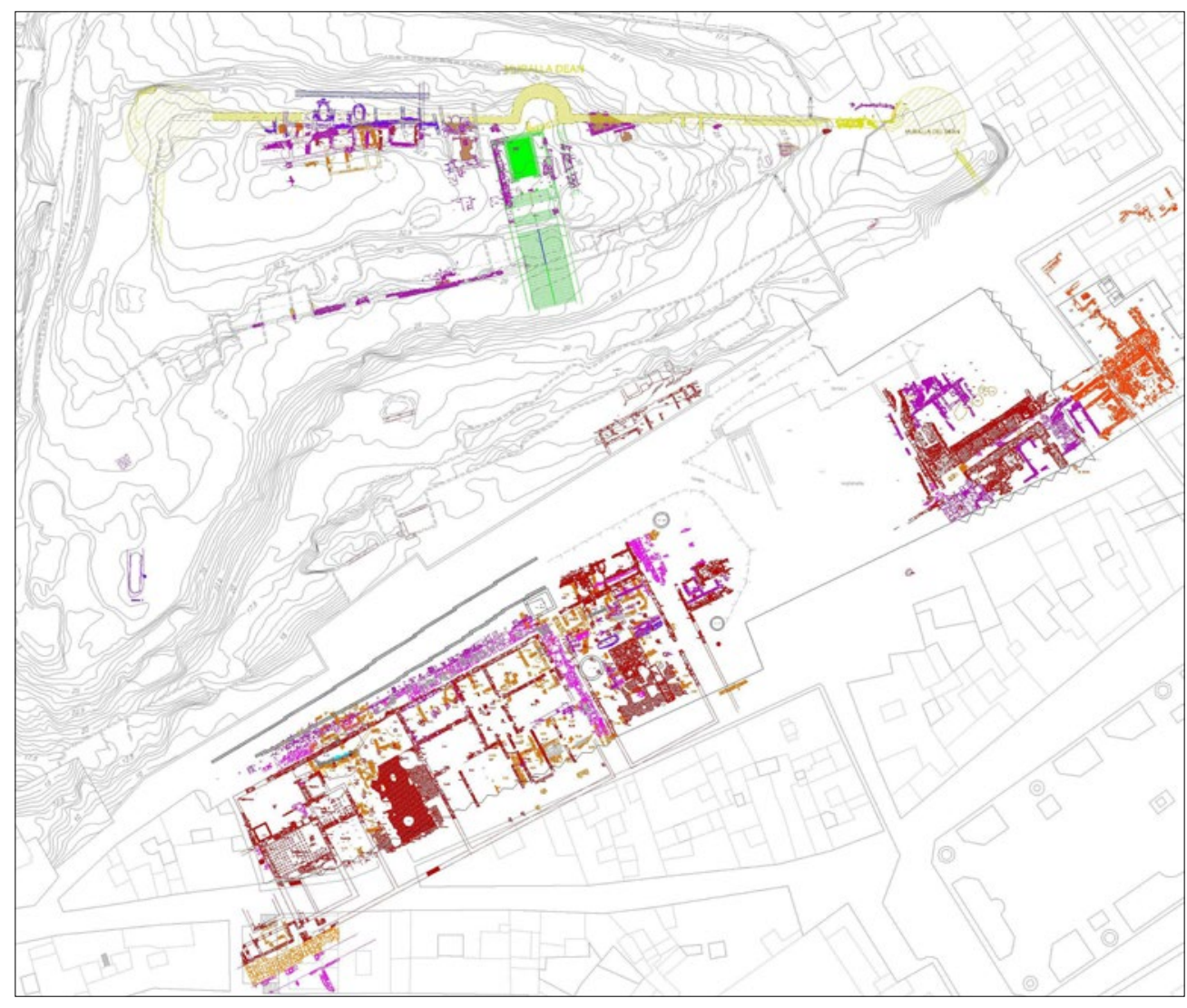

Figura 4. Planimetría arqueológica del cerro del Molinete en Autocad. Archivo gráfico del Proyecto Arx Hasdrubalis.

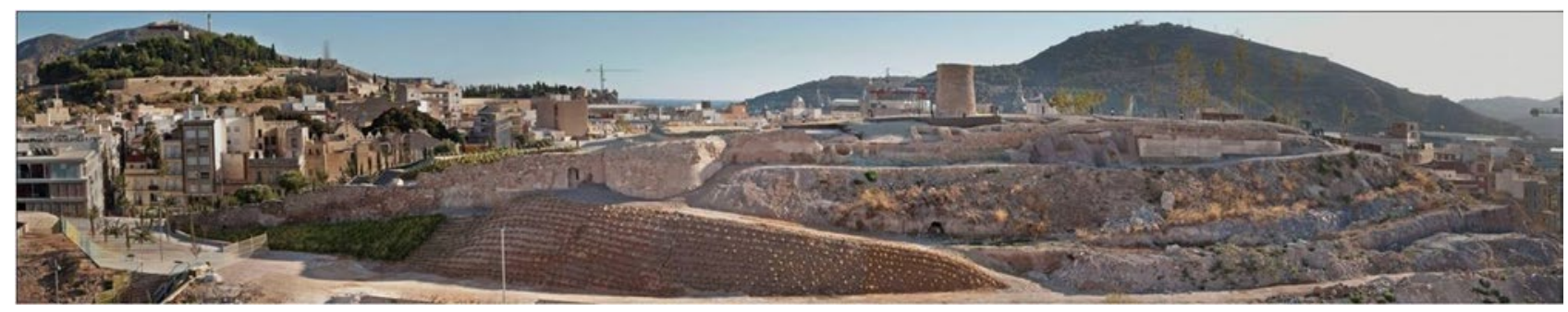

Figura 5. Panorámica de las fortificaciones de la vertiente septentrional de la arx Hasdrubalis. Archivo gráfico del Proyecto Arx Hasdrubalis.

tal se ha constatado cómo a la muralla bárquida se superpuso la cinta muraria romanorrepublicana, cuyo trazado a su vez quedó fosilizado a mediados del siglo Xvi por la muralla promovida por Carlos I y construida por Sebastián Clavijo, deán de Cartagena. ${ }^{6}$ Parece factible que el propio emperador y sus ingenieros, en la visita que realizaron a la ciudad y a este mismo cerro a principios de diciembre de 1541, llegaran a contemplar la primitiva muralla romana ya entonces arruinada, y que para su fortificación decidieran un trazado similar que, además, permitiría utilizar como cantera los materiales empleados en los antiguos muros (Martínez et al. 2014, 182 y 199) (fig. 5).
El cerco tardío reaprovechó en buena medida el lienzo de ca. $34 \mathrm{~m}$ de longitud de la muralla republicana acasamatada, levantada, como hemos referido, sobre los restos destruidos y amortizados de la muralla púnica. Esta dinámica de reutilización no implicó una preservación integral, sino la suma de acciones de remodelación diversas. Así, es posible apreciar desde la amortización y obliteración de ciertos sectores hasta el recrecido y refuerzo de otros. Desde el punto de vista geoestratégico, la disposición del cerco republicano -deudor, insistimos, del precedente bárquida- es la más idónea, pues se alza en la cota más elevada del flanco septentrional del cerro del Molinete

6. Dado que este trabajo se ciñe al periodo tardío, para un estudio minucioso de los diversos cercos remitimos a los sucesivos estudios monográficos. Así, para la cerca bárquida, vid. Noguera, Madrid y Velasco 2011-2012; para la muralla acasamatada romana: Noguera, Madrid y Martínez 2012-2013 y Noguera et al. 2017; y para la muralla renacentista: Martínez et al. 2014. 
y, por consiguiente, a más de $30 \mathrm{~m}$ de altitud sobre el nivel de la laguna interior que delimitaba la ciudad por el norte. La fuerte inclinación de la pendiente en esta zona de la vertiente septentrional del cerro, con un abrupto cambio de nivel, tal y como han demostrado algunos sondeos arqueológicos (Roldán y Miquel 2002, 247), son factores a considerar en la prolongada perduración de este cerco defensivo. De este modo, los paramentos externos o los tirantes perpendiculares que delimitan toda una serie de cajones o compartimentos -de los que se han conservado al menos seis- muestran remodelaciones de diversa entidad constructiva, que se prolongan hasta el siglo VII.

Tales prácticas de reutilización son usuales en la poliorcética tardía, como muestran la Cartago africana, donde se reconstruye la muralla teodosiana (Morrisson y Sodini 2002, 173), o Sucidava, donde se opta por un considerable refuerzo, que aumenta su grosor (Ravegnani 1983, 36-37). Notable es también el caso de Emerita, que, dentro de su trayectoria de capital de la diocesis Hispaniarum y posterior sede sueva, refuerza la muralla precedente con una actuación mucho más ambiciosa y hasta simbólica, intentando evocar la Jerusalén celeste (Mateos 2018, 145-146, fig. 11; Alba 2018, 59-62, fig. 5). También ciudades como Barcino (Puig y Rodà 2007, 617) o Legio VII (García, Morillo y Durán 2007, 392-393) recurrieron a forros que reforzaron, ensancharon y ocultaron los encintados preexistentes. Cabe recordar, igualmente, Itálica, cuyos muros, como refiere Juan de Bíclaro (Ioh. Bicl., Chron., a. 582, 3 y 583), fueron restaurados por Leovigildo $c a$. 583-584. En el caso del sureste, ocupa un lugar especial el Tolmo de Minateda, cuyo baluarte se erige en paralelo a las murallas anteriores (Gutiérrez y Abad 2001, 133143).

En Cartagena por desgracia, esta secuencia solo puede ser reconstruida de forma parcial, pues la dilatada ocupación del cerro del Molinete, sobre todo durante el siglo xIX y la primera mitad del xx, conllevó nuevos episodios «intrusivos», que destruyeron o alteraron parte del depósito estratigráfico. El progresivo surgimiento de un populoso barrio y la construcción de sus calles y casas hicieron que algunas estructuras se recrecieran o se adosaran a los antiguos muros. Asimismo, sus infraestructuras, pozos ciegos, atarjeas y alcantarillados, en ocasiones fueron recortados en la misma roca, eliminando toda la secuencia precedente. En este contexto, uno de los ejemplos más bellos, pero a la par más descorazonadores, es el de una cisterna de tipo helenístico $a$ bagnarola, asociada a la muralla púnica de la cima del cerro; su reutilización como aljibe doméstico hasta época reciente nos ha privado de conocer la casi totalidad de las fases que mediaron entre ambos momentos (Noguera, Madrid y Velasco 20112012, 492-493, fig. 13).

A esta intensa secuencia ocupacional hay que sumarle el impacto ejercido por los sucesivos planes de reforma urbana a partir de los años sesenta del pasado siglo. De hecho, la degradación económica, social y urbana que el cerro del Molinete sufrió en la posguerra española motivó la expropiación y demolición de casi toda la zona. Con ello, en ciertas áreas de este perímetro de unos 3.000 $\mathrm{m}^{2}$ de extensión, la conservación de las estructuras antiguas y sus depósitos asociados es ciertamente precaria.

Las murallas documentadas no se han librado de la afección de estos episodios ocupacionales modernos. Así ocurre, por ejemplo, en el límite occidental de la fortificación republicana, sobre el denominado ambiente $n .^{\circ} 10$, donde los pavimentos de las viviendas del siglo $\mathrm{xx}$ apoyaban directamente sobre la roca natural. Algo similar podemos señalar para el extremo opuesto, el oriental, donde la Muralla de Carlos I parece haber desmantelado los mampuestos romanos. Ambos casos ilustran acerca del arrasamiento de ciertos sectores, haciendo que, en ocasiones, solo podamos seguir la construcción del primitivo cerco a partir del recorte alisado del substrato rocoso, que sirve de cimentación a sus desaparecidos paramentos.

\subsection{Un nuevo tramo de la fortificación de época bizantina: evidencias de datación}

El hecho de que la fortificación tardía reutilice las murallas precedentes, superponiéndose directamente a ellas en algunos tramos, o que la azarosa ocupación de esta parte de la colina haya arrasado ciertos sectores hasta llegar a la roca madre, ha provocado que no dispongamos de rellenos constructivos que favorezcan una datación ajustada del comienzo de la edificación. Solo se han podido registrar contextos de diversa naturaleza que permiten documentar su uso durante la segunda mitad del siglo vi y el primer cuarto del VII.

Para constatar la perduración de las instalaciones defensivas romanas, ha resultado de suma importancia la excavación de un colector longitudinal (UE 11080) conectado a una fosa (UE 11099), que evacuarían las aguas de la cima fortificada. La infraestructura debió de mantenerse en uso hasta un momento avanzado del siglo VI, cuando, de forma coetánea al «repristino» de los muros, se vertieron en ella toda una serie de rellenos (UUEE 11096, 11079, 11108). El primero de ellos (UE 11096) contiene un interesante depósito cerámico (fig. 6). Entre las formas documentadas, destaca una de las ánforas orientales más 




FIgURA 6. Materiales cerámicos más representativos del relleno UE 11096 que colmata el colector asociado a las fortificaciones. Dibujo: Lorenzo Suárez. 
difundidas entre los siglos IV y vII, el tipo LRA 1 / Keay LIII. Se trata de una de sus variantes más tardías (MOL 10 11096-256-1), el tipo LRA 1B1 (Pieri 2005, 15-18 y 75-76). Junto a este único contenedor oriental, se registró otro de módulo cilíndrico y grandes dimensiones (MOL 10 11096159-1), que puede adscribirse al tipo ibicenco RE0103. Su similitud con el tipo norteafricano Keay XXXII había llevado a tenerlo como una posible variante, si bien el análisis de las arcillas y una documentación cada vez más numerosa confirman su origen baleárico, y concretamente ibicenco. Su producción se sitúa entre finales del siglo v y mediados del VII, con un punto álgido de su comercialización durante la segunda mitad del siglo vI (Ramon 2008, fig. 7). Junto con su presencia en las Baleares (Riera 2017, 476-479), se constata ampliamente en la costa levantina, en lugares como Valencia (Ribera y Rosselló 2012), el monasterio de Punta de l'Illa de Cullera o la propia Cartagena (Reynolds 2010, fig. 23b). Curiosamente, buena parte de los ejemplares comparten la abundancia de graffiti, también presentes en el ejemplar analizado. En él, a las inscripciones incisas se une el titulus «Georgius», nombre de origen oriental que, sin embargo, está escrito en grafía latina. Precisamente, esta última también coadyuva a la datación del ejemplar, pues algunos de sus caracteres, con sus «crochets ondulés décoratifs», son propios de la «écriture de la période byzantine» a partir de un momento avanzado del siglo vi (Ennabli 1975, 44-49). Ocurre así, por ejemplo, con la letra $G$, cuyo remate inferior adquiere un desarrollo sinuoso, emulando prácticamente una suerte de $S$ horizontal. Cabe reseñar, por último, que el ánfora conserva su primitivo cierre integrado por un opérculo de yeso.

Junto a otros restos informes de ánforas de producción norteafricana, el relleno del colector contaba también con un abundante lote de cerámicas de cocina de producción local. Destacan las ollas, dos de ellas (MOL 10 11096-184-1 y 184-3) pertenecientes a los tipos CT 3.2 y CT 2 (Laíz y Ruiz 1988, figs. 5 y 6.34). Completan el registro algunos restos malacológicos de procedencia marina que ayudan a comprender la naturaleza del primitivo contexto emisor, posiblemente los habitáculos que se adosan a la muralla tardía.

Para la datación de esta obra defensiva también hemos de considerar las fosas practicadas a lo largo de su trazado, a menudo sobre el mismo paramento septentrional de la muralla republicana que reutiliza. Así sucede, por ejemplo, con la fosa UE 11252, cuyo relleno (UE 11095) incluye un significativo lote de materiales cerámicos. Junto con abundante material residual, sobresalen los recipientes de cocina de producción local, representados tanto por ollas (tipos CT 1.4 y 3.1)

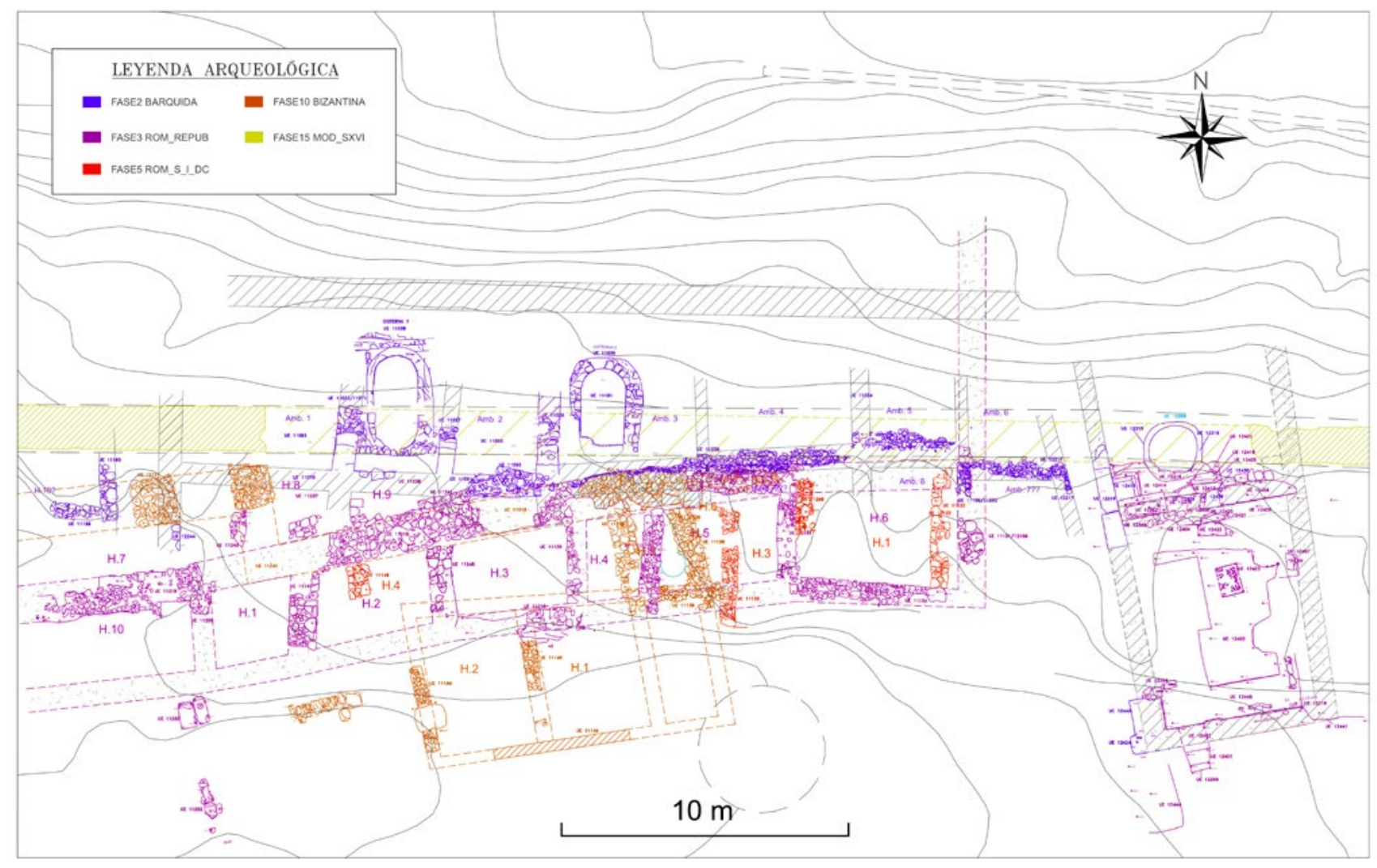

Figura 7. Planimetría de las fortificaciones de la cima de la arx Hasdrubalis. En color marrón se indican los muros pertenecientes a la etapa bizantina. Archivo gráfico del Proyecto Arx Hasdrubalis. 
como por cazuelas (CT 11) y tapaderas (CT 14). Igualmente, se documentan sendos spatheia, así como las típicas ánforas de producción local que imitan el módulo de los contenedores orientales LRA1 / Keay LIII. En esta misma dirección, hay que destacar el relleno (UE 11015) de una trinchera de expolio (UE 11018), que proporcionó un cuenco con listel en terra sigillata africana D, Hayes 91 (Bonifay 2004, 179-181).

Junto con estos depósitos, el entorno más inmediato también proporciona evidencias para aquilatar el periodo de uso de la muralla. Es ilustrativo el ejemplo de la fosa UE 12230, de ca. 2 $\mathrm{m}$ de diámetro, excavada sobre el témenos de un antiguo santuario itálico, abandonado desde hacía mucho tiempo. Sus rellenos (UUEE 12231 y 12315) se componen de abundante material cerámico, entre el que, junto con las habituales ollas y cazuelas de producción local, destaca el cuenco en terra sigillata africana D, Hayes 99 C. Otro tanto podemos señalar para la zona del podium del templo del santuario y su escalinata de acceso, donde se practicaron fosas, como la UE 12161, que han aportado las tradicionales vajillas y, en algún caso, material anfórico, como un posible pivote del contenedor africano Keay LXI / LXII.

Otras evidencias de valor son los aterrazamientos o explanaciones llevados a cabo en esta parte oriental de la colina, en particular sobre el antiguo tejido monumental. Uno de estos estratos (UE 12311) ha proporcionado material claramente fechado a partir de finales del siglo vi, caso del cuenco en terra sigillata africana D, Hayes 108.

En conjunto, como vemos, los materiales cerámicos remiten a los siglos VI y VII, lo que permite, en unión a otras consideraciones de índole estratigráfica y la lectura de los paramentos, defender la erección de la muralla tardía, o al menos una parte sustancial de su remodelación, coincidiendo con la ocupación de los milites romani.

\subsection{La muralla de época bizantina en la cima de la arx Hasdrubalis: análisis edilicio y constructivo}

Aunque es difícil inferir la configuración integral de la fortificación tardoantigua, calibrando su envergadura real y sentido programático, la documentación disponible muestra un diseño vertebrado en torno a un eje longitudinal (fig. 7). El trazado conservado se ciñe a $6 \mathrm{~m}$ de longitud y una anchura de $1,10 \mathrm{~m}$, apoyándose tanto en el paramento exterior de la muralla republicana (UE 11019) como en los muros medianeros de algunos de sus ambientes internos. De hecho, es necesario insistir en la combinación de acciones edilicias diversas y, en ocasiones, aparentemente contradic- torias, como la fosilización, cuando no amortización o incluso parcial desmantelamiento, de una misma estructura.

En el extremo occidental, en una situación avanzada respecto a la muralla republicana, la cinta tardía consta de sendos muros paralelos. Avanzando hacia el este, estos se pliegan hacia el sur, superponiéndose al forro septentrional de la muralla romana. Aunque la documentación es muy parcial, destaca semejante quiebre o retranqueo, testimonio de la adaptación a los condicionantes topográficos y a la estrategia de reempleo de las fortificaciones precedentes. Por otra parte, el forro septentrional republicano es recrecido, y cobija un pequeño conjunto de habitáculos dispuestos en batería, que cuentan con planta alargada y una anchura variable, definiendo un módulo aproximadamente rectangular. Una de estas estancias (n. ${ }^{\circ} 3$ ) conecta directamente con el muro, sirviendo de pieza de enlace para las restantes (n. ${ }^{\circ}$ 1 y 2 ).

Desde el punto de vista constructivo, la obra se edificó con piedras calizas, esquistos y areniscas de mediano y gran tamaño, trabadas con barro. En este punto, cabe señalar que tales refacciones siguen la misma pauta de funcionalidad y modestia constructiva que la muralla del siglo if a. C., de forma que las diferencias entre una y otra fase, $o$ mejor, entre la primitiva y su posterior «repristino», estriban más en la variación de ejes, orientación, etc., que propiamente en el uso de patrones constructivos netamente diversos. Así, del mismo modo que la fortificación republicana cuenta con mampostería irregular trabada con barro y con un careado bastante imperfecto, el cerco tardío tiene también ciertos paños de ejecución técnica sumaria.

Una de las pautas constructivas más destacadas es el intenso reaprovechamiento. En este tramo de muralla tardía lo apreciamos, sobre todo, en el extremo oriental (UE 11117), sector que integra cuatro antiguos sillares, uno de ellos de arenisca y los otros tres, de menor tamaño, elaborados en caliza. No faltan incluso otros materiales privados de su primitiva función, sea el caso de una basa corintia o una placa decorativa, ahora embutidas como mero aglutinante. A lo largo de la cima se han podido documentar diferentes modalidades para acopio de material, tanto «trincheras» como las más usuales fosas de planta circular, del tipo de la UE 11252, de ca. 1,60 m diámetro. En ocasiones, el expolio afecta seriamente a las estructuras precedentes, como ocurre con la trinchera UE 11018, que desmantela parcialmente el ambiente $\mathrm{n} .^{\circ} 1$ de la muralla púnica; o la trinchera UE $11043(4 \times 1 \mathrm{~m})$ y la fosa de planta irregular UE $11251(2 \times 1,5 \mathrm{~m})$, practicadas sobre el forro 
(UE 11246) que refuerza la cara norte del paño exterior de la muralla republicana.

Siendo un comportamiento común al conjunto de la edilicia tardía (Beltrán y Macías 2016, 1821), tal reciclaje es recurrente en la de tipo militar, donde la administración la recomienda, con disposiciones como la del Cod. Theod., xv, 1, 36, que ya en el año 397 emplaza a la reparación de murallas, puentes y otras infraestructuras recurriendo al material proveniente de la demolición de los antiguos templos. En la misma línea, una de las fuentes primordiales para la poliorcética de esta etapa, el anónimo De re strategica (x, 3), datado a finales del siglo vi, recomienda la utilización de piedras ya talladas cuando estas estuvieran disponibles (Ravegnani 1983, 86).

Referente al aparejo, en el cerco tardío la disposición de los materiales suele ser con frecuencia irregular, sin que conformen hiladas horizontales de forma sistemática. De hecho, aunque la precaria conservación de las estructuras sugiere la prudencia, sorprende que no se recurra a la técnica que en otros puntos del cerro, precisamente entre los siglos v y vII, se asocia a la trabazón con material reutilizado, el pseudo opus africanum (Noguera, Vizcaíno y Madrid e. p.). A este respecto, en el lienzo aquí analizado no se reconoce tal técnica, sin embargo muy común en la arquitectura defensiva bizantina del norte de África (Duval 1983), o en fortificaciones hispanas como Pollentia, el Tolmo de Minateda, Sant Julià de Ramis o la misma Valentia (Beltrán y Macías 2016, 25-26, fig. 11-12). Tampoco se constata el opus spicatum, habitual en época altomedieval, sobre todo en fortificaciones, como muestran la muralla de Puig Rom o el castellum de Sant Julià de Ramis (Beltrán y Macías 2016, 23-24, figs. 9 y 13). Con todo, lo cierto es que la arquitectura militar de esta etapa dio cabida a patrones constructivos diversos, determinados por numerosos condicionantes, como la disponibilidad de recursos o la urgencia de prevenir ataques (Zanini 1998, 287; Cagnana 2001, 205-209).

Pasando a un análisis más detallado del lienzo exhumado, el primer elemento a destacar es el potente paramento occidental (UUEE 11121 y 11120), levantado sobre las antiguas estancias republicanas 7 y 8 (fig. 8). La remodelación de este sector implicó la excavación de una fosa de expolio (UE 11253) que cortó los niveles de colmatación y el suelo de la citada estancia n. ${ }^{\circ}$ 7. En esta zona, el desmantelamiento parece ser la tónica dominante. Así, en el caso de la estancia n. ${ }^{\circ} 8$, otra fosa de época bizantina (UE 11251) provoca que no conservemos más que un sillarejo de arenisca del originario muro oriental. Otras zanjas coetáneas (UUEE 11043 y 11018) desarticularon igualmente las estancias anejas, cuyo abandono y amortización, en cualquier caso, parecen situarse ya a finales del siglo II a. C. o comienzos de la siguiente centuria. En este punto, cabe preguntarse si la fase bizantina, con dichas acciones intrusivas, implicó una merma real de las potencialidades defensivas de la fortificación republicana o si, simplemente, prosiguió con la obliteración de los paños ya fuera de uso.

A partir de este extremo noroccidental (UUEE 1121 y 11120), la muralla experimenta el citado retranqueo hacia el mediodía, si bien la documentación es harto fragmentaria, dada la proliferación de fosas y pozos. No es raro que la potencia de algunas de ellas afecte incluso al primitivo cerco púnico, como ocurre con la trinchera de expolio UE 11241, practicada justo donde debió de situarse el arriba mencionado quiebre. Dicha trinchera, en sus $5 \mathrm{~m}$ de longitud y 1,20 $\mathrm{m}$ de ancho, llegó a desmantelar incluso parte del muro septentrional (UE 11091) de uno de los ambientes púnicos (n. ${ }^{\circ}$ 2), situado entre dos de las cisternas de esa etapa. También el expolio afectó al paramento exterior septentrional de la muralla republicana (UUEE 11019-11140). Sobre él se constatan afecciones de diversa entidad, entre las que destaca una zanja (UE 11018) de cierta envergadura (5 x $2 \mathrm{~m}$ ). Sus rellenos (UUEE 11015, 11016, 11051, 11054 y 11055) incluyen piedras de medio y gran tamaño, gravillas y arenas, así como, en algún caso, argamasa y mortero hidráulico.

Tras diferentes «lagunas», la muralla tardía vuelve a documentarse ya casi en el extremo oriental (UE 11117), donde se situaban las casamatas republicanas n. ${ }^{\circ} 4$ y 5 . Precisamente aquí se han podido excavar una serie de estancias anexas datadas en los siglos vi y vII. La primera apoya directamente en el muro maestro UE 11117, conformando una habitación rectangular (n. 3 ), con un espacio interno de ca. $12 \mathrm{~m}^{2}$ (fig. 9). Quedaba limitada a oeste y este, respectivamente, por los muros UUEE 11128 y 11139 . Este último hace de medianero con otro ambiente a oriente, apenas conservado (habitación n. ${ }^{\circ}$ 6). El muro, con una longitud de 3,30 $\mathrm{m}$ y una anchura que alcanzaba un máximo de 0,85 m -reduciéndose, en algunos casos, hasta los 0,50 m-, tenía una orientación norte-sur, y estaba constituido por cinco hileras de piedras de mediano y gran tamaño, también compactadas con barro. La habitación n. ${ }^{\circ} 3$ estaba cerrada al sur por el muro UE 11138, apoyado sobre la roca natural regularizada. Con una longitud de 2,05 m y una anchura máxima de 0,89 $\mathrm{m}$, conserva solo tres hileras de piedras calizas y costras calizas de pequeño y mediano tamaño trabadas con barro. Dicho paramento (UE 11138) parece actuar de muro maestro para, al menos, 


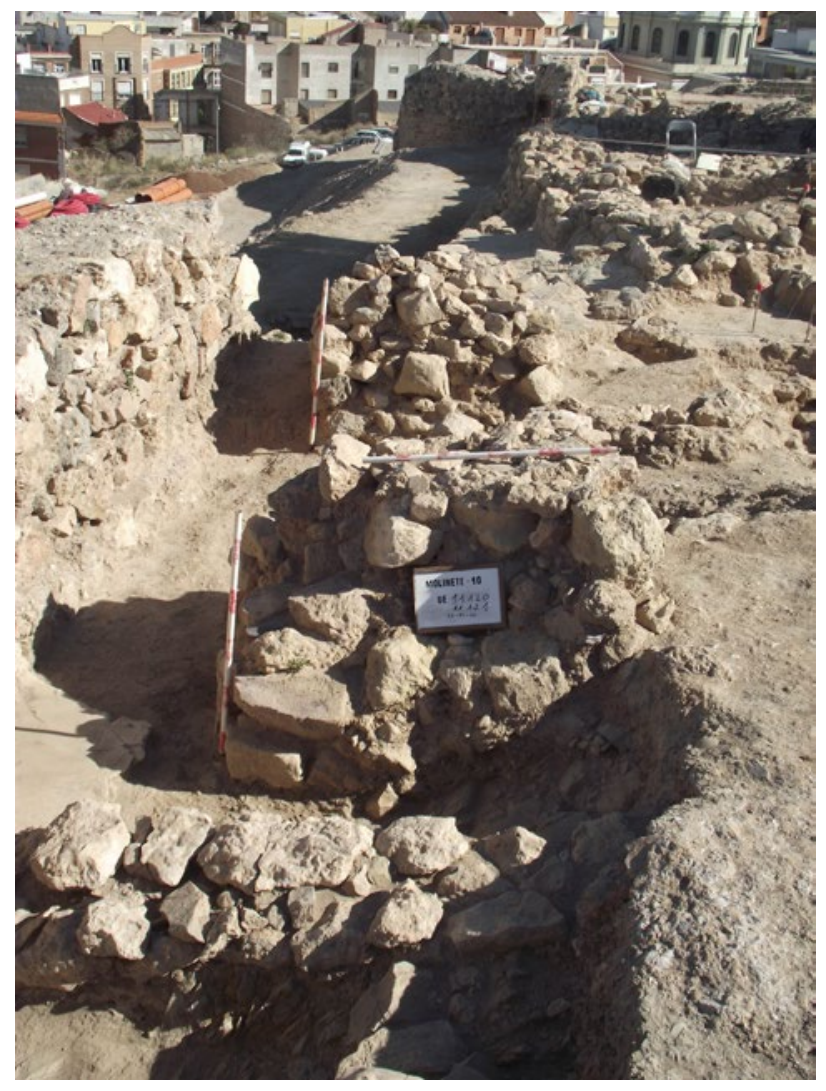

FIgURa 8. Sección de los muros UUEE 11020 y 11021, dispuestos en paralelo a la fortificación de época moderna. Archivo gráfico del Proyecto Arx Hasdrubalis.

tres estancias rectangulares dispuestas en batería. Con todo, desgraciadamente la documentación vuelve a ser muy fragmentaria y apenas queda más que la delimitación de dos de estas habitaciones (n. ${ }^{\circ}$ 1-2) (fig. 10); estas están cerradas en su lado meridional mediante un muro en dirección este-oeste (UE 11149), construido con piedras de tamaño pequeño y mediano trabadas con barro.

En el caso de la habitación $n .^{\circ} 1$, conservamos su delimitación oriental, el muro UE 11254, que apoya en el estrato UE 11185, relleno de la fosa bizantina UE 11072. La estancia contaba con un pavimento (UUEE 11098 y 11141) de tierra arcillosa. Los estratos de colmatación como la UE 11078 , caracterizados por su composición arcillosa de color rojizo-anaranjado, podrían ser fruto de la disolución de adobes que originariamente pudieron completar el alzado de los muros. La abundante presencia de filitas podría indicar su utilización en la desaparecida cubierta, como es tan habitual en la edilicia del periodo.

De la anexa habitación $n .^{\circ} 2$, de planta aproximadamente trapezoidal, tampoco conservamos mucho más. Sí se ha podido documentar su límite occidental en el muro UE 11144, que apoyaría en los mencionados muros maestros UE 11138 y UE 11149. Con unas dimensiones de 1,30 por $0,47 \mathrm{~m}$, restan poco más de tres hiladas. De la misma forma, a pesar de la intensa transformación de épocas posteriores, se pudo registrar su pavimento (UE 11142) de tierra beis clara con carboncillos.

El adosamiento a la muralla de toda una serie de compartimentos en batería es habitual en la poliorcética de época tardía, y se constata en murallas urbanas, fortines y castra. Valga como ejemplo la fortaleza norteafricana de Thamugadi, construida entre los años 539-540, con estancias regulares (4,4 x 2,60 m). En ocasiones, dichas estancias llegaban a tener dos plantas, la inferior de las cuales estaba destinada a los caballos (Ravegnani 2007, 130-132). Dentro de esta nómina destaca el caso de Biograc, una fortificación bajoimperial en los Balcanes reformada durante los siglos VI y vII, don-



Figura 9. Vista de la habitación $n .^{\circ} 3$ adosada a la muralla de época bizantina (UE 11117). Bajo las estructuras señalizadas se aprecian algunos de los muros amortizados de las fortificaciones precedentes. Archivo gráfico del Proyecto Arx Hasdrubalis. 


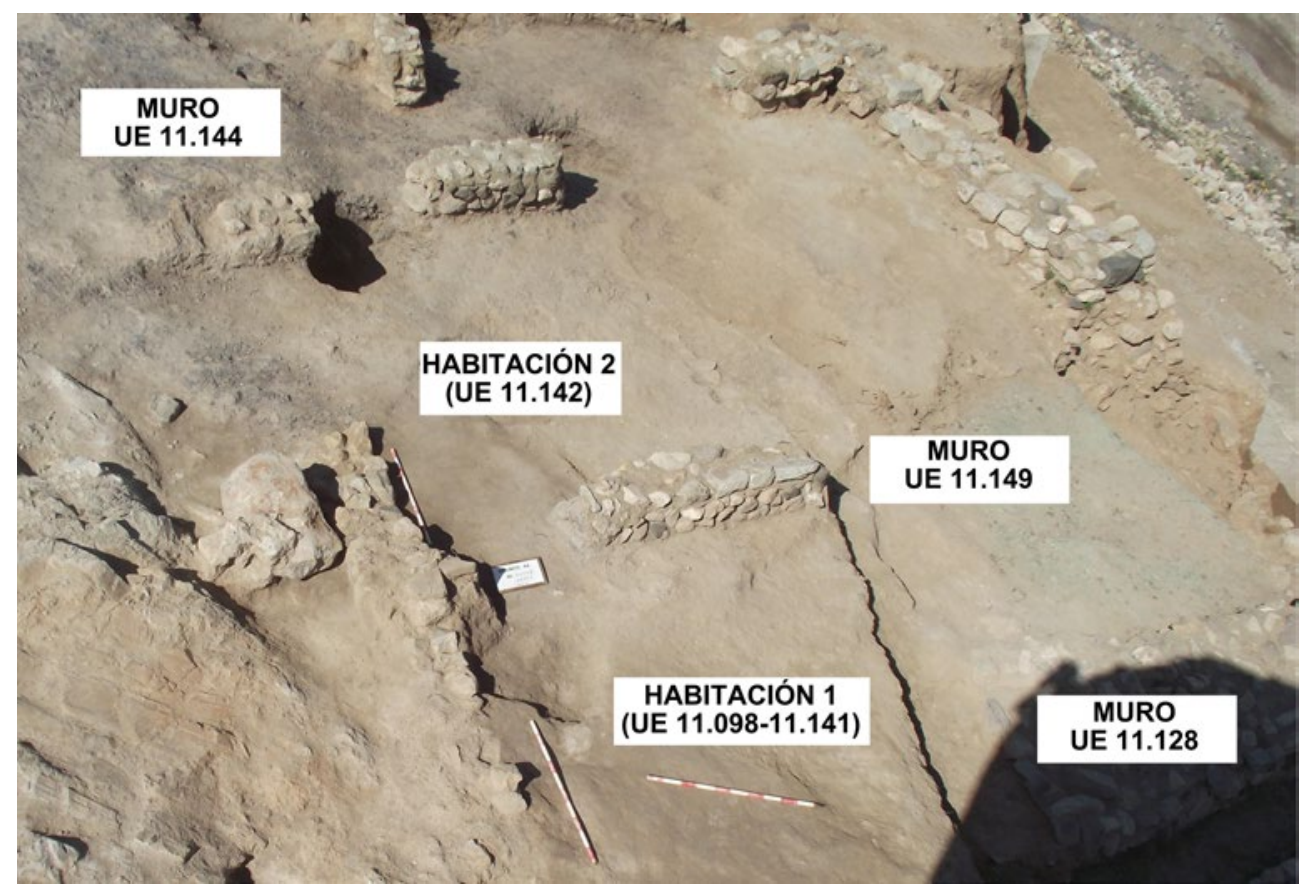

Figura 10. Vista de las habitaciones de época bizantina $n .^{\circ} 1$ y 2. Archivo gráfico del Proyecto Arx Hasdrubalis. de se han individualizado, junto con los barracones para la propia guarnición y sus pertrechos, otros compartimentos dotados de revestimiento hidráulico, que se interpretan como cisternas para el aprovisionamiento hídrico ante eventuales asedios (Špehar 2008, 577-579, fig. 11). En el caso de la ciudad «ideal» de Iustiniana Prima, son las propias viviendas las que a veces se yuxtaponen a los muros (Bavant y Ivanisevic 2001, 966).

En otro orden de cosas, la refacción defensiva de época tardía también comportó una adecuación del conjunto de la cima del cerro, donde se concentraban algunos de los hitos monumentales de época republicana, como un santuario púnico dedicado a Atargatis y un santuario romano republicano aterrazado con un templo de tradición itálica (Noguera y Madrid 2017). Ambos, ya arruinados en época tardía, sirvieron también como eficaz cantera. Se han constatado zanjas como la UE 12434, de forma ovalada (2,10 m de longitud y $1 \mathrm{~m}$ de anchura máxima), que fue practicada sobre el área occidental del témenos del templo itálico y cortó todos los niveles inferiores hasta alcanzar incluso el suelo original. Realizado el acopio de material, la suerte de tal fosa es similar a la de tantas otras dispersas por la colina, convirtiéndose en un potente vertedero, en cuyos vertidos (UUEE 12266, 12354, 12369 y 12379) se documentan abundantes restos orgánicos, además de material cerámico de diversa cronología.

Tales depósitos de vertido, entre los que hay que incluir las fosas UE 12230 o 12161 ya referidas, muestran la realidad de ocupación del área, sus contextos emisores, que habrían de ser sencillos habitáculos apenas distantes de los muros.
Aunque las vicisitudes estratigráficas ya comentadas y, sin duda, el propio carácter "endeble» de estas construcciones secundarias han hecho que apenas queden restos de su trazado, existe alguna evidencia significativa. Es el caso de un nivel de uso (UE 12264), localizado en la parte más meridional del santuario, del que resta un suelo de tierra, de consistencia media-blanda, con algunas piedras y fragmentos de cerámica. También en el área que se corresponde con el cierre del antiguo santuario de Atargatis y la escalera meridional de acceso a la sala se han documentado una serie de estratos de colmatación, entre los que sobresale uno (UE 12274) formado básicamente por bloques de tamaño medio de andesita y costra caliza, posibles restos de las estructuras de la zona.

La habilitación de tales ambientes sobre los restos del antiguo tejido monumental de la cima del cerro también comportó diferentes aterrazamientos o explanaciones. De hecho, durante este periodo culminó el proceso de colmatación del sistema de doble rampa recortado en la roca, que daba acceso al templo itálico. Dicha colmatación, prolongada por sucesivos estratos de amortización que hay que situar a partir del siglo i d. C., registra durante los siglos VI-VII su ritmo más activo, como muestran toda una serie de estratos (UUEE 12309, 12311, 12314, 12319, 12320, 12322 y 12327). Estas unidades integran un depósito cerámico heterogéneo mezclado con arenas y gravas que, trabados y compactados, muestran la intencionalidad de tal acción de aterrazamiento y no su carácter de simple escorrentía. A consecuencia de esa explanación, la primitiva escalera monumental de acceso al templo itálico, que 
constituía parte esencial de la escenografía del conjunto, quedó ahora convertida en una suerte de explanada privada de cualquier perspectiva y connotación simbólica.

\section{Quisquis ardua turrium miraris culmina (CIL II 3420)}

Aunque las excavaciones en la cima del Molinete proporcionan los primeros testimonios materiales acerca de la muralla de Carthago Spartaria durante el periodo bizantino, es preciso ser cautos a la hora de extrapolar sus características a las de otros sectores del encintado. De una parte, las condiciones de conservación, con el arrasamiento de algunas zonas, limitan la comprensión integral de su imagen primitiva. De otra, nada apoya por el momento que dicha fortificación tardía se ejecutara en un mismo momento, ni que el conjunto de los paños que integraban el perímetro amurallado compartiesen las mismas características constructivas. Antes bien, las excavaciones del Molinete parecen probar lo contrario, es decir, cómo un mismo cerco defensivo integra lienzos concebidos y ejecutados de forma diversa en función de los condicionantes topográficos o consideraciones geoestratégicas y simbólicas. Lo vemos claramente para las otras dos etapas de fortificación documentadas, la púnica y la romanorrepublicana, y posiblemente pudo ocurrir lo mismo en época tardía.

En el caso de la muralla púnica, resulta elocuente confrontar el tramo exhumado en el Molinete con el previamente localizado en la principal zona de acceso a Qart Hadasth. Ambos son tributarios de un mismo proyecto defensivo-arquitectónico y comparten una misma tipología acasamatada, pero razones tácticas y simbólicas llevan a que los esfuerzos constructivos y monumentales se centren en el istmo que daba acceso a la ciudad. Así, mientras que este último cuenta con una sólida muralla de sillares de opus quadratum y casamatas de opus africanum, capaz de expresar la grandeza de la capital bárquida a la par que repeler un ataque con arietes $\mathrm{u}$ otros ingenios de guerra, para la defensa de la arx Hasdrubalis, esto es, del flanco noroccidental de la urbe, se optó por una arquitectura de sesgo funcional, desprovista de aparato «escenográfico», con aparejo de mampostería y adobes (Noguera, Madrid y Velasco 2011-2012, 500).

Para época romanorrepublicana también parece clara la coexistencia de soluciones para los diferentes tramos del perímetro amurallado. En este caso, en el cerro de la Concepción (Murcia, Ruiz y Ramallo 2013) o en la calle Mayor, se re- curre a potentes paramentos de mampostería, en tanto que en la arx Hasdrubalis se utiliza el modelo de casamatas, claro reflejo de la impronta "punicizante» que mantuvo la civitas (Noguera et al. 2017). Insistiendo en ello, en la ejecución diacrónica de un mismo encintado a través de sucesivos tramos, con todo lo que puede implicar de heterogeneidad, la documentación epigráfica evidencia acciones constructivas diversas entre finales de la República y época augustea (Díaz 2008).

Todo ello lleva a sugerir que las características de la fortificación tardía de la cima amesetada del cerro del Molinete aquí analizadas han de tenerse como una solución específica, puntual, concebida para este sector concreto de la topografía de la ciudad. La situación relativamente «marginal» del flanco, distante de las calzadas y los accesos a la urbe, limitando la zona de marjal en la que habría devenido la laguna interna, o su protección natural por el propio desnivel del cerro, con cierto escarpe, son factores a tener en cuenta en la entidad de la construcción. Evidentemente, las posibilidades de reaprovechamiento de los encintados previos también son determinantes. En fechas prácticamente coetáneas, no faltan ejemplos de complementariedad de soluciones constructivas para un mismo cerco, como ocurre en Emerita, donde el forro de refuerzo tardío construido a finales del siglo $\mathrm{v}$ con abundante material reutilizado no está presente, por ejemplo, en los lienzos de muralla que cierran algunas de las puertas del anfiteatro (Mateos 2018, 145).

En este mismo orden de cosas, en Carthago Spartaria, la puerta y el lienzo mencionados en la inscripción del patricius Comenciolus, magister militum Spaniae, muy poco o nada tendrían que ver seguramente con el paño exhumado en el cerro del Molinete. Es razonable que los esfuerzos del general missus a Mauricio Augusto contra hostes barbaros en 589-590 se concentraran en torno al principal acceso de la urbe, como verdadero emblema para que sic semper Hispania tali rectore laetetur. Con todo, deben ser considerados también el hecho de que este epígrafe contenga toda una serie de fórmulas estereotipadas según recurso habitual de la ekphrasis, y que en la propia África bizantina se haya podido contrastar este tipo de inscripciones con el verdadero calibre de sus fortificaciones, a veces manifiestamente modesto pese a sus enunciados hiperbólicos (Fontaine 2000). La materialidad de las estructuras referidas por el epígrafe es una de las cuestiones que futuras investigaciones deberán precisar.

Sea como fuere, el tramo de muralla ahora documentado en la cima de la arx Hasdrubalis, así como el barrio que cobija en su ladera sureste, son testimonios de una ocupación bizantina que, en 
buena parte, tiene un fuerte componente militar y debe entenderse en el contexto del conflicto greco-gótico en el sureste hispano (Gutiérrez 1999). No faltan restos de armamento para ilustrar el acuartelamiento de tales efectivos, como es el caso, muy particularmente, de una coraza de tipo laminar o puntas de flecha de tipo ávaro (Vizcaíno 2008b). Es en esas coordenadas, en el despliegue de los milites romani y en su mantenimiento por parte de la renovada annona, en el que también posiblemente debamos entender buena parte de los depósitos cerámicos de Carthago Spartaria durante los siglos VI y VII. El barrio bizantino de la vetusta arx Hasdrubalis aporta como evidencia privilegiada tipos anfóricos que se han vinculado al suministro estatal para abastecer a las tropas desplegadas en las principales ciudades y castra del Mediterráneo occidental, como el caso del $\mathrm{Sa}$ mos cistern type (Arthur 1990). Son datos que habrá que ir tejiendo y que recuerdan, una vez más, la necesidad de un estudio integral, holístico, de estructuras, contextos materiales asociados y, por supuesto, documentación textual.

\section{Bibliografía}

Abascal, J. M.; Ramallo, S. F. 1997: La ciudad de Carthago Nova: la documentación epigráfica, Murcia.

Alba, M. 2018: «Secuencias en la transformación de Augusta Emerita (siglos I-IX): tres concepciones distintas de ser ciudad», en: Panzram, S.; Callegarin, L. Entre civitas y madīna. El mundo de las ciudades en la Península Ibérica y en el norte de África (siglos IV-IX), Collection de la Casa de Velázquez, 167, Madrid, 51-74.

ARthur, P. 1990: "Anfore dall'Alto Adriatico e il problema del Samos cistern type», Aquileia Nostra, LXI, 281-296.

Bavant, B.; Ivanisevic, V. 2001: "Caričin Grad (Yougoslavie): la campagne de fouille de 2001 », en: MEFRM, 113.2, 963-971.

Beltrán, J.; Macías, J. M. 2016: «Técnicas constructivas en la Tarraconensis durante la Antigüedad Tardía. Planteamiento y estrategias de investigación para una propuesta de síntesis», QUARHIS, II, 12, 17-39.

BERnAL, D. 2018: "Continuidad y cesura en las ciudades tardorromanas del estrecho de Gibraltar. El fretum Gaditanum, un ámbito hispanoafricano singular», en: PANZRAM, S.; CALlegarin, L. Entre civitas y madina. El mundo de las ciudades en la Península Ibérica y en el norte de África (siglos IV-IX), Collection de la Casa de Velázquez, 167, Madrid, 105-118.
BONIFAY, M. 2004: Etudes sur la céramique romaine tardive d'Afrique, BAR International Series 1301.

CAGnANA, A. 2001: «Le strutture murarie in pietra: materiali, tecniche, ipotesi sulle maestranze», en: S. Antonino: un insediamento fortificato nella Liguria bizantina, Bordighera, 205-209.

Cantino Wataghin, G. 2007: "Spazio urbano tardoantico: insediamenti e mura nell'Italia Annonaria», en: MARcEnaro, M. (ed.). Albenga città episcopale. Tempi e dinamiche della cristianizzazione tra Liguria di Ponente e Provenza, Génova/Albenga, 109-148.

CRAcco Ruggini, L. 1982: "La città nel mondo antico: realtà e idea», en: WIRTH, G.; SchwARTE, K. H.; HeInRIchs, J. Romanitas-Christianitas. Untersuchungen zur Geschichte und Literatur der römischen Kaiserzeit, Berlín - Nueva York, 61-81.

Diarte, P.; Gurt, J. M. 2015: «La percepción del espacio en el urbanismo tardoantiguo: características evolutivas en el ejemplo hispano», Antiquité Tardive, 23 (Isidore de Séville et son temps), 307-328.

DíAz, B. 2008: "Las murallas romanas de Cartagena en la segunda mitad del siglo I a. C.», Zephyrus, 61.1, 225-234.

Duval, N. 1983: "L'état actuel des recherches sur les fortifications de Justinien en Afrique», en: XXX Corso di cultura sull'arte ravennatte e bizantina, Rávena, 149-204.

EnNABLI, L. 1975: Les inscriptions funéraires chrétiennes de la basilique dite de Sainte-Monique à Carthage, Roma.

Fontaine, J. 2000: "Un général byzantin en Espagne en 589: Observations sur la romanité de l'inscription byzantine de Carthagène (Vives 362)», en: Romanité et cité chrétienne. Permanences et mutations. Intégration et exclusion du Ie au vie siècle, París, 91-100.

García, V.; Morillo, A.; Durán, R. M. ${ }^{a}$ 2007: «La muralla tetrárquica de Legio: Aproximación al conocimiento de su sistema constructivo», en: Rodríguez, A.; RodÀ, I. Murallas de ciudades romanas en el occidente del Imperio. Lvcvs Avgvsti como paradigma, Lugo, 383-399.

GHedinI, F. 1993: «L'Africa Proconsulare», en: Storia di Roma. L'età tardoantica, III.II (I luoghi e le culture), Turín, 310-325.

Giménez, M.; Noguera, J. M.; Madrid, M. ${ }^{a}$ J.; MarTíNEZ, I. 2011: «Proyecto Parque Arqueológico del Molinete: intervención en la cima», en: XXII Jornadas de Patrimonio Cultural de la Región de Murcia, Murcia, 95-118.

Godoy, C. 2005: "Les ciutats d'Hispania sota la protecció dels sants màrtirs. Transformacions del concepte espai religiós entre l'Antiguitat 
Tardana i l'Edat Mitjana», en: VI Reunió d'Arqueologia Cristiana Hispànica, València 2003, Barcelona, 63-72.

Gómez, A.; Munuera, D. 2002: «El sistema defensivo de los Austrias», en: Estudio y catalogación de las defensas de Cartagena y su bahía, Murcia, 121-170.

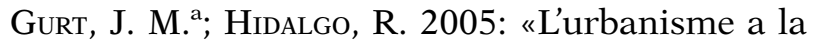
ciutat hispana al llarg de l'Antiguitat Tardana», en: VI Reunió d'Arqueologia Cristiana Hispànica (Valencia, 2003), Barcelona, 73-94.

GuRT, J. M. a; SÁNCHEZ, I. 2010: «Topografía cristiana en Hispania durante los siglos v y VI», en: Morín, J.; López, J.; Martínez, A. El tiempo de los «bárbaros». Pervivencia y transformación en Galia e Hispania (ss. V-VI) (Zona Arqueológica, 11), Madrid, 320-345.

GutiÉRrez, S. 1999: "La ciudad en la antigüedad tardía en el sureste de la provincia Carthaginiensis: La reviviscencia urbana en el marco del conflicto grecogótico», en: Complutum y las ciudades hispanas en la Antigüedad Tardia. Actas del I encuentro Hispania en la Antigüedad Tardía (Alcalá 1996), Alcalá de Henares, 101128.

GutiÉRREZ, S.; ABAD, L. 2001: «Fortificaciones urbanas altomedievales del Tolmo de Minateda (Hellín, Albacete, España): el baluarte occidental», en: Mil Anos de Fortificaçoes na Península Ibérica e no Magreb (500-1500): Actas do Simpósio Internacional sobre Castelos, Lisboa/Palmela, 133-143.

LAíz, M. ${ }^{a}$ D.; RuIZ, E. 1988: “Cerámicas de cocina de los siglos V-VII en Cartagena (C/ Orcel - Don Gil), Antigüedad y Cristianismo, v, 265-301.

MADRID, M. ${ }^{\text {a }}$ J. 2004: "Primeros avances sobre la evolución urbana del sector oriental de Carthago Noua. PERI CA-4/Barrio universitario», Mastia 3, 31-70.

Madrid, M. a J.; Celdrán, E.; Vidal, M. 2005: «La Domus de Salvius. Una casa de época altoimperial en la calle del Alto de Cartagena (PERI CA4 / Barrio Universitario)», Mastia, 4, 117152.

MADRID, M. ${ }^{\text {a }}$ J.; Vizcaíno, J. 2009: «La necrópolis oriental de Carthago Spartaria. Dinámica de un espacio funerario entre el Bajo Imperio y la Antigüedad Tardía», en: Contextos funeraris a la Mediterrània nord-occidental (segles VVIII). Taula rodona - Sant Cugat del Vallès, 1-3 d'octubre de 2009 (Gausac, 34-35), 191-209.

Martín Camino, M. 2006: "La curia de Carthago Nova», Mastia, 5, 61-84.

Martínez, J. A.; Noguera, J. M.; Madrid, M. ${ }^{\text {a }}$ J.; Martínez, I. 2014: "Las defensas de la Cartagena renacentista: evidencias arqueológicas re- cientes de las murallas de Carlos I y Felipe II», AnMurcia, 30, 179-204.

Mateos, P. 2018: «De capital de la Diócesis Hispaniarum a sede temporal de la monarquía sueva. La transformación del urbanismo en Augusta Emerita durante los ss. IV y v», en: SÁNchEZ, I.; Mateos, P. Territorio, topografía y arquitectura de poder durante la Antigüedad Tardía, Mytra, 1, 127-153.

Miquel, L. E. de; Roldán, B. 1999: «Nuevos hallazgos de fortificaciones de la Edad Moderna en el casco urbano de Cartagena», en: Actas de las II Jornadas sobre fortificaciones modernas y contemporáneas, Cartagena, 467-471.

Montañés, S.; Montañés, M. 2009: «El castillo de Medina Sidonia (Cádiz). Metodología, investigación e interpretación histórica», Caetaria, 6-7, 301-316.

Morrisson, C.; Sodini, J. P. 2002: «The Sixth-Century Economy», en: The Economic History of Byzantium. From the Seventh through the Fifteenth Century, Dumbarton Oaks Studies, xxxIX, 171-220.

Murcia, A. J.; Ruiz, E.; Ramallo, S. F. 2013: «La reestructuración del sistema defensivo a finales de la República: los rellenos constructivos de la muralla del siglo i a. C. (Cerro de la Concepción, Cartagena)», AnMurcia, 29, 103-130.

Noguera, J. M. 2016: «Avgvstevm / sede de los augustales (?), Carthago Nova (Cartagena, Murcia)», en: Los espacios de reunión de las asociaciones romanas. Diálogos desde la arqueología y la historia en homenaje a Bertrand Goffaux, Sevilla, 389-395.

Noguera, J. M.; CÁnovas, A.; Madrid, M. ${ }^{\text {a }}$ J.; MartíNEZ, I. 2016: Barrio del Foro Romano. Molinete Cartagena. Proyecto integral de recuperación y conservación, Murcia.

- 2019: Barrio del Foro Romano. Molinete, Cartagena. Santuario de Isis y Serapis (Insula II). Proyecto integral de recuperación y conservación / Roman Forum District. Molinete, Cartagena. Sanctuary of Isis and Serapis (Insula II). Recovery and conservation, Murcia.

Noguera, J. M.; Madrid, M. ' J. 2009: Arx Hasdrubalis. La ciudad reencontrada. Arqueología en el cerro del Molinete, Cartagena, Murcia.

- 2017: "Architettura e etnicità urbana a Carthago Nova: a proposito del santuario tardorepubblicano dell'acropoli», en: Decor. Decorazione e architettura nel mondo romano, Thiasos Monografie, 9, Roma, 643-654.


co, V. 2017: "Las defensas de Cartagena en la Antigüedad: las murallas de la acrópolis en los siglos III y II a.C.», en: Prados, F.; Sala, F. El 
Oriente de Occidente. Fenicios y púnicos en el área ibérica, Alicante, 347-383.

Noguera, J. M.; Madrid, M. ${ }^{a}$ J.; Martínez, J. A. 2012-2013: "Una historia en construcción: las defensas de Cartagena en la Antigüedad. Novedades de la muralla romana republicana», AnCórdoba, 23-24, 35-74.

Noguera, J. M.; Madrid, M. ${ }^{\text {a J }}$; Velasco, V. 20112012: "Novedades sobre la arx Hasdrubalis de Qart Hadast (Cartagena): nuevas evidencias arqueológicas de la muralla púnica», CuPAUAM, 37-38, 479-508.

Noguera, J. M.; Madrid, M. ${ }^{\text {a }}$ J.; Vizcaíno, J. [en prensa]: «Nuevos datos sobre la ocupación bizantina en Carthago Spartaria: el barrio de la antigua arx Hasdrubalis", en: Reunión científica Bizancio en Ceuta. Arqueología y comercio en el Fretum Gaditanum (siglos VI-VII d.C.) (9-10 de marzo de 2018), Ceuta.

Noguera, J. M.; Martín, M.; Soler, B. 2013: «De nuevo sobre el foro de Carthago Nova: la curia de la colonia», en: Las sedes de los ordines decvrionvm en Hispania. Análisis arquitectónico y modelo tipológico, Anejos de AEspA, 67, 135-264.

Noguera, J. M.; Vizcaíno, J.; Madrid, M. ${ }^{\mathrm{a}}$ J. [en prensa]: «Tiempos pasados y una edad nueva: la reactivación del opus africanum en Carthago Spartaria durante la etapa bizantina», en: Reunión Científica Mímesis. Imitación de los modelos clásicos y nuevos valores semánticos en el mundo tardoantiguo y medieval, Universidad de Córdoba, 11 de diciembre de 2017.

Nolla, J. M. ${ }^{\text {a } 2007: ~ « G e r u n d a ~ y ~ l a ~ d e f e n s a ~ d e ~ l a ~ v i a ~}$ Augusta en la Antigüedad Tardía», en: RoDRíGUEZ, A.; RoDÀ, I. Murallas de ciudades romanas en el occidente del Imperio. Lvcvs Avgvsti como paradigma, Lugo, 633-649.

Orfila, M.; Riera, M.; CAU, M. A.; Arribas, A. 2000: «Aproximación a la topografía urbana tardía de Pollentia (Mallorca): construcciones defensivas», en: V Reunión de Arqueología Cristiana Hispánica (Cartagena 1998), Barcelona, 229235.

PIERI, D. 2005: Le commerce du vin oriental à l'époque byzantine ( $v^{e}-V I I^{e}$ siècles). Le témoignage des amphores en Gaule, Beyrouth.

Prego de Lis, A. 2000: «La inscripción de Comitiolus del Museo Municipal de Arqueología de Cartagena», en: V Reunión de Arqueología Cristiana Hispánica (Cartagena 1998), Barcelona, 383-392.

PUIG, F.; RodÀ, I. 2007: «Las murallas de Barcino. Nuevas aportaciones al conocimiento de la evolución de sus sistemas de fortificación», en: Rodríguez A.; RodÀ, I. Murallas de ciudades ro- manas en el occidente del Imperio. Lvcvs Avgvsti como paradigma, Lugo, 597-631.

Ramallo, S. F.; Murcia, A. J.; Vizcaíno, J. 2010: «Carthago Nova y su espacio suburbano. Dinámicas de ocupación en la periferia de la ciuitas», en: Congreso Internacional Las áreas suburbanas en la ciudad histórica. Topografía, usos, función (Córdoba, 19-21 de octubre 2010), Córdoba, 211-254.

Ramallo, S. F.; Ruiz, E.; Berrocal, M. ${ }^{a}$ C. 1997: «Un contexto cerámico del primer cuarto del siglo VII en Cartagena», en: Contextos ceràmics d'època romana tardana $i$ de l'alta edat mitjana (segles $I V-X)$, Arqueo Mediterrània, 2, 203-228.

Ramallo, S. F.; Vizcaíno, J. 2007: «Evolución del sistema defensivo de Cartagena durante la Antigüedad», en: RodríGuez, A.; RodÀ, I. Murallas de ciudades romanas en el occidente del Imperio. Lvcvs Avgvsti como paradigma, Lugo, 483-522.

RAMON, J. 2008: "La cerámica ebusitana en la Antigüedad Tardía», en: Cerámicas hispanorromanas. Un estado de la cuestión (Rei Cretariae Romanae Fautores, xxvI), Cádiz, 563-583.

RAVEGNANI, G. 1983: Castelli e città fortificate nel VI secolo. Romania (Quaderni di storia bizantina e slava), Ravenna.

- 2007: Soldados de Bizancio en tiempos de Justiniano, Madrid (trad. al español del original, Bolonia, 1988).

Reynolds, P. 2010: Hispania and the Roman Mediterranean, AD 100-700: ceramics and trade, Oxford.

Ribera, A.; Rosselló, M. 2012: "Las ánforas tardoantiguas de Valentia», en: Rei Cretariae Romanae Fautorum Acta, 42, 385-396.

RIERA, M. 2017: El monacat insular de la Mediterrània occidental. El monestir de Cabrera (Balears, segles V-VIII), Barcelona.

RodRíGUEZ, A.; RodÀ, I. (coord.) 2007: Murallas de ciudades romanas en el occidente del Imperio. Lvcvs Avgvsti como paradigma. Actas del Congreso Internacional celebrado en Lugo (26-29, $X I, 2005)$ en el $v$ aniversario de la declaración, por la UNESCO, de la Muralla de Lugo como Patrimonio de la Humanidad, Lugo.

Roldán, B.; MiQuel, L. de 2002: «Intervención arqueológica en el cerro del Molinete (Cartagena). Años 1995-1996. Valoración histórica del yacimiento», en: Memorias de Arqueología (Región de Murcia), 10, Murcia, 247-294.

RuIz, M. D. 2018: Dinámicas topográficas urbanas en Hispania. El espacio intramuros entre los siglos II y vil d.C., Bari.

Ruiz, E. (ed.) 2017: Cartagena. Colonia Urbs Julia Nova Carthago, Ciudades Romanas de Hispania, 5, Roma. 
ŠPEHAR, P. 2008: «Late Antique and Early Byzantine fortifications in Bosnia and Herzegovina (hinterland of the province of Dalmatia)», en: Höhensiedlungen zwischen Antike und Mittelalter, Reallexikon der Germanischen Altertumskunde - Ergänzungsbände, 58, Berlín, 559594.

VAllejo, M. 2012: Hispania y Bizancio. Una relación desconocida, Madrid.

VizcAíno, J. 1999: «Transformaciones del urbanismo tardoantiguo en Cartagena. El caso de los vertederos», AnMurcia, 15, 87-98.

- 2008a: «Carthago Spartaria, una ciudad hispana bajo el dominio de los milites Romani», en: Olmo, L. Recópolis y la ciudad en época visigoda (Zona Arqueológica, 9), Alcalá de Henares, 338360.

- 2008b: «Early Byzantine Lamellar Armour from Carthago Spartaria (Cartagena, Spain)», Gladius, XXVIII, 195-210.

- 2009: La presencia bizantina en Hispania (siglos VI-VII). La documentación arqueológica, Murcia.

- 2011: «Cementerios tardoantiguos de la costa sureste. Indicios de cristianización», Scripta Fulgentina, 37-38 (año XIx), 129-167.

- 2016: «El barrio bizantino de los siglos VI y VII d.C.», en: Noguera, J. M.; CÁnovas, A.; Madrid, M. a J.; Martínez, I. Barrio del Foro Romano. Molinete Cartagena. Proyecto integral de recuperación y conservación, Murcia, 146-151.

- 2018: "Ad pristinum decus. La metamorfosis urbana de Carthago Spartaria durante el siglo v», en: Panzram, S.; Callegarin, L. Entre civitas $y$ madīna. El mundo de las ciudades en la Península Ibérica y en el norte de África (siglos IV-IX), Collection de la Casa de Velázquez, 167, Madrid, 75-104.

- 2019: «¿Epílogo o comienzo? La ocupación bizantina en el antiguo santuario de Isis», en: Noguera, J. M. et al. (eds.). Barrio del Foro Romano. Molinete, Cartagena. Santuario de Isis y Serapis (Insula II). Proyecto integral de recuperación y conservación / Roman Forum District. Molinete, Cartagena. Sanctuary of Isis and Serapis (Insula II). Recovery and conservation, Murcia, 123-129.

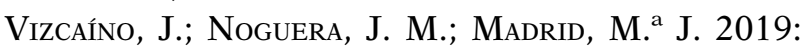
«Del motivo a la imagen. Acerca de la iconografía cristiana en Terra Sigillata Africana D empleada en época bizantina. Una visión desde el barrio de la arx Hasdrubalis de Carthago Spartaria (Cartagena)», en: 4t Congrés Internacional d'Arqueologia i Món Antic. VII Reunió d'Arqueologia Cristiana Hispànica «El cristianisme en l'Antiguitat Tardana. Noves perspectives», Tarragona, 463-470.

- 2020: «El almacén anfórico del barrio del Molinete en Carthago Spartaria (Cartagena): un nuevo contexto cerámico del siglo II en la Hispania bizantina», Pyrenae, 51.2, 99-129.

ZANINI, E. 1998: Le Italie byzantine. Territorio, insediamenti ed economia nella Provincia Bizantina d'Italia (VI-VII secoli), Bari. 



\title{
EL RECINTO AMURALLADO DE IDANHA-A-VELHA (PORTUGAL) ${ }^{1}$
}

\author{
Jorge Morín de Pablos, ${ }^{2}$ Isabel SÁnchez Ramos ${ }^{3}$
}

\section{Resumen}

Idanha-a-Velha conserva uno de los recintos amurallados más interesantes del oeste peninsular. Sin embargo, no está clara la fecha de construcción del conjunto, que implicó una reducción de la antigua urbe altoimperial. Lo cierto es que la muralla puede tener su origen en época bajoimperial, pero también presentar reparaciones amplias de época visigoda y andalusí. Por último, se ha interpretado que algunas ausencias de tramos se deben al expolio continuo de los materiales, cuando quizás se puedan explicar por otras causas. En este trabajo se presenta un avance de los resultados de la investigación realizada en la muralla por el Proyecto IdaVe siguiendo técnicas no invasivas.

\begin{abstract}
Idanha-a-Velha preserves one of the most interesting urban walls in the western Iberian Peninsula. However, the construction date of the complex, which involved a spatial reduction of the Roman town, not clear yet. The defences may have been built in the early late Roman period, although some repairs were made to it between Late Antiquity and the Middle Ages. Finally, the loss of some of the materials has been interpreted as the result of continuous plundering over time. This study suggests that this can be explained by other factors and presents some of the research's results carried out by the IdaVe project using non-invasive methods.
\end{abstract}

1. Este trabajo se ha realizado durante el proyecto «Urban landscape of power in the Iberian Peninsula from Late Antiquity to the Early Middle Ages», que ha recibido financiación de la Comisión Europea en el marco de las Marie SkłodowskaCurie Actions «Horizon 2020-MSCA-IF-EF-ST-2016», y está siendo desarrollado por Isabel Sánchez gracias al «Grant Agreement No. 740123». Las investigaciones de Idanha-a-Velha forman parte del PIPA de la Direçao Genéral do Património de Portugal bajo el título «Paisajes culturales de la sede episcopal de Egitania en época tardoantigua» (2012-2019). El proyecto IdaVe ha recibido financiación en 2015 y 2017 del Ministerio de Cultura en su programa de Ayudas para Proyectos de Excavación en el Exterior (ref.: G-45206596), con el respaldo institucional de la Real Fundación Toledo.

2. Audema, Auditores de Energía y Medio Ambiente, Madrid (calle Felipe Campos, 3, 28002) - j.morin@audema.com.

3. UCL Institute of Archaeology, Londres (31-34 Gordon Square, WC1H 0PY) - i.sanchez@ucl.ac.uk. 


\section{Introducción. Breve historia de las inves- tigaciones}

El recinto amurallado conservado en Idanhaa-Velha es una de las estructuras urbanas de la antigua ciuitas Igaeditanorum que mayor interés ha despertado entre los investigadores, junto con la Sé-catedral y la denominada Torre de los Templarios, asentada sobre el podium del templo romano. Sin embargo, no disponemos de fuentes literarias ni epigráficas relacionadas con las murallas hasta época andalusí. Las primeras referencias escritas fueron aportadas por el geógrafo Al-Razi en el siglo x (Coelho 1972, 44). Los testimonios son más numerosos en épocas moderna y contemporánea, que citan de forma indirecta la muralla al tratar las inscripciones romanas que se iban recuperando de la fábrica del recinto.

En la historiografía portuguesa, el tema de la muralla de Idanha-a-Velha se afronta desde inicios del siglo xx. Francisco Tavares Proença Júnior es el primero en abordar un sucinto estudio del conjunto egitano, aunque no publica ninguna imagen en sus trabajos. Crispiano de Fonseca, en una publicación local, dedica una breve descripción a las murallas aportando alguna fotografía. António Marrocos, Félix Alves Pereira y José Landeiro, entre otros eruditos, también se interesaron por la muralla en el marco de estudios históricos más generales sobre la freguesía egitana (Pereira 1914, 2; Fonseca 1927, 5, 10 y 14; Marrocos 1936, 6; Landeiro 1940; 1942; 1952).

La primera planta del recinto amurallado se debe al investigador Fernando de Almeida, quien trabajó intensamente en Idanha-a-Velha en la segunda mitad del siglo xx. F. de Almeida realizó al mismo tiempo las primeras series fotográficas de la muralla, pero sus intervenciones de restauración y excavación se centraron fundamentalmente en otros espacios urbanos, caso del Paço dos Bispos, por lo que no dedicó un estudio exhaustivo al recinto fortificado (Almeida 1956, fig. 5). Posteriormente, en el último cuarto del siglo $\mathrm{xx}$, Jorge de Alarcão y Pedro Salvado, respectivamente, retomaron la investigación de la muralla proponiendo una nueva interpretación del trazado murario (Alarcão 1973, fig. 21; Salvado 1983).

Frente a la tradición historiográfica del siglo xx que defendía una cronología bajoimperial del recinto amurallado, Cláudio Torres (1992) propuso fechar el recinto en época andalusí, generando una nueva planta del conjunto, que luego mejorará en una revisión publicada conjuntamente con Santiago Macias. A pesar de que la revisión de otros recintos peninsulares concluye una datación andalusí para una serie de fortificaciones del sur y suroeste peninsular (Zozaya 2002, 45-48), la cronología andalusí que $\mathrm{C}$. Torres asignó a la muralla fue polémica y no ha sido aceptada por la investigación posterior.

Con la puesta en marcha de diferentes programas de restauración y puesta en valor, a partir de 1983 se reactivaron los trabajos arqueológicos en Idanha-a-Velha por parte del Departamento de Arqueologia do Instituto Português do Património Cultural y la Universidad de Coímbra. La Câmara Municipal de Idanha-a-Nova también realizó en 1995 intensas intervenciones arqueológicas bajo la dirección de José Luis Gil Cristóvão. En este último escenario, la muralla fue excavada en sectores concretos de su recorrido situados en la Rua do Espírito Santo, Puerta Norte, Escola Nova

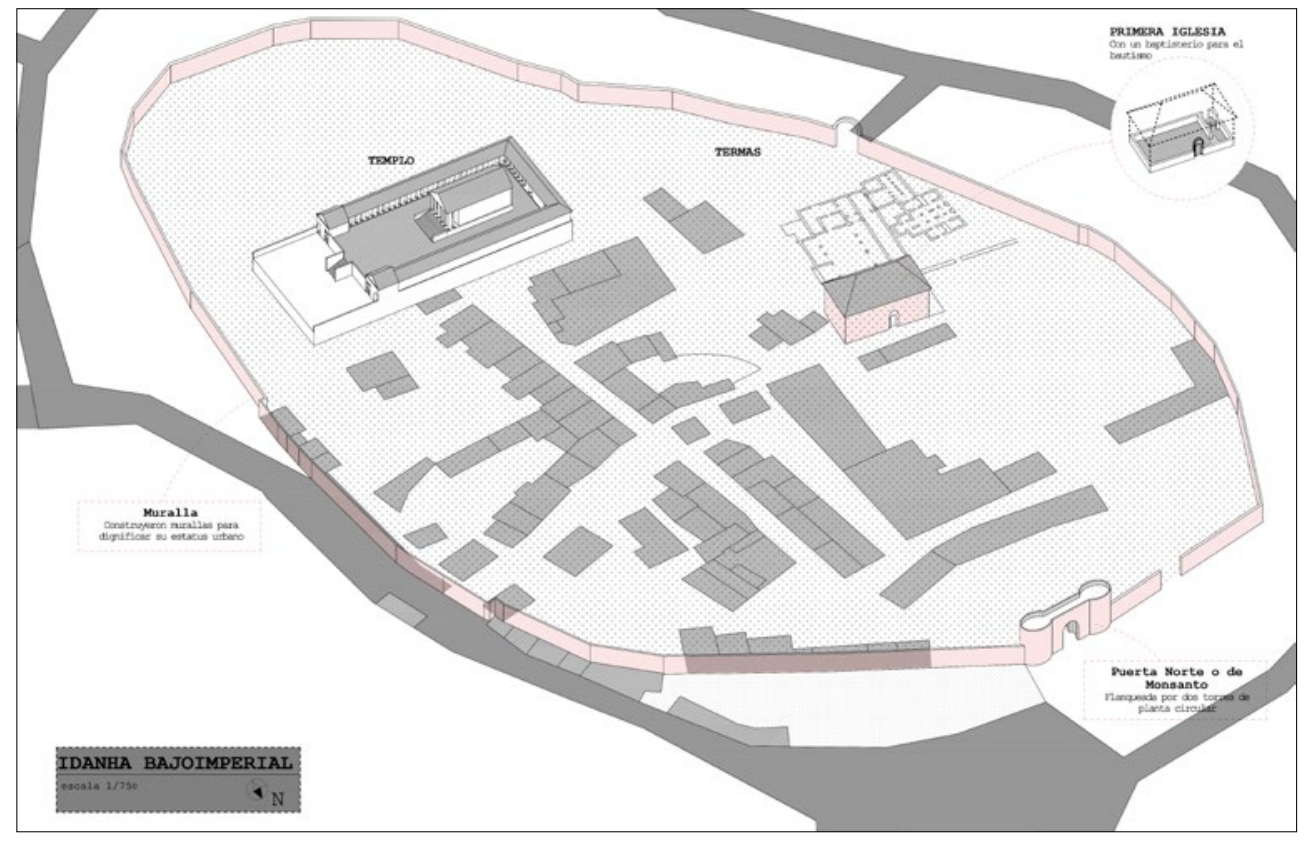

FIguRA 1. Propuesta de restitución de la topografía con los principales conjuntos urbanos en épocas romana y tardoantigua según autores (@) Proyecto IdaVe). 


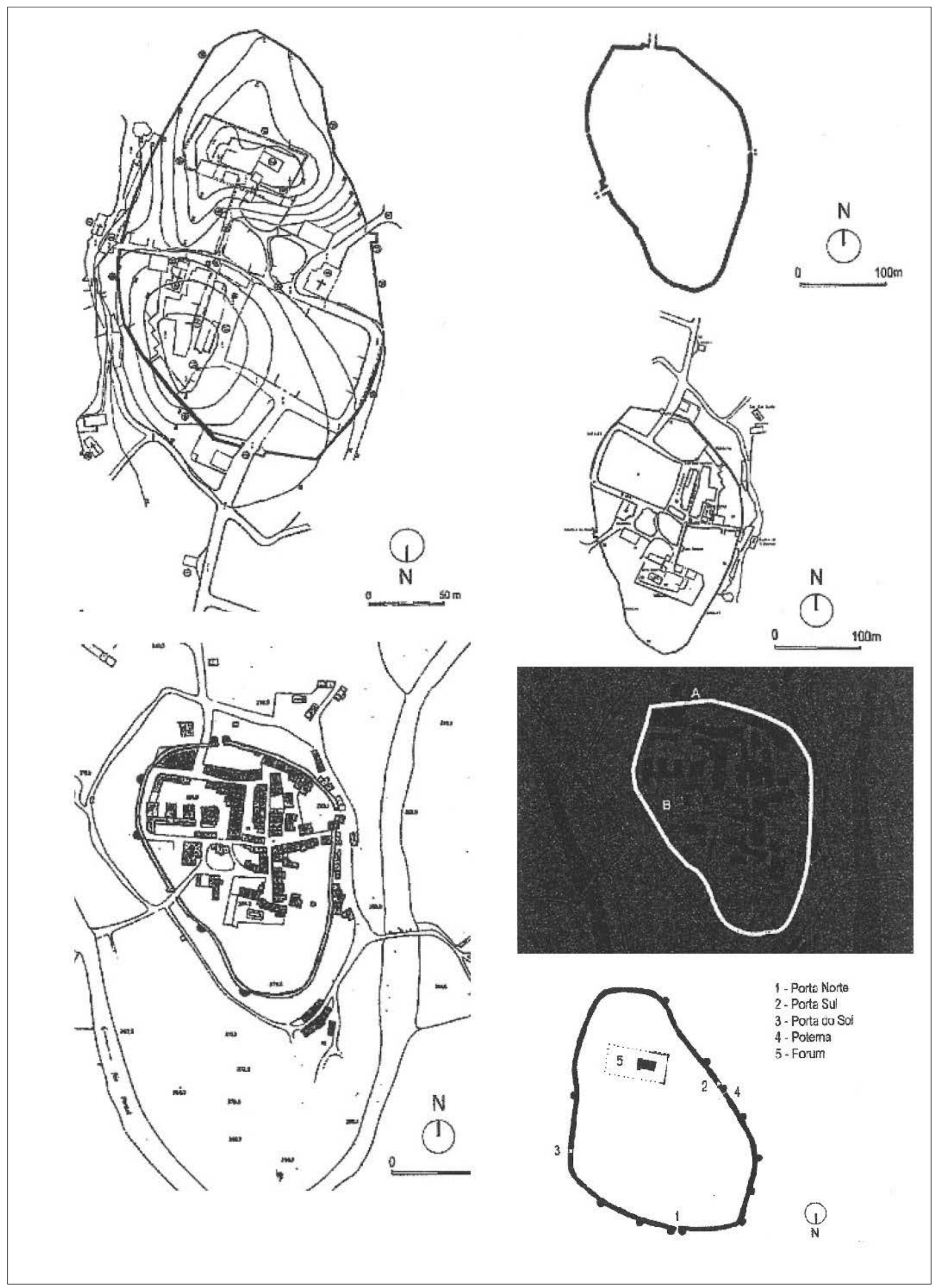

FiguRA 2. Plantas del recinto amurallado: Almeida 1956; Alarcão 1973; Raposo 1985; Torres 1992; Macias y Torres 2002 (@ Ginja). 
y Lagar do Varas. Desgraciadamente, al igual que ocurre con todas las excavaciones acometidas en Idanha-a-Velha, no se han publicado las memorias arqueológicas con la secuencia estratigráfica y los materiales asociados, ni tampoco se puede consultar con facilidad el expediente administrativo. J. Cristóvão se ocupó de forma monográfica de la muralla posteriormente en su trabajo de máster, titulado "As muralhas romanas de Idanha-aVelha». Se trata de un estudio principalmente de carácter historiográfico que no incorpora los nuevos datos obtenidos en sus excavaciones, o lo hace de manera muy parcial, con escasas referencias a los contextos cerámicos (Cristóvão 2002). En definitiva, a pesar de las distintas intervenciones realizadas que se han mencionado, el problema cronológico del recinto fortificado de la ciudad no se había solucionado cuando comenzamos el proyecto IdaVe en 2012 (Sánchez y Morín 2019).

\section{Metodología para el estudio de la mu- ralla egitana desde la arqueología no invasiva}

El proyecto IdaVe intentó desde los primeros momentos el desarrollo de técnicas no invasivas que permitieran avanzar en la documentación de los espacios más significativos de la Antigüedad Tardía. Como hemos explicado, no existían ortoimágenes de la freguesía previas a nuestros trabajos, por lo que la única alternativa para avanzar en la investigación sobre el urbanismo de la ciudad romana y tardoantigua era la elaboración de cartografías fiables y exactas de todas las estructuras urbanas visibles, así como su asociación al recinto amurallado. Tampoco sobre la muralla de Idanha-a-Velha disponíamos de una documentación detallada de su perímetro y alzados para poder afrontar un estudio preciso de la misma.

Sin embargo, el objeto prioritario del proyecto era el grupo episcopal tardoantiguo, ligado a las estructuras excavadas en torno a la Sé-catedral que se sitúa en el denominado Paço dos Bispos (Sánchez y Morín 2015, 398-428). Para la documentación de las construcciones tardoantiguas se empleó un láser escáner para obtener la planta y la información de ese espacio junto al tramo occidental de muralla asociado, que lo delimita al oeste, donde, además, se encuentran la puerta sur y una poterna (Fleming 2001, 67-88; Díaz-Andreu et al. 2005, 2-6; Arayici 2007, 816-829; Höfle y Pfeifer 2007, 415-433; Armesto-González et al. 2010, 3038). Por un lado, se realizaron varias ortofotografías de este sector urbano. Por otro, para la obtención de los alzados de todo el recinto murario, en sus diferentes tramos, se empleó la fotogrametría terrestre, complementada con un dron.

\subsection{Láser escáner y dron}

Tras recibir la autorización pertinente de la Direção Regional de Cultura do Centro (2011), la fase inicial del proyecto consistió en la utilización combinada de varios sistemas de tratamiento de la información cartografiable, como el láser escáner y el GPS, por el amplio abanico de posibilidades de registro y análisis que ofrecen estas técnicas a la arqueología (Arayici 2007, 816-829). La digitalización de las estructuras arqueológicas con un láser escáner 3D terrestre nos permitió, por un lado, conocer con exactitud las dimensiones y la posición UTM de las estructuras en el espacio (geográficamente referenciadas en su posición correcta), es decir, la articulación espacial del conjunto y su planta; y por otro, reunir los datos completos de los alzados o muros escaneados para construir un modelo digital tridimensional (Armesto-González et al. 2010, 30-38).

Para el escaneado de las estructuras se empleó un láser escáner con cámara fotográfica incorporada para reflejar el color a las nubes de puntos. El escáner utilizado ha sido un Riegl LMS-Z420i con una cámara digital Nikon D200 de 10.2 me-

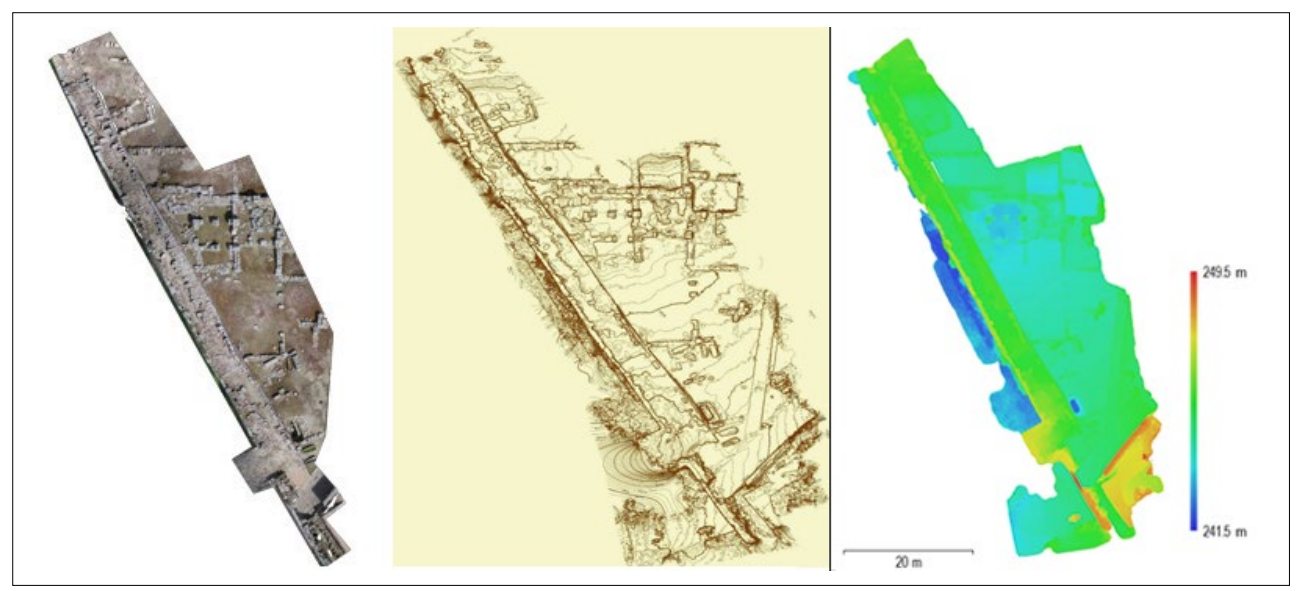

FIGURA 3.

Fotogrametría del recinto amurallado en el área del episcopio; curvas de nivel; recinto amurallado en el área del episcopio, modelo digital terrestre (C) Proyecto IdaVe). 
gapíxeles de resolución. La integración de la cámara fotográfica calibrada con el láser escáner nos ha permitido generar una reconstrucción virtual de las construcciones identificadas con texturas reales a buena resolución (Díaz-Andreu et al. 2005, 2-6). Mientras que para obtener el modelo 3D, sobre el que aún trabajamos, es necesario unir varias nubes de puntos y recalibrarlas, así como establecer para cada edificación un punto central propio. De esta manera se navega de forma más intuitiva para analizar detalles de cada construcción. Igualmente, se reduce la densidad de los puntos en los modelos hasta adaptarlos a una cantidad de memoria ajustada para que un ordenador de media/alta prestación pueda gestionar la información. La cantidad de puntos en los modelos de 3D se ha establecido en 500.000600.000 con color RBG asociado (Höfle y Pfeifer 2007, 415-433).

Otro recurso metodológico no invasivo empleado en el Paço dos Bispos de Idanha-a-Velha ha sido la obtención de dos ortofotos por procedimientos fotogramétricos y altimétricos con la utilización de un dron. Se han practicado dos vuelos con una altura que oscila entre los 50 y los 150 metros. La imagen captada con la cámara del dron ha sido fundamental para plantear nuevas cuestiones relacionadas con la topografía antigua de la ciudad romana; por ejemplo, la restitución de los límites o el perímetro urbano de la ciudad romana, el trazado de los ejes viarios, así como reformular la ubicación de ciertos espacios públicos significativos como el foro romano (Sánchez y Morín 2015, 398-428).

\subsection{Fotogrametría terrestre}

Entre 2017 y 2018 se llevó a cabo la documentación fotogramétrica de todos los alzados del recinto amurallado de Idanha-a-Velha con el objetivo de poder realizar una lectura vertical de los paramentos de los diferentes tramos murarios. El trabajo de fotogrametría se organizó en cinco zonas de documentación: a) la muralla de la ciudad, dividida a su vez en siete tramos; b) la iglesia; c) la torre medieval; d) el pequeño tramo conservado del criptopórtico; y e) una fuente histórica a las afueras de la población. Para la obtención de cada una de las imágenes se planificaron varios proyectos fotogramétricos en función de las zonas. En el caso de la muralla, la documentación fotográfica se corresponde con los sectores siguientes:

- 01 - tramo 1 (zona muralla norte-este). Se han realizado un total de 530 fotografías para la documentación de este tramo. Para ello se ha ejecutado un vuelo para cubrir tanto el alzado como la planta de esta parte de la muralla. Estas imágenes se han complementado con fotogrametría terrestre con una cámara réflex, Nikon d5200, del alzado interior y exterior, así como de la planta de la muralla.

- 02 - tramo 2 (puerta de entrada norte, reconstruida). En este tramo se han seleccionado 540 imágenes para obtener un único proyecto fotogramétrico.

- 03 - tramo 3 (muralla norte-oeste). Tramo de pequeña longitud en el que tan solo se conserva la parte exterior de la muralla, ya que el interior ha sido parcialmente desmantelado por las estructuras adyacentes. En total, se ha documentado con 224 fotografías. Se ha realizado un vuelo para el alzado, la planta y oblicuas. Para complementar estas imágenes se ha usado la cámara Sony A5000 en el alzado exterior. Este tramo presenta dificultades al encontrarse en una parcela privada con vehículos estacionados al lado de la muralla.

- 04 - tramo 4 (muralla oeste-norte). En la documentación de este tramo se han obtenido 390 fotografías a partir de dos vuelos, uno general y otro de detalle. Además, se han tomado fotografías de detalle con la cámara réflex Nikon 5200.

- 05 - tramo 5 (muralla oeste), zona de la Sécatedral. En total, se han realizado 913 fotografías a partir de tres vuelos sobre esta zona, uno para el alzado interior, otro para la planta y un tercero para el alzado exterior. Todo ello se ha completado con fotografías terrestres realizadas por la cámara Nikon D5200.

- 06 - tramo 6 (muralla oeste-sur). Se han seleccionado 205 fotografías obtenidas con la cámara Nikon d5200. Debido a las condiciones de conservación del tramo de muralla, con abundante vegetación, solo se han podido utilizar las imágenes terrestres.

- 07 - tramo 7 (muralla este-sur). Finalmente, se han seleccionado 280 fotografías, tanto de un vuelo como de una toma terrestre con una cámara Sony A5000. Debido a las condiciones de conservación del tramo de muralla, con abundante vegetación, solo se han podido utilizar las imágenes terrestres.

Posteriormente al trabajo de campo, se seleccionaron las imágenes para cada una de las zonas de documentación y se procesaron en un programa de fotogrametría para obtener una nube de puntos dispersa con el emparejamiento de imágenes y la localización de cámaras con respecto a la nube de puntos. A continuación, se generó la nube de puntos densa, a una buena calidad, que se editó al eliminar los puntos superfluos. Por último, se editaron las ortofotos y el MDT, primero en programas de edición raster-GIMP o Photoshop-, y luego en programas de tipo vectorial, como Corel o Inkscape, y se adaptaron para su uso en Cad, 




FIgURA 4. Fotogrametría de los lienzos conservados del recinto amurallado (๔ Proyecto IdaVe).

que nos permitió trabajar con los datos de la lectura vertical de paramentos.

\section{La muralla de la ciuitas Igaeditanorum}

No existen evidencias arqueológicas de que la ciuitas Igaeditanorum estuviera amurallada en época altoimperial. La urbe romana se extendía aprovechando un meandro del río Pônsul, así como la existencia de dos vados situados al este y al oeste, respectivamente. Algunos autores, como Octavio Ferreira, defendieron un origen prerromano de la ciudad justificando simplemente que debía de estar amurallada (Ferreira 1978, 233), a pesar de no haber ningún argumento arqueológico para presuponer una fundación previa a la augustea. F. Almeida también propuso la hipótesis de que hubiera un recinto fortificado fundacional del siglo I (Almeida 1977a, 41). Sin embargo, todos estos planteamientos son puramente especulativos y carentes de confirmación arqueológica. La visión tradicional con mayor consenso en la investigación defiende la cronología bajoimperial de la muralla, ejecutada seguramente de for- ma unitaria. Su trazado supuso la destrucción de gran parte de las edificaciones altoimperiales, ya que fueron desmantelados edificios públicos y privados para utilizar sus materiales en la construcción del recinto amurallado. La nueva estructura urbana implicó paralelamente una importante reducción del perímetro urbano, aunque no cabría descartar que algunos espacios exteriores o suburbiales (p. ej., unas termas localizadas al sur del centro monumental) continuaran en uso después de su construcción.

En este sentido, la construcción de la muralla pudo estar ligada a un fenómeno que en la actualidad conocemos con algo más de precisión. Se trata de la inflexión aparejada a un decaimiento en la estructura urbana, a veces definido como «crisis», que experimentaron algunas ciudades de la península ibérica a partir del siglo III (Abel 2004, 149-166; Fernández-Ochoa, Morillo y López 2005, 95-120). Este fenómeno no es homogéneo en toda Hispania, ni tampoco extensible a toda la provincia de Lusitania, ya que mientras que algunas ciudades prácticamente desaparecieron o su vida urbana languideció, otras, por el contrario, mantuvieron una actividad pujante a partir de 
este momento, lo que implicó, entre otras cuestiones, la construcción de nuevas murallas (De Man 2011). En Augusta Emerita, los datos arqueológicos reflejan las profundas transformaciones urbanas que experimentó la capital de Lusitania desde los comienzos del siglo Iv, cuando albergaba la sede del vicario de la Dioecesis Hispaniarum, hasta convertirse, a lo largo del siglo v, en la sede temporal de la monarquía sueva. Las estructuras arquitectónicas y urbanísticas de la antigua colonia emeritense fueron progresivamente sustituidas por nuevos referentes urbanos. La ciudad mantuvo su rol en el control y la vertebración de un amplio territorio, aunque los espacios urbanos cambiaron radicalmente en lo que se refiere al concepto de lo público y lo privado, la desaparición de los edificios de ocio y representación de la arquitectura del poder -y su progresiva sustitu- ción por una nueva arquitectura religiosa- y, por último, la manifestación de un espacio urbano y territorial donde el peso de la Iglesia y sus estructuras de poder es manifiesto (Mateos 2018, 134).

Estas transformaciones que se han podido documentar arqueológicamente en Mérida están presentes también en otros espacios urbanos lusitanos del oeste peninsular, como Coninbriga, Ammaia y Myrtilis. La evidencia material en la ciuitas Igaeditanorum sugiere unas transformaciones similares en su topografía, arquitectura y estructura urbana: la progresiva sustitución de lo público por lo privado, la cristianización de los antiguos espacios de poder, la generación de nuevos espacios dentro de la ciudad ligados a la sede episcopal y la construcción ex novo de la muralla, lo que ciertamente conllevaría un ingente esfuerzo constructivo.



Figura 5. Muralla de la ciuitas Igaeditanorum (@) Proyecto IdaVe). 


\subsection{Características generales}

El recinto amurallado de Idanha-a-Velha presenta una planta oval, adaptándose a la morfología del meandro del Pônsul, pero con una reducción en su ocupación. El recinto se establece en la curva de nivel más elevada, siguiendo un desarrollo lineal de unos 800 metros y ocupando aproximadamente 2 hectáreas. Un aspecto interesante, que no se menciona en la bibliografía al uso, es que este recinto se dispone sobre dos espacios

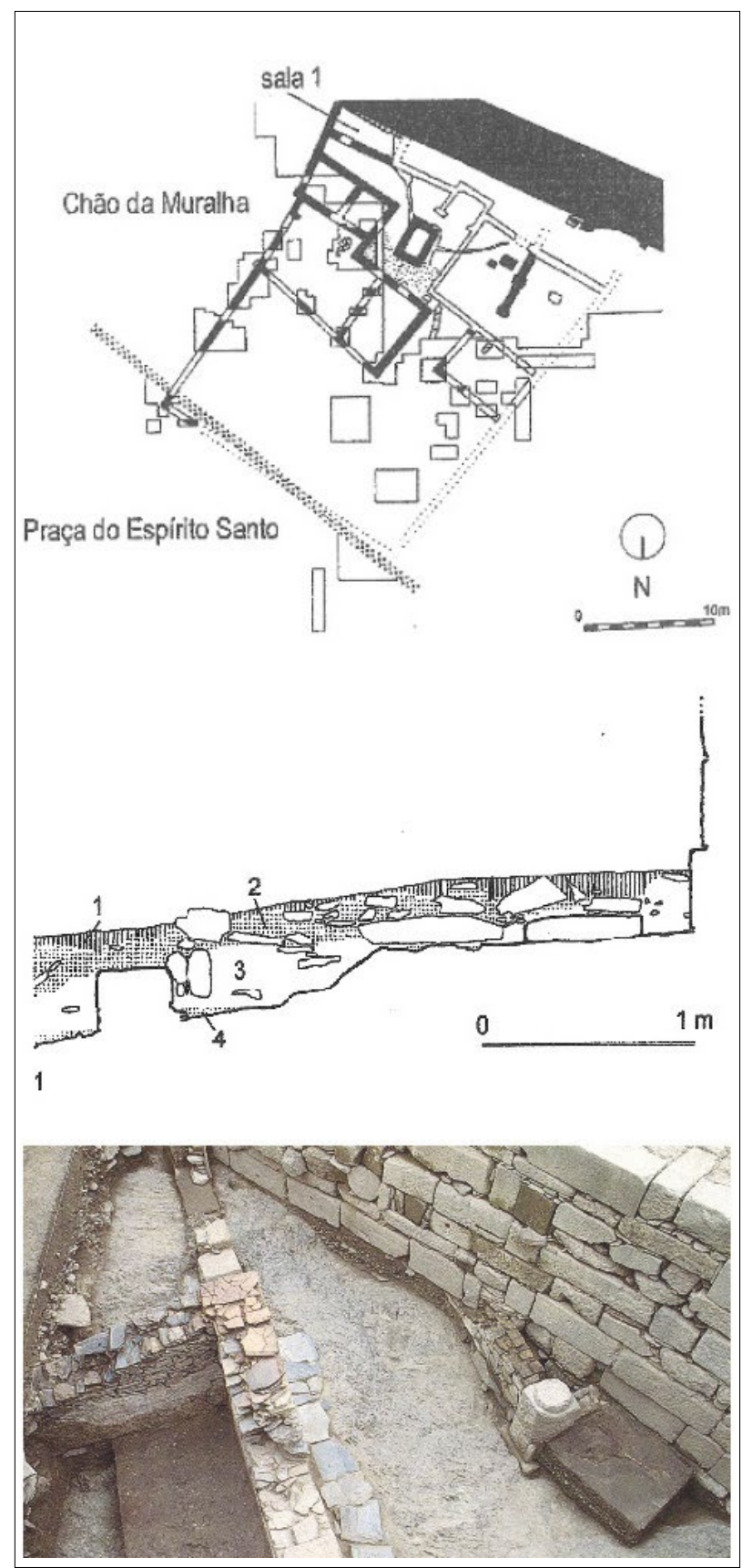

Figura 6. Planta de la casa-atrio excavada en el sector norte (C P. Bernardo y M. Ginja); perfil estratigráfico de la sala 1 (C) P. Bernardo y J. Cristóvão); vista de la casa-atrio con la muralla superpuesta (@) Proyecto IdaVe). geológicos bien diferenciados: uno primero identificado con los depósitos cuaternarios del Pônsul y localizado al sur, y otro segundo, situado al norte, que se corresponde con el batolito granítico. Esta diferencia geológica sobre la que asienta la muralla permite explicar los enormes contrastes de conservación en los distintos tramos de su recorrido, ya que en la parte norte se conserva en buen estado, salvo en el caso de los elementos adosados como las torres, mientras que al sur, por el contrario, los paramentos están desmantelados; esta situación se ha justificado como consecuencia del expolio del material en épocas medieval, moderna y contemporánea. Es cierto que el expolio se produce mayoritariamente en esta zona meridional, pero la causa de la ruina del recinto en este amplio sector, que es aprovechada para expoliar el material, obedece a otras razones, de las que nos ocuparemos más adelante.

Las excavaciones arqueológicas efectuadas en Idanha-a-Velha, a pesar de no haber sido nunca publicadas, y de las que solo se conocen noticias parciales, permiten suponer la existencia de una franja deshabitada en torno a todo el perímetro amurallado en su parte interna, sugiriendo que las construcciones enmarcadas en la arquitectura privada residencial serían desmanteladas y anuladas por la muralla. Parece ser el caso de la domus de atrio excavada en el Quintal do lagar de Varas (Cristóvão 2002, 28). Además, durante la excavación del proyecto IdaVe en 2014 se pudo comprobar en el Sondeo II la existencia de un espacio doméstico que estaba desmantelado hasta los niveles de cimiento, además de presentar una orientación diferente a la del recinto amurallado. Los contextos cerámicos recuperados -TSA C y D-, escasos, nos remiten a una fecha en torno a finales del siglo III d. C. para situar el abandono de las estructuras más antigua excavadas en el Paço dos

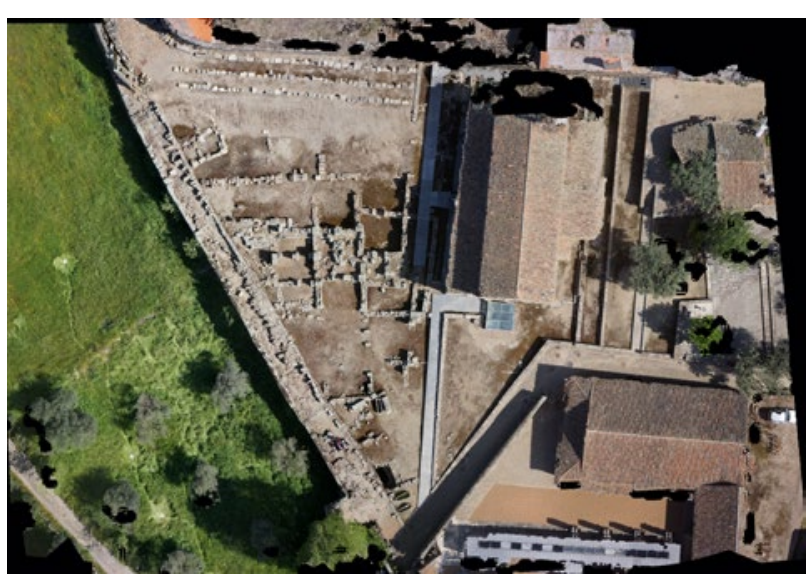

FIGURA 7. Fotografía aérea del episcopio visigodo donde puede apreciarse como las construcciones se adosan a la muralla (C) Proyecto IdaVe). 
Bispos (Sánchez y Morín 2014, 98 y 99). Sin embargo, la existencia de espacios vacíos interiores no se produce en época tardoantigua, al menos en el espacio que ocupa el grupo episcopal, ya que las construcciones del episcopio -horreum, iglesia menor, etc.- se adosan a la muralla. Por otro lado, extramuros, al menos en la zona norte, el espacio estuvo ocupado por una extensa necrópolis que arrancaría desde época altoimperial, aunque con una continuidad de uso posible durante toda la Antigüedad Tardía (Cristóvão 2002, 28-30).

\subsection{Los lienzos}

El recinto amurallado se ajusta a la curva de nivel más elevada, generando un espacio oblongo, lo que obligó a la construcción de tramos rectos y otros curvos. El frente norte, que protege el único espacio donde no está el río Pônsul, es el más rectilíneo. La altura máxima conservada es de unos ocho metros en los tramos del sector norte, que son los mejor preservados, lo que también es lógico, ya que es el sector más expuesto y donde está el acceso principal a la ciudad, que adquiere un aspecto monumental. En el resto del conjunto se conservan alzados de entre cuatro y cinco metros, menos en el lado sur, donde el recinto está muy deteriorado, como decíamos.

Las técnicas constructivas de los paramentos se identifican con un opus quadratum irregular de sillares, combinados con elementos constructivos reciclados como spolia, que es una característica de la edilicia peninsular en la Antigüedad Tardía (Macias 2015, 201-214). Los bloques utilizados son generalmente lisos, de granito, la mayoría de ellos reutilizados de construcciones anteriores altoimperiales que fueron desmanteladas para aprovecharlos en la construcción de la muralla, tanto en su epidermis externa como en el relleno de la estructura. Por tanto, como se ha señalado en otras murallas tardías de Lusitania (De Man 2008, 427-430), parece haber una intencionalidad en la elección de materiales en los paños exteriores, buscando en ellos cierta monumentalidad del recinto. Los alzados también generan hiladas regulares, aunque a veces se utilizan los engatillados. Los bloques están colocados a hueso y calzados con ripios, de pizarra o material latericio -tejas y ladrillos-, sin descartar la utilización esporádica de argamasa en los paños del noroeste (Pereira 1938, 197), mientras que el emplecton de la muralla está configurado también por bloques en línea horizontales, así como argamasa y tierra.

La cronología de los materiales reutilizados en la construcción de la muralla no supera el siglo III d. C., momento en el que la ciudad pudo verse afectada por un decaimiento de la vida urbana si-

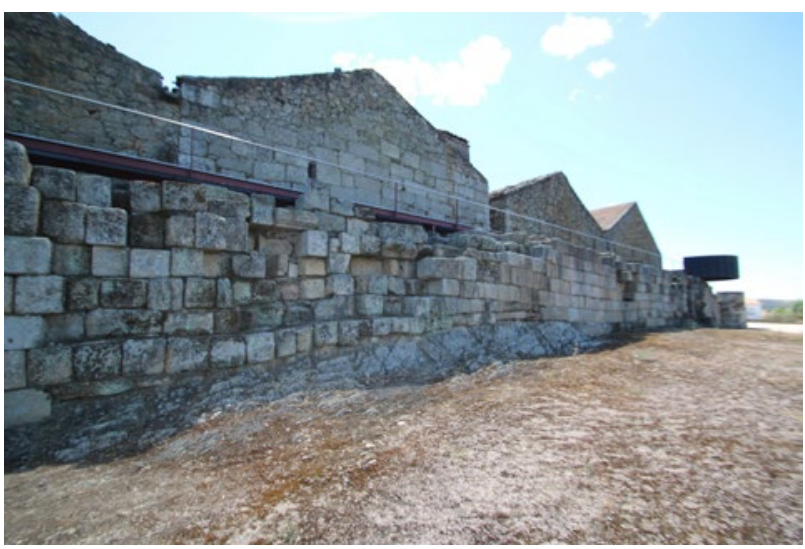

FIgura 8. Detalle de los lienzos del recinto amurallado en su parte noreste (C) Proyecto IdaVe).

milar al de otros centros hispanos. Sin embargo, este argumento de datación por ausencia no debe tenerse en cuenta, ya que se sostiene principalmente en la cronología que aportan los elementos epigráficos, que en Idanha-a-Velha son todos altoimperiales, no existiendo hasta la fecha epigrafía posterior al siglo Iv (Sá 2007).

\subsection{Puertas y portillos}

La construcción del recinto en la ciuitas Igaeditanorum supuso una transformación radical de la topografía urbana romana que afectaría tanto a la arquitectura pública, como a la doméstica, como al viario altoimperial. La evidencia topográfica sugiere localizar los accesos a la ciudad al este y al oeste, ligados a los vados del Pônsul, y a la posible existencia de un puente en el lado oriental de la ciudad. El recinto amurallado dispone de una puerta situada al norte, que fue excavada por $\mathrm{F}$. Almeida en la segunda mitad del siglo xx (Almeida $1956,89 ; 1977 b, 9)$. Una vez más, se desconoce la estratigrafía obtenida en sus excavaciones, lo que dificulta la reinterpretación del recinto fortificado. Además, las torres y los arcos interiores fueron objeto de una profunda restauración que se concluyó en los años noventa del pasado siglo, desvirtuando también así cualquier intento de restitución de la estructura original.

La puerta norte estaba flanqueada por dos torres; el acceso a la misma es directo, pero todavía se pueden ver varios elementos. La puerta tiene tres arcos interiores, dos de los cuales fueron construidos por F. Almeida. El primero es un riel por el que bajaría el rastrillo, mientras que los dos posteriores albergarían los batientes de la puerta, que se pueden ver en planta, así como en el alzado de las paredes. Es probable la existencia de un cuerpo abovedado, sobre el que estaría situado el cuerpo de guardia, como el recientemente descu- 


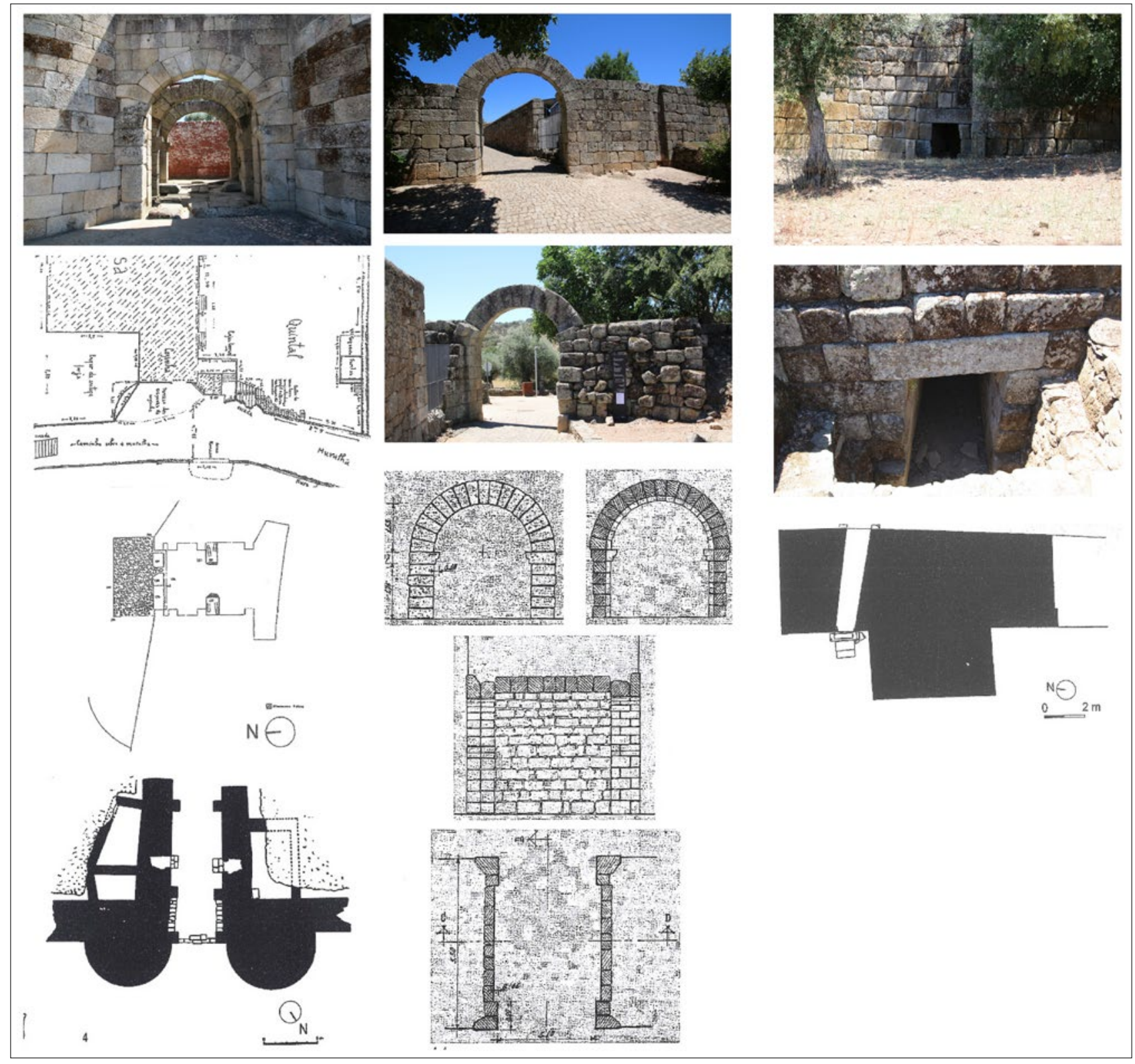

Figura 9. Puerta norte (@ Proyecto IdaVe); planta (@ F. Almeida); planta (@ A. Côrte Real); planta (@ J. Cristóvão); puerta sur reconstruida, exterior e interior (@ Proyecto IdaVe); proyecto de reconstrucción puerta sur (ㄷ A. Lino); poterna exterior e interior (ㄷ Proyecto IdaVe); planta ( P. Bernardo y J. Cristóvão).

bierto en Porta Miña en Lugo (Alcorta 2008, 1549), y un paralelo más cercano es la Puerta del Sol o San Pedro del recinto de Coria (Espada 2011, 57-80). No cabe duda de que este tipo de puertas, con dos torres y aspecto monumental, no solo cumplían funciones defensivas, sino que definían cuál era el acceso principal a la ciudad (González y Carreño 2007, 255-280). Se trata de un fenómeno que se generaliza en el occidente romano (Fernández-Ochoa y Morillo 2006, 253-274) desde Diocleciano (248-305) y Constantino (306-337) hasta Valentiniano (364-375) (Johnson 1983, 47).

F. Almeida propuso la existencia de otras dos puertas de entrada al espacio urbano, entre ellas la puerta del sol, situada al este, dando entrada al decumanus maximus. Del mismo modo, sugi- rió una continuidad sin transformaciones entre el trazado ortogonal altoimperial y el tardoantiguo, situación que no parecen demostrar las excavaciones llevadas a cabo hasta la fecha, en las que el viario altoimperial aparece alterado en época tardía; aunque determinados espacios, como el foro, lógicamente mantendrían sus orientaciones. Las excavaciones de J. G. Cristóvão en Cimo de la Calzada documentaron que la muralla era continua en ese sector, sin que hubiera indicios de ninguna puerta (Almeida 1977b, 17; Cristóvão 2002, 41-42). F. Almeida también defendió la existencia de otra puerta al oeste, controlando el vado del Pônsul, que permitiría el acceso tanto al cardo maximus como al espacio forense (Almeida 1956, 376; 1961, 120). Este acceso fue restaurado 
y reconstruido con la ayuda del arquitecto António Lino. Sin embargo, el recinto actual no cuenta aquí con ninguna puerta, como lo demuestran las excavaciones de P. Carvalho y P. Santos, que localizaron un paño de muralla enterrado (Almeida 1961, 122).

En el tramo oeste de la muralla sí se documenta una pequeña poterna defendida por una torre rectangular. Este acceso está a una cota más baja que la puerta del Pônsul reconstruida por F. Almeida. Las referencias a esta son antiguas: Florián de Docampo se refiere a la poterna como pervetusta cloaca, y también es mencionada por Francisco Proença Junior, al recuperar la inscripción CIL II 437, reaprovechada en uno de los paramentos interiores del corredor del portillo (Docampo 1517-1561, f. 28v; Proença Junior 1910, 21). La poterna se construyó con grandes bloques de granito como cubrición. En el lado interior están los resaltes de la puerta, que lógicamente abre hacia adentro, con el giro en el lado izquierdo. La puerta se cerraba con una tranca, cuyos encajes son todavía visibles. La defensa del portillo se realizaba desde la torre cuadrangular. Aquí encontramos un dato importante, ya que el portillo, debido a su cota y su mecánica constructiva, está claramente relacionado con la fundación original del recinto, pero defendido por una torre rectangular, lo que permitiría pensar en la convivencia de torres semicirculares y rectangulares en el recinto amurallado original. No debe extrañar que para la defensa del portillo se elija una torre rectangular, ya que esta tipología se ajusta más el campo de defensa que las semicirculares. Por otro lado, J. Cristóvão asocia este portillo a la domus altoimperial situada junto al decumanus maximus. Esta casa sufrió una destrucción parcial cuando se construyó la muralla, pero otras zonas de la misma vivienda siguieron en uso hasta el siglo IV d. C. (Cristóvão 2002, 45-47). Más discutible es la supuesta función de drenaje del portillo, al menos de forma coetánea a su uso.

\subsection{Las torres}

La muralla está jalonada por torres semicirculares distantes entre sí con una alternancia en torno a los 35 metros. Esta mecánica de separación de las torres obedece a unos criterios topográficos y de visibilidad que comparte con otros recintos fortificados tardoantiguos peninsulares, pero el ritmo en la alternancia de las torres es bastante variable entre ellos (Paz 2015, 58). En Idanha-aVelha se han documentado catorce torres hasta la fecha, lo que hizo suponer a J. Cristóvão la existencia al menos de un total de dieciocho torres (Cristóvão 2002, 29).
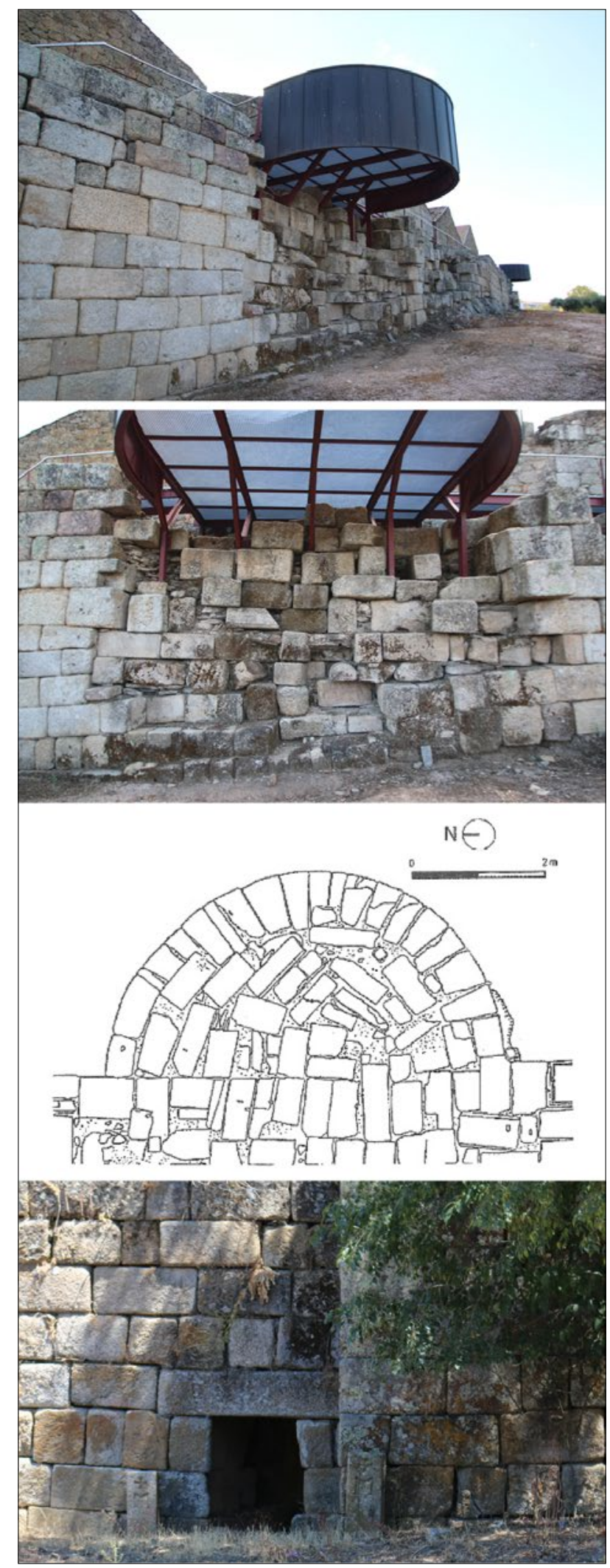

Figura 10. Detalle de las torres del tramo norte ( $($ ) Proyecto IdaVe); planta de la torre excavada en la calle del Espíritu Santo, 38 (ㄷ P. Bernardo y L. Sebastián); torre rectangular protegiendo el portillo oeste (@ Proyecto IdaVe). 
La muralla egitana dispone de torres semicirculares, que son mayoritarias, pero también existen torres rectangulares. Las torres semicirculares tienen un radio que oscila entre 3,15 y 3,50 m. La construcción de los paramentos semicirculares de las torres obligó a la talla específica de los bloques, o a retallar y adaptar elementos reciclados. Las torres buscan el encuentro con los paños de la muralla mediante bloques que penetran en ella o por adosamiento. Esta técnica parece sustentarse en una cuestión táctica, puesto que, si se derribara la torre, ello no afectaría al resto del recinto (Alcorta 2007, 283-311). Además, otro aspecto significativo de su técnica constructiva es que las torres se aligeran en altura. Sin embargo, esta circunstancia lógicamente ha afectado a la conservación de las torres, que en su práctica totalidad estaban desmanteladas, y en algunos casos (puerta norte), como hemos citado, han sido objeto de restauraciones contemporáneas.

Las torres rectangulares se han localizado exclusivamente en el paño oeste del recinto, que está ligado a una potente transformación del espacio que rodea en época tardoantigua. Como ya hemos señalado, en este tramo destaca la torre que protege el portillo existente en el lado oeste. Este espacio fue excavado por F. Almeida, pero la descripción que aporta de los materiales no permite plantear propuestas cronológicas sobre el momento de su construcción. Una vez más, los trabajos del arqueólogo portugués desde el punto de vista metodológico se muestran deficientes y dificultan poder avanzar en nuevas hipótesis (Almeida 1956, 376).

El remate de los cuerpos superiores de las torres nos es desconocido, por lo que no se puede asegurar que llevaran merlones como en Lugo y Barcelona (Alcorta 2007, 283-311), aunque J. Cristóvão interpreta como merlón una pieza procedente del desmonte de la torre de Cimo da Calçada (Cristóvão 2002, vIII, 1).

\section{Evidencias arqueosísmicas en el Paço dos Bispos}

En Idanha-a-Velha se han registrado indicios arqueosísmicos en diferentes puntos de la ciudad que remiten al desencadenamiento de varios episodios sísmicos. Por un lado, ya habíamos adelantado que el tramo meridional de la muralla está prácticamente desaparecido, y en parte lo explica su asentamiento sobre los sedimentos cuaternarios del Pônsul: le faltan los paños exteriores e interiores, mientras que el emplecton presenta bloques con claras evidencias de desplazamiento de los bloques. Esta circunstancia se ha explicado por el expolio de la muralla en fechas recientes. No obstante, resulta imposible extraer bloques de granito cercanos a los mil kilogramos tirando de ellos, para lo que sería necesario el empleo de maquinaria de una gran potencia. No solo podemos observar el desplazamiento de los bloques con la misma orientación, sino también las fracturas en las esquinas o fracturas penetrativas asociadas a pliegues del paño de muralla. La mayor afección de un efecto sísmico en esta zona se debe a que la muralla asienta sobre la terraza más baja del Pônsul, estando además poco cimentada, ya que no existían trincheras de cimentación en la mayor parte de su trazado, o bien eran muy someras. Esta circunstancia habría provocado un efecto de amplificación de la onda sísmica al tratarse de sedimentos no consolidados. Por el contrario, en la zona norte, al asentarse sobre rocas metamórficas ordovícicas, el recinto es más estable y solo se vieron afectadas las torres. Por otro lado, en el sector oeste de la muralla, que delimita intramuros el grupo episcopal tardoantiguo en el Paço dos Bispos, se han podido documentar un número importante de EAEs (Earthquake Archaeological Effects), que no solo afectan a la muralla en la que se documenta el pliegue del lienzo murario, sino también a las construcciones relacionadas con el citado episcopio.

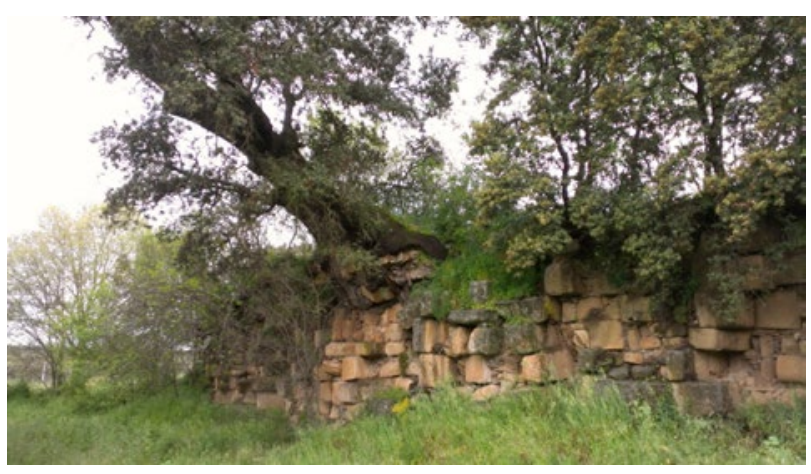

FIgURA 11. Detalle del tramo sur del recinto amurallado de Idanha-a-Velha. Al construirse sobre los sedimentos cuaternarios del río Pônsul ha sido el más afectado por los eventos sísmicos (ㄷ) Proyecto IdaVe).

Los resultados del estudio arqueosísmico sobre todo el espacio urbano concluye que estamos ante la superposición de los efectos de dos terremotos históricos distintos: uno con origen al sur de Idanha-a-Velha, y otro de campo lejano que se puede situar al suroeste de la actual freguesía. El primero de ellos, en campo cercano, afectó al recinto amurallado con una intensidad de entre 6 y 9, con una cronología a fecha de hoy indefinida. Por el contrario, el segundo terremoto, de campo lejano, que afecta a diferentes construcciones de 
la localidad, habría que relacionarlo con el sismo de Lisboa del 1 de noviembre de 1755.

El primer evento sísmico es el que más nos interesa para la época en estudio, ya que causó la destrucción del recinto en toda la zona sur, sin que conste evidencia de su reparación posterior. Además, se produjo el abandono de todo este sector suroccidental, donde desde época tardoantigua se concentraría la ocupación «urbana» de Egitania. Hidacio se refiere a la concurrencia de dos terremotos en la Gallaecia, uno el 26 de septiembre del 451, ligado a un eclipse lunar, y otro en el 453 (Hyd. 151), asociado igualmente a otro eclipse solar. No podemos aventurarnos, con los datos actualmente disponibles, a plantear una cronología de mediados del siglo v para el primer evento sísmico, pero parece que afectó al recinto amurallado en su sector sur, así como a algunos tramos del sector norte, caso de las torres que no fueron reparadas.

La reorganización de la ciudad en un momento impreciso, que cabría situar a partir del siglo v, se materializa con la construcción del primer conjunto cristiano en este sector oeste de la ciudad. Allí se localizó una piscina bautismal de reducidas dimensiones y planta cuadrangular, que iría asociada al espacio cristiano más antiguo constatado. La monumentalización de este escenario se produjo en la segunda mitad del siglo vI, cuando la antigua ciudad adquirió el rango de sede episcopal. Este momento coincidiría también con otros eventos significativos, como la conquista definitiva del reino suevo por parte del reino visigodo y la celebración del III Concilio de Toledo. La nueva fase episcopal de Egitania, nombre con el que se conoce al nuevo obispado en las actas conciliares, se tradujo en la construcción de un conjunto edi- licio mayor integrado por un templo, un palacio episcopal, horreum, capilla, etc.

Es muy significativo el acoplamiento del episcopio visigodo a este tramo occidental de la muralla para conocer las relaciones topográficas entre ambas construcciones. El palacio episcopal -actual Sé-catedral- pudo ocupar una edificación previa de carácter monumental, al igual que el baptisterio episcopal y la ecclesia, de la que apenas se dispone de datos arqueológicos. Por el contrario, el resto de las edificaciones, como el horreum y la capilla, parecen ocupar el espacio que habría quedado libre de edificaciones cuando se construyó la muralla; ahora configurado con nuevas construcciones que se adosan al recinto. Esto supondría la amortización del portillo oeste o, al menos, un claro uso privativo, ya que la diferencia de cota con las edificaciones tardoantiguas complicaría el acceso a este. En este lugar sí parece existir un dato cronológico claro respecto a la muralla. Este tramo ya existía en el siglo VI, y todas las construcciones secundarias del episcopio se adaptan al espacio existente, al abrigo del lienzo fortificado. Se trata de una evidencia que contradice la propuesta de Cláudio Torres de una cronología andalusí para toda la muralla. Que el recinto existiera en época tardoantigua, y que las construcciones episcopales se acoplaran a este, no invalida -y además sería lógico- que las murallas sufrieran refacciones en época andalusí (Azuar 2005, 149-160).

\section{Conclusiones}

En el contexto actual de las investigaciones sobre el recinto amurallado tardoantiguo de Idanha-a-Velha resulta complejo extraer conclusiones

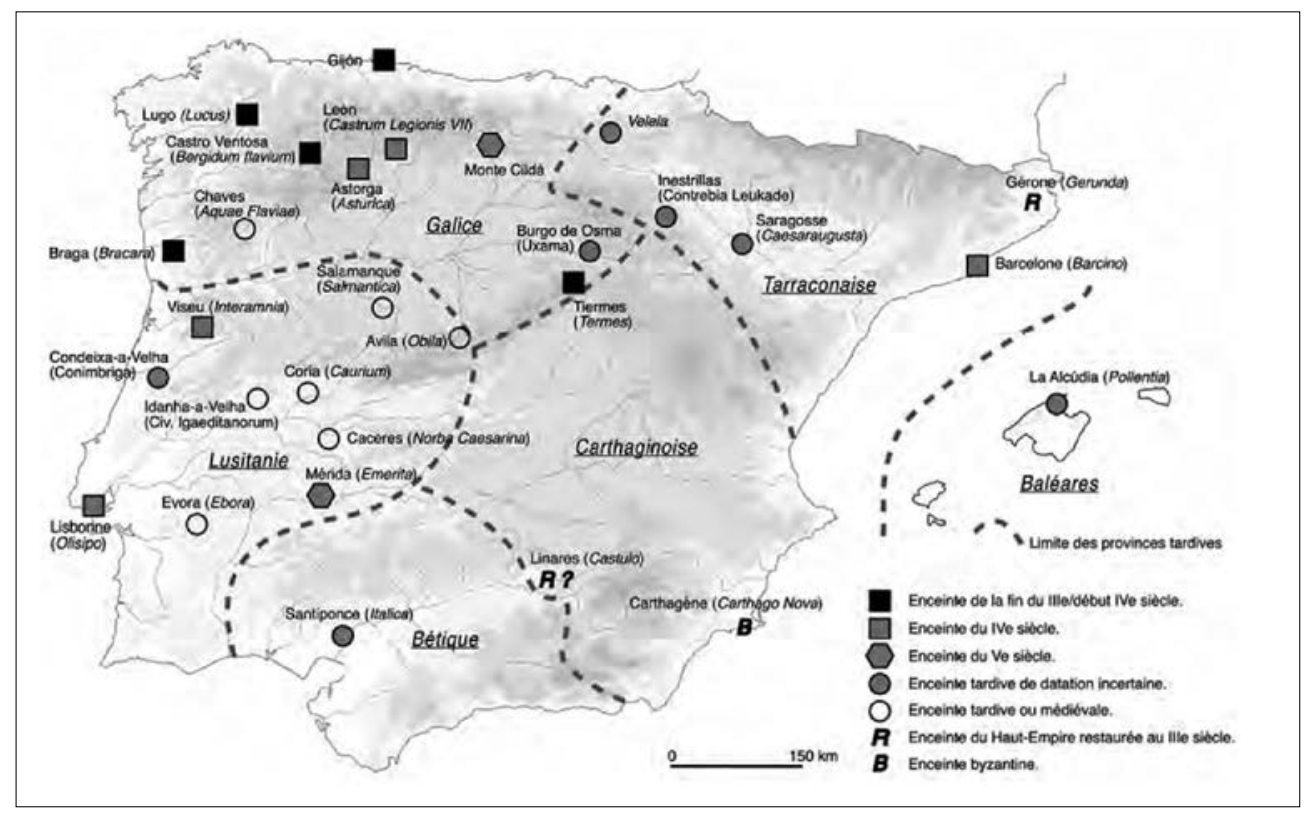

FIGURA 12. Los recintos fortificados de la península ibérica entre los siglos IV y vi (Brassous 2011, 284 , figura 12). 
cronológicas contundentes sobre el momento de construcción de la primera muralla, así como definir con claridad las reformas posteriores. Los distintos argumentos utilizados en su estudio actual parecen concluir que la muralla se construye en un momento indeterminado de la Antigüedad Tardía, y que algunos de sus tramos fueron reconstruidos en diferentes épocas a partir del periodo islámico. Respecto a desestimar la cronología andalusí del recinto propuesta por C. Torres y S. Macias, ya se ha comentado que a finales del siglo vi e inicios del siglo vII la proyección del grupo episcopal, la configuración de nuevos espacios y los edificios del conjunto cristiano (horreum, capilla, etc.) se amoldan al tramo occidental del recinto fortificado, confirmando que la ciudad ya disponía de muralla previamente a la fundación del obispado tardoantiguo.

Si observamos el panorama general del occidente peninsular hispano, siendo conscientes de que es un tema que todavía genera controversia respecto a la datación propuesta para cada uno de los recintos conocidos, existe un cierto consenso entre los investigadores en situar cronológicamente los recintos de Gijón, Lugo, Castro Ventosa y Braga entre los más antiguos, en torno a finales del siglo III o inicios del IV (Fernández-Ochoa, Morillo y Salido 2011, 265-285; Catalán, Fuentes y Sastre 2014). Algo más recientes, en pleno siglo IV, se fechan las murallas de Viseu y Lisboa (De Man 2009, 741-748). Las de Mérida, Coria e Idanha-a-Velha parecen tener un origen común. En este sentido, las reformas realizadas en las murallas de Mérida podrían situarse en el siglo v, pero también existen amplias reformas en plena época visigoda. Quizás la casuística de estas tres sedes episcopales situadas en la zona central de Lusitania podría estar relacionada con la consolidación del reino suevo en su momento de máxima expansión; pero también con el control que posteriormente ostentará Leovigildo sobre los territorios ocupados hasta entonces por los suevos.

\section{Bibliografía}

Abel Vilela, A. de 2004: "A muralla na historia», en: Abel Vilela, A. de; Arias Vilas, F. (coords.). A muralla de Lugo. Patrimonio da Humanidade, Excmo. Concello de Lugo, Lugo, 149-166.

AlarCão, J. de 1973: Portugal romano, Editorial Verbo, Lisboa.

Alcorta Irastorza, E. 2007: «Muros, torres y escaleras. Aproximación al modelo constructivo de la muralla de Lucus Augusti (Lugo)», en: Rodríguez Colmenero, A.; Rodì de Llanza, I. (eds.). Murallas de ciudades romanas en el occi- dente del Imperio. Lucus Augusti como paradigma, Actas del Congreso Internacional celebrado en Lugo (26-29.XI.2005), Lugo, 283-311.

- 2008: «Un ejemplo de ingeniería militar romana bajo imperial: la muralla de Lugo", en: IV Congreso de las Obras Públicas en la Ciudad Romana (Lugo-Guitiriz, 6-8 noviembre 2008), Colegio de Ingenieros Técnicos de Obras Públicas, Madrid, 15-49.

Almeida, F. 1956: Egitania. História e arqueología, Lisboa.

- 1961: «A porta romana do Ponsul, em Idanha-a-Velha», Estudos de Castelo Branco, 1, 119-124.

- 1977a: «As ruínas romanas e visigóticas em Idanha-a-Velha», Anais da Academia Portuguesa da História, 24/2 (2. ${ }^{a}$ série), 39-57.

- 1977b: "Civitas Igaeditanorum et Egitania. Municipium romain - Ville épiscopale wisigothique», en: Thèmes de recherches sur les villes antiques d'Occident, CNRS, París, 39-50.

ARAYICI, Y. 2007: «An approach for real world data modelling with the 3D terrestrial laser scanner for built environment», Automation in Construction, 16, 816-829.

Armesto-GonzÁlez, J.; Riveiro-Rodríguez, B.; GonZÁlez-Aguilera, D.; Rivas-BreA, M. T. 2010: «Terrestrial laser scanning intensity data applied to damage detection for historical buildings», Journal of Archaeological Science, 37, 3037-3047.

Azuar, R. 2005: "Las técnicas constructivas en la formación de al-Andalus», Arqueología de la Arquitectura, 4, 149-160.

BRAssous, L. 2011: "Les enceintes urbaines tardives de la péninsule Ibérique», en: SCHATZMAnN, R.; MARTIN-KILCHER, S. (dirs.). L'Empire romain en mutation. Répercussions sur les villes dans la deuxième moitié du 3e siècle. Colloque International Bern/Augst (Suisse), 3-5 décembre 2009, Archéologie et Histoire Romaine, 20, Montagnac, 275-299.

Carvalho, R. P.; Santos, M. ${ }^{a}$ M. [Idanha-a-Velha 1989], Coimbra: relatório de escavação arqueológica, Serviço Regional de Arqueologia da Zona Centro, Portugal.

Catalán, R.; Fuentes, P.; Sastre, J. C. (eds.) 2014: Fortificaciones en la tardoantigüedad. Élites y articulación del territorio (siglos V-VIII d.C.), La Ergástula, Madrid.

Coelho, A. B. 1972: Portugal na Espanha Árabe, Lisboa, 2 vols.

CRISTÓVÃo, J. L. G. 2002: As muralhas romanas de Idanha-a-Velha, Faculdade de Letras da Universidade de Coimbra (Dissertação de Mestrado em Arqueologia), Coímbra.

De MAN, A. 2008: «Os materiais, as muralhas e as suas interpretações: estratégia baixo-imperial 
e modelo autarcista no norte da Lusitânia», Férvedes, 5, 427-430.

- 2009: «Late urban defences of the lower Mondego. The cases of Aeminiun and Conimbriga», en: Morillo, A.; Hanel, N.; Martin, E. (eds.). Limes XX. XX Congreso Internacional de Estudios sobre la Frontera Romana, León (España), Septiembre 2006, Anejos de Gladius 13, 3 vols., Madrid, Polifemo, 741-748.

- 2011: Defensas urbanas tardías da Lusitânia, Studia Lusitana, 6, Museo Nacional de Arte Romano, Mérida.

Díaz-Andreu, M.; Hobbs, R.; Rosser, N.; Sharpe, K.; TRINKS, I. 2005: «Long Meg: rock art recording using 3D laser scanning», Past: The Newsletter of the Prehistoric Society, 50, 2-6.

Doсамғо 1517-1561 = DocAMPo, F. (1517-1561): Anonymus, Antiquae inscriptiones et epitaphia, ms. siglo XVI conservado en BN, sign. 5973.

Espada Belmonte, J. A. 2011: «El interrogante medioevo en Coria», en: I-II Jornadas de Arqueología e Historia medieval. La Marca Inferior de al-Andalus, Mérida, 57-80.

Fernández-OchoA, C.; Morillo, A. 2006: «Las puertas de las murallas urbanas en la Hispania tardorromana», en: SchatTNER, T. G.; VALDEs Fernández, F. (eds.). Stadttore: Bautyp und Kunstform = Puertas de ciudades: Tipo arquitectónico y forma artística, P. von Zabern, Mainz, 253-274.

Fernández-OchoA, C.; Morillo, A.; López, J. 2005: «La dinámica urbana de las ciudades de la fachada noratlántica y del cuadrante noroeste de Hispania durante el Bajo Imperio y la Antigüedad Tardía (siglos III-VII d. C.)», en: GuRT, J. M.; RiBerA, A. (coords.). VI Reunió d'Arqueologia Cristiana Hispànica. Les ciutats tardoantigues d'Hispania: cristianització $i$ topografia, Valencia, 95-120.

Fernández-OchoA, C.; Morillo, A.; SAlido, J. 2011: "Ciudades amuralladas y annona militaris durante el Bajo Imperio en Hispania. Una cuestión a debate», en: Arce, J.; Goffaux, B. (eds.). Horrea d'Hispanie et de la Méditerranée romaine, Casa de Velázquez, Madrid, 265-285.

FerreIRA, O. da V. 1978: «Subsídio para a carta arqueológica da região egitaniense», Setúbal Arqueológica, 4, 227-241.

Fleming, A. 2001: «Landscape Archaeology in the British Uplands: opportunities and problems», en: Bernardi, M. (ed.). Archeologia del Paesaggio, Florencia, 67-88.

Fonseca, C. da 1927: A Aegitanea - Idanha-a-Velha, Lisboa.

González Fernández, E.; Carreño Gascón, M. C. 2007: "Las puertas romanas de la muralla de Lugo: Los datos arqueológicos», en: RodRíguez
Colmenero, A.; Rodì de Llanza, I. (eds.). Murallas de ciudades romanas en el occidente del Imperio. Lucus Augusti como paradigma. Actas del Congreso Internacional celebrado en Lugo (26-29.XI.2005), Lugo, 255-280.

Höfle, B.; PfeIfer, N. 2007: «Correction of laser scanning intensity data: Data and model-driven approaches", ISPRS, Journal of Photogrammetry and Remote Sensing, 62, 415-433.

Johnson, A. 1983: Roman forts of the 1st and 2nd centuries $A D$ in Britain and German Provinces, Londres.

LANDEIRo, J. M. 1940: Diocese de Guarda com a sede em Idanha-a-Vélha (Egitânia), Penamacôr e Guarda, O Arciprestado de Penamacôr, Vila Nova de Famalição.

- 1942: "Castelos da Beira (XVIII). O de Idanha-aVelha», Renascença, 215, 1 (set. 19), Lisboa.

- 1952: "Da Vélha Egitânia», Revista Beira Alta, 11 (I-II), 13-28.

Macias, S.; Torres, C. 2002: "A mesquita de Mértola», en: MAcias, S. [et al.]. Mértola Mesquital Igreja Matriz, Campo Arqueológico de Mértola, Mértola, 9-33.

Macias i SolÉ, J. M. 2015: «Tècniques constructives i arquitectura del poder al nord-est de la Tarraconense. Metodologia de representació i paràmetres analítics per a la comprensió dels processos evolutius entre l'Alt Imperi i l'Antiguitat Tardana. Activitat duta a terme el 2013-2014», QuarHis, 11, 211-214.

Marrocos, A. M. 1936: Idanha-a-Velha: Estudo Antropogeográfico, Famalicão, Faculdade de Letras, Lisboa, 1936.

Mateos, P. 2018: «De capital de la Diocesis Hispaniarum a sede temporal de la monarquía sueva. La transformación del urbanismo en Augusta Emerita durante los ss. IV y V», en: SÁNCHEZ, I.; Mateos, P. (eds.). Territorio, topografía y arquitectura de poder durante la Antigüedad Tardia, serie Mytra 1 (IAM), Mérida, 127-153.

Paz Peralta, J. A. 2015: Los cubos de las murallas de Zaragoza y del palacio de la Aljafería (10651075): paradigmas de la arquitectura militar en al-Andalus (Caesaraugusta, 84), Zaragoza.

Pereira, F. A. 1914: «Idanha-a-Velha», en: Ávila E DE Bolama, António José d'[Marquês d'Ávila e de Bolama]. A nova carta chorographica de Portugal, vol. 3, Lisboa, 179-184.

- 1938: "Vestígios do passado em Idanha-a-Velha», O Archeologo Português, 30, 186-204.

Proença Junior, F. T. 1910: Archeologia do distrito de Castelo Branco, Leiria.

RAposo, H. 1985: «Beira Baixa. Excursões de Castelo Branco. 8. À Idanha-a-Velha e Monsanto, en: Sant'Anna, D. (dir.). Guia de Portugal, vol. 3, Lisboa, 692-699. 
SÁ, A. 2007: Civitas Igaeditanorum: os deuses e os homens, Idanha-a-Nova.

SALVADO, P. 1983: As muralhas e a torre de Idanhaa-Velha, Idanha-a-Nova.

SÁnchez, I.; Morín, J. 2014: Idanha-a-Velha. Portugal 1. El episcopio de Egitania en época tardoantigua, Madrid.

- 2015: «Nueva lectura arqueológica del conjunto episcopal de Egitania (Idanha-a-Velha, Portugal)», Madrider Mitteilungen, 56, 398-428.

- (eds.) 2019: De ciuitas Igaeditanorum a Laŷdāniyya. Paisajes urbanos de Idanha-a-Vel- ha (Portugal) en épocas tardoantigua y medieval, BAR International Series, 2943, Oxford, 2019.

Torres, C. 1992: "A Sé-catedral da Idanha», Arqueología Medieval, 1, 169-178.

ZozAYA, J. 2002: "Fortificaciones tempranas en al-Andalus - ss. vIII-X», en: Mil Anos de Fortificações na Península Ibérica e no Magreb (5001500): Simpósio Internacional sobre Castelos 2000, Lisboa, 45-58. 


\title{
UNA PRESĖNCIA DIFUSA: DADES I INDICIS PER AL RECONEIXEMENT DE LES PRIMERES FORTIFICACIONS ALTMEDIEVALS A L'ÀREA CATALANA (SEGLES V-VIII)
}

JORDi GIBERT REBULL ${ }^{1}$

\section{Resum}

L'objectiu d'aquest paper passa per intentar donar resposta a la qüestió de l'existència i la dimensió a Catalunya del fenomen de l'aparició de fortificacions i de la reocupació d'assentaments en alçada durant els primers segles de l'edat mitjana. Amb inequívocs exemples coneguts, a l'àrea catalana manca encara una compilació sistemàtica de les dades disponibles que permeti una primera visió de conjunt del fenomen i un assaig preliminar d'interpretació en termes genèrics. Per tal de compensar aquest dèficit, s'ha dut a terme un recull relativament exhaustiu d'informacions que, valorades globalment, porten a distingir a priori dos moments pel que fa al desenvolupament d'aquests establiments, àmpliament dispersos sobre el territori.

\begin{abstract}
This paper aims to answer the question about the existence and the dimension of the phenomenon of the apparition of fortifications and the reoccupation of hillforts during the Early Medieval Period. With unequivocal known examples, in the Catalan area, there is a lack of a systematic compilation of the available data which would allow a general view of the phenomenon and a preliminary essay of interpretation in generic terms. To compensate for this deficiency, relatively exhaustive research of information has been carried out that, globally viewed, indicates the existence of two phases related to the development of these settlements widespread the territory.
\end{abstract}

1. Grup de recerca consolidat en «Ocupació, organització i defensa del territori medieval» (OCORDE, 2014 SGR 1454), reconegut per la Generalitat de Catalunya. Actualment, la recerca es duu a terme en el marc del projecte "Génesis de la nobleza medieval: fortificaciones y poderes territoriales en el nordeste peninsular durante los siglos VIII-XI» (HAR201563661-P), amb finançament MINECO-FEDER. Tot i publicar-se tardanament, aquest article deriva de les recerques efectuades per l'autor els anys 2013 i 2014 com a investigador postdoctoral al LabexMed d'Aix-en-Provence (UMR 7298-LA3M) gràcies a un ajut financer del setè programa marc de la Unió Europea (FP7/2007-2013 - MSCA-COFUND) i en virtut de la convenció de subvenció núm. 245743 - Programme de bourses post-doctorales Braudel-IFER-FMSH. Aprofitem per agrair a Laurent Schneider, investigador del CNRS, el seu suport i la seva ajuda durant aquella estada. 


\section{Introducció: una pregunta inicial}

Els anys 2012 i 2014 es publicaven sengles reculls d'articles al voltant del fenomen de les primeres fortificacions altmedievals, amb treballs centrats especialment en jaciments del quadrant nord-occidental de la península Ibèrica (Quirós i Tejado 2012; Catalán, Fuentes i Sastre 2014). L'edició d'aquests volums constituïa la prova manifesta de l'interès suscitat pel fenomen en el marc de la renovació metodològica i conceptual que l'arqueologia de l'alta edat mitjana ha experimentat en les darreres dues dècades. ${ }^{2}$ No obstant, la qüestió ja havia estat abordada amb antelació en altres sectors de la Mediterrània occidental, com ara el nord d'Itàlia o el sud de la Gàl-lia, espais on els diversos autors han constatat la varietat dels models, alhora que han discutit sobre la natura d'aquests enclavaments i la seva relació amb l'Estat o altres agents polítics (Brogiolo i Gelichi 1996; Schneider 2001; 2011). En els darrers anys, nous desenvolupaments de la qüestió han aprofundit en les seves problemàtiques (Tejerizo i Vigil-Escalera 2017; Tejerizo i Canosa 2018), mentre que han proliferat de manera relativa les intervencions sobre els jaciments arqueològics d'aquest perfil.

Làrea catalana ha entrat molt tangencialment en aquest debat genèric sobre l'aparició i el desenvolupament d'aquestes fortificacions primerenques, si bé recents aproximacions regionals (Folch 2018b; Gibert 2018a, 74-87) han permès iniciar la construcció d'un estat de la qüestió que s'endevina prou ric, mentre que d'altres aportacions han centrat principalment el seu enfocament des de la perspectiva de l'organització militar (Pérez 2012). En canvi, si ens referim a la casuística concreta, són ben coneguts diversos jaciments que responen a enclavaments fortificats en funcionament en algun moment dels segles V-VIII, alguns d'ells actualment en curs d'excavació i estudi -vegeu treballs en aquest mateix volum-, i que aporten dades precioses per a l'anàlisi del fenomen i, per extensió, de tot el període crític que s'esdevé a l'entorn del col-lapse imperial i en els temps immediats.

Davant d'aquest estat de les coses, l'objectiu d'aquest treball no és altre que formular-nos una pregunta ben senzilla: ¿participa el sector nordoriental de la península Ibèrica ${ }^{3}$ del fenomen de l'aparició de fortificacions i assentaments en alçada en el context del final de l'Imperi d'Occident i de l'època visigoda? Per provar de donar-hi resposta, en les pàgines que segueixen es proposa una triple revisió. D’entrada, de la documentació escrita i dels esments que refereixen l'existència de castra o castella. En segon lloc, dels jaciments que ja són coneguts per presentar estructures, estratigrafies i materials de referència. I finalment, i com a aportació principal del treball, de tot un cúmul d'indicis i informacions que són susceptibles de contribuir a dimensionar el fenomen, si més no des d'una primera i preliminar visió de conjunt.

\section{Castra i castella en la documentació es- crita anterior a l'època comtal}

Els castra o castella constitueixen un element essencial en la gradació jeràrquica dels nuclis habitats des de finals del baix Imperi i durant tota l'època visigoda, tal com mostren diversos textos conciliars i legislatius, on aquells ocupen la posició situada entre les ciutats i els nuclis secundaris ubicats per sobre dels dominis d'àmbit rural. ${ }^{4}$ Aquest rol principal en l'organització territorial del moment queda clarament reflectida en la fórmula «civitates et castella» que la documentació de tot tipus reprodueix repetidament per referir-se habitualment als centres administratius i de poder.

D'aquesta manera figura precoçment en el Chronicon escrit pel bisbe Hidaci, quan es descriuen els trasbalsos, contemporanis de l'autor, ocasionats per l'entrada a la Península de vàndals, sueus i alans a inicis del segle v, obra en la qual també es referencia l'existència d'uns castella tutiora des d'on la població romana hauria combatut els sueus a la Gal-lècia. A un nivell més específic, s'esmenten, en relació amb els conflictes entre sueus i gots de mitjan segle v, el Coviacense castrum (Valencia de Don Juan), sobre l'Esla, o el Portucale castrum, a la desembocadura del Duero (Mommsen 1894a, 18-21 i 30-31).

2. Mostra també d'aquest interès, l'any 2014 fou organitzada una taula rodona a Aniane (Hérault) per part de Laurent Schneider i de qui signa aquest article sobre «Castra, oppida et établissements de hauteur de l'Antiquité tardive et du premier Moyen Âge en France et en Espagne ( $\mathrm{V}^{\mathrm{e}}-\mathrm{VIII}{ }^{\mathrm{e}}$ siècles): études de cas et études comparées».

3. Som plenament conscients de l'ahistoricitat de conceptes com Catalunya o àrea catalana quan en realitat ens referim al sector oriental de l'antiga Tarraconesa. No obstant, per comoditat i perquè, al capdavall, la recerca no escapa dels marcs administratius actuals, els emprarem puntualment.

4. Concili de Toledo I (397-400), 3, v: «Presbyter vel diaconus vel subdiaconus vel quilibet ecclesiae deputatus clericus, si intra civitatem fuerit vel in loco in quo est ecclesia aut castelli aut vicus aut villae» (Vives 1963); Leges Visigothorum, IX, 1, 21 (Ègica): «[...] ita ut non sit penitus civitas, castellum, vicus aut villa vel diversorium, in quibus mancipia latere minime dignoscantur» (Zeumer 1902). 
La mateixa expressió ( "civitates/urbes et castella») és emprada de manera reiterada per Joan de Biclar en el seu relat de les conquestes de Leovigild a la Bètica i l'Orospeda en els anys setanta del segle vi (Mommsen 1894b, 213-215). En paral-lel, aquest mateix autor esmenta l'existència de diverses fortificacions al sud de la Gàl-lia en referir les campanyes de Recared en aquest sector, com el castrum Ugerno (Beaucaire), sobre el Roine, o, aquest també citat per Gregori de Tours en el marc dels mateixos esdeveniments, el de Caput Arietis (Cabaret), al nord de Carcassona (Krusch i Levison 1937, 396). Per altra banda, les fonts literàries i hagiogràfiques peninsulars certifiquen, per al segle VII, l'existència concreta de nuclis fortificats que s'erigeixen en centres territorials, com ara el castellum Bilibium, sobre l'Ebre a l'extrem septentrional de La Rioja (Castellanos 2011, 104105), o encara els diversos -Petrense, Leonis, Rufiana- que s'esmenten en l'entorn d'El Bierzo (Martínez 2006, 125).

Pel que fa a l'àrea avui catalana, la Historia Wambae de Julià de Toledo ens informa de l'existència, en el context de la revolta de Pau dels anys 672-673, dels castra pirinencs de Cotlliure/Caucoliberi, Ultrera/Vulturaria, Les Cluses/Clausurae i Llívia/Castrum Libiae (Levison 1910, 511), enclavament aquest últim que ha de correspondre també al Cerritanensem oppidum esmentat per la Crònica del 754 en relació amb la rebel.lió de Munussa de 730-731 (López 2009, 96-97). Situats sobre els principals passos de la serralada, tots ells han estat ben identificats i, juntament amb altres casos reconeguts arqueològicament -cas del Roc d'Enclar, a Andorra-, haurien format part inicialment d'un sistema de control i defensa d'aquells. No obstant, el seu origen, com ja indica l'arqueologia, seria previ als episodis esmentats, per tal com Orosi ja cita genèricament els Pyrenaei claustra en el context de les lluites entre faccions imperials a inicis del segle v (Zangemeister 1889, VII, 40, 6).

Més enllà d'aquestes notícies sobre l'àrea pirinenca, cal anotar que la primera menció expressa d'un castellum a Catalunya la trobem, encara en època baiximperial, en una epístola de l'any 419 de Consenci a Sant Agustí, en què es fa referència a un castellum Seueri -en relació amb el llavors capitost dels priscil-lianistes tarragonins- que cal situar probablement entre Tarragona i Lleida. Tanmateix, J. Arce dubta que aquestes mencions facin referència a indrets en alçada fortificats, tot considerant el concepte castellum com un equivalent de villa, potser fortificada (Arce 2005, 156 i 234-237). Sense que avui coneguem arqueològicament exemples catalans de vil.les d'aquesta natura, és evident que es tracta de no- cions que sovint es presten a confusió, atès que poden referir-se a realitats diverses, que són susceptibles d'evolucionar amb el temps i que només podran clarificar-se amb el recurs al registre material, com veurem tot seguit.

Abans, però, i per acabar amb la qüestió de les fonts documentals, cal dir que, de manera retroactiva, les fonts àrabs relatives a la conquesta islàmica i a la formació d'al-Andalus ens informen sobre l'existència de fortificacions prèvies a l'entrada dels musulmans a la península Ibèrica. Així, per exemple, la Crónica del Moro Rasis i la Crónica de 1344, derivada en bona part de l'anterior, esmenten la presència d'abundants castillos en parlar de la conquesta de les àrees de Lleida i Tarragona (Catalán i De Andrés 1975, 45 i 359). Per la seva banda, les fonts franques més primerenques al-ludeixen a fortificacions que probablement tenen un origen anterior. Així, la Vita Hludovici fa referència als castra de Cardona i Casserres, entre altres fortificacions llavors abandonades que Lluís el Pietós manava consolidar i habitar en els darrers anys del segle vIII en el camí cap a la conquesta de Barcelona, mentre que, poc després, la mateixa font certifica l'existència de castella en l'entorn de Tarragona. Poc més tard, encara la mateixa font $\mathrm{i}$ els Annals Reials fan referència a la Rotam civitatem d'Osona en el context de la revolta de l'any 826 (Abadal 1986, 89 i 272-273). Finalment, i abans de la proliferació de mencions de castells reportades per la documentació d'època comtal en relació amb la xarxa castral creada llavors, podem mencionar encara els esments del Balagiuum oppidum i del Bergam castellum (Balaguer, Berga) en el trasllat del cos de sant Vicenç al monestir de Castres efectuat vers l'any 863 (Abadal 1980, 32-34).

\section{Els primers casos coneguts arqueològica- ment}

Tot i tractar-se encara de casos comptats, comencem a disposar d'un elenc prou significatiu de jaciments -la majoria excavats parcialment- que han generat un volum prou important de dades a tenir en compte. Sense estendre'ns gaire en el detall, atès que tots han estat més o menys publicats i que aportacions sobre alguns d'ells figuren en aquest mateix volum, passem a efectuar un mínim examen d'aquestes informacions. Entre el conjunt, destaca el castrum de Puig Rom, un nucli de planta irregular protegit per una potent muralla que tanca una superfície propera a l'hectàrea. Situat al capdamunt d'un turó abocat sobre el golf de Roses, cal situar la seva cronologia de funcionament, segons els darrers treballs efectuats, en- 
tre mitjans o finals del segle vII i, com a mínim, tot el segle següent (De Palol 2004; Subías et al. 2018). El seu ric registre material, que conté armes però també utillatge agrícola, ramader i de pesca, revela l'existència d'una població agrupada, en el si de la qual s'exerceixen funcions variades. En aquest sentit, i més enllà de l'existència de la muralla, la presència d'alguns elements mobles (moneda d'or, ponderal de bronze, determinats objectes de taula o d'abillament) permet atribuir al lloc una dimensió significada en l'esfera politicoadministrativa, amb una presència evident de membres de la classe dominant.

Prop de la ciutat de Girona, i sobre el congost del Ter, a la muntanya de Sant Julià de Ramis, ha estat excavat en els darrers anys un establiment militar de dimensions considerables, la construcció inicial del qual es pot situar vers finals del segle IV o principis del segle següent i que arriba, amb reformes importants, fins a principis del segle VIII (Burch et al. 2006). Assentat sobre les restes d'un gran oppidum d'època ibèrica, l'establiment, considerat un castellum pels seus excavadors, reaprofita i renova la muralla antiga, a l'interior de la qual, a l'extrem septentrional del recinte, s'han pogut excavar les restes d'un edifici complex i compacte -una segona construcció propera s'ha conservat molt parcialment-, format per una gran nau central rectangular en la qual s'obren diverses habitacions. Els treballs més recents (Burch et al. 2018), per altra banda, han permès constatar l'existència d'un hàbitat contemporani de la fase més tardana del castellum sota l'antic cementiri parroquial, a uns 300 metres de distància d'aquell, a l'extrem oposat de la plataforma. Aquí, per sota dels nivells de la necròpolis medieval, han estat descoberts més de mitja dotzena d'àmbits bastits amb murs de pedra i fang, en alguns casos amb un probable alçat de tovot, la vida dels quals s'allargaria, segons alguns dels materials localitzats, entre la segona meitat del segle vi i entrat el segle vIII, quan la fortificació sembla abandonar-se i es generaria el topònim pel qual es coneix l'emplaçament en la documentació altmedieval: Castellum Fractum.

El cas del castellum de Sant Julià es relaciona habitualment (Nolla 2014) amb altres fortificacions properes d'origen baiximperial o altmedieval primerenc, com la que controla el pas dels Pirineus pel lloc de les Cluses, documentat així -castrum quod vocatur Clausuras-, com apuntàvem, en el relat que fa Julià de Toledo de la rebel-lió de Paulus contra Wamba dels anys 672-673, on també apareixen altres fortificacions pirinenques com Cotlliure, Llívia o Ultrera («castraque Pirineica, quae vocantur Caucoliberi, Vulturaria et castrum Libiae»).
Pel que fa al primer lloc, es tracta de dos potents fortins de planta poligonal amb torres -el Castell dels Moros i la Clusa Alta- que flanquegen el pas fortificat de la via al nord del coll de Panissars, on una torre potser coetània s'hauria erigit sobre les restes del trofeu de Pompeu (Nolla 2014, 46-49). Les dades arqueològiques que en posseïm són més aviat minses, si bé apunten cap a una cronologia de funcionament situada entre mitjans o finals del segle IV i, com a molt, inicis del segle vi.

Més informació és la que tenim sobre el castrum Vulturaria, on, castell feudal a banda, s'han pogut detectar ocupacions prèvies sobre diversos punts de la cresta on aquell es troba, al vessant septentrional de les Alberes (Constant 2008). Entre ells, el Pic Saint-Michel nord mostra dues fases d'ocupació, entre mitjans del segle v i el segle VII -O potser ja VIII-, i ja als segles IX-X, en què la primera d'elles correspondria a diversos àmbits de murs de pedra lligada amb fang que s'obren a un passatge central i on s'han detectat activitats vinculades a la producció agropecuària.

Sobre el castrum documentat a Llívia, les dades arqueològiques són ben escasses pel que fa al cim del Puig del Castell, on tan sols es pot adduir la troballa d'alguns materials tardoantics presents en estrats medievals posteriors (Olesti, Mercadal i Guàrdia 2014, 76-83). No obstant, cal destacar l'ocupació que presenta, al peu del turó, l'àrea del fòrum, on es detecta una presència militar a partir de la troballa de l'enterrament d'un macaco d'una espècie nord-africana, guarnit amb abillaments militars i datat per radiocarboni entre mitjans del segle v i mitjans del segle següent, i d'una ocultació de monedes efectuada en el segle vI, amb algunes peces bizantines del nord d'Àfrica.

Mancat de tota referència documental directa, cal vincular als esmentats castra pirinencs el jaciment del Roc d'Enclar, a Andorra, on es documenta de manera fragmentària una muralla perimetral que inclou algunes torres de planta quadrada que els excavadors atribueixen a un castellum, per al qual es proposa una funció originària, entre mitjans del segle IV i mitjans del segle v, de vigilància del pas de la vall d'Andorra i una posterior reconversió en centre administratiu del poder (Llovera 1997, 98-109). Potser una funció similar s'hauria pogut desenvolupar, en algun moment, des del jaciment dels Altimiris (Sant Esteve de la Sarga), encara en curs d'excavació i ubicat en una cresta de difícil accés molt a prop del congost de Mont-rebei, per on la Noguera Ribagorçana travessa el massís del Montsec. Aquí, un edifici de planta quadrangular bastit amb la tècnica de l'encofrat i amb sòl d'opus signinum s'havia identificat inicialment amb una torre, si bé les darreres interpretacions del jaciment advoquen per una 
natura monàstica de l'establiment, que funcionaria principalment entre finals del segle v i el segle VII, amb una prolongació fins al segle IX (Sancho 2019). Vers l'extrem oposat del Montsec d'Ares, el jaciment de Sant Martí de les Tombetes presenta paral.lels amb l'exemple anterior, si bé mereix ser destacada una excepcional necròpolis de tombes picades a la roca de bona factura (Alegría i Hidalgo 2015).

Altres exemples mereixen ser portats a collació, abans de donar per acabada aquesta ràpida revisió. En primer lloc, la redimensió del jaciment de l'Esquerda, a Osona, que cal identificar amb la Roda civitas de les cròniques carolíngies. Situat en una península allargassada formada per un tancat meandre del Ter, el jaciment presenta ocupacions importants en època ibèrica i medieval, quan es crea un vilatge a l'entorn de l'església de Sant Pere, documentada l'any 927 (Ollich 1999). Ha estat en els darrers anys que s'ha pogut identificar una potent muralla altmedieval, avançada i sobre la fortificació ibèrica que tancava la península pel sector septentrional, l'únic fàcilment accessible (Ollich et al. 2015). Es tracta d'una obra prou imponent, amb un llenç de pràcticament 150 metres de llargada, que arriba a tenir una amplada de gairebé 3 metres i que presenta diverses torres quadrangulars adossades. Al seu interior immediat ha estat igualment detectat un extens camp de sitges, l'ús del qual l'equip excavador situa entre els segles V-VIII. Aquesta muralla es complementaria amb un fossat potser corresponent a la fase carolíngia per tal com talla alguna de les diverses tombes que han aparegut en aquest sector exterior situat davant per davant del mur defensiu. Es tracta d'un grup de sepultures orientades est-oest, tant en fossa simple com en caixa de lloses, sobre les quals s'han practicat diverses datacions radiocarbòniques els resultats de les quals permeten ubicar-les entre molt avançat el segle VII i en ple segle VIII. Aquestes darreres precisions cronològiques permeten assegurar que el lloc va estar ocupat si més no des de la segona meitat del segle VII -extrem de la datació radiocarbònica d'una mostra de fauna d'una de les sitges-, a la vegada que les referències documentals de la primera meitat del segle Ix citades abans es veurien confirmades ara definitivament per la troballa d'un diner de Lluís el Pietós que els és contemporani. Encara a Osona, els darrers treballs efectuats dalt del turó del castell de Besora, a més de mil metres d'alçada i ja a tocar del Ripollès, han detectat una ocupació prèvia a la fortificació d'època comtal, intuïda fins fa poc tan sols per la presència descontextualitzada de fragments de sigil-lada gàl-lica tardana o d'àmfora (Busquets et al. 2017). Recentment, però, a l'extrem occidental de la plataforma superior del turó, de gairebé una hectàrea de superfície i on també es documenten vestigis d'època ibèrica, s'han excavat les restes d'un edifici rectangular ( $6 \times 4$ metres $)$ a l'interior del qual, tot i no conservar-se el paviment, s'ha pogut documentar l'existència d'una tomba en caixa de lloses i llit de morter. Les mostres preses sobre els dos individus sebollits, un d'ells en posició primària i l'altre sota la forma d'un dipòsit secundari, han aportat datacions radiocarbòniques que situen les morts respectives entre l'últim terç del segle VII i finals del segle IX (665-770, 95,4\%; 765$895,88,3 \%)$.

Al Berguedà, cal atorgar un lloc destacat dins del grup al jaciment del Serrat dels Tres Hereus, sobre un tossal on es conserven les restes d'un poblat d'època iberoromana, en un enclavament des d'on es domina tot el Baix Berguedà, especialment la vall del Llobregat i els plans de Casserres i Avià, així com els primers contraforts pirinencs (Rodrigo, Martín i Canal 1999-2000). Per sobre d'aquestes restes, en alguns dels sondejos practicats s'ha pogut identificar una fase posterior a partir del reaprofitament del mur perimetral antic i de la construcció d'alguns murs de blocs units amb fang que s'hi associen (Folch et al. 2007). Així, per sota del nivell d'enderroc es va poder detectar, al costat d'alguns indicis que delataven l'acció d'un possible incendi general, un nivell de circulació on es va recuperar un important conjunt de material ceràmic, amb algunes peces senceres, així com diverses moles de molí manual rotatori i alguns objectes metàl-lics. De fet, un estudi recent sobre aquests darrers en l'àmbit global del jaciment ha posat en relleu l'existència d'una quantitat notable i diversa d'objectes pertanyents a aquesta segona fase. Entre ells, destaquen estris vinculats a l'explotació de recursos animals, com un cardador de llana i un raspador per adobar pells, així com un gran nombre de claus que podrien procedir de la porta que tancava un dels accessos a l'assentament (Morell 2006). Es fa difícil, sense més precisions i mancats de datacions absolutes, precisar la cronologia d'aquesta ocupació, si bé les característiques del material exhumat ens porten a situar-la aproximadament entorn dels segles VII-VIII, sense que es pugui tampoc descartar un allargament d'aquest arc cronològic fins entrat el segle Ix. ${ }^{5}$

5. Aquí cal tenir en compte de nou la inclusió de Casserres -Castaserram-entre els oppida deserta que havien d'ocupar els exèrcits francs a finals del segle vIII per manament de Lluís, fill de Carlemany (Abadal 1986, 89). 
Dalt d'un penyal penjat sobre la ciutat de Berga, amb un ampli control visual sobre la localitat i sobre un important sector de la conca del Llobregat, l'església de Sant Pere de Madrona conté al subsol, i presumiblement al seu voltant, restes que els excavadors del jaciment atribueixen a un possible castellum construït cap a finals de l'època visigoda (Fierro 2011). Així, constitueixen els vestigis més antics una sèrie de murs que defineixen dues crugies que segueixen la mateixa orientació del temple actual, la cronologia dels quals s'estableix a partir de la presència, en els nivells fundacionals, de restes d'olles de llavi bisellat, un fragment d'àmfora africana i una datació obtinguda per termoluminescència $(680 \pm 77)$.

Finalment, cal integrar a l'anàlisi les primeres dades obtingudes en relació amb l'ocupació d'època visigoda del jaciment del Tossal del Moro (Castellserà, Urgell), amb precedents ibèrics i reconeguda per l'excavació de diverses unitats habitacionals complexes construïdes al capdamunt d'un turó, encerclades per una muralla i articulades a l'entorn d'una gran plaça (Escala, Mulet i Colet 2011; Escala et al. 2018). Els murs presenten sòcol de pedra lligada amb fang i un alçat de terra, tot plegat cobert amb sostres de terra i elements vegetals. La manca de materials ceràmics d'importació, així com la presència de sivelles liriformes i d'algunes peces numismàtiques, permeten proposar als seus excavadors una cronologia en diverses fases que s'esglaonarien entre mitjans del segle VII i tot el segle viII.

\section{Una presència sospitosa (i fins fa no gaire insospitada)}

Els exemples descrits són la prova fefaent del fet que en terres avui catalanes l'existència d'enclavaments en alçada fortificats durant la primera edat mitjana fou una realitat, si bé el nombre més aviat pobre de casos coneguts, la parcialitat d'algunes de les intervencions i la diversitat cronològica, morfològica i funcional que s'albira ja des d'un primer moment no permeten, per ara, obtenir una visió nítida i global del fenomen. Davant la possibilitat, fàcilment intuïble, que el repertori fins ara conegut pugui constituir tan sols una part d'un registre més extens, no sabem si molt o poc, pensem que és urgent començar a revisar i prendre nota d'algunes evidències que mereixen ser examinades de manera conjunta i articulada. Amb aquest objectiu, hem dut a terme un recull, extens però segurament no exhaustiu, de notícies que delaten la presència de materials arqueològics vinculats a l'arc cronològic situat entre els segles v-VIII en emplaçaments situats en alçada i que sovint són coneguts per l'existència d'ocupacions d'època ibèrica. En aquest context, ja avancem que un element director han estat les monedes baiximperials, tot i que també hem tingut en compte els materials ceràmics o els objectes d'abillament personal, com ara les sivelles de cinturó.

Si iniciem el recorregut de nord a sud per l'àrea més propera al litoral, cal fer esment en primer lloc de la troballa en superfície de materials baiximperials i d'època visigoda-sigil-lades, àmfora i comunes descrites imprecisament- a la Roca de Miralles (Vilajuïga), emplaçament del castell homònim documentat al segle $\mathrm{x}$ (Catalunya Romànica 1984, 913-914). Materials semblants han estat observats, així mateix, al proper cim del Castellar (Espolla), on s'associen a un recinte que l'envolta i a altres estructures construïdes en sec (Catalunya Romànica 1989, 47-48). Ja al Baix Empordà, al Puig de la Fonollera (Torroella de Montgrí), prop del mar i de l'actual desembocadura del Ter, sobre nivells protohistòrics i romanorepublicans s'ha pogut detectar una fase que cal situar en el segle $v$, amb presència d'àmfora de procedència lusitana (Keay XIX), de sigil-lada africana D (Hayes 91) i potser també de sud-gàl-lica tardana, així com de dues monedes de l'emperador Valent (364-378) (Pons [ed.] 1986, 122-123; Nolla 1977, 188). A pocs quilòmetres vers el sud, al castell de Begur, cal fer esment de la detecció en superfície de ceràmica sigil-lada gàl-lica tardana i de la troballa d'una lluerna d'època baiximperial (IPAC; Nolla i Casas 1984, 119).

A l'altre extrem de les comarques gironines, cal destacar la localització de quatre monedes dels emperadors Constantí i Constanci II, datades entre els anys 330 i 364 i atribuïbles a la seca de Constantinoble, trobades dins un dels murs del castell de Torcafelló, a Maçanet de la Selva, emplaçament on també es registra una ocupació de finals d'època ibèrica (Llinàs, Manzano i Ramírez 1994, 144; Folch et al. 2000). Sense que s'hagin pogut identificar restes estructurals coetànies, aquestes peces haurien de correspondre molt probablement a la mateixa ocupació a la qual també pertanyerien diversos fragments de ceràmica, entre ells una base de sigil.lada gàl.lica tardana. Encara a la Selva, cal esmentar la documentació de materials tardoantics -tegulae, dolia, sigil.lada africana D, ceràmica comuna- durant l'excavació, fa dècades, del poblat medieval de Caulers Vell (Caldes de Malavella), on les restes d'una torre aproximadament quadrangular de 4 metres de costat, amb contraforts als angles, han estat atribuïdes a aquesta mateixa fase (Folch 2019, 34-35).

A les muntanyes del Vallès, els indicis que hi hem pogut trobar fan referència curiosament a dos enclavaments situats sobre mateix del Con- 
gost i del Tenes, prop de la seva sortida cap a la plana (Estrada 1969, 42 i 48). Així, al Turó de Can Noguera (la Garriga), anomenat «castellar» a l'edat mitjana, hi ha notícia de la presència de tombes de lloses, així com de fragments de sigillada gàl-lica tardana, de sigil-lada africana D i d'àmfora. Per la seva banda, al Turó del Rull (Bigues i Riells), la troballa d'un fragment de ceràmica sigil-lada africana D de la forma Hayes 91 en el context d'un poblat ibèric indicaria una ocupació indeterminada vers els segles v-VI. No gaire lluny dels anteriors, l'excavació parcial fa anys de l'església de Sant Sadurní de Gallifa, situada al capdamunt de la Mola i envoltada d'unes espectaculars cingleres, va permetre constatar la presència d'una tomba de lloses prèvia al temple preromànic, documentat al segle $\mathrm{x}$ (Sancho, Raurich i Mestre 1994); així mateix, es va poder recuperar, fora del seu context original, una moneda que, tot i mostrar un important nivell de desgast que en dificulta la lectura, bé podria correspondre a una emissió constantiniana de la sèrie Urbs Roma, a datar entre els anys 330 i 337 (Royo 2008, 40-41), peça que potser pot vincular-se a alguns materials -ceràmica comuna, fragments de tegula- probablement tardans.

Sobre el congost de Martorell, el Castellvell de Rosanes mostra alguns indicis d'haver estat ocupat vers la fi de l'antiguitat, com ho indicaria la presència detectada en el passat d'alguns materials romans imprecisos i d'una tomba de tegulae prop de la seva gran torre circular, que en un altre lloc hem argumentat que seria ja del segle VIII (Mauri 2014, 37; Gibert 2006). En aquest punt, interessa posar en relleu el fet que el seu homònim del Penedès, el Castellvell de la Marca, mostra també materials que denoten una ocupació d'època tardoantiga. Les dades obtingudes fins ara en el marc del projecte d'excavació en curs limiten, de moment, el reconeixement d'aquesta ocupació als nivells que cobreixen la roca i les seves escletxes a la part superior del cim del castell, on aquests materials -sigil.lades i comunes africanes, comunes locals- es presenten molt trossejats. Sense que de moment els puguem atribuir amb seguretat a aquesta fase, cal destacar igualment la troballa en superfície relativament abundant de fragments de tegulae i dolia al vessant de la muntanya del castell (Folch et al. 2018).

Seguint al Penedès, l'excavació del sector proper a la muralla d'Olèrdola, jaciment conegut per les fases, amb potents estructures, d'època ibèrica, romanorepublicana i comtal, ha permès recuperar tres monedes del segle IV, totes elles objecte d'un fort desgast a causa probablement d'un temps dilatat de circulació, ${ }^{6}$ a les quals cal afegir encara notícies anteriors que refereixen la troballa de tres bronzes més del mateix moment. ${ }^{7}$ Localitzada una d'aquelles en una sitja d'època comtal, cal destacar que una altra fou trobada entre les cendres d'un fogar situat estratigràficament després de l'ocupació republicana i abans de les primeres estructures clarament medievals (Molist 2009). No gaire lluny, al poblat ibèric del Pujol d'en Figueres, cim prominent que s'alça sobre la plana davant del castell de Subirats, s'han localitzat diverses monedes ibèriques, romanes altimperials i modernes, a banda de les quals cal destacar un petit conjunt homogeni cronològicament format per una moneda de Crispus (317-326), una de Constantí (306-327) i una d'Honori (395-423) (Mateu 1985-1986, 67; Járrega 2003, 399).

A les comarques tarragonines tampoc no hi manquen els indicis. Així, al Puig de Gallicant (Arbolí), a les muntanyes de Prades, s'observen les restes d'un mur que envolta el cim i encara la presència d'un fossat; aquí han estat localitzades algunes monedes ibèriques i republicanes, si bé alguns analistes no descarten que el topònim tingui a veure amb la presència de tropes procedents de la Gàl.lia -Gallicani- en època tardoromana (Olesti i Olesti 2013, 50 i 53). De fet, aquesta hipòtesi ha estat formulada igualment en relació amb el turó de Gallissà, a Bellver de Cerdanya, una elevació que domina el pas del Segre i on es coneix la troballa de monedes tardoantigues (Olesti, Mercadal i Guàrdia 2014, 82). A l'extrem septentrional de les mateixes muntanyes, la torre de Castellfollit (Vimbodí i Poblet) és un edifici singular que s'aixeca sobre un espadat de la vall homònima. De planta aproximadament quadrangular i bastida amb el sistema de l'encofrat, hauria estat coberta amb tegulae, segons es desprèn dels nivells interns d'enderroc observats en superfície (Carreras 1981). La prospecció dels seus voltants ha permès constatar la presència d'alguns materials ceràmics d'aspecte groller, alguns d'altmedievals però també d'altres de la prehistòria recent, així com alguns fragments d'àmfora indeterminada, mentre que s'ha pogut observar l'existència d'altres d'estructures de fortificació en l'entorn de la cresta on s'ubica la torre (Gonzalo i Martí 2015, 725-726). Més al sud, les muntanyes del Priorat i de Tivissa-Vandellòs podrien constituir aparent-

6. Un nummus il-legible d'entre 335-341, un AE3 de Constanci Gal o Julià II (351-361) i un AE2 de Magne Màxim d'entre 383 i 387 (Campo 2009).

7. Constanci II (350-361), Teodosi (379-395) i Honori (395-423) (Ferrer 1949, 64). 
ment un context idoni per a l'existència d'algun tipus d'establiment en alçada. Sense dades arqueològiques que ho confirmin, caldrà prestar una especial atenció a enclavaments singulars, com la muntanya de la Miloquera, on es troba el castell de Marçà i on es coneix la presència de materials imprecisos d'època romana (IPAC), o com la Mola de Genessies (Tivissa-Vandellòs), una àmplia plataforma de més de 3 hectàrees i mitja de superfície, envoltada d'alts espadats i on àdhuc s'albiren diverses estructures en superfície, atribuïdes fins ara de manera hipotètica a un poblat ibèric ( $\mathrm{Du}-$ pré 2006, 26).

A l'altra banda de l'Ebre, a la Terra Alta, documentem encara alguns pocs exemples, com la Pena de Gall (Horta de Sant Joan), una elevació rocosa als estreps dels Ports, de planta triangular i pendent considerable, on un mur protegeix l'únic accés practicable. Aquí, alguns fragments de sigil-lada africana $\mathrm{D}$ testimonien una ocupació posterior a l'establiment ibèric que també s'hi localitza, com sembla succeir també al proper jaciment del Mas de Manresa, sobre un petit turó enmig de camps al peu de la serra (Puch 19861987, 25-28). Tot i que fora ja dels límits imposats per a aquest article, no volem deixar de fer esment dels clars indicis que, malgrat el seu caràcter fragmentari, assenyalen la continuïtat del fenomen cap al nord del País Valencià, on són múltiples les troballes de materials que delaten la reocupació vers el segle $v$ de jaciments ibèrics en alçada entre el Sénia i el Palància. ${ }^{8}$ Entre aquests destaca principalment el poblat de Sant Josep, a la Vall d'Uixó, on materials diversos apunten cap a una ocupació, potser de caràcter militar, que reaprofitaria, en el segle v, estructures de l'antic poblat ibèric (Arasa i Rosas 1994; Rosas 1996-1997). Val a dir, en aquest punt, que altres recintes en alçada fortificats d'aquest sector, com els que trobem als jaciments del Mollet (Vilafamés), del Tossal de la Vila (Serra d'en Galceran) o fins i tot del Punt del Cid (Almenara), semblen correspondre a iniciatives ja d'època emiral, i per tant posteriors al marc cronològic estricte d'aquest paper (Negre et al. en premsa).

Si dirigim ara la mirada cap a les terres interiors, i anant més enllà dels casos ja comentats per als quals comptem amb estructures i estratigrafies excavades com són l'Esquerda de Roda de Ter, el castell de Besora o el Serrat dels Tres Hereus de Casserres (Berguedà), els indicis són també significatius (Gibert 2018a, 74-86). Així, a Osona són diversos els enclavaments en alçada situats al voltant de la Plana de Vic que ofereixen materials o fins i tot estructures que podrien vincular-se als segles V-VII. No lluny de l'Esquerda, i també a l'extrem d'una península envoltada d'espadats roquers i formada per un meandre del Ter, el monestir vescomtal de Sant Pere de Casserres podria tenir precedents anteriors, si es tenen en compte alguns indicis. En primer lloc, caldrà obtenir més dades que precisin el context fundacional de la muralla que tanca la península al sud del monestir, una construcció de blocs lligats amb morter d'uns 230 metres de longitud (Chávez i Pastor 2014). Per altra banda, i sense que l'excavació del solar del monestir hagi pogut detectar cap ocupació antiga més enllà de les diverses desenes de tombes antropomorfes excavades a la roca que evidencien l'existència de l'església documentada al segle $\mathrm{x}$, tampoc identificada materialment (Catalunya Romànica 1998, 201-206), resten per considerar alguns elements mobles que podrien constituir indicis d'una ocupació tardoantiga del lloc, si bé per la seva pròpia naturalesa no es pot descartar que hagin estat aportats en èpoques molt posteriors a la seva fabricació. Ens referim a una ara d'altar de marbre blanc -que, malgrat algunes modificacions posteriors, ha estat considerada d'època paleocristiana (De Palol 1957-1958, 87)-, a un sarcòfag amb decoració de dos paons i una creu potençada en la seva cara frontal, motius de clara filiació paleocristiana però que alguns autors consideren fruit d'un cert arcaisme en una obra ja dels segles IX-X (Catalunya Romànica 1998, 206); i, finalment, a una ampulla o eulogia localitzada dins l'altar principal de l'església del monestir, on complia funcions de lipsanoteca. De procedència oriental i utilitzat probablement per dur relíquies de Terra Santa, ha estat proposada una cronologia per a l'objecte de vers el segle vII, si bé hi ha qui el considera un mica més tardà (segles VIII-X) i dipositat amb motiu de la consagració de l'església a mitjans del segle XI (Arad 2007).

Amb una superfície de poc menys de 3 hectàrees, el Pla del Castell de Tona se situa al capdamunt d'un dels característics "turons-testimoni» que hom troba a la Plana de Vic. Ocupat ja en època ibèrica (Rocafiguera 1995, 39), avui els únics edificis en peus són l'església de Sant Andreu, d'orígens romànics, i una torre situada en un angle del pla, envoltada per un fossat excavat a la roca. Aquesta darrera construcció, de planta quadrada amb costats de poc menys de 5 metres,

8. S'han trobat materials tardans, per exemple, als jaciments del Puig de la Nau i la Tossa Alta (Benicarló), el Poaig (Peníscola), la Curolla (Cervera del Maestrat), el Cormulló dels Moros (Albocàsser), el Tossal de la Balaguera (la Pobla Tornesa), el Tossal de l'Assut i Montnegre (Borriol), el Castell de la Magdalena (Castelló de la Plana), la Muntanya de Santa Bàrbara (la Vilavella), el Castellar (Xilxes) o el poblat de Malpàs (Castellnou) (Arasa 1996-1997; Fletcher 1945). 
presenta una singular tècnica constructiva en encofrat de pedres i morter que ha motivat una certa controvèrsia a l'hora d'atribuir-li una cronologia fundacional. Els resultats de l'excavació del seu interior feta l'any 1972 romanen pràcticament inèdits i només sabem que, sota un primer nivell remogut amb materials de diverses èpoques, es trobava un estrat que contenia ceràmica grollera medieval, alguns fragments baiximperials, uns altres d'època ibèrica i encara de campaniana, així com restes de vidre, de fauna i de ferro (Catalunya Romànica 1986, 636-639). Per la seva banda, l'església de Sant Andreu presenta alguns indicis que aparentment podrien delatar una major antiguitat tant en relació amb la seva obra romànica del segle xi com pel que fa a la seva consagració de l'any 888, quan temple i castell apareixen per primera vegada en la documentació (Catalunya Romànica 1986, 639-644). Així, la seva excavació l'any 1943 va permetre constatar l'existència d'una església prèvia, de dimensions menors i amb absis carrat, acompanyada d'un nivell d'enterraments amb fosses de tipus antropomorf, que bé podria correspondre a la consagrada a finals del segle Ix. No obstant, sembla que existiria un nivell d'enterraments encara més antic, atès que, en algun sector exterior del temple, hi apareixia un grup de tombes de lloses situades a més profunditat i, per tant, anteriors als segles IX-X. D'altra banda, un indici en favor de l'existència d'una església antiga -O potser d'un mausoleu- al turó del castell de Tona el constitueix la troballa, a la mateixa excavació dels anys quaranta del segle $\mathrm{xx}$, de dos petits fragments d'un sarcòfag de producció local que previsiblement cal datar en el segle v (Vidal 2000).

Per tancar el capítol osonenc, un emplaçament idoni el constitueix l'entorn del castell de Sant Llorenç del Munt, documentat des de finals del segle Ix i situat a l'extrem d'una plataforma de més de 5 hectàrees de superfície -el Pla del Castelldes d'on s'obté un extens domini visual tant de la Plana de Vic com de les Guilleries. Tot i tractar-se d'un indici més aviat precari, aquí cal assenyalar que fou localitzat dins l'església de Sant Llorenç un fragment de dolium -o tegula?-, probablement reutilitzat com a tapadora d'un reliquiari, amb diversos noms inscrits vers el segle x (Catalunya Romànica 1986, 492).

Pel que fa al Berguedà, cal assenyalar en primer lloc les informacions relatives al jaciment de Can Maurí (Berga), en un esperó rocallós envoltat per un penya-segat que sorgeix del vessant meridional de la muntanya de la Figuerassa, a uns 1.200 metres d'alçada. Les restes en superfície es detecten en una plataforma en pendent que no arribaria a l'hectàrea de superfície, protegida tant naturalment com per la presència intermitent d'un mur perimetral i on s'havia observat la presència de murs bastits amb blocs lligats amb fang o pràcticament en sec. Alguns sondejos efectuats l'any 1961 (Castillo i Riu 1962) posaren efectivament de manifest l'existència d'àmbits, a l'interior dels quals es documentaren materials diversos, entre ells ceràmiques de factura grollera, que, a banda d'una ocupació d'època ibèrica, delataven l'existència d'un assentament altmedieval molt primerenc que prospeccions posteriors han situat vers els segles VII-VIII (Martí i Camprubí 1997-2001).

Tot prosseguint cap al Solsonès, cal fer esment en primer lloc del Turó del Vilaró Vell (Olius), un assentament ibèric constituït per una muralla perimetral que defineix un recinte de planta ovalada dins del qual s'ubiquen diverses construccions. Al seu exterior immediat es documentaren fins a vint tombes d'adults i tres d'infants en caixa de lloses, que han de vincular-se a un hàbitat altmedieval, si bé no podem assegurar que aquest correspongui a una reocupació del mateix turó (Llorens 1986, 64-65). Al mateix terme municipal, el jaciment i el conjunt monumental de Sant Esteve, en una elevació sobre el Cardener, presenten seqüències d'ocupació diverses fonamentalment vinculades a l'establiment d'un nucli emmurallat d'època ibèrica i a la presència d'un castell i d'una església d'època comtal (Chorén i Calduch 2006). En relació amb aquesta ocupació medieval, les excavacions han pogut constatar l'existència d'un extens camp de sitges sobreposat als també abundants dipòsits d'època ibèrica, un graner on les estructures es creen i s'amortitzen durant un període que els autors proposen situar entre els segles x i XIV (Asensio et al. 2003). L'horitzó cronològic més antic dins aquesta ocupació medieval correspondria tan sols a dues sitges que haurien fornit alguns exemplars de sitra, unes peces que, com els mateixos excavadors reconeixen, cal situar grosso modo entre els segles IX i XI. No obstant, sorprèn la presència, als mateixos dipòsits, de diverses olles globulars amb vores exvasades amb el llavi de tendència bisellada o quadrangular, uns trets que habitualment s'atribueixen a materials més antics dins l'alta edat mitjana i que són similars, per exemple, als observats en l'ocupació altmedieval del Serrat dels Tres Hereus de Casserres. Així mateix, encara es pot considerar un darrer indici d'aquesta ocupació altmedieval del lloc la troballa, al segle xIX, d'una placa de sivella de bronze en fer obres prop de l'església. Es tracta d'un objecte profusament decorat que té paral.lels a l'àrea burgúndia i que es pot datar, segons algunes opinions, entre un segle vI avançat i fins al segle vIII (Ripoll i Chavarría 1999).

Ja a l'altra banda del Segre, cal destacar la troballa recent de materials tardoantics al capda- 
munt de la Roca del Corb (Peramola), a prop dels mil metres d'alçada (Remolins 2015). A l'extrem oest d'aquesta roca prominent, i més enllà d'un primer horitzó vinculat a la prehistòria recent, la prospecció ha permès observar la presència relativament abundant de materials arqueològics, principalment ceràmica, però també vidre, objectes de bronze i ferro i escòries, un conjunt que se situa genèricament entre els segles IV i vIII. No obstant, i pel que fa a la ceràmica, els autors de la prospecció assenyalen les similituds amb produccions de sigil.lada gàl.lica tardana, mentre que els parallels per als fragments de vidre remeten també a peces de vers el segle v. Segre avall, el jaciment d'Antona (Artesa de Segre), en una posició dominant sobre el riu i envoltat d'espadats, presenta dues importants ocupacions en època ibèrica $i$ durant l'edat mitjana, quan la fortificació allà bastida fou coneguda per un temps com el castell de Malagastre. No obstant, la localització fa una quarantena d'anys d'una sivella liriforme sota un dels paviments del castell durant les excavacions de J. Maluquer de Motes posa de manifest l'eventual existència d'una ocupació d'època visigoda encara no reconeguda a escala estratigràfica i d'estructures, en la qual potser tindria un paper la muralla de grans carreus considerada d'època ibèrica, una imponent construcció de quatre metres d'amplada situada per sota de la fortificació medieval (Ros i Solanes 2001-2002; Camats i Ros 2018).

A banda dels jaciments citats més amunt dels Altimiris i de Sant Martí de les Tombetes, o de magres i puntuals notícies com la que refereix la presència de materials romans tardans en l'entorn del castell d'Orcau (Catalunya Romànica 1993, 89), els indicis que apuntarien vers altres ocupacions tardoantigues en alçada al Prepirineu de Ponent es mostren ben poc tangibles i cal complementar-les amb alguna menció documental antiga o amb la pròpia toponímia. En aquest sentit, un treball recent (Sancho 2018, 13-18) crida l'atenció sobre l'emplaçament d'alguns castells documentats en els segles Ix i x, situats sobre mateix o a tocar dels cursos dels principals rius. Així, al castell d'Orrit, sobre la Noguera Ribagorçana, ha estat localitzada una inscripció d'època romana, mentre que la menció precoç, en ple segle vI, d'un Orritensi territorio podria fer pensar que el turó del castell podria haver-se erigit ja llavors en un centre territorial. Segons la mateixa autora, la dualitat que s'estableix entre el castell d'Orrit i el d'Areny, a l'altra banda del riu i on ha estat excavada una important necròpolis de tombes picades a la roca, podria tenir rèpliques en altres indrets similars, com succeiria en el cas dels castells d'Oliana i de Castell-llebre (Kastello Veteri), sobre el Segre, o, sobre la Noguera Pallaresa, en el dels de Llimiana i Mur, fortificació aquesta darrera on encara cal confirmar l'antiguitat d'un mur de grans carreus que envoltaria el turó del castell i que es considera anterior a l'època comtal.

Finalment, i pel que fa al Pirineu axial, al jaciment cerdà de Sant Feliu de Castellvell (Llo) s'hi va trobar una moneda de Constanci II (337-361), mentre que tenim la notícia imprecisa de la troballa de ceràmica sigil-lada tardana a la roca de Sant Pere de Tor (Alins), on es presumeix l'existència d'una fortificació tardoromana (Padró 1988, 256 i 259). No gaire lluny d'aquest darrer, el Pui de Sant Martí (Vall de Cardós), sobre la Noguera de Cardós, era anomenat antigament Civitas, segons l'acta de consagració de la seva església de l'any 1146 (Catalunya Romànica 1993, 24 i 290-292). Sense que coneguem cap dada arqueològica que permeti establir aquesta suposada antiguitat, val a dir que les condicions i la ubicació de l'enclavament són les idònies per albergar un d'aquells Pyrenaei claustra, ateses les clares concomitàncies amb Llívia o el Roc d'Enclar.

\section{Conclusions: una constatació i algunes reflexions}

Les dades fins aquí exposades posen de manifest una realitat objectiva, a la vegada que permeten el plantejament d'algunes reflexions $\mathrm{i}$ interpretacions sobre el fenomen de les ocupacions en alçada d'època tardoantiga. Pel que fa a la primera, i per respondre a la pregunta formulada a l'inici del treball, es fa evident que l'àrea avui catalana no resta al marge del fenomen i que, amb tots els matisos que li puguin ser propis, s'integra perfectament en el context ampli de l'ocàs de l'antic occident romà i les seves conseqüències pel que fa a la reorganització del poblament i de l'estructura territorial. De fet, l'escenari arqueològic que hem descrit per a l'extrem nord-est de la península Ibèrica mostra una remarcable continuïtat general amb el que hom ha pogut observar en relació amb les àrees limítrofes del Llenguadoc i de la Provença, del País Valencià o àdhuc de les Balears (Schneider 2011; Arasa 1996-1997; Aramburu-Zabala 2001; Cau, Mas i Lladó 2005).

La presència reiterada, per tant, de certs objectes en indrets situats en alçada $i$ on sovint es documenta l'existència d'establiments protohistòrics o ibèrics no pot considerar-se un fenomen casual, sinó que requereix una explicació global que integri allò que coneixem dels jaciments que sí que han estat excavats. Així, la detecció en múltiples indrets de numerari baiximperial de bronze coincideix amb la seva presència en els nivells d'alguns dels jaciments excavats, com ara el Roc 
d'Enclar, els Altimiris o Sant Martí de les Tombetes, mentre que la moneda d'or visigoda és present de manera molt més puntual, com succeeix en l'estratègic castrum de Puig Rom. Per a la correcta comprensió d'aquest registre, cal tenir en compte que durant els segles V-VI, i encara posteriorment, les monedes encunyades en el segle IV o inicis del segle següent, moment en què s'estronca l'emissió habitual de nou numerari, tingueren un paper actiu en l'economia del període, tal com també succeeix amb les successives imitacions posteriors que s'han pogut identificar darrerament (Marot 1997). En aquest sentit, aquestes monedes no han de presentar una correspondència cronològica estricta entre la data d'emissió vinculada a l'emperador de torn i el seu període d'ús, que pot ser força més dilatat, com ho demostra la presència recurrent d'aquest numerari en contextos arqueològics formats molt posteriorment (Doménech i Gutiérrez 2006).

Objecte possiblement d'un fenomen similar de perdurabilitat o de residualitat, el principal problema del material ceràmic rau, però, en el reconeixement del propi registre. En aquest sentit, les mencions reiterades a tipus determinats d'àmfora o de ceràmica sigil.lada, africana o gàl-lica, podrien arribar a sobredimensionar els horitzons cronològics que els són vinculats habitualment, més en tractar-se d'informacions sempre molt limitades i sovint antigues, de moments en què no es disposava dels coneixements que darrerament hem pogut atènyer sobre les sèries ceràmiques del període (Macias 1999; Roig i Coll 2011). Es tracta igualment de notícies del tot imprecises pel que fa a les tipologies detectades, i, sense un reestudi aprofundit dels materials eventualment disponibles, ens hem d'acontentar amb assenyalar el reconeixement puntual de la forma Hayes 91 -a la Fonollera i al Turó del Rull- sense especificació de la variant, de manera que l'espectre cronològic que ofereix abasta genèricament els segles V-VI (Raynaud 1993a). En tot cas, la notícia reiterada de la troballa de sigil-lada sud-gàl-lica tardana -o de les seves imitacions regionals-, també sense determinació de les formes, ${ }^{9}$ permet, en certa consonància amb el registre numismàtic, situar el segle $\mathrm{v}-\mathrm{i}$ entrat parcialment el vI- com un moment segur d'ocupació de molts dels jaciments ressenyats, en coincidència $\mathrm{amb}$ el període màxim de producció i difusió d'aquestes ceràmiques (Raynaud 1993b). Es tractaria, de fet, i dit sempre amb la prudència que aconsella la qualitat de les informacions, d'uns contextos que serien genèri- cament coincidents amb els que hom atribueix als moments finals i d'abandó de les villae baiximperials (Coll i Roig 2011).

Per altra banda, la detecció de sivelles o altres elements de vestimenta o abillament és també significativa i permet considerar la possibilitat d'una ocupació coetània allà on aquella es produeixi, com és el cas del jaciment d'Antona, amb un exemplar de sivella liriforme similar a les localitzades a les excavacions de Puig Rom, del castellum de Sant Julià de Ramis o del Tossal del Moro de Castellserà. Així mateix, la presència total o fragmentada d'elements religiosos, cultuals o àdhuc funeraris, com són ares d'altar o sarcòfags -recordem els casos de Casserres d'Osona o de Tona-, pot ser també un indicador d'ocupacions altmedievals que podrien fins i tot integrar una església, com succeeix en el cas llenguadocià del Roc de Pampelune, amb un sarcòfag decorat localitzat a l'interior de l'església que presideix el conjunt (Schneider 2011).

Un darrer element a tenir en compte fa referència a les construccions conservades, habitualment de manera parcial. Hem vist com la torre de Castellfollit, prop de Poblet, es presenta com un edifici quadrangular construït segons la tècnica de l'encofrat i amb el que sembla una coberta de tegulae, uns atributs que permeten adjudicar-li preliminarment una cronologia dins l'antiguitat tardana. En paral.lel, la torre del castell de Tona o l'edifici rectangular dels Altimiris mostren certes similituds en les dimensions i la tècnica constructiva, mentre que d'altres torres semblants, com la de Panissars o la de Caulers Vell, s'atribueixen igualment al període tardoantic, com succeeix també amb l'edifici funerari localitzat al castell de Besora. Serà necessari, per tant, tenir presents aquests casos davant d'eventuals troballes de característiques similars, però també de cara a la revisió d'elements coneguts, com ara la primera torre del castell d'Ardèvol, la construcció situada al capdamunt del Castellot de Viver o l'edifici a l'origen de la capella del Castellot de Castellví de la Marca (Gibert 2018b, 118-122).

Constatada l'existència d'aquestes ocupacions, i preses les dades en conjunt, s'intueix una certa seqüència pel que fa a aquests establiments, amb diverses fases diferenciades si més no cronològicament, tot i que en paral.lel s'adverteix una varietat pel que fa als emplaçaments triats que sembla implicar una diversitat en relació amb els usos i propòsits per als quals foren creats. Així, alguns dels jaciments amb materials més antics són els Corb.

9. Se n'han trobat fragments a la Fonollera, a Torcafelló, al Turó de Can Noguera, al castell de Besora o a la Roca del 
que poden vincular-se al control viari i a la custòdia de passos estratègics encara en el marc de l'últim segle de l'Imperi i en relació principalment amb la travessa dels Pirineus, a l'extrem occidental dels quals també es testimonien unes actuacions en el mateix sentit (Tobie 1997). Les Cluses, el castellum de Sant Julià de Ramis o la fortificació del Roc d'Enclar presenten ocupacions inicials que hom ha situat vers mitjans o finals del segle IV, unes fortificacions a les quals caldrà sumar, en un futur, altres possibles establiments estratègics amb funcions similars que puguin anar apareixent prop dels passos pirinencs o encara sobre les vies que uneixen les ciutats principals.

No obstant, més enllà d'aquestes fortaleses militars, les dades esparses que hem pogut recollir apunten cap al desenvolupament d'unes ocupacions en alçada aparentment de menys entitat, la cronologia inicial de les quals cal situar en un moment més avançat, ja entrat el segle v. La seva interpretació constitueix un problema a resoldre, tot i que hem de reconèixer que no deixa de ser temptador acollir-se al plantejament tradicional que posava l'accent en el daltabaix que va suposar la fi de l'estat romà i en les seves suposades conseqüències pel que fa a la fugida de la població que buscava recer davant l'entrada dels invasors. Arraconats aquests posicionaments historiogràfics, és evident que avui tampoc no podem menystenir els efectes de la crisi que acompanya la liquidació de l'Imperi a la Tarraconesa, context en el qual, per exemple, veiem esfondrar-se definitivament el sistema de villae en no gaire més de dues generacions (Canal et al. 2007; Coll i Roig 2011). En aquest sentit, podrien ser reveladors els contextos materials localitzats en multitud de coves (Raynaud 2001; Gibert 2018a, 86-87), molt similars als que detectem en alguns dels establiments en alçada, amb profusió de bronzes tardoromans i de peces de ceràmica sigil-lada gàl-lica tardana i africana D. I encara podríem adduir en aquesta línia les referències d'alguns textos de l'època a les commocions derivades dels enfrontaments entre romans i bàrbars. Sempre des de la perspectiva de les elits romanes i de l'alta jerarquia eclesiàstica, autors del segle v com Salvià de Marsella o Hidaci, que hem citat en un apartat anterior, testimonien com la població -o part d'ella-, presa del terror en aquell context convuls, fugia cap als castella (Pauly 1883, 116), un context que aquelles elits haurien pogut aprofitar per treure rèdit, en una versió particular de la contemporània «doctrina del shock» (Tejerizo i Canosa 2018, 20-23).

Tanmateix, jaciments excavats en àrees properes amb orígens en aquell moment crític mostren una solidesa constructiva i una perdurabilitat prou dilatada per atribuir a la seva fundació unes intencions vinculades estrictament a la simple recerca d'un refugi. Així, l'estudi de detall de materials procedents d'algunes de les fortificacions del quadrant nord-occidental de la península Ibèrica situa l'origen de bona part dels casos entre inicis i mitjans del segle $\mathrm{v}$, amb ocupacions que no acostumen a anar més enllà de mitjans del segle vi i que defineixen allò que hom ha convingut a denominar "castells de primera generació» (Tejerizo i Vigil-Escalera 2017). Es tracta d'ocupacions que són prou duradores per no vincular-se purament a la conjuntura del període de les invasions i que mostren una entitat edilícia, si més no pel que fa als elements fortificats, sens dubte atribuïble a la seva natura de centres de poder. En aquest sentit, i més enllà de les circumstàncies específiques de la seva aparició, aquests establiments tindrien a veure, en el seu desenvolupament, amb la rearticulació dels poders locals i regionals posterior a la liquidació de l'estructura imperial i en el marc del procés formatiu dels estats successors (Castellanos i Martín 2005).

Si a la Meseta i el seu entorn els castra arqueològicament coneguts semblen aparèixer en els primers compassos del segle $\mathrm{v}$, en coincidència amb l'entrada de sueus, vàndals $i$ alans $i$ amb la fi de l'Imperi en aquest sector, al sud de la Gàl-lia el fenomen sembla sensiblement més tardà. Aquí, alguns dels grans recintes de diverses hectàrees dotats d'una o diverses esglésies, com Saint-Blaise o Constantine, en l'entorn de l'estany de Berre, semblen originar-se vers mitjans o finals del segle $\mathrm{v}$, si bé el segon presenta una datació fundacional menys precisa, però sempre dins la mateixa centúria. Per la seva banda, la fundació del recinte del Roc de Pampelune, a la garriga montpellerina, no és anterior al darrer quart de segle, com tampoc ho seria la del castellum de la Malène, sobre l'engorjat del Tarn i en plena frontera franco-visigoda (Schneider 2004; 2011).

En aquest sentit, l'aparició de fortificacions en alçada al Llenguadoc i la Provença sembla inscriure's especialment en els temps tot just posteriors a la desaparició efectiva de l'Imperi occidental, que en aquest sector, com a la Tarraconesa, perdura fins a la seva extinció genèrica a inicis del darrer quart del segle v. Aquest podria constituir, per tant, un marc propici per al registre que detectem a l'àrea catalana, si bé no ho podem encara assegurar, atesa la migradesa de les informacions. Per la mateixa raó, no podem tampoc dir res sobre l'aspecte físic d'aquestes ocupacions ni sobre la seva entitat constructiva, ni encara menys, per tant, sobre les seves eventuals funcions. En qualsevol cas, ens interessa posar en relleu que, com en altres regions, la conjuntura general de la fi de l'Imperi no ha d'explicar-ho tot per ella mateixa, i 
que caldrà tenir en compte fenòmens com la reorganització del poblament i dels grups dominants a partir d'aquell moment, juntament amb altres factors com l'explotació econòmica de nous espais i recursos.

Al costat de tot el conjunt d'indicis que apunten cap a una ocupació de llocs en alçada en el segle $\mathrm{v}$, bona part de les dades ofertes pels diversos projectes d'excavació assenyalen l'existència d'una segona onada pel que fa a l'aparició de nuclis fortificats, una nova fase que es pot situar genèricament entre finals del segle vi i entrat el segle VIII, en coincidència en bona part amb la consolidació i el desenvolupament del regne visigot de Toledo i fins que en època andalusina les alçades s'ocupin principalment per establir sistemes de control i comunicació a través de noves xarxes de torres (Martí i Viladrich 2018). Les muralles de Puig Rom o de l'Esquerda, o també el desenvolupament del castellum de Sant Julià de Ramis, són bona prova d'aquest nou context, en coincidència amb el que alguns investigadors consideren el sorgiment dels "castells de segona generació»(Quirós 2012, 22-23). En paral-lel, altres casos com el Serrat dels Tres Hereus de Casserres o el Tossal del Moro de Castellserà, de dimensions i entitats més modestes, es poden interpretar en termes de residència de grups dominants i de control de l'entorn sobre el qual s'instal-len. No obstant, en tots ells, més grans o més petits, la presència reiterada d'eines vinculades a l'explotació agropecuària, tot i que amb una gens negligible orientació ramadera -estris d'adoberia, tisores d'esquilar, cardadors-, és senyal de la presència de població treballadora, mentre que també és significativa la troballa d'armament en alguns dels establiments més potents, com Puig Rom o el castellum de Sant Julià de Ramis (Garcia i Vivó 2003).

En tot cas, creiem que tots ells poden considerar-se fruit de la consolidació, a diferent escala, de poders territorials vinculats a l'estructura de l'estat visigot, segurament un dels més forts d'entre les diverses formacions polítiques postromanes de l'occident europeu (Wickham 2009, 162-173). Com a tal, el regnum comptava sens dubte amb un esquema territorial organitzat i jerarquitzat, fonamentat en aquella gradació esmentada més amunt i en el binomi format per la civitas i el castrum/castellum. En aquest sentit, no deixen de cridar l'atenció algunes associacions, d'altra banda prou evidents, que es poden plantejar entre enclavaments d'ambdues natures i encara amb d'altres com ara el vicus o aglomeració secundària. És el cas, per exemple, de la relació que hom pot establir fàcilment entre els jaciments de Puig Rom i de la Ciutadella de Roses, on el castrum sembla substituir, si més no durant els segles VII i VIII, l'es- tabliment de natura pràcticament urbana -la vella Rhode-que es desenvolupava des de temps antics a peu de platja (Folch 2018a,73-74). També resulten obvis els vincles entre les ciutats i seus episcopals de Girona i Ausa (Vic) amb, respectivament, el castellum de Sant Julià de Ramis i la fortificació de Roda, considerada curiosament una civitas en els textos primerencs dels segles IX-X. Se'ns presenta, per tant, la possibilitat que aquesta dualitat respongui a la formació de pols de poder complementaris amb atribucions diferenciades pel que fa a les esferes del poder civil, eclesiàstic i militar.

De fet, la documentació d'època carolíngia i comtal més primerenca presenta també alguns binomis significatius pel que fa a l'organització del territori. Es documenta així l'existència de centres secundaris vinculats a ciutats o nuclis principals, que habitualment responen a l'apellatiu de castrum i que acostumen a tenir precedents en època tardoantiga. Aquest fenomen és prou evident a l'antiga Septimània, on alguns castra d'època carolíngia presenten una entitat territorial notable -anomenada suburbium o àdhuc territorium - que, no obstant, s'integra en la corresponent circumscripció major, com en els casos de Nimes i Anduze, de Magalona i Substantion, de Narbona i Menerba, de Carcassona i Cabaret, de Rennes-le-Château i Perapertusa o de Besiers i Cabrières (Schneider 2010). A banda dels casos citats més amunt, a Catalunya aquesta dualitat esdevé patent en l'associació entre la ciutat de Barcelona i el Terracium castellum al llarg de l'alta edat mitjana (Soler 2003), mentre que una relació semblant podria haver-se donat entre la ciutat de Girona i Besalú, castrum -o potser vicus-i centre d'un territori propi, amb una ocupació tardoantiga contrastada (Folch 2018a, 72-73). Aquest darrer cas podria ser comparable al de Manresa, molt menys conegut arqueològicament, però on sabem de l'existència, al Puig Cardener, d'una necròpolis tardoantiga i de la troballa d'una moneda atribuïble a l'emperador Constant (337-350), avui perduda (Gibert 2018a, 45-46 i 105).

En síntesi i per acabar, l'anàlisi preliminar de les dades aportades i un primer assaig d'interpretació sobre el fenomen de les primeres fortificacions altmedievals no només demostren que aquestes van existir, cosa que òbviament ja coneixíem a través de l'excavació d'alguns pocs però remarcables casos amb registres dels segles VI-VIII, sinó que permeten constatar l'existència d'una fase primerenca que cal situar en el segle $v$, tot i que encara es troba molt mal caracteritzada materialment. La troballa reiterada de monedes, ceràmiques i altres objectes d'aquest moment en punts encimbellats no permet dubtar d'aquesta primera onada d'ocupacions, que no sabem si poden arribar 
a presentar l'entitat que exhibeixen les primeres fortificacions detectades en l'àmbit del nord-oest peninsular o del sud de la Gàl.lia.

Sabut això, ara toca dirigir els esforços cap a la consecució de noves i més sòlides dades materials que permetin una interpretació del fenomen més solvent que la que aquí hàgim pogut oferir. Caldrà, en aquest sentit, orientar la investigació cap a la revisió i el reestudi d'excavacions practicades fins avui en jaciments en alçada d'època ibèrica o protohistòrica, tot advertint els companys que treballen sobre aquest tipus de jaciments, amb qui caldrà sumar esforços, de l'eventualitat de topar-se amb estructures, nivells i materials cronològicament posteriors. En paral.lel, castells com els de Castellvell -de Rosanes i de la Marca-, Besora, Tona, Miralles, Begur o Torcafelló, entre d'altres, testimonien que l'emplaçament de fortificacions comtals pot coincidir amb ocupacions prèvies. Com en el cas al-ludit de la Septimània, caldrà estar atents especialment a aquells castells comtals que, per les seves característiques físiques -habitualment un pla suficientment ampli i preferiblement envoltat d'espadats de roca- o per indicis raonables sobre la seva preeminència més enllà de l'estricte terme castral feudal, siguin susceptibles de contenir al seu solar restes altmedievals prèvies. Pensem, per exemple, en certs castells que hom situa al capdavant d'un pagus en la documentació del segle $\mathrm{x}$, com poden ser els de Lluçà o Balsareny, o també evidentment en el de Cardona, documentat precoçment a finals del segle vIII (Gibert 2018a, 104-107). Així mateix, castells rellevants de primera època comtal, amb grans termes adscrits i als quals s'associen delegats comtals -veguers-, han de ser estudiats amb atenció, com pot ser el cas d'Eramprunyà, de Montbui, de Cabrera o de Tarabau, tots sobre imponents serrats o moles (Bolòs 2003, 75-78). I encara, finalment, caldrà prestar tothora atenció als topònims del tipus castellar, castellot, castellvell/castellví o similars. Si bé està clar que poden fer referència també a establiments ibèrics o protohistòrics, ja hem vist que indrets diversos amb aquesta denominació aporten registres altmedievals. Igualment, el topònim ciutat, o civitas en la documentació medieval, pot ser susceptible d'encobrir ocupacions del període, com en el cas segur de la "Roda civitas» de l'Esquerda o en el possible del Pui de Sant Martí, la Vall de Cardós. Hi podríem afegir altres topònims similars que sovint fan referència a plataformes àmplies en al-



Figura 1. Situació dels jaciments esmentats en el text. 
çada, ben defensades naturalment, ${ }^{10}$ com també ho són Castellciutat, sobre la Seu d'Urgell, ${ }^{11}$ el poble de Llimiana -«Civitate Limignana»-, al nord del Montsec (Sancho 2018, 214-216) o el mateix jaciment ibèric de Puig Ciutat, a Oristà, on de moment, però, no es coneix cap ocupació altmedieval.

\section{Bibliografia}

ABADAL, R. d' 1980: Els primers comtes catalans, Edicions Vicens-Vives, Barcelona.

- 1986: Catalunya Carolíngia I-1. El domini carolingi a Catalunya, Institut d'Estudis Catalans, Barcelona.

Alegría, W.; Hidalgo, I. 2015: «Els materials ceràmics dels Altimiris i Sant Martí de les Tombetes, dos jaciments tardoantics i altmedievals al Prepirineu de Lleida», a: $V$ Congrés d'Arqueologia Medieval i Moderna a Catalunya, 2014, Barcelona, 1041-1056.

ARAD, L. 2007: «The Holy Land ampulla of Sant Pere de Casserres. A liturgical and art-historical interpretation», Miscel-lània Litúrgica Catalana, 15, Barcelona, 59-86.

Aramburu-Zabala, J. 2001: «Dos fortificaciones tardorromanas en la sierra de Mallorca», <https:// www.academia.edu/20194786/Dos_fortificaciones_tardorromanas_en_la_sierra_de_Mallorca> [Consulta: 15 maig 2020].

ARASA, F. 1996-1997: "Les comarques septentrionals del litoral valencià entre els segles IV i VI», Annals de l'Institut d'Estudis Gironins, 37, 1145-1160.

Arasa, F.; Rosas, M. 1994: "Les ceràmiques fines tardoromanes del jaciment de Sant Josep (la Vall d'Uixó, Castelló)», a: III Reunió d'Arqueologia Cristiana Hispànica, Barcelona, 445-450.

ARce, J. 2005: Bárbaros y romanos en Hispania (400-507 AD), Marcial Pons, Madrid.

Asensio, D.; Cardona, R.; Ferrer, C.; Morer, J.; Pou, J. 2003: «La fase medieval del jaciment de Sant Esteve d'Olius (Olius, Solsonès). Estudi d'una agrupació de sitges d'entre els segles X-XIV dC», a: II Congrés d'Arqueologia Medieval i Moderna a Catalunya, Sant Cugat del Vallès, 745-754.

Bolòs, J. 2003: «Fortificacions de la marca i organització del territori a Catalunya (segles vIIIXII)», a: Actes del congrés "Els castells medievals a la Mediterrània nord-occidental», Arbúcies, 67-88.

Brogiolo, G. P.; Gelichi, S. 1996: Nuove ricerche sui castelli altomedievali in Italia settentrionale, All'Insegna del Giglio, Florència.

Burch, J. M.; García, G.; Nolla, J. M.; Palahí, L.; Sagrera, J.; Sureda, M.; Vivó, D.; Miquel, I. 2006: El Castellum. Excavacions arqueològiques a la muntanya de Sant Julià de Ramis, 2, Ajuntament de Sant Julià de Ramis, Girona.

Burch, J. M.; Sagrera, J.; Vivó, D.; Coromina, N. 2018: «Poblat ibèric i castellum de Sant Julià de Ramis (el Gironès). El sector del vell cementiri parroquial. Campanyes de 2016 i 2017», a: XIV Jornades d'Arqueologia de les Comarques de Girona, Caldes de Malavella, 369-385.

Busquets, F.; FÀbregas, M.; Corts, A.; Capdevila, N. 2017: «El conjunt monumental del castell de Besora: primeres aproximacions a un assentament amb més de dos mil anys d'història», Ausa, 179, 107-126.

CAmats, A.; Ros, J. 2018: «Darreres investigacions al jaciment arqueològic d'Antona (Artesa de Segre, la Noguera», a: Primeres Jornades d'Arqueologia i Paleontologia de Ponent, Departament de Cultura de la Generalitat de Catalunya, 254-261.

CAMPO, M. 2009: «Les troballes monetàries al sector $01 »$, a: Molist, N. (ed.). La intervenció al sector 01 del conjunt històric d'Olèrdola. De la prehistòria a l'etapa romana (campanyes 19952006), Museu d'Arqueologia de Catalunya, Barcelona, 407-410.

Canal, J.; Canal, E.; Nolla, J. M.; Sagrera, J. 2007: «La crisi de les villae i de la noblesa de la Tarraconenesis en el canvi del segle v al vi. Fonts textuals i evidències arqueològiques», Empúries, 55, Barcelona, 185-198.

CARreras, A. 1981: «La torre de guaita de Castellfollit (Serra de Prades). Notes arqueològiques i planimetria», Butlletí Arqueològic, 3, Tarragona, 65-99.

Castellanos, S. 2011: Poder social, aristocracias y hombre santo en la Hispania visigoda. La Vita Aemiliani de Braulio de Zaragoza, Universidad de la Rioja.

Castellanos, S.; Martín, I. 2005: «The local articulation of central power in the north of the Iberian peninsula (500-1000)», Early Medieval Europe, 13 (I), 1-42.

10. Una ràpida revisió ens permet atribuir aquestes característiques al lloc de Ciutat, al Coll de Nargó, al Serrat de Ciutat, sobre el Pont de Montanyana, al Pla de Ciutat, a Pinós, o al Turó de la Ciutat, a la Ribera d'Urgellet.

11. Anomenada al segle $\mathrm{x}$ «Civitate Fracta», en coincidència, potser significativa, amb el «Castellum Fractum» de Sant Julià de Ramis. 
CAstillo, A. del; RiU, M. 1962: «El poblado bergistano de Camp-Maurí», a: VII Congreso Arqueológico Nacional, Saragossa, 426-431.

Catalán, D.; Andrés, M. S. de 1975: Crónica del moro Rasis, Seminario Menéndez Pidal- Editorial Gredos, Madrid.

Catalán, R.; Fuentes, P.; Sastre, J. C. (ed.) 2014: Las fortificaciones en la Tardoantigüedad. Élites y articulación del territorio (siglos V-VIII d. C.), La Ergástula Ediciones, Madrid.

[Catalunya Romànica] 1986: Catalunya Romànica, III. Osona II, Enciclopèdia Catalana, Barcelona.

- 1989: Catalunya Romànica, VIII. L'Empordà I, Enciclopèdia Catalana, Barcelona.

- 1990: Catalunya Romànica, IX. L'Empordà II, Enciclopèdia Catalana, Barcelona.

- 1993: Catalunya Romànica, XV. El Pallars, Enciclopèdia Catalana, Barcelona.

- 1998: Catalunya Romànica, XXVII. Visió de síntesi, restauracions $i$ noves troballes. Bibliografia. Índexs generals, Enciclopèdia Catalana, Barcelona.

CAU, M. A.; MAs, C.; Lladó, J. C. 2005: «Fortificaciones de la Antigüedad Tardía en Baleares», a: L'Antiguitat clàssica $i$ la seva pervivència a les illes Balears (XXIII Jornades d'Estudis Històrics Locals), Palma, 217-229.

Chávez, A.; Pastor, I. 2014: «La muralla de Sant Pere de Casserres. Neteja forestal i sondejos arqueològics (Masies de Roda, Osona)», a: II Jornades d'Arqueologia de la Catalunya Central. Actes. Vic, 13, 14 i 15 de desembre de 2012, Departament de Cultura de la Generalitat de Catalunya - Museu Episcopal de Vic, Barcelona, 205-208.

Chorén, J.; CALduch, N. 2006: «L'assentament ibèric de Sant Esteve d'Olius (Olius, Solsonès): intervenció a la muralla i al camí d'accés. Primera fase de l'adequació del camp de sitges fortificat del segle II aC», Oppidum, 5, Solsona, 23-33.

Coll, J. M.; Roig, J. 2011: «La fi de les vil.les romanes baiximperials a la Depressió Prelitoral (segles IV-v): contextos estratigràfics i registre material per datar-los», a: IV Congrés d'Arqueologia Medieval i Moderna a Catalunya, Tarragona, 161-172.

Constant, A. 2008: "Fouilles récentes au castrum Vulturaria / Ultréra (Argelès-sur-Mer, Pyrénées-Orientales)», a: MARTí, R. (ed.). Fars de l'Islam. Antigues alimares d'al-Andalus, EDAR, Barcelona, 39-55.

Doménech, C.; GutiérRez, S. 2006: «Viejas y nuevas monedas en la ciudad emiral de Madinat Iyyuh (El Tolmo de Minateda, Hellín, Albacete)», AlQantara, XXVII-2, 337-374.
Dupré, X. 2006: Ibers i grecs a l'Hospitalet de l'Infant, Museu Nacional Arqueològic de Tarragona, Tarragona.

Escala, O.; Colet, A.; Mulet, M.; Mazuque, J.; MarTínEZ, J. 2018: «El jaciment ibèric i visigot del Tossal del Moro (Castellserà, l'Urgell). Darreres novetats», a: Primeres Jornades d'Arqueologia $i$ Paleontologia de Ponent, Departament de Cultura de la Generalitat de Catalunya, 202-209.

Escala, O.; Mulet, M.; Colet, A. 2011: «El Tossal del Moro. Un jaciment visigot i ibèric a l'Urgell? Primers resultats», Urtx, 25, Tàrrega, 243-252.

Estrada, J. 1969: Vías y poblamiento romanos en el territorio del área metropolitana de Barcelona, Cuadernos de la Comisión de Urbanismo de Barcelona.

FErrer, A. 1949: "El castro antiguo de San Miguel de Olèrdola», Archivo Español de Arqueología, 22, 21-73.

Fierro, X. 2011: «El castell i l'església de Sant Pere de Madrona (Berga). Un jaciment tardoantic i altmedieval», a: IV Congrés d'Arqueologia Medieval i Moderna a Catalunya, 2010, Tarragona, 659-666.

FLETCHER, D. 1945: «La cueva y el poblado de La Torre del Mal Paso (Castellnovo-Castellón)», Archivo de Prehistoria Levantina, 5, 187-224.

Folch, C. 2018a: «Territorios y poblamiento en el noreste de la Tarraconense en época visigoda (siglos VI-VIII): una nueva aproximación al estudio de la organización territorial y de las formas de asentamiento», a: GASC, S.; SÉNAC, Ph.; Venco-Salaün, C.; Laliena, C. (ed.). Les frontières pyrénéennes au Moyen Âge ( $V I^{e}-X V^{e}$ siècles), Universidad de Zaragoza, Saragossa, 67-105.

- 2018b: «Fortificacions i assentaments en alçada a l'àmbit rural del nord-est de Catalunya durant l'Alta Edat Mitjana (segles VI-XI)», Treballs d'Arqueologia, 22, 29-49.

Folch, C.; Gibert, J.; Gonzalo, X.; Martí, R.; MartíNEZ, N. 2018: «La fortificació antiga i medieval de Castellví de la Marca (Barcelona), primeres dades arqueològiques", Treballs d'Arqueologia, 22, 83-105.

Folch, C.; Gibert, J.; Martín, J.; Rodrigo, E. 2007: "L'ocupació de l'Alta Edat Mitjana del jaciment del Serrat dels Tres Hereus (Casserres, Berguedà)», a: III Congrés d'Arqueologia Medieval $i$ Moderna a Catalunya, Sabadell, 753-757.

Folch, C.; Llinàs, J.; Montalbán, C.; Ramírez, A.; Sureda, M. 2000: «Primera campanya d'excavacions al castell de Torcafelló», a: Cinquenes Jornades d'Arqueologia de les Comarques de Girona, 217-220.

GARCIA, G.; Vivó, D. 2003: «Sant Julià de Ramis y Puig Rom: dos ejemplos de yacimientos con armamento y equipamiento militar visigodo 
en el noreste peninsular», Gladius, 23, 161190.

GIBERT, J. 2006: «La torre sobirana de Castellví de Rosanes, un edifici vinculat a la conquesta islàmica», Materials del Baix Llobregat, 12, 53-57.

- 2018a: La fi del món antic $i$ els inicis de l'Edat Mitjana a la Catalunya Central. Economia, societat $i$ territori entre els segles $v i$ VIII, Institut Català d'Arqueologia Clàssica, Tarragona.

- 2018b: L'expressió material del poder durant la conquesta comtal. Esglésies, castells $i$ torres a la Catalunya Central (segles X-XI), Ajuntament de la Pobla de Claramunt.

Gonzalo, X.; MARTí, R. 2015: «El poblament altmedieval del territori de Tarragona: campanyes de prospecció arqueològica a l'Alt Camp i la Conca de Barberà (2012-2013). Primers resultats», a: V Congrés d'Arqueologia Medieval $i$ Moderna a Catalunya, 2014, Barcelona, 721-728.

IPAC: Inventari del Patrimoni Arqueològic de Catalunya [en línia].

JÁRregA, R. 2003: "L’Antiguitat Tardana a les comarques de l'Alt Penedès, el Baix Penedès i el Garraf. Estat actual dels coneixements», a: Guitart, J.; PALET, J. M. (coord.). Territoris antics a la Mediterrània i a la Cossetània Oriental. Actes del Simposi Internacional d'Arqueologia del Vendrell, Generalitat de Catalunya, Barcelona, 393-404.

KRusch, B.; LeVIson, W. 1937: Gregorii episcopi Turonensis historiarum libri x (Monumenta Germaniae Historica, Scriptores rerum Merovingicarum, 1.1), Hannover.

LeVISON, W. 1910: Historia Wambae regis auctore Iuliano episcopo Toletano (Monumenta Germaniae Historica, Scriptores rerum Merovingicarum, 5), Hannover.

Llinàs, J.; Manzano, S.; Ramírez, A. 1994: "Món ibèric i romanització al terme de Maçanet de la Selva. Estat de la qüestió», Quaderns de la Selva, 7, 143-149.

Llorens, A. 1986: Solsona i el Solsonès en la història de Catalunya, Editorial Virgili \& Pagès, Lleida.

Llovera, X. (coord.) 1997: Roc d'Enclar. Transformacions d'un espai dominant (segles IV-XIX), Monografies del Patrimoni Cultural d'Andorra, 4, Andorra la Vella.

López, J. E. 2009: Continuatio Isidoriana Hispana. Crónica del 754, Lleó.

Macias, J. M. 1999: La ceràmica comuna tardoantiga a Tàrraco. Anàlisi tipològica i històrica (segles v-VII), Museu Nacional Arqueològic de Tarragona, Tarragona.

MAROT, T. 1997: «Aproximación a la circulación monetaria en la Península Ibérica y las Islas Baleares durante los siglos v y vi: la incidencia de las emisiones vándalas y bizantinas», Revue Numismatique, 152, 157-190.

Martí, R.; CAmprubí, J. 1997-2001: «Evolució del poblament a la Plana Central del Berguedà des de l'època baix-imperial fins l'alta edat mitjana, 1997-2001 », informes i memòries inèdits dipositats al Servei d'Arqueologia de la Generalitat de Catalunya, Barcelona.

Martí, R.; Viladrich, M. 2018: «Les torres de planta circular de la frontera extrema d'alAndalus a Catalunya (segles VIII-X)», Treballs d'Arqueologia, 22, 51-81.

Martínez, J. I. 2006: «El vocabulario de los asentamientos rurales (siglos I-IX d.C.): evolución de la terminología», a: Chavarría, A.; ARCE, J.; BRoGIOLO, G. P. (ed.). Villas tardoantiguas en el Mediterráneo Occidental, Anejos de AEspA, XxxIx, CSIC, Madrid, 113-131.

MAteU, F. 1985-1986: «Hallazgos monetarios (xXVII)», Numisma, 192-203, 47-71.

Mauri, A. 2014: El Castellvell de Rosanes, Centre d'Estudis Martorellencs, Martorell.

Molist, N. 2009: "Testimonis d'ocupacions durant l'alt i baix imperi (segles I-V dC)», a: MoLIST, N. (ed.). La intervenció al sector 01 del conjunt històric d'Olèrdola. De la prehistòria a l'etapa romana (campanyes 1995-2006), Museu d'Arqueologia de Catalunya, Barcelona, 283.

Mommsen, Th. 1894a: Hydatii Lemici. Continuatio Chronicorum Hieronymianorum, Chronica minora saec. IV.V.VI.VII, vol. II (Monumenta Germaniae Historica, Auctores Antiquissimi, vol. 11), Berlín.

- 1894b: Iohannis abbatis Biclarensis Chronica, Chronica minora saec. IV.V.VI.VII, vol. II (Monumenta Germaniae Historica, Auctores Antiquissimi, vol. 11), Berlín.

Morell, N. 2006: «Forjant el passat. Recerques arqueològiques entorn la metal-lúrgia del ferro al Serrat dels Tres Hereus», L'Erol, 91, Berga, 19-23.

Negre, J.; Falomir, F.; Pérez-Polo, M.; Blasco, M.; Aguilella, G.; Medina, P. [en premsa]: «Una lectura contextual del recinto emiral del Tossal de la Vila (Castelló). Algunas reflexiones sobre el origen, morfología y funciones de los asentamientos en altura en el extremo septentrional del Šarq al-Andalus», a: International Workshop: El sitio de las cosas (La Alta Edad Media en contexto, siglos $V I I-X)$, Universitat d'Alacant, 26 i 28 de setembre de 2018.

Nolla, J. M. 1977: «Estudio preliminar de la cerámica romana hallada en el yacimiento de la Fonollera», a: Pons, E. (dir.). La Fonollera (Torroella de Montgrí, Girona). Un poblado al aire libre del Bronce Final, Diputació de Girona, 184-198. 
- 2014: "Ciudades, torres y castella. La defensa de la Vía Augusta», a: Catalán, R.; Fuentes, P.; SASTRE, J. C. (ed.) 2014: Las fortificaciones en la Tardoantigüedad. Élites y articulación del territorio (siglos v-VIII d. C.), La Ergástula Ediciones, Madrid, 43-56.

Nolla, J. M.; CaSAS, J. 1984: Carta arqueològica de les comarques de Girona. El poblament d'època romana al Nord-est de Catalunya, Girona.

Olesti, O.; Mercadal, O.; Guàrdia, J. 2014: «El fin del sueño urbano en Iulia Livica (Llívia, Cerdanya)», a: Ramallo, F. S.; Quevedo, A. (ed.). Las ciudades de la Tarraconense oriental entre los s. II-IV d.C. Evolución urbanística y contextos materiales, Ediciones de la Universidad de Murcia, Múrcia, 61-88.

Olesti, O.; Olesti, F. 2013: «L'Ager Tarraconensis i les muntanyes de Prades. Un espai colonial mal conegut», a: Prevosti, M.; LóPez, J.; Guitart, J. (ed.). Ager Tarraconensis 5. Paisatge, poblament, cultura material i història. Actes del Simposi internacional, Institut Català d'Arqueologia Clàssica, Tarragona, 45-56.

Ollich, I. 1999: «Roda: L'Esquerda. La ciutat carolíngia», a: Catalunya a l'època carolíngia. Art $i$ cultura abans del romànic (segles IX $i_{X}$ ), Museu Nacional d'Art de Catalunya, Barcelona, 84-88.

Ollich, I.; Rocafiguera, M.; Amblàs, O.; PratdeSABA, A.; Pujol, M. A. 2015: «Visigots i carolingis a Osona. Novetats arqueològiques des del jaciment de l'Esquerda», a: III Jornades d'Arqueologia de la Catalunya Central, Roda de Ter, 2014, Barcelona, 14-22.

PADRó, J. 1988: «El poblament d'època romana a les comarques pirinenques», a: VII Col-loqui Internacional d'Arqueologia de Puigcerdà. Prehistòria i arqueologia de la conca del Segre. Homenatge al Prof. Dr. Joan Maluquer de Motes, Institut d'Estudis Ceretans, Puigcerdà, 253261.

PaLol, P. de 1957-1958: «Las mesas de altar paleocristianas en la Tarraconense», Ampurias, 1920, Barcelona, 81-102.

- 2004: El castrum del Puig de les Muralles de Puig Rom (Roses, Alt Empordà), Museu d'Arqueologia de Catalunya, Girona.

Pauly, F. (ed.) 1883: Salviani presbyteri Massiliensis opera omnia, Corpus Scriptorum Ecclesiasticorum Latinorum, 8, Viena.

Pérez, V. Ll. 2012: «Late Roman and Visigothic military fortifications in Conventus Tarraconensis (Hispania): The organization of border defence», Aqvila Legionis, 15, 165-202.

Pons, E. (ed.) 1986: Aproximació a una memòria científica dedicada al jaciment arqueològic de la Fonollera a Torroella de Montgrí, Servei d'Arqueologia de la Generalitat de Catalunya.
Puch, E. 1986-1987: «Poblamiento ibérico en la mitad meridional de la Terra Alta (Arnes, Bot y Horta de San Juan)», Butlletí Arqueològic, 8-9, 15-33.

Quirós, J. A. 2012: «Los castillos altomedievales del cuadrante noroccidental de la Península Ibérica», a: Quirós, J. A.; TEJADo, J. M. (ed.). Los castillos altomedievales en el noroeste de la Península Ibérica, Euskal Herriko Unibertsitatea, Bilbao.

Quirós, J. A.; Tejado, J. M. (ed.) 2012: Los castillos altomedievales en el noroeste de la Península Ibérica, Euskal Herriko Unibertsitatea, Bilbao.

RAYNAUD, C. 1993a: "Céramique africaine Claire D», Lattara, 6, 190-197.

- 1993b: «Céramique Estampée grise et orangée dite "derivée de sigillée paléochrétienne" », Lattara, 6, 410-418.

- 2001: «L'occupation des grottes en Gaule méditerranéenne, à la fin de l'Antiquité», a: Ouzoulias, P.; Pellecuer, C.; Raynaud, C.; Van Ossel, P.; GARMY, P. (dir.). Les campagnes de la Gaule à la fin de l'Antiquité, Éditions APDCA, Antibes, 449-471.

Remolins, G. 2015: «Estudi i avaluació del potencial arqueològic del municipi de Peramola», a: Primeres Jornades d'Arqueologia i Paleontologia del Pirineu i Aran, Departament de Cultura de la Generalitat de Catalunya, Lleida, 68-75.

Ripoll, G.; Chavarría, A. 1999: «Placa de sivella d'Olius», a: Palol, P. de (coord.). Del romà al romànic. Història, art i cultura de la Tarraconense entre els segles IV $i \mathrm{X}$, Enciclopèdia Catalana, Barcelona, 321-322.

RocAFIGUERA, M. 1995: Osona ibèrica. El territori dels antics ausetans, Patronat d'Estudis Osonencs, Vic.

Rodrigo, E.; Martín, J.; CANAL, D. 1999-2000: «El poblat ibero-romà del Serrat dels Tres Hereus (Casserres): un assentament del segle I aC al Berguedà», Tribuna d'Arqueologia 1999-2000, Barcelona, 127-146.

RoIG, J.; Coll, J. M. 2011: «El registre ceràmic dels assentaments i vilatges de l'Antiguitat Tardana de la Depressió Litoral i Prelitoral (s. VI-VIII): caracterització de les produccions i estudi morfològic», a: IV Congrés d'Arqueologia Medieval i Moderna a Catalunya, 2010, Tarragona, 211-226.

Ros, J.; Solanes, E. 2001-2002: «La recerca arqueològica a Antona (Artesa de Segre). Estat de la qüestió», Revista d'Arqueologia de Ponent, 11-12, 277-290.

Rosas, M. 1996-1997: «Algunes àmfores africanes i hispàniques del moment tardoromà del poblat de Sant Josep (la Vall d'Uixó, Castelló)», Annals de l'Institut d'Estudis Gironins, 37, 1161-1168. 
Royo, M. del M. 2008: «Simbología y poder en las emisiones de bronce constantinianas», Gaceta Numismática, 168, 15-44.

SANcho, M. 2018: «Apunts per una arqueologia dels castells i fortificacions prefeudals a l'Alt Pirineu (Urgell, Pallars i Ribagorça), segles VIX», a: Treballs d'Arqueologia, 22, 5-28.

- 2019: «Evidencias arqueológicas de un monasterio de los siglos VI-VII en el Prepirineo catalán: Santa Cecilia de Els Altimiris», a: LE BLÉvec, D. (dir.). Monastères et couvents de montagne: circulation, réseaux, influences au Moyen Âge, Éditions du Comité des travaux historiques et scientifiques, París.

Sancho, M.; Raurich, X.; Mestre, A. M. 1994: «Memòria de l'excavació de l'ermita de Sant Sadurní de Gallifa (Gallifa, Vallès Occidental). Agost de 1991», memòria inèdita dipositada al Servei d'Arqueologia de la Generalitat de Catalunya.

SchneIDER, L. 2001: "Oppida et castra tardo-antiques. À propos des établissements de hauteur de la Gaule méditerranéenne», a: Ouzoulias, P.; Pellecuer, C.; Raynaud, C.; Van Ossel, P.; GaRMY, P. (dir.). Les campagnes de la Gaule à la fin de l'Antiquité, Éditions APDCA, Antibes, 443448.

- 2004: «Entre Antiquité et haut Moyen Age: tradition et renouveau de l'habitat de hauteur dans la Gaule du sud-est», a: Fixот, M. (dir.). Paul-Albert Février, de l'Antiquité au Moyen Age, Actes du colloque de Fréjus, 7 et 8 avril 2001, Publications de l'Université de Provence, 173200.

- 2010: «Castra, vicariae et circonscriptions intermédiaires du haut Moyen Âge méridional (IX ${ }^{\mathrm{e}}$ $\mathrm{x}^{\mathrm{e}}$ siècle). Le cas de la Septimanie-Gothie», a: Boisseuil, D.; Chastang, P.; Feller, L.; Morsel, J. Écritures de l'espace social. Mélanges d'histoire médiévale offerts à Monique Bourin, Publications de la Sorbonne, 237-266.
- 2011: «Établissements perchés de France méridionale ( $\mathrm{V}^{\mathrm{e}}-\mathrm{IX}{ }^{\mathrm{e}}$ siècles)», Dossiers d'Archéologie, 344, 24-29.

Soler, J. 2003: «El territori d'Ègara, des de la seu episcopal fins al castrum Terracense (segles $\mathrm{v}-\mathrm{X}$ ). Alguns residus antics en la toponímia altmedieval», Terme, 18, 59-95.

Subías, E.; Puig, A. M.; Codina, D.; Fiz, J. I. 2018: «Les campanyes del bienni 2016-2017 al nucli fortificat del Puig Rom (Roses, Alt Empordà)», a: XIV Jornades d'Arqueologia de les Comarques de Girona, Caldes de Malavella, 357-368.

Tejerizo, C.; Canosa, J. 2018: «Power, control and social agency in post-roman northern Iberia: and archaeological analysis of hillfort occupations», Journal of Medieval Iberian Studies, 10, 295-323.

Tejerizo, C.; Vigil-Escalera, A. 2017: «Castro Ventosa y la Cabeza de Navasangil: Una revisión de sus secuencias de ocupación y del fenómeno de los asentamientos fortificados altomedievales», Nailos, 4, 129-161.

ToвIE, J.-L. 1997: «Deux nouveaux sites de l'antiquité tardive en Basse Navarre: Gazteluzahar à Lantabat/Larceveau et Arteketa/Campaita à Uhart/Cize», Isturitz. Cuadernos de PrehistoriaArqueología, 8, 125-136.

VIDAL, S. 2000: «El sarcófago tardorromano de Tona», CuPAUAM, 26, 169-178.

Vives, J. 1963: Concilios visigóticos e hispano-romanos, CSIC, Barcelona-Madrid.

Wicкнам, C. 2009: Una historia nueva de la Alta Edad Media. Europa y el mundo mediterráneo, 400-800, Crítica, Barcelona.

Zangemeister, K. 1889: Pauli Orosii Historiae adversum paganos libri VII.

Zeumer, K. 1902: «Leges Visigothorum», a: Monumenta Germaniae Historica, Legum sectio I. Legum nationum Germanicarum, I, HannoverLeipzig. 



\title{
EL EDIFICIO VISIGODO DE ELS CASALS DEL MAS DE SABATER, MORELLA, ELS PORTS (CASTELLÓ)
}

\author{
José Manuel de Antonio Otal, ${ }^{1}$ Ramiro Pérez Milián ${ }^{1}$
}

\section{Resumen}

Presentamos un yacimiento de época tardoantigua y medieval inédito. Estamos arrancando la recta final de unos trabajos surgidos a raíz de un proyecto minero que afecta al entorno del yacimiento arqueológico, obligando a la empresa concesionaria de la explotación a realizar una intervención integral sobre este y otros bienes culturales afectados. En Els Casals (aún en proceso de excavación y estudio), destaca un edificio singular de origen visigodo, que protagoniza el contenido de este artículo. Además de introducir sus rasgos arquitectónicos generales, pretendemos también encuadrarlo en una tipología edilicia, referenciándolo respecto a paralelos formales peninsulares datados entre los siglos v y Ix. Finalmente, a lo largo de la exposición, se proponen unas líneas de interpretación, basándose en la caracterización de un entorno físico único, sin la cual resulta difícil explicar la existencia de un centro de estas características en un territorio más bien marginal.

\begin{abstract}
We present an unpublished ancient and medieval archaeological site. We are starting the final stretch of some works that arose as a result of a mining project that affects the environment of the archaeological site, forcing the concession company of the exploitation to carry out a comprehensive intervention on this and other affected cultural assets. In Els Casals (still in the process of excavation and study), a singular building of Visigoth origin stands out, which is the main topic of this chapter. In addition to introducing its general architectural features, we also intend to frame it in a building typology, referencing it with respect to formal peninsular parallels dated between the 5th and 9th centuries. Finally, throughout the exhibition, some lines of interpretation are proposed, based on the characterization of a unique physical environment, without which it is difficult to explain the existence of a center of these characteristics in a rather marginal territory.
\end{abstract}




\section{Introducción}

\subsection{Marco de los trabajos. Breve cronología}

La causa principal que ha movido los trabajos arqueológicos que esbozaremos a continuación no ha sido otra que el interés mostrado desde finales del siglo xx por la explotación a gran escala de las excelentes arcillas de la Vega del Moll. La empresa minera Arcillas Vega del Moll inicia en esos momentos los trámites para obtener concesiones mineras y abrir una cantera, y así arranca la historia del descubrimiento de Els Casals del Mas de Sabater, entonces llamado Bancal Mas de Sabater I.

El alumbramiento tiene lugar durante la campaña de prospecciones arqueológicas llevadas a cabo en 1999 y 2000 en la Vega del Moll, dirigidas por la arqueóloga Pilar Ulloa Chamorro, con la participación en los trabajos de campo de Miquel Guardiola Fígols, quien en esos momentos llamó la atención sobre el lugar donde ahora sabemos que se encuentra el singular edificio de Els Casals.

Hasta 2004 no se vuelven a realizar trabajos arqueológicos en el entorno del edificio (ya bajo la dirección de Ramiro Pérez Milián), aunque sea en relación con unos restos de época ibérica situados a escasos metros. Al año siguiente se realiza una nueva intervención en un área sepulcral (Mas de Macià Querol), situada a $150 \mathrm{~m}$ de nuestro edificio, dirigida por Ramiro Pérez Milián y Elisa García-Prósper. También en 2005 se inicia la delimitación del área de interés arqueológico Bancal del Mas de Sabater I, para su protección y posterior estudio de detalle, tras el cual se identifican dos posibles edificios.

No será hasta 2011 que comiencen a excavarse los primeros sondeos para tratar de establecer una cronología para las estructuras que se identifican en superficie, ya bajo la codirección de quienes firmamos este artículo. Tanto las catas realizadas ese año en el Edificio 1 como la excavación de una parte del Edificio 2 en 2012 dieron una cronología andalusí. La Dirección General de Cultura (Generalitat Valenciana) resuelve que Arcillas Vega del Moll deberá encargarse de la excavación completa del yacimiento arqueológico para que se autorice la ampliación de la explotación minera.

Así pues, en 2014 se inició una excavación arqueológica en extensión, tras la cual quedó establecido que parte del complejo edilicio andalusí se superponía a una edificación anterior, amortizada por su propio derrumbe, y cuya planta singular sobrepasaba la extensión del Edificio 1.

A partir de 2014 se da un giro radical en la consideración del yacimiento arqueológico Ban- cal Mas de Sabater I, así como en el enfoque y la planificación de los trabajos. Es evidente que el proyecto de excavación se debe replantear a la luz de los nuevos datos, y centrarse, casi exclusivamente, en el nuevo edificio aparecido bajo los niveles andalusíes.

A lo largo de los años 2014, 2015, 2016 y 2017 se realizaron cuatro campañas de excavaciones arqueológicas (y, en paralelo, se iniciaron los trabajos de protección y consolidación, así como el diseño de un proyecto de puesta en valor futura), las cuales sumaron un total de más de veinte meses de trabajo de campo.

El plan de excavación ha contemplado diversos objetivos por fases. En primer lugar, la excavación completa de las unidades correspondientes al edificio andalusí. Una vez registrada y retirada la parte superpuesta de dicho edificio, se ha excavado íntegramente el potente estrato de derrumbes del propio edificio, y seguidamente se ha acometido la excavación de los diferentes ámbitos del mismo, así como una parte de su perímetro exterior. En este punto es en el que se encuentra el proyecto en el momento de celebrarse estas II Jornades Internacionals d'Arqueologia de Ribaroja de Túria.

\subsection{Equipo y agradecimientos}

Nuestro equipo de trabajo de campo lo han formado Susana Arribas, Josep Beltrán, Silvia Fabregat, Paco Meseguer, Ximo Niñerola, Ramón Pascual, Sebas Redó y Nando Rubert, con quienes hemos compartido emociones, dolores de espal$\mathrm{da}$, desconciertos y euforia, entre otras muchas cosas. En el tratamiento, clasificación e inventariado del material cerámico tenemos a nuestro lado a Susana Arribas. El arqueólogo David Cardo está realizando un excelente trabajo de registro fotogramétrico, y gracias a él tenemos un «ojo en el cielo».

A María José Adelantado y Víctor Beltrán, gerentes de la empresa Arcillas Vega del Moll S.L., les agradecemos su apoyo constante y su implicación; así como a toda la plantilla de la explotación, que se han puesto a nuestra disposición siempre que ha sido necesario.

A Albert Ribera, Josep Maria Macias y Miquel Rosselló, gracias por las facilidades dadas para poder presentar nuestro trabajo en las II Jornades Internacionals d'Arqueologia de Riba-roja de Túria y por hacerlo tan agradable una vez allí.

Gracias a las/los participantes en dichas jornadas, porque ha sido un honor conoceros personalmente, y en especial a Ferran Arasa, Sonia Gutiérrez, Lauro Olmo y Enrico Zanini, gracias por el sincero apoyo expresado. 


\section{Situación y entorno físico}

Els Casals de Mas de Sabater se encuentra en la comarca de Els Ports, extremo NO de Castelló, lugar de encuentro con las provincias de Tarragona y Teruel. El medio físico de la comarca se define como de media montaña (900-1000 m s. n. m.), y su paisaje mesomediterráneo es abrupto y escaso de suelo agrícola, aunque excelente para la ganadería extensiva.

Els Casals se encuentra en una unidad paisajística singular dentro del dominio de la comarca: la Vega del Moll, donde precisamente la falta de tierras de labor encuentra su excepción. Se trata del principal corredor de la Formación Morella (antes conocida como Tierras Rojas de Morella), justo donde esta formación tiene su máxima anchura y potencia, además de una orientación este-oeste. Por una parte, la composición de estas tierras rojas es muy adecuada para el cultivo de cereales: arcillas ricas en óxido de hierro, esponjadas y enriquecidas gracias a las arenas y limos procedentes de la disgregación de los bancos de gres que cierran el flanco norte del corredor. Estas condiciones naturales se ven mejoradas por siglos de fertilización antrópica, ya que las roturaciones se iniciarían al final del Neolítico. Además, las tierras de la Vega del Moll son llanas o con pendientes moderadas, bien drenadas, están magníficamente orientadas, y la anchura del corredor (entre 600 y $1.500 \mathrm{~m}$ ) permite hablar de una unidad agrícola excepcional para esta comarca, de aproximadamente 1.500 hectáreas aprovechables. El investigador de la comarca Miquel Guardiola lo expone de esta manera: «És evident que es tracta d'un territori molt apte per a la vida agrícola i ramadera, almenys el més apte a la comarca dels Ports, i una bona prova és que dels dinou nuclis de població, quinze estan a menys d'1,5 km de la Formació Morella. [...] En l'època medieval, la Partida del Moll produïa gran part de la collita de cereals de Morella. Envers el baix imperi romà, quan les villae proliferaven, les trobem concentrades a la Vega del Moll.» (Guardiola 2005, 94). De igual forma, concentra la mayoría de las masías de la comarca que han sobrevivido a la despoblación actual.

Els Casals del Mas de Sabater está ubicado en el punto medio de los casi $15 \mathrm{~km}$ de longitud que tiene el corredor (no obstante, el control visual es mayor sobre el sector occidental). Esta equidistancia respecto a ambos extremos revela que la elección del lugar es consciente y racional, probablemente vinculada a la voluntad de organizar este espacio productivo en torno a Els Casals. La Vega del Moll es cruzada transversalmente por el conocido como Camí de València, vía mencionada en documentos del siglo XIII como "viam que vadit apud Valenciam» (Garcia y Garcia 1995, 30 y 35), por un punto que no dista más de $2.500 \mathrm{~m}$ de Els Casals en dirección este. Su proximidad y fácil acceso a esta vía de comunicación son circunstancias favorables que se suman a los rasgos propios de este entorno. Este camino es la vía tradicional

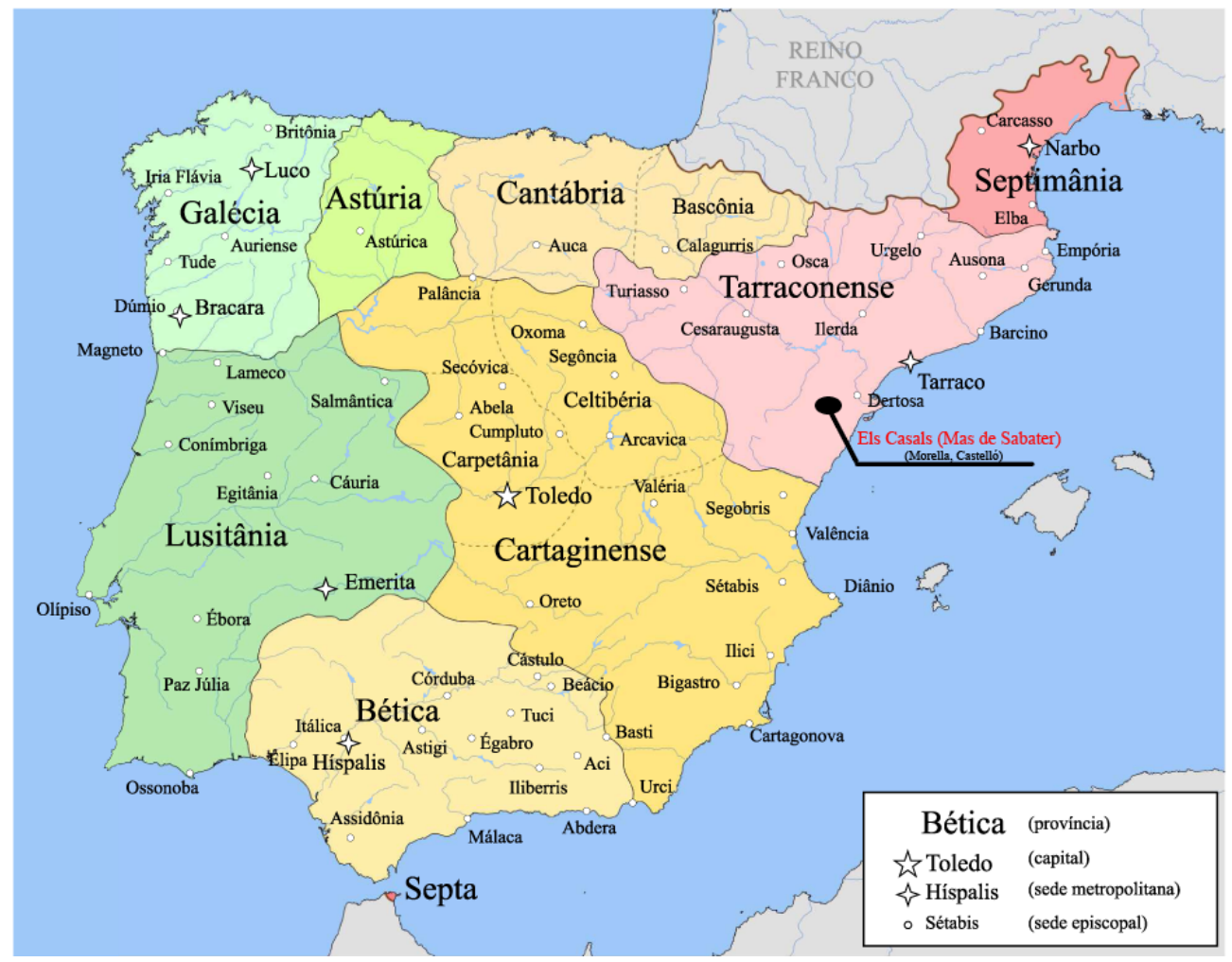

FiguRa 1. Mapa del reino visigodo de Toledo con la ubicación del yacimiento arqueológico de Els Casals de Mas de Sabater (Morella, Castelló) <www. pinterest.es $>$. 


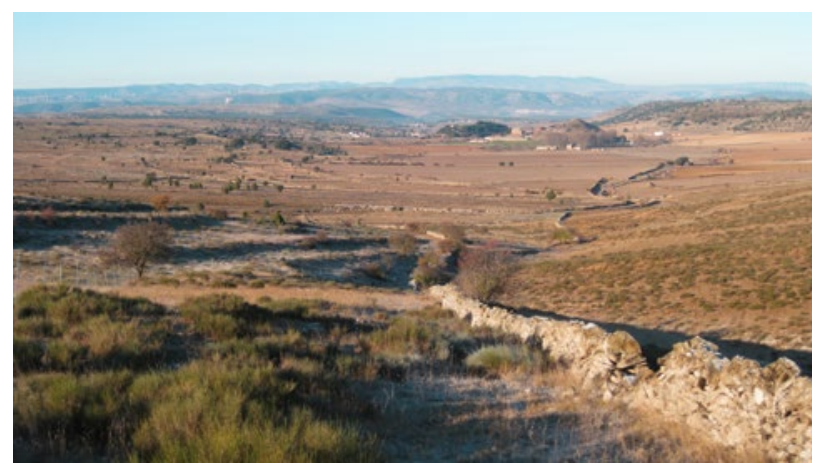

Figura 2. Panorámica longitudinal de la Vega del Moll tomada desde el extremo oriental. Al fondo, distante unos $15 \mathrm{~km}$, se aprecia la localidad de Cinctorres () José Manuel de Antonio Otal).

de comunicación que, atravesando la comarca de Els Ports, penetra desde el sur de la actual provincia de Castellón hacia el Bajo Aragón y el Medio Ebro. No es uno de los itinerarios mencionados en las fuentes romanas (posiblemente tuvo un carácter secundario en ese momento, al igual que toda la comarca), pero cobra relevancia a partir de la Tardoantigüedad y sobre todo en época medieval, como acreditan fuentes andalusíes (Negre 2013, 220).

\section{Una ojeada a la historiografía y la ar- queología locales}

Hay que señalar la escasez de información disponible por fuentes historiográficas para este periodo, tanto en el ámbito local como en el comarcal. Estas quedan reducidas a vagas referencias repetidas en las obras de historiadores locales, como Francisco Oliet (1861), Segura Barreda (1868) u Ortí Miralles (1958), entre otros, refirién- dose a una supuesta destrucción de las defensas de Morella por parte del rey Witiza, sin mencionar fuentes.

Por otra parte, Ferran Arasa recoge los hallazgos descontextualizados de tres objetos de bronce encuadrables en la Tardoantigüedad de la comarca. Una placa de cinturón liriforme procedente de Cinctorres (posiblemente relacionada con una necrópolis a unos 4,5 km de Els Casals); otra similar de Bel (Rossell, municipio situado a unos 26 $\mathrm{km}$ ); y un osculatorio presuntamente encontrado en Portell de Morella (localidad distante unos 12 km) (Arasa 1991).

Mucho más elocuente es la localización y excavación de dos conjuntos funerarios en el término de Morella (Duarte et al. 2009), dentro del ámbito rural, asociados a dos áreas productivas agrícolas de la formación de arcillas rojas de Morella:

- Mas de la Perera, situada a 8,5 km de Els Casals, dirigida por Francesc-Xavier Duarte Martínez y Francisco José Hernández García. La datación por $\mathrm{C}^{14}$ dio 660-790 d. C. (2Sigma).

- Mas de Macià Querol, situada a 150 m de nuestro edificio, dirigida por Ramiro Pérez Milián y Elisa García-Prósper. La datación por $\mathrm{C}^{14}$ dio 410-600 d. C. (2Sigma).

\section{El edificio}

\subsection{Descripción y proyecto constructivo}

A través de una primera lectura en planta, se infiere que el edificio exhumado en el yacimiento arqueológico de Els Casals del Mas de Sabater presenta unos rasgos que permiten encuadrarlo, claramente, en la arquitectura de representación de época tardoantigua.

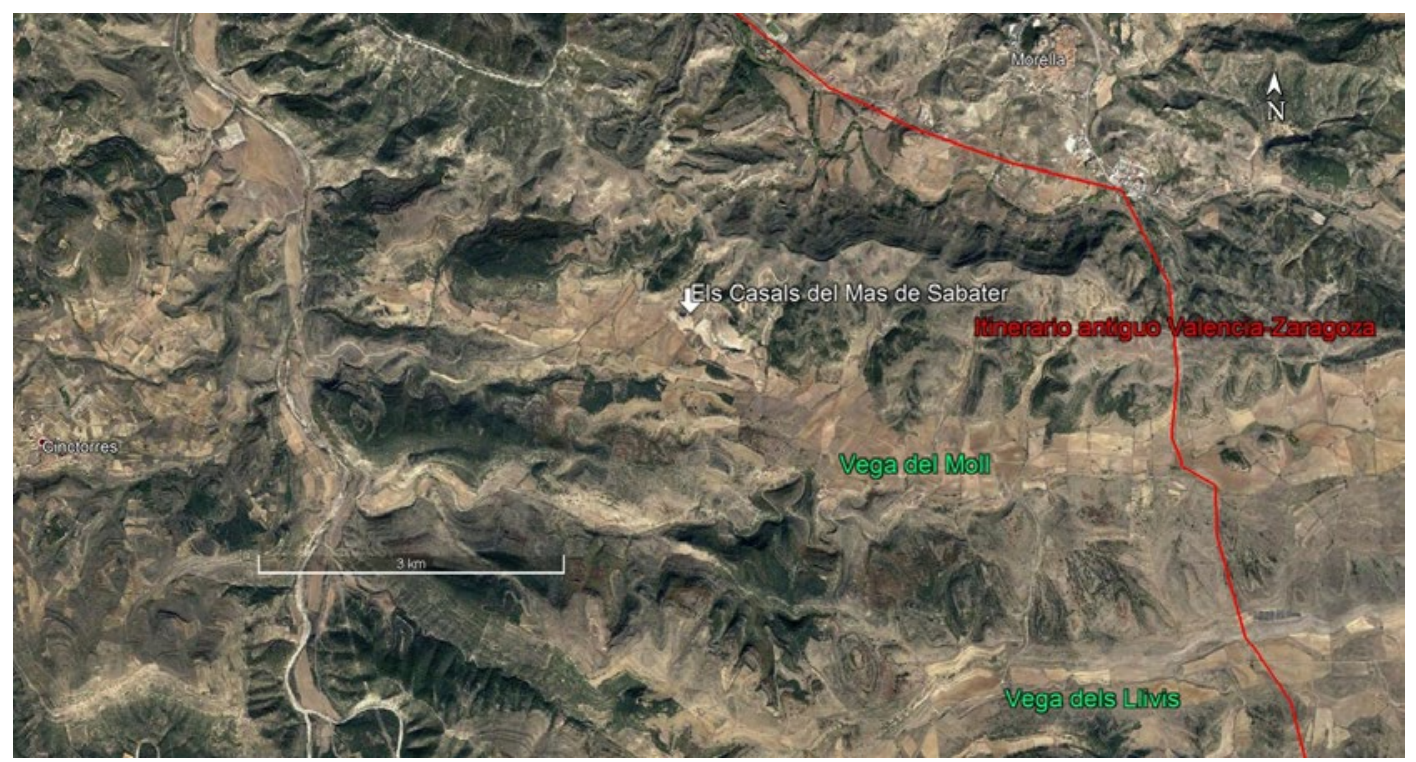

FIGURA 3. Ortofoto de la Vega del Moll y área circundante, con el trazado aproximado del antiguo camino de Valencia (Google Earth). 
En primer lugar, se construyó siguiendo un diseño y un proyecto minuciosamente establecidos, y de una complejidad considerable. Morfológicamente, la planta está constituida por tres naves longitudinales y una cuarta transversal, que cierra el edificio en su cabecera. El eje de la nave central marca una simetría perfecta, con una orientación SE-NO y una longitud total de 22,80 metros. La anchura oscila entre 18,90 y 13 metros (según tramos). El grueso de los muros oscila entre 0,65 y 0,70 metros.

La fachada principal (SE) y la trasera fueron rectas, mientras que las laterales están retranqueadas regularmente, dándole a los flancos una fisonomía abastionada. Hay que destacar la ubicación de dos absidiolos, uno en cada fachada lateral, rompiendo el ritmo de los retranqueos, aunque perfectamente repartidos respecto al eje de simetría.

Dispone de un único acceso por la fachada principal, situado en la nave central, que da paso

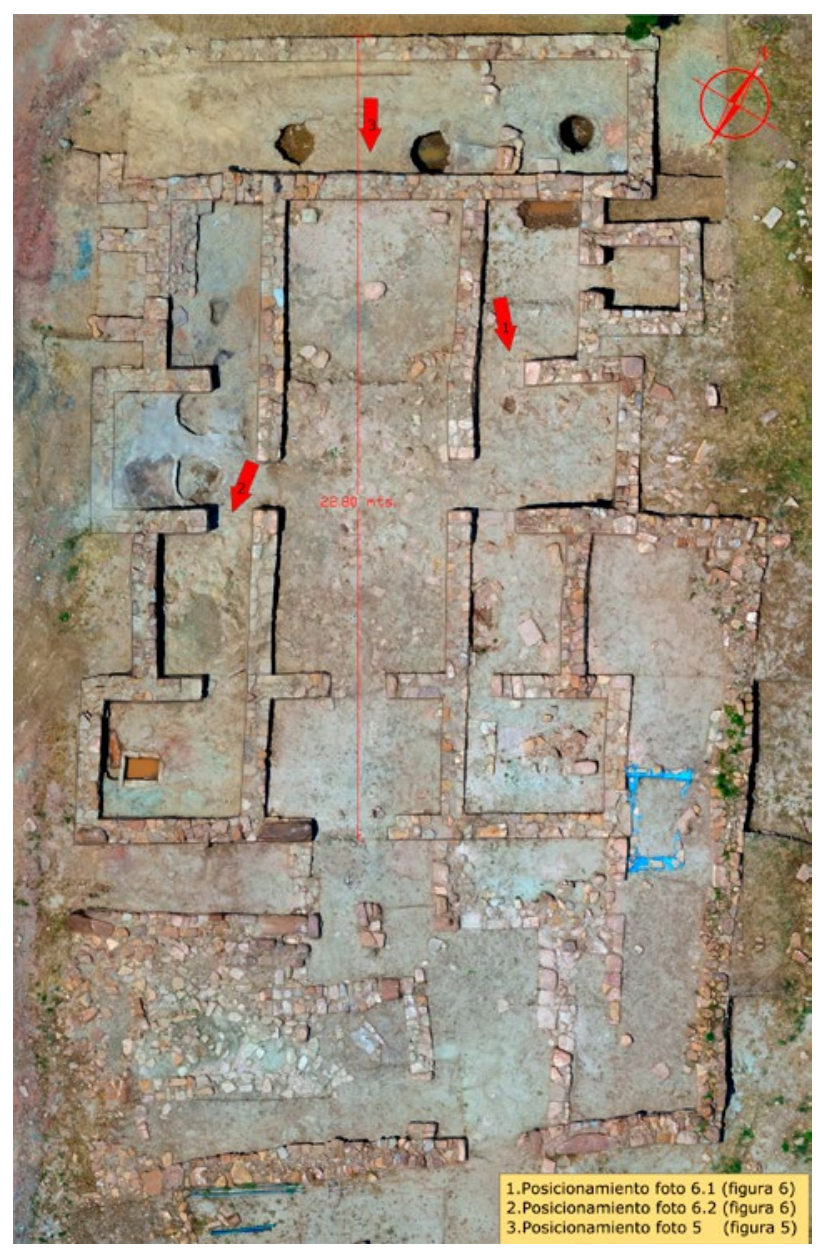

Figura 4. Ortofoto de la planta completa del edificio de Els Casals del Mas de Sabater (remarcado con línea negra). Se señala el posicionamiento de las fotos de detalle que ilustran este texto (ㄷ David Cardo Madrid). a un atrio de $16 \mathrm{~m}^{2}$. Desde este se accede al salón central a través de un vano encarado con el anterior. Esta gran estancia tiene unas dimensiones de 17,50 x 4,80 metros, y en el centro exacto de su cabecera se conserva una base pétrea clavada en el suelo.



FiguRA 5. Cabecera de la nave central. Detalle de la superficie del pavimento de la Fase II, con manchas de combustión y base pétrea en el centro, incrustada en los niveles de solera del edificio. Los bloques de las esquinas se apoyan sobre el pavimento de esta fase (C) José Manuel de Antonio Otal).

Antes de recorrer medio salón, se encuentra cada uno de los vanos que dan acceso a las naves laterales, únicos accesos de que estas disponen. Cuentan con cuatro ámbitos y un absidiolo cada una. Los cuatro ámbitos se comunican de uno al otro a través de vanos enfilados, constituyendo casi un corredor que sigue el sentido longitudinal del edificio. Desde los dos ámbitos más cercanos a la cabecera se accede a los absidiolos (en giro de $90^{\circ}$ ) y a la nave transversal que cierra el edificio, la cual consiste en un gran espacio unitario de 14,15 x 3,15 metros.

Otra cuestión a destacar, tras una primera lectura de la planta, es la distribución y las dimensiones de los vanos de comunicación interna. Su diseño también es minucioso, y muy revelador de las intenciones de los propietarios del edificio (en lo referente a la planta baja, claro está), debido a que lleva implícita, originalmente, una jerarquización de los espacios, a partir de la cual será posible comenzar a profundizar en su posible carácter y funcionalidad. Así pues, de manera genérica, podemos interpretar que los dos ámbitos de la nave central son espacios de "recepción», destinados al contacto entre propios y extraños. Para acceder a las naves laterales ya hay que atravesar un tercer vano y recorrer la mitad del salón, nivel que implica ser propio o contar con autorización de un propio. Acceder a los absidiolos o a ciertos 
ámbitos, así como a la nave transversal, implica un recorrido a través de cinco vanos, penetrando en lo más privado del edificio, y teniendo que regresar siempre por el mismo camino de entrada.

Tras una primera fase de uso del edificio, esta concepción original del espacio, implícita en su diseño, se verá completamente trastocada, como vamos a enunciar más adelante.

\subsection{Pautas y materiales constructivos utiliza- dos}

Las pautas de ejecución de la obra reafirman la idea de un proyecto edilicio de carácter oficial y de representación del poder. En primer lugar, se planteó un cimiento corrido en toda la planta del edificio, previa nivelación del terreno de la suave ladera donde se ubica. Así mismo, se utilizó robusta sillería en las jambas y los refuerzos de las esquinas, que contrasta con la mampostería irregular cogida con argamasa de barro del resto de los muros. La ausencia de morteros u hormigones de cal y de elementos arquitectónicos ornamentales no restaría monumentalidad ni efectividad representativa al conjunto. Por otra parte, el hecho de usar hábilmente materiales constructivos del entorno inmediato (piedra arenisca, arcillas y áridos varios) introduce una interesante variable en el análisis arquitectónico: el factor autóctono combinado con un poder "externo», interactuando en el proceso constructivo.

Sobre la base de estos elementos conservados, no hay duda de que el edificio se pudo alzar una o dos plantas sobre los cimientos y basamentos estudiados, algo especialmente seguro en la nave central, que podía descargar enormes fuerzas en las laterales, que actuarían como potentes contrafuertes. Por tanto, resulta técnicamente posible cubrir esta nave con una bóveda de cañón. Por encima, sobre la cubierta a dos aguas de la nave central y las de las tres naves más bajas que la en-

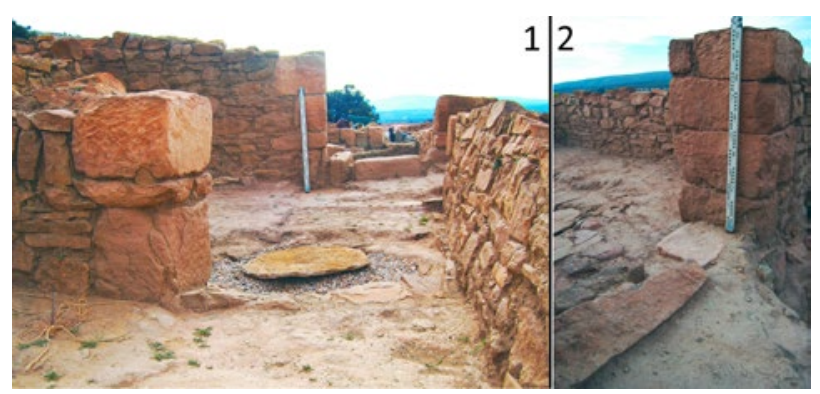

Figura 6. Detalle de los vanos que comunican los distintos ámbitos de las naves laterales en las zonas donde se encuentran los alzados máximos conservados ( José Manuel de Antonio Otal). Posicionamiento de las fotos en la fig. 4. vuelven, se dispondría un tejado de lajas pétreas, que se han podido localizar en los niveles inferiores de los derrumbes. No se ha localizado, por el contrario, ni un solo fragmento de material constructivo de barro cocido.

\section{Cuestiones arqueológicas e interpreta- ción}

\subsection{Entorno arqueológico inmediato}

El edificio singular de Els Casals forma parte de un yacimiento arqueológico mucho más amplio (podría extenderse un mínimo de 6 hectáreas), aún bastante desconocido y escasamente conservado, que ocupa terrenos de tres masías actuales, cuyas tierras confluyen en este punto.

En el Mas de Sabater se encuentra el edificio de Els Casals y restos de fases posteriores. El vecino Mas de Macià Querol alberga una necrópolis a la que nos hemos referido más arriba, y que nos ha servido para fijar el inicio de la Fase I (fundacional), que, por estar en proceso de excavación en el edificio, no es posible caracterizar aún. Provisionalmente, se sitúa en las últimas dos décadas del siglo vi (datación radiocarbónica de una inhumación de la necrópolis). Entre la necrópolis y el edificio existe una zona bastante arrasada, aunque con suficientes restos como para pensar en una continuidad espacial del asentamiento.

Por último, también en el Mas de Macià Querol, sobre un cerro y dominando todo el conjunto, está el Tossal de Pereu, con un complejo fortificado que está por estudiar y que, junto con la necrópolis de Macià Querol, se postulan como futuros objetos de investigación.

\subsection{Fases de ocupación y uso del edificio}

En este apartado esbozamos un esquema preliminar y básico de la secuencia de ocupación y abandono del interior del edificio, basado en la interpretación de la estratigrafía documentada durante la excavación. Puntualmente, hacemos mención de algún elemento de datación absoluta, directo o indirecto, como la moneda y las dataciones radiocarbónicas, únicamente como guías cronológicas. El estudio pormenorizado de los materiales cerámicos y metálicos hallados no está concluido, y su publicación se acometerá en futuros trabajos.

La construcción y primera ocupación del edificio son hechos que todavía no se han podido datar con precisión. No existen indicios de asentamientos anteriores respecto a la nueva fundación. Se trata, pues, de un edificio de nueva planta, de una 


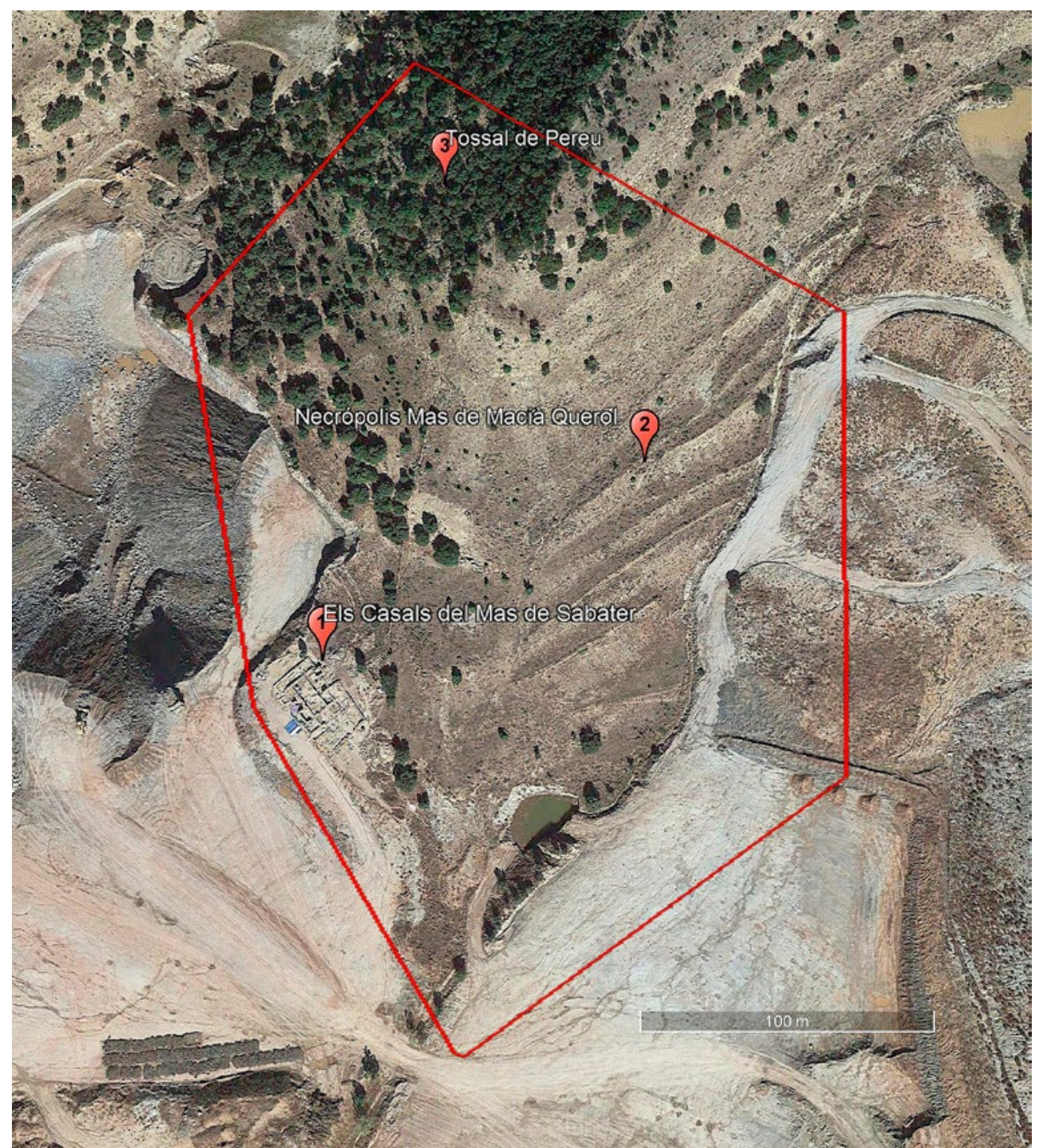

Figura 7. Ortofoto del área con restos arqueológicos posiblemente relacionados con el yacimiento arqueológico de Els Casals (Google Earth). instalación ex novo en un territorio que suponemos habitado, aunque sin una presencia efectiva, o sin una visibilidad tan próxima del poder como la que se implanta a partir de dicha fundación. Como se apunta más arriba, la necrópolis de Macià Querol ya está en uso antes de arrancar el siglo vII, y, aunque con cautela, utilizaremos provisionalmente dicha referencia.

Al abandono del edificio por parte de la élite que lo fundó le sigue, sin pausa, la Fase II, que supone una verdadera reconversión del edificio. Varios hechos caracterizan a este momento: reorganización del espacio interno, excavación de silos en el subsuelo interior, repavimentación y ubicación de hogares sobre estos suelos. Esta fase se ha podido datar en el tránsito del siglo viI al VIII (más probablemente en la primera década del siglo VIII), gracias al hallazgo de un tremís del rey Witiza, acuñado en Caesaraugusta. Esta fase se inscribe en los últimos momentos del reino visigodo, con un poder debilitado, en un escenario de luchas internas y pérdida progresiva del control efectivo del territorio.
Si ya durante la Fase II se constata la degradación de algunas partes del edificio, la Fase III parece que se desarrolla a la par que se consuma el colapso generalizado de su estructura. Se ha detectado un uso residual sobre los primeros paquetes de derrumbes, con los silos y parte del edificio ya amortizados, centrado en reducidos

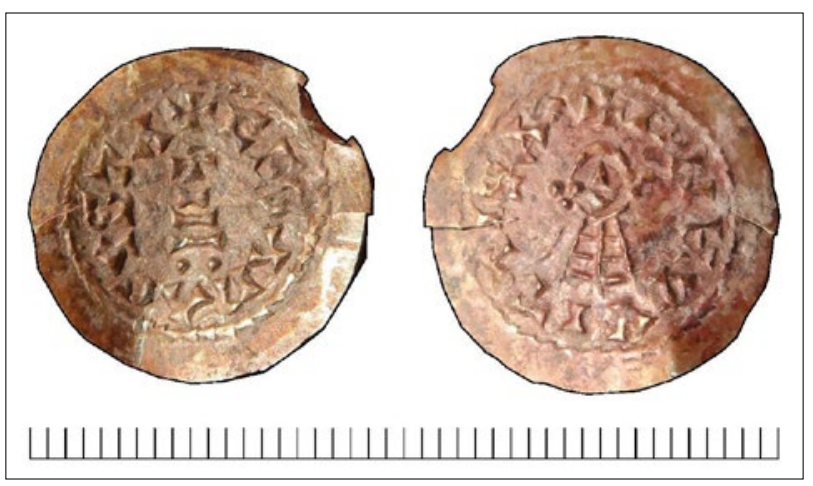

Figura 8. Moneda localizada en la cabecera de la nave central, sobre la capa de pavimentación de la Fase II (@ Ximo Niñerola Cuartiella). 


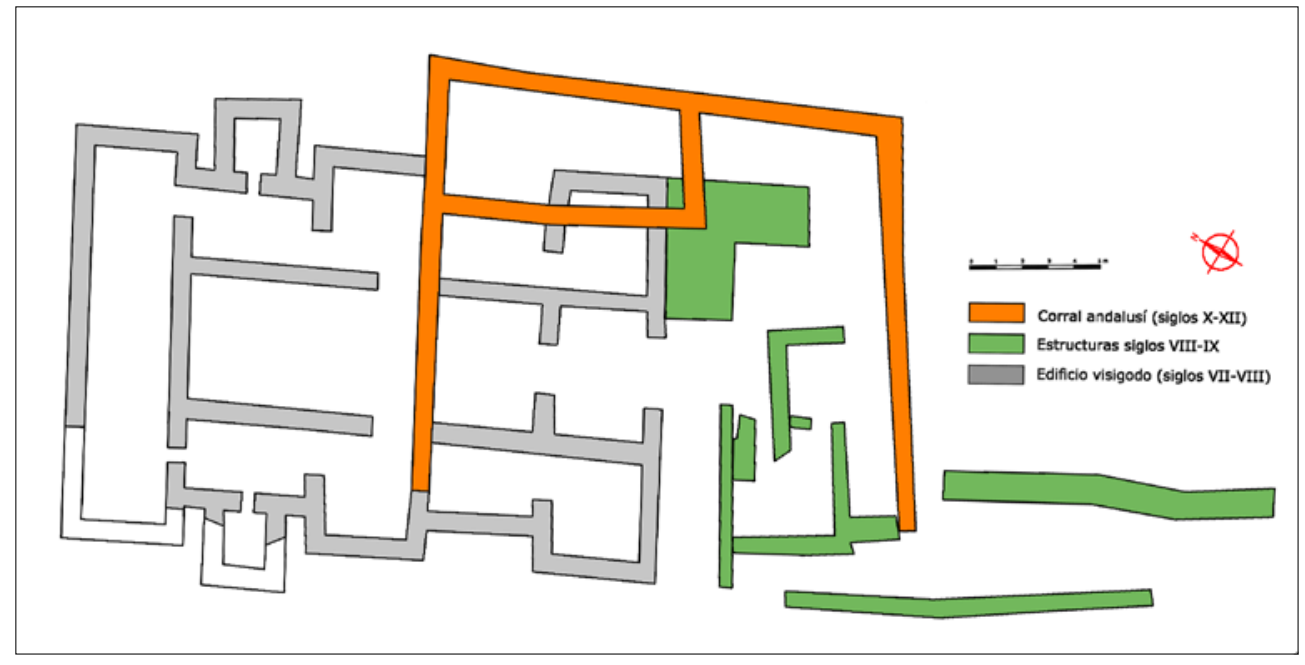

Figura 9. Planta básica de las estructuras de las tres fases de ocupación directamente asociadas al edificio de Els Casals. En blanco, restitución de segmentos de muros eliminados probablemente durante la Fase II (C) autores).

ámbitos de las antiguas estancias. Estos hechos están confirmando el abandono del edificio y solo se pueden dar en un ambiente de ocupación esporádica. Los materiales cerámicos de esta fase son escasos, aunque permiten vislumbrar un horizonte todavía visigodo, cronológicamente adentrado en el siglo vIII.

Tras un abandono persistente, se volverán a instalar nuevas edificaciones, consistentes en infraestructuras ganaderas, ya en pleno periodo andalusí. Las ruinas del edificio visigodo servirán de base a estos corrales y recintos asociados, así como de cantera, fenómeno documentado en las fosas de rebusca detectadas en los derrumbes del mismo.

\section{Primeras conclusiones}

Después de caracterizar los rasgos constructivos principales del edificio de Els Casals, resulta evidente que encajan con aquellos que ya se han descrito y sistematizado en trabajos de síntesis acerca de la arquitectura de época visigoda, tanto en el ámbito más inmediato de la Tarraconensis como, en general, en toda Hispania. Estos paralelismos son válidos tanto para su diseño y ejecución originales como para la reconversión en ámbitos domésticos sufrida en la Fase II (Beltrán 2009; Beltrán y Macias 2016; 2018).

Es patente el carácter representativo que confiere al edificio la estricta planificación espacial que se lee en su planta y distribución, con claras semejanzas con el palacio episcopal de Barcino (Grupo Episcopal de la segunda mitad del siglo vI) (Bonnet y Beltrán 2000; 2005; Perich 2014). También es muy significativo el uso del pes Drusianus de 0,332 metros como unidad de medida. Este dato se lo debemos al Dr. Lorenzo Arias Páramo (Universidad de Oviedo), quien muy amablemente, por mediación del Dr. Ricardo González Villaescusa, se ha brindado a realizar un primer análisis del patrón metrológico del edificio. Nue-

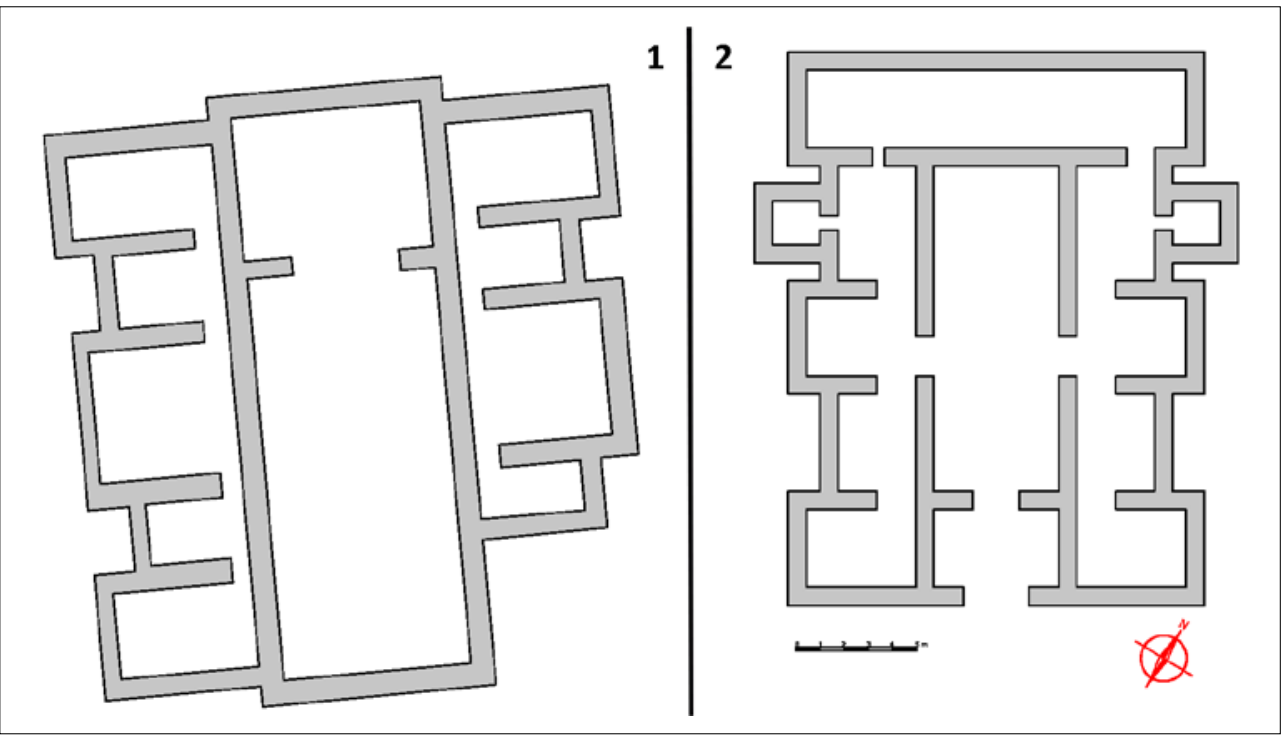

Figura 10. (1)

Planta del Palacio Episcopal de Barcino (Beltrán y Revilla 2009). (2) Edificio de Els Casals. Aunque parecen partir de un mismo prototipo, se aprecian rasgos propios en cada uno de los modelos, además de la evidente distinción de los entornos en que se ubican. 
vamente, observamos un claro paralelismo en el palacio episcopal de Barcino, aunque su unidad de medida es un pes Romanus o Capitolinus de 0,3015 (Beltrán y Revilla 2009, 171).

Otro ejemplo de edificio de representación, esta vez con origen en el siglo v, es el Castellum de la Muntanya de Sant Julià de Ramis (Girona) (Burch et al. 2006). Los edificios emirales de Morería (Mérida) responden también al prototipo edilicio, con una cronología que se acercaría al siglo IX (Alba 2004; 2009; Mateos y Alba 2000).

Finalmente, creemos que, aparte de los nuevos datos aportados por el estudio de los materiales arqueológicos en sus contextos, hay que insistir -y sacarle el máximo partido- en el estudio de la arquitectura fundacional del edificio; máxime cuando esta información va a ser la base de la comprensión del carácter y la funcionalidad de los ámbitos, ante la insuficiencia (por el momento) de otros indicadores arqueológicos para la Fase I.

\section{Bibliografía}

Alba, M. 2004: "Arquitectura emiral palacial en el enclave del Templo de Diana», Excavaciones Arqueológicas en Mérida 2001. Memoria, 7, 5572.

- 2009: «Los edificios emirales de Morería (Mérida), una muestra de arquitectura del poder», Anales de Arqueología Cordobesa, 20, 379-418.

ARASA, F. 1991: "Un osculatori i dues plaques de cinturó de la comarca dels Ports (Castelló)», Saguntum, 24, 203-210.

Beltrán de Heredia, J. 2009: «Sistemas de construcción en Barcino durante la antigüedad tardía. Materiales, técnicas y morteros: un fósil director en el yacimiento de Plaza del Rey», Quarhis, 5, MHCB, 142-169.

Beltrán de Heredia, J.; Revilla, E. 2009: «Metrologia i modulació dels edificis del segle vI del grup episcopal de Barcelona», Quarhis, 5, MHCB, 170-183.

Beltrán de Heredia, J.; Macias Solé, J. M. 2016: "Técnicas constructivas en la Tarraconensis durante la antigüedad tardía. Planteamientos y estrategias de investigación para una propuesta de síntesis», Quarhis, 12, MHCB, 16-38.

- 2018: «Maneras de vivir, formas de construir: el hábitat en la Hispania visigoda», en: Abitare nel Mediterraneo Tardantico. II Convegno Internazionale, Bolonia, 2-5 de marzo (2016), CISEM, 227-235.

Bonnet, Ch.; Beltrán de Heredia, J. 2000: «El primer grupo episcopal de Barcelona», Sedes Re- giae (400-800 d.C.). Memorias de la Real Academia de Buenas Letras de Barcelona, 467-490.

- 2005: «Arqueología y arquitectura de los siglos VI-VII en Barcelona: La reforma y monumentalización del grupo episcopal», en: García MoReNo, L. A.; Rascón, S. Actas IV y V Encuentro Internacional Hispania en la Antigüedad Tardía. Guerra y rebelión en la Antigüedad Tardía. El siglo VII en España y su contexto mediterráneo, Alcalá de Henares (2000), 135-160.

Burch, J.; Garcia, G.; Nolla, J. M.; Miquel, I.; PaLAHÍ, J.; Sagrera, J.; Sureda, M.; VIVÓ, D. 2006: Excavacions arqueològiques a la muntanya de Sant Julià de Ramis, vol. 2: El Castellum, Ajuntament de Sant Julià de Ramis.

Duarte, F. X.; Hernández, F. J.; Núñez, G.; Pérez Milí́n, R. 2009: «Tres conjuntos funerarios rurales en Morella (Els Ports, Castelló), ss. VI-XI: aspectos arqueológicos», en: Polo, M.; GarcíaPrósper, E. Actas del IX Congreso Nacional de Paleopatología (Morella, 2007), Grupo Paleolab, Valencia, 115-134.

Garcia Sanz, A.; Garcia Edo, V. 1995: La Carta Pobla de Morella, Generalitat Valenciana, Picanya, 30 i 35.

GuARDIOLA, M. 2005: «La Formació Morella: un patró geològic per a l'assentament prehistòric a la comarca dels Ports», Quaderns de Prehistòria $i$ Arqueologia de Castelló, 24, 91-110.

Mateos, P.; Alba, M. 2000: «De Emerita Augusta a Marida», en: Caballero, L.; Mateos, P. Visigodos y Omeyas. Un debate entre la Antigüedad Tardía y la Alta Edad Media, Anejos AEspA XXIII, CSIC y Consorcio de la Ciudad Monumental, 143-168.

NegRE, J. 2013: «Evolució de la xarxa viària del territori de Tortosa entre l'Antiguitat i l'Edat Mitjana», Quaderns de Prehistòria i Arqueologia de Castelló, 31, 209-228.

Oliet Palos, F. 1861: Historia de la Muy Noble, Fiel, Fiel, Fuerte y Prudente Villa de Morella, edición facsímil (Josep Alanyà i Roig, 2006), Ajuntament de Morella i Fundació Sexennis de Morella.

Ortí Miralles, F. 1958: Historia de Morella, Ediciones Ortí, Benimodo.

Perich, A. 2014: «Barcino entre los siglos IV y vI d.C. Transformaciones y ascenso de una ciudad mediterránea durante la Antigüedad Tardía», Espacio, Tiempo y Forma. Revista de la Facultad de Geografía e Historia UNED, 7, 6195.

SEgura Barreda, J. 1868: Morella y sus aldeas, 3 t., Morella. 



\section{느느느 \\ ICAC ${ }^{\mathrm{T}}$

